
TÖRTÉNELEMTUDOMÁNYI DOKTORI ISKOLA MEDIEVISZTIKA ALPROGRAM

Szabó Pál

\title{
1440 - Nándorfehérvár első oszmán-török ostroma és elözményei
}

doktori értekezés

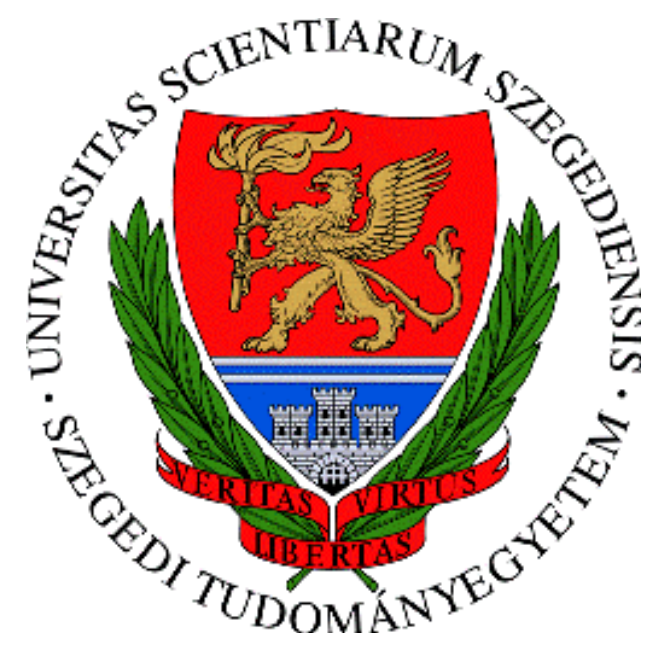

Témavezetők: Prof. Dr. Olajos Terézia,

Dr. Sebők Ferenc

Szeged 


\section{Tartalom}

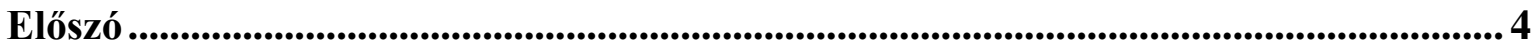

1. „,nem jegyeztek fel többet néhány szükszavú mondatnál” .................................................9

-Nándorfehérvár első török ostroma a magyar történetírásban ..............................9

2. Az ostrom(ok) évtizedének nemzetközi eseményei ..................................................... 27

2. 1. Anglia és Franciaország a százéves háborúban ................................................. 27

2. 2. A Német-Római Császárság és Lengyelország dinasztikus törekvései ............28

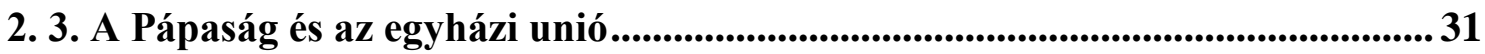

2. 4. Szerbia, Bizánc és az Oszmán Birodalom........................................................35

2. 5. Hatalommegosztás a Mediterráneumban: Rodosz ostromai $(1440,1444)$...... 43

3. Elődök és erődök: A vár középkori újjáépítései ..................................................... 48

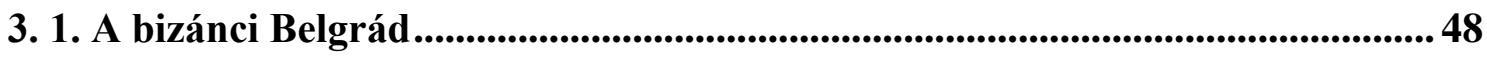

3. 2. A 15. század eleji újjáépítés: a fóváros Belgrád Lazarević István korában .... 51

3. 3. Raguza, Rodosz erődített városai a 14-15. században ......................................... 58

3. 4. Thesszaloniki és Szendrő várfalai a 15. században......................................... 66

4. Belgrádból Nándorfehérvár ..............................................................................72

4. 1. A tatai szerződés és Nándorfehérvár átadása (1426-1427).............................. 72

5. A Tallóciak: a déli végektől Nándorfehérvár kapitányságáig ..................................... 77

5. 1. Részvétel Galambóc 1428. évi ostromában................................................. 77

5. 2. Nemesség és pecséthasználat: a Tallóci címer nyomában ..................................... 85

5. 3. Küzdelem a horvát-szlavón-dalmát bánság megtartásáért .............................92

5. 4. Zsigmond 1437. évi törökellenes hadjárata ................................................................. 94

6. Az 1440. évi török támadás katonai elő́zményei .........................................................99

6. 1. 1429-1432: A Német Lovagrend a Szörénységben ............................................99

6. 2. Okleveles adatok az 1429-1437 közötti török betörésekről ............................... 101

6. 3. II. Murád 1438. évi erdélyi hadjárata ......................................................... 109

6. 4. Szendrö 1439. évi ostroma................................................................................................ 115

7. Az 1440-es ostrom belpolitikai háttere: a magyarországi belháború ...................... 128

7. 1. A megérkezéstől a koronázásig: I. Ulászló ............................................................... 128

7. 2. Nándorfehérvár felmentésének lehetősége és lehetetlensége ............................ 141

7. 3. Az ostrom időszaka a Tallóci-oklevelezésben..................................................... 144 
8. Nándorfehérvár 1440. évi ostroma a forrásokban .................................................. 148

8. 1. A latin nyelvü magyar források........................................................................ 148

8. 2. A latin nyelvü lengyel források.......................................................................... 154

8. 3. A bizánci, klasszicizáló görög nyelvü források ............................................. 167

8. 4. A bizánci-újgörög nyelvü források ............................................................. 171

8. 5. Fejezetek a török nyelvü forrásokból......................................................................... 176

9. Néhány filológiai tanulság...................................................................................................... 182

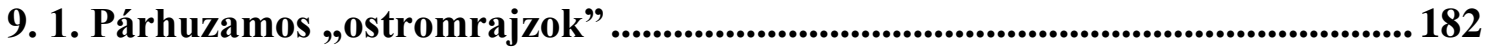

9. 2. A tüzfegyverek, aknák megnevezése az ostrom bizánci forrásaiban ............. 191

10. Elemzések és következtetések ........................................................................................ 196

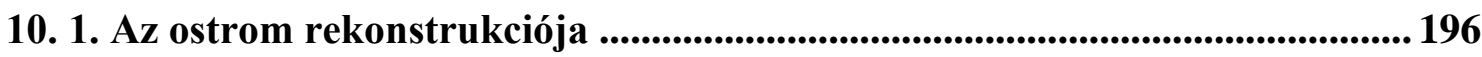

10. 2. Az ostrom kezdete, vége és a szultáni hadsereg akciórádiusza....................... 202

10. 3. A szemben álló seregek létszáma ...................................................................... 211

10. 4. Az ostromban alkalmazott haditechnika: aknászat ................................... 214

10. 5. Lő ,„por"-e a lőpor? -a bizánci források tanulsága ...................................... 225

10. 6. Alkalmazott tüzfegyverek: ágyúk, puskák, mozsarak ................................ 231

11. Vég nélkül... a végeken: a Tallóciak és a Hunyadiak .......................................... 246

12. ,eltekintve Belgrád 1440. évi sikertelen ostromától"? ................................................... 250

-Az ostrom elhelyezése a magyar hadtörténetben ........................................................ 250

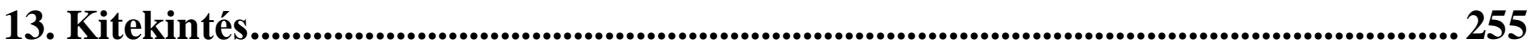

13. 1. Nándorfehérvár megnevezésének egy földrajzi-topográfiai problémája .... 255

13. 2. I. Bayezid szultán hadjáratai a Magyar Királyság ellen ............................... 259

13. 3. Ostromolhatta-e I. Bayezid Nándorfehérvárt? ......................................... 279

13. 4. Hunyadi Mátyás ismeretlen győzelme Nándorfehérvárnál ........................... 291

-Zsarnó ostroma (1463) .......................................................................................................... 291

14. Felhasznált irodalom ................................................................................................................. 300

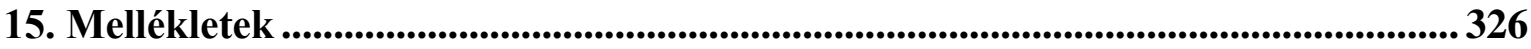


„iter est non trita auctoribus"

(Caius Plinius Secundus:

Nat. hist. praef. 14.)

\section{Előszó}

Alapigazság, hogy egy-egy vár történetének megírásakor a híresebb vagy később elhíresült ostrom sokszor „elfedi” a korábbi sikeres védelmeket, így az egyoldalúan kerül át a köztudatba. Temesvár 1552. évi oszmán-török ostroma (június 24 - július 27) és elfoglalása általában ismert, de arról, hogy egy évvel korábban, 1551 októberében (október 17-27) a védők sikeresen visszaverték a törököket, alig tudhatunk. ${ }^{1}$ Elgondolkodtató az, hogy milyen egyéb tényezők miatt lesz egy-egy ostrom hangsúlyosabb mind a kortársak, mind pedig az utódok emlékezetében, amikor katonailag-hadászatilag volt (voltak) más legalább olyan fontosságú - korábbi (korábbiak) is. Nándorfehérvár szintén jó példát szolgáltat erre, hiszen sok mindent nem tudunk még e vár 1456 elötti oszmán-török ostromainak történetéről. Ez a folyamat - az ostromról szóló magyarországi latin nyelvü krónikák közlése ellenére - már több mint száz évvel az ostrom után a históriás énekekben is nyomon követhető. 1560-ban Nagybáncsai Mátyás Hunyadi János tetteiről szóló énekében Tallóci Jován (,vitéz Szováti János bán”) 1440. évi helytállása a törökverő hős harcai közé kerül, annak mintegy „,bevezetéseként.”2

Vállalkozásom hiánypótló, mert - tudomásom szerint - Nándorfehérvár 1440. évi ostromáról önálló munka azóta sem született, s e körülmény témaválasztásomat és eddigi publikációim igyekezetét feltétlenül indokolttá tette.

A témával egy előadásra készülve a Vásárhelyi Történelmi Kör részére, 2009-ben, a Szegedi Tudományegyetem Bölcsészettudományi Karán, medievisztika szakos doktoranduszként kezdtem foglalkozni az ostrom közelgő jubileuma alkalmából. Az alaposan feldolgozottnak hitt téma szükszavú szakirodalmát látva azonban hamarosan rá kellett jönnöm arra, hogy valójában a forrásokból kiindulva alapkutatásokat kell folytatnom. Ennek első eredményeként, Hódmezővásárhelyen Dani Dániel Pál

\footnotetext{
${ }^{1}$ Erre például Dr. Petrovics István (SZTE-BTK) mutatott rá, Hódmezővásárhelyen, az V. Történettudományi Találkozón megtartott előadásában. A középkori Temesvár és a város 1552. évi eleste (2012. július 17). Érintőlegesen lásd még: Petrovics István: A középkori Temesvár. Fejezetek a Bega-parti város 1552 elötti történetéböl. Capitulum IV. Szeged 2008.

${ }^{2}$ A disszertáció egyes fejezeteihez mottóként választott históriás ének egyik érdekessége, hogy a későbbi Balassi-strófa egyik előképét adja, belső rímek nélkül, négysoros strófákban. Csörsz Rumen István: „Hallám egy ifjúnak minap éneklését” Versformák és dallamok Balassi Bálint költészetében. In.: Balassi Bálint és kora. Budapest 2004. 89.
} 
hadtörténész barátom jóvoltából, a Vásárhelyi Történelmi Kör előadássorozata keretében, 2010. március 19-én tartottam előadást az ostrom 570 évvel ezelötti évfordulója tiszteletére. Ezt követték az anyag bővülésével évenként további hódmezővásárhelyi (2010. július 17; 2011. július 14; 2012. július 17; 2013. július 9, 13), algyői (2011. február 15) és szabadkai előadások (2011. november 11), illetve Budapesten, az MTA-n, Dr. Baán István akadémiai doktori védésén egy hozzászólásom (2011. február 23). 2010-ben addigi eredményeimet Szegeden közzétettem. ${ }^{3} 2011$ szeptemberében kutatásaimat összefoglaló tanulmányomat a Hadtörténelmi Közlemények szerkesztőjének, Dr. Veszprémy Lászlónak küldtem el. Bár munkámat a 2011. decemberi szerkesztőségi ülés későbbi közlésre elfogadta, ám ezidáig (2014. január) részletében sem jelent meg.

2010 és 2014 között a Szegedi Tudományegyetem Bizantinológiai Kutatócsoportja keretében, Dr. Olajos Terézia professzor asszony vezetésével a Magyar-bizánci kapcsolatok a 10-15. században a történelem, politika, müvelödéstörténet, egyház és jog területén címü téma (OTKA K 81 485) intézményes lehetőséget biztosított számomra kutatásaim elmélyítésére és megszilárdította korábbi elkötelezettségemet a téma iránt. Ennek keretében könyvtári és levéltári kutatásokat, helyszíni terepbejárásokat folytathattam. Eredményeimet tudományos konferenciákon bemutattam és különbözö szakmai orgánumokban közzétettem.

A 2011 decemberében elkészült hosszabb tanulmányomat a Vajdasági Magyar Helytörténeti Egyesület - miután a tagjai közé fogadott - az 2011-2012-es évkönyvében közölte, amely végül is 2013 tavaszán jelent meg. ${ }^{4}$

A 2012. év során az ostromról publikáció-sorozatot írtam, amelynek folyamatos közlését - föbb részeivel, több közleményben - a Partium folyóirat vállalta fel. Így az ostrom első hazai historiográfiai áttekintését 2011/2012 telén publikáltam. ${ }^{5}$ Majd ezt követte 2012-ben négy tanulmányom megjelenése, amelyek a legújabb eredményeimet is tartalmazzák. ${ }^{6}$ Ezzel párhuzamosan e témakört kiegészítve további előadásokat tartottam.

\footnotetext{
${ }^{3}$ Szabó Pál:,, Ahol Magyar Királyságunk épsége ered” Nándorfehérvár első török ostroma (1440). Diadalmas viadalmak Belvedere Meridionale 2010/XXII. 3-4. április-május (Szerk.: Halmágyi Miklós) 59-85. A továbbiakban: Szabó 2010a.

${ }^{4}$ Uő: Egy elfeledett hadisiker nyomában: Nándorfehérvár első török ostromáról (1440). Vajdasági Magyar Helytörténeti Társaság, Évkönyv 3. Szerk.: Szabó József. Bajmok, 2013. 3-58. (Szabó 2013a)

${ }^{5}$ Uö:,,nem jegyeztek fel többet néhány szükszavú mondatnál” Nándorfehérvár első török ostroma a magyar történetírásban. Partium 2011/2012 (tél) 12-19. (Szabó 2011d)

${ }^{6}$ Uő: Új fejezetek Nándorfehérvár első török ostromáról (1440, első közlemény). Partium 2012 (nyár) 80-96 (Szabó 2012a); Nándorfehérvár első török ostromának kül- és belpolitikai előzményei (Második közlemény) Partium 2012 (ősz) 8-29 (Szabó 2012c); Nándorfehérvár első török ostromának forrásai (Harmadik közlemény) Partium 2012 (ősz) 109-131 (A továbbiakban: Szabó 2012d); Értékelés és
} 
A két névtelen szerzőtől származó bizánci krónikarészlet fordításáról és összehasonlító elemzéséről 2012 májusában, a Magyar Bizantinológiai Társaság szegedi tagozata által szervezett, nemzetközi bizantinológiai konferencián számoltam be. ${ }^{7}$

2013 júniusában Szegeden, a 8. Medievisztikai Konferencián a vizsgálataimmal immár időben is jobban „előretekintve”, egy I. Bayezid szultán korabeli ostrom lehetőségét vizsgáltam meg. ${ }^{8}$ 2013-ban egy rövid összegzésem jelent meg a Bácsországban, amelyet az I. Bayezid szultán magyarországi hadjárataiba beágyazott „nulladik” ostromról szóló publikációm követett. ${ }^{9}$ Ez a témakör távolabbról kapcsolódik a disszertáció fő témájához annak kialakított arányait nem megbontva - a Kitekintésben kapott helyet. Ide csatoltam a 1440-es ostrom magyarországi latin nyelvü forrásaiban megtalált topográfiai problémát is. A fejezetet Hunyadi Mátyás eddig nem ismert ostromának (1463) bemutatása zárja, a Nándorfehérvárhoz közeli Zsarnó vára ellen.

A könnyebb olvashatóság kedvéért, a görög szavak magyar átírásakor, a Magyar Tudományos Akadémia szabályait követtem, ugyanakkor a magyar nyelvben meghonosodott tulajdonnevek közkeletü átírását meghagytam. A Tallóci névnek a szakirodalomban előforduló különböző alakjait az idézett passzusokban megtartottam, egyébként - Mályusz Elemért követve - a Tallóci névalakot használtam. A disszertációban felhasznált, számos latin és görög nyelvü forrásrészleteket, amennyiben a fordító nevét külön nem jelzem, saját átültetésemben közlöm. A forrásszövegek idézésekor az oldalszámot követően, a vessző után, a sorok számát is jelölöm. A disszertáció témáját jelentő vár, város nevét Nándorfehérvárként illetve Belgrádként egyaránt említem. Amikor magyar kézben volt, az előbbi, amikor nem, az utóbbi néven neveztem.

A disszertáció módszere multidiszciplináris. A források felhasználása során egyesíti magában a görög és latin filológiai módszereket. A történelemtudományok (medievisztika), hadtörténet, a fegyvertörténet, a bizantinológia, az oszmanisztika, a történeti segédtudományok közül a diplomatikai és a szfragisztikai módszerek alkalmazását feltételezi. Jogászként pedig sokszor segítséget adott a középkori jogtörténet

következtetések Nándorfehérvár első török ostromáról (1440) (Negyedik közlemény). Partium 2012/13 (tél) 45-75. (Szabó 2012e)

${ }^{7}$ Névtelen bizánci krónikák Nándorfehérvár első török ostromáról. In.: A Kárpát-medence, a magyarság és Bizánc. Szerkesztette: Olajos Terézia. Szeged 2014 (s. a) (Szabó 2014b)

8 Ostromolhatta-e I. Bayezid szultán Belgrádot? In.: Középkortörténeti tanulmányok 8. Szerk.: Bartha Annamária, Kruták Anita, Tóber Márta. Szeged 2014 (s. a) (Szabó 2014a)

9 Nándorfehérvár első erőpróbája. Történeti szinopszis az 1440. évi szultáni török ostromról. Bácsország 2013 / 2. (65) 24-28 (Szabó 2013b); I. Bayezid szultán Magyarország ellen vezetett hadjáratai és Nándorfehérvár „nulladik” ostromának lehetősége. Partium 2013, XXII. évf. (nyár) 73-89. (A továbbiakban: Szabó 2013c) 
és a római jog eszköztára. Néhány ponton alapvető fontosságú volt a természettudományok köréből a kémia. A disszertáció megalapozottan pozitivista szemléletü, a források elsődlegességére épít, azokból von le következtetéseket. A disszertáció alapjait képező tanulmányaim során a szakirodalomban eddig nem ismert(etett) forrásokat tártam fel és elemeztem elsőként. Ez föleg a bizánci görög nyelvü, a lengyelországi latin nyelvű és az oszmán-török nyelvű krónikás források esetében történt. A bizánci források területén a 2013 decemberében megjelent, Dr. Baán István szöveggyüjteménye is segített, amelynek végső munkálataiba - a fent említett OTKA keretén belül - magam is bekapcsolódtam.

A várostromok kutatásának elengedhetetlen feltétele a helyszíni terepbejárás, adatfelvétel. Nándorfehérvár, Szendrö, Thesszaloniki várainak, bástyáinak és várfalainak, valamint környezetének topográfiai felmérése lehetőséget adott II. Murád szultán ostromtechnikájának jobb megértéséhez, nándorfehérvári ostromának komplex, összehasonlító vizsgálatához.

Mindahhoz, hogy e disszertáció eredményeit elérhessem, eddigi tanulmányaim során, illö méltó köszönetet mondanom. Az SZTE Klasszika-Filológiai Tanszékén az ógörög nyelvi tanulmányaim megkezdéséért és továbbfolytatásáért elsőként Dr. Dér Terézia egyetemi adjunktusnak. A klasszikus tanulmányaimnak és a magyarság középkori történelmének összekapcsolódását a bizantinológia jelenti, amely - mivel az ostrom forrásainak kutatását is leghamarabb a bizánci források keresésével kezdtem - számomra máig meghatározó. Ebben Dr. Olajos Terézia professzor asszonyt, disszertációm türelmes témavezetőjét illeti köszönetem, aki számos részletében segítette munkám végső megformálását. A középkori oklevelek kutatásának további bővítését Dr. Sebök Ferenc egyetemi docensnek köszönöm. Dr. Zombori Istvánnak a lengyel kapcsolatokra vonatkozó észrevételeket. Dani Dániel Pál hadtörténésznek, barátomnak, a Vásárhelyi Történelmi Kör társelnökének mindazon hasznos hadtörténeti tanácsot, észrevételt, biztatást, amellyel munkámat - kezdettől fogva - lelkesen segítette és támogatta. Szajkó István lőporvegyésznek a forrásokban említett fekete lőporra vonatkozó észrevételét, dolgozatának rendelkezésre bocsátását. Lénárd Juditnak dolgozatom utólagos nyelvi lektorálását. Juhász Ágnesnek a Raguzára, Palotás Zsoltnak pedig a rodoszi erődre vonatkozó szakirodalmi segítségét.

$\mathrm{Az}$ ostromnak és körülményeinek vizsgálata rendkívül komplex kutatási módszert igényelt, amelyben a klasszika-filológia, a bizantinológia, a történet- és hadtudományok mellett, megkerülhetetlen az oszmanisztika. A munka során egyértelművé vált számomra a korai oszmán-török források korlátozott elérhetősége. Külön köszönöm Dr. Papp Sándor 
egyetemi docensnek, Dr. Czeglédi Katalin nyelvésznek, Dr. Tóth Hajnalkának és Orovec Borbély Diannának, hogy az oszmán-török források magyar fordítását, értelmezését számomra elkészítették.

Nándorfehérvárnak - a mai Belgrádnak, Szerbia fővárosának - az 1440-es ostromához kapcsolódó szerb szakirodalom részleteinek fordítását Dr. Kacziba Ágnes egyetemi docensnek (SZTE-BTK), Dr. Szikora Istvánnak, a Vajdasági Magyar Helytörténeti Egyesület (Szabadka) elnökének, valamint Vanyúr Katalinnak köszönöm. Az osztrák krónikarészlet átültetését, az SZTE Germán Filológiai Intézet (Német Nyelvészeti Tanszék) egyetemi tanársegédjének, Sántáné Túri Ágnesnek. A publikációkért köszönet illeti a Partium lap főszerkesztőjét, Felhős Szabolcsot és a Bácsország folyóirat szerkesztőségét (Szabadka), hogy ösztönözték kutatásaim részeredményeinek megjelentetését.

Hálás szívvel köszönöm tanulmányaim lehetővé tételét családomnak és mindenkinek, aki munkám során segített.

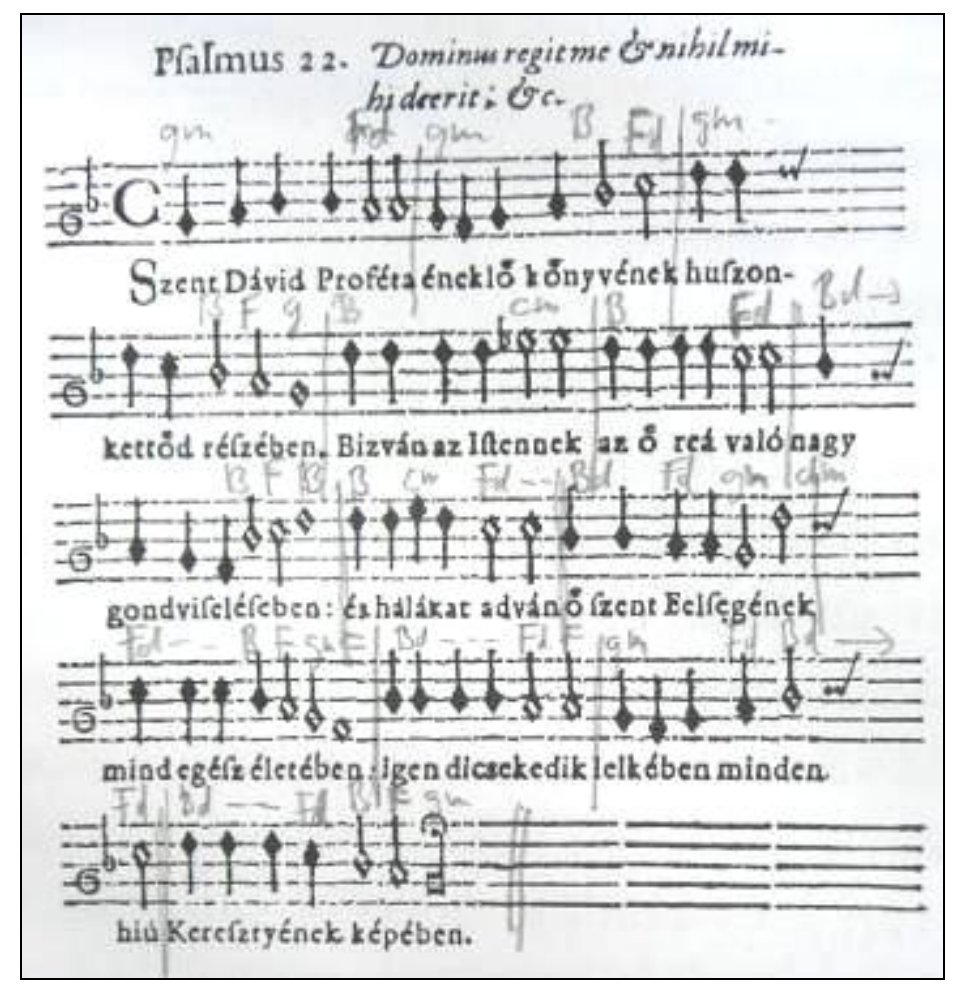

(Nagybáncsai Mátyás históriás énekének zsoltár dallama az általam használt harmóniákkal. Közli: Csörsz Rumen 2004. 89) 


\section{1. „,nem jegyeztek fel többet néhány szükszavú mondatnál” -Nándorfehérvár első török ostroma a magyar történetírásban}

Míg 2011-ben Nándorfehérvár 1456. évi török ostromának 555. évfordulóját méltó módon megünnepelhettük és a magyar Országgyülés az 58/2011. (VII. 7.) számú határozatával törvénybe is iktatta - a nándorfehérvári diadal emléknapjaként - július 22. megünneplését, addig azonban nem csupán a törvényalkotók figyelmét kerülte el az a tény, hogy a vár nem az 1456. évi nándorfehérvári ostrom alkalmával nézett először szembe sikeresen a szultán vezette török haderővel, hanem 1440-ben legalább akkora diadal helyszíne volt. Az pedig a magyar (had)történetírásunknak a hiányossága, hogy eddig - kellő súlyának megfelelően nem vizsgálta Nándorfehérvár első oszmán-török ostromát. ${ }^{10}$

Az 1456. évi ostromhoz több híres történeti mítoszunk is kötődött. A legismertebb talán a Dugovics Titusz személyéhez kapcsolt esemény. Azonban nemrég Szőcs Tibor tanulmánya révén bizonyítást nyert, hogy az ő legendás alakja nem több egy a 19. században megnevezett személynél. ${ }^{11}$ Bár Nándorfehérvár több mítosztól megfosztatott, mégis maradt még említésre méltó történeti ténye, „diadalmas viadalma”. Mert ez a vár nemcsak az 1456. évi szultáni ostromot állta ki, hanem az 1440. évit is, amelynek egyúttal 2010-ben volt az 570. évfordulója. Erről az ostromról a történeti szakirodalom vagy nem, vagy jóval kevesebb szóval emlékezett meg. 1456 jogos dicsősége beragyogja és túlragyogja a 16 évvel korábbi várostromot.

Indokolt értekezésemet egy historiográfiai áttekintéssel kezdeni Nándorfehérvár első török ostromáról vagy annak hiányáról magyar történetírásunkban. Annyit már itt előrebocsátok, hogy e téma kutatástörténetéről nem beszélhetünk, mivel átfogó igénnyel, elsőként - korábbi és jelen kutatásaimat összefoglalva - e disszertáció tárgyalja.

Áttekintésemet a 19. század közepétől indítom és főleg az átfogó történelmi munkákra koncentrálom. Vizsgálódásommal azt szeretném érzékeltetni, hogy Nándorfehérvár első török ostroma mennyiben volt megtalálható történetírásunkban. Ez ugyanis jelentősen motiválta és indokolttá tette jelen témaválasztásomat.

\footnotetext{
${ }^{10}$ Amint erre már felhívtam a figyelmet: Szabó 2011d 12-19.

11 Szőcs Tibor: Egy „legendás” hős: Dugovics Titusz története. Hadtörténelmi Közlemények 2009/1. 335.(Szőcs 2009a)
} 
Az első olyan részmunka, amely nemcsak megemlítette, hanem az akkoriban elérhető források alapján, a pozitivista történetírás szellemében, ismertette az ostromot, a 19. század közepén, a Magyar Tudományos Akadémia első elnökének, gr. Teleki József tollából született és 1852-ben, Pesten jelent meg, a Hunyadiak kora Magyarországon címü sorozatának első kötetében. ${ }^{12}$ Természetesen ez a többkötetes Hunyadi-monográfia sem az ostromról szól, de a témát több oldalon érintette. Teleki alapos munkájának érdeme, hogy az általa felhasznált források között megtaláljuk a latin és bizánci források legtöbbjét (Thuróczy, Bonfini, Dlugos, Callimachus, Khalkokondülész, Dukasz). Teleki ezek alapján, részletesen rekonstruálta az ostrom menetét, említette az akkoriban újnak számító ágyúk használatát. Helyreigazította azt a felbukkanó tévedést, amely Hunyadi Jánosnak tulajdonította a vár 1440-ben történő megvédését is. ${ }^{13}$ Észrevette, hogy a források eltérnek a török ostrom lehetséges kezdési időpontját illetően és elkülönítette azt az 1439. évi eseményektöl. $^{14}$

A 19. század második felében ezután a Telekiéhez mérhető összefoglalás nem született. 1856. július 21-én, az 1456. évi nándorfehérvári diadal négyszáz éves évfordulóján Kiss Károly a Magyar Tudományos Akadémián tartott nagyszabású megemlékező előadást. ${ }^{15}$ Ebben jól érzékelhető az a tudományos megítélés, amely az 1440. évi ostromot az 1456. évi diadal árnyékában helyezi el, az utóbbira helyezve a hangsúlyt. „, a magyar nemzetnek utolsó fényszakából választám azon fegyvertényt thémául értekezésemnek". ${ }^{16}$ Témaválasztásának aktualitását - mindezeken túl - azzal is indokolta, hogy: „,nincs emlékszobra Hunyadi Jánosnak". ${ }^{17}$ Miután áttekintette Nándorfehérvár földrajzi viszonyait, előremutató módon kiemelte a vár stratégiai helyzetét: „Akkori időben Buda és Byzanc közti közlékpontnak tekintetett és Keletnek felöl nyitja volt Magyarországnak." ${ }^{18}$

Kiss - sajátos nyelvezetével egyedi módon - megemlékezik az 1440. ostromról is. „Jól megeröditve, jól fölszerelve Nándorfehérvár 1440-ben Thaloczi Sovány ${ }^{19}$ János vezérlete alatt, ki egyszersmind vránai perjel is volt, két havon át (sic!) ellent állott Murad szultán nagyvezérének, Ali beinek, ki a Dunáról 100 vitorla erösségü flotilla közremunkálásával,

\footnotetext{
${ }^{12}$ Gr. Teleki József: Hunyadiak kora Magyarországon. Első kötet, Pest, 1852. A továbbiakban: Teleki 1852.

${ }^{13}$ Teleki 1852. 225-230.

14 Teleki 1852. 225. (2. lábjegyzet)

15 Kiss Károly: Hunyadi János utolsó hadjárata bolgár- és szerbországban 1454-ben és Nándorfehérvár fölmentése a török táborításától 1456. (A nándorfehérvári diadal negyedik százados napján. júl. 21. 1856) Pest, 1857. A továbbiakban: Kiss 1857.

${ }^{16}$ Kiss 1857. 3.

${ }^{17}$ Kiss 1857. 4.

${ }^{18}$ Kiss 1857. 40.

${ }^{19}$ A várkapitány Tallóci Jován (János) nevéből származó megkettőzött névalak. Nem előzmény nélküli, mert a 16. században Nagybáncsai Mátyás históriás énekében Szováti Jánosnak említi Nándorfehérvár védőjét.
} 
szárazon pedig több magas gátonyról, honnan szakadatlanúl szóratá a közáport a táboritott városra, meg akarta vívni. A várörizet tüzlöveggel felelt az ozmannak minden felhivására. A rohamlók alatt tüzaknákat is röpítettek fel a magyarok, öltek is irgalmatlanúl rakásra sok vakmerö törököt, mígnem Ali felhagyott végre a táboritással, 17000 harcost áldozott fel a nagy próféta dicsöitésére, és szégyennel vonult el Belgrád alól." ${ }^{20}$ Azonnal szembetünő, hogy Kiss nem a szultánt teszi meg a fővezérnek, hanem a bizánci történetíró, Khalkokondülész által említett Ali béget, illetve Thuróczy krónikájából is merített, de elkövetett néhány hibát is. A hét hónapos ostromból így két hónapos lett, amely „félreértés” egészen a 20. század második feléig létezett, lényegesen kisebbítve az 1440-es ostrom tudományos megítélését. ${ }^{21}$ Pedig tudott Teleki előbb említett munkájáról: „...egy nagybecsü munka forog most az irodalom körében, értem: Teleki József gróf feledhetetlen elnökünk Hunyadiak kora cimü munkáját.",22

Kiss az 1456. évi ostrom védőinek rendelkezésére álló tüzérség becslése kapcsán, összehasonlítási alapként, még visszatért az 1440-es eseményekre. Bár itt -valószínü nyomdahiba miatt- 1448. évet olvashatunk, azonban a szövegből egyértelmüen kiderül, hogy melyik nándorfehérvári ostromra gondolt. „Hány ágyú volt Nándorfehérvár falain, szinte nem tudható; azonban bizonyossággal állitható mégis, hogy a tüzérség több ágyúval vett részt az erőd védelmében, mint a történelem mondja, hogy 1448. évben (sic!) midőn II. Murád szultán alatt Alibei megtámadta Belgrádot, Thalóczi Sovány János várparancsnok több ágyut szegezhetett a megtámadók ellen, mint ezeknek volt (t. i. a törököknek), és a várhad lövegei a tüzaknák lobbanásaival vegyest nagy kárt okoztak az ozman seregben."23

Salamon Ferencnél még határozottabban mutatkozik meg az a szemlélet, hogy az 1440. évi ostrom, mintegy a Hunyadi János sikeres harcainak elöhírnöke, ,fényes elöpostája” lett. Salamon a Magyarország a török hóditás korában címü munkájában a tények leírása helyett inkább csak értékelte az eseményeket és kiemelte a várvédő Tallóci tüzérségi jártasságát is. „1440-ben Murád ostrom alá fogja Nándort, melyben Tallóczi János a parancsnok. E papkatonának vakmeröséggel határos bátorsága, az akkori hadtudományokban, kivált a tüzes hadiszerekkel bánásban szerzett avatottsága s belátással párosult erélye megszégyeniti az elszánt és roppant számú ozmán hadsereget, melynek szintén avatott és eszélyes vezérek parancsoltak. Murád szultánra nézve nagyobb volt ez az erkölcsi vereség Belgrád ostromának meghiúsulásában, mint a roppant veszteség

\footnotetext{
${ }^{20}$ Kiss 1857. 41.

${ }^{21}$ Lásd még a 10. 2. fejezetet.

${ }^{22}$ Kiss $1857.46-47$.

${ }^{23}$ Kiss 1857. 53.
} 
embereiben. Az elbizakodott hóditó kész lett a békealkudozásra. Tallóczi és bajtársai győzelme fényes elöpostája a bekövetkezendö diadaloknak. Mintegy kezesség arra, hogy a lángeszü Hunyady János egy új nemzedék újra fellángolt erkölcsi erejére támaszkodhatik.",24

Szalay László Magyarország története címü összefoglalása először Lipcsében, a második kiadása már Pesten jelent meg. Az ostromra vonatkozóan felhasználta a 18. századi jezsuita történetírók eredményeit, így Katona Istvánét, Kollár Ádám Ferencét és már hivatkozott Teleki Józsefre is. A forrásai között Dukasz, Khalkokondülész, Thuróczy és Dlugos szerepelt. Munkájának harmadik kötetében két oldalnyi terjedelemben ismertette az ostromot. ${ }^{25}$ Ö is rámutatott a várvédő Tallóci János haditudományokban való jártasságára. „Nándorfehérvárott Thallóczi János vránai perjel, Máténak testvére volt a parancsnok, vitéz férfiú, s a hadi tudomány új találmányaihoz, a löpor és a tüzfegyverek alkalmazásához értő." A védők által használt tüzfegyverre Dukasz leírását követte és az újdonságnak számító fegyver nehézkes, görög megnevezését ötletes módon magyarította át: „tüzcsövei, melynek öt, söt tíz golyót löttek ki egyszerre, a vívók sorait naponkint ritkitották." Majd Khalkokondülészt idézve a törökök által használt akna leírását, összekapcsolta a Thuróczy krónikájában szereplő akna leírásával. „A török vezér, Ali, Brenez fia, földalatti árkot ásatott az erősséghez". ${ }^{26}$ Szalay László tehát már az 1440. évi ostrom hadászati különlegességeire is felhívta a figyelmet. A továbbiakban Thuróczy leírásából merített, kiegészítve a lengyel forrás, Dlugos beszámolójával.

Horváth Mihály 1868-ban megjelent, A magyarok története rövid elöadásban címü ismertető könyvébe - miközben Szendrő várának török ostromát és körülményeit taglalta már nem fért bele a nándorfehérvári ostrom megemlítése. ${ }^{27}$ A Hunyadyak kora címü fejezetben a polgárháborút, valamint I. Ulászlónak, a felvidéki huszita seregek miatti, akadozó lengyelországi összeköttetését emelte ki (,,I. Ulászló országlata”). ${ }^{28}$ Horváth azonban folytatta a 19. század első felében már megjelentetett munkáinak sorát ( $A$ magyarok története. Pest, Pápa 1842-1846), a Magyarország történelme címmel közzétett köteteinek második és bővített kiadásával. ${ }^{29}$ Nála már jól megmutatkozik az ostrom egyre rövidülő összefoglalásának tendenciája. A második kötetében egyetlen, többszörösen

\footnotetext{
${ }^{24}$ Salamon Ferencz: Magyarország a török hódítás korában. Pest 1864. 29-30.

${ }^{25}$ Magyarország története Szalay László által. Harmadik kötet, Pest 1863. 34-35. A továbbiakban: Szalay 1863.

${ }^{26}$ Szalay 1863.34

${ }^{27}$ Horváth Mihály: A magyarok története rövid előadásban. Pest 1868.198. A továbbiakban: Horváth 1868.

${ }^{28}$ Horváth 1868. 202.

${ }^{29}$ Magyarország történelme. Írta Horváth Mihály. Második kötet. Pest 1871. 543. A továbbiakban: Horváth 1871.
} 
összetett mondattá sủrítette az eseményeket. A tüzfegyverekröl már nem, csupán az ostromban használt aknákról tett említést. „A török sem több hónapi elzárással, sem a falak megrongálásával s az újra meg újra ismételt rohamokkal, sem tüzaknáival nem törhette meg az aránylag csekély, de honszeretettöl lelkesitett várnagy és örsége kitartását $s$ vitézségét, melylyel a megrongált falakat éjente kijavitá, az ostromlókat naponként visszaverte, tüzaknáit ellenásásaival meghiúsitotta."30 A történész azonban, az eredményről szólva, nem osztotta Salamon Ferenc korábbi dicsőséges értékelését, hanem a polgárháborútól sújtott ország szerencséjét emelte ki. „Valóban szerencse volt az országra nézve, hogy a szultán, a várat elhagyván, az országba nem tört, mert itt mind erösebben lobogott a polgári háború tüze."31

Az ostrom e munkákat követően, ha fel is bukkant átfogó történeti munkákban, a sorsa valóban egy-két mondat lett. A Szilágyi Sándor szerkesztette A magyar nemzet története VI. kötetében a vonatkozó részt Fraknói Vilmos írta (A Hunyadiak és a Jagellók kora. I. könyv: I. Ulászló uralkodása). A török ostrom kezdetét áprilisra tette és a tényeket röviden közölte. „1440-ik év április havában Magyarország legfontosabb végvárát, NándorFejérvárt vette ostroma alá, melyet szárazon és vizen körülzárt (t. i. a szultán). De a vár parancsnoka, Thallóci János vránai perjel csekély számú örsereggel hösi ellenállást fejtett ki, a rohamokat visszaverte, a föladásra szólitó fényes ajánlatokat visszautasitotta; úgy hogy a szultán félesztendei eröfeszités után siker nélkül kényszerült visszavonulni. „32

Ekkoriban, erre az ostromra vonatkozóan is, az eddig elhanyagolt oszmán-török források megismerhetősége elvileg javult, mert Thúry József könyvsorozatban kezdte közzétenni a magyar vonatkozású török forrásokat (Török történetírók. Fordította Thúry József, I-II. kötet. Budapest 1893-1896).

Bár a Hadtörténelmi Közleményekben ezidőtájt két tanulmány is született Nándorfehérvár szultáni ostromairól, de egyik sem az 1440-es ostromról. 1889-ben Kiss Lajos az 1521. évi (harmadik) török ostromról (Nándorfehérvár bukása 1521, Hadtörténelmi Közlemények 1889, 389-440, 546-612), majd 1911-ben Balanyi György részéről a második szultáni ostromról: Nándorfehérvár ostroma és felmentése (1456) (Hadtörténelmi Közlemények 1911. 167-196.).

A 20. század első felében írt munkák közül kutatási kiindulópontként a Hadtörténelmi Közlemények hasábjain, 1911-ben Wertner Mór által írt részletes tanulmány szolgálhat.

\footnotetext{
${ }^{30}$ Horváth 1871. 543.

${ }^{31}$ Horváth 1871. 544.

${ }^{32}$ Fraknói Vilmos: A Hunyadiak és a Jagellók kora. I. könyv: I. Ulászló uralkodása In.: A magyar nemzet története. VI. kötet (1440-1526) Budapest 1895². 299. A továbbiakban: Fraknói 1895.
} 
Wertner négy részben, okleveles források alapján tekintette át e korszak magyar hadjáratait, amely munkában helyet kaptak az ostrom idejének okleveles forrásai is. ${ }^{33} \mathrm{~A}$ várvédő Tallóci-családra és Nándorfehérvár 1440 előtti sorsára vonatkozó forrásközléseinek tekintetében is kiemelkedő munka volt az 1907-ben megjelent és Thallóczy Lajos és Áldásy Antal által elkészített Magyarország melléktartományainak oklevéltára II. A Magyarország és Szerbia közötti összeköttetések oklevéltára, 1198-1526.

Nagy előrelépést jelentett a bizánci források egyre javuló hazai elérhetősége is. A 1913ban a Történelmi Szemlében és a Hadtörténelmi Közleményekben Miskolczi Gyula a Hunyadiról szóló beszámolói kapcsán értekezett Khalkokondülészről (Hunyadi János török hadjáratai, Hadtörténelmi Közlemények 1913, 347-369, 545-583). Darkó Jenö viszont már 1906/1907-tól közzétette kutatásait (Budapesti VII. kerületi külső magyar királyi állami fógymnasium értesitőjében), de főmüvét a bizánci szerző müvének teljes kritikai kiadása jelentette. Ebben az ostrom szempontjából fontos rész 1923-ban vált elérhetővé (Laonici Chalcocondylae Historiarum demonstrationes. Tomi II. Pars prior. Libros V-VII. continens. Ad fidem codicum recensuit, emendavit annotatibusque criticis instruxit Eugenius Darkó Budapestini MCMXXIII.). 1934-ben -ebben a vonatkozásban ismérföldkőnek számított Moravcsik Gyula A magyar történet bizánci forrásai címü munkája, amelynek a vegyesházi királyokról szóló fejezetében megtalálhatóak lettek az ostromra vonatkozó bizánci források adatai is. ${ }^{34}$

$\mathrm{Az}$ ostrom kutathatóságának megjavult feltételei ellenére jelentős változás mégsem következett be a hadtörténészek, történészek munkáiban. A két világháború közötti hadtörténészek közül Doberdói Bánlaky (Breit) József $A$ magyar nemzet hadtörténelme címü 22 kötetes, monumentális sorozatának tizedik kötetében kis fejezetet kapott, amelyben a főbb forrásokra utalt (Thuróczy, Callimachus, Khalkokondülész, Dukasz). Az viszont kevéssé érthető, hogy -jobb híján- a Hunyadi korszak hadtörténetébe helyezte el az ostromot, de a Hunyadiak háborúihoz képest mégis aránytalanul kisebb terjedelemben (A Hunyadiak kora. Hunyadi János 1437-1456. III. fejezet Nándorfehérvár ostroma a törökök által 1440-ben). ${ }^{35} \mathrm{Az}$ 1936-ban megjelent Hóman-Szekfü szerzőpáros által jegyzett Magyar történet II. kötetét Hóman Bálint írta. Hóman rövid tudósításába némi

\footnotetext{
${ }^{33}$ Dr. Wertner Mór: Magyar hadjáratok a XV. század első felében. Négy közleményben. Hadtörténelmi Közlemények 1911. márczius (1401-1406) 63-76; junius (1407-1418) 251-276; szeptember (1419-1432) 410-448; deczember (1433-1450) 537-574. A továbbiakban: Wertner 1911

34 Moravcsik Gyula: A magyar történet bizánci forrásai. Budapest 1934. 225, 229, 238-239. A továbbiakban: Moravcsik 1934.

${ }^{35}$ Bánlaky (Doberdói Breit) József: A magyar nemzet hadtörténelme. 10. Budapest 1928. (www. mek. oszk. hu, belépés ideje: 2012. II. 7) A továbbiakban: Bánlaky Doberdói 1928.
} 
újabb elemek kerültek be, így Tallóci Matkónak az ostrom előtti fogsága, és II. Murád szultán súlyos békefeltételei is. „Murád szultán már 1440 áprilisában új hadsereggel jelent meg a Dunánál...ostrom alá vette Nándorfehérvárt. A várat erös örség élén a származására nézve idegen, de vitézségére magyar Thallóczy János vránai perjel védte, akinek testvérét Ulászló megválasztása miatt épp ezidőtájt vetette fogságra Erzsébet királyné. Thallóczy elöbb nyilt mezei csatába bocsátkozott, majd a túlerö elöl a várba zárkózott és hónapokon át megismételt rohamok következetes visszautasitásával fárasztotta ki Murád hadát. Nándorfehérvár átadását és Szerbia zavartalan birtoklásának biztositását követelte, amit a király nem fogadhatott el." $" 36$

A 20. század második felében írt munkák már vagy „,visszaesést” vagy „vegyes” képet mutatnak. A teljesség kedvéért egy a marxista történetírás szellemében írt munkát megemlítek. 1951-ben A magyar nép története címü kötet célul tüzte ki, hogy: „a marxizmus-leninizmus tudományának fényénél feltárjuk népünk igaz történetét”. A szerzők ezt azért érezték fontosnak, hogy „rávilágitsunk oly sokszor megrágalmazott népünk hösi harcaira, haladó hagyományaira." A vonatkozó időszakot a szegedi egyetemen tanító Karácsonyi Béla írta és két mondatban bár, de szerepeltette az 1440. évi ostromot. „A kettôs királyválasztásban kifejezésre jutott anarchiát a török tüstént kihasználta. 1440 elején ostrom alá vette Nándorfehérvárt (a mai Belgrádot). ${ }^{, 37} \mathrm{Ez}$ a marxista szellemben írt kötet az akkori új, középiskolai magyar történelem tankönyv anyaga lett és elvileg megvolt annak a lehetösége, hogy 1440 is bekerüljön a közoktatásba.

Az 1956-os év nyara - ebben a vonatkozásban - nem hozott áttörést, mert az 1456-os ostrom 500. évfordulója kapcsán ismét a második szultáni ostrom került előtérbe, amelyről az újra indult Hadtörténelmi Közlemények emlékezett meg (A nándorfehérvári diadal 500. évfordulóján.). ${ }^{38}$ Rázsó Gyula 1973-ban, a Hadtörténelmi Közleményekben megjelent munkájában feldolgozta a korai török-magyar háborúkat, de csak Zsigmond haláláig ( $A$ Zsigmond-kori Magyarország és a török veszély. 1393-1437). Ez kétségkívül nagyobb figyelmet irányított a korai oszmán-török háborúinkra, de 1440-et nem érinthette. ${ }^{39}$

\footnotetext{
${ }^{36}$ Hóman Bálint-Szekfü Gyula: Magyar történet. II. kötet, írta Hóman Bálint. Budapest, 1936. 419-420. A továbbiakban: Hóman 1936.

37 Heckenast Gusztáv, Karácsonyi Béla, Lukács Lajos, Spira György: A magyar nép története (rövid áttekintés). Budapest 1951. 79. A továbbiakban: Magyar nép története 1951.

38 A nándorfehérvári diadal 500. évfordulóján. Hadtörténelmi Közlemények. 1956 (3. évf) 2. szám. 3-8. A továbbiakban: Nándorfehérvár évfordulóján 1956.

39 Rázsó Gyula: A Zsigmond-kori Magyarország és a török veszély (1393-1437). Hadtörténelmi Közlemények 1973/ 3. 403-441. A továbbiakban: Rázsó 1973
} 
Nagy várakozással tekintett a szakma és a közvélemény is a Pach Zsigmond Pál vezetésével, 1976-tól meginduló Magyarország története tíz kötetben címü munkára. Ennek második kötete az 1242 és 1526 közötti időszakot ölelte volna át, de sajnos sohasem jelent meg. Szakály Ferenc a Hadtörténelmi Közlemények hasábjain, 1978-ban az 1521. évi ostromról írt, de bevezetőjében felsorolta a korábbi szultáni ostromokat is: „a helyi török erök gyakori alkalmi próbálkozásait nem számítva maga a szultáni sereg is három izben vette ostrom alá a Száva és a Duna torkolatánál emelkedö erösséget. 1440-ben II. Murád, 1456-ban II. Mehmed, 1521-ben pedig I. Szulejmán szultán személyes irányitásával. " ${ }^{40}$ Perjés Géza: Mohács című könyvében (Budapest 1979) a török-magyar háborúk sorában, az első periódusban (1356-1453) tudta elhelyezni ezt az ostromot, amely azonban számára inkább kivételt jelentett. A törökök ugyanis „Megalapozatlan vállalkozásba nem fogtak, és a zsákmányszerzést és felderitést szolgáló portyázásokon kívül nagyobb szabású hadjáratba nem kezdtek, eltekintve Belgrád 1440. évi sikertelen ostromától. ${ }^{, 41}$ Erre a megállapításra azonban -mint majd később látni fogjuk- II. Murád többszöri hadjáratainak számbavétele inkább rácáfol. A török-magyar háborúk Mohács előtti szakaszait összegző jelleggel először Szakály Ferenc tekintette át angol nyelvü tanulmányában 1979-ben, ${ }^{42}$ majd 1986-ban magyarul a Mohács emlékkönyvben. 1440. évi ostromot az 1438-1442 közötti török támadássorozat részeként helyezte el, de mindössze 3 hónapos ostromnak tartotta. ${ }^{43}$

Teke Zsuzsa 1980-ban a Magyar História sorozatban megjelent Hunyadimonográfiájában már mint ismert tényre hivatkozott az 1440-es „próbálkozásra”, anélkül, hogy kifejtette volna (Hunyadi János és kora). A nándorfehérvári erődítési munkálatokról szólva így írt: „A munkálatokat az a feltevés indokolta, hogy a török -1440 nyarán végrehajtott sikertelen próbálkozása után- újból megkísérli majd a vár bevételét."44 Némileg ellensúlyozta ezt a hiányt az 1984-ben megjelent Magyarország hadtörténete I.

40 Szakály Ferenc: Nándorfehérvár 1521-es ostromához. Hadtörténelmi Közlemények 1978/ 4. 484. A továbbiakban: Szakály 1978.

${ }^{41}$ Perjés Géza: Mohács. Budapest 1979. 69-70. A továbbiakban: Perjés 1979. A második periódust 14531521 közé helyezi. Perjés 1979. 72. Lásd még a 12. fejezetet.

${ }^{42}$ Szakály, Ferenc: Phases of Hungarian Warfare before the Battle of Mohács (1365-1526). Acta Orientalia Academiae Scientiarum Hungariae 33 (1979) 65-111. (Szakály 1979)

43 Szakály Ferenc: A török-magyar küzdelem szakaszai a mohácsi csata elött (1365-1526). Mohács. Tanulmányok a mohácsi csata 450. évfordulója alkalmából (szerk.: Rúzsás Lajos, Szakály Ferenc) Budapest, 1986. 31. A továbbiakban: Szakály 1986.

${ }^{44}$ Teke Zsuzsa: Hunyadi János és kora. Budapest 1980. 106. A továbbiakban: Teke 1980. 
kötete, amelyben az 1440-es ostromról -a latin nyelvü források alapján- egy oldalban Rázsó Gyula írt. ${ }^{45}$

Az ostrom kutatásával a szakma továbbra is adós maradt, de mintegy a jövőben elvégzendő feladatot számon tartotta. Legmarkánsabban Mályusz Elemér 1980-ban, a Tallóciakról megjelent nagyszabású tanulmányában ( $A$ négy Tallóci fivér) mutatott rá erre a hiányosságra: „,...vannak történelmünknek olyan mozzanatai, amelyek a kutatók figyelmét fontosságuk ellenére nem vonták magukra ... tudósok és laikus olvasók Belgrád 1440. évi ostromát alig-alig méltatva figyelemre, átsiklanak a török-magyar élethalál küzdelem legfelemelőbb mozzanatán." ${ }^{46}$ Mályusz az 1984-ben megjelent Zsigmond-monográfiájában (Zsigmond király uralma Magyarországon) is kiemelte a várvédő Tallóciak szerepét az 1440-es ostrom kapcsán. „Belgrád megerősitésének méreteire nemcsak abból következtethetünk, hogy a vár az 1440. évi ostromot kiállotta, hanem a felszereléséböl is." Ezután megemlíti a tüzfegyvereket és Dukasz érdeklödését is. ${ }^{47}$ Abban egyetérthetünk, hogy Mályusz volt az a történész, aki a 20. század második felében a legtöbbet tette e feladat elvégzéséért. De ebben követők nélkül maradt. Barta Gábor 1985-ös, az 1456. évi (második) nándorfehérvári ostromról szóló munkája nem említette. ${ }^{48}$ Generál Tibor az oszmán-törökök felemelkedéséről és hadseregükről írott könyvében II. Murád szultán sosrsdöntő csatái közül szintén kimaradt. ${ }^{49}$ 1981-ben Bernard Lewis az oszmán civilizációról szóló, magyarul is megjelent könyvében egy mondatot találunk. „az 1440. évi belgrádi (nándorfehérvári) ostromot a törököknek félbe kellett szakitaniok"

A 80-as években az 1440. évi ostrom tüzérségi vonatkozásban bukkant fel a Hadtörténelmi Közleményekben. 1988-ban, Veszprémy László Taccola-tanulmányának egyik lábjegyzetében, az egyik fontos bizánci forrásnak, Dukasznak az ostromra vonatkozó szövegét tette közzé Déri Balázs fordításában (Egy korareneszánsz haditechnikai kézirat és szerzője. Mariano di Jacopo detto il Taccola: De rebus militaribus.). ${ }^{51}$ A további folytatás azonban ismét elmaradt, és szerencsés esetben csupán az ostrom megemlítéseivel

\footnotetext{
${ }^{45}$ Magyarország hadtörténete I. A honfoglalástól a kiegyezésig (főszerk. Liptai Ervin, szerk. Borus József). Budapest 1984. 99. (Magyarország hadtörténete 1984)

${ }^{46}$ Mályusz Elemér: A négy Tallóci fivér. Klió szolgálatában. Szerk. Soós István. Budapest 2003. 131. (Eredeti megjelenési helye: Történelmi Szemle 23 (1980), 531-576) A továbbiakban: Mályusz 2003.

47 Mályusz Elemér: Zsigmond király uralma Magyarországon. Budapest 1984. 127. A továbbiakban: Mályusz 1984.

${ }^{48}$ Barta Gábor: Nándorfehérvár 1456. Budapest 1985. A továbbiakban: Barta 1985

${ }^{49}$ Generál Tibor: Allah hadserege. Budapest 1987. A továbbiakban: Generál 1987.

${ }^{50}$ Bernard Lewis: Isztambul és az oszmán civilizáció. Budapest 1981. 30. (Lewis 1981)

51 Veszprémy László: Egy korareneszánsz haditechnikai kézirat és szerzője. Mariano di Jacopo detto il Taccola: De rebus militaribus. In: Lovagvilág Magyarországon. Lovagok, keresztesek, hadmérnökök a középkori Magyarországon. (Válogatott tanulmányok) Budapest 2008. 218. A továbbiakban: Veszprémy 2008a. (Eredeti megjelenési helyén: Hadtörténelmi Közlemények 1988/1. 19)
} 
találkozunk a korszakot érintő munkákban. A kivételek közé sorolhatjuk Matuz József 1985-ben németül és 1990-ben magyarul megjelentetett, az oszmán történelemről megjelent nagyívü könyvét, amely röviden megemlítette a város török ostromát is. „Magyarországgal szemben eleinte nem nagyon jártak sikerrel az oszmán hadmüveletek: Nándorfehérvár 1440-es ostromát meg kellett szakitani anélkül, hogy különösebb eredményt elértek volna...."52 Az ostrom lehetséges kutatása szempontjából az oszmán tüzérséggel kapcsolatos munkák különös fontossággal bírnak, amelyek közül Ágoston Gábor tanulmányait említjük meg (pl: Az európai hadügyi forradalom és az oszmánok. Párhuzamok és eltérések az oszmán és az európai tüzérség fejlödésében a 15-17. században. Történelmi Szemle 1995. 4. sz; 1992. 3-4. sz).

Az ostrom kutatásának helyzete a magyar történetírás akkori általános tendenciájával is magyarázható volt. 1990-ben Magyarok Európában sorozatcímmel négy kötetből álló sorozat indult el Glatz Ferenc szerkesztésében. A második kötetet Szakály Ferenc írta, aki könyvét éppen az 1440. évvel indította (Virágkor és hanyatlás 1440-1711). A hadtörténész bevezetőjében a nemzeti (had)történetírás védelmében így összegezte véleményét: „A magyar történetírás az elmúlt évtizedekben addig küszködött a szinte önálló diszciplínává vált gazdaság-, müvelödés- és társadalomtörténet egyenjogúsitásáért, mígnem elfeledkezett a politikatörténet fejlesztéséröl, az eseménymenetben tátongó rések feltöltéséröl."53 Szakály ennek megfelelően könyvének második fejezetét az 1440. évi ostrommal kezdi, de csak egy mondatban. „II. Murád szultán hadai 1440-ben hónapokon keresztül ostromolták a magyar határvédelem legfontosabb erösségét, Nándorfehérvárt." ${ }^{„ 1}$ Így továbbra is érvényes maradt Pálosfalvi Tamás 2000-ben leírt sommás megállapítása. Nevezetesen az, hogy a 15. század közepének politikatörténete a magyar középkor legkevésbé feltárt területe. $^{55}$ 1996-ban Pálffy Géza a védelmi rendszer szempontjából értékelte az ostromot. „Nándorfehérvár 1440. évi ostroma jelzésül szolgált: az oszmán elörenyomulásban hamarosan felörlödnek azok a balkáni ütközöállamok... „56

Az 1998-ban megjelent új egyetemi tankönyvben Engel Pál is megjegyezte: „Míg a vár 1456. évi ostromára ... az egész világ figyelt, erröl az ostromról nem jegyeztek fel többet

\footnotetext{
${ }^{52}$ Matuz József: Az Oszmán Birodalom története. Budapest 1990. 47. A továbbiakban: Matuz 1990.

${ }^{53}$ Szakály Ferenc: Virágkor és hanyatlás 1440-1711. Magyarok Európában II. Budapest 1990. 11-12. A továbbiakban. Szakály 1990.

${ }^{54}$ Szakály 1990. 35.

${ }^{55}$ Pálosfalvi Tamás: Cilleiek és Tallóciak: küzdelem Szlavóniáért (1440-1448). Századok 2000/1. 45. (Pálosfalvi 2000)

56 Pálffy Géza: A török elleni védelmi rendszer szervezetének története a kezdetektől a 18. század elejéig. Történelmi Szemle 1996/2-3. 169. (Pálffy 1996)
} 
néhány szükszavú mondatnál." ${ }^{, 57}$ Az Oszmán Birodalom és Bizánc történelme kapcsán a hazai bizantinológusok is olvashattak az ostromról, Louis Bréhier nagy könyvtrilógiájának 1997-ben magyarul megjelentetett első kötetében, egy mondat erejéig. „Murád azonban két egymást követö ostrommal sem tudta bevenni Nándorfehérvárat." ${ }^{\text {58 }} \mathrm{Az}$ oszmanista történészek közül Papp Sándor folytatva Szakály Ferenc rendszerezését a török-magyar háborúk első szakaszáról, azt elsősorban oszmán-török oldalról, a diplomáciai kapcsolatok története szempontjából egészítette ki. ${ }^{59}$

Az ezredfordulóra megjelent történeti-, hadtörténeti müvek nagy részéből hiányzott az 1440. évi török ostrom. Így a Magyar Századok sorozatában Draskóczy István sem említette. ${ }^{60}$ A 2001-ben napvilágot látott Milleniumi Magyar történetbe sem került bele. ${ }^{61}$ Sőt, a Magyarország története. Előidőktől 2000-ig című összegző egykötetes munkában, a vonatkozó rész szerzője, Kristó Gyula sem emlékezett meg róla. ${ }^{62}$ Üdítő kivételt jelentett 2000-ben a Nagy képes milleniumi hadtörténet, amelyben E. Kovács Péter a Hunyadiak háborúiról szóló részben nemcsak megemlítette, hanem rövid leírást is adott. Soraiba azonban pontatlanságok is belekerültek. Így a szultáni sereg az akkori oszmán székhely, Drinápoly helyett, Isztambulból (sic!) indult el. Majd megemlítette, hogy a török hadak április végén indulhattak csak el, és júliusnál előbb nem érkezhettek Nándorfehérvár alá. Ezután szerinte - amely vélhetően nyomdahiba - áprilisban a török hadak végleg elvonultak. Viszont jól tud a török seregben kitört járványról és az ellátási problémákról. ${ }^{63}$ 2001-ben, Pálosfalvi Tamás a Történelmi Szemlében - Engel Pál emlékére - megjelent tanulmányában az 1442-es erdélyi török betörés lehetséges további célpontjai között felvetette, hogy lehetett volna az „akár az 1440-ben egyszer már sikertelenül ostromolt Nándorfehérvár is." 64

${ }^{57}$ Engel Pál-Kristó Gyula-Kubinyi András: Magyarország története 1301-1526. Budapest 1998. 202. A továbbiakban: Engel-Kristó-Kubinyi 1998.

${ }^{58}$ Louis Bréhier: Bizánc tündöklése és hanyatlása. II. Fordította: Baán István. Budapest 1997. 452. (A továbbiakban: Bréhier 1997) Az évszám nyilvánvalóan a nyomdahiba miatt tévesen 1140.

${ }^{59}$ Papp Sándor: Magyarország és az Oszmán Birodalom (A kezdetektől 1540-ig) Közép-Európa harca a török ellen a 16. század elsö felében. (szerkesztette: Zombori István) Budapest 2004. 37-90. A továbbiakban: Papp 2004.

${ }^{60}$ Draskóczy István: A tizenötödik század története. Budapest 2000. (Draskóczy 2000)

${ }^{61}$ Milleniumi magyar történet (Magyarország története a honfoglalástól napjainkig) Budapest 2001. (Milleniumi magyar történet 2001) A Magyarország a késő középkorban (1382-1526) című rész Szendrő várának ostromát említette meg, 1440 -et nem.

${ }^{62}$ Kristó Gyula-Barta János-Gergely Jenő: Magyarország története. Előidőktől 2000-ig. Budapest 2002. (Kristó-Barta-Gergely 2002)

${ }^{63}$ Nagy Képes Milleniumi hadtörténet. 1000 év a hadak útján. Budapest 2000. 68. (Nagy képes milleniumi 2000)

${ }^{64}$ Pálosfalvi Tamás: Az 1442. márciusi török hadjárat. Adalékok Hunyadi János első törökellenes harcaihoz. Történelmi Szemle 2001/1-2. 48. A továbbiakban: Pálosfalvi 2001. 
2003-ban a magyar hadtörténelem nagy csatáit ismertető könyvben Négyesi Lajos tárgyalta az 1456-os nándorfehérvári ostromot és megemlítette az 1440-es előzményét is. „A Magyarország kulcsát jelentő várat a törökök 1440-ben hónapokig ostromolták, de bevenni nem tudták." ${ }^{65}$ Hasonlóképpen Tringli István 2003-ban megjelent egyetemi tankönyvnek szánt művében is szólt az ostrom tényéről. „A vár kapitánya Tallóci Jován vránai perjel ${ }^{66}$ több hónapon át sikerrel védekezett a szultán ellen, aki végül felhagyott az ostrommal. ${ }^{, 67}$

Pálosfalvi Tamás 2005-ös könyvében, amelyben a Nikápolytól Mohácsig terjedő hadtörténetet tekintette át, újabb sajátos értékelést kapott az ostrom. A történész-kutatónak ambivalens és túlzó a véleménye az esemény megítélésében. „A vár első ostroma késő középkori hadtörténetünk egyik legdicsöségesebb, de páratlanul rosszul ismert fejezete (ezért is nem kaphatott külön fejezetet e könyvben).” Az ostromot néhány mondatban - a többi forrást mellőzve - föleg Dlugost követve tekintette át. ${ }^{68}$ Így néhány pontatlanságot ö sem tudott kiküszöbölni, mert a forrásokban fellelhetö hasonlóságokat és ellentmondásokat nem ismertette. Például a magyarországi latin nyelvü forrásokban említett föld alatti aknák alkalmazását és berobbantását, csupán a latin nyelvü lengyel forrásokban szereplő várárkok meggyújtását. A Tallóci fivéreket - ebben a forrás tévedését is követve - raguzai eredetűnek mondja. Továbbá, az oszmán ostromot ő is túl rövidnek, három hónaposnak tartotta. Dlugos szerint valóban, amikor a király megérkezett az országba már három hónapja folyt az ostrom, de Ulászló királynak a szultánhoz küldött követét Murád csak újabb három hónap múlva, az ostrom befejeztével, engedte szabadon. A krónikás egyébként maga is leírja, hogy összesen hat hónapos volt a török ostrom.

2005-ben - immár a Georgetown University vendégprofesszoraként - Ágoston Gábor angolul írt munkájában elsőként foglalta össze az Oszmán Birodalom hadiiparának és haderejének kérdését (Guns for the Sultan. Military Power and the Weapons Industry in the Ottoman Empire. Cambridge University Press 2005). Kutatási eredményei és következtetései -a forrásainkkal összevetve- jól hasznosíthatók az 1440. évi ostromló török haderö tüzérségére vonatkozóan.

2006-ban, a második szultáni ostrom 550. évfordulóját követve a népszerüsítő lapok közül a História folyóirat 2007. évi 1. számában tematikus összeállítást szentelt ennek az

\footnotetext{
65 Négyesi Lajos: Nándorfehérvár ostroma 1456. július 4-22. In.: „Fegyvert s vitézt...” A magyar hadtörténelem nagy csatái Szerk.: Hermann Róbert, Budapest 2003. 48-49. A továbbiakban: Négyesi 2003.

${ }^{66}$ A könyvben nyomdahiba miatt várnai perjel szerepel.

${ }^{67}$ Tringli István: Az újkor hajnala. Magyarország története 1440-1541. Budapest 2003. 25.(Tringli 2003)

${ }^{68}$ Pálosfalvi Tamás: Nikápolytól Mohácsig 1396-1526. Budapest 2005. 67. A továbbiakban: Pálosfalvi 2005.
} 
ostromnak (Nándorfehérvár 1456). A neves budapesti szerzőgárda (Kubinyi András, Klaniczay Gábor, Érszegi Géza, Fodor Pál, Pálosfalvi Tamás, Cs. Kottra Gyöngyi) által megírt cikkekből szintén hiányzott az első ostrom. Pálosfalvi Tamás írása időben érinthette volna (Kettős hatalom és török veszély Magyarországon: a Magyar Királyság 14401456.), de az 1440. év eseményeiről csupán a polgárháború kapcsán esett szó. ${ }^{69}$ Más folyóiratok is tematikus lapszámot szenteltek 1456-nak, amelyben szegedi történészek is publikáltak. Például a délvidéki Bácsországban Petrovics István, a Szeged folyóiratban Tóth Sándor László. ${ }^{70}$ Petrovics az 1456. évi ostrom előzményeként megemlítette: „A Tallóci-fivérek, akik nemcsak kiváló katonák, hanem remek pénzügyi szakemberek is voltak, hathatósan gondoskodtak a déli határ védelméröl - miként ezt Nándorfehérvár 1440. évi sikeres megtartása is bizonyitja.",71

A Hadtörténeti Múzeum 2006. június 15-tól „Európa védelmében” címmel kettős jubileumi kiállítással emlékezett meg Nándorfehérvár 1456. évi ostromának és Kapisztrán Szent János halálának 550. évfordulójáról, amelyhez a Magyar Tudományos Akadémia Történettudományi Intézetével közösen szervezett nemzetközi tudományos konferencia is társult; az előadásokat tartalmazó kötet 2013-ban jelent meg. ${ }^{72}$ A kiállításról írott beszámolójában Veszprémy László hozzáfüzte: „Nándorfehérvárt elöször 1440-ben próbálta meg elfoglalni II. Murád szultán. A védők Tallóci János vránai perjel vezetésével hónapokon át hösiesen és sikerrel tartóztatták fel a törököt."73

A fenti eseménysorozathoz kapcsolódott Kubinyi András könyvének megjelentetése 2007-ben. Kubinyi, bár a Mátyás- és a Jagelló-kor hadtörténetébe kalauzol el, de 1456. évi ostrom kapcsán megemlékezik 1440-ről is. Kubinyi -Mályuszhoz és Engelhez hasonlóanismét felvette a téma kutatásának igényét: „II. Murád 1440 áprilisában hat hónapig tartotta ostrom alatt a Tallóci Jován által védett Nándorfehérvárat. Sajnos erröl alig tudunk valamit."74 Szintén 2007-ben jelent meg egy pályázat díjazottjaként Cseh Valentin tollából az 1456. évi (második) török ostromot mintaszerüen feldolgozó monográfia, amely

${ }^{69}$ História. Nándorfehérvár 1456. 2007/ 1. 11-14. (História 2007)

70 Petrovics István: A délvidék és a török veszély: a nándorfehérvári diadal és előzményei. Bácsország 2006/2. 11-19 (Petrovics 2006); Tóth Sándor László: Harangszó és diadal: Nándorfehérvár, 1456. Szeged (A város folyóirata) 2006/7-8. 9-12. (Tóth 2006)

${ }^{71}$ Petrovics 2006. 12.

${ }^{72}$ Európa védelmében. Kapisztrán Szent János és a nándorfehérvári diadal emlékezete. (szerk.: Kálmán Peregrin-Veszprémy László) Budapest 2013. (Az alábbiakban: Kálmán-Veszprémy 2013) A konferencián szegedi előadó is részt vett. Petrovics István: Capystranus. Egy 1515-ben Londonban kinyomtatott névtelen angol elbeszélő költemény. In: Kálmán-Veszprémy 2015. 126-134.

${ }^{73}$ Veszprémy László: „Európa védelmében” Időszaki kiállítás a Hadtörténeti Múzeumban. 2006. június 15 2007. szeptember 30. A Hadtörténeti Múzeum Értesitöje 9. Budapest 2007. 294-295. (Veszprémy 2007)

${ }^{74}$ Kubinyi András: Nándorfehérvártól Mohácsig. A Mátyás- és Jagelló-kor hadtörténete. Budapest, 2007. 12. A továbbiakban: Kubinyi 2007. 
a vár előtörténete során már több oldalon kitér a korábbi várostromra is. ${ }^{75}$ Pálosfalvi Tamás ezidőben a balkáni történelem kutatója, Thallóczy Lajos születésének (1857-1916) százötvenedik évfordulójára, Szarajevőban megrendezett konferencián áttekintette a Tallóci-család pályafutását 1429-1452 között (Die Familie Tallóci im Mittelalter). ${ }^{76}$

2008-ban, még mindig 1456 kapcsán, de igen előremutató módon az ostrom nemzetközi beágyazottságáról írt Fodor Pál - a História 2007. évi 1. számában megjelent tanulmánya angol nyelvü változatában - az Acta Orientalia hasábjain (The Ottoman Empire, Byzantium and Western Christianity the implications of the siege of Belgrade, 1456.). ${ }^{77}$

2009-ben a magyar történelemről írt, Romsics Ignác által szerkesztett Magyarország története címü huszonnégy kötetes könyvsorozat hetedik kötetében szerepelt az 1440. évi ostrom is. Pálosfalvi Tamás szerint: „A következö esztendőben, kihasználva a kettős királykoronázást követö magyarországi zürzavart, Murád szultán személyesen vonult Nándorfehérvár ostromára. A jól felszerelt és megerösitett végvárat ugyan a Tallóci fivérek sikeresen megvédték, az ostrom mégis komoly figyelmeztetés volt a polgárháborúba merült országnak."78

2011-ben volt az 1456. évi török ostrom - mint előbb említettük - 555 éves évfordulója, amely közvetve ismét lehetőséget biztosított volna a téma exponálásának. Fedeles Tamás a Rubicon-ban megjelent ismeretterjesztő cikkében, 1456 kapcsán, megemlékezik az 1440. évi ostromról és azt „első támadásnak” minősítette, az 1521. évi harmadik ostrom mellett (Nemzeti nagylétünk tanúsága. Nándorfehérvár 1456). ${ }^{79}$ 2011-ben egy szép megjelenésű, gyüjteményes kötettel gazdagodott az 1456-ról szóló irodalom. A Déli harangszó Magyarországon és a nagyvilágban címü könyv szerzői között a vár régészeti kutatója, a Marco Popović is helyet kapott, aki a vár 1440. évi ostromáról is megemlékezett. Az ostromló sereg létszámát húszezer föben becsülte meg, és az ostromot öt hónaposnak tartotta. ${ }^{80}$

Véleményem szerint az ismertetett munkák közül az 1440. évi ostrom eddigiekhez képest legátfogóbb, tudományos ismertetését nem magyar történész végezte el. A

\footnotetext{
${ }^{75}$ Cseh Valentin: Nándorfehérvár ostroma 1456. Keszthely 2007. 33-36. A továbbiakban: Cseh 2007.

76 Tamás Pálosfalvi: Die Familie Tallóci im Mittelalter. In.: Lajos Thallóczy, der Historiker und Politiker, Die Entdeckung der Vergangenheit von Bosnien-Herzegowina und die moderne Geschichtswissenschaft. Hrsg. von Dževad Jubašić. Sarajevo-Budapest 2010. 183-191. (Pálosfalvi 2010a)

77 Fodor, Pál: The Ottoman Empire, Byzantium and Western Christianity the implications of the siege of Belgrade, 1456. Acta Orinetalia 2008. (68) 1-2. sz. 43-51. (Fodor 2008)

${ }^{78}$ Pálosfalvi Tamás: A Hunyadiak kora 1437-1490. Magyarország története 7. Budapest 2009. 16-17.

${ }^{79}$ Fedeles Tamás: Nemzeti nagylétünk tanúsága. Nándorfehérvár 1456. Rubicon 2011/7. 9. (Fedeles 2011)

${ }^{80}$ Marco Popović: Belgrád 15. századi erődítményei. In.: Déli harangszó Magyarországon és a nagyvilágban. Szerk.: Visy Zsolt. Budapest 2011. 36. A továbbiakban: Popović 2011.
} 
közelmúltban, 2012-ben a Krakkói Egyetem hadtörténésze, John Jefferson könyvet szentelt Ulászló király és Murád szultán közötti harcoknak. Ennek egyik fejezetében szólt az ostromról. ${ }^{81}$ A források közül föleg Dlugost és Thuróczyt használja, az előbbire téve nagyobb hangsúlyt. Egy keltezetlen levélre hivatkozva két, esetleg három hónaposnak tartja az ostromot. ${ }^{82}$

Ez azért is volt fontos, mert a 20. századi nemzetközi szakirodalomban is az ostrom korlátozottan vagy röviden jelenik meg. Például az Iszlám Enciklopédiában B. Djurdjev, a Szarajevói Egyetem kutatója Belgrádról szóló szócikkében röviden szerepel. Az iszlám időszámítás szerint 843-844-ben (1440) a vár ellenállt a hat hónapos ostromnak. ${ }^{83}$ A Cambridge Medieval History kötetében egy-egy mondatban megtalálható. A Balkán történetéről szóló fejezetben M. Dinić, a belgrádi egyetem professzora hat hónaposnak tartotta az ostromot. Az Oszmán Birodalomról írt fejezetben F. Taeschner professzor szerint Evrenoszade Ali bég ostromolta a várat, de a hat hónapos ostrom végén III. Ulászló lengyel-magyar király felmentette a várost. ${ }^{84}$ A Cambridge History of Turkey kötetében ezt az időszakot Fodor Pál írta meg, aki elsősorban az oszmán tüzérségi fejlődést ismertette, az ostromot ebből a szempontból nem. ${ }^{85}$ Természetesen meg kell említeni a szerb nyelven írt szerb történeti munkákat is, amelyek közül itt elsősorban Jovanka Kalić 1967-ben és 2001-ben megjelent könyveire kell utalni, amelyeket értekezésem több pontján felhasználtam. ${ }^{86}$ A magyar nyelvű szerb történelemről szóló munkák közül Heka László 2005-ben, Szegeden megjelent könyvében egymondatos helyet kapott az ostrom. „Murad 1440-ben elöször indult a magyar kézen levő Nándorfehérvár ellen, amelyet Talovác Iván vranai perjel, Máté horvát bán fivére védelmezett, és a török sereg 17000 harcos eleste után kénytelen volt visszavonulni." ${ }^{\circledR 7}$ A korai tüzérségi technikáról több alapos tanulmányt író Kelly DeVries főleg a nyugat-európai ostromokat kutatta, a

\footnotetext{
${ }^{81}$ John Jefferson: The Holy Wars of King Wladislaus and Sultan Murad. The Ottoman-Christian conflict from 1438-1444. Leiden -Boston 2012. 235-246. A továbbiakban: Jefferson 2012.

82 Jefferson 2012. 240.

${ }^{83}$ B. Djurdjev: Belgrade In.: The Encyclopaedia of Islam. New edition, volume I. A-B. Edited by: H. A. R. Gibb; J. H. Kramers; E. Lèvi-Provençal; J. Schlacht. Leiden-London 1960. 1163. (Djurdjev 1960)

${ }^{84}$ The Cambridge Medieval History. Volume IV. Part I. The Byzantine Empire. Edited by: J. M. Hussey. Cambridge 1966. 553; 770. (Cambridge Medieval History 1966)

${ }^{85}$ Fodor, Pál: Ottoman warfare 1300-1453. In.: The Cambridge History of Turkey. Volume I. Byzantion to Turkey. Edited by: Kate Fleet. Cambridge 2009. 192-219. A továbbiakban: Fodor 2009.

86 Јованка Калић-Мијушковић: Београд у средњем веку. Београд 1967 (A továbbiakban: КалићМијушковић 1967); Срби у позном средњем веку. Београд 2001. (A továbbiakban: Калић 2001)

${ }^{87}$ Heka László: Szerbia állam- és jogtörténete. Szeged. 2005. 38. (A továbbiakban: Heka 2005)
} 
nándorfehérvári ostrom korai tüzfegyvereiről nem tett említést 2002-ben megjelent gyüjteményes tanulmány kötetében sem. ${ }^{88}$

Az Oszmán Birodalom történetéről szóló munkákban csak kivételesen nem szerepel az 1440-es ostrom. Így például Caroline Finkel könyvében. ${ }^{89}$ Ez nem általános, mert Halil İnalcik 1973-ban megjelent nagy monográfiájában egy mondatban megemlítette. ${ }^{90}$ Colin Imber 1990-ben megjelent könyvében az 1440-es ostromkísérletet beilleszti a szerbiai oszmán-török hódítások menetébe. ${ }^{91}$ 2002-ben írt nagyívű oszmán történetében pedig érintőlegesen szerepeltette. ${ }^{92}$ A török nyelvü átfogó szakirodalmi munkákban is megjelenik, amelyekben a bizánci forrásban szereplő Evrenosoğlu Ali béget tartják az ostrom vezetőjének. Például az 1983-es a többször kiadott Osmanli Tarihi második kötetében. ${ }^{93}$ Vagy a többkötetes kronológiai munkákban is. ${ }^{94}$ De az Iszlám Enciklopédia Evrenos családról szóló szócikkében is ez szerepel. ${ }^{95}$ A belgrádi oszmán-török ostromok szisztematikus áttekintését 2011-ben megjelent értékes tanulmányában Selim Aslantaş professzor végezte el, elsősorban a török források alapján. ${ }^{96}$

Érdekes jelenség, hogy a kortárs magyar szépirodalom viszont - a maga szabad írói eszközeivel - elvégezte ezt a feladatot. Bán János (írói nevén Bán Mór) Hunyadi Jánosról szóló többkötetes történelmi regénysorozatának ötödik része ${ }^{97}$ ( mennydörgés kapuja) 2011 októberében jelent meg. Ebben Nándorfehérvár 1440. évi ostromát is szerepeltette. Dramaturgiai szempontból viszont eljátszott azzal a források által nem bizonyított feltevéssel, hogy már ebben részt vett Hunyadi és egyedül ő hozott segítséget Tallóci várkapitánynak. ${ }^{98} \mathrm{Az}$ írói fantáziától a forrásokhoz jobban visszatért Gáspár Ferenc író történelmi kalandregényének 2011-ben megjelent legutóbbi kötetében. ${ }^{99}$ A Pogányokkal

88 Kelly DeVries: Guns and Men in Medieval Europe 1200-1500. Studies in Military History and Technology. Aldershot-Burlington 2002. (DeVries 2002)

${ }^{89}$ Caroline Finkel: Osman's dream. The story of the Ottoman Empire 1300-1923. 2006. 43. (Finkel 2006)

${ }^{90}$ Halil İnalcik: The Ottoman Empire. The Classical Age 1300-1600. London 1973. 20. (İnalcik 1973)

${ }^{91}$ Colin Imber: The Ottoman Empire. 1300-1481. İstanbul 1990. 118-119. A továbbiakban: Imber 1990.

92 Colin Imber: The Ottoman Empire. 1300-1650. The structure of power. New York, 2002. 25. A továbbiakban: Imber 2002.

${ }^{93}$ Osmanli Tarihi II. Cilt. 4. Bask1. Ankara 1983. 15. (Osmanli Tarihi 1983)

94 İsmail Hami Danişmend: İzahli Osmanli Tarihi Kronolojisi Cilt 1. İstanbul 1925-1947. 206. (Osmanli Tarihi Kronolojisi 1927-1947)

${ }^{95}$ I. Melikoff: Ali Ewrenos Oghullari In.: The Encyclopaedia of Islam. New edition, volume II. C - G Edited by: B Lewis; J. Schacht; Ch. Pellart Leiden-Boston 1965. 721. (A továbbiakban: Melikoff 1965)

${ }^{96}$ Selim Aslantaş: Belgrad-i Dárü'l-Cihád. Hacettepe Üniversitesi Türkiyat Arastirmalari Ankara, 2 Aralık 2011. 13-37. A továbbiakban: Aslantaş 2011.

${ }^{97}$ Bán Mór: Hunyadi. I. A hajnalcsillag fénye. Budapest 2009; Hunyadi II. Az üstökös lángja. Budapest 2009; Hunyadi III. A csillagösvény hídja. Budapest 2009; Hunyadi IV. A hadak villáma. Budapest 2010.

${ }^{98}$ Bán Mór: Hunyadi. V. A mennydörgés kapuja. Budapest 2011.

99 A regényről szóló ismertetésem: (Diószegi) Szabó Pál: Reinkarnáció, kalandregény, történelem: Nándorfehérvár török ostroma 1440-ben. SzegediLap. Portál-fólió. Szerk. Bene Zoltán, Szeged 2013. 28 32. (Lásd még: www. szegedilap.hu 2012. április 19) 
táncoló címü történelmi regényében a Tallóciaké a föszerep és a mü az 1440-es ostrommal zárul. $^{100}$

A 20. század második felében és a 21. század elején megjelent magyar történeti munkákban viszont alig történt több az 1440. évi esemény kronológiai szintü számontartásánál. Amit tudni lehetett róla, az a kronológiai munkákban szereplő rövid ismertetés volt. Ebből következően a szakkronológiai kiadványokban rendre szerepelt. Így MTA által 1981-ben megjelentetett Magyarország történeti kronológiája I. kötetében Engel Pál jóvoltából. „Áprilistól II. Murád szultán több hónapon át eredménytelenül ostromolja Nándorfehérvárt."101 Valamint a Magyar történelmi kronológiában. „A török seregek 6 hónapig ostromolták Nándorfehérvárt, de nem tudták bevenni." "102 Az ezredfordulóra megjelent Magyar Századok magyar történelmi kronológiában Draskóczy István megemlítette. „1440. április. II. Murád szultán hónapokig eredménytelenül ostromolja Nándorfehérvárt." 103 Viszont helyet már nem kapott 2010-ben, a Romsicskönyvsorozat záró, kronológiai áttekintésében. ${ }^{104} 2010$ decemberében a Várak, kastélyok, templomok címü folyóiratban tematikus lapszámot szenteltek Nándorfehérvárnak, amelyben Veszprémy László és Cseh Valentin az 1440-es ostromot is megemlítette. ${ }^{105}$ Jómagam 2010-től kezdtem e témában publikálni.

Historiográfiai áttekintésemet egy olyan forráskiadvánnyal zárom, amelyben a költői és történeti források végső megformálásához már személyesen is kapcsolódhattam. 2013 decemberében jelent meg Baán István szöveggyüjteménye, amely az ostromra vonatkozó görög nyelvű, bizánci források széles körben való megismeréséhez is alapvető és elengedhetetlen munka ( $A$ XIV-XVI. századi magyar történelem bizánci és kora újkori görög nyelvü forrásai. Összegyüjtötte, forditotta, bevezetéssel és jegyzetekkel ellátta Baán István. Budapest 2013). ${ }^{106}$

A jelen értekezés címében jelzett „első oszmán-török ostroma” megfogalmazását az indokolta, hogy a fent idézett munkák többsége, amely írt az ostromról, sem úgy emlékezett meg arról, hogy ez volt a vár ellen indított első török ostrom. Szakály Ferenc

\footnotetext{
${ }^{100}$ Gáspár Ferenc: Pogányokkal táncoló. A holló jegyében. Coldwell. Budapest 2011. (Gáspár 2011)

${ }^{101}$ Magyarország történeti kronológiája. I. kötet. Budapest 1981. 259. (Magyar kronológia 1981)

${ }^{102}$ Magyar történelmi kronológia. Az őstörténettől 1970-ig. Budapest 19845. 85. (Magyar kronológia 1984)

${ }^{103}$ A magyar történelem kronológiája (830-2000) Magyar Századok. Budapest 2001. 74. (Magyar kronológia 2001)

${ }^{104}$ Pintér Éva: Időrendi áttekintés. Magyarország története 24. Budapest 2010. (Pintér 2010)

105 Veszprémy László: Nándorfehérvár ostromai - a reneszánsz hadügyi elmélet kezdetei Magyarországon (Veszprémy 2010); Cseh Valentin: Nándorfehérvár szerepe a déli végvárrendszerben 1427-1521. (Cseh 2010) In.: Várak, kastélyok, templomok. 2010. december. 33-35; 29-31.

${ }^{106}$ A továbbiakban: Baán 2013.
} 
vagy legutóbb Pálosfalvi Tamás, Fedeles Tamás megjegyzései ellenére. Az I. Bayezid szultán által a 14. század végén vezetett ostromkísérletet „nulladik” ostromnak neveztem el, amellyel nem változtatom meg a fenti sorszámozást és egyúttal jelzem a kevesebb forrásadottságot is.

Jó példája számozási bizonytalanságnak egy 2000-ben megjelent kislexikon, amelyben Nándorfehérvár örvendetesen kétszer is szerepel. De első ostromként 1456 révén, másodikként pedig az 1717. évi Savoyai Jenő által vezetett ostrommal. ${ }^{107}$ Még tovább növelve ezzel a nándorfehérvári ostromok számontartásában meglévő bizonytalanságot. Mindez abból adódik, hogy - legalább a török ostromok vonatkozásában - 1440-et nem helyezik el a vár ellen indított későbbi szultáni ostromok $(1456,1521)$ sorában.

A hazai történetírásban az 1456. évi második oszmán-török ostrom jogos dicsősége és a magyar történetírás Hunyadi-,,kultusza” túlragyogja a 16 évvel korábbi várostromot, nem fordított figyelmet az éppen megelőző időszakra. Pedig a Hunyadiak felemelkedését a Tallóciak is támogatták. A historiográfiai elhanyagoltságban szerepet játszik az, hogy a várat nem magyar származású, hanem horvát kapitány védte, aki - ahogyan Hóman Bálint megfogalmazta - csak vitézségére nézve lehetett magyar. A nemzeti történetírás jegyében ezt nem lehetett hozzákapcsolni a Hunyadiak katonai sikereihez, azoknak legfeljebb „fényes elöpostája” lett (Salamon Ferenc). Már a kortársak sem fordítottak a szultáni támadásra kellő figyelmet, mert a kettős királyválasztás miatt megosztott ország egyik ligába tömörült része az Ulászlót támogató, a déli határokat védő Tallóciak bukását várta. A várba felmentő sereget nem küldtek. Tallóci Jován több hónapos sikeres helytállása nem volt olyan nemzetközi figyelmet kiváltó esemény, mint az 1456-os diadal.

$\mathrm{Az}$ áttekintésünk végén önmagától adódik a kérdés: Ha a 19-20. századi történészek által ennyire elhanyagoltnak bizonyult a kutatás ebben a témában, akkor ennek vajon nem az az oka, hogy nem is játszott olyan jelentős szerepet a korai török-magyar háborúkban, a Magyar Királyságban? Jelen munkám végeztével azt igyekszem bizonyítani, hogy ez a sommás megállapítás így nem helytálló, pontosításra szorul és az 1440. évi ostromot be kell illesztenünk a korai török-magyar háborúk menetébe, természetesen a maga súlyának megfelelően. Mert ez nemcsak a vár kiépítésének történetében, az ostrom során alkalmazott haditechnikai eszközök használatában, a további szultáni hadjáratok szüneteltetésében, hanem az ország oszmán uralom alá kerülésének késleltetésében is legalább annyira fontos szerepet játszott, mint az 1456. évi ostrom.

${ }^{107}$ Weiszhár Attila-Weiszhár Balázs: Csaták kislexikona. 2000. 158. (Weiszhár A-Weiszhár B. 2000) 


\section{Az ostrom(ok) ${ }^{108}$ évtizedének nemzetközi eseményei}

\section{1. Anglia és Franciaország a százéves háborúban}

Vizsgált időszakunkban a 15. századi Európa nyugati hatalmait a százéves háború (13371453) konfliktusa kötötte le, amely VI. (Valois) Fülöp francia király (1328-1350) és III. Edward angol király (1327-1377) közötti hübérjogi vitából nőtt ki az angol király délfranciaországi birtokai kapcsán. III. Edward sikeres franciaországi hadjáratokat követően ugyan 1360-ban lemondott a francia trónigényéről, de délfrancia területeit hübéri kötelezettségek nélkül megtarthatta. Időközben Angliát parasztfelkelések (Wat Tyler, John Ball) is megrázták, amelyet II. Richard (1377-1399) tudott csak megfékezni. A királynak azonban le kellett mondania és a Lancaster-dinasztia tagjaként IV. Henrik (1399-1413) vette át az uralkodást. ${ }^{109} \mathrm{~A}$ francia király erőit országában a Jacqurie parasztfelkelés és a rendi mozgalom kötötte le. V. Henrik angol uralkodó (1413-1422) sikeres franciaországi hadjárata, és 1415-ös azincourt-i győzelme nyitotta meg a háború lancaster-i szakaszát (1415-1453). A kezdeti győzelmet követően VI. Károly francia király - halála esetén Henriknek ígérte a trónját (troyes-i béke). Mivel 1422-ben mindkét uralkodó meghalt, VI. Henrik (1422-1461) sikerrel tudta trónigényét érvényesíteni. VII. Károly (1422-1461) a déli területekre szorult vissza és fokozatosan szerezte vissza országát. Ebben a küzdelemben nagy szerepe volt Jeanne d'Arc mozgalmának (1429-1431) és annak, hogy Burgundia felhagyott eddigi angolbarát politikájával. 1436-ban Párizs visszafoglalása után átalakították az adórendszert is. ${ }^{110}$ 1439-ben az Általános Rendi Gyülés (États Généraux) a zsoldosok szolgálatba fogadására állandó hadiadót szavazott meg a király számára és lemondott eddigi adómegajánlási jogáról. A királyi hatalom így jelentősen megerősödött. ${ }^{111}$ A háború 1440-es eseményei közül említésre méltó, hogy július 7-én az angolok visszafoglalták Harfleurt. A százéves háború végül 1453. július 17-én, az angolok castillon-i vereségével, békekötés nélkül fejeződött be. ${ }^{112}$ Míg Franciaországban a királyi konszolidáció, Angliában a Rózsák háborúja (1455-1485) során évtizedekig tartó belső anarchia lett úrrá. ${ }^{113}$

\footnotetext{
${ }^{108}$ Figyelembe véve I. Bayezid szultán ostromkísérletét is.

${ }^{109}$ Katus László: A középkor története. Budapest 2000. 271. A továbbiakban: Katus 2000.

${ }^{110}$ Katus 2000. 353.

${ }^{111}$ Both Ödön: Fejezetek a nyugat-európai állam- és jogtörténet köréből. Szeged 2003. 17-18.

112 Szakály 1990. 17; Katus 2000. 354.

${ }^{113}$ Katus 2000. 271.
} 


\section{2. A Német-Római Császárság és Lengyelország dinasztikus törekvései}

A francia hatalom méltó vetélytársává csak a Német-Római Császárság vált. A császári trónra ekkoriban a Luxemburg-család több tagját is megválasztották. Luxemburgi IV. Károly (1346-1378, császár 1355-től) cseh király is volt, aki Prágába helyezte székvárosát. Az 1356-ban kiadott (német) Aranybullában a fejedelemtársait állami főhatalommal ruházta fel, amely fokozta a tartományok megerösödését és a birodalom decentralizálódását. ${ }^{114}$ Károly uralkodása alatt élte Csehország a fénykorát és a cseh korona számára megszerezte Sziléziát és Brandenburgot is. Fia és utóda, IV. Vencel (1378-1400) viszont nem tudott úrrá lenni a belső feszültségeken, ezért 1400-ban lemondatták. Pfalzi Ruprecht rajnai palotagróf uralkodása (1400-1410) után ismét a Luxemburgi-családból választottak német királyt, Vencel öccse, Luxemburgi Zsigmond magyar és cseh király, brandenburgi őrgróf személyében (1410-1437, császár 1433-tól). ${ }^{115}$ Zsigmond az európai nagypolitikában jelentős eredményeket ért el, az általa kezdeményezett konstanzi zsinaton (1414-1418) megszüntette az egyházszakadást. Sőt, megpróbált közvetíteni a felek között a százéves háborúban, és amikor 1416-ban Párizsban és Londonban tárgyalt, végül V. Henrikkel kötött szövetséget. ${ }^{116}$ Fontosnak tartotta a nemzetközi fellépést a fenyegető Oszmán Birodalommal szemben és felvette a harcot a huszitákkal Csehországban (1420-1436). Az ö 1437-ben bekövetkezett halálával kihalt a Luxemburg-ház, leányának, Erzsébet férjének a német trónra kerülésével viszont a Habsburgok jutottak hatalomhoz. Habsburg (II.) Albert német, cseh és magyar király (1438-1439) rövid uralkodása után szintén egy Habsburg, III. Frigyes kezdhette meg évtizedekig tartó, hosszú uralkodását (1440-1493, császár 1452-től). Viszont a középeurópai országok közül nem sikerült megszereznie sem a magyar, sem a cseh trónt, mert a lengyel Jagellók megelőzték. ${ }^{117}$

Az időszakunkban a cseh és lengyel kapcsolatok többször ellenségesek voltak, amelyek a két ország trónján, hol Luxemburgi és Piast, hol Habsburg és Jagelló ellentétként jelentkeztek, de a vegyesházi királyaink korában a magyar trónon is tovább éltek. Ebben az ellentétben a magyar királyok és híveik, hol a közvetítő, hol a harcostárs szerepét töltötték

\footnotetext{
${ }^{114}$ Both 2003. 11.

115 Katus 2000. 360; C. Tóth Norbert: Luxemburgi Zsigmond uralkodása. 1387-1437. Magyarország története 6. Budapest 2009. 9-10. A továbbiakban: C. Tóth 2009.

${ }^{116}$ Szakály 1990. 335.

117 Szakály 1990. 18.
} 
be. Ezt a szövevényes kapcsolatrendszert az 1440. év lengyel kapcsolatfelvétele okán szükséges jobban bemutatnunk.

A több részre tagolt Lengyelországot Lokietek (Piast) I. Ulászló (1320-1333) egyesítette. A cseh-lengyel kapcsolatok viszonylagos nyugvópontra fia, III. (Nagy) Kázmér idején (1333-1370) jutottak, mégpedig az Anjou I. Károly magyar király (13101342) révén, akinek közvetítésével 1335-ben, Trencsénben és Visegrádon megállapodott a két uralkodó. Luxemburgi I. János cseh király (1310-1346) lemondott lengyel trónigényéről, Kázmér pedig a Sziléziára vonatkozó terveiről. ${ }^{118}$ 1339-ben újabb visegrádi találkozón Károly király lemondott a „rex Galiciae” címről. A lengyel királynak ugyanakkor kemény küzdelmet kellett folytatnia a Német Lovagrenddel és a még pogány litvánokkal is. Ebben helyt kapott a lengyel király trónutódlásának rendezése is. Ugyanis Kázmérnak a házasságából származó törvényes fiú utóda nem volt, a trónigény így Lajos magyar király javára szólt. ${ }^{119}$ Halálával kihalt a Piast-uralkodóház, és a magyar királlyal kötött 1355-ös megállapodása értelmében, és mivel nem született fiúörököse, a lengyel trónon a magyar király, Anjou I. Lajos (1370-1382) követte, aki a lengyel királyság irányításával régensként anyját, Lokietek Erzsébetet bízta meg (1370-1375, 1376-1377). Ezzel létrejött az első lengyel-magyar perszonálunió. Azonban ez megosztotta a Nagy- és Kis-Lengyelország előkelőit, mivel Lajos csak a kis-lengyelországi Krakkóban koronáztatta meg magát. Azonban fiú utóda neki sem született, egyik lánya trónörökösödését egy sor privilégium adományozásával tudta csak elfogadtatni (1374, kassai privilégium). A mélyben megbúvó ellentétek Lajos idősebbik lánya, Mária kapcsán újból a felszínre törtek. 1382-ben a lengyel rendek nem fogadták el a Luxemburgi Zsigmonddal házasságot kötött Mária trónörökösödési jogát, hanem helyette húgát, a még nem házas Hedviget (1382-1399) jelölték ki (radomi konföderáció). Hedvig (Jadwiga) leendő férjét pedig a lengyel nemesség a litván Jagelló fejedelem személyében találta meg. ${ }^{120}$ Jagelló II. Ulászló (1386-1434) megkeresztelkedett és megalapította a Jagellódinasztiát. Az uralkodásával egyidejüleg létrejött lengyel-litván perszonálunió révén Lengyelország a térség komoly hatalmává vált (krewói unió). ${ }^{121}$ A németek ellen kivívott óriási sikernek tekinthető, hogy II. Ulászló 1410. július 15-én, a grünwaldi csatában legyőzte a Német Lovagrendet, amelyben maga a nagymester, Ulrich von Jungingen is

\footnotetext{
${ }^{118}$ Engel Pál: Beilleszkedés Európába a kezdetektől 1440-ig. Magyarok Európában I. Budapest 1990. 285. A továbbiakban: Engel 1990.

${ }^{119}$ Font Márta: A német lovagrend alkonya. Pécs 1997. 22. A továbbiakban: Font 1997.

${ }^{120}$ Font 1997. 25.

${ }^{121}$ Szokolay Katalin: Lengyelország története. Budapest 1996. 33-34. A továbbiakban: Szokolay 1996.
} 
meghalt. ${ }^{122}$ Ez új hatalomként a Jagelló-dinasztia növekvő térnyerését hozta a térségben. A Német Lovagrenddel szimpatizáló Zsigmond lengyel földön pedig nem volt népszerü.

A Jagellók a Luxemburgiakkal szembeni lengyel ellentéte - ezúttal Magyarországon Mária királynő halála idején is jól megmutatkozott. Hedvig ekkor igényt formált a magyar trónra. Így 1395-ben férje, II. Ulászló bejelentette igényét a magyar trónra és júliusban sereget is vezetett az országba, amelyet azonban hamarosan visszavertek. 1401-ben, amikor Zsigmondot a vele elégedetlen bárók fogságba ejtették, szintén felmerült a lehetséges királyjelöltek között a lengyel király. ${ }^{123}$

Csehországban hasonló elégedetlenség erősödött meg a Luxemburgiakkal szemben, amikor 1421-ben a husziták letették Zsigmondot a cseh trónról, helyette II. Ulászlót kérték fel. Míg végül a felek, a háború helyett, 1427-ben békét kötöttek. A husziták a Jagellók felé tájékozódtak. A lengyel király követe 1428-1432 között Piotr Łęczycki volt, aki 1440ben is fontos diplomáciai feladatot látott el. ${ }^{124}$ Zsigmond a huszita támogatást úgy próbálta ellensúlyozni, hogy támogatta II. Ulászló unokatestvérének, a grünwaldi csata hősének, Vitold litván nagyfejedelemnek (1392-1430) királlyá való koronázását. Vitold váratlan halálos balesete azonban keresztülhúzta számítását. Zsigmond császár halála után Csehországban újra feléledt a lengyel kapcsolat igénye a Habsburgok trónutódlása ellenében. Míg Habsburg Albertet 1438 júniusában, Prágában megkoronázták, ám Zsigmondtól megörökölt - cseh királyságát a husziták nem ismerték el, inkább a lengyel király felé fordultak. III. Ulászló (1434-1444) testvérét, Jagelló Kázmért választották volna meg cseh királynak, aki be is tört Sziléziába. Albertnek az 1438-es évet csehországi ügyeinek kellett szentelnie, miközben a szultáni hadak Magyarország déli határait fenyegették. II. Murád szultán (1421-1451) még az Albert elleni küzdelemben felajánlotta támogatását III. Ulászló lengyel királynak, csakhogy a magyar végekről is elvonja a két fronton egyszerre készenlétben álló Albert erőit. Ám III. Ulászló - az Albert váratlan halála utáni magyar megosztottságban - elfogadta a számára felajánlott magyar trónt és ezzel ismét újra létrejött a lengyel-magyar perszonálunió. A Jagellók dinasztiája tehát döntésében szem előtt tartotta a Habsburgok német, és a cseh befolyásának megakadályozását a térségben, illetve a török veszély hathatósabb elhárítását, amelyet az 1440. máricus 8-i választási feltételek is tartalmaztak. Az 1440-es év a lengyel-litván

\footnotetext{
${ }^{122}$ Monografikus feldolgozása: Font 1997. 99-134; lásd még: Katus 2000. 389-390.

${ }^{123}$ C Tóth 2009. 33, 40 .

${ }^{124}$ Jadwiga Krzyżaniakowa: Kancelaria królewska Władysława Jagiełły. Studium z dziejów kultury politycznej polski w XV wieku. Poznań. 1979. 142. A továbbiakban: Krzyżaniakowa 1979. Lásd még: Dlugos 2001. 410 (186. lábjegyzet) és a 8. 2. fejezetet.
} 
perszonálunió szempontjából is kivételesnek tekinthető, mert míg III. Ulászló lengyelmagyar királyi címeket birtokolta, addig öccse, Jagelló Kázmér volt a litván nagyfejedelem. $^{125}$

A magyar rendek egy részének lengyel irányultságát, hagyományait és eredményességét jól bebizonyította az a tény, hogy amikor III. Ulászló Magyarországra érkezett és I. Ulászló néven magyar királlyá (1440-1444) koronázták - amikor a törökök már Nándorfehérvárt ostromolták - azonnal bekapcsolódott a török elleni küzdelembe, amelyet a várnai csatában elszenvedett haláláig folytatott. Azt is megállapíthatjuk, hogy a Német-Római Császárság és a Lengyel Királyság dinasztikus ellentéte, amely a cseh és a magyar trónigénynél egyaránt jelentkezett (Luxemburgi, Habsburg, Jagelló) és meghatározó volt Habsburg Albert 1439. évi halála után létrejött lengyel-magyar perszonálunióban is, 1440-ben eredményesen „blokkolta” a török elleni egységes nemzetközi fellépést és keresztény összefogást. Ez jól meglátszott a magyar koronáért folyó versengésben az Albert halála után trónra lépő III. Frigyes német-római király és I. Ulászló közötti ellentétben is.

\section{3. A Pápaság és az egyházi unió}

A törökök elleni tervezett fellépés koordinálását a Pápaság vállalta magára, amelynek látszólagos célja ekkor Bizánc megsegítése volt. A legfontosabb kérdés azonban Róma számára a 15. század első felében ismét az egyházi unió megvalósítása és a török ellen nyújtandó segítség fejében való kikényszerítése volt.

A nyugati és a keleti egyházak uniója - mint segítségnyújtási feltétel - nem volt elözmények nélküli. Mert Konstantinápoly keresztesek általi elfoglalása után nemcsak a megalapított Latin Császárság és a bizánci utódállamok, hanem a két egyház viszonya is igen kényes kérdés maradt. III. Joannész Batatzész nikaiai császár (1222-1254) minden erejét Konstantinápoly visszaszerzésére fordította, és még IV. Ince pápával (1243-1254) is tárgyalt az egyházi unióról a segítség fejében, de halála után a tárgyalások megszakadtak. ${ }^{126}$ Végül X. Gergely pápa (1271-1276) a Konstantinápolyt visszafoglaló VIII. Palaiologosz Mihály császárral (1261-1282) rövid időre létrehozta ugyan a nyugati és a keleti egyház unióját az 1274. évi lyoni zsinaton, de ez a császár által erőszakkal

\footnotetext{
125 Szokolay 1996. 36, 39.

${ }^{126}$ Bréhier 1997. 367.
} 
kikényszerített unió volt, amelyet a bizánci papság alapvetően ellenzett, mivel a Gergelyt követő pápák ellenségesen is viselkedtek a görögökkel szemben. ${ }^{127}$

A 15. század első felében az oszmán-török fenyegetés miatt a bizánci kormányzó, majd társcsászár, Palaiologosz VIII. Joannész (1425-1448) európai segítségkérő diplomáciai körútra indult (1423-1424). ${ }^{128}$ Járt Velencében, Milánóban és Magyarországon. Ezúttal is eredmény nélkül. II. Mánuél (1391-1425) császár kénytelen volt az oszmán-török vazallusi szerződést és adófizetést továbbra is elfogadni. ${ }^{129}$ A nyugati segítségnek ismét nagy volt az ,ára”.

IV. Jenő pápa (1431-1447) a szorult helyzetben lévő Bizánccal ismét az egyházi uniót sürgette. A XVII. Egyetemes Zsinatot (1431-1437) 1431. július 23-án, Báselben Giuliano Cesarini bíboros nyitotta meg, amelyre meghívást kaptak a husziták is. Ennek hátterében az is ott volt, hogy Zsigmond eddig hiába vezetett „keresztes” hadjáratokat a cseh husziták ellen, eredménytelennek bizonyultak. A tárgyalásokat Prágában folytatva 1433. november 30-án megegyeztek (prágai kompaktáták), amelyek mérsékelten, de teljesítették a kelyhesek követeléseit. Azonban a zsinat további - föként a pápa hatalmát csökkentőrendelkezései során az ellentét fokozódni látszott a pápa és a zsinat között. ${ }^{130}$ Ezt az időszakot nevezte Gergely Jenő a konciliarizmus és a papalizmus küzdelmének. ${ }^{131}$

Ekkor érkezett VIII. Joannész segítségkérése az oszmán-törökök fenyegetése miatt. A bizánci császár az egyházi uniót is elfogadva kérte, hogy a tárgyalások közelebbi helyszínen legyenek. Jenő pápa végül a „Doctoris Gentium” kezdetű bullájával a zsinatot Ferrarába helyezte át, ahová csak a kisebbség követte. A ferrarai zsinaton maga a császár, a konstantinápolyi pátriárka és mintegy hétszáz főnyi görög is részt vett. Az 1438 januárjában megnyílt zsinat tulajdonképpen a Báseli Zsinat folytatása, együtt képezik a XVII. Egyetemes Zsinatot. Azonban az uniós tárgyalásokat meg kellett szakítani és a 1439-ben kitört pestisjárvány miatt a zsinatot a pápa áthelyezte Firenzébe. Itt a legföbb eredmény a keleti egyházzal való egyesülés létrehozása volt. Bár a „Laetentur Coeli” kezdetü, az uniót kimondó bulla aláírására 1439. július 6-án sor került, de a bizánciakban kételyek maradtak. ${ }^{132}$ Ahogy az egyházi unió ellenzője, Lukasz Notarasz megasz dux -

\footnotetext{
${ }^{127}$ Bréhier 1997. 377-378.

${ }^{128}$ Az 1424. év eseményeire érdekes adalékkal szolgálhat: Zsigmond kori Oklevéltár XI. (1424). Közzéteszi: C. Tóth Norbert-Neumann Tibor. Budapest, 2009. (C. Tóth-Neumann 2009)

${ }^{129}$ Bréhier 1997. 441.

${ }^{130}$ Szántó Konrád: A katolikus egyház története. I. kötet Budapest 1983. 505-506. A továbbiakban: Szántó 1983.

${ }^{131}$ Gergely Jenő: A pápaság története. Budapest 1999. 131. A továbbiakban: Gergely 1999.

${ }^{132}$ Steven Runciman: Konstantinápoly eleste 1453. Budapest 2000. 27-29. A továbbiakban: Runciman 2000.
} 
Dukasz közlése szerint (37. 10) - tartotta: „Elönyösebb látni a város közepén a törökök császárának turbánját, mint a latin bíborosi kalapot". ${ }^{133}$

A bizánci források - föleg Dukasz - szerint az oszmánok a firenzei határozatok miatt aggódni kezdtek. A hazatérő bizánci császár II. Murádhoz követeket küldött, akik felvilágosították a szultánt, hogy nem kell azoktól a híresztelésektől tartani, hogy az oszmánok ellen szárazföldön és tengeren keresztes hadjárat készülődne. Firenzében csak vallási ügyekben döntöttek. Az oszmánok egy lehetséges keresztes támadástól tartva, egyelöre lemondtak a Konstantinápoly elleni újabb ostromról. Ennek a tartózkodó politikának az élén Halil Chandarli pasa, a Nagyvezír járt (1429-1453). A bizánci követjárás 1439-1443 között Róma és Konstantinápoly között igen gyakori volt, amely megalapozhatta az oszmán félelmeket. Végső soron felerősítette azt az elképzelést is, hogy e veszély megelőzésére Konstantinápolyt kell bevenni és Bizánc létezésére mérni az utolsó csapást. Ezt a katonai tervet a firenzei zsinat mindenképpen meggyorsította. ${ }^{134}$

A Firenzében tárgyalt muszlim-ellenes kérdés azonban nemcsak Európára korlátozódott, az afrikai kereszténység is képviseltette magát a zsinaton. Amikor a ferraraifirenzei zsinaton a nyugati és a keleti egyház oszmán-török ellenes szövetséget kötött, az etióp császár, Zar’a ya'qob (1434-1468) is csatlakozni kívánt ehhez. Tudnunk kell, hogy a 15. századi etióp külpolitikában a Níluson átívelő keresztény kapcsolat megteremtése központi kérdés volt az egyiptomi muszlim Mameluk Szultanátus szomszédságában élő Etiópiának. A ferrarai-firenzei zsinatra Jeruzsálemből etióp küldöttség is érkezett. Rómában etióp kolostort nyitottak. E kapcsolatok felkeltették a muszlim Egyiptom uralkodójának gyanúját. ${ }^{135}$

Amikor 1438-ban al-Zahir Jaqmaq szultán (1438-1453) hatalomra került, felújította a keresztények elleni mameluk támadásokat, elsősorban a rodoszi johannita lovagrend elleni akcióival. A szultánt különösen bosszantotta a kopt keresztény egyház részvétele a firenzei zsinat muszlim-ellenes együttmüködésében. Gyanakvását jól mutatja az a tény is, hogy utasította a kopt pátriárkát, hogy számoljon be minden hírről, amelyet az etióp császártól

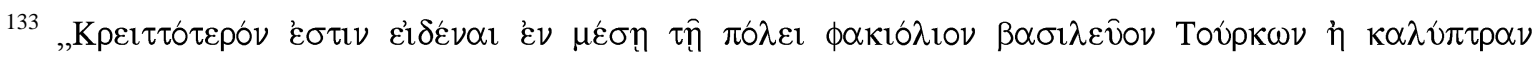

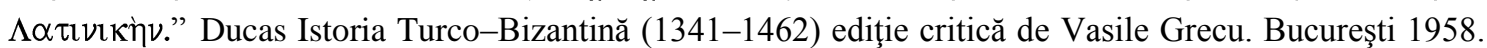
329, 11-12. (A továbbiakban: Grecu 1958). Corpus Scriptorum Historiae Byzantinae. Ducae Michaelis Ducae Nepotis Historia Byzantina. Recognovit Immanuel Bekkerus. Bonnae 1834. 264. (A továbbiakban: Bekker 1834), Runciman 2000. 30; Bréhier 1997. 458.

${ }^{134}$ Halil İnalcik-Mevlûd Oğuz: Gazavât-i Sultân Murâd b. Mehemmed Hân. İzladi ve Varna Savaşları (1443-1444). Üzerinde Anonim Gazavâtnâme. Ankara 1989. 81. (4. lábjegyzet) A továbbiakban: İnalcik-Oğuz 1989.

${ }^{135}$ Haggai Erlich: The Cross and the River. Ethiopia, Egypt, and the Nile. Colorado-London 2002. 45-46. A továbbiakban: Erlich 2002. 
kap. Egyiptomban a koptok visszaszorítására új adókat vezetett be, egyházakat gyújtatott fel. 1443 novemberében Zar'a ya'qob etióp császár egy levélben finoman meg is fenyegette a szultánt. „...nem vagytok annak tudatában ti, és Te, szultán, hogy a Nilus a mi országunkból ered hozzátok és képesek vagyunk megakadályozni, hogy megöntözze a ti országotokat? Minket semmi sem tart vissza ettöl, egyedül csak az Istenben való hit és az ö szolgáiról való gondoskodás..." Jaqmaq szultán ajándékokat vivő követet küldött és kitérö választ adott. Amikor Zar’a ya'qob császár letartóztatta a mameluk követet, akkor Jaqmaq hasonlóan cselekedett az etióp pártiárkával. A térségben az iszlám-keresztény feszültség nem oldódott meg később sem. 1449-ben az etióp császár 200 hajóból álló flottát építtetett például Mekka megtámadására. ${ }^{136}$ Így nemcsak II. Murád oszmán-török szultán, hanem az iszlám világ védelmében kell értékelnünk a Mameluk Szultanátus Rodosz elleni hadjáratait, amelyekkel közvetve déli irányból semlegesítette az esetleges keresztény segítséget.

Az egyházi zsinatot azonban a belső szakadás is veszélyeztette. 1438-ban a Báselben maradt, föleg francia papság, kinyilvánította a zsinat pápafölöttiségét, korlátozta a pápai jogkört és a Rómához való fellebbezést. A határozatokat törvényeknek nyilvánították és ez képezte alapját a későbbi gallikán egyháznak (bourges-i pragmatica sanctio). 1439-ben pedig a „bázeliek” ellenpápát választottak V. Félix (Amadé, savoyai herceg) személyében. ${ }^{137}$

A keleti egyházak is nem sokkal később megszüntették az uniót. Iszidórosz (Izidor), Rusz metropolitája hiába írta alá a nyugati és keleti egyházak közötti uniót, a moszkvai nagyfejedelem III. Vaszilij (1425-1462) nem tartotta kívánatosnak és 1441-ben megszüntette azt. Az alexandriai, antiochiai és jeruzsálemi pátriárkák 1443-ban hasonlóan cselekedtek. $^{138}$

Az ilyen körülmények megnehezítették az unió fejében vállalt egységes keresztény segítségnyújtást is. Nemcsak Bizánc részére. Mindezeknek 1440-ben a magyar államot fenyegető török veszélyre nézve is olyan következménye volt, hogy IV. Jenő pápa, bár szorgalmazta a török elleni fellépést, de egy keresztes háború tényleges megszervezésében ekkor még tervei és szándékai voltak csupán. Azt az ellentétet, amely a két dinasztia között feszült a magyar trón birtoklásáért, ő sem tudta feloldani. Erre csak a megosztottság előtt nyílt volna lehetőség. John Jefferson feltételezi, hogy Zsigmond halála után, Habsburg

\footnotetext{
${ }^{136}$ Erlich 2002. 46.

${ }^{137}$ Szántó 1983. 507-509.

138 Szántó 1983. 513; Font Márta-Krausz Tamás-Niederhauser Emil-Szvák Gyula: Oroszország története. Budapest $2001^{2}$. 97. A továbbiakban: Font-Krausz-Niederhauser-Szvák 2001.
} 
Albert erre tett volna ígéretet, amelyet váratlan halála megakadályozott. ${ }^{139}$ Azonban pápai legátus nem volt az országban. Marchiai Jakab Albert király halála után elhagyta a Magyar Királyságot és a ferrarai zsinaton tartózkodott. ${ }^{140}$

Fraknói Vilmos szerint IV. Jenő pápa a magyar trónviszályban és megosztottságban kezdetben Erzsébet királyné mellett állt, de I. Ulászló felé is akart kapcsolatokat kiépíteni, amelynek feltétele az Erzsébettel való békés megegyezés lett volna. ${ }^{141}$

Jenő pápa békíteni akarta a polgárháborúba sodródott feleket, hogy a török veszély ellen együttesen lépjenek fel. Mindez távoli és naiv elképzelésnek bizonyult, és az oszmántörökök valódi erejének alábecsülését sejtette. Arról nem is szólva, hogy 1440-re az országban olyan mély politikai törésvonal mentén álltak a felek, amelyben az egyik oldal győzelmét és a másik fél bukását a török esetleges győzelme is elősegíthette az összefogás legkisebb - a ránk maradt forrásokból kiolvasható - jele nélkül...

\section{4. Szerbia, Bizánc és az Oszmán Birodalom}

Szerbia virágkora IV. (Dusán) Istvánnal (Stefan Dušan) (1331-1355) kezdődött, uralkodása során kiújultak a szerb-magyar harcok is. Dusán 1349-ben Nándorfehérvárt visszafoglalta I. (Nagy) Lajos (1342-1382) magyar királytól és a Bizánci Birodalom további területeit kezdte meghódítani, mivel szerb uralom alatt kívánta egyesíteni Bizáncot és a balkáni népeket. ${ }^{142}$

A Balkánon a 14-15. században új hatalmi erővonalak alakultak ki. Dusán halála után Szerbia részekre hullott. Délen Dusán helytartója, Branko Mladenović épített ki területi hatalmat, fia Vuk Branković székhelye Koszovo vidéke lett. Északon a másik központ Hrebeljanović Lázár István kenéz vezetésével alakult ki. Lázár kenéz már I. (Nagy) Lajos segítségére támaszkodott, aki viszont hübéri függésbe kényszerítette a Lazarevićeket és hadjáratot indított Szerbiába (1359). ${ }^{143}$ Nagy Lajos Szerbia feldarabolásában részt vett, így elragadta Nándorfehérvárt is.

\footnotetext{
${ }^{139}$ Jefferson 2012. 263.

${ }^{140}$ Galamb György: A ferences obszervancia magyarországi térnyeréséhez. In.: „Magyaroknak eleiröl” Ünnepi tanulmányok a hatvan esztendős Makk Ferenc tiszteletére. Szerk.: Piti Ferenc, 2000. 180. (Galamb 2000)

${ }^{141}$ Fraknói Vilmos: Magyarország egyházi és politikai összeköttetései a Római-Szent-Székkel. II. kötet. A konstanzi zsinattól a mohácsi vészig (1418-1526). Budapest 1902. 41. (Fraknói 1902)

142 Bréhier 1997. 408; Engel-Kristó-Kubinyi 1998. 77.

${ }^{143}$ Engel-Kristó-Kubinyi 1998. 85.
} 
A Bolgár Cárságot 1364-ben még Sándor cár (1331-1371) osztotta ketté két fiai között, hogy elkerülje a trónért való testvérharcot. Idősebbik fia, Ivan Stracimir (1364-1396) Vidin központtal északnyugat Bulgáriát, a cár második feleségtől származó kisebbik fia, Ivan Shisman (1371-1393) pedig apja halála után Közép-Bulgáriát vezette. ${ }^{144}$ Lajos király, amikor pedig Bulgária széttagolódott a Vidini és a Trnovói Bolgár Cárságra, Lajos a szerb-havasalföldi-bolgár szövetség ellen hadjáratot indítva elszakította a viddini bolgár fejedelemséget. Bár Vidin néhány évig magyar bolgár bánokat nevezett ki (1365-1368) Stracimirt kiengedte a magyarországi börtönéből és miután hüségesküt tett, visszahelyezte Vidinbe. ${ }^{145}$ Bréhier szerint ez meggyengítette a fenyegető oszmánokkal szembeni ellenállást. ${ }^{146}$ Bertényi István szerint ez a vád nem megalapozott, mert az első adandó alkalommal szembefordultak Lajossal, így Shisman és Stracimir cár is. ${ }^{147}$ E magatartásuk pedig I. Bayezid (1389-1402) szultán hódító politikájával szemben számukra végzetessé vált. $^{148}$

Az oszmán-törökök elleni küzdelem legfontosabb európai nagypolitikai fokméröje a Bizánci Birodalom megsegítésének kérdése lett. Az oszmán veszélyt jelezte, hogy 1366ban a bizánci császár, V. Palaiologosz Joannész (1341-1379) személyesen megkereste Lajost és vele folytatott tárgyalásokat. A helyszín azonban nem Buda, hanem Vidin (magyar nevén Bodony) lehetett. A szakirodalomba többször tévesen bekerült információ oka - ahogyan arra Papp Sándor felhívta a figyelmet - Buda és Vidin latin nevének hasonlósága. ${ }^{149}$

A magyar király V. Orbán pápa (1362-1370) tervei szerint az általa hirdetett keresztes hadjárat (1365) szárazföldi hadseregének vezetője lett volna. ${ }^{150} 1371$-ben I. Murád szultán (1362-1389) viszont legyőzte Vukasin (1366-1371) túlerőben lévő szerb seregét a Maricafolyónál. A korai oszmán-török források a Marica melletti csatát korábbra, 1365-1366 körülre helyezik, amikor a szultán fiait, Bayezidet és öccsét, Yakub Cselebit körülmetélték. ${ }^{151}$ A magyar király, I. (Nagy) Lajos részvételéröl sincs adat a török forrásokban. ${ }^{152}$ Akárhogyan történt, a csata következménye az lett, hogy déli szerb

\footnotetext{
${ }^{144}$ Bertényi Iván: Nagy Lajos király. Budapest 1989. 92-93. A továbbiakban: Bertényi 1989.

145 Bertényi 1989. 95.

${ }^{146}$ Bréhier 1997. 415.

${ }^{147}$ Bertényi 1989. 98-99.

${ }^{148}$ Lásd a 13. 2. fejezetet.

${ }^{149}$ Papp 2004. 46.

${ }^{150}$ Bréhier 1997. 417.

${ }^{151}$ Oruç Beğ Tarihi (Osmanli Tarihi 1288-1502) Hazırlayan Prof. Dr. Necdet Öztürk. Istanbul 2007. 26. A továbbiakban: Oruç 2007.

${ }^{152}$ Papp 2004. 51.
} 
részfejedelmek török vazallussá váltak. A töröktől független területek Észak-Szerbiára korlátozódtak, ahol Lázár kenéz gyakorolta a hatalmat. ${ }^{153}$ Szerbia egysége többé nem állt helyre. A balkáni oszmán térhódítás és Bizánc sorsa összefonódott.

XI. Gergely pápa (1370-1378) a maricai vereség hírének hatására, Konstantinápoly megsegítésére keresztes hadjáratot tervezett és 1373-ra Thébaiba kongresszust hívott össze. Ehhez a magyar királyt és Velencét szerette volna megnyerni. De a bizánci követjárásnál a követ Ióannész Laszkarisz Kalopherosz volt - több ezúttal sem történt. ${ }^{154}$ I. Murád hódításai folytatódtak, amelyek az Oszmán Birodalom történetében is sorsfordítónak bizonyultak. Még 1361-ben elfoglalta Drinápolyt a bizánciaktól és székhelyévé tette. Bizánc viszont kénytelen volt adót fizetni a szultánnak és 1374-ben szerződést kötöttek, amely szerint V. (Palaiologosz) Joannész (1341-1391) a szultán vazallusa lett.

$\mathrm{Az}$ erősödő terjeszkedést mutatta, hogy Murád célja a Bizánci Birodalom második legnagyobb városa, Thesszaloniki lett. A várost az első oszmán-török ostrom során a szultán több mint három éves, hosszú ostrom után, - 1387. áprilisában - tudta csak elfoglaltatni. ${ }^{155}$

Az Oszmán hódítások módszeréről İnalcik professzor - a legutóbbi vele készített interjúban - kiemelte, hogy a szakirodalomban az általa felismert és nálunk Rázsó Gyula által felvetett több szakaszos hódítás ${ }^{156}$ elvén túl, sikeresen alkalmazták a szomszédos ország népének megnyerését is (adókedvezmény, szabad vallásgyakorlat). Ebbe beletartozott az is, hogy fellázítsák őket a saját közigazgatásuk ellen és segítséget nyújtsanak. ${ }^{157}$ Látjuk, hogy ezt még Bizánccal szemben is milyen sikerrel alkalmazták. Az oszmán hódítási ideológiában központi szerepe volt még az Arany Alma gondolatkörnek (Kızıl Elma), amely Bizáncból ered. A forrása feltehetően I. Jusztinianosz (527-565) konstantinápolyi lovas szobra. Ezen a császár a kezében tartott egy arany glóbuszt, amely szimbólumává vált a világ feletti uralomnak. ${ }^{158}$ A Kız1l Elma kezdetben Konstantinápolyra vonatkozott, később Budára is. ${ }^{159}$ Csak kérdésként vetjük fel, hogy mivel a szultánok fő célja a vár elfoglalása volt, lehetett-e Nándorfehérvárra is vonatkoztatni?

\footnotetext{
${ }^{153}$ Engel-Kristó-Kubinyi 1998. 87.

${ }^{154}$ Bréhier 1997. 421.

${ }^{155}$ Georg Ostrogorsky: A bizánci állam története. Budapest 2003. 453. A továbbiakban: Ostrogorsky 2003.

${ }^{156}$ Halil İnalcik: Ottoman methods of conquest. Studia Islamica 1954. 103-129. (İnalcik 1954)

157 Papp Sándor: Az oszmán hódítás török szemmel. Beszélgetés Halil Înalcik professzorral. Belvedere Meridionale 1997/ IX. 3-6. 166. A továbbiakban: Papp 1997.

158 Papp 1997. 169. Ez a lovas szobor Konstantinápolyban a Hagia Sophia templom előtti téren állt. A császár bal kezében egy országalmát tartott, a tetején kereszttel. Michael Angold: Bizánc. Híd az ókor és a középkor között. Fordította: Sándor Bea. Budapest 2001. 40. (Angold 2001)

${ }^{159}$ Fodor Pál: Magyarország és a török hódítás. Budapest 1991. 487. A továbbiakban: Fodor 1991.
} 
I. Murád a Duna felé is hódított, a Nándorfehérvár felé is vezető legfontosabb kereskedelmi-stratégiai út központjait, Szófiát (1386) és Ništ (1387) megszerezte. A döntő ütközet 1389-ben Rigómezőnél (Kosovo polje) zajlott. Bár a szultán a sátrában merénylet áldozata lett, a török vazallus Lázár kenéz és szövetségesei vereséget szenvedtek.

A szerb állam központi területe észak felé tolódott el. Ez pedig a Brankovićok területét is érintette. Lázár fejedelem fiának, Lazarević Istvánnak (Stefan Lazarević) (1389-1427) Nándorfehérvár, ekkor Belgrád, lett a központja. Azonban Lazarević kénytelen volt elismerni a török vazallusságot a Gallipoliban megkötött egyezményben (1402), amelyben Szerbia állami létét meghosszabbította. A szerb-moráviai területeket kiszélesíthette, de a hübéri kötelezettsége megmaradt. ${ }^{160}$ Lazarević I. (Villám) Bayezid (1389-1402) hübéreseként harcolt a nikápolyi, majd az ankarai csatában is, Timur Lenk ellen. ${ }^{161}$ Kevéssé ismert, hogy Bayezid veresége után Lazarević útban visszafelé VII. (Palaiologosz) Joannész bizánci császártól $(1390-1399,1402)$ Konstantinápolyban megkapta a despota (deszpotész) címet is, amely a bizánci uralmi hierarchia egyik legmagasabb rangja volt. ${ }^{162}$ Ennek a Komnénosz császárok idején létrehozott címnek első birtokosa még III. Béla magyar király volt, ${ }^{163}$ majd 1190-ben Nemanja István szerb fejedelem is megkapta, sőt 1204 után Épeirosz ura is birtokolta. ${ }^{164}$

A despotát törökök katasztrofális veresége Ankaránál azonban éles külpolitikai váltásra ösztönözte. Vagy másként fogalmazva egyszerre került a törökök és magyarok függése alá. Nem volt ez már más, mint Rázsó Gyula találó kifejezésével élve: „török függésbe torkolló ingadozó reálpolitika". ${ }^{165}$ Ugyanis Luxemburgi Zsigmond magyar király (1387-1437) felé is tájékozódott, aki korábban személyesen indított szerbiai hadjáratokat. 1396-ban Bizánc megsegítésére és az oszmánok ellen indított keresztes hadjárata vereséggel végződött, Nikápolynál. Akkor I. Bayezid szultán folytathatta Konstantinápoly zárlatát, amelynek elfoglalása ezután fő célja lett. II. Manuél bizánci császár (1391-1425) emiatt indult segítséget kérni Nyugat-Európába (Párizs, London), de utazása nem hozott eredményt $(1399-1403) .{ }^{166}$

Lazarević és Zsigmond magyar király között gyümölcsözö együttmüködés alakult ki. Lazarević tagja lett Zsigmond által alapított Sárkányos társaságnak (1408) és Zsigmondhoz

\footnotetext{
${ }^{160}$ Bisztra Cvetkova: A várnai csata. Budapest 1988. 37. A továbbiakban: Cvetkova 1988.

${ }^{161}$ Generál 1987. 46.

162 Зорица Гузина: Тајне Београда. Београд, 2002. 16. A továbbiakban: Гузина 2002.

${ }^{163}$ Makk Ferenc: Magyar külpolitika (896-1196) Szeged 1996. 202. A továbbiakban: Makk 1996.

${ }^{164}$ Louis Bréhier: A bizánci birodalom intézményei. Budapest, 2003. 145, 625. A továbbiakban: Bréhier 2003.

${ }^{165}$ Rázsó 1973.408

${ }^{166}$ Bréhier 1997. 431.
} 
élete végéig hü maradt, akitől a Száván túli, „megmaradt államának” egykori birtokait megkapta. Így a Macsói Bánságot (Száva, Drina-folyók és a Cer-hegység között) és vele együtt Nándorfehérvárt, valamint nagy kiterjedésű magyarországi birtokokat. A legfontosabb azonban az, hogy szerbiai államának székhelyét Nándorfehérváron rendezte be és itt fontos korszerüsítő várépítkezéseket végzett. ${ }^{167} \mathrm{Az}$ addigi kőhalomból korszerü, vastag várfalakat és bástyákat emeltetett, a vidéket pedig zsoldos helyőrség örizte. ${ }^{168}$ Megóvta a déli magyar vármegyéket a török támadásoktól. Ezt Zsigmond király 1404-ben, a burgundiai herceghez írott levelében ki is emelte. „A nevezetes István úr, Rascia despotája és hercege, szintén alárendelve magát hatalmunknak és uralmunknak, csatlakozott hozzánk és elhatározta, hogy olyan nagy erövel indul a törökök és egyéb ellenfeleink, vagyis helyesebben Krisztus ellenfelei ellen, hogy többször viselvén ellenük háborút, győzelmet aratott... "169 Szerbia az ütközőállam mintája lett ebben az időszakban, egészen Lazarević haláláig (1427). ${ }^{170}$

A Zsigmond által vezetett keresztes hadsereg nikápolyi csatavesztésével (1396. szeptember 25.) a török elleni támadó stratégia kudarcra lett ítélve. ${ }^{171}$ Ezeket inkább a bizánci császárok szorgalmazták birodalmuk nyugati megsegítésére. ${ }^{172}$ Itt meg kell említenünk II. (Palaiologosz) Manuél bizánci császár (1391-1425) nyugat-európai segélykérő körutazását vagy az őt követő VIII. Joannész (1425-1448) diplomáciai útját. ${ }^{173}$ Az ilyen török elleni harc fö kérdése az oszmánok által ekkorra teljesen körülzárt, városállammá zsugorodott és oszmán-török vazallus Bizánc megsegítése, megvédése lett volna. Az egységes fellépést megnehezítette Velence ambivalens magatartása is, amely az oszmánokkal való modus vivendi-t kereste keleti birtokai és kereskedelme érdekében. I. „Villám” Bayezid szultán (1389-1402) nagyarányú hódításait Timur Lenk 1402. július 20.i ankarai győzelmével megtörte. ${ }^{174}$ Ekkor kínálkozott volna egyedül lehetőség az oszmántörökök elleni fellépésre, amely végül is kihasználatlanul maradt. Az Oszmán Birodalmat

\footnotetext{
${ }^{167}$ Pálosfalvi 2010b. 7. Lásd a 3. 2. fejezetet.

${ }^{168}$ Cvetkova 1988. 37.

169 Idézi: Cvetkova 1988. 38.

${ }^{170}$ Engel-Kristó-Kubinyi 1998. 155.

171 Pálosfalvi 2005. 50-58. Nikápolyról és következményeiröl lásd bővebben: Engel Pál: A török-magyar háborúk első évei 1389-1392. Hadtörténelmi Közlemények 1998/3. 561-577. Hóvári János: A nikápolyi csata. fordulópont a balkáni oszmán hódítások történetében. Hadtörténelmi Közlemények 1998/3. 578582. (Hóvári 1998) Veszprémy László: A nikápolyi hadjárat értékelése az újabb hadtörténetírásban. Hadtörténelmi Közlemények 1998/3. 603-609. (Veszprémy 1998a)

172 Rázsó 1973. 413.

${ }^{173}$ Ostrogorsky 2003. 459, 463.

${ }^{174}$ Generál 1987. 46-47.
} 
belső trónharcok gyengítették, végül I. Mehmed uralkodása (1413-1421) megbékélést hozott. ${ }^{175}$ Bizánc pedig egy időre megszabadulhatott vazallusi függésétől. ${ }^{176}$

Zsigmond politikájában is a török kérdés egy időre lekerült a napirendröl. A felek inkább fegyverszünetet, békét kötöttek, amelynek időpontjait nehéz megállapítani. A korai oszmán-török-magyar békeszerződésekre vonatkozó adatokat 1526-ig legutóbb Papp Sándor gyüjtötte össze. ${ }^{177}$

A kevés adat ellenére az egyik legfontosabb forrás Eberhard Windecke Zsigmond császárról írt emlékirata (155, 199, 204. fejezetek). Ebből megtudjuk, hogy Zsigmond 1419-ben, Nagyváradon 5 éves fegyverszünetet kötött az oszmánokkal. „Ekkor kereste fel a kegyelmes urat a török szultán követsége, hogy öt(ven) évre szóló békét kössenek" (Skorka Renáta fordítása). ${ }^{178}$ Windecke leírása szerint 1424-ben a budai várban, amikor vendége volt a török ellen segítséget kérő bizánci császár, VIII. (Palaiologosz) Joannész, valamint Lazerević István szerb despota, érkezett elébe a szultán követe, akivel „békét kötöttek, amit azonban később nem tartottak meg." Ami figyelemreméltó az az, hogy a szultáni követ által a királynak átadott ajándékok között tüzfegyver, négy török puska is volt. $^{179} 2$ éves fegyverszünet következett. ${ }^{180} \mathrm{Az}$ oszmán-török-lengyel diplomáciai kapcsolatokat kutató lengyel történész, Dariusz Kołodziejczyk munkája a zsigmond kori török-magyar békeszerződési időpontokat is rekonstruálta. Közlése szerint 1421-ben 5 évre, 1425-ben 2 évre, 1428-ban (Galambóc) 3 évre, 1433-ban 5 évre kötöttek békeszerződést. Ezek az adatok kissé eltérnek a magyar szakirodalomban közöltektől. ${ }^{181}$

Az új szultán, II. Murád (1421-1451) trónra lépése gyökeres fordulatot hozott. Ennek szembetűnő példája, hogy 1422. július 8-án megkezdte a bizánci főváros, Konstantinápoly szabályos ostromát, amelynek erős falai ezúttal is ellenálltak. Az oszmán-török sikertelenség oka Generál Tibor szerint az volt, hogy „az oszmánok sem tüzérséggel és ostromgépekkel, sem hajóhaddal nem rendelkeztek. II. Murád pedig túl fiatal volt ahhoz, hogy a szeldzsuk, keresztes és a mongol ostrommódszereket ismerte volna." Azonban

\footnotetext{
175 Matuz 1990. 41-43.

${ }^{176}$ Ostrogorsky 2003. 460.

${ }^{177}$ Papp 2004. 54-66.

${ }^{178}$ Eberhard Windecke emlékirata Zsigmond királyról és koráról. Fordította, sajtó alá rendezte és a bevezető tanulmányt írta Skorka Renáta. Budapest 2008. 112, 9-11. A továbbiakban: Windecke 2008.

${ }^{179}$ Windecke 20008. 142, 31-32.

${ }^{180}$ Papp 2004. 57.

${ }^{181}$ Dariusz Kołodziejczyk: Ottoman-Polish diplomatic relations (15th-18th century) An annotated edition of 'Ahdnames and other documents. Leiden 2000. 81-82. A továbbiakban: Kołodziejczyk 2000. Lásd még az 5. 1, a 6. 1. és a 6. 2. fejezetek adatait.
} 
1424-ben, a Muráddal megkötött békeszerződésben VIII. Joannésznek ismételten vállalnia kellett a vazallusságot. ${ }^{182}$

Az oszmán hódítás ugyanakkor a még görög területek ellen is irányult. A Moreát az Iszthmosznál védő Hexamilion falat, amelyet II. Manuél emeltetett, áttörték. Amikor pedig Manuél császár szerződésben 50000 dukátért átadta Thesszalonikit a velenceieknek, II. Murád agresszívebben lépett fel a várost „atyai örökségeként” - hivatkozva a korábbi oszmán uralomra - követelte vissza, több adót követelt, végül 1430 márciusának közepén személyesen vette ostrom alá a várost. ${ }^{183}$ Thesszalonikiben a szorongatott velencei védők szövetségeseket kerestek: Athén hercegét, Antonio Acciajuolit; Theodorosz, Mistra despotáját, de fontos kiemelnünk, hogy Zsigmond magyar király segítségében is reménykedtek. Azonban nem szabad figyelmen kívül hagynunk Zsigmond és Velence ellentétét Dalmácia birtoklásáért, amely háborúhoz vezetett. Az első velencei-magyar háborúban (1411-1413) Zsigmond vereséget szenvedett és kénytelen volt Dalmácia és vele az I. Lajos király óta megszerzett Raguza elvesztésébe is belenyugodni. ${ }^{184} 1420$-ban pedig Spalato és Trau is meghódoltak a városköztársaságnak. ${ }^{185}$ A magyar segítség emiatt Thesszaloniki felmentésére nem valósult meg, bár az északi hadszíntéren Zsigmond ekkor konfliktusba keveredett Muráddal a kulcsfontosságú Galambóc várának visszaszerzéséért. 1430-ra világossá vált, hogy a velenceiek nem remélhetnek segítséget az ostrom felmentésére a magyaroktól. ${ }^{186}$ II. Murád szultán viszont néhány hét után, 1430. március 29-én bevette a várost.

II. Murád aktív külpolitikája egyértelműen jelezte, hogy a törökök újra hódításokra törnek és a fegyverszüneteket is ők szegték meg. ${ }^{187}$ Azonban ehhez mi hozzátesszük azt, hogy mindezt nem ok nélkül. Hiszen, ahogyan 1423-ban a Thesszalonikit a velenceieknek átadó bizánci szerződés, ${ }^{188}$ úgy az 1426. évi tatai szerződés a magyar, déli határvédelemben addig fennálló status quo-t alapjaiban rendezte át. ${ }^{189} \mathrm{Az}$ így megnövekedett szerepü Nándorfehérvár 1427. évi magyar kézbe való átvétele után pedig újabb oszmán-török támadástól bármikor lehetett tartani, amelyet Galambóc várának szívós török védelme jól jelzett. Ezért is érdemes a megelőző évek határmenti eseményeit is e szempontból újra átvizsgálnunk. Hiszen e kisebb-nagyobb támadások bármikor

\footnotetext{
182 Generál 1987. 51-53.

${ }^{183}$ Generál 1987. 53; Ostrogorsky 2003. 462.

${ }^{184}$ Lásd a 3. 3. fejezetet.

${ }^{185}$ Engel-Kristó-Kubinyi 1998. 159.

${ }^{186}$ Imber 2002. 23.

187 Rázsó 1973. 426.

188 Ostrogorsky 2003. 463.

${ }^{189}$ Szabó 2010. 61-62.
} 
előkészíthették a szultáni haderő megérkezését. Mivel az egységes európai törökellenes fellépés elmaradt, így II. Murád szultán nyugodtan indulhatott a Duna vonala felé. Thesszaloniki elfoglalása után, az albánok oszmán adófizetők lettek. 1432-ben fellázadtak, végül két éves harcban Turahán-oglu győzte le őket. ${ }^{190}$

A szultán az egyik legerősebb albán erőd bevételével próbálkozott. II. Murád hadjárata azonban 1450-ben, eredmény nélkül végződött, Kruja alól kénytelen volt visszavonulni. ${ }^{191}$ Az albán kérdés az oszmán hódítás számára II. Murád halála után is megoldatlan maradt. II. Mehmed szultán 1457-ben sikertelen hadjárattal próbálkozott a híres Szkander bég, Kasztrióta György ellen. 1461-ben fegyverszünetet kötöttek. Amikor Velence szövetsége megerősödött Albániával, 1463-ban kitört a második velencei-oszmán háború, amely 17 éven át gyötörte a feleket. A fö hadszíntér Moreában volt. II. Mehmed hiába küldte seregeit. 1463-ban Szeremet béget, 1464-ben Balabán basát Kasztrióta sorra legyőzte. 1466-ban a szultán ismételten Kruja ostromával próbálkozott, ezúttal is sikertelenül. A hátrahagyott Balabán basa seregeit Kasztrióta ismét szétverte. Amikor 1468-ban Kasztrióta meghalt, Albánia sorsa megpecsételödött. Kruja és Skhodra erődjei velencei kézen maradnak továbbra is (ahogyan egykor Thesszaloniki is) ${ }^{192}$ 1474-ben Shkodra oszmán ostroma sikertelenül végzödött. Az albán háborúknak 1478-ban Kruja elfoglalása véget vetett. Időközben a velencei-török béke 1479-ben magára hagyta Albániát, Shkodra erődje így kerülhetett oszmán kézbe. ${ }^{193}$

Összegzésképpen megállapíthatjuk, hogy északon II. Murád számára kezdetben az első számú célpont Szerbia lett. Láthatjuk, hogy a középkori szerb állam nagyhatalmak közötti helyzetét, a független államiság megteremtésének lehetőségeit először a Bizánci Birodalom és a Magyar Királyság közötti pozíció határozta meg, amelynek keretében felmerült a Bizánctól való függetlenedés, akár magyar támogatással is. A Bizánci Birodalom gyengülésével és az Oszmán Birodalom terjeszkedésével azonban ez a Bizánc ellenes él megváltozott. Jó példája ennek Lazarević István uralkodása. A despota uralkodásának első szakaszában az oszmán-török vazallusság látszott az egyedüli kiútnak, akár Magyar Királysággal szemben is. Majd az oszmán-törökök átmeneti meggyengülése miatt, a Magyar Királysággal való együttmüködés vállalása az oszmánokkal szemben jellemezte külpolitikai irányultságát. Ez a Magyar Királyság és az Oszmán Birodalom közötti ingadozó reálpolitika Nándorfehérvár birtoklásán és sorsán is jól nyomon követhető.

\footnotetext{
${ }^{190}$ Generál 1987. 54.

${ }^{191}$ Generál 1987. 62.

192 Generál 1987. 71-73.

${ }^{193}$ Generál 1987. 77.
} 
Elfogadjuk Rázsó Gyula azon megállapítását, hogy Zsigmond király legnagyobb sikere az, hogy a tatai szerződés révén Magyarországé lett összesen 17 új végvár és Nándorfehérvár megszerzése és későbbi megtartása 94 évre mentette meg az országot a török hódítástól. ${ }^{194}$

\section{5. Hatalommegosztás a Mediterráneumban: Rodosz ostromai (1440, 1444)}

A nándorfehérvári ostrom nemzetközi szálaihoz közvetetten kapcsolva egy - a balkáni oszmán-török terjeszkedés folyamán - nem méltatott kérdéskörre szeretném felhívni a figyelmet. A Mediterráneumban megtelepedő rodoszi Johannita Lovagrend oszmán-török ellenes erejére, valamint ezzel összefüggésben az Oszmán Birodalom és az egyiptomi Mameluk Szultánság - keresztényekkel szembeni - egymást támogató külpolitikájára.

A 14. században a Rodoszra áttelepült Johannita Rend bekapcsolódott az oszmántörökök elleni harcokba és a latin államok birtokainak megvédésébe a Mediterráneum keleti felén. Így a Rend törökellenes velencei szövetségben először 1324-ben vett részt, majd 1344-ben az elfoglalt Szmürna várának visszafoglalásában. Ugyanakkor egyre nagyobb szerepet vállalt a görög területek védelmezésében is. 1374-ben tervbe vették a törököktől fenyegetett Gallipoli és Thesszaloniki védelmét, de ebből semmi nem valósult meg. 195

Ez nem zárta ki az oszmán-törökök ellen indított európai keresztes hadjáratban való részvételüket és katonai segítségüket. Az 1396. évi Zsigmond magyar király által vezetett európai keresztes hadseregben részt vettek a johanniták Philibert de Naillac nagymester (1395-1421) vezetésével. ${ }^{196}$ Sőt, a bizánci újgörög nyelvű Anonymus Zórasz krónika, valamint Manuél Malaxosz beszámolója szerint is a nagymester a vesztes csata után, Zsigmonddal egy kisebb hajóban menekült meg. ${ }^{197}$

A johanniták föleg a Peloponnészosz latinok uralta részében (Morea) harcoltak a törökök ellen. 1397-1404 között elfoglalták Korinthoszt és nagy szerepük volt az ellenállás

\footnotetext{
${ }^{194}$ Rázsó 1973. 438. Lásd a 4. 1. fejezetet.

195 Stephen C. Spiteri: Fortresses of the Cross. Malta 1994. 68. A továbbiakban: Spiteri 1994.

${ }^{196}$ Kelly DeVries: The Lack of a Western European Military Response to the Ottoman Invasions of Eastern Europe from Nicopolis (1396) to Mohács (1526). In.: Journal of Military History 63 (1999) 540, 541. (8. lábjegyzet) A továbbiakban: DeVries 1999; Spiteri 1994. 74.

197 Baán 2013. 494, 529. Az epizódról a francia történetíró, Froissart is beszámolt. The Chronicles of Froissart. Translated John Bourchier, Lord Berners. Edited and reduced into one volume by G. C. Macaulay. London 1904. 445. A továbbiakban: Froissart 1904.
} 
megszervezésében. 1403-ban, amikor a törökök a várost megtámadták, visszahúzódtak a görög szárazföldröl. 1402-ben pedig Szmürna várát Timur Lenk - miután tőlük elfoglalta lerombolta és lebontatta. A johanniták fenn akartak tartani egy oszmán-török frontot az anatóliai szárazföldön, Bodrum vidékén. Mindeközben a lovagok Rodoszon viszonylagos békében élhettek, csak az egyiptomi mamelukok fenyegették, akik 1440-ben megtámadták, 1444-ben meg is ostromolták a várost, de sikertelenül. ${ }^{198}$ Ez számunkra annyit jelent, hogy a Nándorfehérvárt 1440-ben védő vránai johannita perjel, Tallóci Jován nem is várhatott volna közvetlen katonai segítséget rend ekkori nagymesterétől, Jean de Lastic-tól ${ }^{199}$ (14371454) sem.

Azonban a Rodosz elleni mameluk támadások időpontjai sem tűnnek véletlennek. Bár általában - így Spiteri is - csupán a latin kalózkodással magyarázzák, de indokolt az oszmán-török mameluk kapcsolatok vizsgálata is. Mert ezek a támadások II. Murád szultán európai háborúival egybeesnek, amelyek egyúttal a rodoszi lovagok délről való, oszmán ellenes katonai beavatkozását eleve lehetetlenné tették.

Ha Földközi-tenger feletti kereskedelemi pozíciók megszerzésének igényéből indulunk ki a két nagyhatalom között, Thesszaloniki oszmán-török uralomba vétele mellé sorolhatjuk a Rodosz elleni a mameluk akciókat. ${ }^{200}$ Ide vehetjük még Ciprus Királyságának mameluk vazallus állammá tételét is. Csakhogy itt többről van szó. A kései keresztes hadjáratokban a keresztény államok erőinek katonai egyesítése az Oszmán Birodalom ellen létrehozta az iszlám világ - átmeneti - érdekazonosságát is. Ennek színtere pedig a Mediterráneum keleti medencéje, ahol a két nagyhatalom szomszédságba került egymással. A keresztény-iszlám vallási ellentét Afrikára is kiterjedt. A firenzei-ferrarai zsinaton való kopt részvétel miatti egyiptomi-etióp feszültségekről már szóltunk. Az etióp keresztények miatti haragjában al-Zahir Jaqmaq (Csakmak) egyiptomi (cserkesz) mameluk szultán (1438-1453) folytatta elődje, al-Ashraf Bars-bay (Barszbáj) szultán (1422-1438) hódításait, Rodosz elleni akcióival (1440, 1443, 1444). Amikor Jaqmaq elhatározta a rodosziak elleni támadást, az oszmán szultán, II. Murád, aki eddig is ellenőrzés alatt tartotta az egyiptomiakat, most nem gördített akadályt a vállalkozás elé. 1438-ban Jean de Lastic nagymester első cselekedete az volt, hogy követséget küldjön Kairóba a mamelukokhoz, meghosszabbítani a korábbi fegyverszünetet. Kémei által azt is tudta, hogy Jaqmaq megegyezést kötött II. Muráddal, így a nagymester attól félt, hogy II. Murád

\footnotetext{
${ }^{198}$ Spiteri 1994. 69.

${ }^{199}$ Spiteri 1994. 74.

${ }^{200}$ Hunyadi Zsolt: A keresztes háborúk világa. Debrecen 2011. 128.
} 
semleges marad egy Rodosz elleni támadás esetén. Hiába tárgyalt azonban később mindkét szultánnal, világossá vált, hogy a fegyvereké lesz a döntő szó. ${ }^{201}$ Segítséget kért a pápától, az európai uralkodóktól, de azok nem tudták ezt teljesíteni. ${ }^{202}$

Az első Rodosz elleni mameluk támadás tengeri akció volt, a város erődjét nem érintette. Az egyiptomi flotta 1440 szeptemberében érkezett Rodosz alá 18 gályával és számtalan kisebb hajóval. Azonban a nagymester ügyes vezetéssel megakadályozta az azonnali partraszállást. Elhagyta a flottájával a kikötő biztonságát, hogy a tengeren találkozzon a mameluk flottával, amely erre a hatásos megmozdulásra - az éjszaka előnyét kihasználva - visszavonult. A nagymester, megsejtvén a szándékukat, erre azonnal a nyomukba eredt és úgy elkerülte őket, hogy amikor a mameluk flotta Lango várához megérkezett, ő már harcra készen várta a mamelukokat, akik erre még egyszer visszafordultak és menedéket kerestek egy török erőd tüzérségnél, ahol már biztonságban érezték magukat a johanniták lehetséges támadásától. A nagymester a rodoszi flottával rájuk tört ugyan, ahogyan lehorgonyoztak, de a véres összecsapás döntő eredmény nélkül ért véget. Az egyiptomi flotta meghátrált, a johanniták pedig visszahajóztak Rodoszra. 700 egyiptomi halott és 60 keresztény volt a harc mérlege. ${ }^{203}$ Legutóbb Robert Irwin véleménye szerint az egész mameluk támadás végeredményben nem volt több egy ötletszerü rablóhadjáratnál. ${ }^{204}$

Jaqmaq szultán nem adta fel az újabb ostromot. Az arab források tudnak egy második Rodosz elleni expedícióról is 1442-ben vagy 1443-ban, azonban egyes vélemények szerint (Rossignol) ez az 1440-es hadjáratra vonatkozik. ${ }^{205}$ A mameluk flottát a tengeri vihar visszavetette. ${ }^{206} \mathrm{~A}$ támadás végül felaprózódott néhány keresztény birtok elleni támadásra Kis-Ázsia déli partjainál. ${ }^{207}$

A mameluk szultán a szíriai Țarâbulus kikötőjéből 1444 augusztusában indította utolsó hadjáratát, amely az előzőeknél nagyobb arányú volt. ${ }^{208}$ Az ostromlók partra tudtak szállni és 1444. augusztus 15-én megkezdődött a város ostroma. Kifosztották a környéket és az

\footnotetext{
${ }^{201}$ Withworth Porter: A history of the Knights of Malta. Volume 1. London 1858. 315. A továbbiakban: Withworth 1858.

202 Gilles Rossignol: Pierre d'Aubusson, le "bouclier de la chrétienté". Les Hospitaliers à Rhodes. Besançon 1991. 88. A továbbiakban: Rossignol 1991.

${ }^{203}$ Withworth 1858. 316; Rossignol 1991. 88.

${ }^{204}$ Robert Irwin: Islam and the Crusades 1096-1699. In.: The Oxford History of Crusades. Szerk.: Jonathan Riley-Smith Oxford 1995. 249. A továbbiakban: Irwin 1995.

${ }^{205}$ Rossignol 1991. 90.

${ }^{206}$ Más vélemény szerint 1442 tavaszán. Kadir I. Natho: Circassian history 2009. 212. A továbbiakban: Natho 2009.

${ }^{207}$ Irwin 1995. 249.

${ }^{208}$ Kadir I. Natho szerint 1444 júliusában. Natho 2009. 212.
} 
erődöt körülzárták, a tüzérséggel főleg a város kikötő felőli főkapuját támadták. Amikor szeptember 18-án az újabb támadás is kudarcba fulladt, az ostromot megszüntették. A jól megerősített tornyokkal és bástyákkal a kőhajító gépek és ágyúk sem boldogultak, az ostromlók visszafordultak Kairóba. A mamelukok vesztesége 300 halott és 500 sebesült volt. $^{209}$

Jean De Lastic sikeresen megvédte a várost. A mameluk szultán a francia kereskedő, Jacques Coeur közvetítésével 1446-ban békét kötött a johannitákkal. ${ }^{210}$ Azt tudnunk kell, hogy Jaqmaq továbbra is békés viszonyra törekedett az Oszmánokkal, 1451 májusában például üdvözlő követséget indított az oszmán II. Mehmed szultánhoz hatalomba lépése alkalmából. $^{211}$

A mameluk és az oszmán-török állam egymáshoz való külpolitikai viszonya sajátos kettősséggel jellemezhető. Egyrészt, mindkét nagyhatalomnak „közös” érdekeltsége volt Anatóliában. Elsősorban Kis-Ázsia déli és keleti felében, a türk fejedelemségek egymás közötti kisebb konfliktusaiban - közvetetten - egymás vetélytársai voltak. Főleg a Timur Lenk fia, Sah Ruh vezette mongol birodalom térnyerése és a türk fejedelemségek miatt. Mind Bays-bar, mind pedig II. Murád oszmán szultán idejében e két nagyhatalom háborúkat folytatott e térségben. Azonban, ha csak a külpolitikai-gazdasági-kereskedelmi célokat tekintenénk, nem értenénk meg a legfőbb vezérlő vallási indokokat, azaz, hogy amikor Jaqmaq békés viszonyt teremtett meg Sah Ruh-hal, az iszlámot fenyegető keresztény támadás esetén az Oszmánokat támogatta! Láttuk, hogy ugyanígy lépett fel az iszlám vallás védelmében az európai-etiópiai keresztény összefogás ellen is. Tette mindezt azért, mert a mameluk és oszmán szultánoknak közös érdekük volt a keresztesek és/vagy a keresztény kalózok elleni háború a Mediterráneum keleti részében. Így Robert Irwin véleményével teljesen egyetérthetünk, hogy a mameluk állam az Oszmán Birodalom ellen - ezen időszakban - ezért nem folytatott egymással közvetlen háborút, csupán kis-ázsiai vazallusaik háborúztak. ${ }^{212}$

\footnotetext{
${ }^{209}$ Rossignol 1991. 92-93; Natho 2009. 212; Irwin 1995. 249. A hadjáratokra vonatkozó arab forrásokat, különösen Ibn Taghrībirdī-t lásd: Sami G. Massoud: The Chronicles and Annalistic Sources of the Early Mamluk Circassian Period. Leiden (Brill) 2007. 60-65 (Massoud 2007); History of Egypt. A. D. 13821469, A. D. 1382-1399. Abū Al-Mahāsin, Yūsuf Ibn Taghrībirdī. California 1958. 93-94. (History of Egypt 1958)

${ }^{210}$ Withworth 1858. 317; Irwin 1995. 249.

${ }^{211}$ Natho 2009. 213.

${ }^{212}$ Irwin 1995. 250.
} 
A mameluk-oszmán külkapcsolatok 1444-ben is összehangoltnak tünnek. II. Murád 1444-ben az európai színtéren, Várnánál a keresztények felett győzelme után az egyiptomi mameluk szultánnak győzelmi iratot (fetihnâme) küldött. ${ }^{213}$

A rodoszi haderő mamelukok általi „kiiktatását” pedig azért érdemes figyelembe venni, mert Rodosz, Konstantinápoly 1453. évi oszmán-török elfoglalása után a kereszténység legkeletibb őrállása volt a növekvő Oszmán Birodalom szívében. Lastic nagymester tudatában volt annak, hogy Konstantinápoly eleste után hamarosan Rodosz fog következni, amikor segítséget kért a keresztény államoktól. Utódjának, Pierre d'Aubosson nagymesternek (1476-1503) ezzel kellett szembenéznie. 1480-ban II. Mehmed szultán megpróbálta Rodoszt elfoglalni, de kénytelen volt visszavonulni. ${ }^{214}$ Ezt a sikert a város elsősorban korszerü erődjének köszönhette. Az erődöket az alábbiakban részletesen fogjuk megvizsgálni.

${ }^{213}$ İnalcik-Oğuz 1989. 82. (4. lábjegyzet)

${ }^{214}$ Spiteri 1994. 69. 
„ez a magasba nyúló vár,

a magasan röpülö sas nem szállhat át fölötte,

árka a föld gyomráig lenyúlik,

bástyái a Fiastyúk csillagzatig érnek."

(Lutfi pasa, nagyvezír)

\section{Elődök és erődök: A vár középkori újjáépítései}

\section{1. A bizánci Belgrád}

Nándorfehérvárt (Belgrád) elsősorban földrajzi-stratégiai helyzete emelte ki. Egyrészt a Duna és a Száva folyó találkozása évszázadokon át meghatározó súlyúvá emelte, mert a dunai vízi út kereskedelmi-hadi ellenőrzését tette lehetővé. Másrészt egy fontos ókori római transz-balkáni szárazföldi út állomása volt e hely, amely Belgrádig vezetett Byzantium-Konstantinápolyból a város érintésével a Duna partján felfelé és vissza. ${ }^{215}$ Ezen az útvonalon közlekedhetett az a bizánci követjárás, amely Attila hun nagykirályhoz indult, és amelyet Priszkosz rhétór örökített meg. ${ }^{216}$ De valószínü, hogy ezen az úton jutott el Bulcsú harka is VII. (Bíborbanszületett) Konstantín bizánci császár (945-959) udvarába. ${ }^{217}$ A középkorban pedig nemcsak a keresztes hadjáratok fő szárazföldi útvonalaként szolgált, ${ }^{218}$ hanem még a 15. században, 1433-ban a burgundiai Bertrandon de la Brocquière lovag, tanácsos és fökonyhamester - útleírása szerint - ezen az útvonalon érkezett Konstantinápolyból Nándorfehérvárba. ${ }^{219}$ 1443-ban Hunyadi János téli hadjárata is ezt az útvonalat követte.

A vár középkori (újra)építésében elöször a 12. század közepén végzett bizánci munkálatok voltak jelentősek, mégpedig Zimony körüli harcok alkalmával. Erről bizánci

${ }^{215}$ Ennek kezdete Konstantinápoly, majd Drinápoly (Adrianopolisz), a Marica-folyó völgye, Philippopolisz (a mai Plovdiv), majd megkerülve a Rila-hegyet Szerdika (a mai Szófia), Naisszusz (a mai Niš), Moravafolyó völgye, egészen a Dunáig, majd Belgrád, felfelé a Duna mentén. Dimitri Obolensky: A Bizánci Nemzetközösség. Varia Byzantina IIII. Ford. Bódogh-Szabó Pál, Budapest 1999. 33-35; (A továbbiakban: Obolensky 1999) Barta 1985. 6-7.

${ }^{216}$ R. C. Blockley: The fragmentary classicizing historians of the later Roman Empire. II. Text, translation and historiographical notes. Liverpool 1983. 248-250. A továbbiakban: Priscos 1983.

217 Szabó Pál: Karó vagy bitófa? A bizánci források jogi szóhasználatáról Bulcsú kivégzése kapcsán. In.: Középkortörténeti Tanulmányok 7. Szeged, 2012. 547. (Szabó 2012a)

218 Obolensky 1999. 36.

${ }^{219}$ Régi utazások Magyarországon és a Balkán-félszigeten. Összegyüjtötte és jegyzetekkel kísérte Szamota István, Budapest 1891. 49-78 (A továbbiakban: Szamota 1891); The travels of Bertrandon de la Brocquière. In.: Early travels in Palestine. London 1848. 283-383. (A továbbiakban: Brocquière 1848) 
források is beszámolnak. Joannész Kinnamosz bizánci történetíró ${ }^{220}$ szerint II. István (1116-1131) (1127 körül) megostromolta a bizánci kézben lévő Belgrádot és „,mikor pedig elfoglalta, földig leromboltatta, a köveket hajóval elvitette, s azokból Sirmionban Zeugmé városát emelte" (Moravcsik Gyula fordítása). ${ }^{221}$

II. Géza idején (1141-1162) Komnénosz Manuél császár (1143-1180) 1150/1151-es hadjárata alkalmával átkelt a Dunán ${ }^{222}$ és „a folyó túlpartján volt egy Zeugminon nevü erőd, mely falai szilárdsága és egyébkénti biztonsága folytán meglehetősen erös volt" (Moravcsik Gyula fordítása). ${ }^{223}$ Amikor az ostromlott védők megadták magukat, Manuél császár visszahordatta a köveket Belgrádba. ${ }^{224}$ A bizánci típusú erőddé felépített Belgrádról a szerző úgy emlékezett meg, hogy „E várost, mint mondják, Zeugminon lerombolása után a római sereg (t. i. a bizánci) építette fel, de részt vettek a munkálatokban sokan a hunok (t. i. a magyarok) közül is" (Moravcsik Gyula fordítása). ${ }^{225}$ IV. István (1163-1165) 1164/1165-ben ismét ostrom alá vette Zimonyt, a halála után el is foglalták, de Manuél ismét visszafoglalta. ${ }^{226}$

Ekkor az éppen megújuló magyar ostromtámadások miatt, Manuél bizánci császár figyelme a Duna-Száva menti északnyugati „frontier” zónára összpontosult és alapvetően védekező jellegü volt. A bizánciak megerősítették a Duna-vonalán Zimonyt, Braničevo-t (Barancs) és Niš várát a Morava-folyón. ${ }^{227}$ Kalić szerint is ebbe a sorba illik bele, hogy egy teljesen új erődöt építettek a 12. század közepén Belgrádban, bár ez az erőd sokkal kisebb volt, mint a megelőző, antik eredetű védőfalak. Azok ugyanis téglalap alaprajzot formálva, kb. 200 x 300 méteres védősáncok voltak. ${ }^{228}$ Az építkezés annál is sürgetőbb volt, mert ezeket az ókori eredetü falakat többször lerombolták és a 6. században már csak megerősített földsáncokból állottak. Theophülaktosz Szimokattész bizánci történetíró is

220 Joannész Kinnamosz XII. századi bizánci történetíró, aki Manuél császár titkára, aki elkísérte urát hadjárataira. Így részt vett Zimony 1165. évi ostromában is. Ránk maradt történeti műve 1176-ig tárgyalja az eseményeket. Moravcsik 1934. 189.

${ }^{221}$ Az Árpád-kori magyar történet bizánci forrásai. Összegyüjtötte, fordította Moravcsik Gyula. Budapest 1988. 196. A továbbiakban: ÁMTBF. Lásd részletesen: Makk, Ferenc: The Árpáds and the Comneni. Political relations between Hungary and Byzantium in the 12th century. Budapest 1989. 24. A továbbiakban: Makk 1989.

${ }^{222}$ A kronológiai problémákra lásd: Makk 1989. 54-55.

223 ÁMTBF. 205.

224 ÁMTBF. ,azután Manuel császár uralkodása idején -mintegy viszonzásképpen-alapjáig elhordták, s az egész Belgrád város falainak felépitésére szolgált" (Moravcsik Gyula fordítása).

225 ÁMTBF. 217.

226 ÁMTBF. 234.

${ }^{227}$ Makk 1989. 92.

${ }^{228}$ Paul Stephenson: Manuel I Comnenus and Geza II: A revised context and chronology for HungaroByzantine relations, 1148-1155. Byzantinoslavica Tome LV (1994) Fasc. 2. 268. Továbbiakban: Stephenson 1994. 
többször beszámol Belgrád akkori ostromáról az avar „fronton” (I. 4, 1; VI. 4, 1; VII. 10, $1)^{229}$

Az új bizánci erődöt teljesen kőből és az egykori római védőfalak északnyugati sarkába építették fel, kihasználva a Duna által kialakított, meredek sziklás felszínt. Azonban az egykori védősáncon belüli települést ezek az új bizánci falak már nem védték. A bizánci örségre is csak az erőd védelme volt rábízva, nem pedig a kiterjedt lakott településé. Az erőd pedig el volt különítve az egyesült városi közösségtől, csupán hatósági, közigazgatási és katonai központ volt. ${ }^{230}$

A bizánci Belgrád vára tehát sokkal kisebb volt, de a környező vidéket fellegvár módjára azért uralhatta. Az erőd bejárata a keleti végén volt, délről pedig mély vizesárok és egy nagy, négyszögletű torony védte, amely a meredek lejtőre nézett a folyó felé, ahol az egyetlen fö iránya volt az ellátásnak. A déli falak és a tornyok már „,szegényesebben” épültek. Megmunkálatlan kövekböl készültek, esetenként ún. kettös téglasor rétegekkel (rekeszes vagy vegyes falazás) váltakozva azért, hogy a falak még magasabbak legyenek. Mindezeket erös, meszes habarccsal kötötték össze. A falak 2, 6-2, 8 méter vastagságúak voltak. ${ }^{231}$ A belülről félkör alakúnak látszó, valójában sokszög alakú (poligonális) tornyok egymástól 30 méteres távolságban sorakoztak. A tornyok falvastagsága 2, 2-2, 5 méter volt. A déli falat mély árok védte az egykori, antik sáncokon belül. Ezzel ellentétben a nyugati oldalon lévő tornyok kifaragott kőtömbökből épültek, itt-ott téglákkal vegyítve. Ez érthető is, mert a nyugati falak voltak a legkevésbbé kitéve a támadásoknak. Ebből az irányból ugyanis semmilyen megközelítés nem volt lehetséges, az itt lévő legmeredekebb sziklás lejtő miatt. Tulajdonképpen ez a kiszögellés egy markáns hegyfok, ahol a Duna irányt vált és délre fordul. Ez a rész a folyóról ma is a legjobban látható, még a Duna szemközti partján lévő Zimonyból is. Belgrád bizánci erődje általában a Manuél-féle várépítkezési sajátosságokat mutatja. Más várak is elsősorban kőtörmelékből épültek, téglasorokkal vegyítve. ${ }^{232}$ Belgrád erődjének építési ideje Manuél császár uralkodási idejének első felére tehető, Stephenson szerint - a feltárt bizánci pénzleletek datálása segítségével - nagyjából az 1150-1160 közötti időszakra. ${ }^{233}$

\footnotetext{
229 Stephenson 1994. 268; Theophülaktosz Szimokattész: Világtörténelem. Fordította, a bevezetést és a jegyzeteket írta Olajos Teréz. Budapest 2012. 78, 218, 252. A továbbiakban: Theophülaktosz 2012.

230 Stephenson 1994. 268-269.

${ }^{231}$ Stephenson 1994. 269.

232 Stephenson 1994. 270; C. Foss-D. Winfield: Byzantine Fortifications, an introduction. Praetoria 1986. 149.

${ }^{233}$ Stephenson 1994. 271.
} 
Ez a bizánci típusú kisebb erőd a 13. század során is gyakran cserélhetett gazdát egészen a 15. század elejéig. Nándorfehérvár az Anjouk Magyarországa, I. Károly és I. (Nagy) Lajos királysága (1342-1382) idején játszott újra tevékeny szerepet a térségben. ${ }^{234}$ I. Károly II. Uroš királytól (1282-1321) foglalta el az észak-szerbiai területeket, Macsó várát és 1319 körül Nándorfehérvárt és e terület élére macsói bán címmel helytartót állított. ${ }^{235}$ Ekkoriban indultak meg a Bizánci Birodalomtól függetlenedni akaró szerb elszakadási kísérletek is, amelyet Dusán István (Stefan Dušan) (1332-1355) uralkodása fémjelzett. 1353-ban elfoglalta Macsót és Nándorfehérvárt. Dusán fia, Uroš király (13551371) nem sokáig birtokolta, mert I. Lajos magyar király 1359-ben átkelt a Dunán és visszafoglalta e területeket. ${ }^{236}$ A vár (,,nulladik”) ostromát a 14. század végén megkísérlő I. Bayezid szultánnak is ezzel a várral kellett szembenéznie. A város erődített várossá való kiépítéséig a 15. századig első feléig kellett várni. ${ }^{237}$

\section{2. A 15. század eleji újjáépítés:}

\section{A főváros Belgrád Lazarević István korában}

A 15. század elején nagyarányú átépítések történtek, amelynek jelentős mértékét a korábbi, szerényebb bizánci építkezésekkel összehasonlítva értékelhetünk igazán. Így lett érvényes az, amit Giovanni da Tagliacozzo 1456 után pontosan megfogalmazott: „Ez a vár végvára az országnak, s mintegy fö kapuja a magyar földnek, melyen a legkönnyebben juthatni az országba. ${ }^{, 238} \mathrm{~A}$ Nándorfehérvárhoz vezető út tulajdonképpen az oszmán sereg felvonulási útját képezte Drinápolytól kiindulva. Az 1440. évi ostrom előtt, 1432-ben járt erre Bertrandon de la Brocquière lovag is láthatta a vár megerősítését, felszerelését. ${ }^{239}$ A lovag már korabeli leírást adott a várról és környékéről. ,, azelőtt a despotáé volt, ki azt négy évvel ezelött a magyar királynak engedte át, nehogy a török hatalmába jusson, mint Galambócz (Coulumbach) "240 A földrajzi fekvését ismertetve kiemeli, hogy „A két folyó által képezett csúcsban vagy szögletben terül el ez a város." 241

\footnotetext{
${ }^{234}$ Pálosfalvi 2010b. 6.

${ }^{235}$ Engel Pál: Magyarország világi archontológiája. I. kötet. Budapest 1996. 27. A továbbiakban: Engel 1996. Heka 2005. 31.

${ }^{236}$ Heka 2005. 34.

${ }^{237}$ Lásd a 13. 3. fejezetet.

${ }^{238}$ Idézi: Cseh 2007. 6

${ }^{239}$ Wertner 1911. 436.

${ }^{240}$ Szamota 1891. 78-79.

${ }^{241}$ Szamota 1891. 79.
} 
A korabeli Nándorfehérvár rekonstrukcióját legutóbb - az 1456. évi ostrom kapcsán Cseh Valentin mintaszerüen elvégezte. ${ }^{242}$ Nándorfehérvár várának korszerü kiépítésében Lazarević Istvánnak elévülhetetlen érdemei voltak. Az ő célja nem csupán a bizánci erőd, hanem - az egykori római falak nyomvonalát követve - a város teljes védelme volt.

Miután Lazarević István Zsigmond királytól megkapta a várost, a Szerb Despotátus (Српска Деспотовина) fővárosává tette és megkezdte az addigi vár helyreállítását és jelentős kibővítését. ${ }^{243}$ Meg kell jegyezni, hogy a vár építését - mintegy robotkötelezettségként - mindenki számára elrendelte, és ez alól csak egyes esetekben adott felmentést. E városépítési kötelezettség értelmében a falusiakat messziről is behozták a fővárosba. Jól mutatja ezt az is, hogy Lazarević még halála előtt, 1427. január 20-án kelt oklevelében három falut minden kötelezettség alól felmentett, de a hadi szolgálatban és Nándorfehérvár építésében részt kellett venniük. ${ }^{244}$

Lazarević munkálatainak eredményéről fontos forrásunk a despota életrajzírója, a tanító és diplomata Konstantin Filozófus (Konstantin Kostenečki). ${ }^{245}$ A despota életéröl írt müvében ezzel kapcsolatban kihangsúlyozta Belgrád természetes fekvésének előnyeit (Žitije despota Stefana Lazarevića). A folyók, amikor ostrom alatt van a város, bármilyen nagyszámú is az ellenség, a védőket könnyen megsegíti és lehetőséget ad a hirtelen kihajózásra és támadásra. ${ }^{246}$ Bibliai hasonlatokkal dicsérte a védőtornyokat, amelyeket a despota építtetett. A város falainak védelme ezáltal olyan erős lett, mint Salamon falai, amelyek Jeruzsálemet körülövezték, vagy mint Babilón toronnyal megerősített kapuja volt. Ugyanakkor a despota jól megerősíttette a várost a kettős falon kívül, sok, jól elhelyezett árkokkal is. A filozófus Belgrádot egyenesen a bibliai Jeruzsélemhez hasonlította. Indokait pontokba sorolva ismerteti. Először is a város éppolyan nagy és gyönyörü, hogy úgy tünik, hét dombon terül el, mint Jeruzsálem. Másodszor a folyó miatt emlkeztet erre, a város északi oldalán, ahol a kikötő helyezkedik el. Harmadjára Belgrád jól megerősített kikötője miatt, amely az uralkodó hajóinak biztonságát adja. Negyedszer a Nagy [Lakó] torony miatt, amelynek az építménye, várárka és elhelyezkedése Dávid házához hasonlatos. Ötödször, azért hasonló Jeruzsálem városához mert, ha a Nagy Lakótornyon átmegyünk

\footnotetext{
${ }^{242}$ Марко Поповић: Београдска Тврђава. Београд 1982, Marko Popović: Fortress of Belgrade. Belgrade 1991. munkája alapul vételével. A http:// www.belgradexv.com weboldalon a középkori Belgrád építészek által rekonstruált képe tanulmányozható.

${ }^{243}$ Калић-Мијушковић 1967. 95-101; Калић 2001. 81-85; Гузина 2002. 15.

${ }^{244}$ Калић-Мијушковић 1967. 95

${ }^{245}$ Гузина 2002. 17.

${ }^{246}$ Constantine of Kostenets: Life of Despot Stephen Lazarevic. In.: Kiril Petkov: The Voices of Medieval Bulgaria, Seventh-Fifteenth Century: The Records of a Bygone Culture (East Central and Eastern Europe in the Middle Ages, 450-1450) Leiden 2008. 406, 12-14. A továbbiakban: Petkov 2008.
} 
éppúgy a királyi kincstárt találjuk. Hatodszor, mert keletre nézve éppolyan oszlop választja el a két tornyot. Hetedszer nyugat felé található a második uralkodói épület. ${ }^{247}$

A bibliai párhuzamok szavai mögött azonban jól kivehető a korabeli Belgrád megerősítésére vonatkozó információ, elsősorban a Felsővárosra vonatkozóan. A Felsőváros - azaz a Vár - négy kapuja a négy égtáj felé néz, és egy ötödikkel kapcsolódik az Alsóvároshoz. A déli és a keleti kapuk hatalmasak, óriási tornyokkal, valamint a várárkon átívelő felvonóhíddal. A nyugati és az északi kapuk kisebb méretüek és híddal vannak összekötve az Alsóvárossal a folyón át. Annak a kapunak, amelyik a Fellegvárba vezet, szintén van felvonóhídja a várárkon át. A vár egyedül a déli oldalon megközelíthető, mert a folyók az északi, nyugati és keleti oldalán jól megerősítik. A város keleti felében a metropolita temploma található, amelyhez fogható gazdagságút - Konstantin Filozófus szerint - egész Szerbiában nem találni. A despota egy betegeknek szolgáló ispotályt és egy templomot is építtetett, amelyet a csodatévő Szent Miklósról nevezett el. ${ }^{248}$

Cseh Valentin szerint az 1404 és 1427 közötti építkezései során épült ki korszerü erőddé Nándorfehérvár vára. ${ }^{249}$ Ezt azért fontos a vár védelmével kapcsolatosan kiemelnünk, mert az ostromtüzérség megjelenése megkövetelte a falak átépítését és megerôsítését. Európában a leggyakoribb módszerek a várfalak belső oldalának földdel való megvastagítása, a magasságuk csökkentése, az ágyúgolyók ütését elnyelő földtöltések, támpillérek alkalmazása, a várfalnál magasabb ún. toronybástyák helyett alacsonyabb, a falmagassághoz igazodó, vaskosabb bástyák építése és a kaputornyok alkalmazása voltak. Az átlagos falvastagság pedig 1, 6-2, 6 méter volt. ${ }^{250}$

Lazarević építkezése követte ezeket az európai hadászati-várépítészeti változásokat. Ehhez az anyagi forrásokat elsősorban az ország nemesfémbányáiban találta meg. A kereskedők is özönlöttek a bányászközpontokba, föként a raguzaiak, akik az ércért finom kelméket és élelmet szállítottak. Konstantin filozófus szerint a despota úgy is ösztönözte a kereskedést, hogy egy aranybullával megerősített kiváltságban biztosította az idegen kereskedőknek - ha belgrádi polgárokká akartak lenni - az adó- és vámmentességet az egész országban! Emiatt a szomszédos uralkodók kereskedői Belgrádba települtek és rövid

\footnotetext{
${ }^{247}$ Petkov 2008. 407.

248 Petkov 2008. 407-408.

${ }^{249}$ Cseh 2007. 49

${ }^{250}$ Szántó Imre: A végvári rendszer kiépítése és fénykora Magyarországon 1541-1593, Budapest, 1980. 28. (A továbbiakban: Szántó 1980) Gerő László: Jellegzetes építési korszakok és ezek történeti előzményei az európai várfejlődés keretében. In.: Várépítészetünk, főszerkesztő: Gerő László, Budapest 1975. 14, 25, $29,35,37$.
} 
idő alatt a város elnépesedett. ${ }^{251}$ Valószínűleg a Raguzából Belgrádba áttelepülő Tallócitestvérek is élvezték e kereskedelmi kiváltságot.

A kereskedelmi vámok is a despotát gyarapították. Lazarević fontosnak tartotta a városok, a bányászat fejlesztését. ${ }^{252}$ Szerbia legnagyobb bányászati központja a novo brdoi szerb bányaváros, amely Európa legfontosabb ezüstbányája volt a török hódításig. Itt szakképzett bányászok dolgoztak. Brocquière szerint Novobrdo (Nyeuberg) városában lévő arany és ezüstbányák kb. 200000 arany hasznot hoztak, Konstantin pedig egyenesen ezüst- és aranyvárosnak nevezte. ${ }^{253}$ Hogy mennyire fontos volt e bányaváros birtoklása a törököknek is, azt jól mutatta, hogy az 1440-es nándorfehérvári ostrom után, 1441. június 21-én Szehabeddin ${ }^{254}$ ruméliai beglerbég foglalta el. ${ }^{255}$

Lazarević István 1404 és 1410 közötti első szakaszban bővítette ki a Fellegvárat és a Vízivárost. Majd 1410 táján tíz éven át a Felsőváros erődítéseinek megépítése folyt. 1420 körül, egészen Lazarević haláláig az Alsóváros került kiépítésre. ${ }^{256}$ A vár 15 . századi állapotát Marco Popović-Cseh Valentin térképén mutatom be (1. melléklet).

Minden egykori vár mai falmaradványainak, falak hiányának tanulmányozásához nélkülözhetetlen a légi felvétel. A vár alaprajzát - mai állapotában és nyomaiban müholdfelvételeken lehet nyomon követni (2. melléklet).

A Felsővárosban eredetileg 11 magas torony állt falakkal együtt, a déli kapu Konstantinápoly felé nézett. ${ }^{257} \mathrm{~A}$ várfalak nem pontosan észak-déli tájolásúak és megkettőzöttek.

Az északnyugati fal kettős falrendszerének maradványa ma is jól vizsgálható. A kettős falrendszer egyébként korszerü és ismert volt Európában. ${ }^{258}$ Már Konstantinápoly védelmi rendszerének külső fala 2 méter, a belső fala 4, 8 méter vastag volt. ${ }^{259}$ A nándorfehérvári kettős falat még egy várárokkal is kiegészítették, amely tulajdonképpen háromszoros védelmi vonalat alakított ki. Ezt Brocquière is leírta: „A fekvésénél fogva rendkívül erös

${ }^{251}$ Petkov 2008. 408, 15-22.

${ }^{252}$ Cvetkova 1988. 41.

${ }^{253}$ Szamota 1891. 74.

${ }^{254}$ Melléknevének jelentése: Kule Sahin=Barna Sólyom. Generál 1987. 55.

${ }^{255}$ Историја српског народа II. Београд, 2000. 252. A továbbiakban: Историја 2000.

${ }^{256}$ Cseh 2007. 49. követve Popović korszakolását.

${ }^{257}$ Cseh 2007. 52.

${ }^{258}$ A többszörös védelmi rendszer legjobb középkori mintája Konstantinápoly Kr. u. V. századi erődítése volt. II. Theodosius császár építkezése által a város fö vagy belső fala 96 nagy toronnyal tagolt, a külső szintén 96 kisebb toronnyal, elötte a 18 méter széles és 7 méter mély árokkal. Spiteri 1994. 4.

${ }^{259}$ Csiky Gergely: Konstantinápoly városfalai és a 626. évi avar ostrom. In.: Középkorténeti tanulmányok 7. Szerk.: Kiss P. Attila, Piti Ferenc, Szabados György. Szeged 2012. 168-169. A továbbiakban: Csiky 2012. 
várat árok és kettös fal veszi körül, mely pontosan követi a talaj vázlatát." ${ }^{260}$ A helyszíni méréseim (2012. április 20) alapján az északnyugati belső fal vastagsága 1, 6 méter, a külső falé pedig 3 méter volt. Ez összesen 4, 6 métert tesz ki. A külső fal alacsonyabb és vastagabb, mint a belső. A két fal közötti részt pedig jól láthatóan földdel töltötték fel, amelynek szélessége kb. 3 méter, a falak között alig változik (3. melléklet). A két fal között a földet a külső fal szintjéig töltötték. Az így - a falak közötti földtöltéssel összesen 7, 6 méter szélességü - megerősített fal jobban felfogta és elnyelte az ágyúk lövéseit, anélkül, hogy jelentősen leomlott volna. Méréseim egybecsengnek Cseh Valentin megállapításával, aki szerint a falak átlagosan 5 méteresek voltak. A többi 3 oldal, az északkeleti, a délkeleti, a délnyugati fal kettős falövben folytatódott, amelyet 1410 és 1420 között építettek. ${ }^{261}$

A vár falainak 15. századi állapotát ma legjobban az északkeleti falon tudjuk megvizsgálni, mert ez maradt meg a legjobb állapotban a későbbi átépítések során. Lazarević építkezései idején a régi várfalakat itt megmagasították és a várfalat kívülről külső támfallal jelentősen megvastagították és megerősítették, hogy ellenálljon az ekkoriban megjelenő ostromágyúk tüzerejének (4. melléklet). Nem véletlenül, mert ezen az oldalon volt legjobban kitéve a vár a szárazföldi ostromnak.

Nándorfehérvár kiépítésében a 15. századi, egyes falszakaszokon a bizánci építészetre jellemző erődépítési módszert is felfedezhetünk, az ún. vegyes vagy rekeszes falazás nyomait, amely a 12. századi várban is megvolt. A vegyes falazás azt jelentette, hogy a várfal kövei közé kisebb-nagyobb vízszintes távolságban téglasorokat is beépítettek. Bár nem rétegenkénti szabályossággal, de az ekkoriban épült Despota kapujánál láttam téglákat is beépítve a kőfalba (5. melléklet). Ennek funkciója többek között az volt, hogy rugalmasságot adjon a falnak. Különösen a földrengések vagy az ostrom során a kitartó ágyúlövések esetén. ${ }^{262}$

A nándorfehérvári védőfalakat a várfal szintjéről kiugró tornyokkal tagolták. Ezek ún. külső tornyos rendszerủek, lehetőség volt a tornyokból az oldalazásra, a szomszédos tornyok kölcsönös megvédésére. A tornyok száma igen nagy lehetett. Ezek közül mára a helyszínen csak néhány tanulmányozható. A tornyok eredetileg négyszög vagy félkör alakúak lehettek. A legjobb példája ma az északkeleti és az északnyugati fal találkozásánál 1404 és 1427 között felépített Despota kapujánál, egy félkör alakú kiugró torony, a

\footnotetext{
${ }^{260}$ Szamota 1891. 79.

${ }^{261}$ Cseh 2007. 52.

${ }^{262}$ Csiky 2012. 169.
} 
Dizdar-torony (6. melléklet). ${ }^{263}$ A fal vastagsága itt 1, 5 méter. Ez a torony ugyanakkor érdekes, U-alaprajzú, amely - akár csak a sokszögletü tornyok - egyesíti magában a körés a négyszögletü-tornyok előnyös tulajdonságait. ${ }^{264}$ Azaz, hatásosan lecsökkenti a négyzet alakú tornyok be nem látható, „holt tereit.”

Sajnos a tornyok legtöbbjét csak későbbi leírásokból, metszetek ábrázolásaiból ismerjük. Így például a 16. századi Wolfgang Resch, a 17. századi J. G. Gump, Giacomo de Rossi, a 18.századi Johann Martwil, K. Veimosauch metszeteiről. A délkeleti falon volt a Vár főbejárata: a Déli kapu 2 toronnyal közrefogva, felvonóhíddal ellátva. ${ }^{265}$

Konstantin Filozófustól tudjuk, hogy Lazarević megerösítette a Fellegvárat is, az egykori bizánci erődöt, mert ide helyezte saját székhelyét, a királyi lakosztályt. A Fellegvár ekkor két részre tagolódott és mély árok választotta el a Felsővárostól. A Nagy Lakótorony neve lehetett a „Ne bojsa” (=Ne félj!) a királyi lakosztállyal, amelynek méretei nem ismertek, mert 1717 után, a törökellenes háború után lebontották és nem azonos a mai ilyen nevü toronnyal. Az udvaron át a Nagy Lakótorony mögött volt a Belsővár vagy „harmadik vár", ahonnan -menekülés esetén- titkos ajtó vezetett a Dunára és a városba. A Fellegvár vízellátása a Dunából és az Alsóvárosból történhetett. ${ }^{266}$

A Fellegvárral együtt építette ki Lazarević István a Vizivárost. Ez tulajdonképpen a Nyugati Alsóváros, amely a Száva partjáig ér. Kikötőjét tornyokkal védték. Az egyik tornya a folyómederbe épült, alatta átfolyt a Száva és egy vízimalmot müködtetett. A Malomtorony nevét innen kapta. Brocquière a kikötőben és a folyón gályákat is látott. „A mintegy 15-20 gálya befogadására képes kis kikötöt két torony védi, az egyik toronytól a másikig húzódó lánczczal az egész könnyen elzárható. Ezt azonban csak hallomásból tudom...A Száván hat gályát és öt naszádot láttam. "267 A Vízivárost partmenti fal és északi oldalról is fal védte. Az északi fal tornyokkal oltalmazta a Fellegvártól a Malomtoronyig terjedő szakaszt. A déli fala viszont kettős falrendszerü lett, amely a Fellegvárig és a Felsőváros délnyugati kettős faláig húzódott. Mára a Víziváros nem maradt fenn. ${ }^{268}$

Nándorfehérvár legnagyobb része az Alsóváros, maga a város, amely a Duna felőli parttól a Felsővárosig és a Vízivárosig terjedt. A Duna partján végig tervezték egy fal építését, de nem tudjuk, hogy ez Lazarević idején elkészült-e. Itt volt a város

\footnotetext{
${ }^{263}$ A dizdar, dézdár szó törökül várparancsnokot jelent. A torony későbbi elnevezése lehet. Ilyen értelemben szerepel például Zrinyi Miklós: Szigeti veszedelem címü munkájában (VII. ének 26. vers). Zrínyi Miklós: Szigeti veszedelem, Az török áfium ellen való orvosság. Budapest 2009. 117, 316. (Zrínyi 2009)

${ }^{264}$ Spiteri 1994. 11.

${ }^{265}$ Cseh 2007. 54-57.

${ }^{266}$ Cseh 2007. 62.

${ }^{267}$ Szamota $1891.79-80$.

${ }^{268}$ Cseh 2007. 63-64.
} 
leggyengébben megerődített része, mert maga a Duna is védte. Az Alsóváros főbejárata a keleti kapu, amely megsérülhetett az 1440. évi ostrom során a tüzfegyverektől, mivel később Hunyadi és Újlaki e kapu védelmére építtetett 2 félkör alapú külső tornyot (barbakán), amely 1456-ra már készen volt.

Az Alsóvárosban élt a lakosság, az iparosok és a kereskedők. Itt volt a piactér, a görögkeleti érseki palota és a nándorfehérvári püspöki székesegyház. Nándorfehérvár katolikus püspökei ez idő tájt főleg ferencesek voltak. ${ }^{269}$

A lakosság összetétele vegyes volt. Bár sok magyar telepedett itt le, a lakosság többségét szerbek és raguzai kereskedők alkották. Innen kerültek ki a Tallóci fivérek is. ${ }^{270}$ Brocquière elöször elcsodálkozott, hogy Tallóci Matkó akkori várkapitány 25 felfegyverzett németet hozatott a vár védelmére, nem pedig helybelieket vagy magyarokat. „Erre a következö felvilágositást kaptam: a szerbek a törökök alattvalói és adófizetői lévén, óvakodni kell tölök, a magyarok pedig annyira remegnek tölök, hogy ha a török megjelennék, nem mernék ellene védni bármily erös legyen is a vár. Ezért tehát idegeneket kellett hívni. ${ }^{271}$ A szerb szakirodalom szerint is bár a Felsővárosban volt a magyar hadsereg, ez elkülönítve állomásozott, mert a szerbeknek nem volt szabad ide bemenniük. Zsigmond király ugyan próbálkozott magyar lakosság betelepítésével, de az Alsóvárost többségében szerbek lakták. ${ }^{272}$

Lazarević halála után, a tatai szerződést követően, a Tallóciak folytatták a vár kiépítésének munkálatait, amelynek következő szakasza 1427-től az ő irányításukkal történt egészen az 1440. évi ostromig. A Tallóciak építkezéséről viszont alig van adatunk. Ennek tekintetében különösen érdekes lehet, hogy az ostrom elött három évvel, 1437-ben raguzai mestereket fogadtak fel. ${ }^{273}$ Olyanokat, akik a téglaégető kemence üzemeltetéséhez értettek. Valamint a ciszternák és boltívek építéséhez értő kőművesmestert is. Mivel a falak építéséhez szükséges kő a bányászással nehézségekbe ütközött, a vár alapjait bonthatta volna meg, így azt égetett téglákkal pótolták. Ezt bizonyíthatják az előbb említett rekeszes vagy vegyes falazási technika maradványai a várfalakban.

\footnotetext{
269 1419. május 30-tól Nekcsey Gergelyt, 1420. augusztus 30-tól Csapai Mátét, 1429. február 8-án János fia Balázst választotta a király és a pápa nándorfehérvári püspökké. Dr. Karácsonyi János: Szt Ferenc rendjének története Magyarországon 1711-ig. I. kötet, Budapest 1922. 56. (Karácsonyi 1922)

${ }^{270}$ Cseh 2007. 66-67.

${ }^{271}$ Szamota 1891. 81.

272 Бранко Вујовиђ: Београд у прошлости и садашњости. Београд, 2003. 29. (Вујовиђ 2003)

${ }^{273}$ Mályusz 2003. 150; Cseh 2007. 50.
} 


\section{3. Raguza, Rodosz erődített városai a 14-15. században}

Önmagában véve nem kielégítő azonban a fenti építési adatokat ismernünk. Nándorfehérvár 15. századi kiépített állapotában a korszerü, európai erődített városok sorába illeszthető. Akkor tudjuk valójában megítélni az értékét - és ezáltal alaposan megítélni az 1440. évi ostrom visszaverésének sikerét is - ha Nándorfehérvár erődjének erejét összehasonlítjuk a korabeli Európa néhány jelentős erődített városával, erődjével. A magyar szakirodalomban eddig - főleg 1456 kapcsán - a vár kiépítettségét önmagában vizsgálták. Ezért a továbbiakban tágítjuk a látókörünket olyan irányba is, amely közvetlenül vagy közvetetten - kapcsolatba hozható Nándorfehérvár 1440-es ostromával.

A középkori Raguza (a mai Dubrovnik) szilárd falaival jól megerősített város és vár is egyben, amely Európában szinte a legjobb állapotban maradt ránk. A város vizsgálódásunk tárgyát azért képezi, mert a Nándorfehérvárt védő Tallóci-testvérek kezdetben Raguzai-nak nevezték magukat az okleveleikben. Látniuk kellett a város erődítésének megoldásait, a falak megerősítését és e tapasztalatokat magukkal hozhatták, amikor Lazarević István Nándorfehérvár várát és városát kiépíttette és megerősíttette. Azért is indokolt a korabeli raguzai erőd, elsősorban a városfalak vizsgálata, mert véleményem szerint nem szabad figyelmen kívül hagyni a lehetséges raguzai mintát Nándorfehérvár 15. századi kiépítésének vizsgálatakor és megítélésekor. Mindemellett az egyik legjobban dokumentált, korabeli összehasonítási alapként is megállja a helyét a Lazarević-féle építkezések értékelése során.

A várost 1358-tól a Velenceiektől I. (Nagy) Lajos magyar király vette uralma alá akkor, amikor Dalmáciát is meghódította. Raguza városa egészen a török hódításig a magyar királyok fennhatósága alatt állott. ${ }^{274}$ Ugyanis 1358-ban a velencei-magyar háború lezárásaképp megkötött zárai béke értelmében Dalmácia, vele Raguza is, magyar uralom alá került. Azonban nem volt ilyen egyszerü a helyzet. 1358. május 27-én külön államközi szerződést is kötöttek, amely szerint Raguza városa tulajdonképpen önállóan intézhette a bel- és külügyeket. A város első emberét saját maga választhatta meg, ebben a magyar királynak jóváhagyási joga volt. A város évenkénti adót fizetett a magyar királynak. A raguzaiak továbbá szabadon kereskedhettek Szerbiával is, a magyar-szerb háborús helyzettől függetlenül. ${ }^{275}$ Ezt jól példázza, hogy a Tallóciak kereskedelmi összeköttetése

\footnotetext{
${ }^{274}$ Vujičić D. Stojan-Szabóky Zsolt: Dubrovnik. Budapest 1978. 6. A továbbiakban: Stojan-Szabóky 1978.

275 Juhász Ágnes: A raguzai (dubrovniki) diplomácia a XIV. század közepén (1343-1367). In.: Középkortörténeti tanulmányok 6. Szerk.: G. Tóth Péter-Szabó Pál, Szeged 2010. 95-96. (Juhász 2010)
} 
megmaradt Raguzával azután is, hogy kereskedelmi kapcsolatot létesítettek a szerb despotával.

A város közössége (Communitas Ragusiana) azonban belső ügyeit és kereskedelmét önállóan intézte. A szervezete élén a rektor (knez) állt, aki a hatalmát megosztotta a Nagy és Kis Tanáccsal, valamint a Szenátussal. Tengeri kereskedelmének kibontakozását Velence sokáig beárnyékolta, így a szárazföldi kereskedelem lett a város fö profilja. A raguzai kereskedők a Balkán-félszigeten, elsősorban Szerbiával és Boszniával kereskedtek gazdag bányavárosaik miatt. Állandó kereskedőkolóniáik voltak Belgrádban (Nándorfehérváron), Szkopjében, Szófiában és Konstantinápolyban. ${ }^{276}$ Tudnunk kell, hogy a Balkán-félsziget másik, Raguzától délebbre lévő, szárazföldi kereskedelmi útja - az ókori római Via Egnatia útvonalán - Dürrakhiont (Durazzo) kötötte össze Thesszalonikin át Konstantinápollyal. ${ }^{277}$

Luksa Beritić vizsgálatai szerint a Raguza városát védő fal helyenként a 25 métert is eléri. A falak átlagos vastagsága a szárazföld felöl $4-6$ méter, a tenger felöl 1, 5 - 3 méter. ${ }^{278}$ A városfal 12-13. századi eredetű, mai alakja és nagysága 1453 - 1660 között alakult ki. A városnak négy kapuja van, kettő a tenger felől, kettő a szárazföld felől.

Nándorfehérvár kiépítésének összehasonlítása szempontjából a 15. században elvégzett munkálatok relevánsak. A kezdeti városfalak még a 12-13. században épültek kőből, fából és földből, mész használata nélkül. 1296-ra készültek el kő és mész felhasználásával épített új, egyszeres városfalak, amelyek teljesen körülfogták a város területét. Raguza - időben jóval megelőzve Nándorfehérvárt - erődített város lett ${ }^{279}$ (7. melléklet).

A város és a falak kiépítése tulajdonképpen még két évszázadon át folyamatosan történt, az 1667-es nagy földrengés idejéig. ${ }^{280}$ A 14. században kiépített új falszakasz 1, 25 - 1, 50 méter széles, de elég sérülékeny volt. A 14. században a kezdetleges városfalakhoz 15 négyszögletü tornyot is építettek. Egyesek ma is állnak, másokat megerősítettek vagy teljesen átépítettek. Továbbá ekkor kezdték az előfalat, védőfalat felépíteni és a várárkot kiásni.

Ugyanakkor 1358-ban, I. Lajos fennhatósága kezdetekor, amikor a város felszabadult az 1205-töl tartó velencei védnökség alól, még intenzívebb építkezés kezdődött. 1453-ban Konstantinápoly oszmán-török elfoglalása és a Balkánon megjelenő török veszély csak

\footnotetext{
${ }^{276}$ Stojan-Szabóky 1978. 7-8.

${ }^{277}$ A Lefkosz Pürgosz Múzeum kiállítási anyaga alapján (Thesszaloniki).

${ }^{278}$ Luksa Beritić: The city walls of Dubrovnik. Dubrovnik 1989. 5. A továbbiakban: Beritić 1989; StojanSzabóky 1978. 10.

${ }^{279}$ Stojan-Szabóky 1978. 6.

${ }^{280}$ Stojan-Szabóky 1978. 10.
} 
sürgette Raguza erődrendszerének további kiépítését. 4 méter széles falszakaszokat kezdtek ekkor építeni. ${ }^{281}$ Nézzük meg alaposabban a város falait és tornyait!

A Pile-kapu sokáig a város egyetlen nyugati bejárata volt a szárazföld felöl, amelyet egy nagy, négyszögletü toronybástya (Pile-torony) védett már a 10. században (972). A várárkon kőhíd és fa felvonóhíd vezet át a kapuhoz. 1461-ben a Pile-kapuhoz vezető falat itt megerösítették még egy 1 méter széles fallal is. ${ }^{282}$ A ferences monostorhoz közel lévő Szent Ferenc nevü, négyszögletű tornyot a 14. században építették fel. ${ }^{283}$

A Minčeta-torony az északi és a nyugati városfalak találkozási pontján egy nagy, kör alakú, masszív várbástya, amely egyben a raguzai erődrendszer legmagasabb pontja is. ${ }^{284}$ Eredetileg négyszögletü torony volt, amely mai kör alakját 1455-ben nyerte el, amikor is jelentősen megerősítették e stratégiai ponton lévő tornyot, majd 1461-ben ezt tovább folytatták. $^{285}$

A Pile-kaputól a Minčeta-toronyig húzódó szárazföldi falszakasz 5, 5 méter széles. Kettős falból áll, a régi 1, 5 méter széles városfalból és a külső, 4 méter széles falból, amelyet 1455-1465 között építettek fel. ${ }^{286}$ A Minčeta-toronytól keletre - az északi falon az első négyszögletű torony a Szent Barbara-torony, amely 14. századi, de 1415-ben megmagasították, a belsejét pedig földdel, kővel hordták tele, hogy megerősítsék. A következő keleti irányban a Szent Lucia-torony szintén 14. századi, és a belsejét 1411-ben ugyanúgy földdel és kővel töltötték fel. A Szent Katalin-tornyot, amely nevét a vele szemben álló Szent Katalin templomról kapta, akárcsak az összes négyszögletü tornyot, a 14. században építették. A 15. században a só elhelyezésére közraktárként használták egészen 1464-ig. A Drezvenik-bástya is 14. századi, négyszögletü volt, de az 1667-es nagy földrengés alkalmával összedőlt. A Minčeta-torony és a Drezvenik-torony közötti falszakasz a 12-13. századi városfalból állt, amelyet kívülről 1453-1455 között egy másik fallal megkettőztek. A tornyok közé új, 2, 5 méter széles falat építettek, míg a régi 1, 5 méter széles városfalat vagy helyreállították vagy újjáépítették. ${ }^{287}$ A Szent Jakab-torony szintén négyszögletü volt, amely 12-13. században a város erődrendszerének északkeleti sarokpontját képezte. A Drezvenik- és Szent Jakab-torony közötti régi falszakasz

\footnotetext{
${ }^{281}$ Beritić 1989. 9-10.

282 Beritić 1989. 11.

${ }^{283}$ A torony fogalma alatt a várfal horizontális szintjénél magasabb, kiugró építményt értjük, míg a várfal magassának szintjéhez igazodó építmény a bástya. A 15. században a bástya már nem toronyszerü építmény.

${ }^{284}$ Stojan-Szabóky 1978. 11.

${ }^{285}$ Beritić 1989. 12-13.

${ }^{286}$ Beritić 1989. 14.

${ }^{287}$ Beritić 1989. 16-17.
} 
vastagsága 1, 5 méter volt, majd a 15. századi átépítés során 4 méteressé lett. Keleten a Ploče-kapu bejárata felől egy háromszögletü toronybástya emelkedik, az Asimon-torony, amely 14. századi és lezárja az északi városfalat. 1381-ben még Saroktoronynak nevezték, 1438-ban Ploče-toronynak, később az „arx inter moenia” (=,,bástya a falak között”) kifejezésből rövidült az Asimon megnevezése. 1453-ban a régi városfalat - a Szent Jakabtoronytól idáig - belülröl egy 2, 5 méter széles újabb fallal erősítették meg, az így létrehozott kétszeres fal 4 méter széles lett. ${ }^{288}$

A város északkeleti pontján a Ploče-kapu a keleti, szárazföldi bejárat, amelyet Szent Lucia-kapunak is neveznek a források a közeli kápolna nevéről. Kettős kapu, a belső kapu 2 méter széles, a külső, nagyobb kaput pedig 1450-ben Simeon de la Cava építette. A rombusz alakú Szent Lukács-torony a legrégebbi a város bástyái közül, a 12. században épült, sokáig a kikötő védelmezésének legfontosabb eleme volt a Szent János erőddel. A Ploče-kaputól a Szent Lukács-toronyig húzódó fal 13. századi, amelyet 1381-1387 között megmagasítottak. Majd 1462-ben belülről egy alacsonyabb, de vastagabb 4 méter szélességü második falat építettek, amely kifelé lövés esetén az ágyúknak kiváló talapzatként szolgált a magas külső fal mögött. ${ }^{289}$ A Ploče-kapuval szemben a város keleti partján egy árokkal elválasztott, de híddal összekötött erödöt találunk, a Revelin-t. Szabálytalan négyszög alakú, északkeleti szöglete hegyesen kinyúlik. 1463-ban kezdték el építeni. A fó feladata a keleti városkapu védelme volt. ${ }^{290}$

A város keleti oldalán a kikötőtől a tengerparti falak, kapuk és bástyák következnek. A Szent Domonkos-torony négyszögletü és 1381-1387 között épült. Akárcsak a tenger felöli bejárat a Halpiac-kapu, amely akkoriban a város legnagyobb kapuja volt (Velika Vrata). A Mészárszék-kapu szintén 1381-1387 között épült. A kikötő felöli oldalon 1, 5 méter vastag. Egy új városi falszakaszt is építettek a régihez, amely a Domonkosok kolostorát is bekerítette. A kis Arzenál hajójavító mühelyként és raktárként üzemelt. ${ }^{291}$ A Nagy Arzenálban épültek a hajók, a gályák és ugyanitt javították, raktározták azokat. Az épület 8. századi, de a 14. században megerősítették a jobb védhetőség érdekében. A délkeleti sarkán van a Fenyítö-torony (Kaznena), amely 14. századi. Alacsonyabb volt a többi toronynál, ezért 1420-1424 között megmagasították. A Rektori Palota részét képezte a Rektor-torony, amely kezdetben még a városfalon kívül állt, hogy védje a közeli városkaput. A torony földszintjén tárolták az akkor újnak számító, kisebb tüzfegyvereket.

\footnotetext{
${ }^{288}$ Beritić 1989. 18-19.

${ }^{289}$ Beritić 1989. 20-22.

${ }^{290}$ Beritić 1989. 38-39; Stojan-Szabóky 1978. 11.

${ }^{291}$ Beritić 1989. 23-25.
} 
Már itt felhívjuk a figyelmet arra, hogy a tüzfegyverek 14-15. századi közép-európai és balkáni elterjesztésében Raguza központi szerepet játszott. A 15. században a Rektortorony felső emeletein a lőport és a lőszereket tárolták. ${ }^{292}$

A Kikötői-kaputól védőfal húzódik a Szent János-erődig. A régi városfal itt vékonyabb (kb. 1 méter széles) és magasabb volt, 1475-1477 között építettek egy vastagabb (2, 5 méter) de alacsonyabb falat (8, 5 méter) a jobb védhetőség érdekében. A város legkeletibb kiszögellésénél, a kikötő végén lévő Szent János-erőd több szakaszban épült. Eredetileg 1346-ban építettek ide egy bástyát, hogy a Szent Lukács-toronnyal egy lánccal összekötve, lezárja a kikötőt, amennyiben szükség volt rá. A munkálatok 1557-ig tartottak, ekkorra alakult ki a Szent János-erőd. ${ }^{293}$ A kikötői bejáratnál 1485-ben építettek egy hosszú hullámtörő gátat is, amely a várost a tenger felől védelmezte a hullámoktól, de az ellenséges hajóktól is. ${ }^{294}$

A várost délről, a tenger felöli szirteken szintén falak és tornyok védték. Ez a déli falszakasz is tornyokkal tagolt, mint például a Margit-torony. Nevét a közeli templomról kapta, amely a magyarországi Árpád-házi Szent Margit nevét viselte. A déli fal eredetileg alacsonyabb volt a tenger felől. 1418-1427 között megerősítették és részben újjáépítették. A déli falat még a 16-17. században is új tornyokkal tagolták, amelyek egy részét az 1667es nagy földrengés lerombolt. Például a négyszögletü Csillag-toronyot. ${ }^{295}$

A déli falszakaszon nyugat felé haladva az egyik kőszirten van a Szent Mária-torony, amelynek első említése 1426-ból való. 1431-ben megmagasították a városi falak szintjére. Mivel a déli falakat itt függőlegesen építették a sziklákra, így azok a tengerszinttől kb. 20 méter magasságba is elérnek! A 14. századi Kalarinja-torony görög eredetü nevét a közelben egykor lévő kikötőről kapta (szép kikötő), kis négyszögletü bástya, amely 1461tól kezdve, az alatta lévő szirten lévő Bokar-erőd felépítésével jelentőségét elvesztette. A fő feladata a Pile-kapu védelme lett. A nyugati oldalon a szárazföld felőli falszakaszt 1462ben megkettőzték kívülről egy új, 4, 5 méter széles fal felépítésével. ${ }^{296} 1305$-től kezdtek építeni egy újabb bástyát, a Puncjela-tornyot, amely a legnagyobb négyszögletű torony a városban. 1463-ban megerősítették egy külső fal építésével. ${ }^{297}$ A város délnyugati sarkán, egy 37 méter magas, meredek sziklán épült a Szent Lőrinc-erőd (Lovrijenac), amely akárcsak a Revelin a keleti oldalon - el van választva a várostól. Alaprajza háromszöget

\footnotetext{
292 Beritić 1989. 27.

${ }^{293}$ Beritić 1989. 28-29.

${ }^{294}$ Stojan-Szabóky 1978. 12.

${ }^{295}$ Beritić 1989. 31-33.

296 Beritić 1989. 36.

${ }^{297}$ Beritić 1989. 36-37.
} 
formál, és a városban a legnagyobb és legerösebb erőd. A bejáratnál Raguza híres jelmondatát találjuk („Nem jó a köznek, ha a szabadságot aranyért eladják.”) Az erőd falainak vastagsága a tájolás szerint változó: 4 - 12 méter széles, a tengerre néző 1,5 méter, a város felőli oldalon pedig csak 60 centiméter. A szikla, amelyen épült uralja a várost, elöször csak várfalakkal erösítették meg, amelyen belül volt az egykori Szent Lőrinc-templom, amelyről a nevét kapta. ${ }^{298}$ Többszöri átépítése során 1464-ben nyugat és észak felől itt is megkettőzték a falat. Az új fal kb. 10 méter széles lett, a nyugati szögletében pedig 12 méteres! A város védőfalainak átépítései később is folytatódtak, amelyek már időhatárunkon kívül esnek. ${ }^{299}$

Raguza erődrendszerének kiépítése az egyik legjobban dokumentált, így alkalmas arra, hogy a korabeli Nándorfehérvár tervezett kiépítésének főbb lépéseit is rekonstruálja. A kiépítés során több tanulságot vonhatunk le. A legszembetünőbb a természeti adottságok magaslatok, tengerparti szirtek - maximális kihasználása az építkezések során. Nándorfehérvár kiépítésével hasonlóságot mutat az, hogy a város falszakaszait - az északi és nyugati falakat - a szárazföld felöli oldalon megkettőzték. A legtöbbször úgy, hogy a régi fal elé egy újat emeltek fel. A tornyok építésében a gótikus stílusú, magas, négyszögletü bástyatoronyok helyett alacsonyabb, kör vagy félkör alakú bástyákat építettek fel. Ennek kiváltó oka elsősorban a várostromló tüzérség rohamos fejlődése volt.

Európa keleti felén is érdemes tanulmányozni az erődépítészet korabeli állapotát. Ugyanis már a 12-13. században a keresztes államokban kiépített erődöknek a szeldzsuktörök ostromokkal kellett folyamatosan szembe nézniük. A várépítészetben a frank vártornyok különböző típusai mellett megtaláljuk a római-bizánci négyszögletes alaprajzú, sarok- és közbülső tornyokkal egyaránt tagolt castrum-típusokat (például Belvoir, Coliath, Giblet, Akkon várai) vagy a konstantinápolyi mintájú, körkörös alaprajzú erődített városokat is - mint például a híres Crac des Chevaliers vára- vagy akár a háromszög alaprajzú erődített várost, mint Margat városát. ${ }^{300}$

Mi a Mediterráneumban Rodosz erődjét és a johanniták általi kiépítését vizsgáljuk (8. melléklet). Egyrészt azért, mert a korabeli európai erődök, erődített városok sorában Nándorfehérvár kiépítettségét és stratégiai fontosságát tekintve méltó párja lehetett Rodosz erődített városának, különösen Konstantinápoly eleste után, akárcsak Raguza vagy az igen korán elfoglalt Thesszaloniki. A másik ok talán kissé távoli, de kézenfekvő. A

\footnotetext{
298 Beritić 1989. 43; Stojan-Szabóky 1978. 13.

299 Beritić 1989. 45.

${ }^{300}$ Spiteri 1994. 10, 41-50.
} 
Nándorfehérvárt 1440-ben védő Tallóci-testvér, Jován egyúttal a vránai johannita perjelséget is viselte. Ezt még Habsburg Albert magyar királytól nyerte a királyi fökegyúri jog alapján, 1439-ben, pápai kinevezés nélkül. Jovánt ez nem hagyta nyugodni, mert 1444ben a pápától kérte utólagos kinevezését. Ennek feltétele a rodoszi johannita konventbe való felvétele és fogadalomtétele volt. 1444. február 21-én hivatalosan is vránai perjel lett. ${ }^{301} \mathrm{~A}$ magyarországi perjelség központja, Vrána Dalmáciában, Zara mellett található. A vránai perjel a Magyar Királyságban egyenrangú volt a püspökökkel és állandó helye volt a királyi tanácsban. Saját serege élén a királyi sereget kellett támogatnia. Bár a perjelség a Johannita Rend részeként alakult, de a gyakorlatban igen nagy önállósággal bírt. A perjel választását a király nevezése alapján a nagymester erősítette meg. A vránai perjelt a 15 . században már nem a rend tagjai közül választották, hanem a magyarországi világi nemesek köréböl. A nagymester a magyar perjelség ügyeibe nem nagyon avatkozott be, 1380 után pedig a rodoszi központnak járó adó fizetéséröl sincs tudomásunk. ${ }^{302}$

A Johannita Rend központja 1309-től Rodosz szigete, amely egykor a Bizánci Birodalom Kibürrhaiótón tengeri themájához tartozott, annak ellennére, hogy hivatalosan nem itt volt a thema központja. Jelentős szerepet töltött be a keresztes hadjáratok során, amikor 1097-1099 között a sziget hajói szállították az utánpótlást Antiokhiába. ${ }^{303}$

1309-ben, amikor a johanniták elfoglalták a szigetet a bizánciaktól, megelégedtek a bizánci erődök felújításával. Mivel a 14. század második felére a város dél és kelet felé túlnőtt az egykori bizánci városfalakon, a johanniták korai erődítésükkel az egész várost hosszú fallal védték. Körkörös alaprajzú, kettős falrendszert építettek ki. A belső és magasabb fal 2 méter széles volt, a külső alacsonyabb. A falakat négyszögletü tornyok tagolták. A két fal közötti távolság a belső fal egynegyede volt. A külső fal előtt pedig árok védte a várost. A Jean Fernandez de Heredia nagymester idején (1377-1395) épített tornyok négyszögletủek voltak, amelyek a város északi, tengerparti oldalán épültek fel a Szent Péter és Pál torony közötti falszakaszon. ${ }^{304}$ A kör alakú tornyok viszonylag későn, a 15. század első felében, a puskaporral müködő tüzfegyverek alkalmazásával egy időben jelentek meg. Különösen a várfaltól elkülönített, ún. albarra-típusú faltornyok.

\footnotetext{
${ }^{301}$ Mályusz 2003. 161.

${ }^{302}$ Pál, Engel: The estates of the Hospitallers in Hungary at the end of the Middle Ages. In.: The Crusades and the Military Orders. Expanding the Frontiers of the Medieval Latin Christianity. Edited by Zsolt Hunyadi, József Laszlovszky. Budapest 2001. 291. (Engel 2001)

${ }^{303}$ A thema megszervezésére lásd még: Szabó Pál: Árukidobás a tengeren? - A bizánci nomosz rhodión nautikosz római jogi párhuzamairól. Középkortörténeti tanulmányok 6. Szerk.: G. Tóth Péter-Szabó Pál, Szeged 2010. 217. (Szabó 2010b)

${ }^{304}$ Spiteri 1994. 70.
} 
A késő 14. században a puskaporral müködő ágyúk alapvető technikai átalakulást hoztak a rodoszi várépítészetben is. A magas falak, amelyek egykor az ostromlétráknak ellenálltak, most védtelen célpontokká váltak. Ezeket vagy megvastagították vagy belső támfalakkal erősítették meg, hogy ellen tudjanak állni a lövések erejének. A védelem szempontjából pedig az ágyúk felszerelése és a várban való használata kívánt meg átalakításokat. A rodoszi erődben a legkorábbi nyoma az ágyúk védelemben való használatának Antonio Fluviano nagymester idejében (1421-1437) mutatható ki (a Szent György toronyban). Ez csak angliai viszonylatban késői időpont - mert ott már az 1380-as évektől megjelent -, a nándorfehérvári Lazarević-féle építkezésekkel összevetve viszont korszerü alkalmazást jelentett. Az 1454-1467 közötti időszakban - Jacques de Milly nagymester vezetése alatt - a johanniták egyre több nagy és sokszög alakú tornyot építtettek a külső városfalakhoz. Ezek valójában már olyan - a fal szintjéhez illeszkedő bástyák voltak, amelyek kizárólag ágyúk alkalmazására szolgáltak és az első lépést jelentették a későbbi olaszbástyákhoz a 16. században. ${ }^{305}$

Spiteri szerint az első szakasz a várépítésben 1309-1377 között, Foulques Villaret és Robert de Juilly nagymesterek korában volt, amikor is a johanniták elsősorban a meglévő, nagyméretű bizánci falak felújítását, karbantartását végezték el. ${ }^{306} \mathrm{~A}$ második nagyobb építési szakasz Jean Fernandez de Heredia nagymester és Jean De Lastic idejében különíthető el (1371-1454). Heredia megerősítette a kikötő és város falait és tornyait. A falak vastagsága körülbelül 2 - 4 méteres lett. Akárcsak Raguzában, a kikötőt tornyok védték a mólók végénél, a bejáratnál. Azonban a rodoszi kikötő két részre volt elkülönítve, a hadikikötőre és a kereskedelmi kikötőre. A hadikikötő bejáratát 1361-ben felépített Szent Miklós-torony védte. Új tornyokat is építettek. Így a kereskedelmi kikötő nyugati bejáratánál a Naillac-tornyot, a keletinél a Szent Angyal-tornyot 1436-ban. ${ }^{307}$ A városfalak megerősítésében a Konstantinápolyban meglévő, bizánci módszert alkalmazták. A magas és erős városfal előtt egy alacsonyabb másodikat húztak fel, amelybe - egyenlő távolságban - négyszögletű tornyokat építettek. A második falat kívül még egy mély és széles árok védte. A falaktól elkülönített albarra tornyok is épültek. A kikötőben, a rakodópart végében 1440-1454 között építették fel a Malomtornyot is a szélmalmok védelmére. A védelem esetén a torony lánccal volt összekötve a szemben lévő Naillactoronnyal. Rodosz szárazföldi mameluk ostrománál (1444) sikeresen helytálltak ezek a

\footnotetext{
305 Spiteri 1994. 72.

${ }^{306}$ Spiteri 1994. 77.

307 J. E. Kaufmann-H. W. Kaufmann: The Medieval Fortress. Castles, forts and walled cities of the Middle Ages. London 2001. 171. A továbbiakban: J. E. Kaufmann-H. W. Kaufmann 2001.
} 
megerősítések. Konstantinápoly eleste után viszont az oszmán-török várostromra alkalmas nehéztüzérségének fenyegetése sürgette a további építkezéseket. ${ }^{308}$

A 1454-1461-tól meginduló újabb rodoszi várépítkezéseket az jellemezte, hogy a négyszögletü tornyok elé sokszög alakú bástyákat vagy rondellákat, félrondellákat emeltek, akár csak Raguzában. Ezeket földdel töltötték fel, és a bennük kiépített kazamatákban ágyúkat helyeztek el. Az építkezések különösen Pierre D’ Aubusson nagymester időszakában (1476-1503) gyorsultak fel. A környékbeli fákat kivágták, a városfalon kívüli templomokat és házakat elbontották. A II. Mehmed szultán által vezetett 1480-as oszmán-török ostrom során például az erőddé kiépített Szent Miklós-torony óriási szerepet játszott a sikeres védekezésben. ${ }^{309} \mathrm{Az}$ ostrom után a sérülékeny magas városfalakat megvastagították és széles támfalakat építettek hozzá, amely a védők számára járhatóvá vált és a tüzérséget is el lehetett rajta helyezni. Négyet a fö tornyok közül megerősítettek és a falaktól elválasztottak sokszög alakú bástyák kiépítésével. A Naillactorony fala például 3, 7 méter széles lett. Továbbá egy második külső árkot is ekkor ástak ki. $^{310}$

Az 1480-as rodoszi oszmán-török ostrom tüzérségi szempontból is fordulópontot jelentett. Mert ekkorra már a törökök is birtokában voltak az erőd- és várostromló nehéztüzérségnek, bár a monstrum-ágyúikat nem tudták a tengeren átszállítani. Rodosz korszerü erődrendszerét az 1522-es oszmán-török ostromban az aknák alkalmazása tudta csak meggyengíteni. ${ }^{311}$

\section{4. Thesszaloniki és Szendrő várfalai a 15. században}

Nándorfehérvár falait és 15 . századi kiépítettségét mindenekelőtt érdemes összehasonlítanunk olyan más korabeli várakkal, erődökkel, amelyet II. Murád szultán személyesen megostromolt, és amelyek ebből az időből jobb állapotban maradtak ránk. Mivel Nándorfehérvár a Lazarević-féle építkezések révén várból megerősített város lett,

\footnotetext{
${ }^{308}$ Spiteri 1994. 81-82.

${ }^{309}$ Rodosz elé a török sereg 1480 májusának végén érkezett. A védősereg körülbelül 4000 fö volt, amelyböl 600 volt a johannita lovag, 1500 kereskedő, a többi katona. Az oszmán-török sereget Misac pasa vezette, segítségére volt György tüzérmester is, aki Konstantinápoly ostromakor még a keresztényeket szolgálta. A három ostromágyút a város északi részén állították fel, hogy a Szent Miklós-tornyot lerombolva megnyíljon a kikötő bejárata. Ezt a tornyot tíz napos lövetés után rohamozták meg, sikertelenül. Miután több falszakasz elleni támadás is kudarcba fulladt, az ostromot végül augusztusban függesztették fel. A török veszteség 9000 ember volt, és a 70000 fös török sereg fele megsérült. J. E. Kaufmann-H. W. Kaufmann 2001. 173.

310 Spiteri 1994. 85-87.

${ }^{311}$ J. E. Kaufmann-H. W. Kaufmann 2001. 173.
} 
Thesszaloniki erődített városa igazán méltó párja, amelyet a helyszínen is megvizsgáltam. Azt hozzátehetjük, hogy mivel Thesszaloniki falai és vára, miután 1430-ban másodjára is oszmán-török kézre került nem volt újabb ostromoknak kitéve, így jobb állapotban megmaradt, mint Nándorfehérvár.

A város igen korán az oszmán-törökök figyelmébe került. Amikor I. Murád (13621389) szultán meghódította Philippopoliszt, a törökök délnyugaton az ókori római Via Egnatia útján Thesszaloniki felé hódítottak. ${ }^{312} \mathrm{~A}$ város falai előtt már 1372-ben megjelentek az akindzsi alakulatok. A következő években Evrenosz oszmán-török határvidéki vezér kezdte meg a város meghódítását. 1383-1387 között ostromolták először a várost. ${ }^{313} 1383$-ban az oszmán Khayreddin Chandarli pasa által vezetett „ostrom” vagy blokád több mint 3 éven át tartott. A város csak a negyedik évben, 1387 áprilisában nyitotta csak meg kapuit. ${ }^{314}$

Thesszaloniki ekkori helyzetét legutóbb Nevra Necipoğlu professzor vizsgálta. Ugyanis a török „ostromok” során a várost teljesen elvágták a szárazföld felől, a környező vidéken ellehetetlenítve a földmüvelést. A kereskedelmi kapcsolatok megszüntetése a város a hátországtól való elszigeteléséhez vezetett. Az egyedüli kapcsolat a külvilággal a tenger felöl volt lehetséges. Mindez oda vezetett, hogy ez a városi nagybirtokos arisztokráciát megfosztotta birtokaiktól, a kereskedőket megakadályozta a kereskedelmi tevékenységükben, az alsóbb rétegeket pedig a szegénység és a nyomor eltürésére kényszerítette. $^{315}$

$\mathrm{Az}$ idegen uralom azonban nem volt folyamatos. Úgy tünt, hogy a város az első oszmán-török uralom alatt, rövid idöre, többször lerázta az igát. Emiatt I. Bayezid szultánnak (ekkor még emír) vissza kellett volna állítani a fennhatóságát. Ezek néhány kutató szerint 1391-ben vagy 1394-ben történhettek. G. T. Dennis szerint az 1394. április 21-i „visszafoglalás” Nešri oszmán-török krónikás adatán alapul, az 1391-i pedig a krónika ezen évszámának téves 16. századi latin fordítása nyomán (Leunclavius, 1591) keletkezett. A bizánci források sem adnak erre pontos kronológiai felvilágosítást. ${ }^{316}$

Bizánc - a szultán fogságát és az oszmán trónharcok belső válságát kihasználva - I. Bayezid legidősebb fiával, a trónkövetelő és az európai részeket kormányzó Szulejmánnal

\footnotetext{
312 Generál 1987. 31.

${ }^{313}$ Charalambos Bakirtzis: The Urban Continuity and Size of Late Byzantine Thessalonike. Dumbarton Oaks Papers, (Vol. 57), Symposium on Late Byzantine Thessalonike 2003. 38. A továbbiakban: Bakirtzis 2003.

${ }^{314}$ Imber 2002. 12; Ostrogorsky 2003. 453.

315 Nevra Necipoğlu: Byzantium between the Ottomans and the Latins. Politics and Society in the Late Empire. Cambridge 2009. 55-56. A továbbiakban: Neciploğlu 2009.

${ }^{316}$ G. T. Dennis: The second Turkish capture of Thessalonica 1391, 1394 or 1430? Byzantinische Zeitschrift (57) 1964/ 1. 53, 59. A továbbiakban: Dennis 1964.
} 
1403-ban, Gallipoliban szerződést kötött, amelyben megszüntette a vazallusi kötelezettséget és visszakapta Thesszalonikit, az Athósz-heggyel együtt. ${ }^{317} \mathrm{~A}$ város ismertebb, második oszmán-török ostromáról 1430-ban, amelyet II. Murád szultán vezetett, már szóltunk és a későbbiekben is visszatérünk rá. ${ }^{318}$

A városfalak a 3. századi felépítésük óta nem sokat változtak és bizonyították erejüket. A 7. század első felében történt felújítás során meghagyták a római falakat, ahol pedig kijavították vagy felújították, követték a nyomvonalát. A város területe (a későbbi Alsóváros) is ugyanazt fedte le, mint az ókori vagy kora keresztény időszakban és nem zsugorodott össze középkori kasztronná, mint például a bizánci Belgrád (9. melléklet). Konstantinápoly után a Birodalom „második városaként” említették. Az 5. századi városfalak nagy részét újjáépítették, a tornyokat helyreállították vagy újakat emeltek, kapukat építettek, a védelmi képességet jelentősen megnövelték. 1395/1396-ban ráadásul nagy földrengés rázta meg a várost, így jelentős helyreállításokra volt szükség. Jóannész Anagnósztész írja, hogy a keleti falak az ostrom előestéjén szétmorzsolódtak. ${ }^{319}$

Később egy nagy területü városrész kapcsolódott a város északi oldalához. Ez az északi, háromszög alakú rész, a várostól fallal elválasztott Felsőváros nem ókori eredetü, hanem jellegzetesen bizánci, és a szaracén ostrom után (Kr. u. 904), valószínüleg a 10. században építették (10. melléklet). Felsővárost két kapu kötötte össze az Alsóvárossal. Itt is voltak templomok, víztárolók, házak, de a város első török birtoklása során (1387-1403) ezeket elbontották a törökök. Feltehetőleg azért, hogy ide helyezzék el a várost ellenőrző katonákat.

A Felsőváros északi sarkában áll a Fellegvár vagy Heptapürgion, a Héttorony (Yedi Kule). Ezt a város második elfoglalása (1430) után, a város első török kormányzója, Sungur Csausz bég felújította és itt rendezte be rezidenciáját is. ${ }^{320}$ Sokáig azt hitték, hogy a mai Heptapürgion bizánci munka, amelyhez Csausz bég csak a neve feliratát tette hozzá a bejárati kapunál. A legutóbbi vizsgálatok eredménye szerint (Striker, Kuniholm) azonban az egész vár 1431-1432-ből való, az oszmán katonai építészet kiemelkedő alkotása. ${ }^{321}$ Így a mai falak vizsgálata az eredeti bizánci erőd adataira nézve nem ad számunkra felvilágosítást az 1430-as ostrommal kapcsolatban. Azt is tudjuk, hogy már 1389-1402

\footnotetext{
${ }^{317}$ Imber 2002. 17.

${ }^{318}$ Lásd a 2. 4. és a 10. $4-10.6$. fejezeteket.

${ }^{319}$ Bakirtzis 2003. 41-42.

${ }^{320}$ Bakirtzis 2003. 44-45. A város második oszmán-török elfoglalását lásd a 2. 4. fejezetben.

${ }^{321}$ Machiel Kiel: The incorporation of the Balkans into the Ottoman Empire, 1353-1453. In.: The Cambridge History of Turkey. 1071-1453. Volume I. Byzantion to Turkey. Edited by: Kate Fleet. Cambridge 2009. 176-177. (Kiel 2009)
} 
között I. Bayezid is építtetett egy tornyot a város legmagasabb pontján, feltehetően a Heptapürgionban, ezt azonban 1414-1415 fordulóján II. Manuél császár lebontatta. ${ }^{322}$

A tengerparton, a város délnyugati sarkán épült a kikötő, amely fallal és tornyokkal volt megerősítve. ${ }^{323} \mathrm{~A}$ déli, tengerparti fal ma már nincs meg, csak digitális modellen érzékeltethető (11. melléklet).

A helyszíni terepbejárás alkalmával (2013. szeptember 24) főleg a keleti városfalat vizsgáltam a tengerparttól a Felsővárosig és az északkeleti falig. A parton lévő „Fehér Torony” (Lefkosz Pürgosz) az egykori bizánci torony helyén épült, a déli, tengerparti fal és a keleti fal találkozásánál a 15. század végén, a város második oszmán-török elfoglalása után. Jól tanulmányozható rajta a vegyes falazásos technika, amely Nándorfehérvár 15. századi falszakaszán is szembetűnő volt (12. melléklet). A fal vastagsága a méréseim szerint kb. 2, 4-2, 7 m.

A keleti falszakasz egészen a Felsővárosig jó állapotban ma is áll. Ami első látásra szembetűnő, az a vegyes falazás kitünő állapota, a szabályos egyenes vonalban a falakba beépített téglasor rétegek. A 7. század első felében történt felújítás látható nyomai. Az Alsóvárosban a maradványokban meglévő falcsonkok vastagsága kb. 1, 5-1, 68 m. Ezek lehettek a régi falak, amelyek kisebb méretűek.

A keleti fal a Szent Demeter téren 2, $7-2,8 \mathrm{~m}$. A Felsővárosba átlépve a keleti fal folytatása igen jó állapotú, kb. 3, 10 - 3, 25 m-es. Érdekes, hogy nem kettős falrendszert találunk. A négyszögletű bástyák falaiban $8-9$ vízszintes téglasor réteg van szabályosan beépítve. A bástyákat összekötő falak pedig $4-5$ téglasor réteget tartalmaznak (13. melléklet).

A Felsőváros és a Fellegvár környéke is fallal van elválasztva, ez az északi fal, amelynek vastagsága kb. 3 - 3,6 m. Ez jól mutatja a Fellegvár jobban megerősített védelmét (14. melléklet). A keleti fal és az északi fal találkozásánál épült Trigónion-torony falvastagsága kb. 1,9-2,95 m. Azonban ez az elnevezés csak 20. századi, forrása Jóannész Anagnósztész, aki az 1430-as ostrom szemtanújaként e falszakasznak adta háromszögü alakja - után ezt a nevet. A mai körtorony - nagyjából a Fehér Toronnyal egy időben - rögtön a város elfoglalása, 1430 után épült, hogy megerősítse az északkeleti sarkot és figyelembe vegye az ekkoriban elterjedő tüzfegyverek elleni új védekezési szempontokat is (15. melléklet). A város velencei kézbe kerülése alatt (1423-1430) is történtek javítások a városfalakon, de eltérő minőségben. Az északkeleti sarok falain

\footnotetext{
${ }^{322}$ Bakirtzis 2003. 45. Erről Konstantin Filozófus írt Lazarević István életéről szóló munkájában.

${ }^{323}$ Bakirtzis 2003. 43.
} 
látszott meg legjobban a részleges javítás nyoma, itt volt a város leggyengébb falszakasza, amelyet az 1430-as ostrom során a törökök át is tudtak törni, ahogyan erröl Anagnósztész is beszámolt (munkája 13. fejezetében). ${ }^{324}$

Hasonlóan tanulságos helyszíni méréseket végezni a II. Murád által 1439-ben megostromolt 15. századi erődön, Szendrő várán is. Szendrő várát Branković György szerb despota építtette 1428-1430 között, azzal a céllal, hogy új székvárosa legyen. A Nándorfehérvártól kb. 35 km-re délre, a Duna és a Jezava-folyó torkolatánál felépített vár Európa egyik legnagyobb erődje. Abban hasonló Nándorfehérvárhoz vagy Thesszalonikihez, hogy ez sem csupán erőd, hanem magában foglalja a kisebb települést is. Itt sem találunk kettős falrendszert. Az erőd alaprajza háromszöget formál. Maga a despota kisebb háromszög alakú Fellegvára - a Duna és Jezava felőli sarkában vizesárokkal van elválasztva. Az erődben összesen 25 négyszögletü, a falaknál magasabb torony van a falakba beépítve. Ebből a Fellegvárban 6 torony található. Ezek a faltornyok hátulról a várudvar felől viszont nyitottak (16. melléklet).

Terepbejárásom alkalmával (2012. április 22) jól látszott az, hogy a falak legnagyobb részben faragott kőből épültek, néhol vegyítve beépített téglákkal, hasonlóan Nándorfehérvár északkeleti falához. A despota rezidenciájának megerősítése jelentősen eltért a településétől. A belső Fellegvár egyszeres falvastagsága kb. 5 m (17. melléklet). Míg a külső városfal, amely a települést védte $\mathrm{kb} .3,6 \mathrm{~m}$. A falakba beépített bástyákon a tégla a kő rétegekkel váltakozik (18. melléklet). Azt mondhatjuk, hogy Szendrő erődje Nándorfehérvárral és Thesszalonikivel vagy akár a rodoszi erőddel összehasonlítva falvastagságaira nézve - a legerősebb várak közé sorolható, amely eredményesen ellent tudott volna állni egy tartós ostromnak. Hogy 1439-ben mégsem ez történt, az nem a falaknak, hanem a védőknek volt köszönhető.

A vegyes falazású várak, városfalak mellé összehasonlításunkban figyelmet érdemel még Bács téglaépítésű vára (19. melléklet). A délvidéki vár már az Árpád-kortól magyar királyi és püspöki székhely volt, a bács-kalocsai érsekséghez tartozott. 1338-ban az Anjou I. Károly magyar király birtokba vette, majd négy éven át bővítette és megerősítette, gótikus stílusban. Mindezt azzal indokolta a pápának, hogy a magyar királyság déli határait kívánja megvédeni a szakadár szerb királytól, Dusántól. 1342-ben a pápa kérésére visszaadta a bács-kalocsai érsekségnek. A vár tipikus példáját nyújtja a téglaváraknak, amelyet a 1490-1526 között, egy tüzvész után, a török elleni védelem során jelentősen

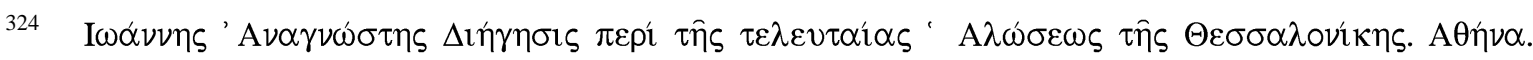

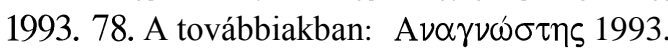


átépítették, megerősítették az újnak számító tűzfegyverek elleni hathatósabb védekezés miatt. ${ }^{325}$ A vár maga a Mostonga-folyó egykori medrében lévő szigeten épült fel, Bács városától elkülönítve. A falakba építve négy torony (3 kör és egy négyszögletü) és belül egy négyszögletű udvari vártorony található. A terepbejárás alkalmával (2013. október 19) a tornyok falvastagsága kb. 2, 3-2, 42 m, a tornyok közti fal vastagsága kb. 1, 85 -2, 4 m. A várakon végzett méréseinket az alábbi táblázatban összesítjük, Raguza és Rodosz szakirodalomban közölt adataival kiegészítve.

\begin{tabular}{|l|l|l|l|}
\hline & Raguza & Rodosz & Nándorfehérvár \\
\hline városfal & 1, 5 (régi); 2, 5 (új) & kb. 2 & 1, 6 (régi); 3 (új) \\
vastagsága $(\mathrm{m})$ & 4 (kettős fal) & 4 (kettős fal) & 4,6 (kettős fal) \\
\hline torony fal $(\mathrm{m})$ & 4 (Minčeta) & 3,7 (Naillac) & 1,5 (Dizdar) \\
\hline
\end{tabular}

\begin{tabular}{|l|l|l|l|}
\hline & Thesszaloniki & Szendrö & Bács \\
\hline $\begin{array}{l}\text { vár(os)fal } \\
\text { vastagsága }(\mathrm{m})\end{array}$ & $\begin{array}{l}1,5-1,6 \text { (régi) } \\
2,4-3,6 \text { (egyszeres) }\end{array}$ & $\begin{array}{l}3,6-5 \\
\text { (egyszeres) }\end{array}$ & $\begin{array}{l}1,85-2,4 \\
\text { (egyszeres) }\end{array}$ \\
\hline torony fal (m) & $\begin{array}{l}1,9-2,95 \\
\text { (Trigónion) }\end{array}$ & 1,6 & $2,3-2,42$ \\
\hline
\end{tabular}

A táblázatból kitünik, hogy a 15. századi Nándorfehérvár falainak vastagságát tekintve beilleszthető a korabeli európai erődített városok sorába. A kétszeres fallal megerősített városok között korszerünek és erősnek minősül. A tornyokkal való összehasonlítást akadályozza, hogy kevés maradt fenn vizsgálható állapotban. A vár gyengébb pontjai a falak közötti tornyok, kapuk lehettek, amelyeknek falai vékonyabbak a kortársaiénál. Itt nyílott lehetőség a falak áttörésére, a várba való bejutásra, amelyről forrásaink említést tettek.

${ }^{325}$ Paškal Cvekan: Franjevci u Baču. Virovitica 1985. 19. A továbbiakban: Cvekan 1985. 
„Király udvarába deszpot jött vala, mert török császártól igen fél vala, hivséggel magát ajánlotta vala..."

(Tinódi Lantos Sebestyén)

\section{Belgrádból Nándorfehérvár \\ 4. 1. A tatai szerződés és Nándorfehérvár átadása (1426-1427)}

1426-ban fontos, közjogi-stratégiai jelentőségű szerződés megkötésére került sor Tatán, ${ }^{326}$ Zsigmond kedvenc pihenőhelyén, mégpedig Lazarević utódlása kapcsán, mert félő volt, hogy a despota fiú utód nélkül hal meg. A szerződés szerint a megmaradt szerbiai és a magyarországi birtokokat Lazarević unokaöccse, ${ }^{327}$ Branković György szerb despota örökli. Két fontos vár azonban magyar kézen marad: Nándorfehérvár és Galambóc. Erről Thuróczy János is beszámol krónikájában, bár ő tévesen nem Lazarevićet említi szerződő félként, hanem már Brankovićot (215. fejezet). ${ }^{328}$ A despota mintegy „hüségének zálogaként” (,fidelitatis pro obside eidem cessit”) átadta ezeket a várakat Zsigmond királynak, aki ennek fejében neki és leszármazottainak Magyarország területén nagy kiterjedésủ birtokokat adományozott. ${ }^{329}$

A tatai szerződésről szóló fontos jogtörténeti dokumentum egy későbbi oklevélátiratban maradt ránk. Ez sokkal szélesebb, közjogi szabályozási tárgykörröl tanúskodik. Először is a felek rögzítették Szerbia és a Magyar Királyság közjogi viszonyát. ${ }^{330}$ Másfelöl tárgyaltak az oszmán-török fenyegetésröl is. Branković György pedig a magyar bárók sorába emelkedett.

A szerb trónutódlás rendjét is „felülszabályozza” az a cikkely, amely szerint a magyar király Szerbiában Lazarević István férfi örökös nélküli halála esetén (magszakadás) csak a rokonát, Branković Györgyöt és az ő férfiágon való törvényes utódait iktatja be. A szerződés további pontjai a birtoklás kérdéseit rendezték Lazarević férfiörökös nélküli

\footnotetext{
${ }^{326}$ Thallóczy Lajos-Áldásy Antal: Magyarország melléktartományainak oklevéltára II. A Magyarország és Szerbia közötti összeköttetések oklevéltára. 1198-1526. 1907. (A 135. sz. okl) A szerződés szövegét fordításban közli: Bevezetés XXV-XXVIII. p. A továbbiakban: Thallóczy-Áldásy 1907.

${ }^{327}$ Vuk Branković ugyanis Lázár István fejedelem lányát, Lazarević testvérét, Marát vette feleségül. Ebből a házasságból született Branković György.

${ }^{328}$ Thuróczy 2001. 259. „De his, qui regis Sigismundi frequentaverunt curiam, et quomodo dezpotus castrum Nandoralbense eidem cessit." Johannes de Thurocz: Chronika Hungarorum. I. Textus. Ediderunt Elisabeth Galántai et Julius Kristó. Budapest 1985. 228, 10. A továbbiakban: Thuróczy Textus 1985. A város elnevezéséről pedig még megjegyzi: ,,amelyet az ókorban Taurinumnak, a mi öregjeink pedig állítólag Bolgárfehérvárnak neveztek”. Thuróczy 2001. 259. Lásd a 13. 1. fejezetet.

${ }^{329}$ A déli vármegyékben (Szerém, Krassó, Torontál), az északkeleti vármegyékben (Szabolcs, Bihar, Abaúj, Zemplén, Bereg, Szatmár). Ezzel az egyik legnagyobb vagyonú magyar bárók közé emelte az uralkodó. C. Tóth 2009. 84-85.

${ }^{330}$ Thallóczy-Áldásy 1907. XXV.
} 
halála esetén. Ebben az esetben ugyanis több felsorolt területet és birtokot, köztük Macsót és Nándorfehérvárt minden tartozékaival, valamint Galambócot minden tartozékával „koronánk és az emlitett Magyarország részére mindenkorra fenntartjuk.” Bár Lazarević ezeket örökös birtokul megkapta, de a család kihalása esetén mindez visszaáramlik a koronára. Továbbá, Branković Györgynek, mint magyarországi bárónak engedelmeskednie kell az uralkodónak, a tanácskozásokban köteles részt venni, beleértve a hadi segítség nyújtásának kötelezettségét is. ${ }^{331}$

A szerződés nemsokára hatályba lépett. 1427-ben egy vadászaton Lazarević rosszul lett, a lováról lefordult és június 19-én meghalt. ${ }^{332}$ A halála után az utódlásban Branković György követte. ${ }^{333}$ Ez azonnal elindította a törékeny együttmüködés és az addigi status quo egyensúlyának megbomlását. Nándorfehérvár birtoklása ismét stratégiai célpont lett. Ez lett az oszmán és a magyar hatalom ütközőpontja.

Zsigmond király sietett a város átvételével. Branković megkapta Lazarević magyarországi birtokait is. Zsigmond, a tatai szerződés értelmében, ünnepélyes szertartással beiktatta Szerbia és Albánia despotájának, megadva neki a korona, országalma és kard viselésének jogát. ${ }^{334}$ Mindezek mellett azonban meg kell jegyeznünk, hogy a deszpotész címe - éppúgy ahogyan Lazarević István esetében is - valójában a bizánci császártól eredt. A bizánci források közül Dukasz szerint (XXX. 3) Brankovićot VIII. (Palaiologosz) János (1425-1448) bizánci császár a megbízottja által iktatta be. „János császár pedig elküldte Geórgios Philanthrópinost a jelvényekkel, s megtette öt Szerbia despotájává." (Baán István fordítása). ${ }^{335}$ Azt is tudjuk, hogy a szerb despota második felesége az előkelő bizánci Eiréné Kantakuzéné volt. ${ }^{336}$

Branković azonban kénytelen volt megváltoztatni politikáját, a két hatalom között igyekezett saját érdekét érvényesíteni. A székhelyét Szendrőre (Smederevo) helyezte át, ${ }^{337}$ bár a Magyar Királyságban hatalmas birtokokkal rendelkezett, és Zsigmond király udvarának tagja is maradt. Branković - mintegy folytatván Lazarević főváros építési példáját - Szendrőt az egyik legnagyobb európai vízi, Duna-parti, erődítménnyé építtette ki. A vár pedig csak évekkel később - 1439-re - készült el. A lengyel krónikás, Dlugos 25 toronyról tudott. Ezt igazolja a helyszíni terepbejárásunk is (2012. április 22).

\footnotetext{
${ }^{331}$ Thallóczy-Áldásy 1907. XXVI-XXX. p.

${ }^{332}$ Калић 2001. 139-140; Калић-Мијушковић 1967. 101.

${ }^{333}$ Thallóczy-Áldásy 1907. XXXIV.

${ }^{334}$ Thallóczy-Áldásy 1907. XXXV.

335 Grecu 1958. 259, 24-25. Baán István: A XIV-XVI. századi magyar történelem bizánci és kora újkori görög nyelvü forrásai. Budapest 2013. 344. A továbbiakban: Baán 2013.

336 ODB 1104. Kantakuzénosz címszó.

${ }^{337}$ Pálosfalvi 2010b. 7.
} 
Ekkor történt - a magyar szakirodalomban szinte közhelyszerűen ismertek szerint -, hogy Galambóc várát átadták a szultánnak. Két oklevél (1437. szeptember 27; 1438. február 24.) szerint a vár szerb kapitánya, a „rácz” Jeremiás adta át a várat. ${ }^{338}$ Természetesen nem ok nélkül. Mert egy kifizetetlen tartozását a magyar király nem ismerte el. ${ }^{339}$ Azaz nem fizették ki neki azt az összeget, amellyel neki a despota tartozott. ${ }^{340}$

Ezáltal viszont közvetlen szomszédságba kerültünk az Oszmán Birodalommal. A vár földrajzi elhelyezkedésénél fogva jó kiindulópontja lett a későbbi török támadásoknak, a török hajók felvonulásának. A törökök katonai tevékenysége érezhetően megnövekedett Szerbiában. Megpróbálkoznak a híres és gazdag Novo Brdo bányaváros ostromával, de szerbek, szászok és a raguzaiak ezúttal még visszaverték. Viszont Niš megszerzése után elfoglalták Krusevácot, a korábbi szerb fővárost is, Lázár fejedelem és Lazarević István korábbi székhelyét. ${ }^{341}$

Azt mindenképpen hozzá kell tennünk, hogy Branković György Szerbiában a török szorításában uralkodott, és nemcsak a szerződés miatt. 1432 óta oszmán vazallus. ${ }^{342}$ Két lánya közül az egyiket, Marát (Mária) kiengesztelésképpen II. Murád szultán (1421-1451) háremébe volt kénytelen küldeni. Marának 1435 szeptemberében kellett elindulnia a szultánhoz. Erröl még a szultán tetteit összefoglaló oszmán-török annales, a Murád Évkönyve is megemlékezett, a hidzsra 838. évének eseményei között (1434. augusztus 7 1435. július 26). ${ }^{343}$

Arany János balladáihoz méltó történet, amint Mara tudta és megértette, hogy apja és Szerbia megmaradásának ő az ára, a despota pedig „országa és hazája megmaradása érdekében, szorultságból" áldozta fel a lányát. A másik lánya, Katarina (Katalin) pedig a nagyhatalmú Cillei Ulrik felesége lett. ${ }^{344}$ Két fiútestvére, Gergely (Grgur) és István (Stefan) kísérte el Marát az oszmán fővárosba, Drinápolyba. Mara továbbra is hủ maradt a kereszténységhez. ${ }^{345}$ A hazatérő testvéreket később Szendrő ostromakor, Murád szultán,

\footnotetext{
338 Thallóczy-Áldásy 1907. 112 (184. sz), ,ex tradimento illius perfidissimi et sceleratissimi Jeremie”, 123. (185. sz) , ex tradimento cuiusdam perfidi Jeremie Rasciani”

${ }^{339}$ Калић-Мијушковић 1967. 105.

340 Tringli 2003. 24.

${ }^{341}$ ODB. 348. Krusevac címszó, S. M. Stern.

342 Generál 1987. 54.

343 V. L. Ménage: The 'Annals of Murād II' Bulletin of the School of Oriental and African Studies, University of London. Vol. 39, No. 3. (1976) 576. A továbbiakban: Ménage 1976.

${ }^{344}$ Историја 2000. 241.

${ }^{345}$ Majd II. Mehmed küldte vissza apjához. Brankovics két fiának, Gergelynek és Istvánnak a sorsa szintén megrendítő. Murád később megvakíttatta és udvarában túszként tartotta őket. Историја 2000. 241-242, 289.
} 
hogy uralkodásra alkalmatlanná tegye, bizánci gyakorlat szerint megvakíttatta. ${ }^{346} \mathrm{Az}$ idős Brankovićot e családi tragédia életre szólóan megviselte. A török mégsem mozdította el őt tisztségéből. Brocquière szerint, mert a despota még évi 50000 arany adót fizetett a szultánnak, aki állítólag úgy nyilatkozott: „Több hasznom van belőle, mintha az enyém volna, mivel helytartóimtól semmit sem kapnék."347

A tatai szerződés végrehajtása a törökök szempontjából mindenképpen veszélyes volt szerbiai politikájukra nézve. A magyar déli védelem súlypontja eddig a temesi ispán tisztségén alapult, amelyet ekkor Rozgonyi István viselt. A tatai szerzödés értelmében viszont Temesvár jelentősége csökkent, a védelem kulcsa az ismét magyar kézbe kerülö Nándorfehérvár lett. A déli védelmi övezet legfontosabb részévé vált, mert ez a vár akadályozta meg a Duna mentén, észak felé, az oszmán terjeszkedést. ${ }^{348}$ Azt a megállapítást is megkockáztatjuk, hogy ekkorra Nándorfehérvár vára a Balkánon, a szorongatott bizánci föváros, Konstantinápoly mellett, méltó északi ellenponttá és egyik felvonulási úttá vált a török európai terjeszkedésével szemben. Sőt a későbbiek ismeretében azt is mondhatjuk, hogy a szultánok I. Bayezidtől kezdve II. Mehmedig addig nem ostromolhatták biztonságosan a bizánci fővárost, míg Nándorfehérvár idegen kézen volt, amíg az innen kiinduló transz-balkáni úton vagy akár a Duna vízi útján át felmentő sereg, utánpótlás küldésének a lehetősége fennállott. Jól láthatjuk ezt az 1453. évi ostrom bizánci forrásaiból, hiszen a bizánci szerzők (főleg Szphrantzész) leírása szerint Konstantinápoly oszmán-török ostromakor a védők még várták Hunyadi János segítségét, és a szultáni táborba érkező magyar követeket a törökök az ostrom kimeneteléig visszatartották. ${ }^{349}$

Nándorfehérvár birtoklásának jelentőségét Zsigmond király is felismerte és a déli védelmi rendszert egy kézben egyesítette. Tudjuk, hogy korábban már közvetlenül királyi kézbe vette az al-dunai várakat, azokat megerősítette, de újakat is épített. Ezek Pét, a másik Pét vára, Szinice, Drankó, Librasd, Szentlászlóvár és Pozsezsin várai voltak. Már 1419-ben megszerezte Szörény várát is, amelyhez hozzácsatolta az 1329-ben elfoglalt Győrén várát

\footnotetext{
346 Szabó Pál: „kitolta Vazul szemeit” - a megvakítás büntetésének bizánci eredetű gyakorlata a XI-XIII. századi Magyarországon, valamint a szláv és az oszmán-török jogi régiókban. Bácsország 2011/2 (57). 84. (Szabó 2011c) Ld. bővebben: Szabó Pál: „effodit oculos” - A megvakítás büntetésének bizánci eredetü gyakorlatáról a XI-XIII. századi Magyarországon. Jogelméleti Szemle 2011/2 (június 15) http://jesz.ajk.elte.hu

347 Szamota 1891. 77.

${ }^{348}$ Matuz 1990. 47.

349 Kapitánffy István: Propugnacula Christianitatis. Magyar-bizánci kapcsolatok a birodalom bukásának idején. In: Hungaro-Byzantina. Budapest 2003. 102. (Kapitánffy 2003)
} 
és Miháld, valamint Orsova, Sebes és Halmás várait és várkerületeit. 1427-ben pedig ezekből újjáalakította a Szörényi Bánságot. ${ }^{350}$

Az ún. első végvári vonal Szörényvártól az Adriáig húzódott. Erdélyben ugyanis nem alakult ki ennyire egységes végvárrendszer. A szász városok például erős fallal körülvéve védekeztek a betörések ellen. ${ }^{351}$ Zsigmond a magyarországi déli vármegyék egy részét pedig a temesi ispán irányítása alá vonta Temesi Bánság néven. ${ }^{352}$ A végvárrendszerben voltak azonban nagyobb királyi várak, amelyek a környékbeli, kisebb várak tevékenységét is irányították. Ezek közül Szörény mellett Nándorfehérvár volt a legfontosabb, amely eredetileg a Macsói Bánsághoz tartozott. A Macsói Bánság pedig az I. Károly király által meghódított észak szerb területekből és a rajta levő királyi várakból állt (Macsó, Bitva). ${ }^{353}$ Nyugaton pedig a végvonalat a Horvát-Szlavón Bánság várai folytatták. Ugyanakkor tudnunk kell, hogy a törökök három úton juthattak el az országba. Egyrészt délen Szerbiából a Morava-folyó völgyén át a kevei átkelőhelyig, másrészt Nándorfehérváron át, harmadrészt a Vaskapu mellett, Szörény váránál. ${ }^{354}$

Itt röviden elörebocsátjuk, hogy Zsigmond kezdetben a déli határ védelmét a Német Lovagrenddel végeztette el (1429-1432) Szörény és Haram közötti végvárak esetében. A lovagrend csapatát azonban 1432-ben a törökök megsemmisítették. ${ }^{355}$ A vereség után Zsigmond a külföldi származású Tallóciakat helyezte ezek élére és ehhez hatalmas gazdasági potenciált alakított ki. E döntése Nándorfehérvár sikeres megvédésében helyesnek bizonyult.

\footnotetext{
${ }^{350}$ Engel 1996. 32.

351 Szakály Ferenc-Fodor Pál: A kenyérmezei csata (1479. október 13). Hadtörténelmi Közlemények 1998/2. 315. A továbbiakban: Szakály-Fodor 1998.

352 Cseh 2007. 23.

${ }^{353}$ Engel 1996. 27

${ }^{354}$ Milleker Bódog: A törököknek első betörései Dél-Magyarországon Zsigmond és Albert királyok idejében és Keve és Krassó vármegyék megszünése 1393-1439. Temesvár 1914. 6. A továbbiakban: Milleker 1914.

${ }^{355}$ Lásd a 6. 1. fejezetet.
} 
„Ozorai Pipó, nádorispán vala, magzat nélkül világból kimúlt vala, Matkó bán néki atyjafia vala,

Franko, Prejko, Zováno nagy úr vala..."

(Tinódi Lantos Sebestyén)

\section{A Tallóciak: a déli végektől Nándorfehérvár kapitányságáig}

\section{1. Részvétel Galambóc 1428. évi ostromában}

1440-ben a Tallóci-család legifjabb tagja, Jován látta el a vár (fö)kapitányságát. A Tallóciak és Nándorfehérvár kapcsolata azonban már korábban kezdődött. A vár védelmében és korszerü tűzfegyverekkel való felszerelésében betöltött meghatározó szerepük miatt érdemes részletesebben megismerni őket.

A Tallóci család történetének jelentős részét Mályusz Elemér kutatásai alapján ismerjük. ${ }^{356}$ Ehhez azóta Pálosfalvi Tamás tanulmánya szolgált kiegészítésül. ${ }^{357}$ A négy Tallóci testvér: Matkó (Máté), Frank, (Ferenc, Franko), Petko (Péter) és a legifjabb: Jován (Zowanus, Giovanni, János) voltak. ${ }^{358}$

Legkorábban a legidősebb testvér, Matkó hagyta el szülőföldjét, Curzolát és Raguzába ment, amely ekkor élte virágkorát. ${ }^{359}$ Valószínűleg Matkót követték Raguzába testvérei, Frank és Petkó is. Matkó önálló vállalkozó lett, Nándorfehérvárba települt, ahol tekintélyes raguzai kolónia élt. Itt saját képviselőjük, „,consuljuk” is volt, aki széles hatáskörrel és 2 bírótárssal ítélkezett a raguzaiak ügyében. ${ }^{360}$ Matkóról tudjuk, hogy „,consulként” többször is eljárt (1424-ben) és tekintélyes raguzai kereskedő-vállalkozóként élt. Ami számunkra fontos az az, hogy kapcsolatba került Lazarević István udvarával: áruhitelei, vám- és

\footnotetext{
${ }^{356}$ A forrásokban nem Tallóciként, hanem Ragusaiakként szerepelnek, bár nem raguzai születésủek, hanem Curzola szigetéről (a mai Korčula) származtak. Apjuk, akinek négy fia született, helyi patrícius lehetett.

${ }^{357}$ Pálosfalvi Tamás: Cilleiek és Tallóciak: küzdelem Szlavóniáért (1440-1448) Századok 2000/1. 45-98. A továbbiakban: Pálosfalvi 2000. Lásd: Pálosfalvi 2010a.

${ }^{358}$ Mályusz 2003. 132-133.

${ }^{359}$ Raguza a Velencétől független közvetítő kereskedelem központja volt a Balkán, Itália és Nyugat-Európa között. Befolyása magyar földre is elért, volt képviseletük a szerémségi Újlakon, kolóniájuk Nagybányán. A Balkán felé a luxuscikkeket (selyem, bársony, ötvösművek, ékszerek, üveg) raguzaiak szállították. Nem bankházaik voltak, hanem társas gazdasági vállalkozás (entega, collegantia) keretei közt kereskedtek. Mályusz 2003. 134-135. Legutóbb a középkori Raguzával Juhász Ágnes foglalkozott több tanulmányában. Pl: A raguzai mindennapok egy kézműves szakma tükrében: cipőkészítők a XIII. század végén - XIV. század elején. Belvedere 2009/XXI. 1-2. 64-72. Uő.: A raguzai tisztségviselők a XIV. század közepén. In.: Középkor történeti tanulmányok 5. Szerk. Révész Éva-Halmágyi Miklós. Szeged 2007. 41-53. Uö.: A raguzai (dubrovniki) diplomácia a XIV. század közepén (1343-1367) In.: Középkor történeti tanulmányok 6. Szerk. G. Tóth Péter-Szabó Pál. Szeged 2010. 95-108.

${ }^{360}$ Mályusz 2003. 136.
} 
bányabérletei révén. ${ }^{361}$ Mályusz szerint így kapott részt a despota magyarországi uradalmainak kormányzásából is.

Ezen a ponton nem hagyhatjuk figyelmen kívül a lehetséges raguzai várépítési tapasztalatokat, mintákat a Lazarević István-féle építkezések során. Elég visszautalnunk korábbi fejezetünkre, hogy felidézzük, Raguza középkori városfala, erődje is magában foglalta a város települését. ${ }^{362}$ A 14-15. században a meredek felszíni szakaszokon felépített falakban kör és négyszög alakú tornyokat is építettek. ${ }^{363}$ Ezeket a Tallóciak is láthatták, ismerhették. A helyi mesteremberek szakértelmében bízva ezért is fogadtak fel raguzai téglaégető mestereket a nándorfehérvári építkezések folytatásához.

Tallóci Matkó azonban a katonai szolgálatokban is kiemelkedett. Zsigmond király a saját szolgálatába fogadta és a törököknek átadott Galambóc várának visszafoglalására sereggel őt vezényelte ki. Matkó 1428 júniusában Galambóc magyar ostrománál már 200 fónyi fegyveressel és saját vármegyei familiárisaival jelent meg. ${ }^{364}$

Galambóc ostromáról legutóbb Veszprémy László ${ }^{365}$ értekezett, illetve Petrovics István írt szócikket. ${ }^{366}$ Az ostrom elökészületeként a várral szemközti Duna parton már korábban, mint - a szakirodalomban szereplő - 1427/1428 telén megépítették Szentlászló várát. ${ }^{367}$ A magyar csapatok mellett ott voltak Czarny Zawisa ${ }^{368}$ lengyel és Dan, havasalföldi vajda csapatai is. Veszprémy idézi Mályusz Elemér azon véleményét, amely szerint valószínű, hogy a Tallóci vezette sereg létszámában benne volt a Branković György által küldött segélycsapat is, ezt a tényt azonban a neki, 1437-ben kiállított oklevél elhallgatta. ${ }^{369}$

Azonban Tallócinak a vár ostrománál tanúsított cselekedeteit az 1437. szeptember 27-én kiállított adományozó oklevél (DL 44 167) böségesen részletezi, amelyre már Mályusz Elemér is felhívta a figyelmet. Számunkra azért is érdekes, mert a vár ostrománál Tallóci Matkó tüzérségi szakértelmét és az akkor újdonságnak számító bombavető mozsarak használatát is megemlíti. Ez azért is fontos, mert Brocquière szerint Galambóc ,igen erös vár, jóllehet tüzérséggel könnyen körül lehet zárolni és minden segitségtöl elvágható”.

\footnotetext{
${ }^{361}$ Mályusz 2003. 136.

${ }^{362}$ Lásd a 3. 3. fejezetet.

${ }^{363}$ Beritić 1989. 5.

${ }^{364}$ Mályusz 2003. 137.

${ }^{365}$ Veszprémy László: Zsigmond Galambócnál 1428-ban. Hadtörténelmi Közlemények 2008. június (2. szám). A továbbiakban: Veszprémy 2008c.

366 Petrovics István: Galambóc ostroma. In.: Nagy képes millenniumi hadtörténet. Szerk. Rácz Árpád, Budapest 2000. 64. A továbbiakban: Petrovics 2000.

${ }^{367}$ Petrovics István a vár építésének kezdetét már Zsigmond 1419-es al-dunai hadjáratához kötötte. Petrovics 2000. 64.

${ }^{368}$ A hösi halált halt lengyel lovag emlékét ma emléktábla őrzi a galambóci várban.

${ }^{369}$ Veszprémy 2008c. 289.
} 
(Szamota István fordítása) ${ }^{370}$ E taktikának megfeleltethetően, az oklevél szerint Tallóci Matkó „,elszánt és serény férfi, nyugtalanitó gondot okozva, ennek a (t. i. várnak) némely falaiban és tornyaiban a kölövedékek sokaságával, a bombavetö mozsarakkal - lövés lövést követve - bátran ostromolt. E férfiú buzgó gondoskodásának és leleményes elörelátásának eredményeképpen az elöbb emlitett vár tornyainak és falainak nevezetes részeit ugyanezen köveknek, avagy kögolyóknak és bombavetöknek erös lövései áttörték. "371

A magyar csapatokat Rozgonyi vezette. Azonban hadvezéri tehetségéről Mályusz és Veszprémy kételyeiknek adtak hangot. ${ }^{372}$ Ezzel annyiban értek egyet, hogy feltételezhetően a vár ostrománál, a fenti oklevél alapján inkább Tallóci lehetett a tüzérség tényleges vezetője és irányítója is. Rozgonyi István, temesi ispán az oklevelek szerint (DL 59 120, 1428. december 28; 1436. április 10.) az ostromra rendelt ágyúk egyikét igazgatta és a vár egyik tornyának nagy részét rommá lőtte. Rozgonyi felesége, Szentgyörgyi-Bazini Gróf Péter leánya, Cecília (Cicelle) is részt vállalt a vár lövetésében. Bár ez utóbbi esemény adott évben való történésében kételyek merültek fel, ez a leírás azonban egy eddig fel nem ismert és nagyon is praktikus vízi ostromtaktikát fed fel, amely megtörténtét a leírás igazolja. Ugyanis „oda merészelt jönni és egy fegyveres gályánkra, melyet többek közt éppen ott a Duna folyamon tartottunk, nemcsak leküzdve az asszonyi és női nemmel járó gyenge, remegö, megijedö lelki állapotot, de sőt, lelkesedéssel és katonai bátorsággal vakmerően felszállott és azzal a mondott Duna folyamon serényen most ide, majd oda evezett, a harczi támadás megkezdése után pedig abba belevegyülve több gyözelmes rohamot intézett, továbbá ugyanarról a gályáról az ostromágyúkból vagy bombardákból, ködobógépekböl és más e czélra szolgáló hadi szerszámokból ... többször sőt ismételten lövetni nem félt." 373

Veszprémy László megállapítása szerint a vár lövetése a szemközti Szentlászló várából (kb. 1-1,5 km távolságból) lehetséges lehetett, de célzott lövés aligha. A török források pedig szárazföldi és nem vízi előrenyomulásról írnak. A hadtörténész itt nem említ faltörő

\footnotetext{
${ }^{370}$ Szamota 1891. 80.

${ }^{371}$ Thallóczy-Áldásy 1907. 112. (184. sz). ,,vir strenuus et agilis curam ferens solicitam, ipsum in certis eius meniis et turribus per crebras lapidum, bombardarum emissiones ictus ictibus continuans fortiter fecit impugnari ex cuius diligenti sollicitudine et solerti procuratione notabilies turrium et murorum castri pretacti partes per ipsorum lapidum seu globulorum, bombardarum violentos impulsus dirute extiterunt."

${ }^{372}$ Veszprémy 2008c. 289.

373 Az oklevelet latinul és magyarul közzétette még: A magyar nemzet története. VI. kötet (1440-1526) Szerk. Szilágyi Sándor. Budapest $1895^{2}$. 203. A továbbiakban: Szilágyi $1895^{2}$. A magyar fordítást innen idézi: Cseh 2007. 29. (9. lábjegyzet); Veszprémy 2008c. 289.
} 
mozsarak használat sem. ${ }^{374}$ Azzal egyetértünk, hogy ilyen távolságból, alacsony szögtartományban, ágyúkkal Galambóc meredek falai nem löhetők. Azonban a fent ismertetett Tallóci oklevél, de a Rozgonyi Cecília számára kiállított oklevél is bombardákat említett. A lövedékeket „ex pixidibus seu bombardis balistis et aliis” lövette ki. ${ }^{375}$ Ahogy legutóbb Fedeles Tamás is megállapította a bombarda kifejezést egyrészt általánosan az ágyúkra használták, másrészt viszont azoknak egy fajtáját is jelölték vele. ${ }^{376}$ Itt e bombardákat mi nem faltörö mozsaraknak, hanem inkább bombavetö mozsaraknak fordítjuk, amelyeknek lövedékei a falat nem törik át, hanem mintegy felülről „,megkerülve” hullnak a védőkre. Galambóc meredeken álló, magas falai ellen ilyen tüzfegyverek használhatók (20. melléklet). Ilyen mozsarak létezését - éppen Nándorfehérváron - egy olasz nyelvü, Mátyás-korabeli, 1479-es hadianyag-összeírás is megerösíti, amely a bombardák több fajtáját megnevezi. Így a ,falbontó bombardák” mellett volt még „magasra vető nagy bombarda, amelyet köznyelven mortari-nak neveznek” (Óváry Lipót fordítása). ${ }^{377}$ Milleker Bódog is hasonló értelemben fordította a fenti oklevél részletet: „Szentgyörgyi Czeczilia, ki egy gályát vezényelt és evvel ide-oda evezett és abból mozsaraival és követö gépeivel a török hajókat rongálta..."378 Rázsó Gyula is hasonló értelemben jegyezte meg, hogy „ágyúsnaszádokról is bombáztak."379

Az ostrom során a túlpart tényleg túl messze lehetett, így nem innen, hanem a Dunáról lövették a várat - mintegy úszó ütegként -, a gályával serényen ide-oda evezve, haladva és hátrálva ,in dicto Danubio hinc inde strenue modo currens, modoque discurrens". ${ }^{380}$ Azaz, beállították a mozsárnak is megfelelő lőtávolságot, ahová a védők fegyverei sem értek el, miközben onnan biztonságosan lehetett bombákat „ráejteni” a meredeken épül várra! Véleményem szerint ez az első említése az úszó ütegek magyar várostromban való alkalmazásának. Azt is tudnunk kell, hogy a Duna akkori vízszintje a maiénál jóval alacsonyabb volt, mert a 20 . századi folyóduzzasztás folytán a vár alsó részeit a víz teljesen elárasztotta (21. melléklet). Hasonló ostromtechnikát fedezhetünk fel Szabács várának

\footnotetext{
${ }^{374}$ Veszprémy 2008c. 288-289.

375 Szilágyi $1895^{2} .203$.

${ }^{376}$ Fedeles Tamás: Fegyverek, felszerelés, logisztika a késő középkori Magyarországon. In.: Középkortörténeti tanulmányok 7. Szerk.: Kiss P. Attila, Piti Ferenc, Szabados György. Szeged 2012. 506. A továbbiakban: Fedeles 2012.

377 Óváry Lipót: Jelentés olaszországi kutatásaimból. Századok (18) 1884. 510. (Óváry 1884)

${ }^{378}$ Milleker 1914. 27.

${ }^{379}$ Rázsó 1973.439.

${ }^{380}$ Szilágyi $1895^{2}$. 203.
} 
ostromakor (1475-76). Hunyadi Mátyás a Száva-folyón hajókra rakatta a nehézágyúk egy részét és onnan lövette a vár gyenge pontjait. ${ }^{381}$

A török kontrollforrások közül a történetíró Nesri is említi Galambóc (Gögerdsinlik) magyar ágyúzását. Murád szultán Szinán ruméliai beglerbéget küldte a várhoz, hogy védje meg, ahol „az ágyúk dörgése miatt lovaink széttépik kötőfékeiket”. De ami a lovaiknak ismeretlen, az török fülnek már ismerős lehetett: ,de a mi füleink hozzá vannak szokva az ágyúdörgéshez"(Thúry József fordítása). ${ }^{382}$

A másik megjegyzésünk a Rozgonyi Cecília adománylevelében lévő „ex pixidibus” fordításához kapcsolódik. Az egyébként görög eredetü, latin pixida jelentései között a középkori latinságban nemcsak az ágyút, hanem a puskát, kézipuskát is megtaláljuk (pixida manualis). ${ }^{383}$ Véleményem szerint e kifejezés puskáknak is fordítható, csupán össze kell hasonlítani más korabeli hadászati forrással, ahol szintén szerepel. Itt a későbbiekben tárgyalandó 1437. évi Marcali-féle hadijelentésre kell utalnom, ahol a fenti szókapcsolat „pixidibus bombardisque” alakban fordul elö. ${ }^{384}$

Visszatérve még a Rozgonyi oklevélben lévő „bombardis balistis et aliis” kifejezésekre. Ha e szintagmában leválasztjuk a balistis-t és önállóan értelmezzük, az ugyanezen 1437-es hadijelentésben balistis/balistris alakokban is megtalálható, de számszeríj jelentésben. Így fordíthatnánk mi is, mert nem valószínü, hogy a Galambócnál, a Dunán hajózó gályákra nehéz, nagy kőhajítógépeket is felszereltek volna a bombavető mozsarak mellett.

A magyar szakirodalom lehetségesnek tartotta, hogy Galambóc felmentésére szultáni sereg érkezett, II. Murád szultán vezetésével. Generál Tibor azonban Szinán ruméliai beglerbég mellett szólt, bár megemlítette, hogy a magyar források írnak a szultáni vezetésröl. ${ }^{385}$ Mégis az 1428. augusztus 28-i, Szentlászlói András fia Márk részére kiállított királyi oklevélben Szinán béget (,Zynanbeg Turcus”) találjuk. ${ }^{386}$

Legutóbb Veszprémy László amellett foglalt állást, hogy mivel további török források (Âșik Pașazade, Murád Évkönyve) sem tesznek említést a szultánról, a vezér valószínüleg a Nesri által említett Szinán lehetett. ${ }^{387}$ Azonban a Murád Évkönyve Ménage-féle kiadásában

\footnotetext{
${ }^{381}$ Rázsó Gyula: Hunyadi Mátyás török politikája. Hunyadi Mátyás. Emlékkönyv Mátyás király halálának 500. évfrodulójára. Budapest 1990. 185. A továbbiakban: Rázsó 1990.

382 Török történetírók I. Ford. Thúry József, Budapest 1893. 53. A továbbiakban: Török történetírók I. 1893.

${ }^{383}$ Glossarium mediae et infimae latinitatis regni Hungariae. Condidit Antonius Bartal. Lipsiae 1901. 494. A továbbiakban: Bartal 1901. A kérdésre lásd még: Fedeles 2012. 507-508.

${ }^{384}$ Lásd: az 5. 4. fejezetet.

385 Generál 1987. 53.

${ }^{386}$ DL 30 431. Lásd még a 6. 2. fejezetet.

${ }^{387}$ Veszprémy 2008c. 290. Idézi Fodor Pál kutatásait.
} 
a 831. évnél (1427. október 22 - 1428. október 10) azt találjuk, hogy a szultán ment a Láz népéhez (t. i. a szerbekhez) és Gügercinligi-t legyőzte. ${ }^{388}$

A legtöbb oszmán-török forrás nem szultáni vezetésröl ír. Szeád-Eddin ezt megerősíti, mert szerinte is Murád szultán Szinán béget, a ruméliai beglerbéget küldte Galambóchoz. ${ }^{389}$ Tallóci Matkó tehát itt nem találkozhatott még szultáni haderővel.

Az 1486. évi Névtelen szerző Murád hódításai között csak általánosságban sorolja fel Galambócot is. „Aztán Murád khán Dsám-adaszit és Göderdsinliket, meg Láz-ihi-t (t. i. Szerbiát, Lázár országát) váraival együtt elfoglalta. A hidsre 831. évében történt." (1427. október 22 -1428. október 10). ${ }^{390}$ Egyébként Colin Imber rámutatott arra, hogy mivel II. Murád szultán 1424-től Anatóliába vezetett hadjáratot 1428-ig, Galambócnál nem lehetett jelen személyesen. Ugyanis 1425-re meghódította Menthesét, három év múlva befejezte ázsiai hódításait, 1428-ban pedig Germiyant szerezte meg. ${ }^{391}$ Ehhez azt teszem hozzá, hogy figyelembe kell venni azt is, hogy Galambóc ostroma idején már folyt Thesszaloniki évekkel korábban megkezdett oszmán-török blokádja is, amely jelentős oszmán erők átcsoportosítását követelte meg a szultántól. Szaloniki védői még magyar segítségben is reménykedtek. Ez sem valószínűsíti, hogy Murád ott lett volna Galambócnál. ${ }^{392}$

Az előbbiekben már idézett 1437. évi Tallóci-oklevél szerint Zsigmond feladta Galambóc ostromát: „Mi végül ezen város ostromától elálltunk, miután megbízható fegyverszünetet kötöttünk és erösitettük meg: közöttünk és a török uralkodó, valamint a törökök között és ezen fegyverszünet értelmében bármiféle eröszak alkalmazása nélkül akartunk a Dunán átkelni."393 A megkötött fegyverszünetröl a király értesítette 1428. június 3-án kelt oklevelében nándorfehérvári várnagyát (castellanus Nandoralbensi), Bátmonostori Töttös Jánost is és kérte, hogy néhányadmagával jelenjen meg a királynál. ${ }^{394}$

A visszavonulás során, amikor a sereg nagyobbik része már átkelt és csak kis védősereg maradt a királlyal, a törökök rátámadtak a Dunán átkelőkre. Mivel az összes hajót elfoglalták, a sereg hátra maradt részére nem maradt más hajó, sőt nem volt hajó, amellyel

\footnotetext{
${ }^{388}$ Ménage 1976. 574.

389 Török történetírók I. 1893. 125-126.

390 Török történetírók I. 1893. 17.

${ }^{391}$ Imber 2002. 23.

392 Lásd a 2. 4. fejezetet.

${ }^{393}$ Thallóczy-Áldásy 1907. 112. (184. sz). „Nobisque tandem ab ipsius castri obsidione factis et firmatis inter nos et dominum Turcorum atque Turcos certis treugis discendibus, Danubiumque absque aliquali fortitudine sub huiusmodi treugis pacis transfretare volentibus."

394 DL 80 167. A Zichy és Vásonkeői Gróf Zichy-család idősb ágának okmánytára. VIII. Szerk. Kammerer Ernő, Budapest, 1895. 354. (240. sz. okl) ,,inter nostram maiestatem et dominum Turcorum treuga sive concordia facta est et conclusa” A továbbiakban: Zichy 1895.
} 
magát Zsigmond királyt is átvihették volna. ${ }^{395}$ Matkó hősies helytállását - e válságos pillanatban - folytatja az elöbbi oklevél: „, ugyanennek a Matkó bánnak és más híveinknek tanácsából és gondoskodásából találtunk egy hajót, amelyre felszállva megkezdtük az átkelést. Magát Matkó bánt más báróinkkal együtt az örködés és a seregeink védelmére a hátramaradottak részéböl, azalatt, amíg az ottmaradt sereg átkelhet... (t. i. kirendeltük). Ekkor Matkó bán eközben aggodalmas fáradságot viselve, egész éjjel, a hajnal eljöttéig a törökökkel vitézül harcolva övéivel velük szemben hathatósan ellenállt ... maga Matkó bán a törökökkel keményen harcolva alig menekült meg a hirtelen halál vészétöl abban a révben". ${ }^{396}$ Zsigmondot is alig tudták megmenteni. Ebben a harcban Rozgonyi István is részt vett, aki a hajóra szállva megvédte a királyt attól, hogy fogságba ejtsék, miközben Rozgonyi maga majdnem a vízbe fulladt. ${ }^{397}$ Brocquière szerint mivel Zsigmond nem ismerte a török haditaktikát, így fordult elö, hogy bár 25-30 000 magyar katonája volt, 200 lombardiai és genovai íjásza fenntartotta a török támadásokat az átkelő sereg ellen, és 6000 oláh vesztette életét, mégis kénytelen volt visszavonulni. ${ }^{398}$

Az uralkodó Tallóci Matkó Galambóc ostromakor tanúsított vitézségéröl nem feledkezett meg. Nándorfehérvár királyi kapitányának 1428. január 25-én elöször egy helybeli birtokost, Bátmonostori Töttös Jánost, annak halála után testvérét, Töttös Lászlót, majd 1429 szeptemberében Tallóci Matkót nevezte ki, aki szeptember 3-án átvette Bátmonostori Töttös Lászlótól a vár felszereléseit. ${ }^{399}$ „Raguzai” Matkó e várkapitányságán túl együttesen Keve, Csanád, Krassó ispánja is volt. Matkó, helyetteséül, maga mellé vette öccsét, Frankot. ${ }^{400}$ Ezt Brocquière lovag is megerősítette: „A vár fökapitánya, vagyis parancsnoka, raguzai Máté (Mathico de Aragouse), helyettese pedig egyik fivére volt." (Szamota István fordítása) ${ }^{401}$ Meg kell jegyezni a nándorfehérvári várkapitány (capitanenus) mellett volt várnagy (castellanus) is. Míg a várkapitány a helyőrség, a katonaság irányítását, a várnagy a várhoz tartozó gazdasági jellegü teendőket látta el.

\footnotetext{
395 Wertner 1911. 438.

396 Thallóczy-Áldásy 1907. 113. (184. sz). „...tandem ex consilio et procuratione ipsius Mathkonis bani et aliorum certorum fidelium nostrorum quadam inventa navi eandem conscendens transfretare cepissemus, ipsumque Mathkonem banum cum aliis certis baronibus nostris pro custodia et defensione gentium nostrarum ex illa parte remanentium interim donec ipse gentes residue possent transfretari...Tunc ipse Mathko banus in hiis curam gerens sollicitam, per totam illam noctem usque auroram contra ipsos Turcos viriliter cum suis dimicando, eisdem potenter restitit...et ipse Mathko banus contra ipsos Turcos acriter pugnando vix dire mortis pernicem portu in eodem evasit..."

${ }^{397}$ Wertner 1911. 436.

${ }^{398}$ Szamota 1891. 87.

${ }^{399}$ Mályusz 2003. 137. Milleker 1914.

${ }^{400}$ Mályusz 2003. 138.

${ }^{401}$ Szamota 1891. 80
} 
Marko Popović szerint e várkapitány és a várnagy egymáshoz való viszonyát nehéz megállapítani, de sokszor a két tisztséget ugyanazon személy viselte. ${ }^{402}$

Frank kevei ispánként és nándorfehérvári kapitányként többször is intézkedett, amelyet oklevelek tanúsítanak. ${ }^{403}$ Főleg akkor, amikor Matkó Zsigmondot kísérte el évekig tartó európai útjára. Keve vármegyének is voltak raguzai kapcsolatai, mert a szerbiai karavánutak elértek ide is.

Tallóci-testvérek a végvonalba kerültek saját gazdasági vállalkozásukkal. Gyakorlatilag a vagyonukat fektették be a feladatba. Növekvő súlyukat mutatta, hogy Matkó már a legnépesebb kísérettel vett részt Zsigmond római császárkoronázásán. ${ }^{404}$

A Tallóci-testvérek összehangolt tevékenységet folytattak. egyfajta „munkamegosztásban” látták el tisztségeiket is. A müködtetéshez szükséges gazdasági potenciál kialakítása érdekében a király a kapitánysághoz kapcsolta még más tisztségek jövedelmeit is. Ebben már volt előzmény, az ország déli határszakaszának védelmét egy ideig ellátó Német Lovagrend esetében.

Tallóci Frank az üresedésben lévő kalocsai érsekség jövedelmeit kapta meg, amikor 1433-ban számára kiutalták kormányzóságba az érsekség birtokállományát. ${ }^{405} 1434$. július 14-én Zsigmond király elrendelte, hogy a nagyváradi püspökség kormányzójának, Tallóci Matkónak a bázeli szent zsinat határozata alapján a hívek jövedelmük huszad részét (,semidecima, id est vigesima pars decimarum”) fizessék ki a husziták elleni hadjárat költségeire. ${ }^{406}$ Az egyházi tized felét, azaz egyhuszad részét. E tisztségekhez továbbá mi hozzávennénk még a királyi sókamarák kezelését is. Nándorfehérvárott 1434. március 24én Tallóci Matkó, mint kevei és bizonyos királyi sókamarák ispánja (,,Kowyniensis et certarum camerarum salium regalium comes”) bocsátott ki rendelkezést. ${ }^{407}$ Zsigmond király 1435. december 9-én kelt oklevelében Tallóci Matkót, mint a szegedi királyi sókamara ispánját (,,comes camararum salium nostrarum Zegediensium”) említi. ${ }^{408}$

\footnotetext{
402 Popović 2011. 34.

403 Például 1435. augusztus 19-én kelt oklevélben Frank, mint kevei ispán és nándorfehérvári kapitány szerepel (,,comes Kovynensis ac capitaneus Nandoralbensis”). Zichy 1895. (385. sz. okl)

${ }^{404}$ Mályusz 2003. 140.

405 Mályusz 2003. 141-142.

406 Zichy 1895. 537-538. (365. sz. okl)

${ }^{407}$ Zichy 1895. 534-535. (362. sz. okl) Bátmonostori Töttös László birtokháborítási ügyében.

${ }^{408}$ DL 80 543. Zichy 1895. 565. (390. sz. okl). A király Bátmonostori Töttös László házassági költségeire 500 arany értékben sót utalt ki, amelynek átadását Tallóci Matkó szlavón bánra bízta.
} 


\section{2. Nemesség és pecséthasználat: a Tallóci címer nyomában}

A Tallóciak életútját tanulmányozva felvetődött bennem az a kérdés, hogy a Tallóciak tagjai lehettek-e a Zsigmond által megalapított Sárkányos Rendnek is? Az 1408. december 12-én keltezett „alapítólevélben” - amelyben akkor még csak 22 előkelő báró szerepelt biztosítva volt az előmenetel is: „megadjuk a nekik megadható tiszteletet és tiszt(es)séget, őket és minden egyesüket magasabbra felemeljük..." (Baranyai Béla fordítása). ${ }^{409}$ Azt lehet mondani, hogy valamennyi királyi méltóságviselő egyúttal a rend tagja is volt. ${ }^{410} \mathrm{~A}$ rend jelképét is meghatározták, azaz a „,körré görbült sárkány jelét vagyis képét, amint farkát nyaka köré tekeri..." (Baranyai Béla fordítása). ${ }^{411}$ Ezek megjelentek a kor nemesi címereiben is, mivel a lovagrend tagjai a rend jelvényét címerükbe vagy a címerpajzs köré felvették. Perdöntő lenne, ha az 1420-as években a budai várban készített palotakályhák díszes csempéin, amelyeknek fennmaradt töredékein a rend tagjainak címerképe látható, az eddig azonosítatlan címerek között, megtalálnánk a Tallóciak címerét. A rend jelvényét a Tallóciak pecsétjeinek vizsgálata során a címerábrázolásukban sem találtam. Annyit tudunk, hogy polgári származásúak voltak, nem tudunk nemességükröl, sem magyarországi címeradományukról. A Cillei Krónika írta Tallóci Matkóról: „nem volt nemesi születésü, hanem Zsigmond császár emelte fel és tette bánná."

Azonban felettébb érdekes, hogy Matkó még a római útja előtt, amikor 1431-ben a királytól a Verőce megyei Tallócot kapta birtokként, az addig használt „Raguzai” (polgár) nevét a nemesien hangzó „Tallóci”-ra változtatta (,,de Thallouz alias de Ragusio”). ${ }^{413} \mathrm{E}$ névváltoztatás véleményem szerint jogi státusváltozást mutat. A névváltoztatás a címerhasználatnál is biztosabb jele a nemességnek. Matkó egy raguzai városi polgárból magyarországi nemessé vált. Míg „Raguzai”-ként az országban többen hívhatták magukat, de „Tallóci”-ként csak ő és testvérei. Az adományul kapott birtoknak sem akárki volt a tulajdonosa! Zsigmond királynak a nikápolyi csata után fogságba esett nádorának, Ilsvai Lestáknak a birtoka volt, amelyről - miután a váltságdíj összegyüjtése eredménytelennek bizonyult - 1400. január 20-án, Metelin szigetén úgy végrendelkezett: „,...Tallóc birtokot minden tartozékával Miklós fiára, Gergelyre hagyja, mivel ez a fogságból való

\footnotetext{
${ }^{409}$ Baranyai Béla: Zsigmond király ún. Sárkány-rendje (1. közlemény) Századok 1926. 576. A továbbiakban: Baranyai 1926.

410 Fügedi Erik: Uram, királyom... A XV. századi Magyarország hatalmasai. Budapest 1974. 166. A továbbiakban: Fügedi 1974.

${ }^{411}$ Baranyai 1926. 575.

${ }^{412}$ Idézi: Pálosfalvi 2000. 48. (14. lábjegyzet)

${ }^{413}$ Mályusz 2003. 141.
} 
kiszabaditása érdekében nagyon sokat fáradt..." (C. Tóth Norbert fordítása). ${ }^{414}$ Jól gondolta ezt Mályusz Elemér is, aki szerint ennek a birtoknak ,mintha az értékét nem a jobbágytelkeinek száma adta volna meg, hanem a neve, azzal a rendeltetéssel, hogy felvételével az addig csak »a Ragusai«-nak nevezett család elfelejthesse jöttment voltát."415 Sajnos e birtokról szóló adománylevél nem maradt ránk. Érdemes tehát a Tallóciak nemességének kérdését újra vizsgálat alá venni.

Amennyiben a királytól későbbiekben kapott birtokaikat is vesszük figyelembe - a birtokadományozás ténye alapján - a nemesség megléte feltételezhető. Werbőczy szerint (I. 4.) „...midön fejedelmünk bármely sorsban élö embert jeles tettei és szolgálatai fejében várral, várossal, faluval vagy más ingatlan jószággal megajándékoz: az a fejedelemnek adománya által (ha törvényszerü beigtatása is megtörtént) azonnal valóságos nemessé tétetik...” (Csiky Kálmán fordítása). ${ }^{416} \mathrm{Ne}$ feledjük, hogy a négy Tallóci testvér Zsigmond királytól 1437. szeptember 27-én a valkó vármegyei birtokokat, 1438. március 31-én pedig Albert királytól a temes vármegyei és kevei birtokadományokat nekik és az ő örököseiknek és azok leszármazottjainak örökjogon és visszavonhatatlanul adományozták. ${ }^{417}$

Nem szabad figyelmen kívül hagynunk azt sem, hogy Zsigmond uralkodása alatt a felemelkedésre a familiárisok mellett nagy lehetősége volt a hivatalviselőknek is. Azt Fügedi Erik is elismerte, hogy a polgári származású családok közül „a Tallóciaknak sikerült a bárók közé jutnia."418 Azaz közülük csak Matkó emelkedett az országos tisztséget viselő bárók sorába. ${ }^{419}$ Ezzel jól egybecseng Thuróczy-krónika a királyról és a Tallóciakról tett megjegyzése (214. fejezet) „Ez a király nemcsak alacsony származású nemeseket, hanem igen sok közrendü embert is magas méltóságokra emelt, és hatalmassá tett országában...Matkó bán és fivérei: Frankó, Petkó és Zován-akiknek utódai most nem nagy részt birtokolnak az atyai vagyonból - raguzaiak voltak. Bár ök városi polgárok voltak, mégis élvezték e király nagy jóindulatát, böségesen volt aranyuk és földjük, s míg éltek hatalmasak voltak az országban.”(Bellus Ibolya fordítása) ${ }^{420}$ Ez még e fejezet élén

\footnotetext{
${ }^{414}$ Idézi: C. Tóth 2009. 35.

415 Mályusz 2003. 141.

416 Werbőczy István: Tripartitum. A dicsőséges Magyar Királyság szokásjogának Hármaskönyve. Latinmagyar kétnyelvü kiadás. Budapest 1990. 67. A továbbiakban: Werbőczy 1990.

417 Thallóczy-Áldásy 1907. 123, 126. (184. és 187. sz. okl)

${ }^{418}$ Fügedi 1974. 187.

${ }^{419}$ Fügedi 1974. 170.

${ }^{420}$ Thuróczy 2001. 258, 21-23, 27-32.
} 
mottóul választott Tinódi Lantos Sebestyén versszakban is megőrződött, igaz téves genealógiával. $^{421}$

De gondolnunk kell Matkó mellett a legkisebb testvérre, Tallóci Jovánra, aki a nándorfehérvári kapitányságot a vránai perjel tisztségével együtt viselte. A perjeleket pedig ekkor a világi nemesek közül választották. Tallóci Jován 1438-tól haláláig viselte e címet, a johannita rend magyarországi tartományának főnökeként. ${ }^{422}$

Az 1431. vagy az 1437. évi birtokadománya után, ha a Sárkányos Rend tagságára Tallóci Matkónak nem is lehetett volna komoly esélye, a renddel való szoros családi kapcsolatát egyáltalán nem zárhatjuk ki. Mégpedig az egyik alapító rendtag, Lévai Cseh Péter erdélyi vajda révén, aki a Garai-családdal alakított ki rokonságot. Sörös Pongrác a Századokban írt tanulmányában áttekintette Lévai életútját. ${ }^{423}$ Leányát az idős Garai Miklós nádor fiához, az ifjabb Garai Miklóshoz adta feleségül, Zsigmond tiltakozása ellenére. Egy leányuk született. Azonban a férj korai halála után, 1439-ben Lévai Cseh Margit már Tallóci Matkó felesége lett. ${ }^{424}$ Albert 1439. szeptember 5-én kelt királyi oklevele Garai Miklós macsói bánnak tett adomány során megemlítette a Matkóval való rokonságát is. Mert felesége, Lévai Cseh Margit úrnő, a macsói bán testvérének, ifjabb Miklósnak özvegye volt, akinek tőle Katalin nevü leánya van. ${ }^{425}$

1439-ben Lévai Cseh Péter - felesége, Katalin asszony után - Margit testvérére, Lászlóra is hagyományozott birtokokat. ${ }^{426}$ Lévai Cseh Péter hamarosan meg is halt, mert egy 1440. július 1-i, Ulászló által kibocsátott oklevél már néhai Péter vajda fiát, Lászlót említette. $^{427}$

Lévai Cseh Margit második házassága esetén felmerülhet a nemes és nem nemes (birtoktalan) házasságának magánjogi vetülete is. Ez azt a kérdést veti fel, hogy a nemesi származású feleség közvetíthetett-e nemességet nem nemesi származású férjének, amennyiben nem lett volna már eleve az? Tallóci Matkó házassága kapcsán nem tudunk arról, hogy ő ilyen „felesége utáni nemes” lett volna feltehetően azért, mert nem volt rá szükség. Ezen argumentum ex silentio alapján is gyaníthatjuk Matkó nemességét. A nem

\footnotetext{
${ }^{421}$ Tinódi Lantos Sebestyén: Zsigmond király és császárnak históriája. In.: Tinódi Lantos Sebestyén összes müvei. Régi Magyar Költők Tára III. kötet. Budapest 1881.349. A továbbiakban: Tinódi 1881.

${ }^{422}$ Mályusz 1984. 130.

${ }^{423}$ Apja Sárói László temesifőispán, Szlavónia bánja, aki feltehetően a nikápolyi csatában halhatott meg. Fia, a fent említett Lévai Cseh Péter egyébként Lévai Péter, Sárói László fia Péter néven is szerepel az oklevelekben. Zsigmond feltétlen híveként, a Sárkány - rend alapító tagja, fölovászmester és macsói bán. Sörös Pongrác: Lévai Cseh Péter. Századok 37 (1903) 825-827. A továbbiakban Sörös 1903.

${ }^{424}$ Sörös 1903.837; Fügedi 1974. 172.

${ }^{425}$ DL 13436

${ }^{426}$ DL 59257

${ }^{427}$ DL 59262
} 
nemes férj nemes feleséggel való házasodásának egyéb magánjogi kérdése egyébként éppen ezekben az években a törvényi szintű szabályozási szintjére emelkedett. Zsigmond király - egykorú - 1435. évi Decretum Maius-a például a leánynegyed birtokban vagy pénzben való kiadása kapcsán szabályozza a nem nemes férj és a nemes feleség házasságának esetét $(19-20 \S)$.

Matkó testvérei szintén bárói családokból vettek feleséget. Tallóci Péter (Petkó) Garai nádor öccsének, Garai Jánosnak Hedvig nevü leányát, Tallóci Frank pedig Kusalyi Jakcs Ilonát. ${ }^{428}$ Frank házassági kapcsolata a báró Kusalyi Jakcs-családdal (Jakch de Kussal) számára is előrelépést hozott. Felesége apja, Kusalyi Jakcs László erdélyi vajda (14401441) lett. Nagybátyjai közül, Kusalyi Jakcs János (1427-1431) és Mihály (1427-1438) együtt töltötték be a székely ispáni tisztet, Kusalyi Jakcs Dénes pedig váradi püspök volt. $^{429}$ I. Ulászló király 1440 nyarán Kusalyi Jakcs Mihály volt székelyispánt utóbb erdélyi vajdává nevezte ki, Lászlóval együtt, mivel az előző vajda, Losonci Dezső (14381441) Erzsébet királyné híveként ellenállást tanúsított, így őt hütlenség vétke elkövetése miatt leváltotta. ${ }^{430} \mathrm{~A}$ székelyispáni méltóság intézménytörténetét kutató Kordé Zoltán szerint a Kusalyi Jakcs unokatestvérek székelyispánságának újabb eleme az erdélyi sókamarákkal való kapcsolatuk. ${ }^{431}$ A Tallóciakkal való házassági kapcsolat alapján ez nem meglepő, hiszen a két család - a magyarországi és erdélyi - sókamara ispánságai révén is közel kerülhetett egymáshoz. Kusalyi Jakcs Mihály - János halála után - is megtartotta sókamara ispáni tisztét. ${ }^{432}$

A Tallóciak Sárkány rendhez füződő kapcsolata indított el a címerük vizsgálatához. Bár Werbőczy Hármaskönyve szerint a „czímer nem szükséges kelléke, hanem csak javára szolgál a nemességnek. Magában véve ugyanis a czímer adományozása nem nemesít valakit...” (I. 6. 1., Csiky Kálmán fordítása) ${ }^{433}$ azaz a nemesség igazolásához a címer nem bizonyító erejü, azonban érdemes szfragisztikai-heraldikai elemzés alá venni a Tallóciak fennmaradt okleveleinek pecsétjeit is. A Matkó által később kiadott oklevelek némelyikén ugyanis megmaradt a pecsét, amely valamilyen címerábrázolást sejtet. Az MNL adatbázisában végzett kutatásom során a legjobb állapotú pecsétlenyomatot Matkó 1437.

\footnotetext{
${ }^{428}$ Mályusz 1984. 130. Mályusz 2003. 152. Tallóci Frank felesége, Ilona (Elena) szerepel egy 1447. június 21-i (DL 29 778), egy 1453. november 30-i oklevélben (DL 14 755), valamint 1461. június 11-i oklevélben (DL 15 535).

${ }^{429}$ Engel 1996. 193-194. Kusalyi Jakcs Dénesről lásd: DL 11 744. (1431. február 2)

${ }^{430}$ DL 27 303. (1441. március 2) Lásd még: Kordé Zoltán: A székelyispáni méltóság a Zsigmond korban. Történelmi Szemle 2004/3-4. 220. A továbbiakban: Kordé 2004.

${ }^{431}$ Kordé 2004. 211.

${ }^{432}$ Kordé 2004. 213. DF 253327 (1436. április 25)

${ }^{433}$ Werbőczy 1990. 69.
} 
január 29-én, dalmát bánként - Frangepán János és özvegye, Katalin a király elleni, hütlenségi ügyében - kiadott oklevelén találtam. ${ }^{434}$ Azonban a bán a körpecsétjét fordítva nyomta bele a sárgás-barna viaszágyba öntött zöld viaszba, és mivel nem a család kihalásáról van szó, a kerektalpú címerpajzs képét 180 fokkal meg kell fordítani, azaz a talpára kell állítani (22. melléklet). Így az MNL adatbázisában megtalálható címerleírás ezért nem fogadható el, amely szerint ezen egy hosszában kettéosztott pajzs jobb (sic!) oldalán egy stilizált virág, baloldalán (sic!) egy álló alak lenne látható.

E vizsgálat kontrolljaként segíthetne még az I. Ulászló magyar király által 1440. június 15-én kibocsátott oklevél is, amelyet számos báró mellett, Tallóci Matkó is megerösített. Ezen is jó állapotú a pecsét, azonban a figurák nem felismerhetőek. ${ }^{435}$

Visszatérve az előbb említett 1437. január 29-i oklevél pecsétjére, ez alapján újra rekonstruálhatjuk a Tallóciak címerképét. Ezt először 1910-ben a Frangepán-oklevéltárban Thallóczy Lajos, Barabás Samu tette meg. ${ }^{436}$ Az oklevél átírása során egy pecsétleírást is közzétettek: „Kerektalpú hasitott paizs alján korona. A jobb mezöben jobbra fordult ágaskodó, koronás, két farkú, ragadozásra kész oroszlán; a bal mezöben a hasitás vonalából kinövö koronás, kétfejü, kiterjesztett szárnyú félsas. ${ }^{~} 437$ Az megállapítható, hogy az MNL adatbázisának címerleírása hibás. Szükséges a pecsét fényképét is alaposabban szemügyre vennünk.

Ugyanis Tallóci Matkó DF-DL 88112 számú oklevelének pecsétlenyomatán a kerektalpú pajzs középen hasított. A pajzsmező mázai (fémek, színek) nem jelöltek, vonalazás, pontozás nélküliek. Azzal egyetérhetünk, hogy a címerpajzs jobb szélén a hátsó lábain ágaskodó, egymásba szimmetrikusan fonódó kettős, bojtos farokkal ábrázolt oroszlán alakját véljük felfedezni, amely háromágú koronát visel. A pajzs bal szélén kiterjesztett szárnyú, hosszú nyakú, fejével hátra forduló, kinyitott csőrü madár alakja körvonalazódik. Talán sas is lehet, ahogy ezt az elöbb idézett címerleírás megállapította. Talán daru, amely a heraldikában a hűséget, valamint az éberséget jelképező madár, amely a várvédelemre és a határvédelmre is utalhat. De új elemet is véltünk felfedezni. Tallóci Matkó pecsétjén a pajzsmezőt középen egy hosszú, egyenes, vércsatornával rendelkező pallos hasítja két egyenlö részre, amely a méltóságával járó pallosjogra utalhat. Mert Tallóci Frank pecsétjein nem látunk pallost, sem cölöpöt, hanem címertanilag csak karót

\footnotetext{
${ }^{434}$ DF-DL 88112

${ }^{435}$ DF-DL 13554.

436 A Frangepán család oklevéltára. (In.: Magyar Történelmi Emlékek. Első osztály, okmánytárak, harmincötödik kötet) Kiadják: Dr. Thallóczy Lajos, Barabás Samu. Első kötet 1133-1453. Budapest 1910. 276. (285. sz. okl). A továbbiakban: Thallóczy-Barabás 1910.

437 Thallóczy-Barabás 1910. 276.
} 
vagy szált a Matkóéval egyébként megegyező címeren. Hasonló ábrázolással Matkó 1440. október 1-én, a Körös megyei Grubosincon horvát-szlavón-dalmát bánként kiadott oklevelén, papírral fedett gyürüspecsét lenyomatán jól látszik az oroszlán hátának körvonala. ${ }^{438}$ (23. melléklet)

A címerállatokat tekintve az oroszlán, a sas a leggyakoribb. Azonban Áldásy Lajos szerint a kettős farkú oroszlánt csak a 15 . századtól ábrázoltak. ${ }^{439}$ Feltűnik a kettősfarkú oroszlán a magyarországi nemesi családok címereiben is, mint például a felső-szelestei Szelestey-, harinnai Farkas-, vingárti Geréb-család címereiben is. ${ }^{440}$ A kialakulása onnan eredt, hogy az oroszlánfarok díszítésekor a göndör fürtjeit ábrázolták úgy, mintha két farok volna. Legtipikusabb példája a cseh királyi oroszlán. ${ }^{441} \mathrm{Az}$ is feltünő, hogy a Tallócicímerben koronás oroszlánt látunk, amely nem a polgári származásra utal, hanem valószínűleg a királyhoz kapcsolódó nemesítésre, esetleg tisztségre vagy birtokadományra.

Érdemes elgondolkodnunk a Tallóci-címer raguzai eredetének lehetőségén is, mert a későbbi, 16. századi tekintélyes raguzai nemesi családok címerében is találhatunk oroszlánt és a félsast, azonban darut nem. A Binciola, a Croce-családi címerben oroszlánt, a Bassegli-családéban félsast. Az is megállapítható, hogy mindegyik címerpajzs tetején ötágú koronát találunk. ${ }^{442}$

$\mathrm{Az}$ is gyanítható, hogy ez az - akár Raguzából eredő, akár Zsigmond király által adományozott - Tallóci-címer családi címer lehet, mert a másik testvér, Tallóci Frank nándorfehérvári kapitányként és volt szörényi bánként 1440. május 20-án, a Körös megyei Zalatnokon és július 7-én, Szegeden, illetve kiadott oklevelén is hasonló körvonalú, papírral fedett gyűrüs pecsétlenyomatot látunk (24. melléklet). ${ }^{43}$ Az egyedüli különbség a címert kettéhasító pallos hiánya. Tallóci Frank szörényi bánként kiadott 1439. március 16-i oklevél papírral fedett gyürüs pecsétjén viszont szépen látszanak a címer körvonalai (DFDL 253 329). Tallóci Frank 1432. augusztus 5-én, csanádi ispánként DF-DL 54798 számú oklevelén elmosódott a pecsét, akárcsak az 1432. február 6-án, kevei ispánként és nándorfehérvári kapitányként kibocsátotton (DL 54 782).

A DF-DL 80468 számú 1434. augusztus 13-i oklevélen, amelyet Tallóci Frank kevei ispánként bocsátott ki, ugyanez a címer látható jobbra döntve, a címerpajzs bal sarkára helyezett gótikus, tollbokrétával díszített csőrsisakkal kiegészítve, amely hasonlít a

\footnotetext{
${ }^{438}$ DF-DL 44302

439 Áldásy Antal: Címertan. Máriabesnyő-Gödöllő 2008² . 34. A továbbiakban: Áldásy $2008^{2}$.

${ }^{440}$ Bárczay Oszkár: A heraldika kézikönyve. Budapest 1897. 12. A továbbiakban: Bárczay 1897.

${ }^{441}$ Bárczay 1897. 132.

${ }^{442}$ Köszönöm Juhász Ágnesnek, aki rendelkezésemre bocsátotta címeres fényképeit.

${ }^{443}$ DF-DL 55 204, DF-DL 55215
} 
címerben lévő madár tolldíszéhez (25. melléklet). Habár a címer alakja elmosódik, az oroszlán kettős farkának körvonala jól azonosítható. Csakhogy a pecsét köriratán nem Frank, hanem Matkó neve olvasható, azaz Tallóci Frank Tallóci Matkó pecsétjét használhatta. A Zichy oklevéltár közlésében téves, hogy a pecsét Tallóci Franké lenne.

A Zichy oklevéltár VIII. kötete ezt az oklevelet 1435-re keltezi, amelyben egyébként Tallóci Frank mint kevei ispán, nándorfehérvári kapitány a thovankúti jobbágyainak és népeinek vitáját Bátmonostori Töttös László szentgyörgyi jobbágyaival és népeivel válaszott bírák elé utalja. ${ }^{44}$ A Zichy oklevéltár kötetében azonban a keltezés dátuma - az évszám eltérésen túl - feloldva augusztus $19 .{ }^{445} \mathrm{Ez}$ is téves, mert 1434-ben az ünnep (augusztus 15) előtti legközelebbi feria sexta 13-án volt. 1435-ben pedig augusztus 12-én, nem 19-én. ${ }^{446} \mathrm{Az}$ MNL adatbázisában lévő fénykép vizsgálata alapján pedig megállapítható, hogy ugyanarról az oklevélről van szó. Az is látható, hogy az évszám: $14344^{447}$

Tallóci Matkó szlavón bánként 1435. november 12-én, ${ }^{448}$ illetve az 1436 . július 15 -én kiadott oklevelein töredékes pecséteket találunk. ${ }^{449} \mathrm{Az}$ előbbin a pecsét nem értelmezhető felső töredéke maradt csak fenn, az utóbbin viszont elég jól kivehető a jobbra döntött címerpajzs bal sarkára helyezett gótikus csöbör sisak, illetve a pajzs bal szélén az ágaskodó oroszlán feje és mellső lábai. Albert király és Erzsébet királyné 1439. szeptember 17-én, Titelnél (Tüdőrév) kiadott oklevelén - a fennmaradt 15 pecsét között - megtaláljuk Matkó pecsétjét is, de a körirat épsége ellenére a címerpajzs talpa és a jobb sarka teljesen hiányzik, a bal szélén kivehető a madárszárny felső íve (26. melléklet). ${ }^{450}$ A pecsétek között figyelmet érdemel Branković György despota vörös viaszba nyomott pecsétje is, amelynek fényképét megfelelően elforgatva felismerhető a szarvval ellátott csöbör sisak (27. melléklet). ${ }^{451}$

A Tallóci-címer új vizsgálata azért fontos adalék, mert Zsigmond király idejében indult meg a címeradományozások sorozata. ${ }^{452}$ Különösen a konstanzi zsinat kezdetével, amikor

\footnotetext{
${ }^{444}$ Zichy 1895. 561-562. (385. sz. okl)

445 „feria sexta proxime ante festum assumptionis Marie, anno domini millesimo quadringentesimo tricesimo quinto" Zichy 1895. 562.

${ }^{446}$ Lásd: Szentpétery Imre: A kronológia kézikönyve. Budapest 1985. 145, 185. A továbbiakban: Szentpétery 1985.

${ }^{447}$ Dr. Sebők Ferenc megállapítása nyomán.

${ }^{448}$ DF-DL 35952

${ }^{449}$ DF-DL 35953

${ }^{450}$ DL 39290

${ }^{451}$ A despota címerképét egyébként az adatbázis meghatározhatatlannak jelezte.

452 Áldásy $2008^{2} .69$.
} 
a király kíséretében számos magyar főur vett részt. ${ }^{453}$ Áldásy Lajos áttekintő munkájában azonban nem tett említést a Tallóciaknak címeréről, mint ahogyan Bárczay Oszkár sem. A jelen adataink birtokában nem dönthető el, hogy a Tallóci-címer Raguzából eredeztethető vagy Magyarországon adományozta nekik Zsigmond király.

\section{3. Küzdelem a horvát-szlavón-dalmát bánság megtartásáért}

A Tallóciak „viharos gyorsaságú felemelkedése” a királyi hatalom másik tartóoszlopa, a Cillei-család hatalmának ellensúlyozására szolgált. Ugyanis Zsigmond apósa, Cillei Hermann halálával (1435. október) a zágrábi püspökség, a vránai johannita perjelség birtokkormányzása mellett Tallóci Matkót nevezte ki szlavón bánná. 1436-ban pedig átvette a horvát-dalmát bánságot is. Ezzel az egyre növekvő délvidéki Cillei érdekszférát veszélyeztette. Horvátországban, 1436-ban Matkó a király nevében hadjáratot indított és lefoglalta Ivan Nelipčić hagyatékát, amelyre a Frangepán-fivérek is igényt tartottak. ${ }^{454}$

A már említett 1437. évi szeptember 27-i adományozó oklevél (DL 44 167) további részéből tudjuk meg a körülményeket, hogy 1436-ban Frangepán János és testvére, István, fellázadt Zsigmond ellen és ők is maguknak követelték a horvát-dalmát báni címet, sőt még II. Murád szultán (,,perfidissimum Omorat Turcorum dominum”) „,saját barátságára és kegyére” (,,in suam amicitiam et favorem”) megnyert más dalmát és bosnyák főurakat is. A királyi sereg élén Tallóci Matkó és testvére, Petko vonult be Dalmáciába, Szlavóniába és Horvátországba. Először a Frangepán kezén lévő várakat foglalta vissza. Zÿn ${ }^{455}$ (Sinj) váránál azonban kemény ellenállásba ütközött. Az oklevél ismét megemlíti, hogy Tallóci Matkó az ostrom során újra együttesen alkalmazta a hagyományos rohamozás mellett a korszerü tüzérséget. „Matkó bán megérkezve maradék seregével és ezen vár megostromlásához szükséges különféle ostromgépekkel ${ }^{456}$ és bombavetőkkel (,,diversis ingeniis et bombardis”), ugyanezt a várat keményen mindezen ostromgépekkel, mind pedig kézitusával sok napon át... megostromolta."457 Azonban a szorongató élelmiszerhiány miatt testvérével együtt kénytelen volt elvonulni a vár alól, a harcok tovább folytak és a két

\footnotetext{
453 Áldásy $2008^{2} .80$.

${ }^{454}$ Mályusz 2003. 142; Pálosfalvi 2000. 47.

${ }^{455}$ A dalmát Szinj vára Wertner értelmezése szerint. Wertner 1911. 545.

${ }^{456}$ Az ingenia (=találmány) általános jelentésén túlmenően ebben a szövegrészletben ostromgépet is rejthet. Lásd: Fedeles 2012. 511.

457 Thallóczy-Áldásy 1907. 118. (184. sz. okl) „...superveniente ipso Mathkone bano cum reliquo suo exercitu, necnon cum diversis ingeniis et bombardis ad expugnationem ipsius castri necessariis, idem castrum fortiter tam per ipsa ingenia, quam manualem pugnam per multos dies ... expugnare”
} 
Tallóci fényes győzelmével végződtek. ${ }^{458}$ Társául pedig Frangepán János halálával (1436. május 11.), majd testvére, István leváltásával (1437. november) Tallóci Matkó maga mellé másik bánnak öccsét, Petkót vette. ${ }^{459}$ Az 1437. január 25-én Matkó dalmát, horvát, szlavón bánként kiadott oklevelében a részletekről is értesülünk. Frangepán János fiúörökös nélkül halt meg, birtokai hütlenség címén a királyra háramlottak. Az összes várat pedig János özvegye, Katalin átadta, akinek a bán megkegyelmezett. ${ }^{460}$ Január 29-én Matkó bán részletezi Frangepán János büneit, nevezetesen, hogy ő a nála lévő elzálogosított királyi várakat, illetve elődje, a korábbi horvát bán magtalan halála után a királyra háramlott várakat is önkényesen, élete végéig, magánál tartotta, ezért a hütlenség bünébe esett. Azonban özvegye, Katalin ezeket a birodalmi és királyi várakat saját hüsége jeléül mind visszaadta, különösen pedig az elzálogosított Knin (Tinnin) várát, ezért a bán - a király nevében - mentesítette őt a hütlenség vétke, valamint a fej- és jószágvesztés büntetése alól. Addig, amíg az özvegyet az urának testvérei az atyai vagyonból ki nem fizetik, a király nevében neki adományozza Tersan várát és Modrus városát. Felszólította egyúttal a nádort, az országbírót és a bírói hatóságokat, hogy Katalin és urának testvérei ügyében addig ne ítélkezzenek, míg ő a király megbízásából nem intézkedik. ${ }^{461}$ Ezt követte még egy, január 29-én kibocsátott oklevél, amely szerint bár Katalin maga is hütlenek közé számított, de mivel ellenállás nélkül, önként átadta Knin (Jinnin) várát, mentesült a bűn alól és megkapta Tersan-t és néhány más várat. ${ }^{462}$

Azonban a Cilleiekkel és szövetségeseikkel folytatott versengés másik ütközőterülete Bosznia volt. Bár a Zsigmonddal 1425-ben szövetségre lépett II. Stefan Tvrtko (14211444) bosnyák király elismerte a magyar király fennhatóságát, de Cillei Hermann megállapodott még I. Tvrtko bosnyák királlyal abban, hogy törvényes utód nélküli halála esetén Cillei Hermannra vagy fiú utódaira ruházza a bosnyák királyi címet. ${ }^{463} 1434$ végén Tallóci Matkó viszont visszahelyezte II. Tvrtkót, de egyúttal saját kezében tartott több boszniai várat. ${ }^{464}$ Így Boszniában is folytattak a Tallóciak háborút. Habsburg Albert király 1438. március 31-i oklevele felsorolja a Tallóciak addigi érdemeit, ezek közt megemlít a

\footnotetext{
${ }^{458}$ Wertner 1911. 544-545.

${ }^{459}$ Mályusz 2003. 148. Ez a kölcsönös munkamegosztás a későbbiekben is megmaradt. Például Tallóci Péter 1444. július 27-én, Kninben keltezett ítéletlevelében azt látjuk, hogy a döntése ellen fellebeztek testvéréhez Tallóci Matkóhoz, aki azonban elfoglaltsága miatt megint testvérére, Péterre bízta a döntést (DF-DL 38 574).

${ }^{460}$ DF-DL 88111

${ }^{461}$ DF-DL 38523

${ }^{462}$ DF-DL 88 112. Ezen az oklevélen található az egyik legépebb állapotú Tallóci-pecsét.

463 Szakály 1986. 27; C. Tóth 2009. 86.

${ }^{464}$ Pálosfalvi 2000. 47.
} 
boszniai harcokat is, amelynek során elfoglalják Jajca, Komothyn (Komotin) és Bachacz (Bočac) várakat. Hadidded ${ }^{465}$ (Hodidjed) ostromakor pedig nagy veszteséget szenvedtek. ${ }^{466}$

$\mathrm{Az}$ mindenképpen kiemelendő, hogy eszerint Tallóci Matkó 1435-ben Jajca várát magyar uralom alá visszahelyezte és a törökök nem mertek beavatkozni. ${ }^{467}$ 1436-ban II. Tvrtko visszakerült Boszniába, de a törököknek adót kellett fizetnie. ${ }^{468}$ Viszont kisebb támadások lehettek, mert egy 1437. július 4-én keltezett oklevelében Matkó azért halasztotta el minden körös vármegyei perét Szent Mihály nyolcadára (október 6), mert éppen Jajca várának védelmében vett részt. ${ }^{469}$

1437-től Matkó és Petkó közösen viselte a horvát-dalmát báni tisztet. Matkó a szlavón báni tisztet továbbra is megtartotta. A harmadik testvér, Tallóci Frank a déli határvédelem keleti részéért volt felelős, szörényi bán volt 1436-tól 1439-ig, azaz a két Hunyadi János kinevezéséig. A szörényi bánként Tallóci Frank pedig Orsova, Szörény, Győrén (Görény), Miháld várainak védelmét látta el. ${ }^{470}$

\section{4. Zsigmond 1437. évi törökellenes hadjárata}

Az 1437. szeptember 27-i oklevél még megemlíti a Tallóciak szerbiai és törökellenes harcait is (,in regno Rascie”). ${ }^{471}$ Ennek előzményéhez hozzátartozott, hogy Galambóc sikertelen magyar ostroma miatt, amelyre még segélycsapatot küldött, Branković György a magyarokkal való addigi szövetség felbontására kényszerült (1428) és át kellett adnia Krusevac várát is a törököknek. Branković - akinek számára egyedül Szendrő maradt még meg - a magyarországi birtokaira távozott. ${ }^{472}$

Az oklevél szerint a minap (,nuper”) Zsigmond király egy hatalmas sereg élére Tallóci Frankot és guti Ország Jánost, Marczali vajdafi János udvarmestert állította. A hadjárat célja az volt, hogy visszafoglalják Krusevac várát (Crusowcz), valamit az, hogy a Moravafolyón (,in fluvio Morwa”) lefelé haladva lángba borítsák és megsemmisítsék a törökök gályáit és hajóit (,galeas seu naves”), amellyel már évek óta az alsó részeket (,,in partibus

\footnotetext{
${ }^{465}$ Wertner szerint a mai Sztarigrad Szarajevótól délkeletre. Wertner 1911. 545. Az azonosításukhoz segítséget ad továbbá a térképvázlaton: C. Tóth 2009. 86.

466 Thallóczy-Áldásy 1907. 125. (187. sz. okl)

${ }^{467}$ Engel-Kristó-Kubinyi 1998. 157.

468 Szakály 1986. 28.

${ }^{469}$ DF-DL 74492

${ }^{470}$ Mályusz 1984. 131.

${ }^{471}$ DL 44 167. Mályusz 2003. 166.

${ }^{472}$ Pálosfalvi 2010. 7.
} 
inferioribus") fosztogatják. ${ }^{473}$ Az átutazó Brocquière is leírta, hogy a Nisava és a Moravafolyók torkolatánál a törökök általában 80-100 gályát, tutajt tartanak, hogy a lovasságot és a sereget átszállítsák háború idején. ${ }^{474}$ Sőt 1432-ben, leírása szerint, Galambócnál „A törököknek itt száz naszádjok van Magyarország megtámadására. E hely parancsnoka a fent emlitett Cenaym bey (Szinán bég)". 475

Az említett hadmozdulatok elökészítését megerősítve az 1437. évi perhalasztási okiratok is nagyarányú nemesi hadba szállásról tanúskodnak Tolna, Csanád, Bodrog, Baranya megyékben. ${ }^{476}$ Sőt a seregben cseh zsoldosok is részt vettek, mert március 26-én kelt oklevelében a király Sopron városát bízza meg, hogy 12 hajót szerezzen a Pozsonyból Nándorfehérvárba való elszállításukra. ${ }^{477}$

Az 1437. évi Tallóci-oklevél szerint a sereg először Galambóc alá érve a vár környékét, falvait és tartozékait felgyújtva megsemmisítette, majd a Morava partján haladva mélyen benyomult Szerbiába, elpusztította a törökök hajóit, Krusevác várát és visszafordult. A törökök csak a már visszavonuló és a Dunán még át nem kelt seregre tudtak rátámadni. Tallóci Frank serege megvédte magát, a törököket megfutamította és több török zászlót (,certa vexilla seu banderia”), néhány fogollyal a Csehországban tartózkodó Zsigmondhoz küldött. $^{478}$

Zsigmond király halála után azonban a török már ekkor megpróbálta ostrom alá venni Szendrő erődjét is. ${ }^{479}$ Azonban Branković György fia, Gergely magyar és cseh seregével vissza tudta verni a támadókat. ${ }^{480} \mathrm{Az}$ eredményhez az is hozzátartozik, hogy egyúttal sikerült felmenteni Szendrő várát, Branković székhelyét is a török ostrom alól. ${ }^{481}$

Erről a hadjáratról szerencsékre fennmaradt Marczali Jánosnak a királynak megírt hadijelentése is, amely alapján pontosíthatjuk az 1437-es hadjárat időpontját és tartamát, továbbá számunkra fontos tüzérségi adatokkal találkozunk Tallóci Frankkal kapcsolatban. ${ }^{482}$ A sereg június 18-án (kedden) érkezett a Pozsezsin (,Kwzeg prope Posesyn”) közelében lévő Kőszegre, ahol Tallóci Frank szörényi bán teljes készülettel,

\footnotetext{
${ }^{473}$ Wertner 1911. 547.

${ }^{474}$ Brocquière 1848. 358. Már az 5. század közepén Attila hasonlóképpen biztosította katonái átkelését az AlDuna szinte azonos helyén Priskos rhétór elbeszélése szerint. Priscos 1982. 248-250.

${ }^{475}$ Szamota 1891. 80-81.

${ }^{476}$ Wertner 1911. 546-547.

${ }^{477}$ Wertner 1911. 547.

478 Thallóczy-Áldásy 1907. 120-121. (184. sz. okl); Wertner 1911. 548.

${ }^{479}$ Ezt tekinthetjük Szendrő első oszmán-török ostromának.

${ }^{480}$ Generál 1987. 54.

${ }^{481}$ C. Tóth 2009. 89.

482 Karácsonyi János: Az első magyar hadijelentés (1437). Hadtörténelmi Közlemények 1910. 15-22. A továbbiakban: Karácsonyi 1910.
} 
hajókkal, gályákkal, kompokkal várakozott (,cum pleno apparato navium videlicet et galearum portuque"). ${ }^{483}$ Haditanács tartása után, június 19-én átkeltek a Dunán, ahol Tallóci hátra maradt a dunai rév védelmére. ${ }^{484}$ Majd a Morava-folyón a török gályák felé haladtak tovább. Június 22-én (szombaton) érkeztek meg a török hajók gyülö-helyére, ahol tüzérségi támadással megsemmisítették azokat. Marczali hadijelentése felsorolja a felhasznált hadiszereket is, amelyek között a hagyományos fegyvereken túl helyt kaptak a korszerü tüzérségi eszközök is. „nyársakkal, lándzsákkal, paizsokkal, ijakkal, nyilakkal, számszerijakkal, puskákkal, ágyúkkal és sok puskaporral (,,pixidibus, bombardisque et pulverum copia”)..."485 Látható, hogy forrásunk már a bombardák mellett, puskák használatáról is tudósít a Tallóciak környezetében. „és az emlitett ágyúkat, puskákat, számszeríjjakat elrendezvén azokat hirtelen kisütöttük és kilőttük nagy tüzet okozván...a hajókat az emlitett Morava-folyón a Dunára s onnan a tengerre ${ }^{486}$ eresztettük el..."487 Június 23-án (vasárnap) érték el Krusevác várát („Crusolz”), ahol felégették a környező vidéket. Ezt folytatva - fontos néprajzi adalékként, némi humorral - Marczali beszámol arról is, hogy este - folytatva a tüzgyújtást - megtartották Szent Iván előestéjét ünneplö népszokást is. A vár tartozékaiból, épületfáiból hatalmas tüzet raktak. ${ }^{488}$ Másnap, június 24-én átkelve a Morava-folyón Branković György despota területére érkeztek, a király kifejezett tiltása ellenére. Innen a Morava és Szendrő vára közötti Kövi ${ }^{489}$ felé vonult vissza a sereg, ahol időközben Tallóci Frank várakozott. ${ }^{490}$ Június 27-én, Szent László ünnepén az átkelést viszont már a törökök is megpróbálták megakadályozni. Mert „a kegyetlen és gonosz Ali bég” (,ille sevissimus et nequam Allebeg”) vidini seregével megérkezett és üldözni kezdte a támadókat azért, hogy a szendrői átkelésnél megzavarja őket. Azonban a királyi sereg szembefordult a törökökkel és megfutamították Ali bég seregét. A vezért is majdnem foglyul ejtették, aki tartalékban tartott lován el tudott szökni: „a roppant gonosz Ali béget is majdnem felséged színe elé küldtük, de sebesen, második e végböl készen tartott lovára kapott..." (Karácsonyi János fordításai). A zsákmányokból Ali

\footnotetext{
${ }^{483}$ Karácsonyi 1910. 16.

${ }^{484}$ Karácsonyi 1910. 17.

485 Karácsonyi 1910. 18. „(cum) cuspidibus, lanceis, clipeis, arcubus, sagittis, balistris, pixidibus, bombardisque et pulverum copia..."

${ }^{486}$ Azaz a Fekete-tengerre.

${ }^{487}$ Karácsonyi 1910. 18. „predictis bombardis, balist(r)is et pixidibus dispositis, scilicet protinus...et multo ignis incendio combusi et consumi fecimus pulverem, ipsas (naves) per dictum fluvium Morua ad Danubium, deinde ad mare transmisimus..."

488 Karácsonyi 1910. 19.

489 Temeskubin

${ }^{490}$ Karácsonyi 1910. 20. „...versus Kowinien inter fluvium Morva et Zendrem existentem ...”
} 
bég három zászlóját („tria banderia ipsius Allebeg”) elküldték Zsigmond királynak. ${ }^{491}$ Véleményem szerint erősen feltételezhető, hogy ez az Ali bég a török forrásokban szereplő Evrenosz fia Ali-val azonos.

A Marczali-féle hadijelentés jól kiegészíti az 1437. szeptember 27-i Tallócioklevelünket, amelynek vonatkozó részletéből viszont megtudjuk Tallóci Frank e hadjáratban betöltött szerepét, cselekedeteit. Míg kezdetben a királyi sereg elindulásakor „maga saját seregével ugyanezen dunai átkelö megörzésére és kezelésére hátramaradt... ${ }^{, 492}$ Azonban a nyári napforduló idején, június 24-én Galambóc felé indított hadjáratot, hogy a törökök figyelmét elterelje a Krusevác és a hajók elleni akcióról. „Az év közepén ${ }^{493}$ pedig, amikor tudniillik a másik seregünk már visszafordult, Frank bán ugyanezen saját maga felállitott seregével az elöbb emlitett Galambóc vára felé nyomult elöre, ennek egész területét és összes falvait és tartozékait ...tüzzel elemésztve, és a kiirtás más módján elöre elpusztította és felégette, a mi felségünknek és Magyar Királyságunk Szent Koronájának kedvére, söt igenis hasznára, annak engedelmeskedve..."

„A Három testvér bán” Zsigmond uralkodása végére az országnagyok közé tartozott. ${ }^{495}$ A király halálakor pedig a Cilleiekkel folytatott versengésben is óriási helyzeti elönyt élveztek, hiszen nemcsak szlavón, dalmát-horvát és szörényi bánok voltak, hanem a kalocsai érsekség, a zágrábi és csanádi püspökség, a vránai perjelség birtokait is kormányozhatták. ${ }^{496}$ A Valkó és Pozsega megyében lévő déli birtokaik közvetlenül érdekeltté tették a Tallóciakat az ország védelmében. Mindezek példaként szolgálhattak az ifjú Hunyadi János és testvére, az ifjabb János számára is. Valóságos Tallóci gazdasági „birodalom” nőtt ki, és egymásnak tudtak segíteni a gazdasági tartalékaikkal: birtokaik, raguzai kereskedelmi kapcsolataik, jobbágyaik bevonásával. Ezt 1440-ben a hosszú török ostromkor tudták megmutatni.

\footnotetext{
491 Karácsonyi 1910. 21.

492 Thallóczy-Áldásy 1907. 118. (184. sz. okl) 120. „ipso solo propria scilicet sua in persona cum reliquis suis gentibus pro conservatione et gubernatione portus ipsius Danubii remanente..."

493 A Marczali-féle hadijelentést alapul véve az „év közepét” mi a nyári napfordulónak értelmeztük.

494 Thallóczy-Áldásy 1907. 118. (184. sz. okl) 120. „,medio autem tempore infra scilicet eorundem aliorum fidelium nostrorum habitam reversionem, ipse Franko banus cum eisdem gentibus suis secum constitutis versus castrum Galambocz supratactum precedens, totum territorium ac universas villas et pertinentias eiusdem castri...modo per ignis voraginem, modo vero per alia desolationum genera prorsus devastari et anichilari fecisset maiestati nostre et sacre regni nostri Hungarie corone grata et admodum proficua in eo obsequia exhibendo."

495 Mályusz 2003. 149.

${ }^{496}$ Pálosfalvi 2000. 48.
} 
Arról már korábban szóltunk, hogy Tallóci Matkó és Frank is részt vettek Nándorfehérvár kiépítésében. ${ }^{497} \mathrm{~A}$ fejlesztés az akkoriban újnak számító tüzérségre is kiterjedt, amit az 1432-ben Brocquière lovag is tanúsított. A várat 5 erődre, erősségre különítette el. „Öt erősségböl áll, közülük három az említett magaslaton, kettő pedig a víz mellett emelkedik. ... Mind az öt eröd jól föl van szerelve tüzérséggel" (Szamota István fordítása). ${ }^{498}$

A későbbi várvédő, a legfiatalabb testvér, János (Johannes, Jován, Zowanus) müködéséröl kevés adat maradt fenn. ${ }^{499}$ A vránai perjelségéről már szóltunk. Frank mellett kitanulhatta a katonai mesterséget. Habsburg Albert magyar király (1438-1439) öt nevezhette ki nándorfehérvári kapitánynak, hiszen a korábban említett 1438. évi március 31-i oklevélben már a legfiatalabb Tallócit találjuk e tisztségben. ${ }^{500}$ Ennek indoka talán az lehetett, hogy a Tallóciak őt támogatták, és 1437 decemberében éppen Tallóci Matkó tartóztatta le az Albert ellen szervezkedő Borbála királynét. Ennek eredménye az lett, hogy Matkó és Frank örökjogon megkapta a Kőrös megyei Szentgyörgy várát, továbbá a zágrábi püspök a Tallóciak rokona, Curzolai vagy, ahogy nálunk nevezték, Korcsulai Ábel, Matkó unokaöccse lett. ${ }^{501}$ Vélhetően ide sorolhatjuk be János várkapitányi kinevezését is.

\footnotetext{
${ }^{497}$ Lásd a 3. 2. fejezetet.

498 Szamota 1891. 79.

${ }^{499}$ Mályusz 2003. 151.

${ }^{500}$ DL 44 241.Thallóczy-Áldásy 1907. 125. (187. sz. okl), Mályusz 2003. 152.

${ }^{501}$ Pálosfalvi 2000. 49.
} 


\section{Az 1440. évi török támadás katonai előzményei \\ 6. 1. 1429-1432: A Német Lovagrend a Szörénységben}

Zsigmond király uralkodása kezdetétől katonai-gazdasági-pénzügyi kapcsolatokat tartott a Német Lovagrenddel is. ${ }^{502}$ Már a nikápolyi csatavesztés után, 1397. október 21-i levelében ajánlatot tett a Lovagrendnek, amelyben megígérte, hogy visszaadná a Barcaságot számukra, ahonnan még II. András űzte ki őket 1225-ben. Természetesen a törökök elleni határvédelem fejében. Azonban ekkor még a Lovagrend az orosz területek felé tájékozódott. ${ }^{503}$ A galambóci kudarc után Zsigmond újra elővette korábbi tervét és 1428 . október 9-i levelében több várat is felajánlott a déli határvidéken. 1429 májusában érkeztek meg a Német Lovagrend lovagjai Nicolaus von Redewitz vezetésével. A lovagok a Szörényi Bánság és az al-dunai új várak védelmét kapták meg, Temestől Szörényvárig. ${ }^{504}$ Míg a Tallóciak ekkor már a Krassó, Keve vármegyei határszakasz védelmét látták el. A lovagok Krassó megyében még Illyéd, Krassófö, Borzafő várakat is kezelésbe kapták. ${ }^{505}$

Zsigmond biztosította a védelem nyugodt kiépítését azzal is, hogy 1429 februárjában 3 éves fegyverszünetet kötött II. Muráddal. ${ }^{506}$ Szultáni támadástól egyenlöre nem kellett tartani. Azonban a határ túloldalán voltak kisebb török csapatmozgások, amelyek föleg Nándorfehérvár környékét érintették.

A Német Lovagrend viszont korszerü fegyverkezésből ígéretes példát sejtetett. Erről számszerü adataink is vannak. Redewitz a szörényi végeken 1370 fös várőrséget, 550 lovast tervezett. Továbbá a folyami erőt is fontosnak tarthatta, mert 1400 dunai matrózról is említést tett védelmi tervezetében. De már az ekkor újnak számító tüzérséget is felhasználta, mert 328 tüzért állított volna a végekre. Az éves zsold pedig összesen évi 314 822 aranyforintba kerülne a királynak. Zsigmond ezt meg is próbálta biztosítani. Ez az összeg olyan magas volt, hogy a nemesség ellenkezését is kiváltotta. Pósán László szerint a „négy déli sókamara éves 100000 forint jövedelmét engedte át a lovagoknak, továbbá Brassó és Nagyszeben pénzverdéinek jövedelmét, az erdélyi ökör- és juhötvenedet, a kalocsai érsekség bortizedeit, a dunai halászat bevételeit, valamint Magyarországon belül

\footnotetext{
502 Pósán László: Zsigmond és a Német Lovagrend. In: Hadtörténelmi Közlemények 1998. 3. 630-656. Továbbiakban: Pósán 1998. 630.

503 Pósán 1998. 637.

${ }^{504}$ Pósán 1998. 653.

${ }^{505}$ Engel 1996. 32.

${ }^{506}$ Pósán 1998. 654.
} 
a jász-kun területek, a szegedi és szolnoki gabona szállitási és értékesitési jogát. A lovagok vezetőjét kinevezte a nagyszebeni pénzverésért felelös kamaragrófnak." ${ }^{207}$

A török-magyar fegyverszünet végére a szörényi erődítési munkálatok nem fejeződhettek még be. Mert az 1432-ben megújuló török támadások ezeket lerombolták. A helyzet olyan súlyos volt, hogy Redewitz a Lovagrend nagymesteréhez írt 1432. március 7 i levelében már arról számolt be, hogy nem tudják tartani a végeket. ${ }^{508}$ Ezek föleg határmenti fogolyszerzö, fosztogató betörések voltak, amelyek közül való lehetett a török források által említett Evrenosz fia, Ali támadása is, amelyet végül a király győzött le. Horváth Mihály úgy tudja, hogy a törökök egy Erdélybe való betörés alkalmával támadták meg Szörény várát, majd azután Barcaságot, Brassó vidékét és a székelyek földjét fosztogatták. ${ }^{509}$

A Német Lovagrend végül lemondott a magyar határszakasz védelmezéséről és a lovagokat visszahívták a Szörénységböl, egyedül Redewitz maradt még szörényi bánként a király szolgálatában, de ez már csak az elszámolást és átadást szolgálta. ${ }^{510}$ Engel Pál adatai szerint az 1435-1436 között üresedés volt a báni tisztségben. ${ }^{511}$ Ez 1436-ig is eltarthatott, mert 1436 májusában a király már Tallóci Frankot nevezte ki szörényi bánnak. ${ }^{512}$ Ezáltal majdnem a teljes déli határszakasz - a Temesi Bánság és a Macsói Bánság kivételével védelme és fenntartása Szörénytől Nándorfehérvárig és a Horvát-Szlavón Bánságig a Tallóci-testvérek kezében egyesült!

Mindenesetre Zsigmond 1433. évi honvédelmi szabályzata ismét a törökkel való fegyverszünetre utalt (35. fejezet). „de magával a törökkel is tárgyalások folynak az esetleg megkötendö fegyverszünetre, ami ha létre jön; úgy a török ellen szánt hadsereg igen alkalmasan forditható más ellenséges népek megtámadására...”(Köszeghy Sándor fordítása) $)^{513}$

Bár a Lovagrend katonai szereplése csupán rövid időszakot jelentett a Zsigmond-kori határvédelemben, de gazdasági-kereskedelmi szempontból mégis jelentős. A Német Lovagrend városai már a 13. századtól a kereskedelemben Hansa-jogokat élveztek (Marienwerder, Elbling, Königsberg, Memel, Marienburg) és a külkereskedelemben a Hansa-joggal rendelkező városok nagy hasznot húztak. A lovagrendi állam önmagában

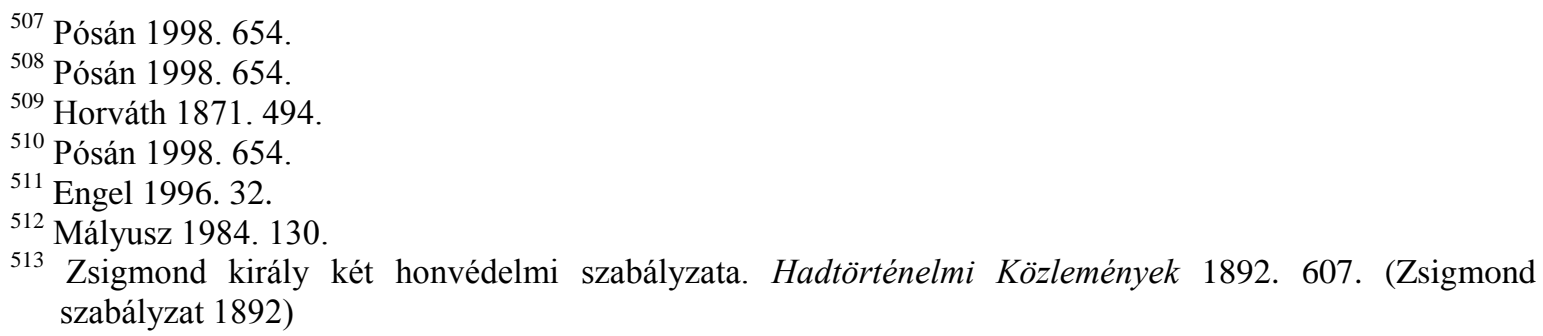


szinte egy „kereskedőtársaságot” is alkotott, amelynek Marienburg és Königsberg voltak a kereskedelmi központjai. Innen vízi vagy szárazföldi úton jutottak tovább az árucikkei. ${ }^{514}$ Zsigmond király pedig a lovagrend által kereskedelmi kapcsolatot tudott felvenni a Hansavárosokkal is. Ez a kereskedelmi irány a Velence és Raguza által uralt déli kereskedelemmel szemben létesült. Ezen a kereskedelmi úton is érkezhettek korszerü tüzfegyverek a végvárakba, hiszen a védelem ellátásában - láttuk - Redewitz jelentős tüzérséggel is számolt. A Német Lovagrend fővárosában, Marienburgban ágyúöntöde volt, ahol készültek mozsarak (például 1409-ben a Faule Grete). Már a 14. század második felében sokfelé öntöttek ágyúkat német földön (Aachen, Augsburg, Passau, Regensburg, Speier). ${ }^{515}$ Azt is hozzátesszük, hogy a Német Lovagrenddel való kapcsolat eredményesebbnek ígérkezett, mint Tallóci Jován perjel lehetősége a távoli és a mamelukok elleni harccal elfoglalt rodoszi johannitákkal a Mediterráneumban.

\section{2. Okleveles adatok az 1429-1437 közötti török betörésekről}

Bár szultáni támadás az előbb említett 1429-es hároméves fegyverszünet alatt nem volt, az ostrom közvetlen elözményeihez a határ menti török betörések hozzátartoznak, amelyeket 1438-1440 között váltották fel a szultáni, reguláris haderők hódító, szisztematikus támadásai.

Véleményem szerint már a korai török-magyar háborúk újabb alszakaszát vezette be a fentiekben ismertetett Galambóc magyar ostroma, amelyet tekintélyes volta miatt, ha nem is II. Murád szultán, de a ruméliai sereg mentett fel. Ez az alszakasz - szerintem - az 1440. évi ostromig, Murád Magyarország elleni támadásainak végéig tartott. Ezt az időszakot az ún. Tallóci-szakasznak tekintem, mert a határvédelmet egyre inkább a Tallóci testvérek irányították tisztségeikben.

Már 1427 nyarán és őszén, amikor a magyar király hadjáratot vezetett a törökök ellen Havasalföldre, onnan Szerbiába kellett sietnie, mert II. Murád azt megtámadta. Ennek során megjelentek Nándorfehérvár alatt is török seregek, bár a város elleni támadásra nincs közvetlen adatunk, csupán a környéken rabolhattak. ${ }^{516}$ Erről tesz említést Zsigmond király Szentlászlói András fia, Márk részére kiállított 1428. augusztus 27-i oklevele, amely - a Galambóc melletti harcok mellett - Nándorfehérvár védelmezését is megemlíti: „,miután

\footnotetext{
${ }^{514}$ Font 1997. 59-60.

${ }^{515}$ Iványi Béla: A tüzérség története Magyarországon 1711-ig. Hadtörténelmi Közlemények (27) 1926. 6. A továbbiakban: Iványi 1926. Lásd még a 10. 6. fejezetet.

${ }^{516}$ Калић-Мијушковић 1967. 106.
} 
havasalföldi részeinket elhagyván rácz országunk felé vonultunk, amelyet a vad Omorath (II. Murád), a törökök ura, egész hadserege élén, személyes vezetése alatt megtámadott, nevezett Márk, Újlaki István házi tisztje, urának zászlaja alatt harcolt, mire még Nándorfehérvár védelmezésében is részt vett. "(Wertner Mór fordítása) ${ }^{517}$

A várban lévőknek folyamatos készültségben kellett lenniük, mert többször hírek jöttek török betörésekröl. Engel Pál szerint ebben az időszakban egy helyi nagybirtokos, Bátmonostori Töttös László királyi várkapitányságáról tudunk, aki az Alsóváros és Felsőváros kapitányságát vagy várnagyságát is ellátta. (castellanus interioris castri, castellanus superioris castri). ${ }^{518} \mathrm{E}$ két tisztség egymáshoz való viszonya nehezen állapítható meg. ${ }^{519}$

Bár az oklevelekből csak mozaikok állíthatók helyre, de a perjogi okiratok közhitelességük okán - hasznosnak bizonyulnak számunkra. 1429-ben januárról májusra azért kerül sor perhalasztásra, mert egy február 15-i királyi értesítés szerint Töttös László Nándorfehérvár védelmével van elfoglalva. ${ }^{520}$ Sajnos többet erről nem tudunk. Ugyanez az esemény a következő évben megismétlődik, Nándorfehérvár védelme miatt Töttös László perét 1430 januárjáról májusra halasztották. ${ }^{521}$ Sőt 1430. április 18-án a király Töttös László tisztjeit még a husziták és táboriták elleni hadjárat alól is mentesítette. ${ }^{522}$ Ezek viszont nem feltétlenül jelentenek tényleges török támadások elleni védekezéseket, hiszen fegyverszünet volt érvényben, hanem magukban foglalhatnak egyéb, a vár felszerelésével, megerősítésével kapcsolatos munkálatokat is.

Raguzai $^{523}$ Matkó nándorfehérvári kapitányként (capitaneus Nandoralbensis) 1430. november 29-én, Bedefalván kiadott oklevelében utasítja a temesvári kamarást, hogy familiárisainak Remetei Himfi Imrének, Lászlónak és Franknak fejenként 100 aranyat sóban fizessen ki. ${ }^{524}$

Meghatározott katonai intézkedésről van szó viszont egy 1430. december 10-én, Panczalon keltezett mozgósítási parancsban, amelyet Raguzai Matkó, mint nándorfehérvári kapitány (capitaneus Nandoralbensis) intézett Remetei Himfi Imre familiárisához, hogy

\footnotetext{
${ }^{517}$ DL 30 431. Wertner 1911. 432-433; Thallóczy-Áldásy 1907. 78.

${ }^{518}$ Engel 1996. 374. A család székhelye Bátmonostor, amelyet az oklevelek 1409-től említenek. Engel 1996. 274. Lásd a 13. 3. fejezetet.

${ }^{519}$ Lásd az 5. 1. fejezetet is.

${ }^{520}$ Wertner 1911. 440.

${ }^{521}$ Wertner 1911. 442.

${ }^{522}$ DL 80 265. Wertner 1911. 441.

${ }^{523} \mathrm{Az} 1431$. évi birtokadománya előtt Raguzaiként nevezi magát. Lásd az 5. 2. fejezetet.

${ }^{524}$ DF-DL 54730
} 
húsz jó lovassal és jó lóval, felszereléssel (ruhák, páncélok) siessen a familiárisaival a Duna mellékére, Tornistyére. ${ }^{525}$

Különösen veszélyes volt a téli időszak, amikor a folyók befagytak és a törökök átkelhettek rajta. 1430/31 telén Raguzai (Tallóci) Matkó kapitány gyalogos és lovas erősítést kért a Duna befagyása miatt. A következő évben ugyanez megismétlődött. ${ }^{526}$ 1431. január 17-én, Nándorfehérvárból kelt az a parancs, amelyet Matkó testvére, Raguzai Frank, mint kapitány (capitaneus Nandoralbensis) intézett a kevei alispánoknak, hogy egész Keve vármegye közönségét - a szolgabírák kihirdetése útján - szólítsa hadba, mert „,három napja a Duna teljesen befagyott és a törökök a saját hadinépeikkel készenlétben állnak, hogy Magyarországba vonuljanak. "527

Minden bizonnyal az év hátralévő részében visszatért az élet a békés menetébe. 1431. augusztus 5-én Matkót krassói, kevei és csanádi ispánkként Mezősomlyón találjuk, amikor is Remetei Himfi László ügyében perbeli bizonyító eskü letételét rendelte el. ${ }^{528}$

1432 telén viszont ismét tartottak oszmán-török támadástól és reális esélye volt egy Nándorfehérvár elleni ostromnak. Itt már nyomon követhetjük az önellátás módszerét. 1432. január 29-én kiadott oklevelében Tallóci Frank nándorfehérvári kapitány (capitaneus Nandoralbensis) és kevei ispán beszámolt arról, újabb híreket kapott a szerb despotától, mind pedig a méltóságoktól, prelátusoktól és familiárisaiktól, hogy Szinán bég (Zynambeg wayuoda) teljes török seregével az Alsóbb Részekbe szándékozik betörni. Ez a Szinán azonos Szinán ruméliai beglerbéggel, akit - Nesri török történetíró beszámolója szerint - a szultán már Galambóc alá is kiküldött. Brocquière szerint görög származású és „az Oláhországtól Szlavóniáig terjedö óriási vidék" parancsnoka volt. ${ }^{529}$ Értesülései szerint Dysem (Dsem) bég a Fekete-tengertől Oláhországig, Ysaac (Izsák) bég Boszniától Szlavóniáig (Morava-folyón túli) terjedő török határtartományokat kormányozta. ${ }^{530}$ Tallóci az újabb hírek alapján tehát Keve lakosait hadba hívta - amennyiben még nincsenek úton , hogy a lehető leggyorsabban és legsürgősebben siessenek a dunai révéhez és gázlójához, Keve felé, fegyverrel, felszereléssel a lehetőségeik szerint. Remetei Péter fia István fia Imre alispán vezetése alatt, akinek szintén parancslevélben rendelte el ugyanezt. ${ }^{531}$

\footnotetext{
${ }^{525}$ DF-DL 54 731, Thallóczy-Áldásy 1907. 87-88. (január 10-i dátummal)

${ }^{526}$ Калић-Мијушковић 1967. 107.

${ }^{527}$ DF-DL 54 734, Thallóczy-Áldásy 1907. 88; „Danubium usque tres dies erit plenarie congellatum, et Turci cum ipsorum gentibus sunt promti venire in Hungariam." Wertner 1911. 443.

${ }^{528}$ DF-DL 54673

529 Török történetírók I. 1893. 52-53; Szamota 1891. 73, 81.

${ }^{530}$ Szamota 1891. 76.

${ }^{531}$ DF-DL 54 781, Thallóczy-Áldásy 1907. 90; Wertner 1911. 446.
} 
Februárban azonban Kevéről nem jött még a segítség, így Tallóci Frank február 6-án kelt újabb parancslevelében már arról írt, hogy Izsák vajda, helyettes fővezér nagy erővel Nándorfehérvár felé vonul. A forrásban említett Izsák (Īsa), az Evrenosz-család tagja, később Hunyadi János ellenfele. Testvére, Evrenosoglu Ali, aki szintén fontos szereplője lesz a határmenti oszmán-török betöréseknek. ${ }^{532}$ Tallóci Frank (capitaneus Nandoralbensis) a február 6-i levelében egyetemes és egyenkénti megjelenést követel mind a gyalogság, mind a lovasság teljes részvételével, elrendelve azt is, hogy a kihirdetéstől számított nyolcadik napon, aki nem jelenik meg, azt fej- és jószágvesztésre ítéli. ${ }^{533}$ Egy, február 18-án kelt oklevél pedig huszárokról (,, huzerones”) tett már említést a mozgósítás során, amely - Hunyadi Mátyás 1459. január 5-i szegedi dekrétuma előtt - az egyik fontos említése a huszárságnak. ${ }^{534}$ A török veszélyröl szóló hír igaznak bizonyult. II. Murád átlépte a Dunát, de távolabb: a Havasalföldre támadt. ${ }^{535}$

A török forrásaink közül az 1486. évi Névtelen szerző is beszámol egy újabb török betörésről, amelyet kronológiailag ide sorolunk. ,ebben az évben... napfogyatkozás volt $s$ olyan sötét lett, mint éjjel. Egyszersmind ez évben üstököscsillag is látszott. Evrenosz fia, Ali bég rablóportyázás czéljából becsapott Magyarországra, de vereséget szenvedett. A hidsre 836. évében történt (1432. augusztus 28 - 1433. augusztus 17. Thúry József fordítása). ${ }^{536}$ Ugyanerröl a török történetíró, Szeád-Eddin ír, de kronológiájában korábbra helyezte, a hidsre szerinti 833. évben (1429. szeptember 30.-1430. szeptember 18.) Ali, Evrenosz bég fia, aki a ruméliai (európai) török sereg szipeszalárja ${ }^{537}$ (hadvezére, föparancsnoka) volt, a Dunán átkelve betört az országba. Azonban a zsákmányszerzés, foglyok szedése közben, amikor „mindegyikük egy egy tündér arczút rabolván, kéjelgésbe merültek és a czukor édességü ajkakat nyalogatván, legyek módjára ellepték vágyaik

\footnotetext{
${ }^{532}$ Az 1432. februári Nándorfehérvár elleni támadási kísérletet az Evrenoszról írt szócikkében megemlíti I. Mélikoff is. Ewrenos Oghullari. In.: The Encyclopaedia of Islam. New edition, volume II. C - G Edited by: B Lewis; J. Schacht; Ch. Pellart Leiden-Boston 1965. 721. (Mélikoff 1965) Pesty Frigyes szerint 1432 februárjában Izsák Nándorfehérvár megvívására indult. Pesty Frigyes: Krassó vármegye története. III. kötet 1882. 244. (Pesty 1882)

${ }_{533}^{53}$ DF-DL 54 782, Thallóczy-Áldásy 1907. 91-92; Wertner 1911. 446.

${ }^{534}$ DF-DL 54 788, Thallóczy-Áldásy 1907. 92; Wertner 1911. 446; legutóbb: Veszprémy László: „Latrunculi, cursatores, hussarones” Megjegyzések Kézai latinságához. In.: „Magyaroknak eleiről” Ünnepi tanulmányok a hatvan esztendős Makk Ferenc tiszteletére. Szerk.: Piti Ferenc, 2000. 677-678. (Veszprémy 2000)

${ }_{535}^{535}$ Калић-Мијушковић 1967. 108.

${ }^{536}$ Török történetírók I. 1893. 17.

537 Gustav Bayerle: Pashas, begs and effendis. A historical dictionary of titles and terms in the Ottoman Empire. Istanbul 1997. 146. (sipeh-sālār=commander-in-chief) (Bayerle 1997); Török hadak Magyarországon. 1526-1566. Kortárs török történetírók naplórészletei. Thúry József fordítását válogatta, jegyzeteit bővítette Kiss Gábor. Budapest 1984. 235. (Török hadak 1984)
} 
mézét" (Thúry József fordítása) a király viszont kétszeres sereggel megverte a törököket és Ali bég vereséget szenvedett. ${ }^{538}$

Az oszmán-török annales-ek közül jól felhasználható forrás a Murád Évkönyve, amely 836. évben (1432. augusztus 28 - 1433. augusztus 17) szintén megemlít egy napfogyatkozást és az azt követő félelmet. „a világ sötétségben vala, csillag látszott” (Czeglédi Katalin fordítása) továbbá ugyanebben az évben Evrenosz-oglu Ali Bég támadását is. ${ }^{539}$

Az idézett török forrásaink időpontbeli bizonytalanságai ellenére, ennek a török betörésnek az idejét - természettudományi eszközökkel - pontosítani tudjuk, mert a Névtelen szerző, valamint a Murád Évkönyve is megemlített egy abban az évben történt napfogyatkozást is. Az amerikai Nemzeti Légügyi és Ürügynökség (NASA) erre vonatkozó katalógusának $^{540}$ közzétett adatait megvizsgálva (Catalog of Solar Eclipses 1401 to 1500) az e területről, ezen időszakban látható napfogyatkozások közül csak az 1433. június 17-i napfogyatkozás jöhet számításba. ${ }^{541} \mathrm{E}$ jelenség láthatósági sávja magában foglalta a német, magyar területeket, a Balkánt és Kis-Ázsiát is (ld. térképvázlat, melléklet). Az 1433. év a Névtelen szerző és a Murád Évkönyve adatát igazolja Ali, Evrenosz fiának betöréséről és vereségéröl.

Egyelöre nem volt újabb török támadás, csak a betörések folytatódtak. Viszont ez idő tájt érdekes színfoltja Zsigmond török ellenes politikájának az, hogy a növekvő Oszmán Birodalom ellenségeivel is fel kívánta venni a kapcsolatokat. Egy 1428. február 16-i oklevél említi meg a 16 évi török fogságban lévő, Gereci Szerecsen Miklós lovagot (Nicolaus Sarachenus filius Philippi de Gorcez), akit a Kara-juluk fejedelemhez küldte követségbe. Miklós Timur Lenk (Demerling) fiával, Sacheomerze fejedelemmel is jó kapcsolatokat hozott létre. 1435 júniusában a Kara-juluk követe meg is érkezett Nagyszombatba. ${ }^{542}$

Zsigmond nemcsak az oszmánok távoli ellenségeit kereste, hanem a szultán családjából hozzá menekülő családtagokat is szívesen látott. 1373-ban I. Murád szultán (1360-1389)

\footnotetext{
${ }^{538}$ Török történetírók I. 1893. 125.

${ }^{539}$ Ménage 1976. 576.

${ }^{540} \mathrm{http}$ ://eclipse.gsfc.nasa.gov (A belépés ideje: 2012. 03. 13)

541 Napfogyatkozások voltak még 1430. február 22-én, augusztus 19-én, 1431. augusztus 8-án, 1433. december 11-én, 1434. november 30-án, 1437. június 7-én, de ezek a NASA nyilvántartása szerint Európából nem voltak láthatóak. Egyedül 1431. február 12-én volt még olyan napfogyatkozás, amely Magyarországról, esetleg Belgrádról látható lehetett, de ez a téli időszakra esett és nem egyeztethető össze Szeád-Eddin adatával.

542 Wertner 1911. 433. Idézi: Fejér X. 6, 917-918; X. 8, 647. Továbbá: Tardy Lajos: Régi magyar követjárások Keleten. Budapest, 1971. 17-18. A továbbiakban: Tardy 1971.
} 
már adófizetővé tudta kényszeríteni a Bizánci Birodalmat, amikor Palaiologosz V. Joannész császár (1341-1391) ellen legidősebb fia, IV. (Palaiologosz) Andronikosz fellázadt és szövetkezett Murád legidősebb fiával, a Ruméliát kormányzó Szaudzsi béggel

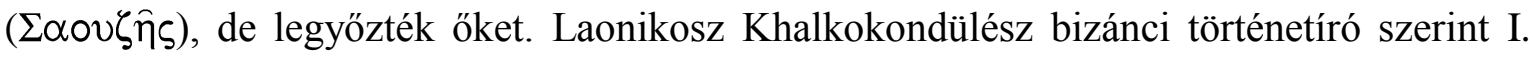
Murád nemcsak saját fiát vakíttatta meg, hanem követet küldött a bizánci császárhoz, hogy ő is hasonlóképpen cselekedjék. ${ }^{543}$ Szaudzsi, akit apja megvakított és a trónra lépő I. Bayezid bátyja volt, Magyarországra menekült és Zsigmond befogadta, fiaival együtt. A magyarországi oklevelek csak „,vak török császár”-ként említik és személyét 1893-as tanulmányában Thúry József azonosította. ${ }^{544}$ Továbbá 1904-ben Wertner Mór is megemlékezett róla. ${ }^{545} 1440$ vagy 1446 körül halt meg. A „,császár” fiai, Daud Cselebi (az oklevelekben Chalapia David) és Orkhán az országban birtokokat is kaptak. Cselebi birtokai Csanád megyében voltak. ${ }^{546} 1439$. október 9-én kelt oklevelében Daud Cselebi „török császárnak” még Albert király is juttatott 1000 aranyforint fizetséget Bátmonostori Töttös László kincstartó megbízásával - a kunok és besenyők adóiból, november 4-én pedig Erzsébet özvegy királyné tette ugyanezt. ${ }^{547}$ Azonban nem fizettek neki, mert november 5-én Cselebi válaszolt, a Szeged melletti Röszkéről (Rezke). ${ }^{548}$ Daud Cselebi 1448-ban II. Murád ellen harcolt a második rigómezei csatában, majd - Dlugos beszámolója szerint - II. Murád halála után, 1451-ben Lengyelországon át az Oszmán Birodalomba ment, hogy megszerezze a trónt, de vállalkozása kudarcba fulladt és visszatért Magyarországba. V. László király 1456. május 4-i oklevele már néhai Csalapia Dávidnak mondja. ${ }^{549}$ Szaudzsinak egy lánya is volt, aki megkeresztelkedve a Katalin nevet kapta és a nép „Császár Katalinnak” nevezte. ${ }^{550}$

543 Laonici Chalcocondylae Historiarum Demonstrationes. Ad fidem codicum recensuit, emendavit annotatibusque criticis instruxit Eugenius Darkó. Tomus I. Praefationem, codicum catalogum et libros IIV. continens. Budapestini 1922. 39, 10-42, 4. (Darkó 1922) Lásd: Szabó Pál: „kitolta Vazul szemeit” - a megvakítás büntetésének bizánci eredetü gyakorlata a XI-XIII. századi Magyarországon, valamint a szláv és az oszmán-török jogi régiókban. Bácsország 2011/2 (57). 84

544 Thúry József: Ki volt „,a vak török császár”? Századok 1893. 839-849. A továbbiakban: Thúry 1893. Az azonosítást megnehezíti, hogy a források eltérő néven említették, sokszor tévesen. Dlugos Musztafának, a bizánci Dukasz Gunduz-nak, Szphrantzész Musza Cselebinek. Thúry 1893. 845.

545 Dr. Wertner Mór: „Baxat imperator turcorum” Családtörténeti adalékok 1904. 31-33. A továbbiakban: Wertner 1904.

546 Thúry 1893. 840.

${ }^{547}$ Zichy 1895. 670-671 (466. és 468. sz. okl)

${ }^{548}$ Zichy 1895. 671-672. (469. sz. okl)

549 Thúry 1893. 841; Wertner 1904. 31. A bátyja, Orkhán viszont 1488-ban még élt.

550 Milleker 1914. 31. Az 1571. évi Szendrői Névtelen mủve, a Szilágyi-Hajmási széphistória róla és szerelméről szól. Sokáig hajadon volt, a fent említett 1456. május 4-i adománylevél férjeként Hunyadi János tisztviselőjét, Salgói Török Pált említi. Megözvegyült és 1459. augusztus 8-i oklevél szerint már Liptói és Gesztelyi Nagy János felesége. 1488. november 19-e után halt meg, gyermektelenül. Thúry 1893. 841; Wertner 1904. 
$\mathrm{Az}$ 1432-es év további Tallóci-oklevelei között nem találunk török támadásra vonatkozókat. Egy május 5-én, Nándorfehérváron kiadott oklevélből megismerjük Tallóci Frank kevei alispánjait, Remetei Himfi Lászlót, Miklóst és Frankot, akiket a megyei közgyülésre magához hívatott. ${ }^{551}$ Június 1-én pedig utasította őket egy károkozásban való elégtételre. ${ }^{552}$ Június 9-én, Pünkösd második napján pedig meghagyja nekik, hogy a megyei nemességgel jöjjenek el a megyei közgyülésre. ${ }^{553}$ A familiárisai néha túllépték a hatalmukat, mert egy 1452. április 4-i oklevél szerint Remetei Himfi Imre, László, Miklós és Frank kevei alispánok Zsigmond idejében Ittebei Györgytől például 100 aranyforintot és egy 40 aranyforint értékű lovat erőszakkal elvittek. ${ }^{554}$

1432. augusztus 5-én Tallóci Frank csanádi, kevei, krassói ispánként adott ki oklevelet a keve megyei Szentlászlóvárán. ${ }^{555}$

1434. április 4-én, Nándorfehérváron Matkó kevei, krassói ispánként és a kunok bírájaként - immár Tallóci néven - jobbágy abductio ügyében intézkedett. ${ }^{556}$

A következő évben, 1435. szeptember 14-én, a krassó megyei Haram határvárában kelt oklevelében Tallóci Frank értesíti Remetei Himfi Frankot, hogy katonai szolgálattételre nem a várnál, hanem a hadseregnél kell jelentkeznie. ${ }^{557} \mathrm{Ez}$ mindenképpen valamilyen hadmozdulatról tesz tanúbizonyságot. Az 1435. év perhalasztási adatai pedig érdekes nándorfehérvári munkálatokról tanúskodnak. Töttös László perhalasztást kapott böjt középről 1435 augusztusára, mert akkor királyi szolgálattal volt elfoglalva (,,in servitiis regalibus foret occupatus”). ${ }^{558}$ A részleteket csak abból az oklevélből tudjuk meg, amelyben 1435 októberéről 1436 januárjára kapott ismét perhalasztást Töttös, mert Nándorfehérvárba hadigépeket hajókon küldtek. ${ }^{559}$ Azaz, , ,a királyi Felségnek ágyúiból és más ostromgépeiböl, hadieszközeiböl hajókon az Alsóbb Részek felé, Nándorfehérvárba indult." 1435. november 19-én Báthori István országbíró ugyanerről a perről szóló oklevelében szintén ugyanezen okot jelöli meg a perhalasztásra, 1436 januárjára. ${ }^{560}$ „, ugyanö királyi szolgálatban a királyi Felség hajóinak Nándorfehérvárra való vezetésével

\footnotetext{
${ }^{551}$ DF-DL 43914

552 DF-DL 43916

${ }^{553}$ DF-DL 43918

${ }^{554}$ DL 55511

${ }_{555}$ DF-DL 54798

${ }^{556}$ DF-DL 43992

${ }^{557}$ DF-DL 54977

${ }^{558}$ Zichy 1895. 461.

559 Zichy 1895. 461. (323. sz. okl. lábjegyzete) „,cum navibus bombardarum Regie Maiesatis et aliorum ingeniorum ac instrumentum bellicalium versus partes inferiores ad Nandoralban est destinatus." Wertner 1911. 542.

${ }^{560}$ Zichy 1895. 388. „quod idem in servitiis regalibus in adducentis navibus eiusdem regie maiestatis versus Albamnandor fuerit occupatus",
} 
volt elfoglalva..." Láthatjuk, hogy a várba a fegyverszállításokat nem szárazföldi, hanem a biztonságosabb dunai vízi úton végezték, valamint a szállítások egész év végéig is elhúzódtak, tehát több alkalommal kerülhetett rájuk sor. Egyébként a Pozsony-BudaNándorfehérvár vízi út a korban később is használatos volt hadiszerek szállítására. ${ }^{561} \mathrm{~A}$ 1435. évi forrásunk nemcsak a hagyományos, hanem a haditechnikai újdonságokról, találmányokról is megemlékezik.

Ez az eljárás nem volt újdonság, mert már Zsigmond 1413. május 26-i oklevelében is találunk hasonlót. Amikor azt írta, hogy a magyarok által ostromolt Dévénynél már nem kell ostromtornyokat emelni, mert a nagy ágyúja Budán van és azt ágyúmesterével bármikor a vár alá tudja küldetni. ${ }^{562}$ A király tehát nagy ostromágyúit Budán készenlétben tartotta és az egyes hadjáratokra vagy várostromokra onnan szállítatta a célállomásra, föleg vízi úton. ${ }^{563}$ De a királyi ágyúkat szárazföldi úton is szállították. 1411. évi oklevél arról tudósított, hogy Budáról Kassára kilenc szekéren küldtek ágyúkat. ${ }^{564}$ Ezek, minden bizonnyal, kisebb súlyú és méretü ágyúk lehettek.

A következő évben is szó lehetett mozgósításról, mert 1436. március 5-én, Kevén kelt oklevelében Tallóci Frank Remetei Himfi Frank fia Tamás megbüntetését kérte, mert az bár a hadba vonulás ígéretével felvette a zsoldját, de annak nem tett eleget. ${ }^{565}$ A másik Tallóci testvér, Matkó május 11-én szlavón bánként, Körösön intézkedett egy nemes özvegynek járó hitbér és jegyajándék pénzben való kifizetése okán. ${ }^{566}$

Az 1437. február 25-i oklevél egy újabb Töttös-per perhalasztása kapcsán már egy általános nemesi hadfelkelést (,,presentem generalem exercitualem expeditionem”) említ a törökök ellen, akik az alsó részeket támadták Baranyában. ${ }^{567} 1437$ első hónapjaiban tehát a török csapatok a déli területeket fosztogatták, erre a már fent ismertetett Tallóci Frank által vezetett szerbiai ellentámadás volt a válasz, amelynek során magyar, cseh, lengyel sereg kelt át a Dunán, a Moravánál a török hajókat megsemmisítették. Tudjuk, hogy ebben a műveletben Nándorfehérvár serege is részt vett. ${ }^{568}$

Erről és Krusevác magyar ostromáról a török források is beszámoltak. Szeád-Eddin szerint, amíg a szultán a karamánok ellen háborúzott, addig a király „Alad-a-Hiszár várát

\footnotetext{
${ }^{561}$ Iványi 1926. 135.

562 Veszprémy László: Haditechnikai újítások és kéziratok Zsigmond környezetében. In.: Lovagvilág Magyarországon. Budapest 2008. 198. A továbbiakban: Veszprémy 2008 b.

563 Pálosfalvi 2005. 62.

${ }^{564}$ Veszprémy 2008b 200.

565 DF-DL 55014

${ }^{566}$ DF-DL 65880

${ }^{567}$ Zichy 1895. 595-596. (411. sz. okl)

${ }^{568}$ Калић-Мијушковић 1967. 108-109. Lásd még az 5. 4. fejezetet.
} 
nem foglalta el s rablással és pusztítással megelégedve visszatért. ${ }^{\text {} 569}$ A török történetíró szerint ez a magyar akció volt a kiváltó oka annak, hogy Ali, Evrenosz fiát seregével magyar földre küldte ki.

Azt megemlítjük még, hogy az oklevelek tanúsága aszerint 1437-től (1439-ig) Tallóci Frank már mint szörényi bán intézkedett. 1439. november 11-én például a krassó megyei szentlászlói várnagy panaszában, december 16-án pedig Remetei Himfi Imre özvegyének ügyeiben. ${ }^{570}$

\section{3. II. Murád 1438. évi erdélyi hadjárata}

Zsigmond király halála után Habsburg Albert rövid uralkodását is beárnyékolta a török fenyegetés, amelyet jól mutatnak az 1438. évi perhalasztó oklevelek is. ${ }^{571} 1438$ augusztusában ugyanis az oszmánok ezúttal Erdély déli részébe törtek be. Mályusz Elemér Albert király uralkodásáról szóló tanulmánya szerint augusztus 5-én lépték át a határt a törökök. ${ }^{572}$ „Az első alkalom, hogy immár nem a határvidék, hanem az ország belsejében

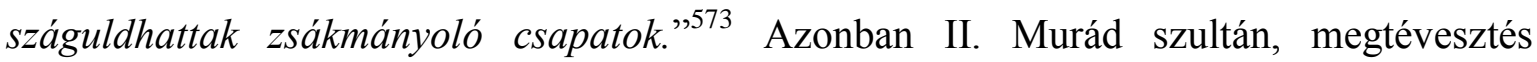
céljából, sokáig bizonytalanságban tartotta Losonci Dezső erdélyi vajda seregeit abban a tekintetben, hogy melyik lesz a fö támadási irány, mert úgy mutatta, hogy a török sereg a Havasalföld ellen fog vonulni. Várak, városok ostromára nem gondoltak, inkább a zsákmány- és fogolyszerzés volt a céljuk. ${ }^{574}$

Szeptember 14-én kelt oklevelében Pelsőczi Bebek Imre székely ispán (1438-1441) ${ }^{575}$ a törcsvári út védelmezésére szólította fel a brassói és a barcasági szászokat, mert a törökök ezen az úton akartak előrenyomulni. ${ }^{576}$ Az oszmán időzítés ismét remekül sikerült, mert Albert ekkor cseh trónjának megtartásáért a huszitákkal és a lengyelekkel háborúzott, távol

\footnotetext{
${ }^{569}$ Török történetírók I. 1893. 127.

${ }^{570}$ DF-DL 55 106, DF-DL 44182

${ }^{571}$ Wertner 1911. 550-551.

${ }^{572}$ Mályusz Elemér: Az első Habsburg a magyar trónon. Aetas 1994/1. 134. A továbbiakban: Mályusz 1994. ${ }^{573}$ Uo.

${ }^{575}$ Engel 1996. 194. Egyébként Bebek Imre ebben az oklevélben szerepel először székely ispánként. Kordé 2004. 217. A székely ispáni tisztségről lásd még: Uő: A székely ispáni méltóság a Zsigmond halála utáni években. Acta Universitatis Szegediensis de Attila József Nominatae. Acta Historica, Tomus CXVI. Szeged, 2002. 49-58 (Kordé 2002). Uő: Megjegyzések a székely ispánok 1467 előtti katonai szerepéhez. Hadtörténelmi Közlemények 2005/3. 721-732. (Kordé 2005)

576 Wertner 1911. 550; Székely Oklevéltár. Szerkesztette: Szabó Károly. III. kötet (1270-1571) Kolozsvár 1890. 54-55. (A 445. sz. okl.) A továbbiakban: SZOkl.1890.

„...nunc perfidissimi Turci fidei christiane persecutores hostes et inimici nostri nuper sub Castro Terch viam et publicam stratam unde prefati huc ad oprimendum et deuastandum hoc Regnum venire possent laboraverunt. mandamus...prefatam viam ob respectum amoris domini nostri Regis necnon huius Regni secundum quod vobis fideles nostri Castellani deelevabunt cum fortitudine maiori et forciori potueritis, cum tali fortitudine prefatam viam laborare non prolongetis."
} 
kellett maradnia az országtól. Ugyanis időközben megválasztották német királlyá, azaz Zsigmond örökösének elismerték. Mint korábban láttuk, a katolikus cseh rendek Prágában cseh királynak elfogadták. Azonban a husziták (kelyhesek) májusban vele szemben az ifjú, 13 éves Jagelló Kázmér lengyel herceget, III. (Jagelló) Ulászló lengyel király testvérét, választották meg cseh királynak. Albertnek háborút kellett viselnie mind a husziták, mind Kázmér lengyel serege ellen, az Erdélyt fenyegető szultáni hadjárat árnyékában. Így kétfrontos, rosszabb esetben háromfrontos háborúban találta magát. Elöször a husziták ellen tudott fellépni. Albert sietett is Csehországba és június 29-én, Prágában, megkoronáztatta magát. Augusztusra a huszitákat Tábor városába szorította vissza, végül Kázmér csapatait verte vissza. Ebben őt az is támogatta, hogy Rozgonyi István vezetésével egy nagy magyar sereg a Szepességből támadott a lengyelekre. ${ }^{577}$ De Albert nem jött Magyarországra.

Az erdélyi török támadásról Magyarországi György domonkos barát (Georgius De Hungaria), -a korábbi szakirodalomban a Szászsebesi Névtelen- is beszámolt, aki maga is erdélyi születésü. 1438 augusztusában, Szászsebes török ostroma alkalmával török fogságba esett. ${ }^{578}$ Húsz éves török fogságában írta Tractatus-át (Értekezés a törökök szokásairól, viszonyairól és gonoszságáról). ${ }^{579}$ Számunkra azért bír fontos forrásértékkel beszámolója, mert ebből kiderül, hogy II. Murád szultán már 1437-ben, a Zsigmond halálát követő trónviszályt felhasználva, elhatározott egy nagyarányú hadjáratot az ország ellen és személyesen vezette a hadsereget. „Nagy egyenetlenség támadt a magyarok és németek közt a királyválasztás vonatkozásában, abból következöen, hogy az uralkodó nem hagyott hátra törvényes (fiú)utódot, Murád bég - az ez idő szerint uralkodó Mehmed bégnek atyjaseregének óriási tömegével belépett amaz országrészekbe. Arról beszéltek, hogy 300000 lovasa volt, s azzal a szándékkal jött, hogy az egész Magyarországot elpusztítsa. Ezt meg is tette volna, ha Isten rendeléséböl egy folyó kiáradása ebben meg nem akadályozza. Miután pedig fenti szándéka így meghiúsult, seregét a hegyen túli tartomány felé fordította, melyet Hétvárnak neveznek, s mindazt, ami csak eléje került, kegyetlenül végigpusztította $s$ lerombolta; itt már senki sem állta útját." ${ }^{, 580}$ Magyarországi György diák 15-16 évesen ekkor Szászsebesen (Mühlbach) tanult „Amikor a török ehhez a városhoz érkezett, $s$ letáborozva elötte, hozzáfogott ostromlásához." A török sereggel volt a havasalföldi

\footnotetext{
${ }^{577}$ Szalay 1863. 7; Horváth 1871. 528.

578 Rabok, követek, kalmárok az Oszmán Birodalomról. Közreadja: Tardy Lajos. Budapest 1977. A továbbiakban: Tardy 1977.

579 „Incipit prohemium in tractatum de moribus, conditionibus et nequicia Turcorum” Tardy 1977. 49.

580 Tardy 1977. 51-52.
} 
fejedelem, II. Vlad (Drakul) is, akinek viszont a vár békés átadását kellett javasolnia. Azonban a várnagy az egyik toronyba húzódott és ellenállt. „Kijelentette: százszor inkább vállalja a halált, semhogy magát, feleségét s fiait a törökök kezére adja; erre sok más személyt is rábeszélt...Velük együtt mentem tehát én is."581 A törökök az adott fegyverszüneti idö lejártával a kivonuló polgárokat a város kapujánál összeírták és elhurcolták őket a vagyonukkal együtt. Viszont a zsákmány reményében az ellenálló vártornyot viszont szabályosan megostromolták, ehhez ostromgépeket is használhattak. Ami tanulságos számunkra, hogy a szultáni seregben ezek (tüz)ereje -akár kőhajítógépről, akár már kőgolyót kilövő ágyúról lehetett szó-, a várfalak lerombolására még itt sem volt alkalmas. „Olyan nyíl- és közápor zúdult ránk, hogy az esőnél, avagy a jégesönél is sürübbnek tünt...és mivel a torony nagyon mélyen feküdt, közvetlenül a tetejét verették nyilaikkal és köveikkel. Ám a falak erössége miatt semmiképpen sem tudtak úrrá lenni rajta." Végül más módot alkalmaztak: „A farakást azután csaknem olyan magasra épitették fel, amekkora a torony volt. Miután tüzbe boritották a farakást, úgy sütöttek meg bennünket, ahogyan a kemencében sülnek a kenyerek. És amikor már csaknem mindenki meghalt, s látták, hogy a toronyban többé nem mozog senki, szétverték a tüzet, berontottak a kapun át, $s$ ha rátaláltak egy-egy félholt emberre, azt mihelyt magához tért, kihurcolták. Engem is ugyanezen a módon hurcoltak ki s adtak át a kalmároknak eladás céljából. Ezek aztán láncra vertek, s a többi fogollyal együtt - a Dunán átkelve- elvittek egészen Drinápolyig, a Nagy Török (t. i. Murád) székvárosáig."(Kenéz Győző fordításai) ${ }^{582}$

Ez az 1438. évi szultáni hadjárat a lengyelek számára is fontos könnyítő tényező lehetett, mert a hátországában fenyegette Albert királyt, akinek ekkor Kázmér ellen Csehországban kellett háborút viselnie. A török támadásról, a latin nyelvü lengyel forrásaink közül, röviden Dlugos is beszámolt (Tizenkettedik könyv, A török szultán megtámadta Magyarországot). „Ugyanennek az évnek nyarán a törökök szultánja erös és hatalmas hadsereggel, miután összegyüjtötte és miután kedvezö lehetöség adatott, megtámadta a Magyar Királyságot. Az erdélyi részeket pusztította és fosztotta ki és sok embert elfogván mindkét nemböl, őket örökös szolgaság alá vetette..."583

\footnotetext{
${ }^{581}$ Tardy 1977. 52.

582 Tardy 1977. 53-54.

${ }^{583}$ Dlugos: Annales seu Cronicae incliti regni Poloniae. Liber duodecimus. Varsaviae, 2001. 190. „Turcorum caesar Hungariam invadit. In media estate anni eiusdem Turcorum cesar valido et potenti exercitu collecto oportunitate nacta Regnum Hungarie ingreditur et partes Transsilvanas vastat et spoliat multisque hominibus utriusque sexus comprehensis, illos in perpetuam servitutem abducit." A továbbiakban: Dlugos 2001.
} 
Eberhard Windecke Zsigmond király tetteiről szóló emlékiratában az 1438-as év eseményei között beszámol egy török betörésről, bár azt némiképp összemosta az 1439-es szultáni hadjárattal. Azonban tudósításából az világosan kitünik, hogy a pusztítás bár hatalmas lehetett, de a várakkal a törökök nem boldogultak. „...azok pedig elfoglalták Nagy-Havasalföldet és a kicsit, a Barcaságot, Erdélyt egészen Temesvárig, és az egész tartományt elpusztitották és feldúlták, kivéve Brassót, Nagyszebent és néhány várat." (Skorka Renáta fordítása) $^{584}$

Az erdélyi betörésről azonban részletesen bizánci forrásaink közül Dukasz számol be, amelyből a sereg útvonala is megállapítható (XXIX. 10, XXX. 1-2). A támadás Havasalföld felöl érkezett és Erdély déli területeit érintette. A szultáni sereget a havasalföldi fejedelem, Vlad vezette át országán, mert már korábban „Leborulva meghódolt neki és felajánlotta, hogy valahányszor csak Murád Magyarországra megy, ö átkelést biztosit számára, előkészíti neki az utat Alamannia és Oroszföld határáig" (Baán István fordítása). ${ }^{55}$ „Amikor elközeledett az idő, Murád már nyáron hadjáratot indít Magyarországra, és Nikápolyon keresztül a Dunán átkelve találkozott vele Dragulios, igen nagy örömmel megölelték egymást, és seregével együtt folytatja útját Muráddal" (Baán István fordítása). ${ }^{586} \mathrm{~A}$ további leírásból úgy tünik, hogy a törökök csak kiürített területeket találtak. Losonci Dezső erdélyi vajda (1438-1441) hiába hívta hadba az erdélyi sereget, kevesen gyültek össze, így inkább a nomád harcmodorból az ókor óta ismert „felperzselt föld” haditaktikáját tudta alkalmazni. ${ }^{587}$ A déli részekről eltelepítette a lakosokat. ${ }^{588}$ „És amikor már négy napja meneteltek, kietlenül találták a területet, ugyanis a magyarok Murád jöveteléröl értesülve áttelepitették a falvakat és a kisvárosokat. A törökök pedig teljesen puszta földön haladtak, és semmiféle hasznuk sem volt belöle, kivéve egy kicsinyke erödöt, s az is csak várakozáson felül történt.” (Baán István fordítása). ${ }^{589}$ Majd Szeben városához vonultak. „Amikor pedig Szebenhez értek - ez Magyarország egyik igen híres városa -, nem merték megközeliteni. A lakosok vad pillantást vetettek a törökökre, szemtöl szembe felvették velük a harcot: nem zárták be a kapukat - azok ugyanis tárva-nyitva

\footnotetext{
${ }^{584}$ Windecke 2008. 340.

585 Grecu 1958. 255, 23-26; Baán 2013. 341.

${ }^{586}$ Grecu 1958. 259, 1-3; Baán 2013. 343-344.

587 Lásd: Szabó Pál: Megjegyzések a középkori nomád harcmodor ókori előzményeihez. Belvedere Meridionale (XXI. évf) 2009. (február-március) 79-86. (Szabó 2009)

${ }^{588}$ Horváth 1871. 529.

${ }^{589}$ Grecu 1958. 259, 4-7; Baán 2013. 343.
} 
voltak -, sok törököt megölve hátba támadták a mindig elöörsként szolgáló Draguliost, attól félt ugyanis Murád, nehogy Dragulios cselt vessen ellene." (Baán István fordítása). ${ }^{590}$

$\mathrm{Az}$ 1438. évi hadjáratról a török források is beszámolnak, bár ezekből kevéssé rekonstruálható a lehetséges útvonala. ${ }^{591}$ Miután Szebent is sikertelenül ostromolták, Medgyes, és Brassó külvárosait dúlták fel. ${ }^{592} \mathrm{Az}$ 1486. évi Névtelen rövid leírása erre a hadjáratra vonatkoztatható. Thúry József fordítása szerint II. Murád „hadjáratot inditván Magyarországba, átkelt a Dunán, s miután Magyarországnak hat várát elfoglalta, visszatért Edrenébe. A hidsre 841. évében történt (1437. július $5-1438$. június 23.) ${ }^{593} \mathrm{~A}$ Névtelen ezután már a Nándorfehérvár elleni ostromot ismerteti. A Murád Évkönyve is a 841. évnél írja le, hogy a szultán Ungurus-ba ment, 6 várat ostromolt és 45 napig járt az országban. $^{594}$

Nesri történetíró korábbra teszi ezt a török hadjáratot, de megemlít egy ezt megelőző felderítő támadást Evrenosz fia, Ali vezetésével. A törökök Demesfar (Temesvár) mellett vonultak el és „,mikor bementek Üngürüszbe, egy hónapig ellenséget sem láttak. Csoda sok zsákmányt ejtettek ${ }^{, 595}$ Ezután Murád szultán „,nagy sereggel Viddin felé ment, Láz-oglu ${ }^{596}$ kalauzolása mellett átkeltek Viddinnél, az összes akindsik is átkeltek, Magyarországnak több várát elfoglalván...45 napig gázolván, tipratván Magyarországot, mindenféle zsákmánnyal megrakodtak." A szultáni sereg akadálytalanul pusztíthatott és a visszavonulásukkor az Al-Dunánál Gyurgyevó várát építették fel. „Egyetlen gyaur sem szegült ellene az uralkodónak, hanem mind meghódolt, ö pedig győztes és diadalmas lett. Azután Jerköki várát ${ }^{597}$ fölépítette, örséget helyezett bele és visszatért Edrenébe. E csata a hidsre 839. évében történt (1435. július 27 - 1436. július 15; Thúry József fordításai) ${ }^{598}$ Nesri bár korábbra helyezte ezt a szultáni hadjáratot, de hasonlóképpen Nándorfehérvár 1440. évi ostromát is (a hidsre 841. éve $=1437$. július $5-1438$. június 23.). Így a relatív kronológiája megállhatja a helyét, mert a két esemény közötti két évet megtartotta. Azt is

\footnotetext{
${ }^{590}$ Grecu 1958. 259. 10-16; Baán 2013. 344.

${ }^{591}$ Dávid Géza és Tardy Lajos lábjegyzete: Szörény várát ágyúkkal ostromolta, majd a Vaskapu felé haladva Orsova, Mehadia, Szászsebes volt az útja. Ezután Nagyszeben alá volnult 15 napi ostrom után Brassó felé vette útját. Tardy 1977. 143.

${ }^{592}$ Horváth 1871. 529.

593 Török történetírók. I. 1893. 17.

${ }^{594}$ Ménage 1976. 576.

595 Török történetírók. I. 1893. 53.

${ }^{596}$ Valószínüleg tévedés. Dukasz szerint sem Lázár fia, Lazarevics, hanem Vlad kalauzolta a török sereget.

${ }^{597}$ Gyurgyevó (Giurgevo). Ld.: Joseph von Hammer: Geschichte des Osmanischen Reiches. (magyarul) Pest 1830. 579. (Hammer 1830)

598 Török történetírók. I. 1893. 54.
} 
meg kell említenünk, hogy a török források egy része szerint nem a szultán vezette a hadmüveletet.

Szeád-Eddin leírása szerint ezt Murád parancsára Ali, Evrenosz fia hajtotta végre. „Ali bég tehát a szultáni parancs értelmében a rumilii harczosokkal átkelt a Duna vizén és Demesfar mellett vonult el s innen minden irányban portyázó csapatokat küldött ki. Negyven napig folymatosan tiporta a gyözelmes sereg Magyarországot s igen sok zsákmánnyal, élö és élettelen ragadmánnyal rakodott meg."599 Ali visszatérve pedig „Magyarország szépségének elbeszélésével feltüzelte a padisaht Magyarország meghóditására.” Akinek „ez ország ellen inditandó hadjárat gondolata szüntelenül csiklandozta elméjét." ${ }^{600}$ Szeád-Eddin ezután már Nándorfehérvár ostromát tárgyalja (A hidzsra 843. éve $=1439$. június $14-1440$. június 1.), és csak ezután kerül sorra Szendrő várának elfoglalása. Ellenkező történetírói véleményt nem fogad el, sőt hangot is ad kronológiai kételyeinek. „,némely történeti munkában úgy van előadva, hogy Belgrád ostroma és Novaberdo elfoglalása Szemendre meghóditása után történt, igy a többi közt Mevlána Nesri Szemendre bevételét 842-re teszi." ${ }^{601}$ (Thúry József fordítása)

Az erdélyi török hadjáratra is vonatkozó dokumentumot fedezett fel és ismertetett Halil İnalcık 1955-ben, a X. Nemzetközi Bizantinológiai Kongresszuson, Isztambulban (szept. 15-21) (Topkapi Szeráj Levéltára, Ar. 6374. jelzet). A keltezetlen, 15. századi oszmánli nyelven írt hivatalos jelentés egyrészt I. Bayezid Magyarország és Havasalföld elleni hadjáratáról, másrészt II. Murád szultán Erdély elleni támadását ismerteti. ${ }^{602}$ Ez utóbbit Inalcik nem, hanem Aurel Decei tette közzé 1974-ben, majd a 1978-ban. ${ }^{603}$

A beszámoló leírja a szultáni betörés útját. A törökök egy Kamen nevü átkelöhelyen átkeltek a Dunán, Szörény váráig vonultak, ahol az ágyút is elsütötték, de az nem okozott örömet. Ezután a Vaskapu-szoroson át Orsova várát, a Cserna-folyót érintve Mehádia várát $^{604}$ támadták meg, majd Sebes erődjét, de ezekkel a várakkal nem volt nagy sikerük. Így nem ostromolták tovább, hanem a Maros-folyó folyásának közepéig, Szeben váráig

\footnotetext{
${ }^{599}$ Török történetírók. I. 1893. 128.

${ }^{600}$ Török történetírók. I. 1893. 129.

${ }^{601}$ Török történetírók. I. 1893. 132.

${ }^{602}$ H. İnalcık: An Ottoman document on Bayezid I. S Expedition into Hungary and Wallachia. In.: X. Milletlerarasi Bizans Tetkikleri Kongresi Tebliğleri-Actes d' X. Congres International D'Etudes Byzantines. İstanbul 1957. 220. A továbbiakban: İnalcik 1957.

603 Aurel Decei: Două documente Turceşti privitoare la expediţiile sultanilor Baiazid I. şi Murad al il-lea în ţările române. In.: Relaţii Româno-orientale. București, 1978. 209-222. A továbbiakban: Decei 1978.

${ }^{604}$ Mehádia vidéke az Orsovától északra induló fontos út és a Belareka-folyó mellett található. Legismertebb erődje Miháld vára. Szabó Tibor: Mehádia várai. Várak, kastélyok, templomok. 2011 (február) 7. Mehádia várának első említését 1614-től tartják számon, e korábbi beszámoló módosítja azt. (Szabó 2011a)
} 
törtek elöre. Ott 5-10 napig maradtak, könnyüszerrel sok zsákmányt szereztek. Majd Brassó felé támadtak, átkeltek a Kárpátokon, majd kivonultak Erdélyből Havasalföldre és Gyugyevónál átkeltek a Dunán. A zsákmánnyal épségben a Boldogság Trónjához visszatértek. ${ }^{605}$ A forrásból - a pontos vonulási útvonalon túl - megtudjuk, hogy a várak ostromával ekkor még nem bírt az oszmán sereg, és bár ágyút is használtak, de az nem lehetett alkalmas a várostromokra.

Az 1438-as betörés ezen túl mindenképpen megmutatta, hogy nem az eddigi szokványos határmenti betörésről, hanem egy reguláris hadsereg támadásáról volt szó, amelynek célja Temesvár, esetleg talán - távolabbi célként - Buda is lehetett. ${ }^{606} \mathrm{Ha}$ a szultán nem az erdélyi, hanem a másik útvonalat választja, el kell foglalni a Duna-vonalán lévő végvárakat, hogy szabaddá váljon az út az ország belseje felé.

\section{4. Szendrő 1439. évi ostroma}

Az oszmán külpolitika európai katonai aktivitásával kapcsolatosan meg kell említeni, hogy II. Murád ekkoriban váltotta le egyik vezérét, Mehmed agát, helyébe pedig Hekīm Fazlullāh-ot nevezte ki, aki a háborút szorgalmazta. ${ }^{607}$ A bizánci történetíró, Dukasz őt $\Phi \alpha \delta$ ov $\alpha \alpha \chi$ néven említi. Töle tudjuk, hogy ö kezdetben a kormányzat bevételeinek főszámvevője volt, aki felettébb ellenségesen viszonyult a keresztényekhez, Murád ezért tette meg vezérei egyikévé. Dukasz szerint a Szerbia elleni támadást is ő sürgette. ${ }^{608}$

Ez az epizód mindenesetre jelezte, hogy egy olyan kisebb katonai csoport alakul ki Murád környezetében, amely ellenezte a nagyvezír politikáját. Így került ismét előtérbe a háború. Imber szerint valószínủleg már 1438-ban az ő sugalmazására használta ki Murád Magyarország átmeneti gyengeségét. Murád úgy tekintett Szerbia meghódítására, mint az első alapvető lépés a Magyar Királyság elleni támadásra. ${ }^{609}$

Az oszmán nagypolitika folyamatosságát ugyanakkor egy régi oszmán nagybirtokos családból való nagyvezír alakja jelezte immár 1429 óta: Halil Chandarli pasa, aki inkább a konzervatív irányvonalat, a béke és megegyezés politikáját képviselte. Mivel ő egyaránt tartott a keleti fenyegetettségtől és a nyugatról érkező keresztes háborútól, fontos politikai

\footnotetext{
${ }^{605}$ Czeglédi Katalin és Papp Sándor fordítása nyomán, akiknek ezúton köszönöm segítségüket.

${ }^{606}$ Erdély története. A kezdetektől 1606-ig. Szerk.: Makkai László, Mócsy András. Budapest 1986. 357. (Erdély 1986)

${ }^{607}$ Imber 1990. 116.

${ }^{608}$ Grecu 1958. 261; Baán 2013. 345-346.

${ }^{609}$ Imber 1990. 117.
} 
eredménye volt Szerbia államiságának helyreállítása 1444-ben és a Bizánccal való fenntartható béke, így alapvetően ellenezte Konstantinápoly elfoglalását is. ${ }^{610}$

II. Murád közvetlen célpontja Szerbia volt, mégpedig az újonnan felépített fővárosa, Szendrő erődje. A 25 tornyú, háromszög alaprajzú erődöt Branković György építtette 1428-1430 között a szultán engedélyével. ${ }^{611}$ Albert királynak most már, 1439-ben életében először - és utoljára - hadba kellett ellenük vonulnia, mert a törökök Szendrőt ostromolták, II. Murád személyes vezetésével.

A lengyel Dlugos nemcsak beszámolt Szendrö ostromáról (A törökök megtámadják Szerbiát, Albert meghal), hanem megemlítette a csehországi háború végét és a lengyelekkel való megbékélést. Így elöször azt, hogy Albertnek Lengyelországba kellett volna mennie -az ifjú lengyel királlyal, III. Jagelló Ulászlóval (1434-1444) való személyes találkozóra és megegyezésre, de a török támadás hírére, ezt nem tehette meg. „Elérkezett Szüz Mária születésének ünnepe (t.i. szeptember 8), bár Ulászló a megállapodás szerint személyesen jött Biecz-be, hogy személyes találkozót tartson a béke megkötéséröl Alberttel, a római, magyar és cseh királlyal, Albert maga azonban sehogyan sem tudott odajönni. Ugyanis a törökök szultánja nagy és erös hadsereggel megérkezve, elfoglalta és a maga uralma alá helyezte az egész maradék Szerbiát. Szendrö várát, amelyet a despota újonnan a Duna fölött, nagy költséggel felépitett és 25 toronnyal megerösitett, megostromolta. Így hogy visszaverje a szultánt az ostromtól, Albert király a szerb despota, István ${ }^{612}$ kérései által feltüzelve és könnyei által meggyözve, miután Magyarországról és saját Ausztriájából összegyüjtötte a hadsereget a törökök ellen, segítséget nem várva, elörenyomult, hogy a törököket visszaverje az emlitett vár ostromától. Sok napon át a táborban idözött, látva a magyarok aggódó lelkét és az összegyülekezésre való gyengeségét, és látva azt is, hogy saját serege kisebb a barbárokénál, elhalasztotta a támadást. Időközben a török (t. i. a szultán) megegyezést kötött Szendrő vezetőivel, öket nagy ajándékokkal megvesztegetve, miután a mondott várat katonákkal és legerösebb fegyverekkel birtokába vette, és azután, hogy megvakitotta a despota fiát és annak nővérét feleségül vette, hazatért... "613

${ }^{610}$ Halil İnalcık: Ottoman methods of conquest. In.: Studia Islamica. no. 2. (1954) 106. A továbbiakban: İnalcık 1954. 1453-ban a Konstantinápoly kérdésében való ellentéte miatt a trónra lépő II. Mehmed szultán kivégeztette. Matuz 1990. 52-53. Lásd még a 2. 4. fejezetet.

${ }^{611}$ Szakály 1986. 28.

${ }^{612}$ Itt Dlugos téved, mert a segítséget Brankovics György kérte, aki Istvánt Szendrőben hagyta a vár védelmére.

${ }^{613}$ Dlugos 2001. 209. „Festo Nativitatis Sancte Marie adveniente, quamvis Wladislaus Polonie rex iuxta conventa venisset personaliter in Biecz, ad tenendam convencionem personalem cum Alberto Romanorum, Hungarie et Bohemie rege pro pace concludenda, ipse tamen Albertus nullatenus venire potuit. Turcorum enim cesar cum magno et forti exercitu veniens, occupata et in dicionem tota redacta Rascia, castrum Smideroph, quod despotus noviter supra Danubium magnis sumptibus edificaverat et 
Thuróczy János krónikájában Szendrő elfoglalásáról röviden szólt, ám beszámolója szerint Murád célja már ekkor (is) Magyarország megtámadása volt, csak „amikor megtudta, hogy a király az ország védelmére elegendő katonával és fegyveres erövel rendelkezik, ostrommal bevette Szendrö várát, csaknem az egész Rácország földjét hatalma alá vetette..." (Horváth János fordítása). ${ }^{614}$ Ezután említi - kronológiailag tévesen - II. Murád Thesszaloniki elleni ostromát.

Antonio Bonfini szerint „a király segédcsapatok nélkül megindította táborát Murád török király ellen, és a Tisza meg a Duna között állapodott meg. Mialatt a sürgetett segitséget várta, a törökök bekeritették Szendröt, éjjel-nappal hevesen támadták, és annál erösebben rohamoztak, minél közelebb tudták a segítségül érkezö ellenfelet, nem kímélték az ostromgépeket...mielött Albert a táborral odaért volna, bevették a várat.” „A város elfoglalása után szokásuk szerint kegyetlenkednek, elfogják Istvánt, a despota fiát, szemét kinyomják...Hasonlóképpen megvakitják ${ }^{615}$ István öccsét, Gergelyt...a török várakozáson felül kiterjesztette birodalmát, közvetlenül Magyarország határaira érkezett..."(3.4. 90 95, Kulcsár Péter fordítása). ${ }^{616}$

A bizánci történetíró, Laonikosz Khalkokondülész beszámolója számunkra azért érdekes, mert megemlíti Murád itt használt, várostromra még nem alkalmas tüzérségét is. „A deszpotész (Branković) hátrahagyta fiát, Gergelyt (Gurgurosz), hogy az a vár ügyeit irányitsa és a falakat megvédje, ha az ellenség odaérkezik. Ö maga a paiónokhoz (magyarokhoz) ment el, hogy segitséget kérjen. Mivel rendelkezésére állt paión (magyar) területen nem csekély értékü, számos és szép város, amelyeket még Lazarević (Eleazarosz) cserélt el a magyarok császárával, Zsigmonddal (Szigiszmondosz) Belgrád városáért, amelyet átadott a császárnak, hogy ezáltal az átkelöhelyen biztonságosan birtokolja a vidéket. Tehát a fiát (Gergelyt) hátrahagyta a vár ügyeinek irányítására, és ö felkészült egy esetleges ostromra. Murád (Amouratész) odavonulva lerohanta a vidéket és a várat

viginti quinque turribus muniverat, obsedit. Ad repellendum itaque illum ab obsidione Albertus rex precibus despoti Rascie Stephani sollicitatus et victus lacrimis, collecto ex Hungaris et eius Australibus exercitu contra Turcos non expectatis auxiliis processit ad repellendum illos a prefati castri obsidione. Multis itaque diebus in campo comoratus, videns animos Hungarorum timidos et pusillanimes ad congrediendum, videns eciam exercitum suum barbarico inferiorem, confligere distulit. Turcus vero interim facta paccione cum castri Smiderow rectoribus, multis largicionibus illos corrumpens, castro predicto situ et municione fortissimo potitus est, excecatoque despoti filio, cuius sororem in matrimoniam habuerat, domum abiit."

${ }^{614}$ Thuróczy János: A magyarok krónikája. Fordította Horváth János Budapest 1978. 367. A továbbiakban: Thuróczy 1978.

615 Antonio Bonfini: A magyar történelem tizedei. Ford. Kulcsár Péter, Budapest. 1995. 572. Bonfini a despota két fia kapcsán a megvakítás egy enyhébb módját ismerteti (3. 4. 95). „A törökök által kitalált módszert alkalmazták, tüzes vasat húztak el a szemük elött, igy az irgalmatlan höségtől kiszikkadt szem elveszitette a tisztaságát, és olyan benyomást keltett, mintha vak lenne” (Kulcsár Péter fordítása)

${ }^{616}$ Bonfini 1995. 572. 
ostromolta. Mindenféle ostromszerkezetet (mékhanasz pantoiasz) a falhoz odavontatva megkisérelte elfoglalni a várat. Azt azonban mégsem tudta elérni. Hatalmas ágyúkkal (téleboloisz megisztoisz) - már amelyek abban az időben voltak - rémisztette a várat, de a falak a lövésektöl nem gyengülnek. Ekkor a deszpotész fia, Gergely attól félvén, hogy a vár az ágyúk által (hüpo tón télebolón) elesik, elfogadta a (török) császártól az ajánlatot a megegyezésre és megkötötte a szerzödést, amely értelmében át kellett adni a várat a császárnak...$^{617}$ ez tehát átadta a várat, bemenvén a táborba, a szultánnál tartózkodott testvérével, Istvánnal (Sztefanosz). Nem sokkal később, amint a szultán megtudta, hogy az apjuk ellene készül, és hogy a fiak megkapván apjuktól a tervet, titokban követet küldtek az elpártolást szorgalmazva, elfogván mindkét fiút, mindkettőnek mindkét szemét kivájatta. Így hódította meg Szendröt (Szpenderovót), a triballoszok (azaz a szerbek) fövárosát; a várban elegendö örséget hagyott hátra és rögtön sereggel vonult a paiónok (azaz magyarok) városa, Belgrád ellen. "618 Ez utóbbi eseményeket a történetíró egybefoglalta, bár ezek később történtek. A szultán Gergelyt és Istvánt az apjukkal való titkos levelezésük miatt Kis-Ázsiába vitette és csak 1441. május 8-án vakíttatta meg. ${ }^{619}$

Igazolja idézett bizánci forrásunk leírását a helyszíni megfigyelésünk is. Szendrő várának falvastagsága méréseink (2012. április 21.) alapján 5 métert tett ki. Ha összehasonlítjuk a Nándorfehérváron mért falszakasz adataival, akkor bátran megállapíthatjuk, hogy Szendrő is eredményesen állhatott volna ellent a korabeli oszmán-

${ }^{617}$ Laonici Chalcocondylae Historiarum Demonstrationes. Tomus II. Pars prior (libros V-VII. continens) Ed.: Eugenius Darkó. Budapestini 1923. 23. 21; 24. 1-19. A továbbiakban: Darkó 1923.

${ }^{618}$ Darkó 1923. 24, 20-21; 25, 1-8. E forrásrészlet további magyar fordításai: Szabó 2012d 20-21; Baán 2013. 219-220.

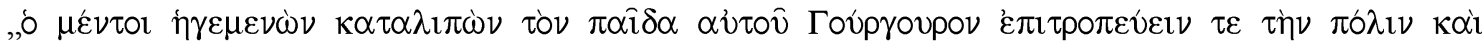

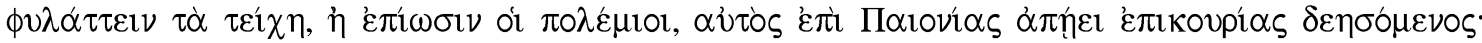

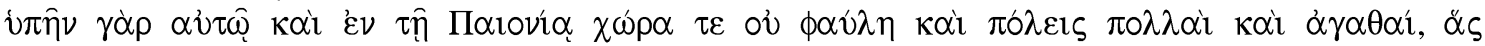

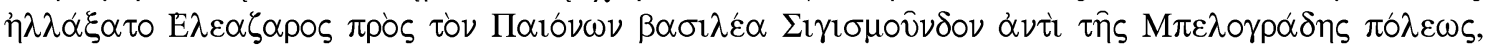

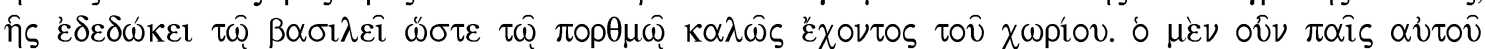

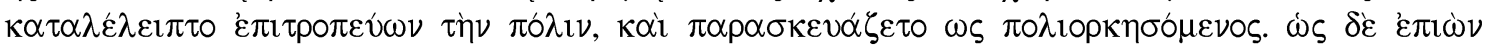

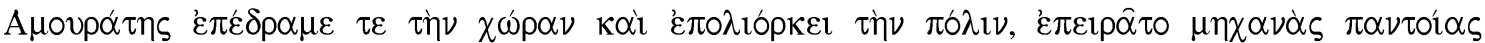

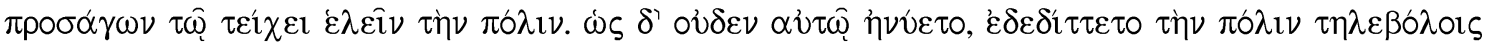

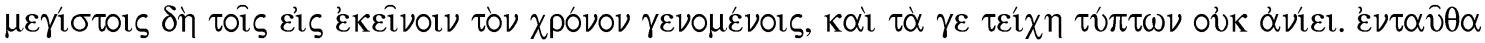

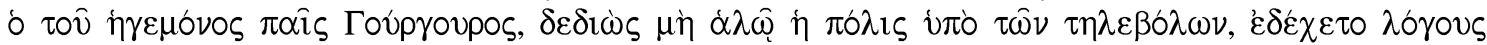

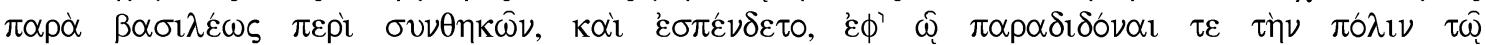

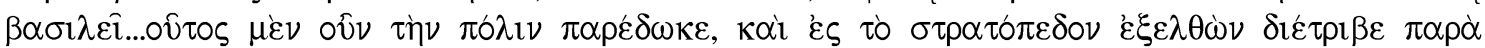

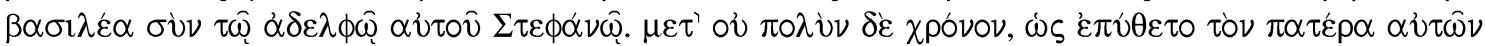

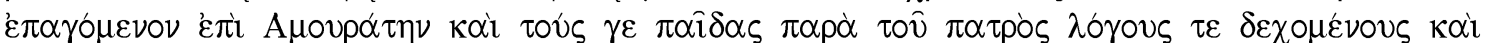

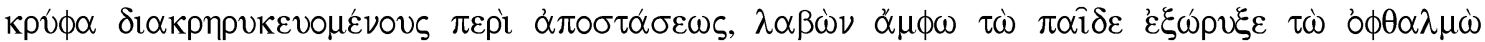

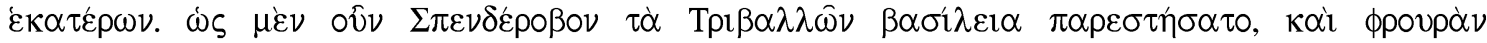

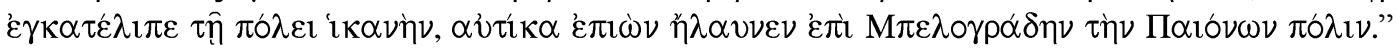

${ }^{619}$ Константин Јиречек: Історија Срба. Веоград 1952. 365. A továbbiakban: Јиречек 1952. 
török tüzérségnek. ${ }^{620}$ Azaz, Laonikosz Khalkokondülész tudósítása alapján a későbbiek szempontjából fontosnak tartjuk kiemelni, hogy a szultán a túlerejével, várostromra még nem alkalmas tüzérség híján, valamint a régi ostromgépekkel (kőhajítógépek) hasztalanul ostromolta volna a várat, amelyet csak átadás révén tudott megszerezni. Miközben a segítségül hívott magyar sereg még messze, Titelnél várakozott. ${ }^{621}$ Gergelyt és testvérét, Istvánt megvakították, azaz - bizánci gyakorlat szerint - uralkodásra alkalmatlanná tették. Ezzel Szerbia elfoglalását Murád teljesítette. Ráadásul időközben a magyar táborban kitört járványnak köszönhetően októberben Albert király is meghalt. ${ }^{622}$ Soha vissza nem térő alkalom adódott a déli végek elleni támadásra. A török ekkorra időzítette Nándorfehérvár megtámadását.

Más bizánci források nem így számolnak be ostromról. Dukasz szerint Murád kiéheztetéssel szerezte meg a várat (XXX. 4). „Elöször tehát Szendrőbe megy aratás idején, a vár csüre ugyanis üres volt, meg a többi éléstár is. S kikémlelve, hogy itt az alkalom, körülzárta a városkát, $s$ három hónapig táborozott mellette, míg aztán az élelemhiány miatt fel nem adták, ö pedig esküvel kezeskedett arról, hogy senkin sem áll bosszút. Kinyitották tehát a kapukat és kijöttek, hogy hódoljanak neki. Bent volt a despota elsö fia ${ }^{623}$ és anyai nagybátyja, Thomas Kantakuzenos. ${ }^{624}$ Elegendö törököt hagyott tehát a vár örzésére..." (Baán István fordítása). ${ }^{625}$

Egy 17. századi újgörög nyelvü forrás, a Codex Barberinus Graecus 111-ben

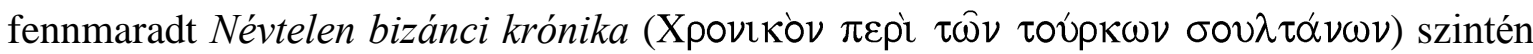
beszámol Szendrő (Sziderovia) ostromáról és Albert hadba vonulásáról $\left(40^{r}\right)$. E leírás leginkább Bonfini beszámolójával mutat hasonlóságot.

„Amikor Zsigmond (Szigiszmontosz) meghalt, királyi tisztségébe Albert (Albertosz) lépett Hungáriában; akkor az ő összes seregét összegyüjtötte és anélkül, hogy másoktól segitséget kért volna, Murád (Muratész) ellen vonult. Letáborozott egy Tibiszkosznak (Tibiscus=Tisza) nevezett helynél, a Duna - (Dunavisz) folyóhoz közel és várakozott arra, hogy segélycsapatok érkezzenek. Murád viszont nem várakozott, hanem megostromolta Szendröt nappal és éjjel és mielött megérkezett volna Albert segitsége Hungáriából, a szultán bevette Szendröt; a legtöbbjüket (a védőket) levágta és sokakat szolgává tett. Elfogta a deszpotész fiát, István (Sztephanoszt) és kiszúratta a szemeit. Megvakitatta egy

\footnotetext{
${ }^{620}$ Lásd a 3. 2. és a 3. 4. fejezetet.

${ }^{621}$ Engel-Kristó-Kubinyi 1998. 199.

${ }^{622}$ Pálosfalvi 2009. 11.

${ }^{623}$ Brankovics Gergely

${ }^{624}$ Brankovics György feleségének testvére.

${ }^{625}$ Grecu 1958. 261, 27-33; Baán 2013. 346-347.
} 
testvérét is, amikor később elfogta öt. Azt mondják, hogy Szendrö (bevétele) gyorsabb volt Szalonikéénél. ${ }^{626}$ Akkor, amikor Murád szultán bevette Szendröt, kiterjesztette és megnövelte országát egészen Hungáriáig... „627

A Névtelen Krónika ezután már Nándorfehérvár ostromának előzményeit kezdi el és Szendrő ostromának egy másik változatát ismerteti, amely inkább a fegyveres harc nélküli átadás Dukasz-féle leírásához kapcsolható, de a kiéheztetés említése nélkül. „,Mások azt mondják, hogy a két testvér, lévén Lázár deszpotész fiai, István (Sztephanosz) és Gergely (Gregoriosz) átadták Szendröt a szultánnak az ö akarata szerint. De ha nem akarták volna átadni, (a szultán) nem tudta volna elfoglalni, mivel a vár erös (dünato kastro) volt. A harmadik testvér, atyja tanácsa szerint Hungáriába ment azért, hogy segitséget kérjen. "628

Természetesen a török források is beszámolnak a Szendrő elleni ostromról. A korai oszmán történetíró és kortárs Âșik Pașazade (1400-1484k.) Az Oszmán-ház története címủ munkájában ${ }^{629}$ kronológiailag azonban felcserélve, hamarabb tárgyalta Nándorfehérvár - 1440. évi - ostromát (Bölüm 111.) Szendrőénél (Bölüm 112.). A beszámolója néhány ponton azonban ellentmond a fenti forrásainknak is. Az ostrom elött a szultán - a vazallusi engedelmesség alapján - Drinápolyba rendelte Dirakolát (II. Vlad Dracul) és Vilkoğlu-t (Branković Vuk fia, György) és mindkettő fiait elfogatta. Vlad fiait Gallipoliba (Gelibolu), Branković fiait Tokat várába záratta a szultán. ${ }^{630}$ Amikor nyár lett,

${ }^{626}$ Tudniillik Thesszaloniki 1430. évi oszmán ostrománál.

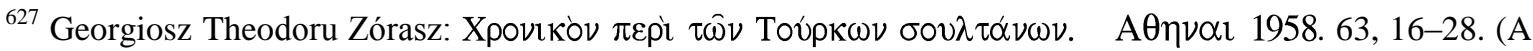

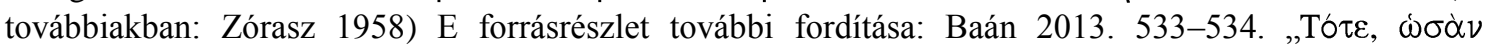

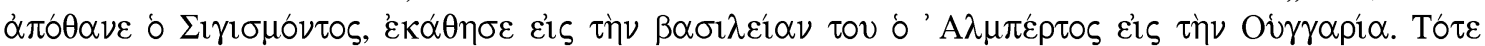

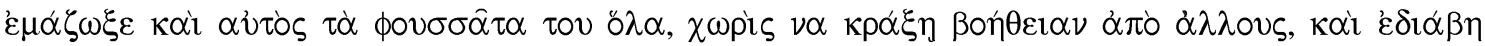

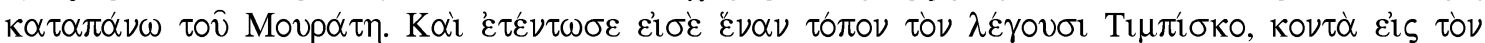

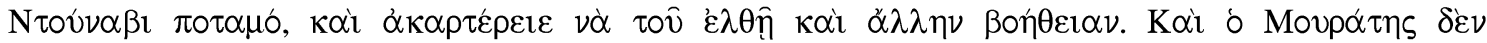

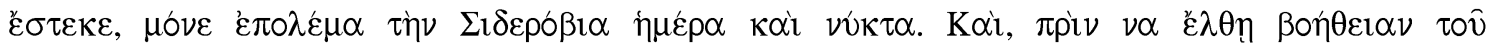

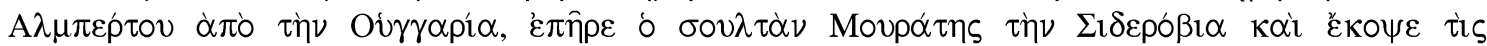

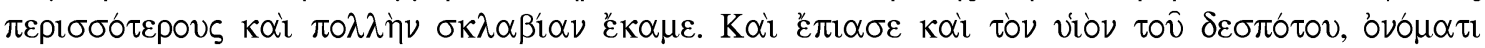

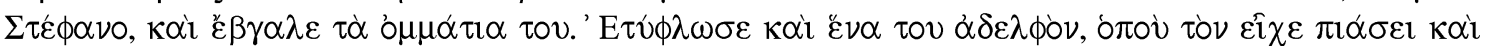

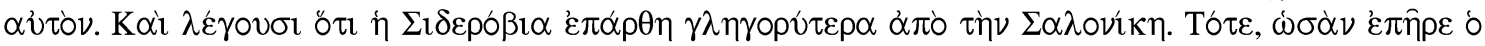

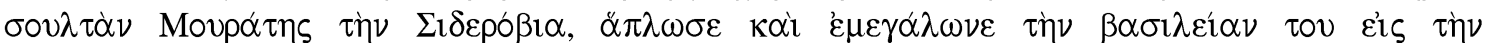

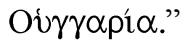

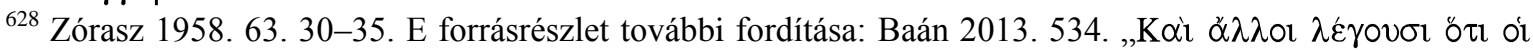

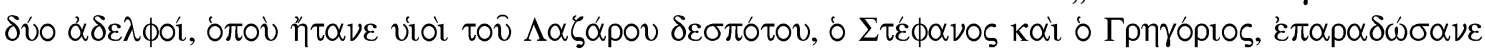

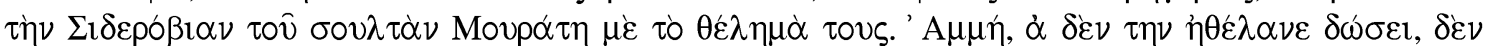

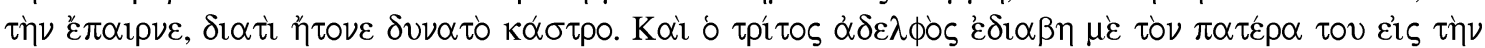

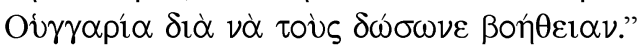

${ }^{629}$ Lásd Papp 1997. 166. A mủ kiadása: Âșik Paşazade Osmanoğulları'nim Tarihi. Hazırlayanlar Kemal Yavuz-M. A. Saraç İstanbul, 2007. A továbbiakban: Yavuz-Saraç 2007. A mü német fordítása: Osmanische Geschichtsschreiber. Herausgegeben von Dr. Richard F. Kreutel. Band 3. Vom Hirtenzeit zur Hohen Pforte. Übersetz, eingeleitet und erklärt von Richard F. Kreutel. Graz-Wien-Köln. 1959. (A továbbiakban: Kreutel 1959)

${ }^{630}$ Yavuz-Saraç 2007. 170-171, illetve 399; Kreutel 1959. 173. (Itt 113. fejezetként szerepel Szendrő ostroma) 
a szultán megostromolta Szendrőt (Semendire). Ezalatt Izsák bég zarándokútra ment Mekkába. A szerző az ostromról nem ír. Murád a szerb területeket pusztította és a lakosságból foglyokat szedett. Olyan nagy zsákmánnyal tértek vissza, hogy egy négyéves gyereket 20 ezüstpénzért adtak el. Mire Izsák visszatért a zarándoklatáról a várat még nem foglalták el. A portyázásokban Âșik Pașazade személyesen is részt vett, amelyekben inkább a foglyok szedése (és eladása) volt a cél. ${ }^{631}$

Nesri szerint Szendrőt (Szemendre) két hónapos ostrom után a törökök elfoglalták, Vulk-oglu (Branković Vuk fia, György) két fiát Tokatban vakították meg. Szeád-Eddin ír ágyúk, puskák használatáról, amelyek inkább füstöltek, mintsem eredményesek voltak. „, $A$ gyözedelmes sereg az ágyúk és puskák füstjével a hitetlenek szeme elött a világot sötétté téve, két hónapig szüntelenül harczolt s éjjel-nappal öldökölte a tévelygö csapatot. Végre a vár népe erötlenség, kimerültség, levertség és végső nyomor következtében kegyelmet kérvén, félelmében átadta a vár kulcsát. " ${ }^{632}$ (Thúry József fordítása)

Tudjuk, hogy Albert király Szegednél szállt táborba, 1439. július végén, augusztus elején, nem kelt át a Tiszán, hanem a jobb parton, Titelre vonult és másfél hónapig itt táborozott. ${ }^{633}$ Erről a Névtelen bizánci krónika is beszámolt. Azonban Mályusz Elemér mutatott rá arra, hogy ezt nem feltétlenül kell egy helyben „toporgás”-nak értékelnünk. Mert II. Murád szultán sem döntötte el a fő támadási irányt és reális volt a Temesköz elleni támadás veszélye is, miként egy évvel korábban. Így egyetértünk Mályusz értékelésével is. „A Titel környéki táborozás megmentette Magyarországot a múlt évi erdélyi pusztuláshoz hasonló veszteségtöl, így ezért nem mondható kárbaveszettnek, az azonban a ráforditott eröfeszitéssel nem állt arányban." ${ }^{634}$

Megfigyelhetjük, hogy az oszmán-török haditaktika fontos része volt ugyanis a déli, hosszú frontvonal támadása esetén a pontos támadási cél bizonytalanságban tartása vagy több célpont egyidejű támadása vagy párhuzamos hadoszlopban való felvonulás a valódi főerő eltitkolásával, amely eleve lehetetlenné teszi a koncentrált védekezést, amint erre az 1442-es, az erdélyi Vaskapunál történt hirtelen betörés is jó példát szolgáltatott. ${ }^{635}$

Albert király törökellenes politikáját sem szabad túlzottan lebecsülnünk, mert a tervébe bepillantást enged egy, a Titelnél, pontosabban a bács megyei Tüdőrévnél 1439. szeptember 17-én kiállított dekrétuma, amelyben ünnepélyesen ígéretet tett arra, hogy a

\footnotetext{
${ }^{631}$ Yavuz-Saraç 2007. 171-172, illetve 399-400; Kreutel 1959. 176-177.

632 Török történetírók I. 1893. 56, 130.

${ }^{633}$ Mályusz 1994. 139.

${ }^{634}$ Mályusz 1994. 140.

${ }^{635}$ Pálosfalvi 2001. 53.
} 
következő nyáron személyesen, az elérhető legnagyobb sereggel fog a törökök ellen vonulni. ${ }^{636}$ Albert király és Erzsébet királyné az ünnepélyesen kiállított oklevélben azon túl, hogy Szendrő várának körülzárását és Szerbia elfoglalását konstatálják, az általános nemesi hadfelkelés összehívását, késlekedését és eredménytelenségét is kénytelenek voltak megállapítani. „...mert bizonyos késlekedés miatt a sereg egy része hazafelé széledt...” Ezzel a maradék sereggel nem merték megtámadni a Szendrőt ostromló szultáni sereget, így a vár elesett. A török ellen a következő év tavaszán nagy sereget kívántak indítani, amely 1440-re esett volna! Viszont ennek a hadseregnek az alapját nem az általános nemesi hadfelkelő sereg alkotta volna, hanem nagyrészt zsoldosokból (multitudinem stipendiatorum armigerorum) állna. Ennek fedezésére pedig - a királyi és királynői jövedelmeken túl - az egész országra kiterjedő általános hadiadót vetnek ki. ${ }^{637}$ A terv szinte a későbbi Mátyás-féle koncepció előlegezésének tekinthető. Mindamellett a király megígéri, hogy külföldröl is katonai segítséget fog szerezni és személyesen áll majd a hadsereg élére. A hadiadó - nem népszerü - behajtását az ország főurai és nemesei segíteni fogják, nemcsak saját birtokaikon, hanem másoknál is. Az ellenszegülőkkel szemben a királlyal és a királynéval egyetemben fognak eljárni egészen a fej- és jószágvesztésig. Az ígéretek teljesítését aláírásukkal illetőleg pecsétjükkel a bárók és országnagyok közül többen megigérték.

Az oklevél méltóságnévsora különös figyelmet érdemel, mert az aláírók és jelenlévők között találjuk a Tallóci testvérek közül, a dalmát-horvát-szlavón bán Matkót és a szörényi bán Frankot. ${ }^{638}$ Bátmonostori Töttös László kincstartót. De már ott szerepelt igaz ekkor még cím nélkül - az egyik Hunyadi János is (Johannes de Hwnyad). A két székelyispán, Csáki Ferenc és Pelsőczi Bebek Imre neve szintén. ${ }^{639}$ Figyelemre méltó, hogy az aláírók között találjuk Branković György szerb despotát is, aki minden bizonnyal reményt láthatott ennek a hadseregnek a következő évi összehívásában és felállításában.

A külföldi segítséggel kapcsolatban John Jefferson feltételezi, hogy Albert király valójában egy keresztes háborút tervezett volna. Ezt, 1439-ben, IV. Jenő pápa sürgette volna a következő év nyarára, azonban Albert halála megakadályozta. ${ }^{640}$

\footnotetext{
${ }^{636}$ DL 39 290. Közzétette: Gr. Teleki József: Hunyadiak kora Magyarországon. Tizedik kötet. Pest, 1853. 70-73. A továbbiakban: Teleki 1853.

${ }^{637}$ Ezt a hadiadót minden házzal rendelkező jobbágy, minden conditionarius nemes és jobbágy nélküli nemes is fizetné. A hadiadó házanként 100 dénár. (150 dénár ért 1 aranyforintot)

${ }^{638}$ Teleki 1853. 72.

${ }^{639}$ Kordé 2004. 218.

${ }^{640}$ Jefferson 2012.57 .
} 
Azt nem tudjuk, hogy II. Murád Albert király szándékáról tudomást szerezhetett-e, és a Magyar Királyság elleni következő évi hadjáratát ez sürgette-e, de a kül- és belpolitikai események egyértelműen a javára fordultak.

Véleményem szerint Szendrő eleste több fontos tanulsággal szolgált - Nándorfehérvár szempontjából is - mert elöre vetítette egy újabb szultáni várostrom esetleges sikerét, de lehetséges kudarcát is.

Először is megnehezíti a központilag szervezendő védekezést, ha a király nem tartózkodik az országban. Ez perszonálunió megléte esetén elkerülhetetlen és Albert királlyal szemben is felmerülő problémává vált. Itt vissza kell utalnunk már az 1438. évi erdélyi szultáni betörés idejére is. Albertnek már 1438 tavaszán külföldre kellett mennie, mert a csehországi háborúval kellett foglalkoznia. Így 1438 folyamán végig távol maradt Magyarországtól. 1439 januárjában, Boroszlóban a IV. Jenő pápa által kezdeményezett béketárgyalásokon kellett részt vennie, de időközben eltörte a lábát és csak 1439 márciusában, az újabb szultáni támadás hírére tudott visszajönni. ${ }^{641}$

Másodsorban érdemes a hadászatra ekkoriban hatályos törvényi szabályozást is megvizsgálnunk. Mert ez sem kedvezett egy esetleges török támadás elleni gyors és hathatós fellépésnek. A király az 1439 májusára összehívott budai országgyülésen megerősödött rendi mozgalommal találta magát szemben, amelynek engedni volt kénytelen. ${ }^{642} \mathrm{Az}$ 1439. évi dekrétum (május 29) több szakaszában visszalépést jelentett a Zsigmond által „,behozott káros újítások”- hoz képest (4. cikkely). ${ }^{643} \mathrm{~A}$ rendek nem törődve a perszonálunió okozta problémákkal a 22. cikkelyben azt is elöírták, hogy a királynak a székhelyét az országban kell tartania és állandóan itt kell tartózkodnia. ${ }^{644}$ A 3. cikkelyben elfogadták, hogy az ország védelmében és a végvidékeken a király által alkalmazott katonák zsoldját a király fizesse, hogy azok ne raboljanak. A 3. cikkely a haderő mozgósításának fokozatát is felállította. Elsősorban a zsoldoskatonák feladata az ország védelme, így a várakban is, egészen addig, amíg az ellenségnek ellent tudnak állni. Ezek arra voltak elegendők, hogy a végeken a kisebb-nagyobb betörésekkel megvédjék a várakat, de egy szultáni haderővel nem vehették fel a harcot. Az 1438-as szultáni hadjárat tanulsága az is, hogy ha pedig a végvonalon gyors támadással rést ütöttek vagy kikerülték,

\footnotetext{
${ }^{641}$ Szalay 1863. 9; Horváth 1871. 527-529.

${ }^{642}$ Engel-Kristó-Kubinyi 1998. 198.

${ }^{643}$ Corpus Juris Hungarici. Magyar Törvénytár. 1000-1526. évi törvényczikkek. Budapest, 1899. 281. A továbbiakban: CJH. Decreta Regni Hungariae. Gesetze und verordnungen Ungarns 1301-1457. Collectionem manuscriptam additamentis auxerunt, commentariis notisque illustraverunt Georgius Bónis, Franciscus Döry, Vera Bácskai. Budapest 1976. 288. A továbbiakban: Decreta 1976.

${ }^{644}$ CJH. 289; Decreta 1976. 292.
} 
akkor nemesi hadfelkelés összehívása és összegyülése elött a zsákmánnyal kivonulhattak az országból. A cikkely következő szakasza szerint csak, ha már nem képesek az ország védelmére, lehet összehívni az általános nemesi hadfelkelést (exercitus generalis, 4. §.). A nemesuraknak segítséget nyújtani a végeken tehát elviekben nem kötelessége, így egy vár felmentése sem, csak a szabályosan a király által kihirdetett nemesi felkelés keretében. Ez egy esetleges „felmentő sereg” összeállítását és elindulását is korlátozhatja. Ráadásul a törvény további szakasza a régi általános nemesi hadfelkelés vonatkozásában visszatért az 1222. évi Aranybullában szabályozott rendhez (1222. évi 7. cikkely), amely megkülönböztette az ország határain belüli és azon kívüli hadviselést. A nemesi hadfelkelö sereget az ország határain és szélein túl (ultra metas et confinia regni) nem viheti a király (3. §.). ${ }^{645}$ Pontosabban viheti, ha önkéntesen követik és fizet érte az uralkodó. Ehhez hozzátehetjük azt, hogy már Zsigmond is kísérletezett az Aranybullában lévő „ország határai” fogalmának kiterjesztő jogértelmezésével azért, hogy igénybe vehesse a hadfelkelő sereget többször is. 1433. évi honvédelmi szabályzatából legalább is ez a kérdés tünik elő (26. fejezet). ,mivel tudják jól sokan, hogy Szerbia vagy Rácország, Bolgária vagy Nagy-Oláhország és különösen a szörényi részek a magyar király és magyar korona alá tartoznak: Vajjon azoknak tekintik-e és akarják-e azoknak tartani eme -az országba bekebelezett- tartományokat? És azoknak határai értetnek-e magyar határok alatt? Mert ez igy volt és igy kell lennie: és akkor azt kéri ö felsége, hogy neveztessenek meg és állapittassanak meg az ország határoknak tekintendö végpontok, amelyekig, az elfoglalt területekért, az ország derékhada táborba szállni köteles, hogy ö felsége tisztában legyen azzal, vajjon az ország védelmére, vagy az elfoglalt területek visszafoglalására meddig menjenek?"'(Kőszeghy Sándor fordítása) ${ }^{646}$

Csak megjegyezzük, hogy az általános nemesi hadfelkelés esetén érvényesülhetett még az ún. osztozatlan testvérek korlátozott hadba vonulásának szokásjogi szabálya (,consuetudo regni ab antiquo”) is. Ez azt jelentette, hogy az osztályra bocsátás (divisio) elött álló testvérek (fratres indivisi) közül - akik még „egy kenyéren élnek” -, ha egy testvér már hadra kelt, akkor a többi már nem köteles hadba szállni. Ez az élethelyzet Losonci János szabolcsi ispán 1440. augusztus 8-án, Budán kelt oklevelében meg is jelent. $^{647}$

\footnotetext{
${ }^{645}$ CJH. 281. Decreta 1976. 287.

${ }^{646}$ Zsigmond szabályzat 1892. 601.

${ }^{647}$ DL 62284
} 
Harmadsorban a bizánci források többségének - Khalkokondülész, Névtelen bizánci krónika és hallgatólagosan Dukasz is - tanúsága szerint Szendrő erős vár volt és azt a szultán csupán a „tüzérségével” nem tudta elfoglalni. Egy erős falrendszerrel megépített vár - ostromra alkalmas nehéztüzérség hiányában - képes ellenállni a szultáni haderőnek.

Az első szempontra visszatérve a szultán az 1438-as erdélyi betörése alkalmával kihasználhatta a király távollétét, amelyet idézett török forrásaink kiemeltek: az akadálytalan pusztítást. Szendrő ostromakor azonban már nem, mert a király - az utolsó pillanatban, de - mégis az országban tartózkodott.

A második szempontunkból viszont a török már hasznot tudott húzni. A kétfokozatú mozgósítási rendszer rendkívül lassúnak bizonyult. A zsoldoskatonák arra elegendők voltak, hogy a végeken a kisebb-nagyobb betörésekkel szemben megvédjék a várakat, de egy szultáni haderővel nem vehették fel a harcot. Így amikor Murád hadseregével megjelent Szendrőnél, a király az általános nemesi hadfelkelést hirdette ki, és táborhelyként a Tisza alsó vidékét jelölte ki. A sereg még Szendrő eleste előtt összegyült, de létszámukat kevesellte az uralkodó és kénytelen volt kivárni a többbieket egész augusztusban, még Szegeden is időzött. Szeptember elején érkezett a titeli táborba, ahol fegyelmezetlenséget talált és seregét naponta hagyták el, amelyről forrásaink is említést tettek (Thuróczy 27. Bonfini 3. 4. 414., 1439. évi szeptember 17-i dekrétum). Azonban a seregből néhányan részt vettek a Szendrő körüli harcokban. Így hallunk a két Hunyadi Jánosról is, akik „,kiváló tetteket hajtottak végre." ${ }^{\circ 48}$ Végül az élelmezés hiánya és a vérhas járvány hatására szeptember 17-én kénytelen volt feloszlatni a megmaradt hadsereget, a szerencse az volt, hogy időközben II. Murád szultán Bosznia felé vonult. ${ }^{649}$

Egyedül a harmadik szempontunk az, amely az első kettőt kiiktathatta volna, mert Szendrő elfoglalásának egyedüli nehézségét várfalainak erőssége adta. Ez a tény ugyanakkor előrevetítette - Nándorfehérvár vonatkozásában - azt is, hogy egy túlerőben lévő szultáni támadás hasonló várral „blokkolható.” Egy jól kiépített erődnek ez is a fő feladata. Carl von Clausewitz (1780-1831) porosz tábornok alapvető megállapítása szerint, „Az olyan vár, mely az ellenséget ostromlásra kényszeríti s amely az ostromlást ki is állja, mindenesetre többet nyom a háború mérlegében, mint az olyan, amely ellenséges eröket le nem köt s nem emészt fel." ${ }^{650}$ Továbbá „a támadónak a vár körülzárolására...kétannyi

\footnotetext{
${ }^{648}$ Teke 1980. 96.

${ }^{649}$ Horváth 1871. 533-534.

${ }^{650}$ A háborúról. Clausewitz Károly tábornok hátrahagyott műve. Magyarra fordította és magyarázatokkal ellátta Báró Hazai Samu. (Második kiadás, Budapest 1917) Reprint: Veszprém 1999. 340. A továbbiakban: Clausewitz 1999.
} 
emberre van szüksége, mint a várörség létszáma." (Hazai Samu fordításai) ${ }^{651}$ Úgy is mondhatjuk, hogy a vár védelmének akkor van értelme, ha nagyobb eröt tud lekötni, mint védők ereje vagy remény van a felmentésére.

Végezetül Szendrő elestének fontos diplomáciai következményei is voltak, amelyekről csupán lengyel krónikásaink írtak, és amelyekre Dariusz Kołodziejczyk, a varsói egyetem professzora is felhívta a figyelmet. ${ }^{652}$ Dlugostól tudjuk azt is, hogy a török hírszerzés jól értesült és hogy 1439-ben a török szultán - egyúttal a lengyeleknek Alberttel való csehországi konfliktusát kihasználva - követséget menesztett a lengyel királyhoz, Ulászlóhoz Krakkóba egy magyarellenes szövetség létrehozására. Azt is mondhatjuk, hogy II. Murád megpróbálta diplomáciailag is elökészíteni Magyarország elleni támadását, elszigetelni az országot lehetséges szövetségesétől. „Murád, a törökök szultánja Ulászló lengyel királyhoz nemes követet küldött a leggazdagabb ajándékokkal. Elöször is a barátságát, békéjét és szövetségét óhajtotta elnyerni, azután felajánlotta minden jóindulatát, végül, mivel tudomására jutott, hogy ö Albert római és magyar királlyal háborút visel, kilátásba helyezte és megígérte, hogy öt pénzzel is 100000 katonával is támogatja. Ulászló király miután a követ nagyvonalúan szólott, elrendelte, hogy öt nála tartsák (vissza) addig, amíg meglátja, hogy Albert halálát követöen hogyan érnek véget a Magyar Királysággal folyó tárgyalások., ${ }^{653}$

Az itáliai származású lengyelországi humanista, Callimachus Experiensnél is szerepel ez a rendkívül fontos feladattal megbízott török követség. Callimachus leírása szerint felgyorsultak az események, mert előbb a magyar követség adta elő királyválasztó kérését.

Egyfajta diplomáciai „versenyfutás” indult meg a lengyel király szövetségéért. „Míg ezeket elöadták és kérték a magyarok, török követek keresték fel (t. i. a királyt) - e már korábban elküldött követeket már útközben érte Albert halála, amely valóban ismeretlen volt számukra vagy színlelték azt - és elöadták a rájuk bízottakat. Murád, a törökök császára katonát és pénzt igért Ulászlónak az Albert elleni, a Csehországban vívott háborúhoz, amely ország Zsigmond halála után két részre szakadt. Az egyik része Kázmérra, Ulászló testvérére bizta a királyságot, a másik rész a felesége öröksége révén, Albertet követte. (A szultán) szilárd szövetség kötését kérte, hogy az egész Csehország

${ }^{651}$ Clausewitz 1999. 363.

${ }^{652}$ Kołodziejczyk 2000. 100.

${ }^{653}$ Dlugos 2001. 210. „Turcorum cesar Amurathbek ad Wladislaum Polonie regem notabilem nuncium cum amplissimis donis transmittit, primumque suam amiciciam expetit et ligam atque fedus, deinde sua omnia ad beneplacitum suum offert; postremo quia audierat illum cum Alberto Romanorum et Hungarie rege bellum gerere, subvenire illi et pecuniis et centum millibus hominum exhibet et promittit. Wladislaus autem rex nuncio benigne appellato, illum retinere apud se constituit, donec videret, quem finem essent negocia Regni Hungarie, morte Alberti secuta, habitura." 
Kázmér hatalmában legyen, és hogy Ulászló tartózkodjon a magyarokkal való barátságtól és szövetségtöl. Így, mivel Albert halála után a dolog még nem dölt el, a követeket különféle ürügyekkel Krakkóban visszatartották arra várakozva, hogy a magyar események a király halála után merre fognak fordulni." 654

A hamarosan kialakuló belpolitikai állapotokat figyelembe véve, ha Nándorfehérvár már 1440-ben elesett volna, erre a pártokra szakadt Magyarországnak is nagy esélye lett volna. $^{655}$ A fiatal III. (Jagelló) Ulászló döntésén Magyarország sorsa múlott. Vagy elfogadja a törökkel való békekötést és kiszolgáltatja az országot a jövőbeli szultáni támadásnak vagy ellenáll. Óriási szerencsénkre ez utóbbit választotta. Nem lépett szövetségre a törökkel, Muráddal nem kötött békét, hanem - Dlugos szerint - ekkor értesülve a magyar rendek azon kéréséről, hogy őt megválasztanák magyar királynak, várakozó álláspontra helyezkedett.

${ }^{654}$ Philippus Callimachus: Historia de rege Vladislao. Edidit: Irmina Lichonska. Commentariis historicis illustravit: Thadeus Kowalewski. In linguam Polonam traduxit: Anna Komornicka. Varsoviae 1961. 28. 6-15. „Dum haec agerentur peterunturque ab Hungaris, aderant et Turci oratores, quos iam pridem missos deprehenderat in uia mors Alberti, qua seu uere incomperta seu ad tentandum dissimulata peregerant mandata. Offerebat per eam legationem Amoratus Turcorum imperator militem ac pecuniam Vladislao ad gerendum bellum contra Albertum in Boemia, quae mortuo Sigismundo in duas factiones abierat et una quidem Casimiro Vladislai fratri regnum deferebat, altera propter uxoriam successionem Albertum sequebatur. Ceterum foedus in id sanciri petebat, quod redacta uniuersa Boemia in potestatem Casimiri Vladislaus ab amicicia et foedere Hungarorum abstineret. Itaque cum defuncto Alberto res integra non esset, oratores per uarias simulationes Cracouiae retinebantur in expectationem, quo res Hungarica post regis mortem inclinaret." (A továbbiakban: Callimachus 1961)

${ }^{655}$ Sakcinski 1886. 97. 
„Írnak vala akkor ezernégyszáz és az negyven jó esztendöben, ifjú Albert király mikor regnál vala Magyarország földében,

az király meghala, felesége kedig megmaradna teröhben..."

(Nagybáncsai Mátyás, 1560)

\section{Az 1440-es ostrom belpolitikai háttere: a magyarországi belháború}

\section{1. A megérkezéstől a koronázásig: I. Ulászló}

Habsburg Albert király halála (1439. október 27.) ismételten nem várt politikai helyzetet teremtett. ${ }^{656} 1440$ tavaszára az ország a királyválasztás kérdésében Albert halála után két „pártra” szakadt, újabb alkalmat adva II. Murád szultánnak hódító hadjárata megismétléséhez (28. melléklet). A magyar nemesség a királynői uralmat nem fogadta el, inkább igyekeztek lehetséges és számukra is elfogadható férjet keresni az özvegy királyné számára. ${ }^{657}$

Branković György despota Erzsébetet támogatta, sőt dinasztikus tervei is voltak, mert Erzsébettel akarta összeházasítani nála maradt fiát, Branković Lázárt. Erzsébet azonban, katolikusként, elutasította, hogy pravoszlávval kössön házasságot. ${ }^{658}$ Erzsébet udvarhölgyének, Kottanner Jánosné Wolfram Ilona emlékiratai kortárs forrásként szolgálnak számunkra. ${ }^{659}$ Kottannerné szerint ezeket mondta: „Kedves urak, ne pogányt adjatok hozzám, inkább egy keresztény parasztot." ${ }^{, 660}$ Felmerült azonban a fiatal Ulászlóval való házasság is. „Ekkor László bán úr, ${ }^{661}$ az ő atyjafia azt kívánta, hogy a lengyel királyt válassza. Erre a magyar nemesurak mind felálltak, hogy ezt tegye, ö azonban ellenkezett, azt válaszolván, megvárja, mit ád neki az Isten, ahhoz igazodik majd, mert összes orvosai azt mondták neki, hogy fiút hordoz méhében...(Mollay Károly fordítása). ${ }^{662}$ A lengyel király mellett fontos érv szólt - akár a legitimitás elvével szembefordulva is -, a fenyegető oszmán-török veszéllyel való küzdelemre való alkalmassága (ideoneitas).

\footnotetext{
${ }^{656}$ Engel 1990. 349.

${ }^{657}$ Pálosfalvi Tamás: A Rozgonyiak és a polgárháború (1440-1444). Századok 2003/4. 902. A továbbiakban: Pálosfalvi 2003.

${ }^{658}$ Историја 2000. 250; Török történetírók I. Budapest 1893. 56, 130.

659 A korona elrablása. Kottanner Jánosné emlékirata 1439/1440. Fordította és közzéteszi Mollay Károly. Budapest 1978. A továbbiakban: Mollay 1978.

${ }^{660}$ Mollay 1978. 13.

${ }^{661}$ Garai László macsói bán

${ }^{662}$ Mollay 1978. 13.
} 
Az elökészületek erre meg is történtek, amelyet III. Ulászló március 8-án, Krakkóban kelt kiváltságlevele tanúsít. ${ }^{663}$ A magyar küldöttség már január 18-án útnak indult. ${ }^{664}$ Tagjai között találjuk Tallóci Matkó dalmát, horvát és szlavón bánt, Perényi János királyi tárnokmestert, Pálóci László királyi udvarmestert és Marcali Imre királyi étekfogómestert, somogyi ispánt. ${ }^{665}$ Ehhez csatlakozott márciusban még Rozgonyi Simon egri püspök is, akinek nagy szerepe volt a döntésével habozó Ulászló megnyerésében. ${ }^{666}$ A küldöttségben több horvátot is találunk. A zrednai Vitéz Jánoson és Tallóci Matkón túl, Ivan Gospodnetić knini püspököt, pápai legátust és a vitrovicai Marko Marcali-t. ${ }^{667}$

Ök Magyarország összes föpapjai, főurai és nemeseinek nevében királlyá választották Ulászlót, aki ezt el is fogadta. Az oklevél szerint a választásnak komoly feltételei voltak. Ulászlónak még a megkoronázása előtt feleségül kell vennie Erzsébet királynét, a házasság megkötését azonban elhalasztják a néhai Albert király halála utáni gyászév leteltéig (október 27-ig). Továbbá biztosítják Albert a felesége részére - a megélhetése érdekében tett intézkedéseinek megtartását. ${ }^{668}$ Ulászló a nemrég megszületett „Utószülött” Lászlót apai örökségében minden eszközzel megvédi. Söt, mint „,választott király”, ha fiú utód nélkül halna meg, „Utószülött” László számára a trónöröklés jogát köteles érintetlenül hagyni. ${ }^{669}$

Az oklevelet végül a jelenlévő lengyel egyháziak és előkelők ellátták pecsétjeikkel. A pecsétek fényképeit megvizsgálva az MNL adatbázisában számomra érdekes volt, hogy a fennmaradt tizenhat függőpecsét tulajdonosai között találtam azt a lengyel előkelő Lukácsot, Wgorka fiát, aki - Callimachus leírása szerint - később az ostromot folytató török szultánhoz küldött követek egyike lett (3. pecsét képe). ${ }^{670}$ Egy másik pecsétnek (6. pecsét képe) az MNL által közölt „Fancisci” körirata és az ötszirmü virágot ábrázoló címerképe pedig igen valószínü, hogy annak a Piotr Łęczyckinek a pecsétje lehet, akit Dlugos Petrus Lanciczki de Lankoschino-nak, a Névtelen lengyel levélíró pedig Petrus Lancziczsky-nek említ, és aki közlésük szerint szintén Ulászló szultáni követe volt 1440-

\footnotetext{
${ }^{663}$ DF-DL 39291

${ }^{664}$ Pálosfalvi 2003. 904.

${ }^{665}$ E névsort Dlugos krónikája is megerősíti. Dlugos 2001. 212, 400.

666 Pálosfalvi 2003. 904.

${ }^{667}$ Ivan Kukuljević Sakcinski: Priorat vranski. Vitezi Templari i Hospitalici St. Ivana u Hrvatskoi. Zagreb 1886. 96. A továbbiakban: Sakcinski 1886.

${ }^{668}$ Ezek a királyné számára adott birtokadományok jövedelmeit jelentették (a zólyomi vár, a zólyom megyei Végles, Lipcse, Sóskő, Dobronya és más várak birtoklása, továbbá Diósgyőr, Komárom, Óbuda, Körmöcbánya és a pénzverő kamarák jövedelmei, egész Szlavónia nyestbőradója)

669 „salvum succedendi jus remanere debet"

${ }^{670}$ Lásd a 8. 2. fejezetet.
} 
ben. ${ }^{671}$ Mindezek azt mutatják, hogy már Krakkóban ott voltak azok a lengyel királyi tisztviselők, akik Ulászlóval az országba érkezve, fontos diplomáciai feladatokat láttak el.

A magyar rendek közötti pillanatnyi egység nem érte meg a király gyászévének leteltét, előbb felbomlott. Az országba való érkezése előtt a lengyel királyhoz indított követségnek Matkó volt az egyik vezetője, bár tagja volt Vitéz János is. ${ }^{672}$ Miközben a visszaúton megpróbált megegyezést közvetíteni a királyné felé, Erzsébet a követségben lévő Matkót és bárótársát, Marcali Imrét váratlanul letartóztatta. Az ötlet pedig valószínüleg Cillei Ulriké, Hermann unokájáé lehetett. Egyúttal a királyné Cillei Frigyest, Hermann fiát nevezte ki szlavón bánná. ${ }^{673} \mathrm{Az}$ eseményekről további fontos részleteket tudhatunk meg Kottanner Jánosné Wolfram Ilona, az özvegy királyné bizalmasának emlékirataiból. „Miután mindez megvolt, és a nemes királyné megtudta, hogy Vajdafi Imre úr és Matkó bán úr visszajöttek a lengyel királytól, akkor önagysága derüsnek és nyíltnak tettette magát, persze csak annyira, amennyire özvegyhez illik. Ezt azért tette, hogy azt higgyék, hozzámegy a lengyel királyhoz, bár ez nem volt szándékában, csak azért, hogy megtudja tölük, milyen álláspontot foglalnak el természetes urukkal szemben. Amikor aztán az urak összejöttek, és tárgyalni akartak, akkor nagyságos úrnöm nem bocsátotta be öket a palotás házba, hanem kiment hozzájuk, és a ház elött beszélgetett velük. Miután ezt befejezte, önagysága megint bement. Ekkor figyelmeztették, ne menjen ki többet a házból, hogy hatalmaskodás áldozatául ne essen. Ezt meg is tette, bebocsátotta az urakat, de elöbb vitézeket engedett be, és a tárgyalást a házban tartották. Miután mindegyik elöadta a maga dolgát, és nagyságos úrnöm tudni akarta, mi az álláspontjuk természetes urukkal, László királlyal szemben, akkor kettejük közül az egyik, Matkó bán vagy Vajdafi Imre, így szólt: » Nagyságos úrnöm, ha tízéves volna is a fia, akkor sem ismernénk el urunknak, mert nem állhatna élünkre a törökök ellen. « Az volt a véleményük, hogy menjen feleségül a lengyel királyhoz. Ez nagyon elkeserítette a nemes királynét, mégsem mutatta, hanem tanácsot kért atyjafiától, Cillei Ulrik gróftól és más hüséges tanácsadóitól, hogyan viselkedjék. Ekkor azt tanácsolták neki, fogassa el a két nemesurat, mármint Matkó bánt és Vajdafi Imrét." (Mollay Károly fordítása.) ${ }^{674}$

${ }^{671}$ A feltételezésemet az is támogatja, hogy Piotr Łęczyckiről tudjuk, hogy címere egy virág, a Rola volt. Krzyżaniakowa 1979. 142. Lásd: „qui insigni Rola utebatur” Dlugos 2001. 410 (186. lábjegyzet). A botanikai irodalomban találtam olyan növényt, amely latin nevében őrizheti e nevet. A Körtikék nemzetségét. A Kereklevelü körtike (Pyrola rotundifola) és a Kis körtike (Pyrola minor) egyaránt szóba jöhet címernövényként. Mindkettőnek öt tagú virága van, hasonlóan a pecsét lévő, pajzson ábrázolt, ötszirmú virághoz.

672 Pálosfalvi 2000. 53.

673 Pálosfalvi 2000. 49-50.

${ }^{674}$ Mollay 1978. 40-41. 
Kottannerné emlékirataiból tudjuk azt is, hogy Tallóci Matkót és Marczali Imrét először Komáromban tartották fogva, majd a királyné később Matkót Sopronba küldette át, ahol Seres Tamás, magyar nótárius házában őrizték. Sopron városa biztonságosabbnak tünt, mert ekkor Cillei Ulrik grófé volt. ${ }^{675}$

A letartóztatás tényét Rozgonyi István pozsonyi ispán április 4-én, a pozsonyiakhoz írott leveléből is megtudhatjuk. ${ }^{676}$ „A mi királynőnk megparancsolta, hogy azokat a bárókat, akik... követségben visszatértek, mindenüktöl fosszák meg, és őket éppen most letartóztatta, a letartóztatottakat egészen mostanáig a legsúlyosabb bilincsekben tartja.” A hír gyorsan eljutott Erdélybe is. Hadadi Jakcs László április 10-én pedig levélben értesíti a dési sókamaraispánt is, hogy a királyné elfogatta Tallóci Matkót, így a sókamarák is veszélyben vannak, a sót át kell menteni a folyón Udvarhelybe. ${ }^{677}$

Amilyen rövid volt Frigyes szlavón bánsága, olyan rövid volt Matkó fogsága, mert Garai László macsói bán által Siklóson, május 3-án keltezett oklevél arról számol be Bátmonostori Töttös Lászlónak, hogy Tallóci Matkó bán már kiszabadult fogságából. ${ }^{678} \mathrm{~A}$ körülményekről többet nem írt, Matkót nem ő szabadította ki. A borbélya és a foglára segítségével szökhetett meg. ${ }^{679}$ Nem derül ki Garainak az ügyben való érdekeltsége sem, pedig - mint láttuk - Matkó feleségéhez, Lévai Cseh Margit úrnőhöz - meghalt testvére, ifjabb Garai Miklós révén - még rokoni szálak is füzték. Matkó tehát, amikor a török már ostrom alatt tartotta Nándorfehérvárt, Erzsébet királyné fogságában volt. Marcali Imre szabadon engedése érdekében viszont a macsói bán a királynéhoz küldöttséget indított. Garai azt is megjegyzi, hogy „Azt is tessék tudomásul venni, hogy Mathkó bán és Kórógyi János a rajtuk elkövetett számos igazságtalanság megtorlása czéljából nagy zavart készülnek elöidézni az országnak" (Wertner Mór fordítása). ${ }^{60}$

Ám - miközben a lengyelországi követség többsége még Krakkóban tartózkodott és a déli határon Nándorfehérvár körülzárása és ostroma már megkezdődött - az özvegy királyné, és hívei pünkösd napján, május 15-én, a 12 hetes csecsemő Utószülött Lászlót, $V$. László néven (1440-1457) megkoronázták. A koronázás szabályszerü volt, bár a Szent

\footnotetext{
${ }^{675}$ Mollay 1978. 42, 46, 95.

${ }^{676}$ Idézi: Pálosfalvi 2000. 50. (a 22. lbj-ben, DF. 23 9755) „domina nostra regina barones illos, qui ... in legationibus sunt reversi, omnino iussit spoliari demumque fecit detinere, quos et detentos pro presenti gravissimis suis tenet in vinculis."

${ }^{677}$ DL 55202

${ }^{678}$ A Zichy és Vásonkeői Gróf Zichy-család idősb ágának okmánytára. IX. kötet, szerk. Kammerer Ernő. Budapest 1899. 9-10. (9. sz. okl). (A továbbiakban: Zichy 1899) DF 80718

${ }^{679}$ Sakcinski 1886. 96. (Cronica der grafen von Cilli)

${ }^{680}$ Wertner 1911. 553.
} 
Koronát Erzsébet Kottanner Jánosné Wolfram Ilonával ellopatta, aki ezt meg is örökítette emlékiratában.

Május 15-e, a gyermek V. László megkoronázása után Garai május 24-én írt levelében már arról tudósít, hogy ők a két király közötti megegyezésen munkálkodnak. Semmi nem tartja vissza attól, hogy ,május 30-án a lengyel királyhoz utazzunk, hogy közte és a királyné között az ország békéje érdekében barátságos megállapodást hozzunk létre és öt rábírjuk, hogy Magyarország nyugalmát ne veszélyeztesse" (Wertner Mór fordítása). ${ }^{681}$ Ebből a megfogalmazásból azonban inkább Ulászló lebeszélése sejlik fel.

A szultáni török sereg már feltételezhetően 3 hónapja Nándorfehérvárnál volt, de a rendek által a trónra időközben meghívott Jagelló Ulászló még nem volt az országban. Április 25-én még Krakkóban adott ki oklevelet Lubló városi kiváltságainak kibővítéséről. ${ }^{682}$ Április 27 -én már a szepes megyei Késmárkon. ${ }^{683}$ Azonban Budát kellett most már elfoglalnia.

E hónapok sűrü eseményeiről igen részletesen számol be egy 1440 júniusában, Budáról küldött, magánlevél, amelynek nándorfehérvári vonatkozására John Jefferson hívta fel a figyelmet. ${ }^{684}$ Ő a szerzőjét ismeretlennek tudja. Meg kell azonban említenünk, hogy 1891ben a levelet kiadó Lewicki csak feltételezte, az 2001-es Dlugos kiadás kommentárja pedig az ismert történetíró, Dlugos levelének tartja, amelyet Budáról küldött. ${ }^{685}$ Ebben állást nem foglalva a továbbiakban névtelen lengyel levélíróként említem a szerzőt. Levelében nemcsak az ekkor ostromlott Nándorfehérvárról ír, hanem az oklevelek tárgyias stílusán túl, közvetlen személyes élményként mutatja be a király Magyarországra érkezését, a kezdődő polgárháborút, annak dilemmáit, a török elleni küzdelem emiatti nehézségeit is. A nándorfehérvári ostrom belpolitikai hátterének alakulását szinte magunk előtt láthatjuk és mindenhez saját megjegyzést füz. Ezért e levelet részletesebben ismertetem.

A levél írója Ulászló királlyal érkezett a magyar földre, írásának stílusából érezhető, hogy müvelt személy lehetett. Kiemelte Rozgonyi Simon egri püspök megérkezését, aki „sokak remegő lelkét megerősítette.”686 A király kíséretéből megemlítette a krakkói érseket, Sbigneus-t és (Sandivogius) Ostrorog poznani palatinus-t. A király és serege Késmárkból Eperjesre („Aperiasch opidum”) vonult, azonban Kassa („Coschicze”) városa

\footnotetext{
${ }^{681}$ Wertner 1911. 554. DF 80719

682 DF-DL 5107

${ }^{683}$ DF-DL 13539

${ }^{684}$ Jefferson 2012. 240. (20. lábjegyzet); Monumenta Medii Aevi Historica Res gestas Poloniae Illustrantia. Tomus XII. Codex Epistolaris saeculi decimi quinti. 1382-1445. Tomus II. Collectus opera Dr. Anatolii Lewicki. Krakowie 1891. 416-421. (275 sz. levél) A továbbiakban: Lewicki 1891.

${ }^{685}$ Dlugos 2001. 410. (186. lábjegyzet)

${ }^{686}$ Lewicki 1891. 417, 21-22.
} 
a kapukat bezárta elöttük, így más utat keresve május 15-én, pünkösdvasárnapra (,ad festum pentescostes”) értek Egerbe (,, in Agriam”). ${ }^{687}$

Mihelyt Rozgonyi Simon kapott 500 lovast a lengyelekből, és ugyanennyit a magyarok közül, nyomban Budára vonult, minden kaput és falat őrökkel megerősített. „Ha ő gyorsan nem ment volna, sohasem jutott volna a mi kezünkbe (a város). Mert a királyné, amint meghallotta, hogy a királyunk nagy erövel vonul, nagy sereget küldött Budára a város elfoglalására... ezer katonával Budáról, nagy félelemmel visszavonult. Közülünk sokan üldözték öket és azokból némelyeket, mégis csak keveset fogtak el...."688 A levélíró további szavait érdemes összevetni Rozgonyiak tevékenységéről szóló, 1440-ből való, királyi oklevelekkel is. Ulászló 1440. október 28-án, Budán kelt oklevele szerint Rozgonyi - mint Ulászló főkancellárja - nagyszámú kíséretével a király elé ment egészen a Szepességig, és több más báróval a királyt Budáig kísérte. A példájával Ulászló oldalára sok más országnagyot is átállított. Jutalmul a királytól a királyné oldalára állt és a hűtlenség vétkébe esett Branković György despota budai kőházát, az Olaszok utcájában, adományul kapta meg. ${ }^{689}$

„...Amíg mi Egerben idöztünk, elérkezett hozzánk a hír, hogy Erzsébetnek, Magyarország királynéjának a fiát, a két vagy három hónapos csecsemőt az esztergomi érsek, ${ }^{690}$ egyetértésben a veszprémi ${ }^{691}$ és györi püspökökkel, ${ }^{692}$ és Magyarország nem kevés, más bárójával egyetemben Székesfehérváron megkoronázta." "993 Ez olyan megdöbbenést okozott, hogy a levélíró szerint elöször nem akarták elhinni, gyanakodtak. „még meg is szidtuk az esztergomi érseket, hogy mivel ö a dekrétumok doktora, ilyen szokatlan dolgot a nép és a bárók egyetértése nélkül nem köteles tenni." ${ }^{694}$ Végül „...mint egy második Ílion-ba, megérkeztünk Buda városába és várába..."695

\footnotetext{
${ }^{687}$ Lewicki 1891. 417, 22-31. 1440-ben a pünkösdvasárnap május 15-ére esett. Szentpétery 1985. 142.

${ }^{688}$ Lewicki 1891. 417, 34-39.,...nisi celeriter venisset, nunquam ad manus nostras devenisset. Regina autem Hungarie audito, quia rex noster cum magna potencia vadit, magnum exercitum in Budam miserat ad occupandum civitatem...uno miliari a Buda cum magno timore reversi sunt: plures nostri eos insecuti sunt et aliquos ex eis, paucos tamen, captivaverunt."

${ }^{689}$ DL 13588

690 Szécsi Dénes

${ }^{691}$ Gathalóczi Mátyás, aki a királyné kancellárja is.

${ }^{692}$ Benedek györi püspök

${ }^{693}$ Lewicki 1891. 417, 40-418, 1. „Nos dum infra dies festos pentecostes in Agria moraremur, novitas nobis allata est, quod regina Hungarie Elizabeth filium suum, infantem etatis duorum aut trium mensium, per archiepiscopum Strigoniensem, consencientibus Wesperimensi et Iauriensi episcopis et nonnullis aliis baronibus Hungarie, paucis tamen, in Alba regali coronaverit."

${ }^{694}$ Lewicki 1891. 418, 5-7. „...arguebamus quoque archiepiscopum Strigoniensem, cum sit decretorum doctor, absque plebis et baronum consensu non debere facere talem novitatem."

${ }^{695}$ Lewicki 1891. 418, 11-12.,,...civitatem Budam, deinde castrum, alterum Ilion, intravimus."
} 
Az 1440. november 4-i oklevél sokkal bővebben egészíti ki a névtelen levélíró fenti beszámolóját. Simon püspök, Ulászlót Eger várában hagyta, ő maga pedig előrement Budára, hogy előkészítse a király útját és biztossá tegye Buda várát és városát, nehogy a város szomszédságában tartózkodó Erzsébet-féle német csapatok azt elfoglalják. Miután a várat és a várost teljesen biztosította, visszatért Egerbe, ahonnan a királyt békében vezette be Budára. ${ }^{696}$ Hédervári Lőrinc nádor habozott a város kapuit megnyitni előttük és a német csapatok is veszélyt jelentettek Ulászló számára. Kottannerné is megemlíti, hogy „amikor a király Buda fóvároshoz érkezett, a városbéliek nem akarták beereszteni. Akkor a nádor a váron át eresztette be." (Mollay Károly fordítása) ${ }^{697}$

Mindezt jól mutatta, hogy Ulászló már május 19.-én Pesten volt, de Budára csak 22-én tudott bevonulni. Ebben - Pálosfalvi szerint - nagy szerepe lehetett a nádor rokonának, Rozgonyi Simon egri püspöknek is. ${ }^{698}$ Ide érkeztek azok a bárók és főurak, akik Ulászló mellé álltak. Dlugos szerint elsőként Tallóci Matkó bán, aki „nemrég szabadult ki Erzsébet királyné bilincseiböl és fogságából, Sopron városából". ${ }^{699}$

A királyné, miután Komáromot is elfoglalták, a fiával együtt Győrbe menekült és követeket küldött a királyhoz azt kérve, hogy „öt és fiát Magyarország kormányzásában ne akadályozza” ${ }^{700}$ Ulászló a város ostromára sereget gyüjtött. A névtelen levélíró értesülése szerint lengyel sereget Johannes Czapek és Derslaus Wlotowsky vezette, a magyar sereg kapitánya pedig pedig az egri püspök lett. Győr városát ugyan bekerítették, de amikor a királyné meghallotta a sereg érkezését, Pozsonyba menekült és „,egészen mostanáig ott van.",701

Erzsébet királynénak - még Győrben - arra is volt figyelme, hogy bosszút álljon, ha Tallóci Matkón már nem, akkor legalább a segítőjén! Mert május 27-én, itt kiadott oklevelében Seres János fia Tamás soproni polgárt hütlenség vétkében elmarasztalta és összes vagyonát és házát Cillei Ulrik kancellárjának adományozta. Ugyanis Tallóci Matkót megszöktette a királyné fogságából. ${ }^{702}$ Seres Tamás sokáig volt még üldöztetésben, mert

\footnotetext{
${ }^{696}$ DL 13589.

${ }^{697}$ Mollay 1978. 56.

${ }^{698}$ Pálosfalvi 2003. 906.

699 „....in primis Mathko de Thaloncz Sclavonie banus, qui recenter ex vinculis et captivitate regine Elizabeth ex opido Soffronio, in quo tenebatur vinctus, subsidio unius barbitonsoris sui effugerat." Dlugos 2001. 231, 27-232, 2.

${ }^{700}$ Lewicki 1891. 418, 18-19. ,...ne eam et filium eius in regimine regni Hungarie inpediret."

${ }^{701}$ Lewicki 1891. 418, 37-41. „...ibi hactenus inmoratur.” 1440. június közepe körül.

${ }^{702}$ Sopron szabad királyi város története. I. rész, 3. kötet. Oklevelek és levelek 1430-tól 1452-ig. Közli vitéz Házi Jenő dr. Sopron 1924. 197, 8-198, 1. (237. sz. okl) DL 1061. „...propter notam infidelitatis, quam idem Thomas nuper in educcione Mathkonis de Talloucz notorii nostri infideli de maiestatis nostre captivitate per ipsum studiose facta, incurrisse dinoscitur..." (A továbbiakban Házi 1924)
} 
Hunyadi János kormányzósága alatt, 1451. augusztus 3-án egy jóakararója levélben kéri a soproni polgárok sorába való visszafogadását és bűnének megbocsátását. ${ }^{703}$

A győri várban a királyné távozása után Cillei Ulrik maradt igen sok német és cseh katonával. Cillei maga a Dunán át titokban elmenekült a várból és a sürü erdőn át Pozsony felé ment, de elfogták őt és övéit. ${ }^{704}$ „Azon nyomban, királyi felség hatalmánál fogva Matkó urat küldték el, hogy öt ebbe a városba kétezer katonával beszoritsa." ${ }^{, 705}$ Dlugos is hasonlóan írt Cillei menekülési kísérletéről: „A várból alattomban eltávozott kevés emberével és a Rába-folyón át, amely a várhoz közel van, átkelt Pozsony felé Erzsébet királynéhoz..."706

Ulászló június második hetében támadást indított Győr városa ellen, mert az Erzsébet királynénak májusban menedéket adott. Ulászló a város ostromára sereget gyüjtött. Ebbéli szándékában a korona visszaszerzése is benne lehetett. ${ }^{707}$ Horváth Richárd szerint a királyi seregeket Rozgonyi Sebestyén és Nánai Kompolt Pál vezették. ${ }^{708}$ A várost nem foglalták el, de június 19-én ${ }^{709}$ Erzsébet hívét, Cillei Ulrikot a király emberei fogságba ejtették, amint erről Dlugos is beszámolt. ${ }^{710}$ De a névtelen levélíró is tanúskodik, bár pontos dátum nélkül.

A királyi sereg a vár ostromától elállt és megállapodást kötöttek. Itt érkezünk el a levél megírásának idejére, mert „...ide a mai napon magával hozta Cillei ispánt sok más nemes és híres katonával."711 Tallóci Matkónak az egykori letartóztatását sugalmazó Cillei Ulrik Budára hozatala nagy örömére szolgálhatott. Az 1440. november 4-i oklevél elfogóként nem Tallócit, hanem Rozgonyi Simont említi meg. Győr alatt foglyul ejtette a német és cseh hadak kapitányát, Cillei Ulrikot, akit mint foglyot a király kezeibe adott át. ${ }^{712} \mathrm{~A}$

${ }^{703}$ Házi 1924. 327-328. (385. sz. okl) DL 1213. Suseki Zrinyi Hengnig levele Sopron város közönségéhez (részlet). „Elért hozzám (a hir), hogy az én odaadó hivemet, Seres Tamást rosszindulat és kegyvesztés érte Matkó bán miatt...nyomatékosan kérem Önt, mint különösen kedves barátom és jóakaróm, hogy Ön neki bocsássa meg bünét és legyen kegyes hozzá és fogadja be maguk közé mint szolgáját és polgártársát és barátját, ahogyan ö azelött is Önök között volt.” (dr. Bugner István fordítása) Lásd még: Mollay 1978. 95-96. Marcali Imrét tovább örizték Fraknó várában.

${ }^{704}$ Lewicki 1891. 418, 42-419, 5. ,per aquam Danubii clam abscessit de castro et per condensa nemora ibat versus Presburg...

${ }^{705}$ Lewicki 1891. 419, 6-7. „,...missus extimplo fuit per regiam maiestatem ad conducendum eum in hanc urbem dominus Mathko cum duobus milibus hominum..."

706, „...clam de castro cum paucis recedit et per fluvium Raba, qui castro vicinus est, transgressus, versus Possonium ad Elizabeth reginam..." Dlugos 2001. 233, 10-12.

${ }^{707}$ Pálosfalvi 2003. 908.

${ }^{708}$ Horváth Richárd: Győr megye hatóságának oklevelei 1328-1525. Győr 2005. 21. (Horváth 2005)

709 „...ferie secunda in die sanctorum Gervasii et Prothasii...” Dlugos 2001. 233, 27-28; 409. (156. lábjegyzet)

${ }^{710}$ Dlugos 2001. 233; Jefferson 2012. 177.

${ }^{711}$ Lewicki 1891. 419, 9-10. „....in locum huc die hodierna ipsum comitem Cilie cum pluribus aliis militibus notabilibus secum captis adduxit..."

${ }^{712}$ DL 13589. 
névtelen levélíró ezt annyiban megerősíti, hogy szerinte is Cilleit az egri püspök vett örizetbe. ${ }^{713}$

Az 1440. november 19-i királyi oklevélböl megtudjuk Simon testvérének, Rozgonyi István pozsonyi ispán szerepét is. Mindvégig testvére mellett harcolt és felmentette Pozsony várát, amelyet a németek és csehek ostromoltak. Már az élelem fogytán volt. István comes áttörte Erzsébet királyné seregének ostromgyürüjét, bejutott a várba és azt ellátta élelemmel - a várban maradt feleségét és gyermekeit is - és megerősítette újabb hadi néppel s így az ellenséggel szemben megvédelmezte. ${ }^{714}$ Erzsébet királyné ezt látva néhány napi fegyverszünetet hozott létre, mialatt egymást kölcsönös jóindulatukról biztosították és ígéretekkel látták el. ${ }^{715}$

$\mathrm{Az}$ is kiderül a névtelen író leveléből, hogy még Ulászló megkoronázása előtt vagyunk, mert „Jó reménnyel vagyunk aziránt, hogy a korona, amely a királyné kezében volt, majd a miénk lesz és az a sok vár is, amelyeket Magyarországon ugyanez az ispán birtokol."716

Eközben Budán a koronázás előtt országgyülést hívtak össze. „A fópapoknak és báróknak nagy sokasága néhány napon belül ide összegyülik. Az esztergomi érsek, aki azt a gyermeket megkoronázta, már megérkezett, a kalocsai érsek és ... mások is, akiknek a címeit nem tudom, és minden báró, kivéve László bánt, aki a legközelebbi feria quintá-n (csütörtökön ${ }^{717}$ ) biztosan meg fog jönni. Amiatt az aggodalma miatt, hogy a koronát elvesztette, ${ }^{718}$ abban az idöben nem is mert eljönni. ${ }^{719}$ Dlugostól is tudjuk, hogy Garaira sokan haragudtak, mert miatta nem tudtak a Szent Koronával koronázni. „Keserüség és lelki gyötrődés sokakat keritett a hatalmába, egyesek józan szavakkal, mások pedig méltatlanokkal, megint mások pedig dühvel illették Garai László bánt amiatt, hogy Visegrád várából, ahol a koronát örizték...azt mintegy az ö tudtával és rábeszélésére vitték

\footnotetext{
${ }^{713}$ Lewicki 1891. 419, 14-15. „Episcopus Agriensis ...dicti comitis habet custodiam.”

${ }^{714}$ DL 13588

${ }^{715}$ DL 13594

${ }^{716}$ Lewicki 1891. 419, 11-13. „Spem bonam habemus, quod et coronam, que erat in regine manibus, habebimus et multa castra, que in regno Hungarie idem comes obtinebat."

${ }^{717}$ Ha június 19-ét vesszük alapul, akkor ez a nap június 23.-a lenne. Szentpétery 1985. 143.

${ }^{718}$ Mert Dlugos szerint Visegrád várát, ahol a Szent Koronát örizték - amikor a királyné azt ellopatta - Garai László bán őrizte. „Castrum autem Visschegrod, quod tunc per Ladislaum banum tenebatur...” Dlugos 2001. 225, 11-12.

${ }^{719}$ Lewicki 1891. 419, 18-23.,Magna multitudo prelatorum et baronum infra paucos dies huc confluxit; iam enim advenit hic Strigoniensis archiepiscopus, qui illum infantem coronaverat, archiepiscopus Colocensis...et plures alii, quorum titulo ignoro, episcopi, barones fere omnes, Ladislao bano excepto, qui feria quinta de certo venturus est; is propter metum, quem habuit de corone ammissione, tanto tempore venire non audebat."
} 
el." ${ }^{, 720}$ Amikor pedig megérkezett Budára: „Mindenki egyetértésével és határozatával Garai Lászlót elfogták, akinek örzésével Rozgonyi Simont, Lörinc nádort és Nikolaus Fristaczki-t bizták meg."721 A macsói bánt július második hetében engedték csak ki a fogságából. ${ }^{722}$

A leendő király egy hónapos haladékot adott a báróknak, hogy csatlakoznak-e hozzá. Ulászló június 15-én már Budáról írt az országnagyokkal, többek között Tallóci Matkó dalmát-horvát-szlavón bánnal és Tallóci Frank volt szörényi bánnal együtt. Az oklevél királyi menlevélben biztosított teljes sértetlenséget személyükre és vagyonukra nézve az összes főnemesnek, nemesnek és kíséretének 30 napig, amennyiben Ulászló választott királlyal tárgyalni szeretnének. ${ }^{723}$

A rendek Budán - Dlugos szerint - június 29-én, Péter és Pál apostolok napján ${ }^{724}$ megerősítették Ulászló királlyá választását és érvénytelenítették V. Lászlóét. ${ }^{725}$ Országgyülést tartottak (június 29 - július 14.). ${ }^{726}$ Dlugos krónikájában közli az országgyülés főbb rendelkezéseit is. ${ }^{727}$

A névtelen levélíró az összehívott országgyüléstől a belső problémák megoldását várja. Jól érezhető, hogy él benne a remény, hogy a lengyel uralkodót a magyar nép elfogadja és a török elleni harcában - akár élete árán is - segíti. Egy fontos gondolata figyelmet érdemel. Felismerte a belpolitikai megosztottság külpolitikai veszélyét, azaz, a Magyar Királyság saját szerencsétlenségei, a polgárháborús eseményei nehogy segítsék a törököket az ország elleni támadásukban.

„Reméljük, hogy az ilyen gyülés (t. i. országgyülés) után minden a legjobbra fordul majd. Hiszen a mi királyunk a közösségnek olyannyira becses, hogy valamennyien elöbb meghalnának, mintsem öt dolgavégezetlenül engednék innen visszatérni. Ugyanis olyan ez a nép, hogy - ha a jó lelkülete vele van és büneink nem akadályozzák - elég erösnek vélhetö a törökökkel szembeni ellenállásra. Ám mivel ebben az országban nagy gonosztetteket és mindenféle szörnyü zsarnokságban gyökerezö dolgokat látok, maguk a barbárok - hogy Szent Jeromos szavaival éljek - a mi hibáink miatt erösek és a mi büneink

720 „Multos amaritudo et animi passio occupat, alii modestis verbis, alii indignacione, alii furore contra Ladislaum banum de Gara, castri Wisschegrad, in quo corona servabatur...quasi eo conscio et suasiore corona ablata sit..." Dlugos 2001. 238, 15-18.

721 „Omnium consensu et decreto Ladislaus de Gara capitur, cuius custodia Simoni Agriensi episcopo, Laurencio palatino et Nicolao Fristaczki mandatur." Dlugos 2001. 238, 23-24.

722 „Secunda mensis Iulii bano Ladislao de captivitate relaxato...” Dlugos 2001. 239, 20.

${ }^{723}$ DF-DL 15554

724, ,..feria quarta in die sanctorum Petri et Pauli apostolorum...”Dlugos 2001. 235, 1.

725 Pálosfalvi 2003. 908.

${ }^{726}$ Mollay 1978. 100. (49. lábjegyzet)

${ }^{727}$ Dlugos 2001, 244-248. 
miatt kényszerül harcra a római, helyesebben szólva a magyar hadsereg. Mégsem tudom, hogy a mi Istenünk mely kegyessége és kimondhatatlan rendelkezése által történt az, hogy amikor ezekben a napokban a törökök hatalmas serege a Magyar Királyság legerösebb várát, Ná[n]dorvárt, másnéven Fehérvárt ostromolta és minden emberi találmányt, annak ostromához felhasznált...,728

A levélíró ennek során tér át Nándorfehérvár ekkori oszmán-török ostromára, amely számára jelen idejü „ezekben a napokban” történik. A forrás emiatt páratlan, belső látószögből tudósít bennünket. A törökök nagy sereggel fogtak hozzá az ostromhoz, de az esemény ténye az ország fölötti Isteni gondviselésben kissé elbizonytalanította, mert nem látta a kimenetelét. $^{729}$

A névtelen levélírónak azonban lehetett oka a bizakodásra is, mert Ulászló június 17-én Nándorfehérvár ostromának megsegítése érdekében a Szepes megyei Szomolnokbánya polgáraihoz - a szabad királyi városokhoz hasonlóan - fordult pénzbeli segítségért. ${ }^{730}$ Több királyi oklevélről Nándorfehérvár védelmével kapcsolatosan nincs tudomásunk. Ulászló július 15-én kelt okleveléből értesülünk a budai várban lévő kincsekről, amelyeket Albert egykori királyi kincstartója a volt nándorfehérvári kapitány, Bátmonostori Töttös László adott át számára. ${ }^{731}$

Július 17-én, Szent Alexiosz napján, ${ }^{732}$ Székesfehérváron a lengyel III. (Jagelló) Ulászlót Szécsi Dénes kardinális, esztergomi érsek koronázta meg magyar királlyá I. Ulászló néven (1440-1444) a Szent Korona nélkül. A koronázásról beszámoló Dlugos szerint abban a Szent Péter és Pál templomban, ahol állítólag Géza fejedelem és felesége volt eltemetve. $^{733}$

\footnotetext{
${ }^{728}$ Lewicki 1891. 419, 23-34. „Speramus, quod ex huiusmodi congregatione finis omnium rerum optimus sequetur; in tantum enim rex noster communitati carus est, ut omnes desiderent prius mori, antequam eum dehinc vacuum permitterent redire. Tantus enim est hic populus, ut ad resistendum Turcis, si bona mens adesset et nostra scelera non impedirent, sufficere eum arbitrarer; verum cum in regno hoc magna video facinora et omnia posita in quadam sevissima tyrranide, barbari ipsi, ut verbo beatissimi Ieronimi utar, viis nostris fortes sunt et sceleribus nostris ipsis Romanus aut verius Hungarorum impugnatur exercitus. Nescio tamen, qua dei nostri clemencia et ineffabili dispositione actum est, ut cum hiis diebus magnus Turcorum exercitus castrum fortissimum regni Hungarie Naderwara alias Album Castrum obsedisset et omnia humana ingenia ad illud expugnandum adhibuisset..."

${ }^{729}$ Az ostrom epizódjáról szóló leírást a források között tárgyalom.

${ }^{730}$ DF-DL 13555

${ }^{731}$ Zichy 1899. 15. (16. sz. okl)

732 „Die Dominico sancti Alexii...” Dlugos 2001. 241, 12.

733 Dlugos 2001. 242, 15-16. A kérdés legújabb, átfogó vizsgálatát lásd: Szöcs Tibor: Nagyfejedelmeink temetkezési helyei az írott források tükrében. Belvedere Meridionale 2009/ 1-2. 26. (Szöcs 2009b)
} 
Az 1440. évi október 28-i oklevél szerint a koronázás is elsősorban Rozgonyi Simon püspök fáradozásának volt az eredménye, amely után a püspök továbbra is a király szolgálatában maradt. ${ }^{734}$

Ezen a koronázáson részt vettek Bosznia követei is. II. Tvrtko boszniai király megújította török ellenes szövetségét a magyar királlyal, és Ulászló mellé állt. ${ }^{735} \mathrm{~A}$ megkoronázott király július 20-án, Székesfehérváron adott ki privilégium levelet. ${ }^{736}$

Ugyanakkor szeptember 10-én Raguza városa is üdvözölte Ulászló királyt megkoronázása alkalmából és biztosította további hüségét az ország Szent Koronája iránt. ${ }^{737}$ A Raguzával való kapcsolatot minden bizonnyal Ulászló idejében is a Tallóciak intézhették. 1439. június 6-án Albert király is Tallóci Matkó bánt utasította, hogy a várost védje meg a boszniai István vajda (Stefan Vukčić) támadásaitól. ${ }^{738} \mathrm{~A}$ gyakorlat régebbi hagyományt követ. Amint azt Juhász Ágnes tanulmányában kimutatta, a raguzai ügyeket már I. Lajos király a dalmát bán közvetítésével intézte. ${ }^{739}$ Így 1439-ben Tallóci Matkó mint dalmát bán járt el hasonlóképpen.

I. Ulászló király Brankovićot pártütőnek nyilvánította, mivel az a kis V. Lászlót támogatta és elvette magyarországi birtokainak egy részét, $\mathrm{s}$ azokat saját híveinek adományozta. Antonio Bonfini szerint ekkor a despota, „minden vagyonával együtt Raguzába húzódott... Azt beszélik, hogy ötször százezer aranyat helyezett el a raguzai kincstárba, hogy ott biztonságban örizzék." (Kulcsár Péter fordítása) $)^{740}$

A szerb szakirodalomban azt találjuk, hogy ekkor Branković a feleségével és száz lovassal 1440 májusának végén Cillei birtokáról elhagyta az országot. Raguzába ment, ahol 1426 óta nem járt. Négy hónapot maradt itt, a következő évben Szerbiába, Zétába távozott. A zétai főnemesek azonban ellenségei maradtak, sőt a boszniai Stefan Vukčić kihasználta Branković ingatag helyzetét, valamint Tallóci Matkó bán távollétét és elfoglalta Omist, valamint poljicai területeket. A törökök elleni harcra tehát Branković sem vállalkozott. $^{741}$

\footnotetext{
${ }^{734}$ DL 13588

${ }^{735}$ Angyal Dávid: Bosznia követei és a budai országgyülés 1440 júniusában. Századok (1911) 1. 50. (Angyal 1911)

${ }^{736}$ DF-DL 13894

${ }^{737}$ Raguza és Magyarország összeköttetéseinek oklevéltára. Összeállította: Gelcich József, bevezetéssel és jegyzetekkel ellátta Thallóczy Lajos. Budapest 1887. 430-431. (260. sz. okl) A továbbiakban: Raguzai oklevéltár 1887.

${ }^{738}$ Raguzai oklevéltár 1887. 428. (258. sz. okl)

739 Juhász Ágnes: A magyar diplomácia a raguzai-cattarói háborúban (1361-1362). In.: Középkortörténeti tanulmányok 7. Szerk.: Kiss P. Attila, Piti Ferenc, Szabados György. Szeged 2012. 479. (Juhász 2012)

${ }^{740}$ Bonfini 1995. 596, 11-12, 14-15.

${ }^{741}$ Историја 2000. 251; Јиречек 1952. 363-364.
} 
Sőt, a török vazallitás szorító tudatában erre nem is vállalkozhatott. Erre több oka is lehetett. Egyrészt nemrég vesztette el újonnan épített székvárosát, Szendrőt, másrészt neki nem volt e vazallusságban olyan együttmüködő kapcsolata II. Muráddal, mint egykor Lazarevićnek I. Bayeziddel, ${ }^{742}$ inkább kivárta az események és az erőviszonyok alakulását. Nem fordult el teljesen a magyaroktól, csupán az „egyik” magyar királyt, V. Lászlót és körét támogatta. Ezt jelezte, hogy 1439-ben V. László apjával, Albert királlyal egyetemben még vállalkozott volna egy török ellenes hadjáratra, ahogyan aláírta és megpecsételte a szeptember 17-én, Tüdőrévnél kibocsátott oklevelet. Azonban Albert halála után, a két király közötti erőviszonyokban már egyértelmüen az özvegy Erzsébet királyné és Cillei rokonsága oldalára állt, akkor is, ha ennek akár Nándorfehérvár elvesztése is az ára.

Legutóbb, Momčilo Spremić 2006-os Branković-monográfiájában, bár kissé módosította az adatokat, de részletesen tárgyalja a szerb despota útjának állomásait. Megemlíti, hogy Branković akkor hagyta el az országot, amikor a szultán megkezdte Nándorfehérvár ostromát, azaz 1440 áprilisában. Először a lányához, Katalinhoz - Cillei Ulrik feleségéhez - ment Zágrábba, de valódi úti célja Zéta volt. Onnan próbálta volna az államát fenntartani. Tulajdonképpen vele együtt elindult az egész szerb udvar is. Nemcsak a felesége és a fia, hanem az államférfiak, egyházi méltóságok, nemesek és 1500 fös lovas katonasága is. ${ }^{743}$ Zágrábból május végén Zenggen át hajózott Kjodju-ba. A Velencei Köztársaságban tartózkodott, a katonaságát Furlani-ban helyezték el. A despota hajókat akart kérni útjának folytatásához Zétába. Egy hónap múlva, 1440. július 9-én két velencei gályával és több kisebb hajóval július 21.-én vagy 22.-én megérkezett Raguzába. A raguzaiak ünnepélyesen fogadták a számüzetésben lévő szerb udvart, de korlátozták a katonai kíséretének belépését. A despota itt körülbelül egy hétig maradt. ${ }^{744}$ Bonfinitől azt is tudjuk, hogy II. Murád szultán állítólag kérte a despota kiadatását, a kincsei nélkül. Ennek fejében örök szövetséget és békét kötött volna a raguzaiakkal. A szenátus azonban egyhangúan utasította el az ajánlatot, a válaszukban a vendégjog sérthetetlenségére hivatkoztak. $^{745}$

A despota Zétába megérkezve a tengerparti Bár városában és Budvában tartózkodott. Megpróbálta megszervezni az összeköttetést a gazdag Novo Brdo bányavárossal, amelynek török megszállása már 1440 tavaszán várható volt. Branković féltette a szerb kincstár nála

\footnotetext{
${ }^{742}$ Erről lásd bővebben a 13. 3. fejezetet.

743 Момчило Спремић: Ђурађ Бранковић 1427-1456. Београд 2006. 91-92. A továbbiakban: Спремић 2006.

744 Спремић 2006. 93.

${ }^{745}$ Bonfini 1995. 596.
} 
lévő értékeit, végül azok egy részét 1440 szeptemberében, a másikat 1441 júliusában Raguzában letétbe helyeztette. ${ }^{746}$

„Várak és várasok, kik királné asszony pártján akkor valának, néppel és éléssel királné asszontól oly igen takartatnak..."

(Nagybáncsai Mátyás, 1560)

\section{2. Nándorfehérvár felmentésének lehetősége és lehetetlensége}

A Nándorfehérvárt kezükben tartó Tallóciak külső segítségre nem számíthattak. Külföldire még kevésbé, hiszen egy török elleni keresztes hadjárat szervezése - Albert halála után ekkor még kilátásban sem volt, mert a Pápaság a firenzei zsinaton előbb a keleti és nyugati keresztény egyházak unióját erőltette, a Habsburg és a Jagelló dinasztikus ellentétet lecsendesíteni nem tudta, az Oszmán Birodalom valódi fenyegető erejét pedig alábecsülte. Pedig láttuk, hogy - az iszlám elleni keresztény összefogás hatására - az Oszmán és a Mameluk állam egymást támogatta. Így Tallóci Jován vránai johannita perjelként a rodoszi lovagoktól - a mameluk támadások miatt - sem kaphatott volna segítséget.

Belföldön pedig hiába állt rendelkezésre a vár felmentésére a bárók számára megfelelő hadsereg, amellyel megrövidíthették volna az ostromot, azt inkább egymás ellen fordították. Láthattuk, hogy Ulászlónak a seregeit a trónért folyó küzdelemben - Erzsébet királyné elleni harcában - Komárom, Győr ostromára, körülzárására vagy a Pozsony körüli ostromzár áttörésére kellett indítania, nem a török ellen.

Cillei Frigyes pedig még Ulászló koronázása előtt két sereget szervezett, amelyről Erzsébet királyné 1440. július 9-i oklevele tesz említést. Branković György szerb despota akinek Cillei Ulrik a veje volt - és aki Albert királlyal 1439. szeptember 17-én még a törökellenes hadjáratban való részvételét fogadta meg, most Zétába ment, onnan készült sereggel betörni az országba. Horvátországban az elégedetlen Frangepán Bertalan mozgósította az Erzsébethez hü híveket. Cilleihez csatlakozott Garai László és a Tallóciak helyi ellenfele, Bátmonostori Töttös László is. Bosznia Ulászlót támogatta. Egyedül Szlavóniát nem érintette a déli végeken a polgárháború. ${ }^{747}$ Albert halálával egyúttal a Tallóci-Cillei vetélkedésben most a Cilleiek jutottak lépéselőnyhöz. Ugyanis ők Erzsébet királyné mellé álltak, míg a Tallóciak Ulászló pártjához csatlakoztak.

\footnotetext{
${ }^{746}$ Спремић 2006. 96-97. Ez utóbbi letétbe helyezö oklevelet lásd: Monumenta Serbica. 1858. 406-409. (338. sz. okl)

747 Pálosfalvi 2000. 53.
} 
Sőt a királyné, a Garai-Cillei-Branković liga számára még jókor is jött a szultáni támadás, mert ők inkább várhatták a Tallóciak nándorfehérvári esetleges kudarcát, amely révén gyorsabban kikerülhettek volna az ország vezetéséböl. Ebben a helyzetben nemcsak a Tallóciak, hanem Nándorfehérvár is végérvényesen magára maradt, ilyen belpolitikai küzdelemben nem számíthatott királyi katonai segítségre, felmentő seregre kívülről, mint később, 1456-ban.

Az 1439. évi dekrétum 3. cikkelye szerint a várak felmentésére a bárók, a nemesek egyébként sem voltak kötelesek, csak a király által meghirdetett általános nemesi felkelés keretében és csak a várban elhelyezett királyi zsoldos csapat haderejének elégtelensége után. ${ }^{748}$ Igaz, hogy Nándorfehérvár éppen az ország határán volt és nem azon kívül, tehát a nemesi felkelés -törvény szerint- meghirdethető lett volna. De rögtön adódik az újabb kérdés: melyik király általi nemesi hadfelkelés? Az egymás elleni küzdelemben ezt egyik sem hirdette meg a török ellen. Nándorfehérvár megvédésének feladata a szultáni sereggel szemben helyi, várkapitányi hatáskörben maradt.

Pálosfalvi Tamás szerint az oklevelek adatai alapján Tallóci Matkót július 15-én, Ulászló koronázásán, Budán találjuk és szeptember előtt nem is ment vissza Szlavóniába, sem Nándorfehérvárra. A történész feltételezése szerint a király oldalán lehetett öccsével, Tallóci Frankkal, aki az ostromlott vár segítségére siethetett. ${ }^{749}$ Azonban a fenti adatok némileg pontosításra szorulnak. Egy július 7-i oklevél tudósítása szerint Tallóci Frank még Szegeden tartózkodott, onnan intézett parancsot a perleki, csáktői, asszonyfalvi, csőregi, újfalui és endrődi jobbágyokhoz. ${ }^{750}$ Több oklevél pedig tőle nem maradt fenn. Ami Tallóci Matkót illeti július 31-én már otthon tartózkodhatott, mert a király öt bízta meg a Knin megyében lévő - hütlenség címén a királyra háramlott - birtokok Nánai Kompolt Jánosnak való átadásával. ${ }^{751}$

Az uralkodók is messze voltak Nándorfehérvártól. Elég, ha megvizsgáljuk a királyné és a király itineráriumát. ${ }^{752}$ Erzsébet januárban Budán, Esztergomban és Visegrádon, februártól május közepéig Komáromban, május hátralévő részében Tatán és Székesfehérváron, júniusban Győrben, júliustól novemberig - kis megszakításokkal (Hainburg, Kismarton) - Pozsonyban tartózkodott. Mindeközben Ulászló januárban még

\footnotetext{
${ }^{748}$ Decreta 1976. 292.

${ }^{749}$ Pálosfalvi 2000. 51-52.

${ }^{750}$ DF-DL 55215

${ }^{751}$ DF-DL 39125

752 I. Ulászlóéről ld. bővebben: Sroka, Stanisław A.: I. Ulászló itineráriuma (1440-1444). In: Acta Universitatis Debreceniensis de Ludovico Kossuth Nominatae. Series Historica XLVIII. Történeti tanulmányok IV. (szerk.: L. Nagy Zsuzsa és Veress Géza) Debrecen, 1996. 21-48. (Sroka 1996)
} 
Krakkóban, áprilistól már Késmárkon, Szandeczen, májustól kezdve pedig már egy IglóEperjes-Szikszó-Emőd-Eger-Hatvan útvonal követhető, a július 15.-i budai megérkezéséig. Az év hátralévő részét pedig Budán töltötte. ${ }^{753}$

A két politikai csoport még a veszély pillanatában sem hagyta abba az egymás elleni háborút, amelyből a Tallóciak sem maradhattak ki. ${ }^{754} \mathrm{Ez}$ volt az egyik körülmény, amelyben más volt ez az ostrom az 1456. évinél. Jól mutatja ezt a tényt, hogy az okleveles forrásokban alig találunk utalásokat Nándorfehérvár ostromára, és azt is csak Ulászló és Tallóciak kibocsátott oklevelei között, amelyeket alább ismertetünk.

Az egykor Lazarević által elkezdett építkezések most vizsgáztak elöször az oszmán szultáni haderővel szemben. A vár korszerü felszereltsége, kiépítése, a tüzfegyverei, a védősereg fegyelmezettsége meghatározó volt, bár a pontos létszámukat nem ismerjük.

Legalább ennyire meghatározó volt a mozgósítható gazdasági források rendelkezésre állása. Amikor már folyt az ostrom, Tallóci János várkapitány számíthatott testvérére. Míg Matkó a lengyel király magyarországi háborújával lehetett elfoglalva, addig 1440. május 20-án kelt oklevelében ${ }^{755}$ Tallóci Frank szörényi bán megadóztatta saját jobbágyait Krassószentmiklóson. Egy aranyforintot (unum florenum auri) kért telkenként (unum fundum integrum seu curiam singulum), külön kiemelvén Nándorfehérvár védelmének fedezését (signanter in tuitione castri Nandoralbensis). ${ }^{756}$ A Tallóciak tehát mintegy „megelőlegezték” a védelem költségeit. A hadvezetést vállalkozási jellegü tevékenységként intézték, megvédték birtokaikat és ehhez saját jobbágyaik erejét is igénybe vették. ${ }^{757}$

A király, I. Ulászló is hozzájárult a költségekhez, utólagosan, amikor a török ostrom már tartott. Nándorfehérvár védelmére a legmodernebb bányatechnikát alkalmazó Szepes megyei Szomolnok (Smolník, Schmöllnitz) bányavároshoz (Zmolnokbanya) írt parancslevelében 400 aranyforint kifizetését kérte. ${ }^{758}$ Ebben az 1440. június 17-én kelt oklevélben ${ }^{759}$ Nándorfehérvár körül felvonuló török haderőnemeket is pontosabban fellelhetjük. „Nándorfehérvár várunkat mind hajókkal mind szárazföldi haderővel

\footnotetext{
${ }^{753}$ Wertner 1911. 556.

${ }^{754}$ Mályusz 2003. 157-158.

${ }^{755}$ DF-DL 55204

756 Thallóczy-Áldásy 1907. 135, 3, 14-16. (197. sz. okl).

${ }^{757}$ Mályusz 2003. 160.

${ }^{758}$ Mályusz 2003. 159.

${ }^{759}$ DL 13555
} 
ellenségesen megostromolták és körülzárták. "760 Az ostrom mellett más várakat is veszélyeztettek a törökök. Több, környékbeli vár ostromát elképzelhetőnek tartották és a fosztogató portyáktól is féltek. Ugyanis a törökök, ,legközelebb az elöbb mondott királyságunknak más végvárait hasonló módon körülzárni és más alsó részekre betörni... kifosztani és teljesen elpusztítani készülnek."761 De a déli végvárak közül Nándorfehérvár a legfontosabb. Szimbólum értéküek azok sorok, melyek szerint „úgy tünik, egyedül Nándorfehérvár, ahol Magyar Királyságunk épsége ered.",762

A magyarországi adatbázisban a további időszakban I. Ulászló király határjáró (június 29), ${ }^{763}$ hatalmaskodást eltiltó (július 1), ${ }^{764}$ birtokátadó (július 13), ${ }^{765}$ adományozó vagy várépítési engedélyt adó (július 25, 26, 31, augusztus 1), ${ }^{766}$ a pálos rendre vonatkozó intézkedéseket (július 30) ${ }^{767}$ tartalmazó okleveleit találjuk.

\section{3. Az ostrom időszaka a Tallóci-oklevelezésben}

Az 1440. évi oszmán-török támadás előzményei kapcsán már vizsgáltam a fellelhető Tallóci-oklevelezést, és megállapítható, hogy abban igen jól tükröződnek a határ menti mozgósítások. Ugyanezen megfontolásból érdemes tovább folytatni a vizsgálatot.

Az ostromot megelőző években Tallóci Matkó dalmát-horvát-szlavón bánként adott ki okleveleket, Nándorfehérvártól távol. A további oklevelei is ebben a tisztségében születtek és a Tallóci testvérek közül a legnagyobb számúak. 1438. március 31-én Matkó horvátdalmát bán, Frank szörényi bán, Péter horvát bán és János nándorfehérvári kapitányok temesi és kevei birtokokat szerb uraktól vásároltak, amelyet Albert király jóváhagyott. ${ }^{768}$ Április 23-án a körös megyei csázmai káptalan elött Tallóci Matkó és Péter körös és varasd megyei birtokokat vásároltak 2000 aranyforintért. ${ }^{769}$

\footnotetext{
${ }^{760}$ Thallóczy-Áldásy 1907. 136, 8-10. (198. sz. okl) „, qualiter ipsi castrum nostrum Nandoralbense tam per navalem, quam per etiam per terrestrem potentiam et exercitum hostiliter obsedissent et circumvallassent"

761 ,in proximoque alia confiniorum pretacti regni nostri castra, modo simili circumvallare, aliasque partes inferiores...invadere, spoliare et omnino devastare intenderent." Thallóczy-Áldásy 1907. 136, 10-13.

762 „signanter Nandoralbensis, in quo salus regni nostri Hungariae existere videtur” Thallóczy-Áldásy 1907. 136, 33-34.

${ }^{763}$ DF-DL 44295

${ }^{764}$ DF-DL 59262

765 DF-DL 65537

${ }^{766}$ DF-DL 68 988, DF-DL 13 558, DF-DL 88 161, DF-DL 13 567, DF-DL 13 566, DF-DL 13567

${ }^{767}$ DF-DL 13 562, DF-DL 13563

${ }^{768}$ DL 44241

${ }^{769}$ DL 100723
} 
Matkó 1438. október 4-én, 1439. január 24-én, március 11-én például egy helyi, emberöléssel végződő, hatalmaskodási ügyben intézkedett. ${ }^{770}$ Január 8-án pedig Albert király Tallóci Matkóhoz utasítást intézett, mint a királyi kamarák ispánjához, a sókamarák comes-éhez, hogy a Buda melletti, Szent Lőrinc pálos kolostornak adjon alazsminaképpen annyi sót, amennyit eddig is évente kaptak. ${ }^{771}$ Március 9-én Matkó Körösön tartott nemesi ülést, ahol tőle a báni pecsétőrök és protonotariusok nemesek általi választásának eddigi kiváltságát kérték visszaállítani, amelyet március 11-én kiadott oklevelében meg is tett. ${ }^{772}$ Március 24-én Matkó, mint dalmát-horvát-szlavón bán és Frank szörényi bán, egyúttal a királyi sókamarák ispánjai azért tiltakoztak, mert a király sóját szállító szekereket feltartóztatták és a sót elvették, Losonci Dezső erdélyi vajda tiltása ellenére. Az elmúlt évi erdélyi török hadjárat után, augusztus 15 . körül az alvinci sóraktárból loptak el sót. ${ }^{773}$ Tallóci Matkó április 6-án, egy pálos kolostor falujához tartozó villa visszaadásában döntött. ${ }^{774}$ Április 9-én ismét egy hatalmaskodási ügyben kezdeményez vizsgálatot Velikén. ${ }^{775}$ Április 14-én és május 8-án a vicebánhoz, Gerebeni Hermannhoz intézett utasítást egy újabb hatalmaskodási ügyben azonnali elégtétel szolgáltatás tárgyában. ${ }^{776}$

Különös érdeklődésre tarthatnak számot Tallóci Matkó a nándorfehérvári ostrom évében, 1440-ben kiadott oklevelei. Március 7-án a körös megyei Prodavicen a vicebánt értesíti a néhai zágrábi püspök arany- és ezüstnemüinek átadásáról. ${ }^{777}$ Március 9-én már Matkót az Ulászlóhoz indított küldöttség tagjaként János zenggi püspökkel, Jánossal, a szentgotthárdi apátság kormányzójával, Perényi János tárnokmesterrel, Pálóci László udvarmesterrel, Marcali Imre asztalnokmesterrel és pozsonyi ispánnal adott ki oklevelet. ${ }^{778}$

Március 16-án az észak-magyarországi Sáros megyei Szebenből mint sókamaraispán utalványozott a szegedi kamarásnak hatvan aranyforint értékü só kifizetéséről familiárisának Dacz-i (Dóci) Mihálynak. ${ }^{779}$ A közbeeső időben Matkó Erzsébet királyné fogságában volt, amint erről korábban szóltunk. Május 16-án a Nógrád megyei Verőcén, már ismét bánként vicebánja, Gerebeni Hermann birtokainak hamis becsüje tárgyában ad ki megintő oklevelet az elkövetőnek. ${ }^{780}$

\footnotetext{
${ }^{770}$ DF-DL 106 830, DF-DL 35 556, DF-DL 35558

${ }^{771}$ DL 13288

772 DF-DL 13326

${ }^{773}$ DL 36390

${ }^{774}$ DF-DL 35559

${ }^{775}$ DF-DL 103589

776 DF-DL 35 560, DF-DL 35562

777 DF-DL 44284

${ }^{778}$ DF-DL 289004

${ }^{779}$ DF-DL 55199

${ }^{780}$ DF-DL 106972
} 
Június 2-án már a Körös megyei Bélán találjuk, ahol feleségével, Lévai Cseh Margittal kötelezték magukat arra, hogy az atyinai várban lévő részüket és tornyot, amelyet egykor szállásul kaptak, visszaadják felesége rokonának, Garai László macsói bánnak. ${ }^{781}$ Június 19-én Losonci Dezső erdélyi vajda kereste meg levélben, Firenzei Papi sókamarást ajánlotta neki. A vajda említést tesz az ez évi folyóáradásról, amely lehetetlenné tette a só szállítást, valamint pestisjárványról is tudósít. ${ }^{782}$ Tallóci Matkó június 21-én Budán volt, ahonnan a szegedi sókamarásához intézett utasítást Dóci Mihály kifizetése ügyében. ${ }^{783}$ Azonban ezután hazatérhetett, így nem adatolt az, hogy Nándorfehérváron lett volna. Ide kapcsolhatjuk a már említett július 31-i oklevelet, amelyet Ulászló intézett hozzá a Knin megyében lévő birtokok átadására. ${ }^{784}$

Augusztus 1-én felesége családi ügyeiben tesznek róla említést a Lévai Cseh Péter özvegye, Katalin és testvére, Borbála, valamint Lévai Cseh Péter fia, László közötti birtokhasználati ügyben. ${ }^{785}$

Szeptember 21-én ismét bánként a bélai várnagyhoz intézett oklevelet a bélavári jobbágyok jogainak és kiváltságának megsértése tárgyában. ${ }^{786}$ Október 1-én pedig arról értesülünk, hogy a bélai várat átadta minden haszonvételeivel Miklós bélai apátnak. ${ }^{787}$

December 14-én dalmát-horvát-szlavón bánként és a zágrábi püspökség kormányzójaként felszólítja a püspökség tizedszedőit, hogy a garigi pálosokat ne zavarják e kolostorukhoz tartozó területeiken lévő szőlőik utáni tized beszedésében. ${ }^{788}$ Meg kellene még említeni Matkó testvérét, Petkót, aki az oklevelei szerint 1437 októberétől dalmát bánként intézkedett, de az 1440-es évből nem maradt ránk oklevele. ${ }^{789}$

Matkó fenti okleveleit áttekintve tehát nem találunk az ostromra vonatkozót. Az a következtetés vonható le, hogy Matkó az ostrom időszaka alatt - nagy valószínűséggel - a bánság ügyeit vezette. Nincs adatunk arra, hogy segítséget vitt vagy vitetett volna a törökök által körülzárt várba. Ezt megerősítik a latin nyelvű krónikás források is, amelyek szintén nem tudnak a vár védőinek felmentéséről vagy ellátás bejuttatásáról.

Tallóci Frank 1440-ben már mint egykori szörényi bán adott ki okleveleket. Május 20án, a Körös megyei Szalatnokon adta ki már idézett oklevelét, amelyben különösen

\footnotetext{
${ }^{781}$ DF-DL 88160

${ }^{782}$ DL 55213

${ }^{783}$ DF-DL 44292

${ }^{784}$ DF-DL 39125

${ }^{785}$ DL 13565

${ }^{786}$ DF-DL 104705

${ }^{787}$ DF-DL 44302

${ }^{788}$ DF-DL 35568

${ }^{789}$ A középkori Magyarország levéltári forrásainak adatbázisa szerint.
} 
Nándorfehérvár védelmére a Krassó megyei Szentmiklós népeire és jobbágyaira subsidiumként 1 aranyforint adót (unum florenum auri) vet ki kúriánként és telkenként. A hadisegély behajtását pedig Dóci Mihályra bízta. ${ }^{790} \mathrm{~A}$ behajtás május végére minden bizonnyal már elörehaladt, mert Frank május 29-én, Váralján írt oklevelében Dóci Mihálynak $^{791}$ azt parancsolja meg, hogy a beszedett pénzből utaljon ki Baróti János famulusának költségeire 10 aranyforintot. ${ }^{792}$ Július 7-én, Szegeden kelt okleveléből pedig azt tudatja a perleki, asszonyfalvi, csáktői csőregi, újfalui, szentkirályi, endrődi jobbágyokkal, hogy a király neki és Matkónak adományozta a torontál megyei Becső várát, ők pedig várnagynak és officiálisnak Dóci Mihályt és Horváth Istvánt tették meg. ${ }^{793}$ Ezek alapján az a feltételezés, hogy Frank Nándorfehérváron lett volna, okleveles forrásokkal szintén nem támasztható alá. Az MNL Adatbázisában további Tallóci Franktól származó oklevélröl, 1440-ből, nem tudunk.

Sajnos a várvédő Tallóci Jovántól (János) egyáltalán nem ismerünk saját kibocsátású oklevelet. Csupán a testvéreivel együtt szerepel Zsigmond és Albert királyok által kibocsátott - a nemességük kapcsán már említett - 1437. szeptember 27-i adományozó, illetve az 1438. március 31-i birtokvásárlási oklevelekben. A hallgatás tényét értékelhetjük úgy is, ami a vár teljes körülzárását bizonyítja. Ugyanakkor megnehezíti a vár 1440. évi ostromára vonatkozó okleveles forrásainak kutatását és továbbra is a krónikás források felé irányítja a kutatót.

\footnotetext{
${ }^{790}$ DF-DL 55204

${ }^{791}$ Dóci (Dolczi) Mihályról később is tudjuk, hogy dikátor és kamara haszna behajtó volt. Például Hunyadi Jánosnak, mint erdélyi vajdának 1443. január 21 -én, Szegeden kiadott oklevele alapján (DL 55 245). 1443. április 25-i és június 7-i okleveleiben pedig Hunyadi officiálisa és tolna megyei dikátora, adóbehajtója és adóellenőre is (DL 55 256, DL 55 260).

792 DF-DL 55206

${ }^{793}$ DF-DL 55215
} 
„Azonközben török Amurátes császár hogy ez dolgot meghallá,

jó Magyarországban ilyen visszavonás az urak között volna, minden erejével Nándorfejérvárat Amurátes megszállá,

hét egész holnapig éjjel-nappal császár löteté, ostromlatá."

(Nagybáncsai Mátyás, 1560)

\section{Nándorfehérvár 1440. évi ostroma a forrásokban}

\section{1. A latin nyelvü magyar források}

„Sajnos erről alig tudunk valamit...”794_ Kubinyi András történész megállapítása 2006-ban megjelent tanulmányában akár elrettentő mottó is lehetett volna számomra, amikor 2010ben elöször próbáltam szisztematikusan összegyüjteni az 1440. évi ostromra vonatkozó forrásokat. ${ }^{795}$ A forrásadottságról Pálosfalvi Tamás hasonlóan nyilatkozott. A kutatásaim során azonban jelentősen bővítettem az ostromra vonatkozó források körét.

$\mathrm{Az}$ eseményre a legnagyobb terjedelemben latin nyelvü forrásokat találunk. Az első latin forráscsoportot Nándorfehérvár 1440. évi török ostromáról a latinul írt „magyar” források képezik, amelyek vélhetően a legismertebbek, és könnyen elérhetőek.

Thuróczy János 1488-ban megjelentetett Magyarok Krónikájában ${ }^{796}$ (Chronica Hungarorum), illetve az Antonio Bonfini: A magyar történelem tizedeiben ${ }^{797}$ (Rerum Ungaricarum Decades) talált leírásokat egy forráscsoportba sorolhatjuk, hiszen hasonlóan írják le a szultáni ostromot. Érdemes összehasonlítani ezeket egymással, bár Bonfini információit - például 1456-tal kapcsolatban - sokan ma is kétesnek tartják. ${ }^{798}$

Thuróczy egy önálló fejezetet szentel Nándorfehérvár ostromának (230. De obsidione castri Nandoralbensis). Murád szultán (cesar Thurcorum Amrates) személyesen vonult hadba és a szultáni sereggel indult Nándorfehérvár ellen. A szerző megemlíti az előző évi szerbiai sikereit is. A szultán a hadjáratának időpontját kifejezetten a belháborúhoz igazította. A törököknek jól működő hírszerző szolgálatuk volt, ezt tanúsítják már II. Murád és II. Mehmed szultánok pontos értesülései a balkáni államokról, valamint a

\footnotetext{
${ }^{794}$ Kubinyi András: Nándorfehérvártól Mohácsig. Kérdések és következtetések. Hadtörténelmi Közlemények 2006/4. 924. (Kubinyi 2006)

795 Szabó 2010. 68-73.

796 Thuróczy 1978. 380-381. Latin szövegkiadása: Thuróczy Textus 1985. 241-243. A továbbiakban: Thuróczy Textus 1985.

797 Bonfini 1995. 590-592. Latin szövegkiadása: Antonius de Bonfinis: Rerum Ungaricarum decades. Ediderunt: I. Fógel-B. Iványi-L. Juhász. Tomus III. Lipsiae 1936. 101-103. A továbbiakban: Rerum 1936.

798 Mint például legutóbb Farkas Péter recenziójában. Farkas Péter: Cseh Valentin Nándorfehérvár ostroma 1456. Hadtörténelmi Közlemények 2009/2. 557.
} 
magyarországi és lengyelországi állapotokról. ${ }^{799}$ Ugyanis „,meghallotta”, hogy a nemesség „, belső háborúskodásban marcangolja egymást, azt gondolta, hogy a meghasonlott nép nem képes saját védelmére”.(Horváth János fordítása) ${ }^{800}$ A török hírszerzők valószínűleg ezúttal is jelentették az országban uralkodó közállapotokat, ekkor meg is indította seregét.

Teljes mozgósítás történhetett: „Fegyverbe szólította az uralma alá tartozó fegyveres erőket, mozgósitotta minden hadifelszerelését"(cunctisque bellicis apparatibus). ${ }^{801}$ II. Murád tehát sereget gyüjtött ázsiai és európai területeiről a szokásos módon és hosszú hadjáratra készült. ${ }^{802}$ Sőt „,hadi-és ostromgépeket” is vitt magával (machinis et tormentis eductis). Thuróczy sajnos nem említi a török hadsereg létszámát, csupán annak „óriási tömegét"(hostilium copiarum ingens esset multitudo). A vár kapitánya ekkor Raguzai Zován (János), azaz Tallóci János, akit raguzai nemzetiségünek mond (Zowanus Ragusiana de natione ortus) és aki Matkó dalmát, horvát és szlavón bán testvére (frater Mathkonis). „Serény és rettenthetetlen”(vir strenuus et animo impavidus). ${ }^{803} \mathrm{~A}$ nyílt összecsapást nem vállalhatta a felvonuló túlerővel szemben, hanem a leírás szerint az ellenség elé vonult és „csatázva vonult vissza a várba” (nec sine certamine in castrum reversus est). Valószínüsítjük, hogy ez a török sereg elővédje, az akindzsi alakulatokkal való csatázást jelentette. Thuróczy kiemeli, hogy a vár felkészülten várta a török ostromot. $^{804}$

Thuróczy nem említi a török sereg létszámát, amely nagy lehetett és rémületet keltett a keresztényekben. Éppen ezért is nehéz a számukat megbecsülni, hiszen könnyen túlzó lehet, kiemelve a helytállás nagyságát. A szerb történész, Kalić például 20000 före becsülte. ${ }^{805}$

A török haderő a vár alá megérkezvén először teljesen körülzárta Nándorfehérvárt. Vagyis teljes blokád alá vette a várat, elvágva mindennemű külső segítségtől. Valószínűleg a szultánnak nem lehetett értesülése a falak gyenge pontjáról, a kiépített falrendszerről. Ezért nem egy helyen összpontosította eröit, hanem „,körös-körül szétosztotta csapatait,

\footnotetext{
${ }^{799}$ Perjés 1979. 21.

800 A továbbiakban ezt a fordítást használjuk az alább idézett részletekben. „Hic cum audivit omnem regnicolarum regni Hungarie cetum se intestinis guerrarum rodere morsibus, divisam plebem in sui deffensionem arbitratus est valere nihil.” Thuróczy Textus 1985. 241, 31-33.

801 „Commoto igitur omni sui principatus armorum robore cunctisque bellicis apparatibus, machinis et tormentis eductis veniens castrum predictum expugnandi gratia aggressus est." Thuróczy Textus 1985. 242, 1-3.

${ }^{802}$ Калић-Мијушковић 1967. 110.

${ }^{803}$ Thuróczy Textus 1985. 242, 3-6.

${ }^{804}$ Thuróczy Textus 1985. 242, 7.

${ }^{805}$ Калић-Мијушковић 1967. 111. Lásd a 10. 3. fejezetet.
} 
mindenfelől őrségeket állitott fel." ${ }^{\text {,866 }}$ Ostromzárral vette körül a várat és felállította az ostromgépeket és egyéb eszközöket (machinis et ceteris tormentorum generibus), ${ }^{807}$ amelyek a falak lerombolására szolgáltak. A kőhajítógépek a helyszínen kivágott fákból készülhettek vagy más városokból húzták ide, ehhez pedig igavonó állatok (ló, ökör) kellettek. A nagy távolság és a rossz utak miatt a törökök sok ostromgépet inkább a helyszínen készítettek el, kézmüves mesterekkel. ${ }^{808}$

Az ostrom kezdeteként a szultán megkezdte a falak töretését az ostromgépekkel. Az eredményességéről szólva Thuróczy általánosan fogalmaz, „rommá lövette (dissipabat) és a föld színével tette egyenlövé a tornyokat és falakat”. De Zován „nem rémült meg a sok ellenség látványától és a kemény ostromtól (ex... dura expugnatione)." ${ }^{\circledR 09}$ A védők a nappal ,fáradtságosan lerontatott" várfalakat éjszaka megerősítették (muniebant), sőt kitámadva zavarták az ellenséget. Elképzelhető, hogy Thuróczynak ez a megjegyzése inkább a külső, alacsonyabb falra vagy a tornyokra vonatkozik. Nem derül ki, hogy a török faltöretés meddig tarthatott, de nem járt sikerrel. A leírásból azt nem tudhatjuk meg, hogy melyik falnál és milyen irányból történhettek ezek. A falak újra felépítése talán a kettős falrendszerü Felsővárosra vonatkozhat.

Az biztos, hogy a támadás fő iránya a szárazföld felöli várfalak voltak, azért, hogy a falakon át jussanak be a várba. A nagy kőgolyók károkat okoztak a falakban, de a védők éjszaka betömték a réseket. Sáncokat emeltek az ellenség elé, hogy megakadályozzák a gyalogság rohamát. ${ }^{810}$

Az ostrom következő szakaszában a szultán (császár) más ostromtechnikát választott. Cselt (aliud genus insidiarum) eszelt ki: Ha falakon át nem tud bejutni, a falak alatt próbálkozik. Ez az, amitől az 1440-es török ostrom különlegessé vált: aknászokat (azaz bányászokat) vetett be. A várhoz közeli kis domb (colliculus) mögött, hogy ne lehessen látni a védőknek, hatalmas ,föld alatti alagutat" (fossam subterraneam) ásatott, amely széles és hosszú (longam latamque) „egészen a vár belsejéig” elér. ${ }^{811}$ A hatalmas földmunkát sok ezer ember végezte. A földet emberek, tevék, lovak, szamarak hordták ki. Mindezt nagyon óvatosan, titokban. Thuróczy nem mondja meg, hogy ez a török alagút a vár melyik részén volt.

\footnotetext{
806 „, circumquaque agminibus districtibus ac excubiis undique ordinatis castro eidem gravi obsidione adherebat” Thuróczy Textus 1985. 242, 10-11.

807 Thuróczy Textus 1985. 242, 12.

${ }^{808}$ Калић-Мијушковић 1967. 111.

809 „, altas turrium munitiones et menia precipitem dissipabat ... Zowanus vero ... ex tanti hostis visione tamque dura expugnatione minime stupefacti” Thuróczy Textus 1985. 242, 12-13.

${ }^{810}$ Калић-Мијушковић 1967. 113.

811 Thuróczy Textus 1985. 242, 23-24.
} 
Thuróczy a szóbeli hagyományt alapul véve közli, hogy a védőket értesítették egy - a várba belőtt - nyíllal az alagút helyéröl. ${ }^{812} \mathrm{Ez}$ valószínủleg a török táborban lévő valamelyik keresztény cselekedete lehetett. Nem feltétlenül magyaré. A török táborban raguzaiak is voltak, akik a kereskedelmi tevékenységük folytatása fejében kedvezményeket kaptak, hogy nem fogják akadályozni a török kereskedelmet Szerbiában. Ezek valószínüleg magánszemélyek lehettek, hiszen a raguzai vezetés elhatárolódott ettől. ${ }^{813}$ De ugyanígy lehettek szerbek, bolgárok, albánok, görögök is, mert Brocquière lovag szerint a törökök „sok keresztényt kényszeritenek hadiszolgálatra ... mindezek gyülölik a törököket... sok bajt okozhatnának elnyomóiknak." (Szamota István fordítása) ${ }^{814}$

Zován ekkor elrendelte a török alagúttal szemben egy hasonló ellen alagút építését (fossam consimiliter subterraneam). ${ }^{815}$ A munka célja az volt, hogy a törökök aknáját idő elött robbantsák be, mielőtt az a várfalak közelébe elérne. Thuróczy a berobbantásának módját is ismerteti. Megtömték salétrommal (saletro), a bombardákhoz használt puskaporral (bombardarumque pulveribus) és egyéb égő anyagokkal, a várban lévő bejáratát ügyesen lezárták és csak a begyújtásra hagytak kis rést. Zován őröket állított a török munka figyelésére. Amikor a török alagút a vár falain belül jutott és elérte a belső alagutat, Zován hirtelen meggyújtatta az alagutat. Az alagútban lévő emberek és állatok bennégtek. A szultán, kudarcát látva, visszatért hazájába. ${ }^{816}$

Az ostrom túlságosan is elhúzódott, idejét Thuróczy 7 hónapban ${ }^{817}$ (septem mensibus obsidione) határozza meg. Thuróczy a török veszteséget óriásira, 17000 före teszi (decem et septem sue gentis millibus) a szóbeli forrásai szerint. Sajnálatosan viszont nem tesz említést a folyón felhajózó török flottáról.

Antonio Bonfini az előbbi értesüléseket bővíti ki ékesebb latin nyelven (3. 4. 345-385.). Néhány helyen viszont módosítani, pontosítani próbál Thuróczy leírásán. „Körülbelül abban az évben, amelyben Albert király eltávozott az életböl" ${ }^{818}$ Murád „király” (Amrates rex Turcorum) ostrom alá vette Görögfejérvárt (Albam Grecam), korábbi nevén Taurun(i)umot. ${ }^{819}$ Bonfini is kiemeli, hogy hadjáratát megkönnyítette az ország belső

\footnotetext{
${ }^{812}$ Thuróczy Textus 1985. 242, 30-32.

${ }^{813}$ Калић-Мијушковић 1967. 111.

${ }^{814}$ Szamota 1891.87.

815 Thuróczy Textus 1985. 242, 34.

816 Thuróczy Textus 1985. 243, 9-12.

${ }^{817}$ Thuróczy Textus 1985. 243,11. Thuróczy 1978. 381. A Horváth János féle fordításban itt két hónap áll. A kérdést lásd a 10. 2. fejezetben.

818 „Eodem fere anno, quo rex Albertus vita decessit ... Albam Grecam Taurunium ... obsedit” Rerum 1936. $101,7,15-16$.

${ }^{819}$ Thuróczy is ezt az elnevezést említi a tatai szerződésről szóló fejezetében. Lásd a 13. 1. fejezetet.
} 
állapota (interregnum): „hiszen a magyar államnak nem volt királya, és megtörte a két frakció meg a belháború". 820

Bonfini szintén raguzai patríciusnak tudja Tallócit. Továbbá, hasonlóképpen Thuróczyhoz, leírja, hogy János (Ioannes) az ellenség elé kirohant és csatába bocsátkozott, majd visszavonult és „bámulatos körültekintéssel megerösítette a várost” (miraque diligentia munivit urbem). Murád közel vonult a falakhoz és a hadigépekkel (tormenta propius bellica admovere) a , lehetö legkeményebb (quam gravissima potest) ostrom alá fogta. ${ }^{821}$ Eközben a várból folytatódtak a védők kitörései (eruptio) és az ellenségnek nagy kárt okoztak. Murád erre nemcsak ostromgépekkel (machinas) törette a falakat és bástyákat (propugnacula), hanem váltogatta az ostromot a falakra indított rohamokkal. Bonfini leírása szerint csak néhány torony (turres) dőlt le. A falak részben tönkrementek, éjszaka kellett helyreállítani. A védők az „összehordott földből, szemétből, állati ürülékből fával borított sáncot (circummunitum) emeltek." ${ }^{, 822}$ A törökök már létrákon (scala) támadtak a falakra. A védők a nyakukba szurkot, ként (picem ac sulphur) zúdítottak, méhrajt eresztettek rájuk. A szultán egyik harcmóddal sem tudott eredményesen szembeszállni, de folytatta tovább a város ostromát. János, úgy tünik, nem bízhatott eléggé a „külső falban”, mert odabent egy árkot és magasabb töltést húzatott (exteriore muro...fossam et aggerem altiorem obducit). ${ }^{823}$ Erről sem tudunk többet, talán a Fellegvár körüli árkot újította meg, és töltéssel megerösítette.

Bonfini a szultán új tervét Thuróczyhoz hasonlóan ismerteti, bár néhol kibővítve. „Rejtett föld alatti aknák” (adactis clam cuniculis) segítségével tervezte bevenni a várost. Egy-két mérföldnyire lévő dombocska (monticulus) mögött kezdték el éjjel-nappal a munkálatokat, miközben cselből tovább folytatták az ostromot. Bonfini szerint 20000 embert állítottak munkába. ${ }^{824}$

A barlangformájú aknából vájt földet a közeli folyóba öntötték. Bonfini sajnos nem közli, hogy az a Duna vagy a Száva lehetett-e. Olyan széles volt, hogy már lovasok is négyes sorban bemehettek rajta. A falig jutott el, ekkor a szóbeszéd szerint vagy egy keresztény katona figyelmeztette a védőket, vagy egy nyílvesszőre tüzött cédula. Bonfini az ellenaknák alkalmazását bevett gyakorlatként ismerteti. A várkapitány „ahogy hasonló

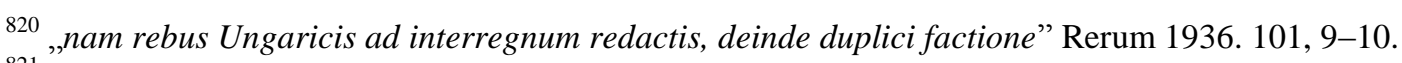

${ }^{821}$ Rerum 1936. 101. 23, 25-26.

${ }^{822}$,fractos noctu muros resarciunt, egesta terra, fimo et pecorum excrementis aggerem lignis circummmunitum ducunt" Rerum 1936. 101. 35-37. Ennek tüzérségi vonatkozásairól lásd a 10. 5. fejezetet.

${ }^{823}$ Rerum 1936. 102, 1-2.

${ }^{824}$ Rerum 1936. 102, 10-14. Bonfini 1995. 591. A létszámot túlzónak tartja Калић-Мијушковић 1967. 113.
} 
esetben szokás" (veluti in re tali fieri solet) ezzel szemben egy másik alagutat fúratott és megtöltötte lőporral, kénnel, (nitro, sulphure) rőzsével, majd egy kis rés kivételével, befalazta. Amikor a törökök alagútjával ez összeért, begyújtatta. Az állatokon kívül 17000 ember pusztult el az aknában. ${ }^{825}$

Bonfini nemcsak a vár ostromáról beszél, hanem város körüli harcokat is sejtet. Hiszen Murád ezen kívül a „város”(sic!) ostromában 8000 embert vesztett. ${ }^{826}$ Ez valószínűleg az Alsóvárosban lévő harcokat és zsákmányszerzést jelenti. Bonfini az ostromot ismételten hosszúnak, 7 hónaposnak (septem mensibus) mondja. Murád rengeteg pénzt és embert veszítve visszavonult, hogy bosszút állhasson. A török flotta felvonulásáról, esetleges harcairól itt sincs említés.

Bonfini kortársa, Petrus Ransanus (1428-1492), aki stílusában átmenetet teremtett a középkori ihletésű Thuróczy és a humanista Bonfini müve között, A magyarok történetének rövid foglalata ${ }^{827}$ (Epithoma Rerum Hungaricarum ${ }^{828}$ ) címü munkájában csak általánosságban tért ki az 1440-es évek közállapotaira. Csupán a körülményeket pontosan ismerő olvasó sejtheti az ebben rejlő szultáni ostromot (23. fejezet). „Egyrészröl ugyanis a magyarok harcoltak egymás ellen, másrészröl a csehek és lengyelek zaklatták Magyarországot, megint másrészröl pedig Murád török uralkodó az ilyenféle viszálykodásból adódó lehetôséget kihasználva elhatározta, hogy megtámadja Magyarországot.” (Blazovich László és Sz. Galántai Erzsébet fordítása). ${ }^{829}$ A két szultáni ostrom „hírértékének” különbözősége a világtörténelmet író Ransanusnál jól lemérhető abban is, hogy míg 1440-ről a fenti, sejtelmes tömörségü mondatban, addig 1456-ról két fejezetben emlékezett meg (26-27. fejezetek).

Szintén közvetetten, az oszmán támadás alatt, jelen időben említi meg ezt az ostromot I. Ulászló július 17-i, ún. koronázási dekrétumának Dlugos lengyel történetíró által közölt szövegrészlete. „...segiteni vágyván és akarván a magunk és az ország nehéz helyzetén,

\footnotetext{
${ }^{825}$ Rerum 1936. 102, 30, 33-34, 103. 1-2. Bonfini 1995. 591-592.

${ }^{826}$ „Preter hec in urbis oppugnatione octo circiter hominum milia desiderata sunt.” Rerum 1936. 103, 5-6. Bonfini 1995. 592.

${ }^{827}$ Petrus Ransanus: A magyarok történetének rövid foglalata. Fordította: Blazovich László és Sz. Galántai Erzsébet. Budapest 1999. A továbbiakban: Ransanus 1999.

${ }^{828}$ Petrus Ransanus: Epithoma Rerum Hungaricarum. Id est annalium omnium temporum liber primus et sexagesimus. Curam gerebat Petrus Kulcsár. Budapest 1977. A továbbiakban: Epithoma 1977.

${ }^{829}$ Ransanus 1999. 115-116; ,Hinc enim arma inter se conferebant Hungari, indeque Bohemus, hac Polonus infestabat Hungariam, alia ex parte Amoractus Turcarum tyrannus eiusmodi discordiarum nactus occasiones Hungariam ipsam invadere cogitabat" (Index XXIII). Epithoma 1977. 142.
} 
amelynek határait most is a betörö ellenségek, pogányok és mások fájdalmas harapásai marcangolják..." (Pálosfalvi Tamás közlése) ${ }^{830}$

\section{2. A latin nyelvü lengyel források}

A latin nyelvü forráscsoporton belül egy második ,alcsoportba” a latinul írt lengyelországi munkákat soroltam. Itt tárgyalom a 2012-ben, John Jefferson által a kutatásba bevont új dokumentumot, amelyből korábban már idéztem. Jefferson szerint ez egy Budáról írt, névtelen - valószínűleg lengyel - szerzőtől származó és ismeretlen, „tiszteletreméltó férfi”nek (honorabilis vir) írt levél, amely részletesen beszámol a friss hírekről I. Ulászló udvarában. Számunkra azért lényeges, mert ebben szó esik Nándorfehérvár szárazon és vízen történő körülzárásáról, a tüzérség által elsüllyesztett török hajóról, valamint egy elfogott török gályáról is. A nándorfehérvári ostrom során részletesen bemutat egy általános török rohamot és annak kudarcát. ${ }^{831}$ A vonatkozó részt közlöm:

„...ezekben a napokban a törökök nagy serege a Magyar Királyság legerösebb várát, Ná[n]dorvárt, azaz Fehérvárt ostromolta és minden emberi fortélyt, ravaszságot annak ostromához felhasznált. Ugyanis az a vár bejárat a Magyar Királyságba, olyannyira, hogy annak megszerzése után, amit Isten hosszú ideig késleltessen, valamennyi más várakat, melyek Magyarországon vannak, (t. i. a törökök) könnyen képesek - amit csak akarnak megtámadni. Végül egy napon, amikor rohamot intéztek a vár ellen, nemcsak szárazon, hanem gályákon a víz felöl is, mivel ott folyik a Hyster, amelyet mi Dunának hívunk. A mi hadinépeink pedig látva nemcsak a saját, hanem az egész haza veszedelmét, olyannyira ellenálltak, hogy azokból, akik a szárazföldön elörenyomultak, többeket megöltek, sokakat megsebesitettek, a többieket pedig megfutamították. Továbbá azokból, akik a vizen ellenük harcoltak, egy gályát a teljes legénységével, akik a hajón voltak, erös kézzel elfogták, és Isten ellenségeit fogolyként a várba vitték. Aztán egy másik gályát, bombavető mozsár lövésétöl eltalálva, az emberekkel, akik azon voltak, a halál vizének ivására kényszeritették. Így azok barbárok, miután szemmel láthatóan vereséget szenvedtek, az ostromtól és a Királyságból visszavonultak." ${ }^{832}$

\footnotetext{
${ }^{830}$ Pálosfalvi 2009. 15. Dlugos 2001. 245, 24-25. „volentes et consulcius cupientes necessitati nostre et regni huius, cuius pronunc confinia per insultancium inimicorum, paganorum scilicet et aliorum morsus asperos continue lacerantur..."

${ }^{831}$ Jefferson 2012. 240. (20. lábjegyzet); Lewicki 1891. 416-421. (275 sz. levél)

832 ,...hiis diebus magnus Turcorum exercitus castrum fortissimum regni Hungarie Naderwara alias Album Castrum obsedisset et omnia humana ingenia ad illud expugnandum adhibuisset - est enim castrum illud quasi introitus in regnum Hungarie, ita ut eo, quod deus in longum protrahat, accquisito, omnia alia, que
} 
Az ostrom előtt és alatt párhuzamosan folyt a király diplomáciai próbálkozása, amelyről a következő mondatok számolnak be. Így értesülünk a követküldésről és a szultánnal való tárgyalási kísérletről is. A névtelen lengyel levélíró még nem tud a tárgyalások végkifejletéről, reménykedik annak eredményességében, amely számunkra éppen azt jelzi, hogy ostrom még tart, a követeket nem küldte vissza a szultán. Fontos adalékot ad azáltal is, hogy megnevezi a király által megbízott lengyel követeket. Mindezeket az információkat csak a latin nyelvü, lengyel forrásaink erősítik meg.

„Mindazonáltal a mi király urunk megbizható kémei által értesült, hogyan készített fel a törökök császára nagy sereget azzal a szándékkal, hogy megtámadja ezt a királyságot és ellenséges haderövel legyözze. A mi király urunk tehát a mondott császárhoz küldte Petrus Lancziczsky-t, ${ }^{833}$ kérve tőle azt, hogy a (király) földjét és országát ne támadja meg, hanem vele mintegy fogadott fiával ${ }^{834}$ és az ö királyságával békében éljen. A követek között, akiket a mi király urunk a császárhoz küldött a fáradtságos tárgyalásokra, volt még tudniillik Odrowansch palatinus ${ }^{835}$ és Laurentius Zaramba Siradiens várnagya, ${ }^{836}$ akik készen álltak az útra. Ami ezután ebben a dologban következik, az Isten kezében van. A törökök fölötti gyözelem dolgában mi mégis nagyon reménykedünk a Mi Megváltónkban, aki kegyeskedett nekünk adományozni az elöbb mondott győzelmet. Mert én úgy itélem meg, hogy mindezen tárgyalás, amelyről ezidáig beszéltünk, nem emberi, hanem isteni (akarat). Mivel a legkevésbbé volt hihetö, hogy mi emberi segitséggel elérjük azt, amit megszerezni kívántunk..." 837

in Hungaria sunt, facile possent quecunque vellent invadere - tandem una die fecerunt sturm contra castrum nedum per terram sed et in galeis per aquam, quoniam Hyster, quem nos Danubium vocamus, illic fluit; nostre autem gentes, videntes nedum suum sed tocius patrie periculum, resistebant adeo, ut eos, qui impetum in terra faciebant, occiderunt plures, multos wlneraverunt, reliquos in fugam converterunt; illis autem, qui per aquam contra eos pugnabant, unam galeam cum omnibus gentibus, que erant in ea, potenti manu receperunt et sic dei hostes captivos in castrum duxerunt; aliam autem galeam, ictu bombarde percussam, cum hominibus, qui erant in ea, aquam mortis coegerunt bibere. Sic barbari illi tam notabili strage recepta ab obsidione et de regno recesserunt." Lewicki 1891. 419, 32-420, 1.

${ }^{833}$ Piotr Łęczycki vagy más néven Piotr Łąkoszyna Łęczyca földjéről. Łęczyca-i várúr, királyi írnok, királyi követ. Magyarországon Luxemburgi Zsigmond uralkodása alatt többször teljesített követséget. 1440-ben III. Ulászló követe volt a szultánnál, amelyet a lengyel történetíró és diplomata, Dlugos is megerősít. Krzyżaniakowa 1979. 142; Dlugos 2001. 410 (186. lábjegyzet). Lásd még a 2. 2. fejezetet.

${ }^{834}$ Utalás a király fiatalabb voltára.

${ }^{835}$ Ioannes Odrowąż de Sprowa (Odrowansch) királyi jegyző, Leopolis (mai Lviv) prépostja, majd püspöke, az Odrowąż-család tagja. Dlugos 2001. 388. (40. lábjegyzet) A család későbbi birtokáról, a radomi Szydłowiec-ről vette fel a nevét, amelynek kiemelkedő -szintén- diplomata tagja volt, Krysztof Szydłowiecki lengyel kancellár (1467-1532). Életéről lásd: Zombori István: Jagelló-Habsburg rendezési kísérlet 1523-ban Krysztof Szydłowiecki naplója alapján. In.: Krysztof Szydłowiecki kancellár naplója 1523-ból. Sajtó alá rendezte: Zombori István. Budapest 2004. 219-335. (Zombori 2004)

${ }^{836}$ Laurentius Zaremba de Kalinowa lengyel föúr, a királyi udvar, majd a királyság marsalcus-a. Dlugos 2001. 343. (114. lábjegyzet)

${ }^{837}$ Lewicki 1891. 420, 2-15. „Informatur tamen dominus noster rex per suos fidos exploratores, qualiter imperator Turcorum magnum parat exercitum, volens regnum hoc invadere et hostili manu debellare: 
Ehhez igen hasonló részleteiben mutatja be és egészíti ki az 1440-es ostromot a latin nyelvü forráscsoportban a lengyel történetíró, krakkói kanonok Jan Dlugos (Brzeżnica, 1415. december 1. - Krakkó, 1480. május 19.) Annales seu Cronicae incliti regni Poloniae címü, korábban már idézett munkája. A hasonlóság, amennyiben a névtelen lengyel levélíróval való személyi azonosság fennáll, természetesen adódik. A szerző a 12. könyvében egy önálló fejezetet szentelt az ostromnak (Turcorum caesar castrum Albam Regalem frustra obsidet), megemlítve a királyi diplomáciát, és az ostrom újabb elemeit írja le. Mivel ez a forrás is a hazai szakirodalomban jóval kevésbé ismert, részletesen szólok róla.

A koronázás után „Wladislaus király Szent Mária Magdaléna napjának (július 22.) hatodik napján (Székes) Fehérvárból kivonult és szombaton Budára érkezett... egész nyáron és összel Budán is maradt, mindig gondot forditva Magyar Királyságának ügyeire és vezetésére." ${ }^{838}$ Ekkor már folyt az ostrom: „, a törökök császára Fehérvár várát, avagy Nándor Fehérvárt, amely Magyarország és Szerbia határain helyezkedik el, és úgyszólván kikötö és elsö bejárat Magyarországba, ostrom(zárral) körülkeritette és az ostromot már három hónapja tovább folytatta úgy gondolván, hogy Szendrö várának (Smiderow) katonáihoz hasonlóan, ellátás és élelem hiján meg tudja szerezni." ${ }^{839}$

E szöveghelyünk lehetővé teszi a török ostrom kezdetének pontosabb meghatározását, és megmutatja, hogy II. Murád - Szendrő ostromának mintájára - a blokád alá vételt akarta és tartós, hosszú ostromra rendezkedhetett be, amelynek részét képezte a kiéheztetés is.

I. Ulászló azonban megkoronázása után első lépésben a diplomáciai utat választotta, amelynek célja egyúttal a magyar királyként való elismertetése, beiktatásának bejelentése is volt. De Dlugos utal az Ulászlóhoz 1439-ben küldött török követségre is, amely értelmében kívánt puhatolózni a szultánnál. A krónikás az oszmán szultán baráti szövetségének betartására vélhetően ezért hivatkozik.

misit igitur dominus noster rex ad dictum imperatorem Petrum Lancziczsky, rogans eum, ne terram et regnum suum invaderet, sed secum tamquam cum adoptivo filio regnisque et dominiis suis in pace viveret; nuncciorum quoque, quos ad eum dominus noster rex misit in arduis negociis, dominorum videlicet palatini Odrowansch et Laurencii Zaramba castellani Siradiensis, prestolabatur adventum. Quid in hac re sequetur, in manu dei est; nos tamen magnam spem in salvatore nostro concepimus de triumpho in Turcis obtinendo, qui in hiis nostris primiciis nobis hanc quam premisimus victoriam largiri dignatus est. Negocia enim omnia hec, que pertractavimus hactenus, non humane ego sed divina quasi iudicio; quoniam humano auxilio plurimum incredibile fuit nos eam rem pro qua venimus accquirere..."

838 „Feria sexta in die sancte Marie Magdalene Wladislaus rex ex Alba Regalis egressus, sabato Budam pervenit ... mansit Bude totam estatem et autumnum, negociis et disposicionibus Regni sui Hungarie semper intendens...” Dlugos 2001. 248, 12-13, 14-15.

839 „, cesar Turcorum castrum Albam Regalem seu Nander Albam in confinibus Hungarie et Rascie situm, quod est quidam portus et primus in Hungariam introitus, obsidione vallaverat obsidionemque ipsam tribus iam mensibus continuaverat, extimans illud in similitudinem castri Smiderow viribus, largicione vel victualium defectu posse conquirere” Dlugos 2001. 248, 16-20. 
Wladislaus király egy lengyel katonát, Petrus Lanciczki de Lankoschino-t ${ }^{840}$ küldte hozzá, jelezte neki (t. i. a szultánnak), Magyar Királyságának megszerzését és kérte, hogy várának ostrom(zár)át oldja fel, álljon el Magyar Királyságának megtámadásától és a baráti szövetséget, amelyet szavakkal előre megígért, tettek végrehajtásával bizonyitsa."841 A védők jól felkészültségét e krónika is kiemeli, illetve magyarázni próbálja a király békés szándékának fenntartását. ,Wladislaus király továbbá nem azért akarta küldeni ezt a követséget, hogy szerfölött óvja és féltse saját hatalmát, hiszen természetesen tudta, hogy az elöbb emlitett, valamint sokféle és bátor népekkel megerösitett várat Ioannes vránai perjel, Mathko bán édestestvére, tapasztalt és serény férfi lévén, azon a helyen, kapitányként megvédi, hanem inkább azért, hogy megtudakolja azt, hogy milyen a törökök császárának a szándéka irányában. "842 Ulászló a tapasztalt, több udvart is megjárt diplomatát azért küldte, hogy kifürkéssze a szultán szándékát. A szultán azonban válaszra sem méltatta. Hozzátehetjük, hogy nyilván azért sem, mert Ulászló - még lengyel királyként - sem fogadta el Murád 1439-es békekötési és szövetségi ajánlatát és akkori követjárását. Újabb három hónap telt el, sőt ez alatt: „Maga a török császár három hónapig késlekedett a válasszal, a királyi követet az akkor már saját hatalma alatt álló Szendrö várába küldte, hogy ott maradjon (t. i. őrizetben)." 843

Murád a szárazföldi ostrom megkezdéséhez nagy erőkkel fogott hozzá, amely vélhetően az északkeleti, a délkeleti, a délnyugati kettős várfalat és a várárkot érinthette: „Minden katonát, cseleket, igéreteket, és találékonyságot a vár felderitésére használt..., hogy könnyebben véghezvigye akaratát, a falak nagy részét bombavetökkel (bombardis) ledöntötte, a vár minden árkát (fossata castri) fahasábokkal (ligna) telehordatta." Mindezt azért, hogy a gyalogroham bejuthasson a várba.

${ }^{840}$ Ugyanaz a Piotr Łęczycki lengyel királyi követ, akit a névtelen levélíró is megemlített. Krzyżaniakowa 1979. 142-143;Dlugos 2001. 410. (186. lábjegyzet)

${ }^{841}$ „,mittit Wladislaus rex militem Polonum Petrum Lanciczki de Lankoschino ad illum, significans sibi, qualiter Regnum Hungarie adeptus est, et requirens, ut castri sui obsidionem solvat et Regnum suum Hungarie armis impetere desinat amiciciamque, quam pretendebat verbis, operis effectu demonstret." Dlugos 2001. 248, 20-22.

${ }^{842}$ „Eam autem legacionem Wladislaus rex Turcorum cesari ideo facere voluit, non quod magnopere curaret aut extimesceret suam potenciam, quippe qui castrum predictum pluribus et animosis gentibus fulcitatum, et Ioannem prepositum de Wrano, germanum Mathkonis bani, virum prudentem et industrium, in eo capitanei loco presidere sciebat, sed ut animum cesaris Turcorum, qualis erga se esset, experietur." Dlugos 2001. 248, 24-26; 249. 1-3.

${ }^{843}$ "Cesar ipse responsionem mensibus tribus dare distulit, nuncium regium ad castrum tunc sue dicionis Smiderow illic moraturum transmittit." Dlugos 2001. 249, 5-7.

${ }^{844}$ „Omnibus viribus, dolis, promissis et ingeniis pro conquisicione castri utitur...Ut autem facilius pociatur votis, magnam partem murorum bombardis demolitur, omnia fossata castri lignis complet." Dlugos 2001. $249,7-8,9-10$. 
Dlugos beszámolójának újdonsága az, hogy a török hajók zárlatáról is tájékoztat. A szultán a várat a víz felöl is teljesen körülzárta a nyugati Alsóvárostól a kikötőig. , ,...A Dunán, amely a várat egyik oldalról körülfolyja, sok, fegyveresekkel megrakott hajót helyezett el, hogy következö napon a várat szárazon és vízen megtámadja." ${ }^{845}$ A lengyel forrásunk is megemlíti a nyíllal végrehajtott üzenetváltásokat a szultán és a védők között. „A szultán látta, hogy igéretekkel és a legdúsabb ajándékok felajánlásával - amelyeket »bolgár nyelven « irt levelekben nyíllal belöttek a várba és amelyeket Wladislaus királynak nyomban Budára jelentettek - nem képes a vár védöinek lelkeit sem megtörni sem megpuhítani. " ${ }^{846}$ Ezután megindította a szárazföldi ostromot.

A falak ellen indított rohamokat a védők leleményes módon visszaverték, mégpedig a várban lévő bombavető mozsarak puskaporának felhasználásával. Ami azért is érdekes, mert Dlugos nem említi a föld alatti aknák alkalmazását, azonban a tüzérséget igen. „A várkapitány, Ioannes vránai perjel... a rákövetkezö éjjel a bombavetők puskaporával (bombardarum pulveribus) a fahasábokat, amelyeket a törökök az árkokba dobáltak, összekeverte és ezeket a fahasábokat elrejtve a puskaporral böségesen befedte. Másnap azután a törökök serege, sáskaként, szárazon és vízen a vár ellen támadott és reménykedett, hogy a túlerővel győzni fog. A várárkokon, amelyeket az elözö napon fahasábokkal megtöltöttek, megszámlálhatatlan csapatokkal és hangos kiáltozással keltek át. Amíg a vár védöi a tervnek megfelelöen, úgy tettek, mintha vissza akarnák verni a rohamokat, azok (t. i. a törököké) száma megkétszerezödött, miközben valamennyien odafutottak és a várbelieknek nem színlelt félelmet okoztak, amíg néhányan a törökök közül létrákkal akartak a várfalakra felmászni, az alkalmasabbnak tünö időben a várbeliek a falról égö fáklyákat, fadarabokat, izzó szénparazsat dobáltak le. A sok és itt-ott hirtelen felgyulladt puskaporban a törökök a lángtól és váratlan büztöl megfulladtak és a már izzó fahasábok által, amelyeken maguk elöbb átkeltek, elégtek. Bizony a többiek megijedtek ettöl az eseménytöl, nem merték a falakat megközeliteni. "847

845 „plures naves in Danubio, qui castrum ab una parte circumfluit, hominibus armatis onustas locat, subsequenti die castrum per terram et mare impetiturus." Dlugos 2001. 249, 11-12.

846 „Videbat enim promissionibus et largicionum amplissimarum oblacionibus, quas iacebat sagittis Bulgarica lingua et literis conscriptas in castrum et que ad Wladislaum regem originaliter in Budam deferebantur, animos gubernatorum castri nec frangi nec emolliri posse." Dlugos 2001. 249, 12-15.

847 „Capitaneus autem castri Ioannes prepositus de Wrano omnia... nocte subsequenti bombardarum pulveribus ligna in fossata per Turcos proiecta commiscet et largo pulvere ligna ipsa in locis abditis consternit. Dum igitur altera die Turcorum exercitus, quasi locuste, impetum per terram et aquam contra castrum facerent et multitudine vincere sperarent, fossata murorum, que pridie lignis impleverant, supergrediuntur cum immensis cohortibus et clamore. Et dum castri defensores ex proposito dissimularent eos repellere, duplicatur eorum numerus, et omnibus accurrentibus pavoremque castellanorum, non dissimulationem pretendentibus, dum aliqui ex illis scalis muros castri conscendere 
A bolgár szakirodalomban, bár Thuróczyra hivatkozik, Cvetkova is ehhez hasonló változatot ismertet. A bolgár történész szerint a védők a várárkokat töltötték meg fával, robbanóanyaggal és erre szórták a lőport. Másnap hajnalban, amikor az oszmán seregek a várárkokon való átkelést megkísérelték, a védők égő fáklyákat hajítottak az árkokra. ${ }^{848} \mathrm{~A}$ legutóbbi többkötetes, szerb történeti összefoglaló munkában a történészek mind a két ostromváltozatot ismertetik. ${ }^{849}$

A szárazföldi ostrommal egyidejüleg a vízi küzdelem is eredménytelen volt, mert a török hajókra a védők bombavetőkkel eredményesen löttek. „Azok, akik a víz felöl, a hajókon harcoltak, sem jártak nagyobb szerencsével. Ugyanis sok hajó a várból kilött bombavetök találatától a vízben elsüllyedt. Egyeseket, akiket a szelek rohama a várfalhoz sodort, amely mint ismeretes a Száva és a Duna medréig elörenyúlik, a várbeliek elfogták. Ez a harc és küzdelem a nap elsö órájától estéig tartott, és a törököknek a vár birtoklásának reményétől feltüzelt lelkét a támadásuk során megrémitette és megtörte. "850

Dlugos szerint mindezek után Murád már nem folytatta tovább az ostromot. „A törökök császára miután a nagy veszteséget belátta, hat hónapot a vár ostromával hiába töltött, amint tábort bontott, rendezetlenül saját földjére távozott. Mégis sok embert mindkét nemböl az ostrom ideje alatt Erdély földjén elfogva siralmas szolgaságba vetett." Mindebből az derül ki, hogy az ostrommal egyidejüleg Erdélybe is portyázó török csapatok törtek be. Erröl a török forrásaink tudósítanak bővebben. ${ }^{852}$

A szultán végül „Nem korábban, mint amikor az ostromot befejezte, Petrus Lancziczki-t Wladislaus királyhoz visszaküldte, megüzenve általa, hogy amennyiben békét akar, Nándor Fehérvár váráról, ahonnan elüzték, mondjon le neki (resignaret) és engedje (vissza)

niterentur, oportuniori viso tempore castrenses emittunt faces, ticiones et carbones ardentes de muro. Et subito in multis et variis locis accensis pulveribus Turci flamma et fetore repentino suffocantur et per igna iam ardencia, que ipsimet congesserant, consumuntur. Ceteri successu tali perterri nec murum contingere ausi sunt." Dlugos 2001. 249, 15-16, 17-28.

${ }^{848}$ Cvetkova 1988. 44.

849 „1440 áprilisában megkezdődött az ostrom. A védőknek az erős tornyok és a mély árkokkal szegélyezett kettös falak jelentették a legnagyobb segitséget ... II. Murad titokban föld alatti alagutat kezdett ásatni ... ök is (t. i. a védök) elkezdtek ásni az ellenséggel szemben ... Katonái (t. i. Murádé) betömték a vár körüli árkot, s létrákon másztak a falakra, ahol nyílzáporral és fáklyaesövel várták öket, s a faanyagokkal együtt ök is meggyulladtak. Súlyos harcok után a törököknek mégis vissza kellett vonulniuk, s Belgrád hat teljes hónapig tartó ostrom után felszabadult” (Kacziba Ágnes fordítása). Историја 2000. 250.

${ }^{850}$ „Hi vero, qui ex aqua in navibus pugnabant, non blandiorem fortunam experti sunt. Plures enim naves fulmine bombardarum a castro percusse ab aquis absorbte sunt, alie impetu ventorum ad murum castri, qui notabiliter in alveos Szawe et Danubii protensus est, appulse, per castrenses capte. Conflictus autem et certamen huiusmodi ad hora prima diei duravit usque in vesperam et animos Turcorum spe pociundi castri alacres successu suo perterruit et confregit.” Dlugos 2001. 249, 28-29, 250. 1-4.

851 „Cesar Turcorum magna clade taliter accepta, sex mensibus in castri obsidione incassum exactis, motis castris in terras suas confusus abiit. Multos tamen utriusque sexus homines sub tempore obsidionis in terra Septemcastrensi comprehensos in servitutem miserabilem abduxit.” Dlugos 2001. 250, 4-7.

${ }^{852}$ Nesri és Ásikpasaze is hasonló portyázásokról tudósít. Lásd: a 8. 5. fejezetet. 
Szerbia területeihez." ${ }^{\nexists 53}$ Ez jól mutatta, hogy a szultán bár az ostrom eredménytelenségét belátta, de a háborút egyáltalán nem érezte eldöntöttnek, sőt ezzel a feltétellel Ulászló királytól tulajdonképpen a tatai szerződés érvénytelenné nyilvánítását kérte. Az általa uralt Szerbiához való visszacsatolás az oszmán uralmat is biztosította volna.

A latin nyelvü lengyel források közé soroljuk az olasz származású Filippo Buonaccorsi, humanista nevén Callimachus Experiens (1437-1496) Ulászló király életéröl (Historia de rege Vladislao) szóló munkájának vonatkozó részeit, amelyek bőségesen és ékes latinsággal megírva kiegészítik eddigi ismereteinket. ${ }^{854}$ A humanista egyébként IV. Kázmér lengyel király (1446-1492) legkisebb fia, Zsigmond lengyel herceg nevelöje volt. ${ }^{855}$ Callimachusszal kapcsolatban állt még a lengyel humanista, Gregorius Sanoceus (Grzegorz z Sanoka, Szánoki Gergely) is, aki Ulászlóval érkezett Magyarországra, később váradi kanonok lett és akiről Callimachus Experiens humanista életrajzot is írt (Vita et mores Gregorii Sanocei). Kristóf Ilona véleménye szerint Callimachusszal kapcsolatban erős kritikát is kell gyakorolnunk, mert más müveiben is sok a ténybeli tévedés, nem ellenőrizte alaposan állításait. ${ }^{856}$

Callimachus is a belháború törökök számára kedvező alkalmát említi, amelyről a szultán a kémei útján értesülhetett. „Eközben a török szultán úgy gondolván, hogy a belháború kedvezö alkalmával Magyarországot könnyen elfoglalhatja, hozzáfogott Belgrád ostromához, és amikor egyik és másik oldalról indított támadással kevés eredményt ért el, ostromzárral akarta azt hatalmába keríteni." ${ }^{, 857}$

Az ostrom alkalmazott módját természetesen meghatározta a vár földrajzi fekvése. Callimachus - humanista történetíró módjára - mielött a történelmi esemény elmondásához hozzá kezdene, a város földrajzi fekvését tárgyalja, de megemlíti a falak erős voltát, sőt a várárkokat is. „Ez a város (oppidum) ahol a Duna és a Száva összefolyik, a hegyoldalban van úgy, hogy ennek Alsó Részét (Alsóváros) mindkét folyó körülveszi.

853 „nec prius, nisi soluta obsidione, Petrum Lancziczki ad Wladislaum regem remisit, denuncians per illum, ut si pacem vellet, castrum Alba Nander, a quo repulsus erat, sibi resignaret et terris Rascie cederet." Dlugos 2001. 250, 7-9.

854 A mű első, augsburgi kiadása: De rege Vladislao (1515. május 30.). Modern, általunk használt latinlengyel kétnyelvü kiadása: Callimachus 1961. A szerzőről ld.: Szörényi László: Az epikureus premachiavellista és Mátyás király udvara. Callimachus Experiens. In: Philologica Hungarolatina Bp., 2002. 38-50. (Szörényi 2002)

${ }^{855}$ Zombori 2004. 219.

${ }^{856}$ Kristóf Ilona: Egy lengyel humanista Magyarországon, az elfeledett Szánoki Gergely. Acta Academiae Paedagogicae Agriensis Sectio Historiae XXXIII. Szerk.: Gebei Sándor. Eger 2006. 21-32. (Kristóf 2006)

857 „Interea Turcus per occasionem intestini belli Hungariam facile ab se occupari posse ratus Belgradum oppugnare adoritur et cum parum uno atque altero impetu profecisset, obsidendo in potestatem redigere volebat" Callimachus 1961. 72, 8-10. 
Ugyanis délkeletre a folyó felé helyezkedik el, szélesen és lejtösen a Duna folyónál ér véget, délen pedig a Száva éri el. A város többi részét pedig kiterjedt fal és várárok választja el a szárazföldtöl." ${ }^{\text {858 }}$

Callimachus is kihangsúlyozta az oszmán-török blokádot. A szultán hajókkal és táborával teljesen körülvette a várat, elvágva a külső segítségtől a védőket. „A törökök tehát hajókat épitettek, amelyekkel mindkét folyón az odahelyezett védelmet, mind az örcsapatokat, mind pedig a ki-be közlekedést elkeritették és akadályozták. A török szultán így különbözö irányból a várat úgy körbevette, hogy az ostromlottakból egyáltalán senki se juthasson ki vagy mehessen be." ${ }^{859}$ A török szultán „ezután nem hagyott fel azzal, hogy feltöltse a várárkokat, sem, hogy ostromgépekkel töresse a falakat, miután szemben faostromtornyokat épittetett elövédként, hogy a védöket a falaktól távol tartsa." ${ }^{860} \mathrm{Fa}$ ostromtornyok használatát egyedül Callimachus említi.

Ugyanakkor, a forrás szerint, a törökök élelemkészlete is fogyatkozóban lehetett, miközben a védők ellenálló képességét a török lebecsülte, a folyamatos, hosszú ostrom fenntartása volt a cél. „Eközben a sajátjai is szenvedtek az élelmezés hiányosságaitól és nem tünt úgy, hogy hosszú ostromot végig tud vinni, minthogy a seregben mindenütt hallatszottak az éhségtöl sorvadók panaszai és egyedül az tartotta vissza, hogy már akkor ne szakadjon félbe az ostrom, mert már elveszett a remény a védök megsegitésében - a belháború miatt, amellyel a királyság el volt foglalva - és egyáltalán nem volt valószínü, hogy a várbeliek hosszú ideig meg tudják magukat majd védeni."

A védők élén azonban vitéz katona állott. „A parancsnok ott már régóta bátor örsereggel Vránai János, egy bátor és a háború dolgában jártas férfi volt, firenzei ${ }^{862}$

${ }^{858}$ Callimachus 1961. 72, 11-15. „Id oppidum inter Danubium Sauumque, ubi commiscentur, sic est situm in cliuo, ut ab utroque amne inferiora eius abluantur: si quidem, qua Eurum spectat, in ripam usque late proneque deuexum desinit in Danubium, qua Austrum excipit, Sauus allabitur. Reliqua ipsius per cliuum extensa muro et fossa ueluti diuiduntur a continenti."

${ }^{859}$ Callimachus 1961. 72, 15-18. „Itaque fabricatis nauibus, quibus in utroque flumine adhibita custodia tam subsidia quam commeatus arcerentur interciperenturque, Turcus castra sic ex diuerso metatus est, ut nemo omnino ab obsessis emitti induciue posset..."

${ }^{860}$ Callimachus 1961. 72, 18-20. „Nec subinde destitit aut opplere fossas aut machinis quassare muros coaedificatis etiam ligneis turribus e regione propugnaculum arcis ad defensores e muro exturbandos."

${ }^{861}$ Callimachus 1961. 72, 21-25. „Cum interim sui quoque inopia commeatuum afficerentur neque appareret diuturnam moram obsidionis toleraturos, quandoquidem passim in exercitu exaudirentur querelae fame extabescentium solumque id, ne iam tum oppugnatio intermitteretur, retinebat, quod desperato suorum auxilio propter intrinseca certamina, quibus regnum agitabatur, minime credibile erat oppidanos dudum se defensuros."

${ }^{862}$ Itt Callimachus téved, mert valójában curzolai, a kortárs források szerint viszont Raguzai eredetű családról van szó. Ök magukat is kezdetben Raguzai-aknak nevezték. Lásd az 5. 2. fejezetet. 
származású lévén, az etruszk találékonyságot ötvözte a magyar bátorsággal és a város védelmében derekasan helytállt minden tekintetben. "863

Ekkorra már híre mehetett a végvár körülzárásának, amely lépéskényszerbe hozta Ulászlót is. Megpróbált időt nyerni azzal, hogy követeket küld a szultánhoz. „Ulászló mivel úgy gondolta, hogy a török szultán vállalkozását vissza kell tartani, amíg sereget gyüjt és felállit -... mindenek elött azt gondolta, hogy az ostrom(zár) feloldása céljából követeket küld." 864 Callimachus azonban a névtelen lengyel levélírótól és Dlugostól eltérően más személyekről tud. „Dobrogostius Ostrorogeus ${ }^{865}$ és Lucas Gorcensis ${ }^{866}$ lettek elküldve..."867

A követek fogadtatása hasonló volt, a már Dlugosnál megismertekhez. Murád nem akart (már) egyezkedni Ulászló követeivel. A szultán a követeket mindenekelőtt Szendrőbe vitette kivizsgálni és próbára tenni „,mintsem hogy nekik válaszoljon. ${ }^{" 868}$ A védőket akarta ajándékokkal a megadásra rábírni. „Tehát (a szultán) előbb a megadásba vetve reményét, miután elfogták a várnagy üzeneteit, végül megvesztegetéssel elpártolásra kezdett buzditani. A (t. i. a török) katonák a megadás böséges díját tartalmazó leveleket, nyílvesszökhöz hozzáerösitve, a falak fölött, hol itt, hol ott a várba röpítették. Amikor pedig valóban semmi válasz sem érkezett, (a szultán) a katonák gyülését hívta össze." $869 \mathrm{Az}$ ostrom leírása csak ezután kezdődik. „Mihelyt kivilágosodott (a törökök) ágakat és rőzsenyalábokat hoztak, hogy a várárkokon át az utat kiegyenlitsék - mert már azelött azokat feltöltve, fahasábokat és gyeptéglákat dobtak bele nagy sietséggel - továbbá létrákat és más, várostromokhoz szükséges eszközöket (oppugnandarum urbium apparatum) vittek és elörenyomultak." ${ }^{870}$

${ }^{863}$ Callimachus 1961. 72, 25-28. „Praefectus iam pridem cum valido illic praesidio erat Ioannes Vranus, uir audax et rei bellicae peritus, quippe quod Florentia ortus atque oriundus Tusco ingenio Hungaricam ferociam adiunxerat et constabat strenue oppidum defendi undique."

${ }^{864}$ Callimachus 1961. 72, 29-32. „Vladislaus, cum censuisset Turci conatus retundendos, dum copias colligeret instrueretque... ante omnia per legatos de dissoluenda obsidione agendum putauit."

${ }^{865}$ Dobrogostius de Ostroróg palatinus, kamenyeci várúr (1443-1467), majd gniezno-i (1468-1478), 1479ben halt meg. Dlugos 2001. 404. (66. lábjegyzet)

${ }^{866}$ Lucas de Górka. Királyi udvari tisztviselő. Poznań-i palatinus, Nagy Lengyelország capitaneus generalis-a 1475-ben bekövetkezett haláláig. Dlugos 2001. 404. (60. lábjegyzet) Ulászló követe volt Murádnál és részt vett a várnai csatában is. Callimachus 1961. 74. Lásd még 7. 1. fejezetet.

${ }^{867}$ Callimachus 1961. 74, 1. „Missi igitur Dobrogostius Ostrorogeus et Lucas Gorcensis...”

${ }^{868}$ Callimachus 1961. 74, 13-15. , in Smiderouum perduci commisit certus secum omnia prius experiri et tentare, quam illis responderet."

${ }^{869}$ Callimachus 1961. 74, 15-18. „Itaque deditionis spem prius aggrediens captatis colloquiis maiori quam aliquando ambitu ad defectionem sollicitare coepit, sed et litterae ingentia defectionis praemia continentes sagittis illigatae a militibus passim supra murum in oppidum excutiebantur. Verum ubi nihil pacati ab aliquo respondebatur, ad uocata contione."

${ }^{870}$ Callimachus 1961. 80, 11-14. „Vbi illuxit, ad murum producti malleolos cratesque aequando itineri per fossas ligno ac cespite coniecto iam pridem tumultuarie oppletas nec minus scalas et uectes ceterumque oppugnandarum urbium apparatum ferentes procedebant" 
„Míg eközben azok, akik a fából készült ostromtornyokból harcoltak semmi esetre sem engedték, hogy a védök a falon szilárdan ottmaradjanak, sürü nyilazással támadva az ellenséget az odavezető utat sajátjaiknak majdnem gondtalanná tették. Amit a várbeliek (oppidani) alig-alig épségben nagyon nehezen viseltek el. Immár kétségtelenné vált, hogy a török szultán eröszakkal próbálkozik, ha a megadás reménye nem válik valóra."871

A védők is berendezkedtek az ellenállásra. „Mialatt (a szultán) a megadásra csábitott, ök maguk (védők) a városnak a folyóig nyúló részeit a vízi támadás ellen katonákkal és védfalakkal és kögolyókat és tüzet kilövö ágyúkkal (machinis ignem aut lapides excutientibus) csendben megerösitették. A másik oldalon (a szárazföldi) pedig amennyit a faltörögépek ereje (muri tormentorum vis) megnyitott, (a falakat) épülettörmelékkel és földdel a megfelelö magasságig serényen felépitették. Az éjszakai csendben pedig azokat a fahasábokat, amelyeket a (törökök) várárkokba dobáltak, szurokkal, olajjal, kénnel és puskaporral (incendiarioque pulvere), amennyi készletük csak volt, leöntötték."872

Mint az örök kárhozat tüze tárul elénk az a várárkokban meggyújtott puskapor általi gyors tüzhalál, amely a törököket ekkor érte, és amely tüz a török táborra is átterjedt. Callimachus szerint ez a veszteség a szárazföldi haderő számára megsemmisítőnek bizonyult, mert az ostromgépeket is elpusztította. Érdekes megemlíteni, hogy eddigi forrásainkkal ellentétben, de - Dlugoshoz hasonlóan - a szerző szintén nem említett aknákat, hanem várárkokat.

„Így amikor a törökök óvatlanabbul, mint szabad, rohamozva a várfalat, szilárdan tartották helyüket a rözsenyalábokon, amelyekkel az utat feltöltötték, hirtelen a védök a várfalról fáklyákat és más, sokféleképpen elökészitett tüzcsóvákat röpítettek (a törökökre), elöbb rendkivül nagy félelmet, majd pedig nem kis veszedelmet idéztek elö. Miután a tüz sok helyen fellobbant, szinte egy pillanat alatt minden anyagra, amelyre a (támadók) ráléptek annyira átterjedt, hogy ugyanabban a pillanatban veszélytelenül sem elörenyomulni, sem visszavonulni nem volt lehetöségük. Ott iszonyú nagy riadalom és küzdelem volt, mert az ostromtornyok lángra lobbantak, (tüz) futott végig a (török) táboron, ahol a levegö összekeverte a füstöt és a lángot, amit a folyóvizek csak a reggeli

${ }^{871}$ Callimachus 1961. 80, 14-18. „qui ex turribus ligneis pugnabant, haudquaquam defensores in muro consistere permittent et crebris sagittis hostem impetendo prope otiosum accessum suis exhiberent. Quod haud sane omnino aegre ferebant oppidani. Certi enim fore, ut Turcus uim experiretur, si deditionis spes non succederet. ',

${ }^{872}$ Callimachus 1961. 80, 18-24. dum ille ad defectionem allicit, ipsi partes oppidi ad flumina porrectas contra naualem impetum hominibus propugnaculisque et machinis, ignem aut lapides excutientibus tacite firmauerant; ex parte uero altera quantum muri tormentorum uis aperuerat, rudere simul et gleba strenue prope ad iustam altitudinem coaedificauerant et per noctis silentium pice, oleo, sulfure incendiarioque puluere, quantum copia fuit, ligna imbuerant..." 
órákra oltottak el. Ez a körülmény pedig magát a várat a tüztöl sértetlenül megörizte. Tehát, amikor a zürzavar kitört a hadrendekben, ki-ki a saját életének megmentésén buzgólkodva mindenfelé tekintgetett, eldobta fegyvereit és amerre a menekülése ekkora vészben szabadabban megnyilt, arra elfutott. De a tüz mind saját magától, mind pedig a levegö áramlásától, gomolyogva, esetlegesen terjedve végig az elökészitett anyagon át, egyrészt a menekülöket, akik a futásban leltek éltető eröt, visszatartotta, másrészt a kivezetö utat, amelyen át menekülni igyekeztek, mintegy öket megelözve tölük elorozta. Egyeseknek a füst a menekülési út látványát, másoknak a zürzavar a (józan) eszét ragadta el... Néhányan az utolsó sorokból és a megégettek és legyengültek a táborba menekültek vissza. A többieket nagy számban a tüzvész elemésztette a hátrahagyott összes ostromgéppel együtt. "873 Callimachus leírásából az következik, hogy valószínűleg a szél nem a védők, hanem a török tábor felé fújt, felgyújtva azt, ez akadályozta meg az ostromlókat a menekülésben.

A vízi ostrom is kudarcba fulladt. „Valójában a hajókról vívott harc sem volt szerencsésebb, ezek közül nem keveset a köhajítógép ereje (vis lapidum tormentis) semmisitett meg, nem keveset pedig a tüz járta át. A többi hajót az evezösök és a kormányosok ijedtsége vagy pedig a veszélyben forgott hajókról a még épen maradt hajókra menekülöket befogadók szándéka igen messze üzte a várostól." ${ }^{874}$ A vízi harc során a bombavetők lövedékei által okozott tüz vagy a görögtüz használata is felmerülhet.

Ebben a helyzetben II. Murád szultán feladta az ostromot, szakrális büntetést látott a kudarcában. „Ettöl a csapástól megrenditve a török szultán, mivel nem emberi erö vagy okosság folytán, hanem valamilyen isten ereje által érte a csapás és miközben éhínség dúlt

873 Callimachus 1961. 80, 27-40; 82. 1-6. „Itaque cum eo incautibus quo licentius Turci ad murum properantes constitissent in cratibus, quibus iter substrauerant, cohorti repente a muro oppidani faculas aliumque multipliciter paratum missilem ignem contorquendo, terrorem ingentem prius, mox haud minorem stragem intulere, excitato pluribus in locis incendio et uno ueluti momento per omnem, quam calcabant, materiam sic propagato, ut neque in eodem uestigio impune perseuerare neque progredi neque regredi facultas esset. Tetra ibi luctatio formidoque, nam turres etiam ignem conceperant trepidabaturque in castris, in quae fumum flamamque conuoluebat aura, quam matutinis temporibus flumina exhalant; quae res ab incendio oppidum immune seruauit. Ruptis igitur conturbatisque ordinibus quisque saluti suae expediendae intentus circumspectare undique, arma abiicere et qua propius liberiusque effugium in tanto malo apparebat, excursare. Sed ignis tam suo quam aurae impetu temere per materiam incendio praeparatam uolitans aut fugientes perstrictis in cursu neruis retinebat aut exitum, per quem effugere properabant, praeueniendo occupabat. Sed et quibusdam fumus prospectum ad fugam, quibusdam conturbatio etiam mentem abstulerat...pauci ex ultimis ordinibus et iidem ambusti debilitatique in castra refugere; ceteros ingenti numero consumpsit incendio cum reliquo" totius oppugnationis apparatu."

${ }^{874}$ Callimachus 1961. 82, 7-10. „Neque uero nauibus felicius pugnatum; quarum nonnullas uis lapidum tormentis efflata dissipauit, nonnullas ignis implicuit. Reliquas fere aut remigum gubernatorumque consternatio aut conatus recipientium se a periclitantibus ad integras naves quam longissime ab oppido naufragas exegit." 
,hogy azon felül a hadsereg lázadás és felkelés nélkül élje túl -amire volt esély elhatározta az ostromzár feloldását." ${ }^{875}$ Azonban más események híre is erre késztette. A forrásaink közül Callimachus tudja a legtöbbet I. Ulászló király tevékenységéről, és a szultán békefeltételeiröl.

„De híre jött annak, hogy a királytól erős, összegyüjtött hadsereg a napokban Szegedre sietett..."876 Murád ezek szerint igyekezett leplezni kudarcát és elhívatta a Szendrőbe küldött lengyel követeket és előadta nekik túlzó békefeltételeit, amelyekben lényegében a tatai szerződés érvénytelenségére és a „nemo plus iuris...”-jogelvére hivatkozik. Ezeket a részleteket egyedül Callimachustól tudjuk. „...ha Ulászló lemond Szerbia azon részeiről, amelyet birtokában tart és az ostromlott Belgrádot, mintegy a szövetségkötés zálogaként kiüritve átadja, akkor majd maga el fog vonulni az ostromtól azért, hogy Ulászlónak haladékot adjon a tárgyalásra. Javasolja, hogy ezekkel a feltételekkel inkább barátságot fogadjanak, mintsem e csekélység megtagadásával, amelyet követelnek, mindkét királysága vita tárgya legyen. Követeli mindazokat (a területeket), amelyek öt a háború jogán megilletik. Mindenekelött Ulászló legyen Magyarországra hívva. Nem lehetséges ${ }^{877}$ az, hogy a magyarok, amit ők maguk sem birtokolnak, más jogába átruházzák. „878

Ulászló egyáltalán nem tétlenkedett. Válaszlépése mindenekelőtt a segítség kérése volt Lengyel Királyságából, amelyről -forrásaink közül- egyedül Callimachus számol be. „Mikor ezeket megüzenték, akkor, mivel, úgy tünt, hogy az ország nyugalma a királynö által semmi esetre sem áll helyre, Ulászló királyt rászoritották arra, hogy Lengyelországba hirt küldjön a magyarországi állapotokról, és hogy milyen török haderö fenyegeti. Azt is kérte, hogy küldjenek katonákat és pénzt zsold céljára. Elhatározták, hogy erre a

${ }^{875}$ Callimachus 1961. 82, 11-13. „Ea clade perculsus Turcus quasi non ope aut consilio humano, sed a numine aliquo suis inflicta esset grassanteque etiam fame supra quam ut sine tumultu et seditione in exercitu ferri iam spes esset, obsidionem dissoluere constituit."

${ }^{876}$ Callimachus 1961. 82, 13-15. „Sed et fame erat exercitum satis ualidum congregatum iam a rege Segedinum accursurumque propediem..."

877 Véleményem szerint ez a mondat lényegében a római jog „nemo plus iuris ad alium transferre potest, quam ipse haberet." (D. 50. 17. 54) Ulpianus megfogalmazásában ránk maradt alapelvét fogalmazza meg. Brósz Róbert-Pólay Elemér: Római jog. Budapest 1989. 230. (Brósz-Pólay 1989), Földi András-Hamza Gábor: A római jog története és instituciói. Budapest 1996. 318. (Földi-Hamza 1996), Molnár ImreJakab Éva: Római jog. Szeged 2003. 199. (Molnár-Jakab 2003) Nótári Tamás: Római köz- és magánjog. Szeged 2011. 150. (Nótári 2011) Az érdekes az, hogy ezt az eredendően magánjogi tulajdonszerzési jogelvet a közjogban alkalmazták.

${ }^{878}$ Callimachus 1961. 82, 17- 23. „si Vladislaus cessisset ea particula Rasciae, quam tenebat, et Belgradum sibi uelut obsidem pignusque foederis uacuum tradidisset. Abscessurum se tum quidem ab obsidione, ut consultandi spatium Vladislao exhiberet; suadere, ut mallet ea conditione in amicitiam recipi quam negando pauca, quae postulabantur, de summa utriusque regni disceptare; petere se ea, quae iure belli sibi deberentur, priusquam Vladislaus foret in Hungariam accitus; non potuisse Hungaros id, quod ipsi non habebant, ius in alium transfundere..." 
követségre Sanoceust ${ }^{879}$ küldik, akinek ékesszólása nem kevesebb, mint amit a helyzet súlyossága megkövetel, ö könnyen el tudta érni, hogy e kívánságokat teljesitsék. A lengyel föurak ugyanennek a megérkezéséig összegyültek Corcinum ${ }^{880}$-ba... „881

Callimachus írásában a Korczynban megtartott lengyel (ország)gyülésen Sanoceus egy hosszú beszédet ad elő, amely eredményesnek bizonyult, mert „mindenki kellö határozottsággal megszavazta ugyan a nyújtandó segitséget, de hogy milyen számban adjanak katonát és pénzt, ezek vita tárgyai maradtak. Voltak ugyanis, akik a Lengyel Királyság minden segitségét megszavazták a hadjáratra és Magyarország békéjének megteremtésére azonnal a török elleni elörenyomulást javasolták, ameddig a török megzavart és fel nem szerelt hadsereggel megakadt Belgrádnál, mintha rendkivüli vihar hajótörése húzná vissza. A többiek, visszautasitva azt, hogy országukat védtelenül hátrahagyják a tatárok szomszédságában és a háborgó Litvánia mellett, meghatározták a katonák és pénz számát, ezekböl azonban a legkevesebbet. Mert akik a legtöbbet, azok 12 000-t, akik a legkevesebbet, azok 2 000-t mondtak. Végül határozat született azokról, akik önként akarnak útra kelni a királyhoz magánemberként, önzetlenül és hogy az állam részéröl 5000 katonát küldenek éves zsolddal együtt. Ez a szám elegendö a királynak Magyarország lecsendesitésére és könnyen lesz növelhető, ha a szükség rákényszeriti..."882

Itt mindenképpen meg kell jegyeznünk, hogy a katonai segítségküldés mértékében és a lengyel külpolitika fő irányultságában 1440-ben megmutatkozó nézetkülönbségek nem pusztán a nemesi csoportok közötti ellentétből, hanem a földrajzilag nem egységes Lengyelország területileg más részét képviselő nemesi csoportok nézeteinek különbségéből adódtak. Zombori István szerint ez a 16. században is markánsan megmutatkozott, főleg a török kérdésben. Nagy-Lengyelország főnemesei, föpapjai a Német Lovagrend és a keleti szomszédok elleni erélyesebb fellépést tartották elsődlegesnek, míg a magyar földdel

${ }^{879}$ Gregorius Sanoceus az ismert lengyel humanista. Lásd: Kristóf 2006.

${ }^{880}$ A mai Korczyn városa.

${ }^{881}$ Callimachus 1961. 82, 26-32. „Ea denuntiatione tum etiam quia domi haudquaquam otium a regina fore apparebat, rex adactus est mittere in Poliniam nuntiatum, quo in statu res Hungarica esset et quae belli moles a Turco immineret petitumque, ut miles et pecunia in stipendium mitteretur. Decretus est ad eam legationem Sanoceus, cuius eloquentia non minus quam rei necessitas persuadebat facile posse postulata impetrari. Polonorum primores sub aduentum ipsius conuenerant ad Corcinum..."

${ }^{882}$ Callimachus 1961. 88, 37; 90, 1-11. „omnes quidem pari asseueratione censuerunt, sed quo numero aut pecunia aut miles mitteretur, ea fuit disceptatio. Erant enim qui uniuersas regni in expeditionem decernerent et pacata Hungaria statim contra Turcum prodeundum dicerent, dum trepidus adhuc imparatusque haesitaret exercitu a Belgrado uelut e naufragio ingentis tempestatis reducto. Ceteri negantes oportere regnum иасиит propter Tartaros et tumultuantem Litifaniam milites et pecuniam definiebant, sed numero minime eodem; nam qui plurimum duodecim, qui minimum duo milia submittenda dicebant. Decretum tandem, ut his, qui sponte uellent, sine fraude esset ad regem priuatim proficisci et ut publicitus quinque milia militum cum annuo stipendio mitterentur; eum numerum satis tunc regi ad pacandam Hungariam facile augeri posse..." 
szomszédos, Krakkó központú, Kis-Lengyelország nemessége fö ellenségnek az oszmántörököket tekintette. E prioritásbeli különbség a lengyel külpolitikában egy évszázaddal később is markánsan jelentkezett. A török elleni elsődleges fellépés akkori vezéralakja, Krysztof Szydłowiecki kancellár tevékenységében. ${ }^{883}$

\section{3. A bizánci, klasszicizáló görög nyelvü források}

A görög nyelvü forráscsoportot két alcsoportra osztottam. Az első alcsoportot az ostromra vonatkozó, klasszicizáló görög nyelvü bizánci források alkotják.

A négy késö-bizánci, az ún. „hanyatlás történetírói” közül, Georgiosz Szphrantzész ${ }^{884}(1401-1478)$ Khronikon címủ munkájában a Palaiologosz bizánci császárok uralmát tekinti át 1258-tól 1476-ig. Ebben a müben, ahol várnánk, nem írt az ostromról (I. könyv, 31. fejezet). ${ }^{885}$ Mikhaél Kritobulosz, ${ }^{886}$ aki a Hisztoriai című történeti monográfiában az 1451-1467 közötti időszaknak, II. Mehmed szultán uralkodásának a történetét írta meg, nem szól Nándorfehérvár 1440-es ostromáról, azonban a korszak tüzérségéről írt megjegyzései figyelemre méltóak. Viszont a másik két bizánci történetíró megemlékezik az ostromról.

Laonikosz Khalkokondülész ${ }^{887}$ bizánci történetíró nagyszabású munkájában (Apodeixisz Hisztorión), melyet 1480 körül az Oszmán dinasztia felemelkedéséről írt, követve a hérodotoszi-thuküdidészi ún. klasszicizáló stílust, egy rövid szakaszban említést tesz

${ }^{883}$ Zombori 2004. 221.

${ }^{884}$ Történetíró, diplomata. 1401-ben született Konstantinápolyban előkelő családban. Fiatal korában bizánci császárok (II. Manuel, VIII. Palaiologosz Joannész) szolgálatában állt a Peloponnészoszon, a misztrai udvarban. Több törökökhöz indított követség tagja volt. 1468-ban szerzetes lesz. 1478 táján halt meg. Munkája az 1413-1477 közötti időszakot tárgyalja. ODB. 1937. (Alice-Mary Talbot szócikke) Moravcsik 1934. 230, Baán 2013. 416-417.

${ }^{885}$ Georgios Sphrantzes, Memorii 1401-1477. Ediţie critică de Vasile Grecu. Bucureşti 1966. (Grecu 1966)

${ }^{886}$ Mikhaél Kritobulosz (meghalt 1470 körül) történetíró. Imrosz szigetén született előkelő családban. Egyes feljegyzések szerint II. Mehmed szultán titkára lett volna, de ez nem bizonyítható. Felismerve az Oszmán Birodalom erejét, az együttmüködést kereste, 1456-tól Imbrosz szigetének kormányzója 1466-ig. Történeti müvét a szultánnak ajánlotta. Stílusában és nyelvezetében a klasszicizáló irányzatot követi. ODB. 1159. (Alice-Mary Talbot szócikke) Szövegkiadása: Critobuli Imbriotae Historiae. Recensuit Diether Roderich Reinsch. (Corpus Fontium Historiae Byzantinae, vol. XXII). Walter de Gruyter, Berolini et Novi Eboracii MCMLXXXIII. (A továbbiakban: Critobulos 1983) Morvacsik 1934. 233; Baán 2013. 371.

887 Laonikosz Khalkokondülész Athénban született 1432-1450 körül, előkelő családban. Onnan a Peloponnészoszra, Misztrába menekült. A török hódítás után Konstantinápolyban élt. 1480-as években írt történeti müvében ismertette az Oszmán Birodalom felemelkedését, Bizánc hanyatlását, az 1298-1463 közötti eseményeket. Közvetlen hozzáférése volt az oszmán dokumentumokhoz. Testvére, Demetriosz kiváló görög grammatikus, aki görög nyelvtant írt Erotemata címmel. Testvérével Itáliába telepedtek le. 1510-ben halt meg. Steven Runciman: Konstantinápoly eleste 1453. Budapest 2000². 192-193. (A továbbiakban: Runciman 2000) ODB 407. (Alice-Mary Talbot szócikke); Moravcsik 1934. 223; Baán 2013. 200-202. 
„Belogradész” (Nándorfehérvár) ostromáról (V. könyv). ${ }^{888}$ Először a város földrajzi fekvését ismerteti: „Ezt a várost kétfelöl 2 folyó fogja körül, egyik oldalról az Isztrosz (Duna), a másik oldalról pedig a Szava (Száva), amely a város mellett torkollik az Isztroszba. ${ }^{, 889} \mathrm{Az}$ előzmények kapcsán megemlíti, hogy miután Murád szultán (Amouratész) Brankovics György két fiát magánál tartotta és megvakíttatta, „Rögtön sereggel elvonult a paiónok (t. i. a magyarok) városához, Belogradészhoz." "890 Ezután következik az ostrom ismertetése a faltöretésről és az ostromlók és a védők által használt tüzfegyverekröl: „Mehmed fia, Murád (Mekhmetész fia, Amouratész) megostromolta a várost. A vár falát ágyúkkal (téleboloisz) ${ }^{891}$ törette és korántsem kis részét lerombolta. Serege pedig a város felöl elhárithatatlanul szenvedett a védök ágyúinak és puskáinak (télebolón kai téleboliszkón) ${ }^{892}$ böséges csapásától, amely rázúdult a szultán táborára, a katonákra, és mintegy ezernyi nyíl eltalálta a tábort." ${ }^{" 893}$ Khalkokondülész név szerint megemlíti az első roham vezetőjét, Alit, Evrenosz fiát, aki eredményesen harcolt seregével, és aki már korábban - mint láttuk - egy határ menti török támadást végrehajtott. A bizánci forrás sem tud föld alatti akna készítéséről, csupán a falak lerombolása után indított rohamról számol be. Ami inkább az aknakészítésnek a másik módozatát, a fal aláaknázását sejteti. „Ott (t. i. a táborban) Ali (Aliész), ${ }^{894}$ Vrenedzésznek a fia, aki a táborban bátorságáról volt hirres, elsőként kezdett harcot a falnál az övéivel, és miután árkot (taphron) ${ }^{895}$ ásott, a városhoz a lehetö legközelebb táborozott le saját csapatával. Ahogyan a falat lerombolták, az újonnan érkezettek bejutottak a várba és a vár nagy részét

${ }^{888}$ Darkó 1923. 25-26.

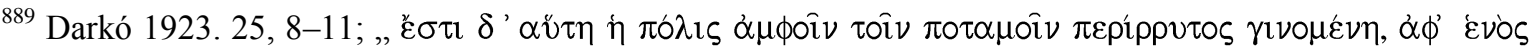

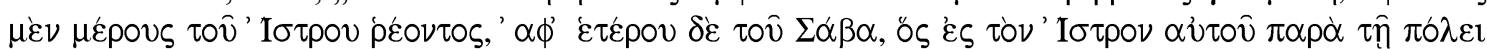

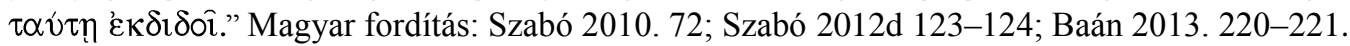

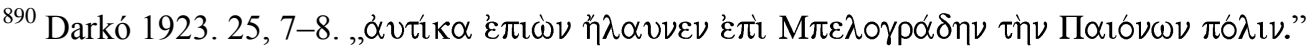

${ }^{891}$ Vesd össze: Szabó 2010. 72. A télebolosz szót itt „,messzire lövő fegyver” jelentésű ágyúnak fordítom, mert a szerző már Murád 1422. évi Konstantinápoly elleni ostromának leírásakor, egyértelmüen azonosíthatóan a korai ágyúkról beszélt. Lásd: még a 10. 4. fejezetet (Darkó 1923. 10-11)

${ }^{892}$ Ugyanennek a szónak a dēminutíváját, a kicsinyítő képzős változatát pedig puskának fordítottam. Lásd a 9. 2. fejezetet.

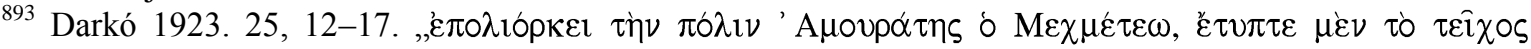

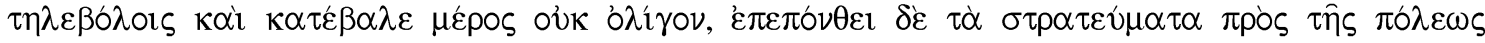

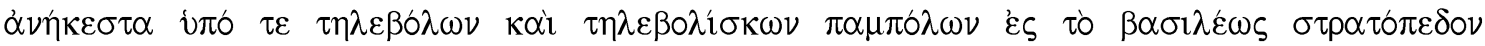

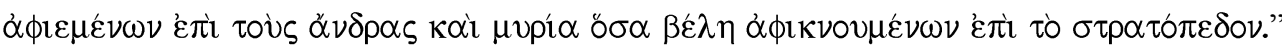

${ }^{894}$ A bizánci görög névalakban leírt Aliész ho tou Vrenedzeó a már korábban megismert Ali, Evrenosz bég fia. Cvetkova 1988. 55. Khalkokondülész előbb mondott munkájában többször megemlíti. Továbbá ő az, aki az 1486. évi névtelen krónikájában is szerepel a mohamedán időszámítás szerinti 834. évben „Evrenos Beg Oghlu Ali beg" In.: Die altosmanischen anonymen Chroniken. Text und Ubersetzung herausgegeben von Dr. Friedrich Giese. Teil II. Leipzig 1925. 88. (A továbbiakban: Giese 1925) Melikoff 1965. 721.

${ }^{895}$ A görög taphrosz szó jelentése kettős: egyrészt sáncot, másrészt pedig árkot is jelent. Mi ez utóbbi esetben a fal leomlását ezzel hozzuk kapcsolatba. Ali aláśsta, vagyis aláaknázta a várfalat. Györkösy AlajosKapitánffy István-Tegyey Imre: Ógörög magyar nagyszótár. Budapest 1993.1056. A továbbiakban: ÓGM. A földsánc kifejezésre a khóma szót használja például Dukasz is (1. uo. 1219). 
hatalmukba keritették. Miután a városban egybegyültek odaérkeztek, közelharcba bocsátkoztak az újonnan betörökkel és kiszoritva visszaverték öket a faltól. Mivel a hadsereget kiverték és a város elfoglalása neki (t. i. Murádnak) nem sikerült, elvezette a sereget és hazatért". 896

A másik, általunk idézett, 15. századi bizánci történetíró, Dukasz, ${ }^{897}$ aki Bizánc története című munkájában ${ }^{898}$ Nándorfehérvár ostromáról (XXX. 6-7.) és az előzményekről részletesebben beszámol. Dukasz leírásában jól érzékelhető, hogy a szultán az egykor magyar királynak vazallus államokat hogyan „semlegesítette” a hadjárata előtt. Murád (Mourat) elfoglalta Szendröt (Szmedrovon). Ebben - a török Âșik Pașazade tudósításához hasonlóan - nála is szerepel Geórgiosz (Branković György) szerb despota két fiának megbilincselése és megvakíttatása. ${ }^{899}$ Megemlíti Drakulioszt (II. Vlad Dracul) is, aki Vlakhiából (Havasalföld) járult Murád elé, hogy behódoljon. De a szultán megbilincselte és Kalliupoliszban (Gallipoli) örizetben tartotta egy bástyatoronyban, mivel attól tartott, hogy átáll a magyarokhoz. Túszként töle is fiait követelte, akiket - miután megkapta - Ázsiában őriztetett, a hüségeskü letétele után pedig elbocsátotta Drakulioszt. ${ }^{900}$

Dukasz nemcsak a város földrajzi helyzetét, hanem - a vár birtoklására vonatkozó - a magyar királlyal kötött (tatai) szerződés indokait is ismerteti. ${ }^{901}$ „Belgrád szerbiai város volt, jól megépitett és nehezen elfoglalható, két folyó a Duna (Danuviosz) és a Száva (Szava) torkolatánál. A magyar király kevés idővel korábban ezt a várost kérte, és Geórgiosz deszpotész nekiadta, attól félve, hogy ezt a törökök elfoglalják és a túlsó partra átkelnek, és majd elfoglalják a magyarok és a deszpotész városait is. Ugyanis a Szerbnek (t. i. a deszpotésznek) a túlsó parton még jelentös városai voltak. Azért, hogy a magyarok

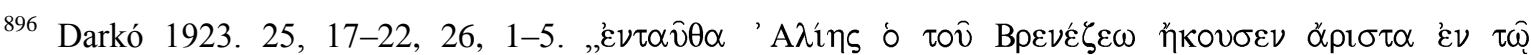

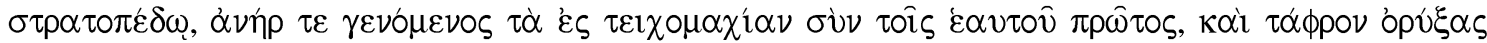

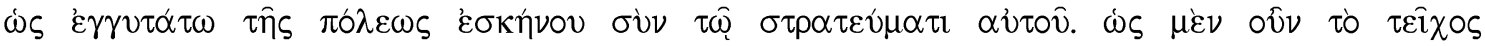

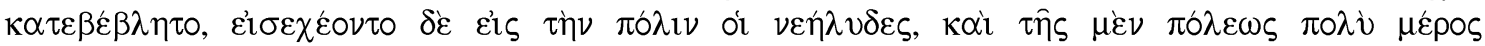

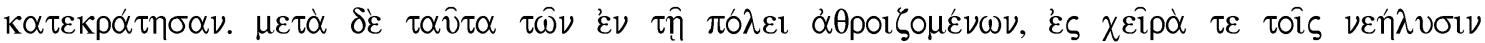

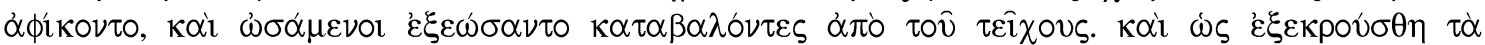

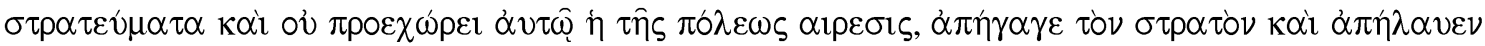
¿̇ं ớ Kov."

${ }^{897}$ Dukasz történetíró. (1400 körül, meghalt 1462-ben vagy később) A nevén kívül személyéről keveset tudunk, keresztneve talán Mihály. Nagyapja Mikhaél Dukasz, VI Joannész császár támogatója volt. Genovai szolgálatban, Giovanni Adorno, genovai podesta titkáraként dolgozott. Művét világtörténeti összefoglalóval kezdi és az 1341-1462 közötti éveket öleli fel. Törökül és olaszul is beszélt, sok esemény szemtanúja volt. Kritobulosszal ellentétben nem osztozott II. Mehmed dicséretében, megemlítette a szultán kegyetlenségét is. ODB. 656-657. (Alice-Mary Talbot szócikke) Runciman 2000. 192; Moravcsik 1934. 227-229; Baán 2013. 329-330.

${ }^{898}$ Kritikai kiadását lásd: Grecu 1958. 263-265.

${ }^{899}$ Szabó 2011

${ }^{900}$ Grecu 1958. 263.

${ }^{901}$ Magyar fordítások: Szabó 2010. 72-73, 77; Szabó 2012d 125; Baán 2013. 348-349. 
erősebbek és harciasabbak legyenek, a deszpotész átadta nekik Belgrádot, hogy ezután ök őrizzék azt. A deszpotész tehát átkelt az Isztroszon, amikor Murád (Murat) Szendrőt (Szmedrovó) magának követelte, ő (deszpotész) a saját városaiban tartózkodott, az öt védelmezö magyarokkal véve körül magát. Ekkoriban a törökök is ellenségesen viseltettek iránta (t.i: a deszpotész iránt)."902

Murád ezután tavasszal vonult Belgrád (Belogradó) ellen. „Miután a tavasz beköszöntött, nagy és erős sereggel elindult Ázsiából és Thrákiából és Belgrád (Pelogradó) városa ellen indított hadjáratot. "903 „Miután (Murád) Belgrádhoz érkezett, a sátrakat körben felállitatta, számos köhajitógépet, mind a kicsiket, mind a nagyokat felszereltette, sáncokat emeltetett és elökészittette, hogy a folyón át több mint száz triéresz hajózzon..."904

Dukasz elég pontosan ismerteti az oszmánok régimódi, szokásos „hideg” tüzérségét, de fontos említést tesz a felvonuló török flottáról is, amelyről más források, is szólnak (I. Ulászló Szomolnokbányához írt parancsa, Dlugos, Callimachus krónikája, a névtelen lengyel levélíró). Az ostrom azonban elhúzódott. , Teljes hat hónapon át körbezárta (t. i. a várat), ám nem boldogult sem szárazon sem vízen, söt sokakat elvesztett az ö legjobb szolgái közül a dögvész betegsége miatt és a várból, a hadiszerkezetekböl kilött lövedékek miatt. "905 Ezek az ólomlövedékek pontoszi „,mogyoró” nagyságúak voltak. ${ }^{906}$ Megtették a hatásukat, az ostrom végső szakaszát eldöntötték. II. Murád kénytelen volt veszteségeit felmérni a hosszú, 6 hónapos ostrom során. Dukasz szerint a seregben pestis is pusztított. Így a szultán hazavonult. A történetíró ezek után a bizánci egyházzal való unió létrehozásának történetével folytatja krónikáját.

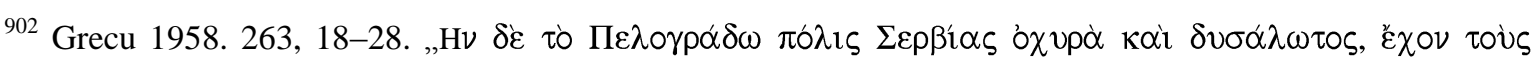

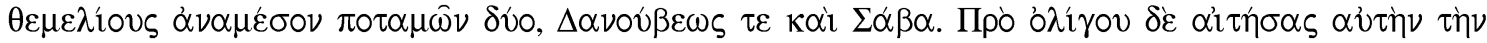

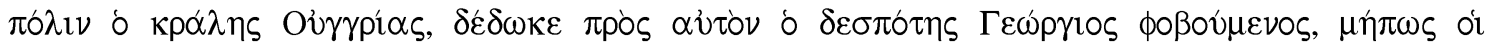

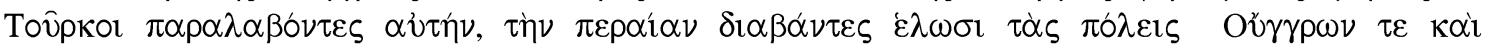

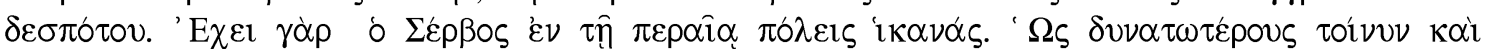

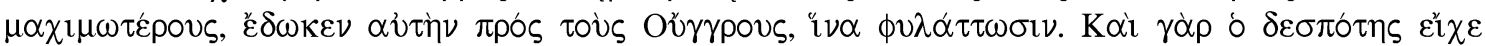

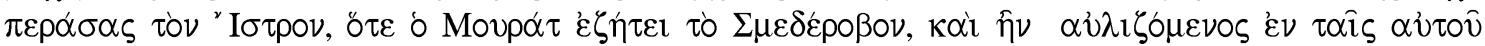

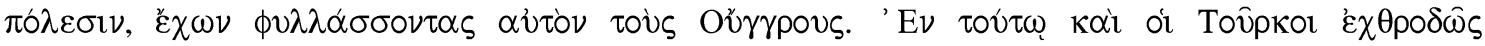

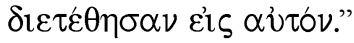

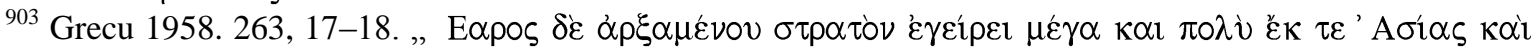

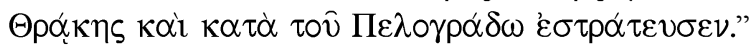

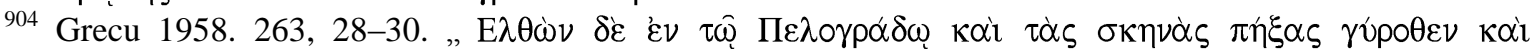

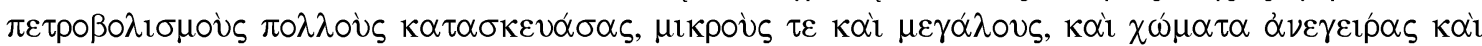

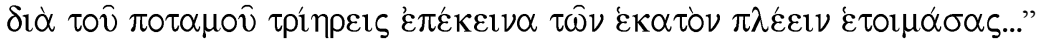

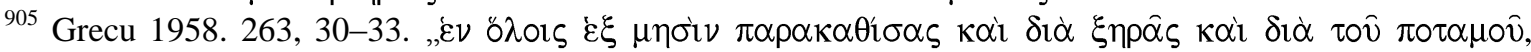

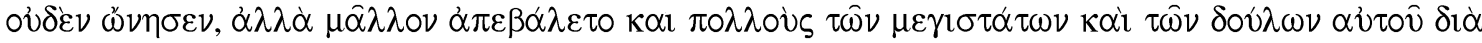

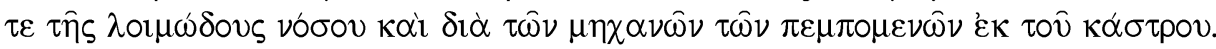

${ }^{906}$ Lásd a 10. 6. fejezetet. 


\section{4. A bizánci-újgörög nyelvü források}

Az antik görög történetírói tradíció megtartása mellett szükség volt olyan történeti munkákra is, amelyek az átlagos műveltségü és korabeli görögöt beszélők nyelvén íródtak. Sőt, a bizánci „hanyatlás történetíróinak” (Dukasz, Khalkokondülész, Kritobulosz, Szphrantzész) az atticizmus nyelvén és szellemében írt munkájuk is igényelte a beszélt görögre való lefordítást. Ez az új „nyelviség” már korábban is megmutatkozott és egy nagy történeti munkában is kimutatható. Ennek az új(görög) irodalomnak az (egyik) első példája a 14. századi Moreai Krónika, amelynek görög verses szövege már a 13-14. századi beszélt görög nyelven íródott. ${ }^{907}$

A 16-17. században már két poszt-bizánci történetírói irányzatot, „iskolát” különíthetünk el. Az egyik, a régi hagyományokat követö, amely még az oszmán-török hódítás alatt is ott maradt a fővárosban, immár Isztambulban, erős egyházi befolyás alatt (pl.: Manuél Malaxosz vagy Gennadiosz Szkholáriosz). A másik, föleg az itáliai görög közösségekben virágzott, vagy azokon a görög területeken, ahol az itáliai befolyás még megmaradt. Marios Philippides szerint ez utóbbi történetírói ,iskola” terméke lehet a korai 17. századi Codex Barberinus Graecus 111. is. ${ }^{908}$ Jól mutatja ezt az, hogy az utóbbi mü nem egyházi témát érintett és világi forrásokra támaszkodott. Sőt, nyugat-európai, latin nyelvü forrásokra! Ez korábban a bizánci történetírásban elképzelhetetlen lett volna.

Philippides szerint ez a „,nyugati görög”, poszt-bizánci történetírói „,iskola” az itáliai humanizmusban és a „Palaiologosz-reneszánszban” gyökerezett, míg a keleti, Isztambulban működő bizánci történetírók visszatértek a klasszikus bizánci történetírók módszereihez, viszont jóval több oszmán-török forrást használtak fel műveikben. ${ }^{909}$

Az atticizmust követő bizánci szerzőink, Khalkokondülész és Dukasz mellett azonban legalább akkora figyelmet kell szentelnünk az újgörög nyelvü, nyugati görög történeti forrásainkra is. Egyebek mellett azért, mert Codex Barberinus Graecus 111. nyelv- és fogalomhasználatában az akkori időszak jelentős haditechnikai, tüzérségi fejlődésének nyomát örizte meg, amelynek különösen az 1440. évi nándorfehérvári ostrom leírásában és források általi rekonstruálásában van kiemelkedő jelentősége.

\footnotetext{
${ }^{907}$ The Chronicle of Morea. Edited by John Schmitt. London 1904. XXIII. A továbbiakban: Schmitt 1904.

908 Byzantium, Europe and the early ottoman sultans 1373-1513. An Anonymous Greek Chronicle of the Seventeenth Century (Codex Barberinus Graecus 111) Translated and annotated by Marios Philippides. (Late Byzantine and Ottoman Studies, 4) New Rochelle, New York 1990. 11. A továbbiakban: Philippides 1990.

${ }^{909}$ Philippides 1990. 12.
} 
Nándorfehérvár 1440. évi ostromát egyebek mellett - a vonatkozó poszt-bizánci, nyugati görög történeti munkák közül - a Codex Barberinus Graecus 111-ban megörzött krónika egy fejezete tárgyalja. ${ }^{910}$ A magyar vonatkozású részekre 1930-ban, A $\gamma \nu \omega \sigma \tau o v$

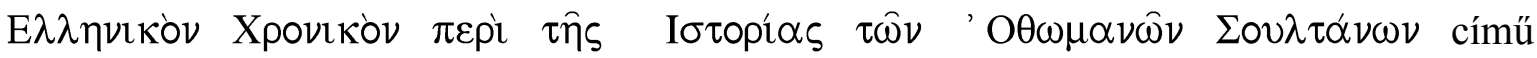
tanulmányában Moravcsik Gyula hívta fel a figyelmet. ${ }^{911}$ Sőt célul tűzte ki a kézirat szövegének kiadását is. Ezt azonban nem ö, hanem Georgiosz T. Zórasz végezte el 1958-

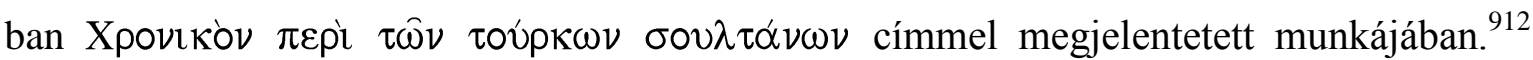
Zórasz kiadása az egyetlen fennmaradt vatikáni kéziratról készült, nem teljes, hiányzik az eleje és a vége, valamint éppen a II. Murád szultán uralkodásának utolsó éveiröl szóló részletek. Ezek közül újabb töredékeket P. Canard fedezett fel, amelyek már III. Mehmed (1595-1603) szultán életéről is beszámolnak. Úgy tünik, hogy ez egyúttal eldöntötte a Névtelen Krónika keletkezési idejének kérdését is: minden bizonnyal 1603-1671 közt írták. A krónika újabb részeit szintén Zórasz publikálta 1966-ban, ${ }^{913} \mathrm{~s}$ azóta több nyelvre lefordítva is napvilágot látott. ${ }^{914} \mathrm{~A}$ hazai szakirodalom azonban adós maradt az értékeléssel, így - 1440 vonatkozásában - ezt pótoljuk.

A krónika a szultánok uralkodásának időrendjében tárgyalja az Oszmán Birodalom eseményeit I. Murád uralkodásától (1373, 1326-1389) egészen II. Bayezid szultánig (1481-1512), az újabb töredékekkel együtt III. Mehmed uralkodásáig.

\footnotetext{
${ }^{910}$ Sajnos a szerzőjének kiléte ismeretlen, így a szakirodalomban a Névtelen Krónika elnevezés is használatos, azonban továbbiakban mi a mü 20. századi kiadójáról Anonymous Zoras-ként említjük. A kéziratot 1907-ben Seymour de Ricci fedezte fel a vatikáni könyvtárban, Antonio Barberini (1607-1671) kardinális könyvtára részeként és a Historia Imperatorum Turcorum címet adta neki. Annak első

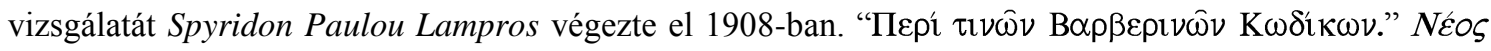

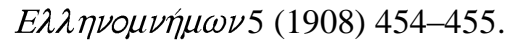

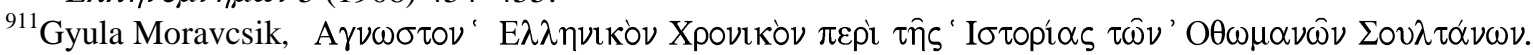

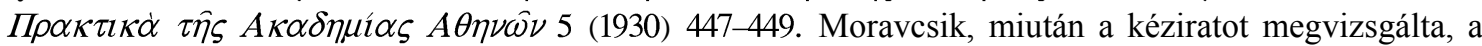
hazai kutatóközönség számára 1934-ben A magyar történet bizánci forrásai című munkájában részletesen ismertette a magyar vonatkozású részek tartalmát, így beszámolt az ebben a kódexben szereplő 1440. évi ostrom leírásáról is $\left(40^{\mathrm{v}}-41^{\mathrm{r}}\right.$, Moravcsik 1934. 239). Majd a Byzantinoturcica I. kötetébe is felvette e kódexet, sőt célul tüzte ki a kézirat szövegének kiadását is. (Gy. Moravcsik: Byzantinoturcica I. Die Byzantinischen Quellen der Geschichte der Türkvölker. Budapest 1942. 160-162) (Moravcsik 1942)

${ }^{912}$ Moravcsik ezután is nyomon követte a mủ sorsát, mert Zórasz szövegkiadásának hazai, elérhető példánya éppen a magyar bizantinológus könyvtárából való. A kötetben lévő bélyegzés legalábbis erről tanúskodik (Moravcsik Gyula könyvtára 1973). A néhány ceruzával írt bejegyzés is valószínűleg Moravcsiktól származhat. Ezt a könyvet Moravcsik Gyula könyvtárának többi kötetével 1973-ban a Magyar Tudományos Akadémia Könyvtára vette fel a nyilvántartásába (Magyar Tudományos Akadémia Könyvtára 4470/1973).

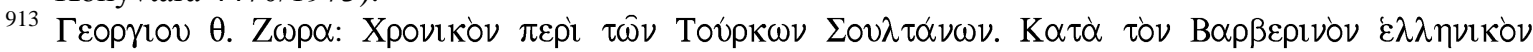
$\kappa \omega \delta \mathrm{i} \alpha \alpha$ 111. A $\theta \eta v \alpha 1$ 1958. Philippides 1990. 14.

${ }^{914}$ Leben und Taten der türkischen Kaiser. Die Anonyme vulgargriechische Chronik Cod. Barb. 111 (Anonymous Zoras). Übersetzt, eingeleitet und erläutert Richard F. Kreutel. Graz 1971. A továbbiakban: Kreutel 1971; Şerif Baştav, 16. asırda yazılmış Grekçe anonim Osmanlı tarihi: giriş ve metin (13731512). Ankara 1973. A továbbiakban: Baştav 1973; Philippides 1990.
} 
A II. Murád uralkodását tárgyaló 9. fejezetben a krónika beszámol a szultán által vezetett katonai akciók között Nándorfehérvár ostromáról is. Elöször az erre vonatkozó szövegrészletet ismertetem.

„Amint elfoglalta Szendröt, Murád szultán egészen Hungáriáig kiterjesztette és megnövelte uralmát. Azért történt ez, mert Albert, Hungária királya meghalt és nagy zürzavar támadt Hungáriában..."915

„Amikor ezekről Murád tudomást szerzett, seregét összegyüjtötte, hogy Hungária ellen vezesse, miután kitudakolta, hogy a magyarok között nagy viszály dúl a királyság miatt. Ekkor Murád szultán megtalálta a megfelelö idöt és elinditotta seregét, elérkezett Belgrádhoz, amely a Duna és a Száva-folyó összefolyásánál, középen van. Belgrád kapitánya, Vránai Jóannész igen vitéz férfiú volt, amint a többiek is. Ezután a törökök éjjel-nappal ostromoltak, a keresztények pedig belülröl ellenálltak és harcoltak. A törökök kivülröl hangos bombardákkal löttek és egész nap rombolták a falakat. A keresztények pedig éjjel újjáépitették azokat. Ekkor Murád üzent a vránainak, hogy ha átadja a várat, öt kitünteti és neki nagy vagyont ad majd. Ö azonban ezt elutasitotta. Amint Murád látta, hogy nem fogadja el (ajánlatát), mestereket hívatott, hogy kivülröl aknákat ássanak a föld alatt azért, hogy bejussanak. És lövetett és ásatott. Ez sikerült is volna, ha egy keresztény nem üzent volna egy nyílvesszővel eljuttatott levélben. Amint ezt megtudta a vránai parancsok, belülről egy ellenaknát ásatott és ásás közben megtalálta a törökök aknáját és tüzet dobatott a puskaporra (sic! „a füre”). Azt mondják, hogy ebben az aknában benn égett több mint 17000 török. A harcban pedig életét vesztette 8000 és az ostrom (körülzárás) 7 hónapig tartott. Murád szultán látva, hogy bizonytalan lett az ostrom kimenetele, lemondott erröl és visszafordult Adrianopoliszba, a székhelyére azért, hogy kipihentesse seregét a háború fáradalmától." 916

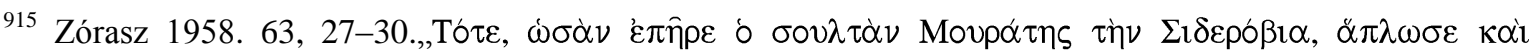

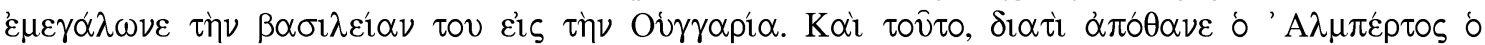

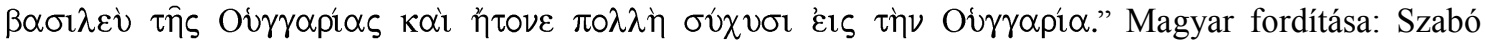
2012d 126, Baán 2013. 534.

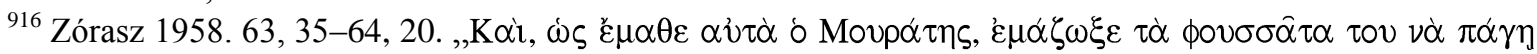

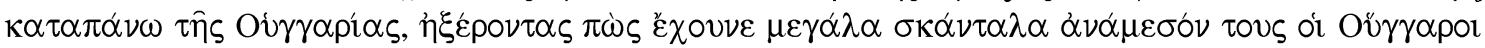

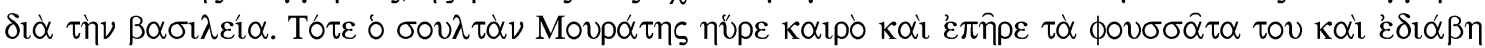

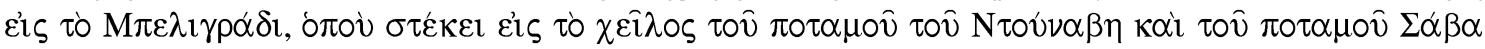

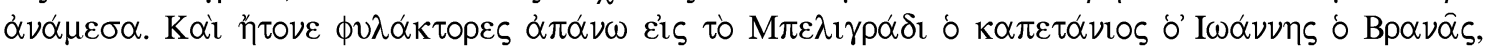

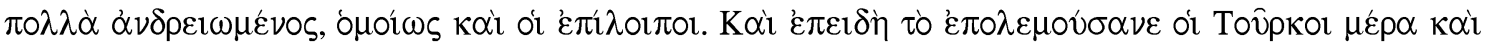

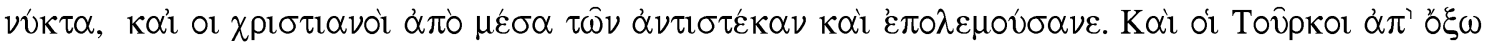

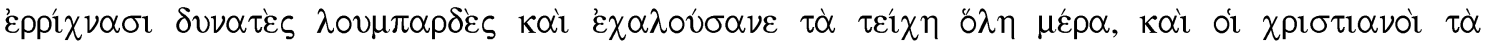

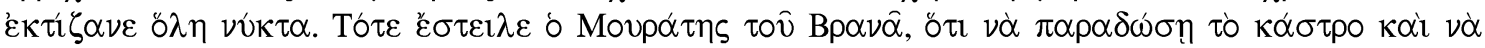

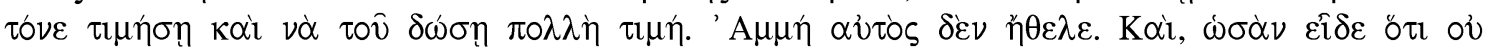

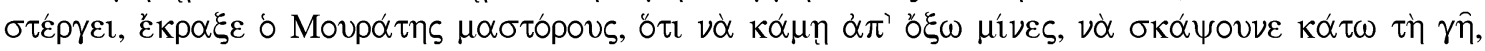


Láthatjuk, hogy ebben a krónikában - akár a latin nyelvü forrásainkban - megtaláljuk a nándorfehérvári ostrom előzményeit, valamint azt is, hogy a szultánnak jó értesülései voltak a magyarországi belháború készülő kitöréséről. A várvédők kapitányának, a vránai Jóannésznek - azaz a Tallóci-testvérek közül Jovánnak - kiemeli kiváló katonai képességeit. Fontos információkat kapunk a seregek tüzérségi felszereltségéről is. A klasszicizáló görög nyelvet használó szerzők közül Khalkokondülészhez hasonlóan ez a krónika is megemlíti a törökök által használt ,hangos ágyúkat” ( $\delta v v \alpha \tau \varepsilon \varsigma ~ \lambda ం v \mu \pi \alpha \rho \delta \varepsilon \varsigma)$. A magyarországi latin nyelvü forrásainkra (Thuróczy, Bonfini) emlékeztetve a névtelen szerző is leírja, hogy a törökök aknát ástak, de a latin nyelvű lengyel krónikákban (Dlugos, Callimachus) szereplő, várárokba hordott puskapor felgyújtásáról nem szól. A magyarországi latin kútfőkhöz hasonlóan említést tesz a várvédő vránai Jóannész által sikeresen alkalmazott ellenakna alkalmazásáról is, valamint a hosszú, hét hónapos ostrom meghiúsulásáról, a szultáni sereg elvonulásáról. Abban is hasonló, hogy a törökök veszteségéről számszerü adatot közöl, de a védők veszteségeiről szintén nem számol be.

$\mathrm{Az}$ 1440-es szultáni ostromra vonatkozó másik forrást 1975-ben Peter Schreiner publikálta a Corpus Fontium Historiae Byzantinae sorozat részeként megjelent Bizánci kiskrónikák (Chronica byzantina breviora) első kötetében, amelyben találunk egy egyetlen mondatos említést az 1440. évi ostromról. ${ }^{917}$

A 72 a Krónika egy szokatlanul kisméretü kódexben (40x60mm) maradt ránk 1624-böl, a kézirat pedig egy bizonyos Mihálytól származik. A kézirat Bestand der Guilford később Philips-Sammlung tulajdona volt, majd 1957-ben került a Yale Egyetem birtokába. A szöveg a Szerbiai török hódítások krónikája címet kapta. Bár Schreiner szerint a krónika számos téves adatot közöl, ez Szendrő és Nándorfehérvár ostromával kapcsolatban véleményem szerint - nem mondható el.

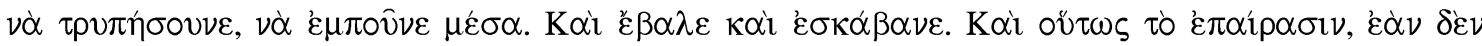

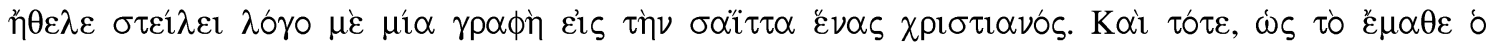

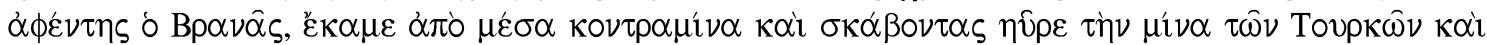

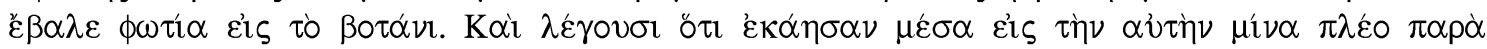

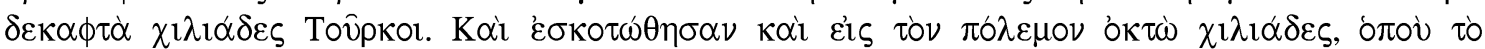

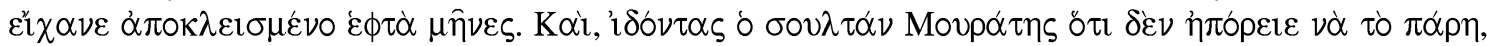

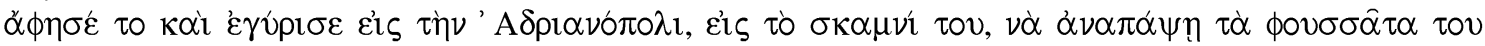

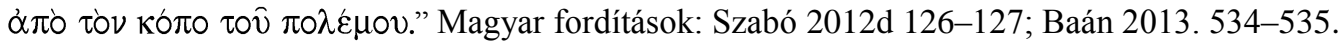

917 Peter Schreiner: Die Byzantinischen kleinchroniken 1. (=Corpus Fontium Historiae Byzantinae XII /1 textus) Wien 1975. 564. (26) A továbbiakban: Schreiner 1975. 
„A 6947. évben (=1439) Murád szultán bevette Szendröt, és Szendrö deszpotésze elmenekült. Elindult és Magyarországra vonult. Murád a (deszpotész) fiait, Gergelyt és Istvánt elfogatta és Húsvétkor megvakittatta." (26.) $)^{918}$

A szerző Szendrő esetében, bár nem említett ostromot, de időben év szerint (1439-ben) elkülönítette ezt az eseményt a nándorfehérvári ostromtól, eltérően más bizánci forrásainktól. Nándorfehérvár ostromára pedig pontos időpontot ad: évmegjelölése a bizánci világév szerinti 6948-6949. év 3-4. indictio, azaz 1440. év áprilisától októberéig terjedő időszak.

„Az 6949. évben maga Murád szultán a magyarországi Belgrád ellen vonult, nem tudta elérni, hogy azt bevegye és visszafordult." 919

Szembeötlö, hogy a kiskrónika szóhasználata mennyire hasonlít a Codex Barberinus Graecus 111 kódexének az ostromra vonatkozó utolsó mondatához. ${ }^{920}$

Ehhez kapcsolódva egy szemantikai megjegyzés kívánkozik. Ki kell térnünk a korábban

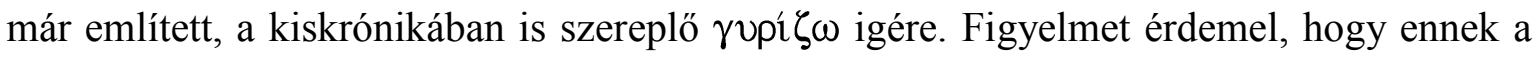
gyakoribb „,visszatér, újra jön, visszafordul” jelentései mellett van ,járkál, kószál, barangol" jelentése is. ${ }^{921}$ A Névtelen Krónika vonatkozó részletének fordításában az igét követő vonzat miatt (t. i. „visszatér valahová”) ezt nem használhatjuk, de az olyan forrásokban, ahol az ige vonzat nélkül áll, már igen és ez jelentősen módosítja a szöveg

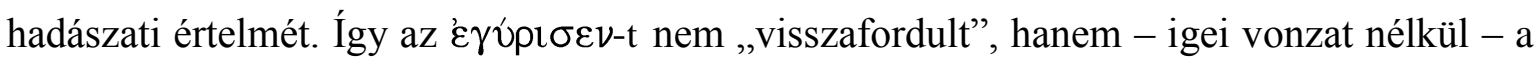
„barangolt” vagy katonailag pontosabb megfelelöjével a „portyázott” szóval is fordíthatjuk. Azaz „Az 6949. évben maga Murád szultán a magyarországi Belgrád ellen vonult, nem tudta elérni, hogy azt bevegye és portyázott." Ez utóbbi egyezik a forrásokkal, hiszen az oszmán-török történetírók megemlítik ezt és beszámolnak a törökök által ejtett hadifoglyok és zsákmány nagy számáról (Főleg Âșik Pașazade, Nesri és Szeád-Eddin). ${ }^{922}$

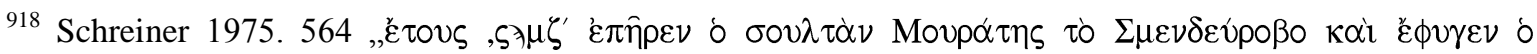

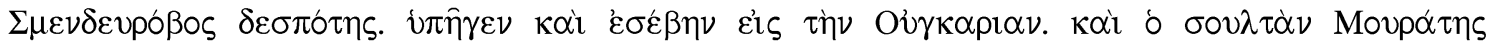

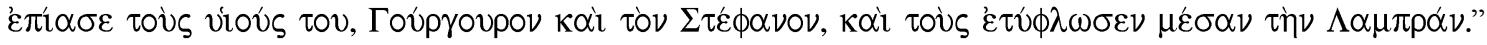
Magyar fordítások Szabó 2012d 127; Baán 2013. 617.

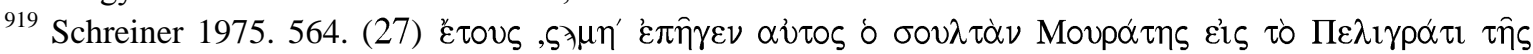

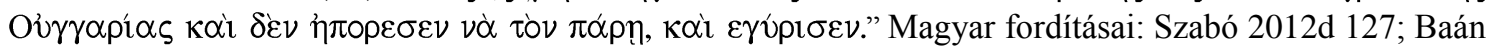
2013. 617.

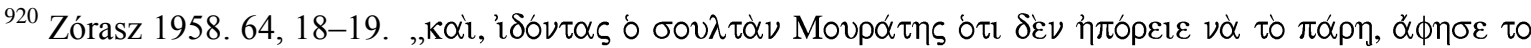

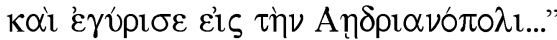

${ }^{921}$ Mohay András: Újgörög-magyar szótár. Budapest 1988. 169. (Mohay 1988)

${ }^{922}$ Szabó 2012d. 128-129.
} 
Mivel a két ismertetett bizánci forrásrészletünk közel egy időben keletkezett, nem lehet eldönteni, hogy melyik szóhasználata a korábbi: az igei vonzat nélküli vagy a vonzatot használó.

Annyit azonban megkockáztatunk, valószínübb, hogy a 72 a Krónika rövid bejegyzését használhatta a Névtelen Krónika szerzője. Mert e két mondat szinte szó szerint megegyezik

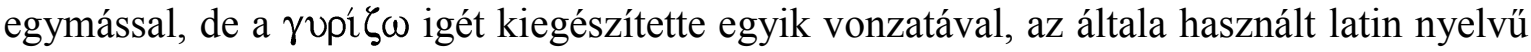
források, köztük Bonfini müvének alapul vételével.

\section{5. Fejezetek a török nyelvü forrásokból}

Várakozásaink ellenére, az eddigiekhez képest, a török nyelvü forráscsoport kevesebb leírással szolgál és a kudarcba fulladt török ostrom más eseményeit rögzíti. Főleg a város körüli eredményes rabló-portyázó harcokat, az ország déli részeinek feldúlását, a mérhetetlen hadizsákmányt és a keresztény foglyok árfolyamát.

A kortárs korai török források között elsőként Âșik Pașazade (1400-1484 k.) Az Oszmán-ház története című művével kezdjük (Bölüm 111). ${ }^{923}$ A szerző kortárs és személyesen vett részt a hadjáratban. A szultán nagyon is tisztában volt Nándorfehérvár, azaz Belgrád fontos védelmi szerepével. Felismerte, hogy Belgrád a Magyarország (Maçar) földjére vezető kapu és most már rászánta magát, hogy azt a kaput feltörje. Mozgósította az Iszlám hadseregét, Belgrád ellen vonult és megállt előtte. ${ }^{924}$

„Murad tisztában volt azzal, hogy Belgrád (Biligrad) nagy vára kapuja a magyar földnek (bildi kim Üngürüz vilâyetinüñ kapusıdur). Szerette volna ezt a kaput elfoglalni. Összegyüjtötte az Iszlám seregét, hogy Magyarország támadására induljon. Szándékában volt elfoglalni a várat. Átkeltek a Száván és a magyar földön Biline-ben pusztítanak. A gházik böségesen kirabolták magukat, 1 csizmáért adtak egy rabnöt. Én magam 100 aszpráért vettem egy fiatal legényt. Azt beszélték akkoriban, hogy az iszlám Portának nem voltak ilyen sikerei, és ez igy is van. Én magam is részt vettem ebben a hadjáratban. Egy nap a szultánhoz megyek, felajánlott nekem rabokat. Én azt mondtam neki: „Szultán, felséges uram! Ahhoz, hogy ezeket a foglyokat elvigyem, kellene ló meg pénz az úthoz." A szultán adott nekem 500 aszprát és két lovat. 9 fogollyal és 4 arab lóval tértem vissza Edirnébe. Eladtam öket, darabját 300 aszpráért, némelyeket 200-ért."925

\footnotetext{
${ }^{923}$ Yavuz-Saraç 2007. 170, 398. Német fordítása: Kreutel. 1959. 174-175.

${ }^{924}$ Yavuz-Saraç 2007. 170, 398; Kreutel 1959. 174.

${ }^{925}$ Idézi szerb fordításban: Калић 2001. 162. A fordítást Vanyúr Katalinnak köszönöm.
} 
A fenti beszámolóból kiderül, hogy nemcsak a vár ellen készültek, hanem ,úgy tettek, mintha a várat ostromolnák", a sereg egy része a Száva folyón átkelt, Biline ellen vonult. Valószínü, hogy Âșik Pașazade ebben a portyázó seregben volt ott, nem a várat ostromlóban, mert ezután a szerző a személyes tapasztalatait írta le, az ostrom további eseményeiről nem szólt. A katonák olyan gazdag zsákmánnyal tértek haza, hogy a rabszolgapiacon egy csizma volt csak az ára egy szolganőnek.

Figyelemre méltó megjegyzése pedig a török hadsereg - forrásaink által nem említett létszámára vonatkozóan az, hogy: „odáig alakult a helyzet, hogy a visszaúton a foglyoknak a száma nagyobb volt a hadseregénél." Ez a krónikás szerint példátlan volt az eddigi hitharcok során. Âșik Pașazade a szultántól még 500 ezüstpénzt és 2 lovat kapott a hazaútra, a hadjáratról pedig összesen 9 szolgával és 4 lóval tért vissza. A szolgákat pedig Drinápolyban jó áron 200-300 ezüstért tudta eladni, így szép summával gazdagodott, amiért is áldotta a szultánt. ${ }^{926}$ A szerző, az időrendet megfordítva, ezután tárgyalja Szendrő ostromát (Bölüm 112.).

Oruç Beğ II. Bayezid szultán idejében (1481-1512) alkotott. Tarihi-ja (Osmanlı Tarihi 1288-1502) ${ }^{927}$ összefoglalja a 843. évben (1439. június $14-1440$. június 6.) történteket. Itt egy rövid megjegyzés erejéig említi az ostromot. „És aztán Murád Szultán Hán a katonákkal együtt megérkezett Belgrádba, végül nagyon sokat csatázva és háborúzva nem hóditotta meg, elismerésben sem volt része. Látta, hogy harccal az nem elfoglalható..." (Tóth Hajnalka fordítása). ${ }^{928}$ Ide sorol a krónikaíró még egy támadást, Evrenos oglu Ali bég vezetésével, aki 30 - 40 ezer akindzsi élén Magyarországra tört be, ahol Mehádia várát támadta meg. Hâdim Şehâbeddîn Paşa pedig Novo Brdo-t foglalta el. ${ }^{929}$

II. Murád szultán tetteiről több oszmán-török forrás maradt ránk. Bisztra Cvetkova a várnai csatáról szóló - magyarul is megjelent - müvében Murád szultán harcai címmel más, későbbi, török események kapcsán többször hivatkozott egy oszmán munkára. ${ }^{930}$ Ebben a Murád szultán szent harcai címü forrásmunkában nem találtunk az ostromra vonatkozó utalást. ${ }^{931}$

\footnotetext{
${ }^{926}$ Yavuz-Saraç 2007. 170, 398; Kreutel 1959. 174-175.

927 Oruç Beğ Tarihi (Osmanli Tarihi 1288-1502) Hazırlayan Prof. Dr. Necdet Öztürk. Istanbul 2007. A továbbiakban: Oruç 2007.

${ }^{928}$ Oruç 2007. 61, 15-18.

${ }^{929}$ Oruç 2007. 61-62. Szabó Tibor: Mehádia várai. Várak, kastélyok, templomok. 2011 (február) 7. Mehádia várának első említését 1614-től tartják számon, e korábbi beszámoló módosítja azt. Lásd még a 6. 3. fejezetet.

${ }^{930}$ Cvetkova 1988. 160-163, 165-166, 170, 177, 179, 180, 182-183, 185.

${ }^{931}$ Halil İnalcik-Mevlûd Oğuz: Gazavât-i Sultân Murâd b. Mehemmed Hân. İzladi ve Varna Savaşları (1443-1444). Üzerinde Anonim Gazavâtnâme. Ankara 1989. A „Mehmed kán fia Murád szultán hadjárata" egy 1949-ben talált anonim krónika, amely a várnai csatára kitünő forrás. Megemlítjük, hogy
} 
A szultán hadjáratait megörökítő becses forrás a Ménage által 1976-ban kiadott Murád Évkönyve. ${ }^{932}$ Ebben a munkában a müfajnak megfelelően, szükszavúan, de rögzítik - II. Murád dicső cselekedetei között - Nándorfehérvár sikertelen ostromát és Novo Brdo elfoglalását. A 843. évnél (1439. június 16 - 1440. június 1) csak annyit közöl, hogy a szultán Belgrádban volt, de győzelem nélkül, onnan visszajőve Novo Brdo erődjét vette be. A szultáni sereg vezére pedig Sehabeddin pasa volt. ${ }^{933}$ A beszámoló nagyon hasonló az ún. 1486-i Névtelen munkájának leírására.

Az 1486-i Névtelen által írt munka egyben az első ránk maradt török történeti munka, melynek címe: Az Oszmán-ház története. ${ }^{934}$ A Névtelen is megemlíti Murád szultán korábbi hadmüveletét, amikor elfoglalta Szemendrét (Szendrő) a hidzsra 842. évében (1438. június 24 - 1439. jún. 13.). Ezután tér rá szúkszavúan, de annál tárgyilagosabban „Belgrád” ostromára. „Murád szultán ezután Belgrádot támadta meg, de nem tudta elfoglalni. Visszatért tehát és útközben Novaberde várát (Novo Brdo) s néhány tartományt hóditott meg. A hidsre 843. évében történt (1439. június 14 - 1440. június 1.).” (Thúry József fordítása $)^{935} \mathrm{Ez}$ is csupán évkönyvszerü bejegyzés, de az évmegjelölése a Giese-féle kiadásban 1 évvel korábbi: $842 .{ }^{936}$ Láttuk azt is, hogy több krónikás a belgrádi ostromot összeköti Novo Brdo elfoglalásával. Ez már egy évvel későbbi esemény volt. Tudjuk, hogy Sehabeddin ruméliai beglerbég foglalta el 1441. június 21-én.

Nesri, aki I. Szelim szultán korában (1512-1520) alkotott Az Oszmán-ház története című munkájában az ostrommal kapcsolatban - Ásikpasazádéhez hasonlóan, szinte őt követve - egészen más, de a törökök számára lényeges mozzanatról számol be: az ostrom során elrabolt óriási zsákmányról. (IX. 183.). „Mondják, hogy Murád szultán, mikor Magyarországot meglátogatta, úgy gondolkozott, hogy Magyarországnak kapuja Belgrád vára: elhatározta tehát, hogy ezt a kaput megnyitja. Murád szultán... összegyüjtvén az iszlám seregét, elindult, Belgrádra támadt, s míg ezt megszállva tartotta, portyázókat küldött át a Száván. A harcosok annyi zsákmányhoz jutottak, hogy egy szép leányt egy csizmáért adtak el. A foglyok száma nagyobb volt a seregénél. Azt mondják, hogy az iszlám keletkezése óta a hit harcosai még nem szereztek ily töménytelen zsákmányt." ${ }^{937}$ (Thúry

\footnotetext{
az 1440-es ostrom kapcsán Cvetkova e forrására nem hivatkozik, csupán Thuróczy Krónikájára, amely megerösítette azt a feltételezésünket, hogy releváns tudósítást nem találhatott benne.

932 Ménage 1976.

933 Ménage 1976. 577.

${ }^{934}$ Ennek teljes és az ostrom előzményeit is tartalmazó kiadása: Giese 1925. 88-89.

935 Török történetírók. I. 1893. 18.

${ }^{936}$ Giese 1925. 89. „, Nach der Einnahme zog Sultan Murad wieder im Jahre 842 nach Belgrad.”

937 Török történetírók. I. 1893. 55.
} 
József fordítása) Az a benyomásunk, mintha az ostrom végső kimenetelét elkendőzné e megszépítő beszámoló. Az évszám itt is korábbi, 841. évre teszi az eseményt.

A perzsa származású, híresen müvelt történetíró Szeád-Eddin: A történetek koronája címü munkájában hasonló beszámolót kapunk, de ékesebb perzsa stílusban. Mivel a vár „,bevétele sok időt kívánt egy nagy harcos csapat küldetett át a Száva vizén, hogy Magyarországot dúlja és rabolja... sok tündérarcút hálójokba ejtettek, megszámlálhatatlan mennyiségü pénzzel és sokféle árukkal rakodtak meg." A foglyok számáról ő is Nesrihez hasonlóan ír: „,annyi volt a fogoly, hogy egy igézö szépségü leány egy pár czipöért, egy cziprustermetü ifjú pedig 150 piaszterért adatott el. "938 A török beszámolók tehát az ostrommal egyidejüleg 1440 nyarán, őszén a déli területekre való betörést, pusztítást örökítették meg.

Az ostrom sikertelenségéről szólva meg kell jegyezni, hogy a török történetírók többségében kiemelik a vár központi helyzetét és jó felépítését.

Szeád-Eddin megállapította: „az ország kapuja és kapujának kulcsa Belgrád vára lévén ... a vár szilárdságában és hozzáférhetetlenségében hegyhez hasonlitott." ${ }^{939}$ Sőt nem maradtak el a költői hasonlatok sem, föleg a vár végzetes 1521. évi török ostroma kapcsán.

Így az albán származású Lutfi pasa, nagyvezír (1539-1541) így írt: „Mihelyt Szulejmán szultán meglátta Belgrádot, azt mondta, hogy ilyen erős várat még nem látott.” „ez a magasba nyúló vár, a magasan röpülő sas nem szállhat át fölötte, árka a föld gyomráig lenyúlik, bástyái a Fiastyúk csillagzatig érnek. Kemény kövön erös bástyája már kétezer éve áll." "940 Valamint Ferdi: A törvényhozó Szulejmán szultán története című munkájában hasonló költői képekkel ír Belgrád váráról: „,mely Magyarországnak nagyon megerősitett és híres, rendkivül szilárd, erös és jelentékeny vára s árkainak mélysége a föld középpontjáig ér le, tornyainak csúcsaiba pedig az égi oroszlán vágta körmeit." (Thúry József fordításai) $)^{941}$

Sokkal részletesebben számol be egy későbbi „„örök” forrás, a Tarihi Üngürüsz ${ }^{942}$ az 1440. évi török ostromról. A szerzője, Mahmud Terdzsüman a magyar királyok történetét ültette át az iszlám világ számára. ${ }^{943}$ Ez nagyon hasonlít az előbbi keresztény, latin nyelvű,

\footnotetext{
938 Török történetírók. I. 1893. 129.

939 Török történetírók. I. 1893. 129.

${ }^{940}$ Török történetírók. II. kötet (1521-1566) Fordította: Thúry József. Budapest 1896. 8. A továbbiakban: Török történetírók. II. 1896.

941 Török történetírók. II. 1896. 51.

942 A magyarok története. (Tarih-i Üngürüsz; Madzsar Tarihi) Fordította Blaskovics József Budapest. 1982. 348-350. A továbbiakban: Blaskovics 1982.

943 1543-as török hadjáratban, Székesfehérvár elfoglalásakor kapott lehetőséget munkája megírására. A helybeli levéltárban ugyanis egy latin nyelvü krónika került a kezébe, Magyarország régi időktől való
} 
- de különösen a lengyel leírásokra -, ugyanis ezeket használhatta, de az iszlám érdekek szerint, máshová helyezve a súlypontjait.

A Tarihi Üngürüsz is röviden megemlíti a király háborúságát népével, amikor is Murád elindult „Belgirád vára ellen”, amelynek Johanisz volt a föparancsnoka. Johanisz elöretört és az iszlám sereg előcsapataival vette fel a harcot. Az iszlám padisahja pedig a vár erődítményeit körülzárta. Johanisz viszont éjszakai kirohanásokkal az iszlám katonaságnak rendkívüli kárt okozott. Murád ekkor hatalmas földsánc(ok) (havale) emelését rendelte el. Olyan magasra, hogy a várfalak magasságáig érjen, erre vontatták fel az ágyúkat, innen minden oldalról kezdték lövetni a várat.

A föld alatti aknák használatának ismertetése során a szerző viszont több forrásból dolgozhatott, mert mintegy „összedolgozta” a Thuróczy, Bonfini-féle akna leírást a lengyel Dlugos vagy Callimachus tudósítása szerinti várárok feltöltésével és felgyújtásával. A vár védői a veszélyt érezve kezdtek ,,föld alatti folyosót” ásni, amelyet lőporral töltöttek meg, ezzel akarták a levegőbe (sic!) röpíteni az iszlám népet. A törökök, amikor ezen „,föld alatti folyosók” fölé (sic!) érkeztek, a védők berobbantották a folyosókat és sok muszlim vértanúhalálát okozták. Murád megtartotta a legfelső dívánt, lemondott a vár bevételéről. Visszafordult és Iszakh (Izsák) pasát hagyva hátra. A támadók a Tarihi Üngürüsz szerint is 7 hónapig ostromolták a várat.

Kemálpasazade vagy İbn Kemal (1486-1534) az Oszmán-uralkodóház történetét a kezdetektől 1527-ig írta meg, amelyben egy-egy kötetet szentelt minden uralkodónak. A krónikás tíz kötetből álló munkájából a VII. defter érinti II. Murád uralkodását, főleg II. Mehmed uralkodásával foglalkozik. ${ }^{944}$ Ebben II. Mehmed 1456. évi nándorfehérvári ostroma kapcsán nincs említés korábbi oszmán-török ostromról. ${ }^{945}$

Hadīdī 16. századi oszmán költő az Oszmán-dinasztiáról szóló 7 000, hazadzs formában írt sorpárokból álló verses krónikáját 1523-24 között fejezte be. Az Előszóban azt állítja, hogy krónikája Âșik Pașazade prózai munkájának verses parafrázisa. ${ }^{946}$ Erre jó példa Nándorfehérvár 1440-es ostroma is, mert erről a költő megemlékezett (90. fejezet, 2817-2829. sorpár). ${ }^{947}$ Az Iszlám Sahjának hadserege gyülekezett, összegyültek a bégfi bégek és tengerméretü hadsereg gyült össze. Belgrád ellen vonultak a lovascsapatok

történeteivel. A könyvet lefordította törökre és Szulejmán szultánnak ajánlotta. Valószínűleg több könyvböl dolgozott, válogathatott a könyvek és kéziratok között.

944 İbn Kemal: Tevârih-i Âl-i Osman. VII. Defter. Ankara, 1957. A továbbiakban: İbn Kemal 1957.

945 İbn Kemal 1957. 119-125.

${ }^{946}$ V. L. Ménage: Hadīdī. In.: The Encyclopaedia of Islam. Volume III. H-IRAM, Edited by: B Lewis, V. L. Ménage, Ch. Pellert, J. Schlacht. Leiden-London 1971. 22-23. (Ménage 1971)

${ }^{947}$ Hadîdî: Tevârih-i Âl-i Osman (1299-1523) Hazırlayan Dr. Necdet Öztürk, İstanbul 1991. 198-199. 
(szpáhik). Majd a hitharcosok egy nap a vár ellen támadtak. A roham közben az akindzsik átkeltek a folyón, Magyar Országra (Üngürûs-ili) betörtek és portyáztak. A király székhelyéhez egészen közel jutottak, égettek, pusztítottak, zsákmányt szereztek és foglyokat ejtettek. A foglyok sora nagyobb volt, mint a katonáké. A költő ezután a foglyok szépségét dicséri. Mindez a Prófétától számítva a 841. évben történt. ${ }^{948}$ Az ostromról szóló versrészlet valóban főleg Âșik Pașazade anyagán alapul, de az országba indított portyázás olyan mélységét, hogy az Budához közel is elért volna, csak a költő említette.

Ide kívánkozik még, hogy támadó portyákról, amely az ostromot követte - a latin nyelvü források közül - Bonfini is említést tett (3. 4. 385). „Murád pedig, aki a fejérvári ostrom alkalmával rengeteg pénzt és embert veszitett... ahol csak lehetett, támadta az országot, hol a Tiszánál pusztitott a Duna túlsó oldaláig, felgyújtotta a falvakat, elhajtotta az embereket és az állatokat, hol meg azt dúlta, rabolta, ami a Dráva és a Száva között fekszik." (Kulcsár Péter fordítása) $)^{949}$

Természetesen szükséges a források további bővítése. (például a Ruhi Tarih-i) Ebben segítséget nyújt Selim Aslantaş professzor 2011-ben megjelent tanulmánya, amely Belgrád oszmán-török ostromait vizsgálta, elsősorban a török források segítségével. ${ }^{950}$

A korai török történeti mủvek magyar vonatkozású beszámolóinak felkutatása, összegyüjtése, fordítása az oszmanisztika feladata. A „fejezetek” alcím jelezni kívánta, hogy a korai török-magyar kapcsolatok területén egy ilyen munkának Thúry József 1893 as kötete óta érezhető a hiánya. ${ }^{951}$ A magunk részéről ezt csak jelezni tudjuk a jövőbeli magyar oszmanisztikai kutatásoknak.

\footnotetext{
${ }^{948}$ AZM-İ SEFER-KERDEN-İ SULTAN MURÂD BE-KASD-I KAL'A-İ BELGIRAD. Köszönöm Papp Sándor segítségét.

${ }^{949}$ Bonfini 1995. 592, 29-33.

${ }^{950}$ Az 1440. évi ostromra lásd: Aslantas 2011. 18-20. Eszerint például Ruhi Tarihi-ja az ostromot három hónaposnak mondja. Ruhi Tarihi. H. E. Cengiz-Y. Yücel (Haz), Belgeler, 1992. 440; Említi: Aslantaş 2011. 20.

${ }^{951}$ A korai oszmán történetírás hazai megjelenése még ritkább, lásd: Fodor Pál: Ahmedi elbeszélése, mint a korai oszmán történelem forrása. Világtörténet 1983/2. 3-18. (Fodor 1983) Feridun M. Emecen: Egy régi imágó újbóli felfedezésére: Oguz hagyomány és Közép Ázsia ismerete. (Fordította: Papp Sándor) Aetas 1999/4. 19-26. (Emecen 1999) Az oguz múlt felé fordulás éppen II. Murád szultán idejében jelentős. Fodor Pál: Török és oszmán: Az oszmán rabszolga elit azonosságtudatáról. Történelmi Szemle 1995/4. 367-383. (Fodor 1995)
} 


\section{Néhány filológiai tanulság}

\section{1. Párhuzamos ,ostromrajzok”}

Az 1440-es ostromra vonatkozó latin nyelvü forrásainknál figyelembe kell venni a forrásszövegek filológiai elemzését is. A források szövegeinek kutatása, fordítása során nem vetettem el azt a lehetőséget sem, hogy a későbbi humanista történetíróink merít(h)ettek az antik szerzőktől is - föleg Liviustól -, amely Nándorfehérvár ostromának leírásakor mintául szolgálhatott. ${ }^{952}$ Először Thuróczy leírásának vizsgálata során kerestem az egyik fö humanista eszménykép, Titus Livius (Kr. e 59 - Kr. u. 17) római történetíró $A$ római nép története címü munkájában olyan ostromleírást, amely aknák használatáról tudósít. Ezt bővítettem ki Livius forrásának, a görög történetíró Polübiosz (Kr. e. 200. k.118) munkájának megfelelő szöveghelyével. Ezeket pedig párba állítottam Thuróczy és Bonfini szövegeivel. Így szövegpárhuzamokat találtam Polübiosz és Livius munkáiban, amely Thuróczy és az őt használó Bonfini leírásával jó néhány ponton egyezést mutatott. A keresett szövegrészlet Kr. e. 189-ben az épeiroszi Ambrakia erődjének ostromáról szól, amelyről Livius előtt, Polübiosz is részletes leírást hagyott ránk (XXI. 27-28.). Ez a leírás Livius fő forrásaként és mintájaként szolgált. E szövegekhez a 10. 4. fejezetben még visszatérek, itt a filológiai összefüggésekre utalok.

Ha a két antik szerző és a két humanista történetíró párba illeszthető, párhuzamos „ostromrajzait” összevetjük, nemcsak taktikai hasonlóságokat mutatnak. Az események hasonló epizódjai a fontosabb „rácspontokban” egymásra illeszthetők. Ahogyan Livius átvette Polübiosz tudósítását Ambrakia ostromáról, úgy Nándorfehérvár ostromáról - a Liviust felhasználó - Bonfini is Thuróczy beszámolóját. Pontokba szedve a főbb epizódokat, összehasonlító táblázatban ábrázoljuk.

Mindez jelentheti azt, hogy Thuróczy mintaként használhatta Livius leírását és erre illesztette az ostrom epizódjainak menetét. De az egyedi eltéréseket, új technikai eszközöket is megörökítette. Az ambrakiai aknában egykor használt „harci gáz” - azaz a hordóba préselt madártoll meggyújtásakor keletkező füst - helyett, például Nándorfehérvár ostrománál már a lőporral való robbantást rögzítette.

\footnotetext{
952 Például Bonfini Livius munkáját különösen a Hunyadiak római eredetének bizonyítása során használta. Kulcsár Péter: Bonfini Magyar Történetének forrásai és keletkezése. Budapest 1973. 111-112. (Kulcsár 1973) Az más kérdés, hogy a „római” név alatt az esetleges bizánci rokonságot is lehetne vizsgálni.
} 
A hasonlóságból a filológiai párhuzamon túl jól látható a várostromok menetének az ókortól meglévő „hagyományos” taktikai sorrendje. Az, hogy a hagyományos faltöretés és rohamok indítása után ugyanúgy alkalmaztak alagutat, aknát a középkori várostromokban.

\begin{tabular}{|c|c|c|c|c|}
\hline & $\begin{array}{l}\text { Polübiosz } \\
\text { (XXI. 27-28) } \\
\text { (XXI }\end{array}$ & $\begin{array}{l}\text { Livius }^{954} \\
\text { (XXXVIII. 5-7) }\end{array}$ & \begin{tabular}{|l} 
Thuróczy \\
(2305 \\
\end{tabular} & $\begin{array}{l}\text { Bonfini }^{956} \\
(3.4 .345-385)\end{array}$ \\
\hline 1. & $\begin{array}{l}\text { Ostromgépekkel, faltörö } \\
\text { kosokkal ,a támadás } \\
\text { mindenfelöl, } \\
\text { erövel } \\
\text { indult,"957 }\end{array}$ & $\begin{array}{l}\text { „A consul befejezte a } \\
\text { város bekeritésére épült } \\
\text { sáncok és falak } \\
\text { megközelitésére } \\
\text { szolgáló ostrommüvek } \\
\text { elkészitését.” } \\
\text { „A falakat faltörö } \\
\text { kosokkal döngették. "958 }\end{array}$ & $\begin{array}{l}\text { „szoros ostromgyürübe } \\
\text { fogta a várat. Felállittatta } \\
\text { az ostromgépeket és } \\
\text { egyéb ágyúfajtákat." } 959\end{array}$ & $\begin{array}{l}\text { „Az ellenség ... odavontatta } \\
\text { a hadigépeket, körülzárta a } \\
\text { várost. }, 960\end{array}$ \\
\hline 2. & 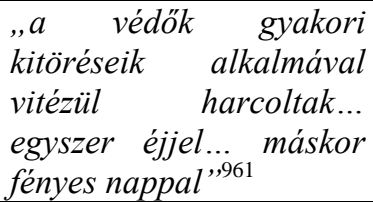 & $\begin{array}{lr}\text { „váratlan } & \text { kitörést } \\
\text { intéztek } & a z \\
\text { ostrommüvek ellen } & \text { "962 }\end{array}$ & $\begin{array}{l}\text { A védők ,gyakran } \\
\text { kirajzottak a várból, mint } \\
\text { a darazsak, s nagy zavart } \\
\text { keltettek.",963 }\end{array}$ & $\begin{array}{l}\text { „a városbeliek... váratlanul } \\
\text { ki-ki törtek a táborra”, } \\
\text { „,gyakori kirohanások" "964 }\end{array}$ \\
\hline
\end{tabular}

953 Polübiosz történeti könyvei. II. kötet Máriabesnyő-Gödöllő 2002. 254-256. A szövegrészletet Kató Péter fordította. A továbbiakban: Polübiosz 2002.

954 Livius: A római nép története a város alapításától. III. kötet. Budapest 1982. 712-716. A szövegrészletet Muraközy Gyula fordította. A továbbiakban: Livius III. 1982.

955 Thuróczy 2001. 276-277. A szövegrészlet Bellus Ibolya fordítása.

${ }^{956}$ Bonfini 1995. 590-592.

${ }^{957}$ Polübiosz 2002. 254, 34-35. Polybius: The Histories. Volume VI. The Loeb Classical Library. Edited by: G. P. Goold. With an English translation by W. R. Paton. Cambridge, Massachusetts, London 1995. 294,

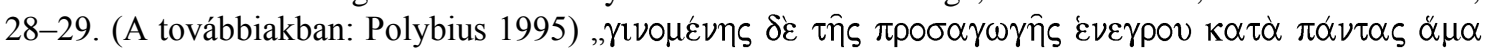

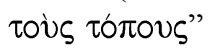

958 Livius III. 1982. 712, 8-9, 14-15. Livy with an English translation in fourteen volumes. XI. Books XXXVIII-XXXIX. Edited by: G. P. Goold. Translated by Evan T. Sage. Cambridge, Massachusetts, London 1983. 14, 18-20, 24. (A továbbiakban: Livius text 1983),Consul iam munimentis quibus saepienda urbs erat, iam operibus, quae admovere muris parabat...Arietibus muros quatiebat”

959 Thuróczy 2001. 276, 24-25. Thuróczy textus 1985. 242, 10-12. „Cesar vero Thurcorum ...castro eidem gravi obsidione adherebat. Nihilominusque machinis et ceteris tormentorum generibus adaptatis..."

960 Bonfini 1995. 590, 24-25. Rerum 1936. 101, 24-25. „tormenta proprius bellicaadmovere, obcludere civitatem..."

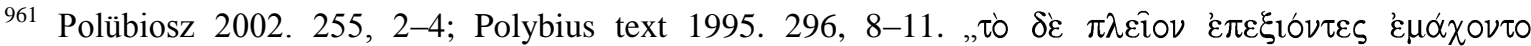

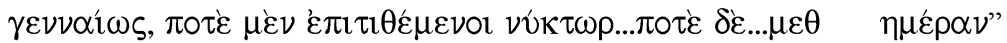

962 Livius III. 1982. 713, 10. Livius text 1983. 16, 7-9. „, ad hoc eruptionibus et nocturnis in custodias operum et diurnis in stationes..."

963 Thuróczy 2001. 276, 30-31. Thuróczy textus 1985. 242, 17-18. „sepiusque de castro adinstar vespium erumpentes magnum in hoste tumultum faciebant."

964 Bonfini 1995. 590, 26-27, 29. Rerum 1936. 101, 26-28, 29. „oppidani...ex improviso in castra erumpere...crebris suos eruptionibus" 


\begin{tabular}{|c|c|c|c|c|}
\hline 3. & $\begin{array}{l}\text { „A rómaiaknak...mindig } \\
\text { sikerült lerombolniuk } \\
\text { egy-egy részt a falakból, } \\
\text { de mégsem tudtak } \\
\text { benyomulni a városba, } \\
\text { mert a bentiek } \\
\text { eredményesen épitették } \\
\text { újra a falakat.",65 }\end{array}$ & $\begin{array}{l}\text {,mégsem tudtak } \\
\text { behatolni a nagyrészt } \\
\text { védtelenné vált } \\
\text { városba, mert a védök a } \\
\text { lerontott fal helyett, a } \\
\text { lehetö leggyorsabban } \\
\text { újat épitettek }\end{array}$ & $\begin{array}{|lr|}\text {,a vár falait, amelyeket a } \\
\text { császár rappal } \\
\text { fáradságosan lerontatott, } \\
\text { éjszaka megerösitették }\end{array}$ & $\begin{array}{l}\text { Murád „, makacsul törette a } \\
\text { falakat és bástyákat” A } \\
\text { védők az ,éjszaka a ledôlt } \\
\text { falakat állitották helyre }\end{array}$ \\
\hline 4. & $\begin{array}{l}\text { „Ezért } \\
\text { tanácstalanságukban } \\
\text { arra jutottak, hogy a föld } \\
\text { alatt kezdenek } \\
\text { valamit és aknát } \\
\text { ásnak,969 }\end{array}$ & $\begin{array}{l}\text { A consul „,mivel } \\
\text { közvetlen támadással } \\
\text { igen kevés eredményt } \\
\text { ért el ... rejtett } \\
\text { akna ásatását kezdte } \\
\text { meg,",970 }\end{array}$ & $\begin{array}{|lr|}\text { „,azt észlelte a } & \text { császár, } \\
\text { hogy Zován a vár } & \text { a } \\
\text { védelmében } & \text { hevesen } \\
\text { ellenáll, egy } & \text { másfajta } \\
\text { cselt eszelt ki ... egy föld } & \text { eg,"y71 } \\
\text { alatti alagutat ásat }\end{array}$ & $\begin{array}{l}\text { „a török látta, hogy sem az } \\
\text { egyik, sem a másik } \\
\text { harcmóddal nem ér el } \\
\text { semmit”,, azt tervezi, hogy } \\
\text { rejtett föld alatti aknák } \\
\text { segitségével," } \\
\text { próbálkozik. }\end{array}$ \\
\hline 5. & $\begin{array}{l}\text { Ezt ,folytatták is szünet } \\
\text { nélkül, éjjel és nappal } \\
\text { váltva egymást }{ }^{9} 973\end{array}$ & ," a rómaiak éjjel- & $\begin{array}{l}\text {,állandóan folyt tehát a } \\
\text { munka }, 975\end{array}$ & $\begin{array}{l}\text { A ,,barlang formájú vájatot } \\
\text { éjjel-nappal ássák }{ }^{, 976}\end{array}$ \\
\hline
\end{tabular}

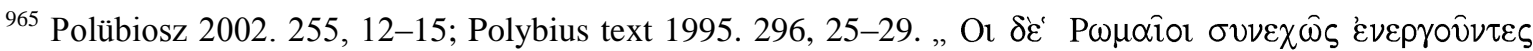

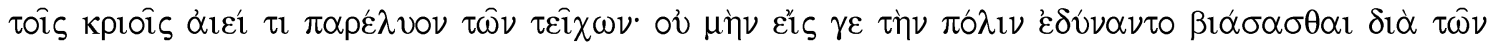

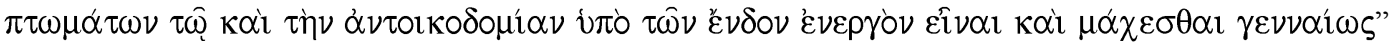

${ }^{966}$ Livius III. 1982. 715, 1-3. Livius text 1983. 20, 22-25. „nec tamen penetrare in urbem poterant; nam et pari celeritate novus pro diruto murus obiciebatur, et armati ruinis superstantes instar munimenti erant."

967 Thuróczy 2001. 277, 29-30. Thuróczy textus 1985. 242, 16-17. „et diurnis cesaris fatigationibus parietes castri prostratos nocturno labore muniebant."

${ }^{968}$ Bonfini 1995. 590, 31-32, 34-35. Rerum 1936. 101, 31-32, 35. „menia et propugnacula pertinacissime quatit... fractos noctu muros resarciunt."

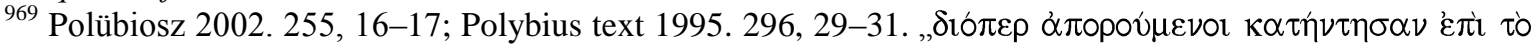

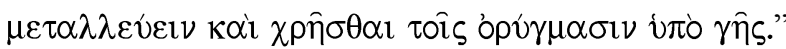

${ }^{970}$ Livius III. 1982. 715, 5-7. Livius text 1983. 20, 25-22, 2. „Itaque cum aperta vi parum procederet consuli res, cuniculum occultum vineis ante contecto loco agere instituit."

971 Thuróczy 2001. 276, 33-277, 5. Thuróczy textus 1985. 242, 18-19, 23-24. „,esar ipse Zowanum in castri eiusdem tutela fortiter sibi obstare animadvertit, aliud genus insidiarum ...excogitavit...cesar ipse fossam subterraneam ...egerere statuit."

${ }^{972}$ Bonfini 1995. 590, 43-591, 1, 11-12. Rerum 1936. 101, 44, 102, 9-10. „Cum uno atque altero prelio se nihil proficere Turcus intelligit ... eam (urbem) adactis clam cuniculis occupare cogitat."

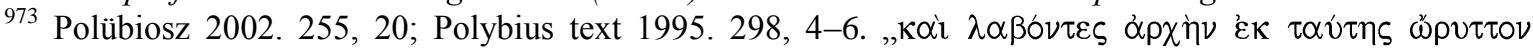

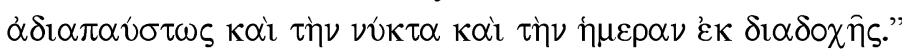

${ }^{974}$ Livius III. 1982. 715, 7-8. Livius text 1983. 22, 3. „dies noctesque in opere essent”

${ }^{975}$ Thuróczy 2001. 277, 6-7. Thuróczy textus 1985. 242, 25. „Adhibitus est igitur labor continuus”

${ }^{976}$ Bonfini 1995. 591, 16. Rerum 1936. 102, 14-15., fossam in antri speciem exordiuntur, die noctuque suffodiunt." 


\begin{tabular}{|c|c|c|c|c|}
\hline 6. & $\begin{array}{l}\text { „,az ostromlottak } \\
\text { vezetöi... } \\
\text {,alagutat ástak a fal } \\
\text { alatt ..., hogy pontosan } \\
\text { szembetalálkozzanak az } \\
\text { ellenséggel,"977 }\end{array}$ & $\begin{array}{l}\text { A védők } \\
\text { „félelmükben ... } \\
\text { elhatározták, hogy } \\
\text { árkot ásnak,",78 }\end{array}$ & \begin{tabular}{|l|}
,Zován ezért elrendelte, \\
hogy....észitsenek \\
egy...föld alatti alagutat \\
császár \\
szemben alagátgával
\end{tabular} & $\begin{array}{l}\text { "Már a falakig vitték az } \\
\text { alagutat..." amikor a } \\
\text { kapitány „egy másik } \\
\text { alagutat fürat amazzal } \\
\text { szemben ",880 }\end{array}$ \\
\hline 7. & $\begin{array}{l}\text { "pontosan } \\
\text { szembetalálkoztak... } \\
\text { harcoltak a föld alatt,"981 }\end{array}$ & $\begin{array}{l}\text { „az ostrommüvek } \\
\text { találkoztak” } \\
\text {,"láthatatlan viadalt } \\
\text { kezdtek a föld alatt,"982 }\end{array}$ & 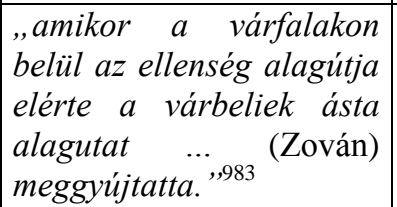 & $\begin{array}{lr}\text {,az ellenséges akna } & \text { a falak } \\
\text { alatt összeért } & \text { az } \\
\text { övével...azonnal } & \text { lángot } \\
\text { dobatott... } & \end{array}$ \\
\hline 8. & 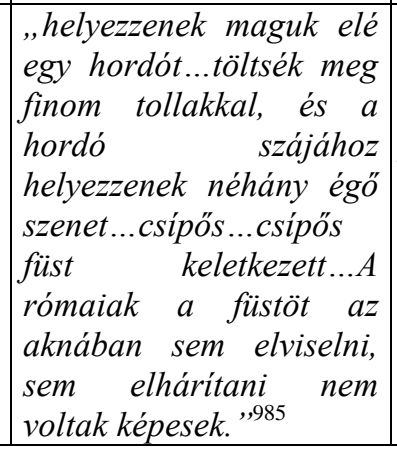 & \begin{tabular}{|lr} 
„A hordót tollpihével \\
töltötték meg...az égö \\
toll nemcsak sürü \\
füsttel, de olyan \\
szörnyü büzzel töltötte \\
meg az egész aknát, \\
hogy alig lett volna \\
képes valaki bent \\
maradni.,"986
\end{tabular} & $\begin{array}{l}, a \quad \text { tüz... elpusztított } \\
\text { minden élölényt }\end{array}$ & $\begin{array}{l}\text { „Az embereket és a } \\
\text { barmokat megölte a tüz és a } \\
\text { füst.."988 }\end{array}$ \\
\hline
\end{tabular}

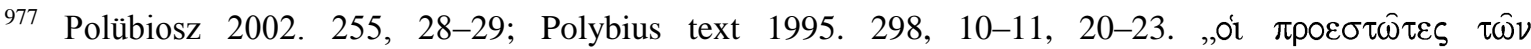

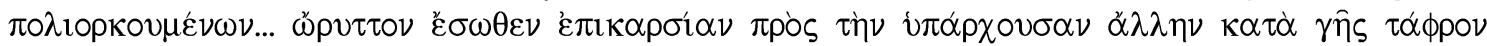

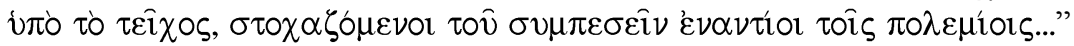

${ }^{978}$ Livius III. 1982. 715, 10, 12. Livius text 1983. 22, 6, 7-8. „...pavidique...fossam intra murum ... ducere instituunt."

979 Thuróczy 2001. 277, 15-17. Thuróczy textus 1985. 242, 32-34. „Unde Zowanus... instructus aliam ... progredientem fossam consimiliter subterraneam fosse cesaris obviam..."

${ }^{980}$ Bonfini 1995. 591, 19, 28-29. Rerum 1936. 102, 20-21, 30-31. „Iam illi ad menia cuniculos continuato... (Prefectus) extemplo alteram contra molitur."

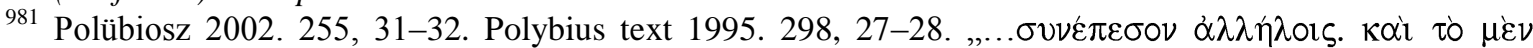

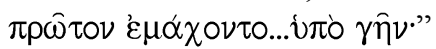

${ }^{982}$ Livius III. 1982. 715, 20, 23-24. Livius text 1983. 22, 16, 19. „ibi commissis operibus...occultam sub terra ediderunt pugnam"

983 Thuróczy 2001. 277, 22-24. Thuróczy textus 1985. 243, 5-7. „Cumque hostilis fossa intra menia ad fossam per castrenses egestam deducta est... mox ignis adhibitus...succendit.”

984 Bonfini 1995. 591, 35-36. Rerum 1936. 102, 38-40. „ubi hostilem fossam cum sua intra menia congruisse...intellexit, ignem repente...immittit."

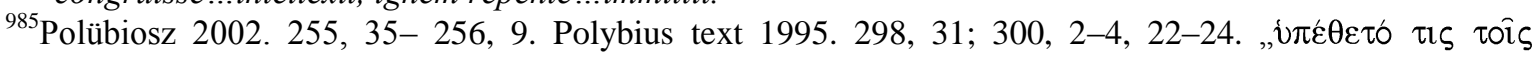

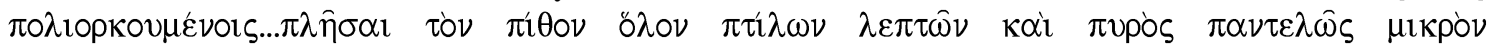

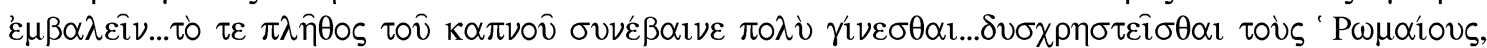

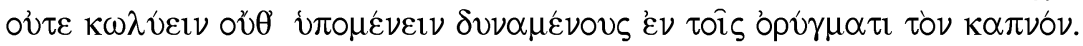

${ }^{986}$ Livius III. 1982. 715, 31-32; 716, 2-4. Livius text 1983. 24, 3-4, 7-9, 11-12. „Hoc tenui pluma completum dolium...scintillam levem ignis inditam plumae folle fabrili ad caput fistulae imposito flando accenderunt...Vix durare quisquam intus poterat."

987 Thuróczy 2001. 277, 25-26. Thuróczy textus 1985. 243, 8-9. „flamma...omne vivens...subita morte necavit."

988 Bonfini 1995. 591, 37-38. Rerum 1936. 102, 41-42.,,homines cum iumentis partim igni, partim fumo absumpti." 
Filológiai vizsgálatom második tárgya a bizánci Névtelen Krónika (Anonymous Zoras), ahol az előbbihez hasonló szövegpárhuzamokat találtam. Legkézenfekvőbbnek tünne a bizánci „klasszicizáló” szerzők felhasználása. Az kétségtelen, hogy a Névtelen Krónika az oszmánok eredetét és felemelkedését tárgyalja, hasonlóan Khalkokondülész munkájához, amelyből szintén merített. Azonban Khalkokondülész és Dukasz az ostrom más és más epizódjait emelte ki. Khalkokondülész inkább a törökök „oldaláról” mond több információt. Így említette meg Evrenosz fia Ali betörését és bejutási kísérletének meghiúsulását. Dukasz pedig a Névtelen Krónikánál is rövidebb beszámolót ad, és inkább a védők által használt, új tüzérségi lőfegyver leírásával foglalkozik. Ezért más források felé kell tájékozódnunk.

Az újgörög nyelvü forrásokra tett megjegyzésekre visszautalva elmondható, hogy a bizánci történetírók nyugati forrásokat is látókörükbe vonhattak (Lásd: 8. 4. fejezet). A Névtelen Krónika (Anonymous Zoras) kiadója és fordítói egyaránt megemlékeznek arról, hogy az ismeretlen szerző felhasznált nyugati, latin nyelvű forrásokat is.

Marios Philippides ezt - 2011-ben publikált müvében is - főleg a Konstantinápoly 1453. évi ostromának feldolgozásával illusztrálta. Megállapítása szerint e résznél a görög szerző a latin forrásoknak görög vagy olasz nyelvű fordítását használta. ${ }^{989}$ Így például a khioszi Leonardo levelét. ${ }^{990}$

A görög és latin nyelvű munkákon túlmenően, léteztek olasz nyelvű művek is a török birodalomról. Például Andrea Gambinié (Commentario della origine de Turci et imperio della casa ottomana. kb. 1528-1538, Firenze). Paolo Giovio munkáját (1552) Zórasz megállapítása szerint a Névtelen Krónika szerzője már biztosan használta. A legnépszerübb olasz nyelvű mü azonban Francesco Sansovinoé, amelynek első kiadása 1561-ben, Velencében látott napvilágot, de 1564-ben olasz nyelvre fordított forrásokkal benne például a Khioszi Leonardo és Khalkokondülész szövegrészleteivel - együtt újra megjelent. Ennek második kiadása 1573-ban jelent meg. E. Zachariadou szerint a Névtelen Krónika szerzője ezt is ismerhette. ${ }^{991}$ Philippides Konstantinápoly 1453. évi oszmán-török ostromának vizsgálata során bevonta a Névtelen Krónika lehetséges

\footnotetext{
989 Az ostrom legújabb feldolgozása: Marios Philippides-Walter K. Hanak: The Siege and the Fall of Constantinople in 1453. Farnham-Burlington, 2011. A továbbiakban: Philippides-Hanak 2011.

990 Philippides 1990. 13.

${ }^{991}$ Philippides 1990. 14.
} 
forrásainak körébe a velencei Giacomo Languschi: Excidio e presa di Constantinopoli nell'anno 1453 címủ mủvét is. ${ }^{992}$

A kutatás azonban korántsem fejeződött be, a krónikában leírt egyes eseményekre vonatkozó más forrásokkal összehasonlítva újabbak kerülhetnek látókörünkbe. Különösen érdekes filológiai eredményre vezet ez az 1440. évi ostrom vonatkozásában.

Azt láttuk, hogy a bizánci Khalkokondülész vagy Dukasz munkájával kevés a hasonlóság. A latin nyelvű források közül a lengyel forrásokkal sem mutat hasonlóságot. A krónika továbbá nem tud az ostromot megelőző lengyel követküldésről, a lengyel krónikákban leírt vízi ostromzárról és vízi harcokról sem. Elkülöníti az is e forráscsoporttól, hogy az ostromban az aknák, alagutak alkalmazását ismeri, a puskaporral megtöltött és meggyújtott várárkokét nem. Az ostrom miatt megszavazott lengyel segítségről sem tud.

Már a fentiekben tett néhány tartalmi megállapításunkból kitünhetett, hogy a magyarországi latin nyelvü forrásokkal ellenben közelebbi a rokonság. Ha filológiailag is megvizsgáljuk a Névtelen Krónika beszámolóját az 1440. évi ostromról, a beszámoló feltünő hasonlóságot mutat a magyarországi latin nyelvü forrásokkal. Érdemes a krónika leírását, mintegy mondataira bontva, összevetni ezekkel. Ezt az alábbi összegző táblázatban teszem meg.

\begin{tabular}{|c|c|c|c|}
\hline & \begin{tabular}{|l|}
$\begin{array}{l}\text { Névtelen Krónika } \\
\left(40^{\mathrm{v}}-41^{\mathrm{r}}\right)\end{array}$ \\
\end{tabular} & \begin{tabular}{|l|} 
Thuróczy \\
$(2304$ \\
\end{tabular} & \begin{tabular}{|l} 
Bonfini $^{995}$ \\
$(3.4 .343-385)$ \\
\end{tabular} \\
\hline 1. & $\begin{array}{l}\text { „Amikor ezekröl Murád tudomást } \\
\text { szerzett, seregét összegyüjtötte, hogy } \\
\text { Hungária ellen vezesse, miután } \\
\text { kitudakolta, hogy a magyarok között } \\
\text { nagy viszály dúl a királyság miatt.,"996 }\end{array}$ & $\begin{array}{l}\text { „Amikor meghallotta, hogy } \\
\text { Magyarország nemességének } \\
\text { egész testülete belsö } \\
\text { háborúságban marja } \\
\text { egymást...,997 } \\
\text { „A vezérsége alá tartozó összes } \\
\text { fegyveres eröt mozgósitva, } \\
\text { minden hadfelszerelést "998 }\end{array}$ & $\begin{array}{l}\text { „Magyarország megtámadására } \\
\text { határozta el magát, amire az } \\
\text { ország belsö meghasonlása } \\
\text { felbátoritotta ...legelöször } \\
\text { ostrom alá vette } \\
\text { Görögfejérvárt..." } 999\end{array}$ \\
\hline
\end{tabular}

992 Marios Philippides: The fall of Constantinople 1453: Bishop Leonardo Giustiniani and his Italian Followers. Viator 29 (1998) 189-227. (Philippides 1998)

993 A szövegrészlet további magyar fordítása: Baán 2013. 533-535.

${ }^{994}$ Latin szövegkiadás: Thuróczy textus 1985. 241-243. Magyar nyelvü fordításai: Thuróczy 1978. 380-381; Thuróczy 2001. 276-277.

${ }^{995}$ Latin szövegkiadás: Rerum 1936. 101-103; magyarul: Bonfini 1995. 590-592.

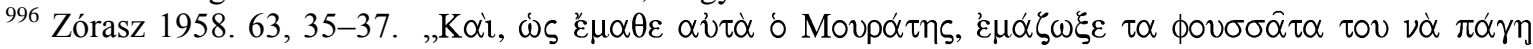

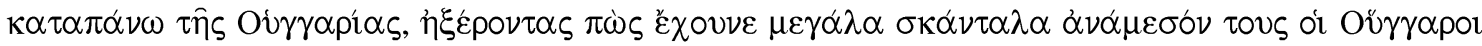

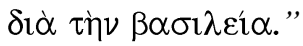

997 Thuróczy 2001. 276, 8-9. Thuróczy textus 1985. 241, 30-31. „Hic cum audivit omnem regnicolarum regni Hungarie cetum se intestinis guerrarum rodere morsibus...”

998 Thuróczy 2001. 276, 12-13.Thuróczy textus 1985. 242, 1-2. „Commoto igitur omni sui principatus armorum robore cunctisque bellicis apparatibus..."

999 Bonfini 1995. 13-14. Rerum 1936. 101, 13-16. ,ad invadendam Ungariam animum appulit, quod ex intestinis, regni discordiis audere facile potuit, imprimisque Albam Grecam ...obsedit." 


\begin{tabular}{|c|c|c|c|}
\hline 2. & $\begin{array}{l}\text {,Belgrád kapitánya, Vránai Jóannész } \\
\text { igen vitéz férfiú volt, amint a többiek } \\
\text { is. } 1000\end{array}$ & \begin{tabular}{|l|} 
„Egy nagyszerü ember volt a \\
kapitány ekkor ebben a várban, \\
János vránai perjel...egy \\
tetterös és rettenthetetlen \\
férfiú,"1001
\end{tabular} & $\begin{array}{l}\text { „A várat János, Vrána katonás } \\
\text { fópapja, buzgó és nagy hirü } \\
\text { férfiú tartotta örséggel” }\end{array}$ \\
\hline 3. & $\begin{array}{l}\text { „, A törökök kivüulröl hangos } \\
\text { bombardákkal löttek és egész nap } \\
\text { rombolták a falakat. }{ }^{1003}\end{array}$ & \begin{tabular}{|l|} 
„Felállittatta az ostromgépeket \\
és egyéb ágyúfajtákat, \\
omladozó rommá lövette és a \\
föld szinével tette egyenlövé a \\
magas torony-eröditményeket \\
és falakat." 1004
\end{tabular} & $\begin{array}{l}\text { „Az ellenség pedig olyan közel } \\
\text { húzódott a falakhoz, amennyire } \\
\text { lehetett...odavontatta a } \\
\text { hadigépeket és a lehetö } \\
\text { legkeményebb ostrom alá } \\
\text { fogta... makacsul törette a } \\
\text { falakat és bástyákat, néhány } \\
\text { tornyot ledöntött" } 1005\end{array}$ \\
\hline 4. & $\begin{array}{l}\text { "A keresztények pedig éjjel } \\
\text { újjáépitették azokat. }{ }^{1006}\end{array}$ & $\begin{array}{l}\text { „a várfalakat, amelyeket a } \\
\text { császár nappal fáradtságosan } \\
\text { lerontatott, éjszaka } \\
\text { megerösitették...,1007 }\end{array}$ & $\begin{array}{l}\text { „A nap mint nap döngetett falak } \\
\text { részben tönkrementek... hiszen } \\
\text { miközben nappal a várost } \\
\text { védelmezték, éjszaka a ledölt } \\
\text { falakat állitották helyre..." } 1008\end{array}$ \\
\hline 5. & $\begin{array}{l}\text { „Ekkor Murád üzent a vránainak, } \\
\text { hogy ha átadja a várat, öt kitünteti és } \\
\text { neki nagy vagyont ad majd. Ö } \\
\text { azonban ezt elutasitotta. }{ }^{1009}\end{array}$ & NINCS ADAT. & $\begin{array}{l}\text { „a városkapitányt ajándékokkal, } \\
\text { igéretekkel titokban gyakran } \\
\text { megkörnyékezte...(ó pedig) üres } \\
\text { igéreteket tesz” (János) }\end{array}$ \\
\hline 6. & $\begin{array}{l}\text { „....mestereket hivatott, hogy kivülröl } \\
\text { aknákat ássanak a föld alatt azért, } \\
\text { hogy bejussanak. }{ }^{1011}\end{array}$ & \begin{tabular}{|l|}
,A császár elhatározta tehát, \\
hogy ennek a dombocskának az \\
oltalmát kihasználva egy föld \\
alatti alagutat ásat egészen a \\
vár belsejéig, olyan hosszút és
\end{tabular} & $\begin{array}{l}\text { "hozzáfog egy } \\
\text { alagúthoz...elkezdenek késziteni } \\
\text { egy barlang formájú vájatot" }{ }^{1013}\end{array}$ \\
\hline
\end{tabular}

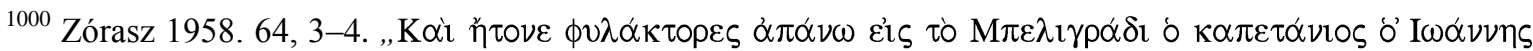

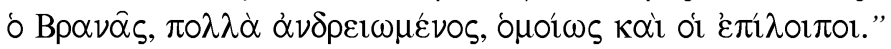

1001 Thuróczy 2001. 276, 15-16, 17-18. Thuróczy textus 1985. 242. 3-4, 6. „Erat tunc castro in eodem capitaneus vir magnificus Johannes prior Aurane... vir strenuus et animo impavidus."

${ }^{1002}$ Bonfini 1995. 590, 16-17. Rerum 1936. 101, 16-17. „Arcem cum presidio Ioannes Aurane militaris antistes vir bello impiger et clarus tenebat..."

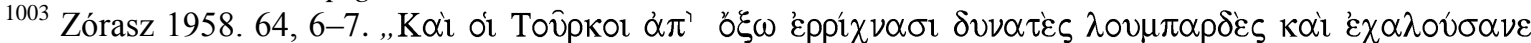

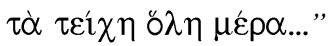

1004 Thuróczy 2001. 276, 24-27. Thuróczy textus 1985. 242. 12-13. „machinis et ceteris tormentorum generibus adaptatis altas turrium munitiones et menia precipitem dissipabat per ruinam, humilique terre adequabat."

${ }^{1005}$ Bonfini 1995. 590, 23-25, 31-32. Rerum 1936. 101, 23-26, 31-32. „menibus approprinquare...tormenta proprius bellica admovere, obcludere civitatem et quam gravissima potest, obsidione coercere...menia et propugnacula pertinacissime quatit, turres nonnullas proterit..."

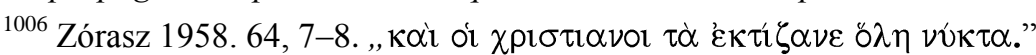

${ }^{1007}$ Thuróczy 2001. 276, 30-31. Thuróczy textus 1985. 242. 16-17. „,diurnis cesaris fatigationibus parietes castri prostratos nocturno labore muniebant..."

1008 Bonfini 1995. 590, 33-35. Rerum 1936. 101, 33-36. „Quassa in dies menia aliqua ex parte labascunt ...qui interdiu urbem protegunt, fractos noctu muros resarciunt ..."

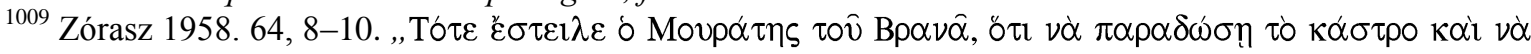

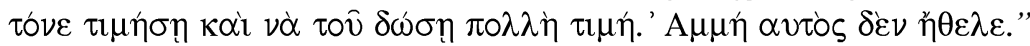

${ }^{1010}$ Bonfini 1995. 591, 2-4. Rerum 1936. 101, 47-48. „,lam sepe muneribus et promissis oppidanum tentat. Obaudit ille, acceptis quandoque muneribus et promissa irrita prestat"

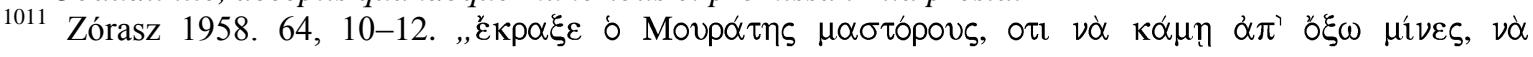

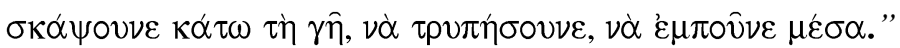




\begin{tabular}{|c|c|c|c|}
\hline & & \begin{tabular}{|l|l} 
széleset, hogy csapatok is \\
átvonulhassanak rajta., 1012
\end{tabular} & \\
\hline 7. & $\begin{array}{l}\text { „Ez sikerült is volna, ha egy } \\
\text { keresztény nem üzent volna egy } \\
\text { nyílvesszövel eljuttatott levélben. }{ }^{1014}\end{array}$ & $\begin{array}{l}\text { „,mint némelyek mondják, hogy } \\
\text { a várba egy nem tudni, ki által } \\
\text { kilött nyilröpült be, amelyre } \\
\text { rátekerve egy irást találtak, és } \\
\text { arról árulkodott, hogy az } \\
\text { emlitett helyen alagutat } \\
\text { ásnak...,"1015 }\end{array}$ & $\begin{array}{l}\text { „, némelyek úgy említik, hogy egy } \\
\text { keresztény katona figyelmeztette } \\
\text { az egyik városlakót; mások úgy } \\
\text { mondják, hogy egy cédula árulta } \\
\text { el, amelyet nyilvesszöre tüzve } \\
\text { belöttek a fal fölött" } 1016\end{array}$ \\
\hline \begin{tabular}{|l|}
8. \\
\end{tabular} & $\begin{array}{l}\text { „Amint ezt megtudta a vránai } \\
\text { parancsok, belülröl egy ellenaknát } \\
\text { ásatott }{ }^{1017}\end{array}$ & $\begin{array}{l}\text { „Zován ezért elrendelte, } \\
\text { hogy... készítsenek egy, a vár } \\
\text { belsejéböl kiinduló föld alatti } \\
\text { alagutat a császár alagútjával } \\
\text { szemben...,1018 }\end{array}$ & $\begin{array}{l}\text { „Fejérvár kapitánya...tüstént } \\
\text { egy másik alagutat fúrat } \\
\text { amazzal szemben ... a törökök } \\
\text { alagútja felé" } 1019\end{array}$ \\
\hline \begin{tabular}{|l}
9. \\
.
\end{tabular} & $\begin{array}{l}\text { „\#...és ásás közben megtalálta a } \\
\text { törökök aknáját és tüzet dobatott a } \\
\text { puskaporra (füre!) }\end{array}$ & $\begin{array}{l}\text { „Amikor a várfalakon belül az } \\
\text { ellenség alagútja elérte a } \\
\text { várbeliek ásta } \\
\text { alagutat ... meggyújtatta az } \\
\text { emlitett összehordott } \\
\text { anyagokat..."1021 }\end{array}$ & $\begin{array}{l}\text { „amikor...megtudta, hogy az } \\
\text { ellenséges akna a falak alatt } \\
\text { összeért az övével...azonnal } \\
\text { lángot dobatott" } 1022\end{array}$ \\
\hline
\end{tabular}

1013 Bonfini 1995. 591, 15-16. Rerum 1936. 102, 13-15. „cunicolorum opus inchoat...fossam in antri speciem exordiuntur..."

1012 Thuróczy 2001. 277, 3-6. Thuróczy textus 1985. 242, 22-25. „Huius igitur colliculi sub umbra cesar ipse fossam subterraneam castri euisdem usque ad interiora penetrantem longam latamque, per quam agmina post sese progredi possent, egerere statuit."

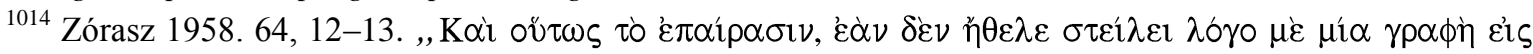

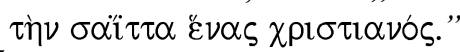

1015 Thuróczy 2001. 277, 12-14. Thuróczy textus 1985. 242, 29-32. „ut quibusdam dicere placuit, quod sagitta, nescitur per quem emissa, in castrum devolasset, cui carta quedam circumvoluta reperta extitisset, que fossam in loco memorato egeri castroque propinquam esse manifestasset."

${ }^{1016}$ Bonfini 1995. 591, 26-28. Rerum 1936. 102, 27-30. „,aliqui a Christiano milite oppidanum quendam admonitum fuisse memorant; brevem epistolam sagitte alligatam immissamque menibus rem patefecisse alii prodidere."

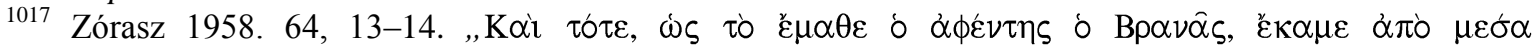

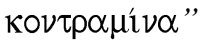

1018 Thuróczy 2001. 277, 15-17. Thuróczy textus 1985. 242, 32-35. „Zowanus...instructus aliam de ipsius castri corpore progredientem fossam consimiliter subterraneam fosse cesaris obviam celeri cum labore effici..."

1019 Bonfini 1995. 591, 29-30. Rerum 1936. 102, 30-31. „Prefectus Albane arcis admonitus...extemplo alteram contra molitur..."

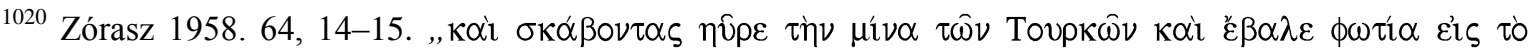

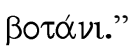

${ }^{1021}$ Thuróczy 2001. 277, 22-25. Thuróczy textus 1985. 243, 5-7. „Cumque hostilis fossa intra menia castri ad fossam per castrenses egestam deducta est...mox ignis adhibitus omnes predictas res compositas succendit..."

1022 Bonfini 1995. 591, 36-37. Rerum 1936. 102, 38-40. „ubi hostilem fossam cum sua intra menia congruisse per exploratores intellexit, ignem repente per foramen immittit..." 


\begin{tabular}{|c|c|c|c|}
\hline 10. & $\begin{array}{l}\text { „Azt mondják, hogy ebben az aknában } \\
\text { benn égett több mint } 17000 \text { török. }\end{array}$ & $\begin{array}{l}\text { „,népéböl - mint mondják- } \\
\text { tizenhétezer embert } \\
\text { elveszitve... }{ }^{1024}\end{array}$ & $\begin{array}{l}\text { „az állatokon kívül } 17000 \\
\text { ember pusztult el az aknában” } \\
1025\end{array}$ \\
\hline 11. & $\begin{array}{l}\text { „A harcban pedig életét vesztette } \\
8000,1026\end{array}$ & NINCS ADAT. & $\begin{array}{l}\text { „a város ostromában körülbelül } \\
8000 \text { embere veszett oda” } 1027\end{array}$ \\
\hline 12. & $\begin{array}{l}\text { „az ostrom (körülzárás) } 7 \text { hónapig } \\
\text { tartott. }{ }^{1028}\end{array}$ & $\begin{array}{l}\text { ", hét hónapot az ostrommal } \\
\text { eltöltve...,1029 }\end{array}$ & $\begin{array}{l}\text { "hét hónap alatt semmit sem } \\
\text { tudott elérni"1030 }\end{array}$ \\
\hline 13. & $\begin{array}{l}\text { „Murád szultán látva, hogy } \\
\text { bizonytalan lett az ostrom kimenetele, } \\
\text { lemondott erröl és visszafordult } \\
\text { Adrianopoliszba, }{ }^{1031}\end{array}$ & $\begin{array}{l}\text { „.... a császár , miután látta, } \\
\text { hogy ez az út sem segít neki a } \\
\text { vár } \\
\text { megszerzésében ...zaklatottan } \\
\text { tért vissza hazájába...,1032 }\end{array}$ & $\begin{array}{l}\text { „,meggondolta...feloldotta az } \\
\text { ostromot...telelöre vonult } \\
\text { vissza...hogy helyreállitsa és } \\
\text { feltöltse a sereget" }{ }^{1033}\end{array}$ \\
\hline
\end{tabular}

Beláthatjuk, hogy a Névtelen Krónika nemcsak tartalmilag, az események sorrendjében követi a Thuróczy és a Bonfini által előadottakat, hanem egyes részeiben szövegszerűen is. Ez a hasonlóság megerösíti a szövegek közötti filológiai kapcsolatot is. A fenti táblázatban sorszámokkal láttam el a párhuzamba állítható szövegrészeket. A Thuróczy Krónikával 11, Bonfini mủvével viszont 13 szövegpárhuzamot találtam. Ezek alapján megállapítható, hogy a Névtelen Szerző az 1440. évi ostromra vonatkozóan használta Bonfini munkáját vagy olyan munkát, amely azt tartalmazta. A Thuróczy Krónikától pedig szöveghasználatában két „differentia specifica” választja el.

$\mathrm{Az}$ is megállapítható, hogy a Névtelen Krónika az ostromra vonatkozó „klasszicizáló” bizánci forrásokkal (Dukasz, Khalkokondülész) viszont nem tart sem formai, sem tartalmi rokonságot. Véleményem szerint ez gyengíti azt a feltételezést is, hogy a szerző

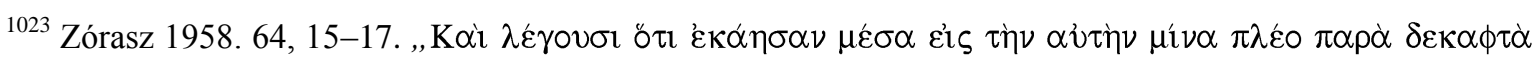
$\chi \imath \lambda \imath \alpha \dot{\delta} \varepsilon \varsigma$ Тойркол."

${ }^{1024}$ Thuróczy 2001. 277, 29. Thuróczy textus 1985. 243, 10-11. „ut fertur, decem et septem sue gentis millibus..."

${ }^{1025}$ Bonfini 1995. 592, 2. Rerum 1936. 103, 1-2., ,preter iumenta septemdecim hominum milia in cuniculis interiere..."

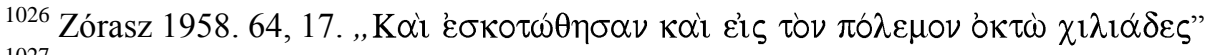

${ }^{1027}$ Bonfini 1995. 592, 5-6. Rerum 1936. 103, 5-6. „Preter hec in urbis oppugnatione octo circiter hominum milia desiderata sunt."

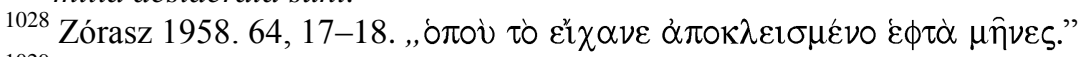

${ }^{1029}$ Thuróczy 2001. 277, 30. Thuróczy textus 1985. 243, 11. „et septem mensibus obsidione in eadem exactis..."

${ }^{1030}$ Bonfini 1995. 592, 6-7. Rerum 1936. 103, 6-7. „Postquam se nihil septem mensibus proficere potuisse cognovit"

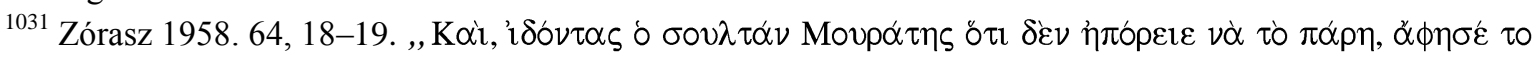

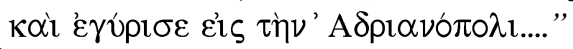

1032 Thuróczy 2001. 277, 28-30. Thuróczy textus 1985. 243, 9-12. „Quapropter cesar ipse cum nec hanc viam sibi in obtentione castri eiusdem iuvamine esse vidit, amissis...confusus repatriavit."

1033 Bonfini 1995. 592, 6-9. Rerum 1936. 103, 7-10. „obsidionem illico solvit...relicta Mysia, ad instaurandum exercitum et comparanda supplementa in Macedoniam et Thraciam hibernatum se recepit." 
Khalkokondülészt vagy Dukaszt teljes körủen használta volna, mert -legalábbis ittmégsem tette. ${ }^{1034}$

Ezek után adódik a kérdés, közvetlen kapcsolatba hozhatók-e az említett krónikák egymással? Ehhez a kiadások történetét kell röviden áttekintenünk. Thuróczy Krónikájának kézirata nem maradt ránk, de 1488-ban két kiadásban is megjelent. 1488. március 20-án a morvaországi Brünnben, Stahel Konrád nyomdájában; illetve június 3-án Augsburgban az átnézett és javított változat Fegher Theobald költségén. ${ }^{1035}$

Bonfini 1488 májusában még csak a megbízását kapta meg a mü megírására Hunyadi Mátyás magyar királytól (1458-1490), amelyet II. (Jagelló) Ulászló király (1490-1516) meghosszabbított. Bonfini hatalmas művéből 1494-1496 között a királyi könyvtár számára először egyes decasokat másoltak le (I-IV. decas). ${ }^{1036}$ Ebben már benne volt az 1440. évi ostromot tartalmazó 3. decas is. A mü népszerüsége megnőtt, a királyi udvarban mintegy 20 másolata volt ismert. Azonban 1510-1515 között a másolatok lassan eltüntek. Nyomtatásban végül az első három decas 1543-ban Baselben jelent meg. 1545-ben adták ki német fordításban, majd 1572-ben egyes részleteket franciául is. Bonfini újabb nyomdai kiadása a polihisztor tudós, Zsámboki János (Johannes Sambucus) nevéhez füződik, aki 1581-ben Frankfurtban újra megjelentette. Ennek újabb kiadása 1606-ban, 1690-ben, 1744ben és utoljára 1771-ben történt. ${ }^{1037}$ Ha elfogadjuk a poszt-bizánci Névtelen Krónika 1603-1671 közötti keletkezését, akkor bizony feltételezhető, hogy a névtelen szerző rendelkezésére állhatott az Európában ekkorra már jól ismert Bonfini munkája vagy annak az 1440. évi ostromot is tartalmazó része.

\section{2. A tüzfegyverek, aknák megnevezése az ostrom bizánci forrásaiban}

A bizánci Névtelen Krónika (Anonymous Zoras) szerzője - akarattalanul -, a nyelvezetében és szóhasználatában is „újat” hozott abban a tekintetben, hogy antik szerzőkre való hivatkozás teljes hiánya jellemzi munkáját. A mindennapok

\footnotetext{
${ }^{1034}$ Azt megjegyezzük, hogy hasonló a tapasztalatunk az 1439-es Szendrő ostromáról szóló tudósítással is. 1035 Thuróczy 1978. 465.

${ }^{1036}$ Bonfini 1995. 1014.

${ }^{1037}$ Bonfini 1995. 1016.
} 
nyelvhasználatát őrizte meg, a 16-17. századi beszélt nyelven, valahol a ión szigetek vidékének dialektusában. ${ }^{1038}$

A népi nyelvhasználat azért fontos, mert a köznapi, beszélt nyelvet egészen a 20 . századig, a dimotiki bevezetéséig, nem használták történeti, irodalmi és tudományos munkákra, inkább az idegen szavaktól megtisztított és ógörög nyelvet örző katharevuszát. ${ }^{1039}$ Így szerzőnk a többszörösen összetett, alá- és fölérendelt tagmondatok (a thuküdidész-i „tengeri kígyók”) helyett a népi nyelvben használt egyszerü mellérendelt mondatokat szerkesztett. Ráadásul szerzőnk vagy a másoló nem volt túl képzett sem, mert a kézirat sok nyelvtani hibát, elírást tartalmaz. ${ }^{1040}$

Legalább ennyire kimutatható a változás a szóhasználatában. A beszélt nyelv szókincséből átvette, használta a még a 14. századi Moreában honos szavakat is. Az utóbbira a legjobb példa a $\gamma \cup p i \zeta \omega$ ige felbukkanása az ostrom leírásának végén. Ez az ige nem található meg a klasszikus görög nyelvben, de a népi nyelven írt Moreai Krónikában többször előfordul. ${ }^{1041}$

Itt az 1440. évi ostrom leírásában előforduló néhány szó használatára kívánom felhívni a figyelmet. Tudjuk, hogy a szerző jól ismerte az olasz és a török szavakat, kifejezéseket is. Sőt, a klasszikus görög fordulatok helyett a hadászati eszközökre inkább az „,idegen”, olasz terminusokat használta. Ezek közül a legfontosabbak - mivel egy ostrom leírásáról van szó - a tüzérségre vonatkozó szakkifejezések, amelyek még a klasszikus nyelven író bizánci történetíróknak is sok nehézséget okoztak. Bizánci forrásainkban ugyanis rendkívül nehéz a tűzfegyverek korai használatát kimutatni, mert a szerzőknek, hogy le tudják írni, új szavakat, fogalmakat kellett alkotniuk. Mariosz Philippidész hívja fel a figyelmet arra, hogy a nyelvük évezredes hagyományait féltő bizánci szerzők tartózkodtak az idegen kifejezések közvetlen átvételétől, inkább igyekeztek archaikus, általános jelentésű szavakat találni. ${ }^{1042}$ A túl általános megnevezések viszont tüzfegyverek használatát is rejthetik, és bennünket arra késztetnek, hogy - akár új, akár már korábban lefordított szöveghelyekről is van szó - ezeket ebböl a szempontból filológiailag is újra meg kell vizsgálni és értelmezni. Érdemes szemügyre venni az 1440-ről szóló bizánci forrásainkat.

\footnotetext{
${ }^{1038}$ Ez a klasszikus görög nyelvtől markánsan különbözik. Többek között a casusok számának csökkenésével és ebből adódóan a praepositio-k használatának megváltozásával.

1039 A XIX. században használt ún. a katharevusza is megőrizte az ógörög nyelvi elemeket, valamint 1976ban történt hivatalos bevezetéséig, a dimotiki sem foglalta magába a népnyelvet, inkább egymásra hatottak. Mohay 1988. 5-6.

${ }^{1040}$ Philippides 1990. 14-15.

${ }^{1041}$ P szövegváltozat 652., 844. és az 1048. soraiban. Schmidt 1904. 45, 58, 71.

1042 Philippides-Hanak 2011. 415.
} 
Erre Khalkokondülész munkájában az ágyúra használt télebolosz szó a legjobb példám. E „,messzire ható/lövő fegyver” jelentésủ szót már Sztrabón használta egy közbevetett megjegyzésében, megkülönböztetésül a közelharc fegyvereitől: „A harci szokásokat és fegyverkezést illetöleg ma sincs mindenütt azonos szokás, és azelött sem volt; egyesek messzeható fegyvereket használtak, amilyenek az ijászok, parittyások és dárdavetők, mások azonban a közelharcra alkalmas fegyvernemeket, amilyeneket a karddal és a kinyújtott dárdával harcolók” (10. 1. 12. , Földy József fordítása.) ${ }^{1043}$ Sztrabón kifejezését már az ágyúra használta Khalkokondülész például Konstantinápoly 1422-es és Szendrő 1439-es török ostrománál.

Jóannész Anagnósztész Thesszaloniki 1430-as oszmán-török ostromakor szkeuéról írt. „Mi mindenekelőtt az úgynevezett ágyút (szkeué) használtunk, amelynek csak a hangját hallottuk, viszont nem láttuk sosem az eredményét..."1044 Azonban a következő szövegrészlet inkább az ágyúnál kisebb tüzfegyverre vonatkozhat, kis ágyúra, azaz valamilyen puskára, amelyet az ostromlók használtak. „Az ostromló tömeg nemcsak nyilakat használt, hanem úgynevezett kis ágyút. (szkeué mikra)”1045 „Látjuk, hogy parancsra az egész tömeg a várfalhoz közeledik. Látunk egyrészt ostromlétrákat, másrészt deszkákat vivöket, másokat pedig vesszökböl font pajzsokkal, egyszóval ostromeszközökkel (helepoleisz)..."1046

Így találkozunk tehát a nyelvüket megőriző „klasszicizáló” bizánci szerzőknél az új találmányú tủzfegyverekre a télebolosz, szkeué, helepolisz, aphetérion megnevezésekkel, míg a latinból vagy olaszból (bombarda) ${ }^{1047}$ közvetlenül átvett boumpardosz, boumparda, loumparda kifejezések ritkák. Kritobulosz bizánci történetíró szerint a legfőbb nyelvi probléma az volt, hogy: „...semmilyen régi elnevezés nem található erre a szerkezetre (mékhané), hacsak nem mondhatná valaki helepolisznak ${ }^{1048}$ (=városvívó, várospusztító)

\footnotetext{
1043 Strabón: Geógraphika. Fordította: Dr. Földy József. Budapest 1977. 477. (Sztrabón 1977)

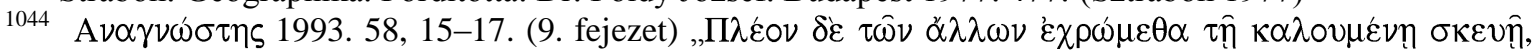

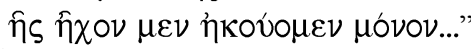

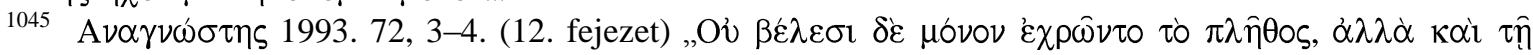

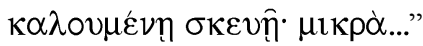

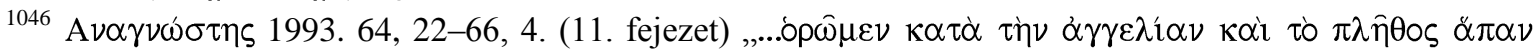

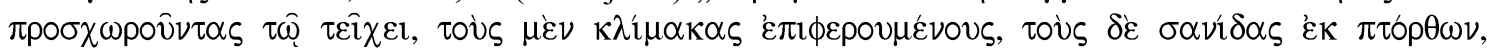

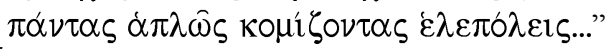

${ }^{1047}$ Herczeg Gyula: Olasz-magyar szótár. I-II. Budapest 1952. 228. A továbbiakban: Herczeg 1952.

$1048 \mathrm{Az}$ ókori hadvezér Démétriosz Poliorkétész hatalmas, kilencemeletes ostromtornyát nevezték így, amelyet Kr. e. 305/304-ben Rodosz ostromakor vetett be.
} 
vagy aphetérionnak (=pattantyú), a mostaniak azonban mind közös elnevezéssel ezt csak szkeuénak (=felszerelés, szerszám, eszköz) nevezik."(I. 30. 8.) ${ }^{1049}$

$\mathrm{Az}$ 1440. évi ostromra vonatkozó forrásaink közül viszont a népi görög nyelven írt Codex Barberinus Graecus 111. kódex névtelen krónikásánál a $\lambda \circ \cup \mu \pi \alpha ́ \rho \delta \varepsilon \varsigma$ szó fordul elő II. Murád 1422-es konstantinápolyi $\left(37^{\mathrm{v}}\right)^{1050}$ és 1440 -es nándorfehérvári várostromainak leírásában $\left(40^{\mathrm{v}}-41^{\mathrm{r}}\right) .{ }^{1051}$ A nyugat-európai nyelvből való közvetlen átvétel korábban, ebben az ún. bizánci „nyelvújításban” elképzelhetetlen lett volna.

Hasonlóképpen a török táborból a várba belőtt nyílvesszőre a Névtelen Krónika a latin

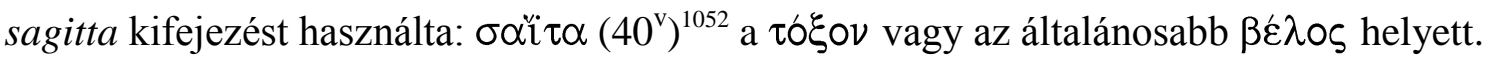

Másik észrevételem az ostromban alkalmazott aknák megnevezésére vonatkozik. Khalkokondülész az 1440. évi ostromnál nem említi ugyan az alagutak használatát, ám amikor II. Murádnak az 1430-as Thesszaloniki elleni ostromát beszéli el, a klasszikus görög tò ő $\phi \varepsilon ́ p o v \tau \alpha) .{ }^{1053} \mathrm{Ez}$ a szó klasszikus használatú, már Polübiosznál is felbukkan Ambrakia ostromának (Kr. e. 189) leírásában (XXI. 27-28). ${ }^{1054}$ A Névtelen Szerző mégsem ezt,

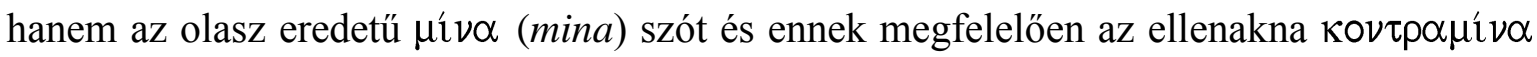
$\left(41^{\mathrm{r}}\right)$ kifejezést alkalmazza. ${ }^{1055}$

Találtam azonban más eseteket is névtelen krónikásunk szóhasználatában, ahol nem követi „klasszicizáló” görög elődöket. Khalkokondülész az újnak számító találmány, az ágyú müködésének leírásakor a fekete vagy „füstös” löporra a konisz (= por) szót használta. ${ }^{1056}$ A Névtelen Krónika nem pornak, hanem „fünek” mondja a fekete lőport, ezen a ponton nem követve latin forrásainak megnevezését (pulver) sem. „...a vránai

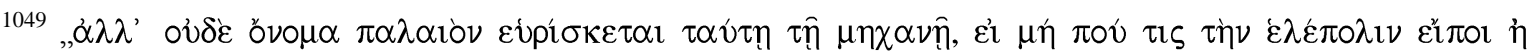

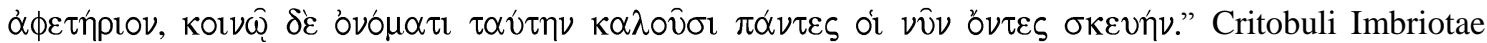
Historiae. Recensuit Diether Roderich Reinsch. (Corpus Fontium Historiae Byzantinae, vol. XXII). Walter de Gruyter, Berolini et Novi Eboracii 1983. 46, 16-19. (A továbbiakban: Critobulos 1983) Korábbi fordítása: Kritobúlosz: II. Mehemet élete. Fordította Szabó Károly. Budapest 1875. 57, 6-10. (A továbbiakban: Kritobúlosz 1875) Idézi: Philippides-Hanak 2011. 415.

${ }^{1050}$ Zórasz 1958. 60, 3, 8.

${ }^{1051}$ Zórasz 1958. 64, 7.

${ }^{1052}$ Zórasz 1958. 64, 13.

${ }^{1053}$ Darkó 1923. 14, 6.

${ }^{1054}$ Polybius text 1995. 296, 298; Polübiosz 2002. 254-256; Szabó 2010. 75.

${ }^{1055}$ Zórasz 1958. 64, 11; Zórasz 1958. 64, 14. Herczeg 1952. 793.

${ }^{1056}$ Lásd: 10. 4. fejezetet. Illetve: Marc C. Bartusis: The late Byzantine army: arms and society, 1204-1453. Philadelphia 1997. 336. A továbbiakban: Bartusis 1997. 
parancsok, belülröl egy ellenaknát ásatott és ásás közben megtalálta a törökök aknáját és tüzet dobatott a puskaporra (sic! t. i. a füre)."1057

Ennek a kérdésnek egyúttal fontos technikatörténeti jelentősége van, amelyet részletesen a technikatörténeti fejezetben tárgyalok (10. 5. fejezet). Felfigyeltem arra, hogy Kritobulosz, Anagnósztész és Dukasz is a botané (= fü, takarmány) megnevezéssel élt.

A névtelen krónikás a puskák elnevezésében sem követi „klasszicizáló” bizánci elődeinek szóhasználatát. A magyarországi latin forrásokon túl, a bizánci Khalkokondülész passzusának újraértelmezéséből megtudjuk, hogy a védők akkoriban újnak számító puskákat is használtak. „A szultán hadserege a város felöl elhárithatatlanul szenvedett a védők ágyúinak és puskáinak (télebolón kai téleboliszkón) ${ }^{1058}$ böséges csapásától... "1059 Előbb mondottuk, hogy az ágyúra Khalkokondülész a legjobban elterjedt télebolosz szót alkalmazta. ${ }^{1060}$ De van egy másik kifejezése is. Mi lehet a védők által használt téleboliszkosz? Nyelvtanilag az előbbi kifejezés dēminutívája: téleboliszkosz, amelyet így „kis ágyú"-nak, azaz puskának fordítottam.

Dukasz is ismertetett egy ilyen puskát, amelyet az archaikus mékhané (=szerkezet, gép, eszköz) szóval nevezett meg. Nándorfehérvár ostrománál azonban elég körülményesen, a megfelelő szavakat keresve, de egyedülálló részletességgel leírja azt a védők által használt, bronzból készített mékhanét, amelynek maga is elismeréssel adózik. ${ }^{1061}$

A Codex Barberinus Graecus 111 Névtelen krónikása Konstantinápolynak II. Murád 1422-es szultáni ostromáról szólva megjegyezte, hogy $\left(37^{\mathrm{v}}\right)$,...ekkoriban még nem volt

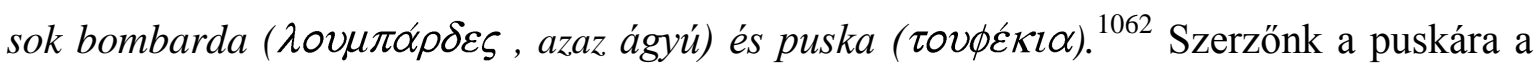

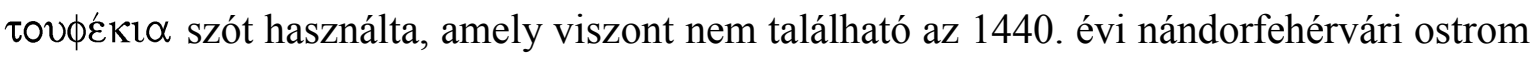
leírásában. Véleményem szerint ezt a kifejezést az oszmán-török szóhasználat is átvette, amikor a puskásokat tüfekçi-knek nevezték. ${ }^{1063}$

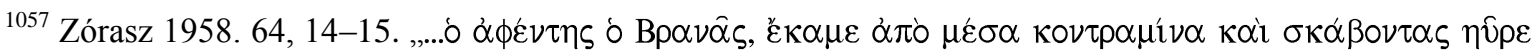

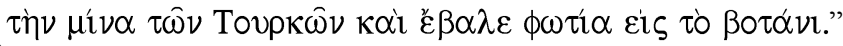

${ }^{1058}$ Lásd: Darkó 1923. 10; Szabó 2012. 124. Lásd a 8. 3. fejezetet.

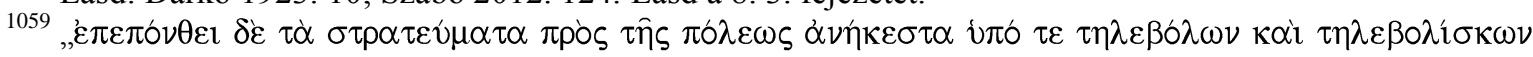

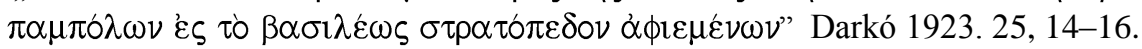

${ }^{1060}$ Philippides-Hanak 2011. 415.

${ }^{1061}$ Grecu 1958. 265, 1-7.

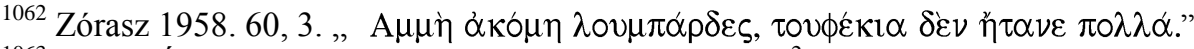

${ }^{1063}$ Csáki Éva: Török-magyar szótár. Budapest 2001. ${ }^{2}$ 344. (tüfekği) (Csáki 2001²); Bayerle 1997. 160 (tüfekçi, tüfeng-endāz=musketeur). 
„Jó vitéz Szováti János bán tisztiben akkoron Fejérvárban az vitézek között forgódik mindönött, vagyon nagy biztatásban, szive bátorságban, bölcs hadakozásban, jeles minden dolgában, vitézekkel tészen Szováti János bán nagy kárt császár hadában."

(Nagybáncsai Mátyás, 1560)

\section{Elemzések és következtetések}

\section{1. Az ostrom rekonstrukciója}

Korántsem lenne teljes az ostromot megelőző körülmények vizsgálata, ha az oszmántörökök szempontjait nem vennénk figyelembe néhány megállapítás erejéig. Az oszmánoknak jól fel kellett készülniük erre az ostromra, amely a megelőző évek szisztematikus szultáni támadásainak végpontjaként érkezett el számukra.

Elörebocsátva mondanivalómat egyetértek azzal a feltételezéssel, hogy az 1390-es években is elérte egy szultáni török támadás Nándorfehérvárt. ${ }^{1064}$ A törökök azonban esetleges elfoglalása esetén - nem tudták volna akkor tartósan megtartani, mert az ország határáig az Oszmán Birodalom még nem ért el, bár a szerbiai területek nagy részét vazallusi függésben tartotta. Egy ilyen vár ellen mozgósítani kellett a birodalom teljes haderejét, amelyet csak szultáni paranccsal lehetett végrehajtani és összehangolni. A 15. századi Nándorfehérvár elleni ostromokat végigkövetve látjuk, hogy ezek mindig a szultánok személyes vezetése alatt álltak.

A megtámadott ország belső meggyengülésére - mint a megfelelő pillanatra - várni kellett, amely egészen Albert király haláláig kitolódott. A kettős királyválasztás miatti polgárháború kitörése erre ismét lehetőséget adott, amelynek befejezése egyhamar nem volt várható. Egy hosszan tartó körülzárással, a falak megvívására alkalmas nehéztüzérséggel, hadifelszereléssel, megfelelö létszámmal végrehajtott ostromra csak ekkorra, 1440 tavaszára értek meg a feltételek, amelyet idézett forrásaink ki is emeltek.

Az 1440. évi szultáni támadó hadjárat iránya is eldőlt. A szultáni had főserege immár nem Erdély felöl támadta meg az országot, mint 1438-ban. Ebben az is szerepet játszott, hogy Erdélyben ebben az évben a vízrajzi viszonyok nem lehettek alkalmasak egy nagy hadsereg felvonulására, folyón való átkelésére. Losonci Dezső erdélyi vajda Tallóci Matkónak, 1440. június 19-én keltezett oklevelében arról írt, hogy a folyók annyira megáradtak, hogy egyben lehetetlenné tették a só szállítását is. ${ }^{1065}$

\footnotetext{
${ }^{1064}$ Lásd: a 13. 3. fejezetet.

1065 DL 55213
} 
$\mathrm{Az}$ ostrom menetének rekonstruálását a rendelkezésre álló források összevetésével kísérlem meg. A latin nyelvü forrásaink az ostromra történő felfejlődést aránylag jól ismertetik. A polgárháborúval elfoglalt ország figyelmét lekötötte az egymás elleni harc, amelyről viszont a törököknek jó ismereteik voltak, ez indokolta a támadás időpontját (Thuróczy, Bonfini, Callimachus). Erről a latin forrásokat felhasználó Névtelen Krónikás, azaz Anonymous Zoras is tudott. Bár az Oszmán Birodalomban teljes mozgósítást sejthetünk, egyik forrásunk sem említi a vár alá felvonuló ostromlók létszámát. A török oldalon, a Dunán felhajózó flottáról egyedül a bizánci forrásaink tesznek említést. Dukasz több mint száz hajóról tudott. Az oszmán-török Âșik Pașazade pedig arról írt, hogy a törökök által szerzett foglyok száma végül nagyobb lett az ostromlókénál.

Az ostrom első szakaszában a várhoz megérkező török sereg teljesen körülzárta a várat, azaz blokád alá vette (Thuróczy, Bonfini, Callimachus). A törökök hosszú ostromra rendezkedtek be, amely megakadályozta a külső segítség bejuttatását és lehetőséget adott a vár védőinek kiéheztetésére is. Ezt Dlugos meg is fogalmazta.

A latin nyelvü lengyel forrásaink említik egyedül I. Ulászló lengyel-magyar király követküldését II. Murád szultánhoz, amelynek célja az időnyerés és a törökök szándékának kiderítése volt. Azonban a szultán a követeket - jogsértő módon - visszatartotta és letartóztatta. A követek száma és személye a névtelen lengyel levélírónál, Dlugosnál, valamint Callimachusnál eltérő. Bár a névtelen lengyel levélíró és Dlugos leírása Piotr Łęczycki személyében megegyezik (Petrus Lancziczsky, Petrus Lanciczki de Lankoschino).

Azt is tudjuk, hogy az ostromló sereg jól fel volt szerelve a vár megvívásához használt, szokásos ostromgépekkel. Thuróczy és Bonfini ezek mibenlétéről még általánosságban fogalmazott. Dlugos tudott az ostromlóknál lévő falbontó bombardákról és a védők által használt bombardákról, amellyel a török hajókat eredményesen lötték. A török hajók elleni sikeres küzdelmet - egy gálya legénységgel együtt való elfogását, egy másik elsüllyesztését - a névtelen lengyel levélíró beszámolója is megerősítette. Callimachus a törökök által használt faltörö gépeket és fából készített ostromtornyokat is megemlített. A bizánci források - szövegértelmezésem szerint - az akkor újnak és korszerünek számító tủzfegyverek használatáról szintén tudtak. Khalkokondülész szerint az ostromlók ágyúkkal törették a falakat, a védők pedig erre ágyúkkal és puskákkal válaszoltak. Amíg Dukasz a támadóknál lévő kőhajító gépekről írt, addig a védőknél puskák használatáról tudott. A Névtelen Krónikás (Anonymous Zoras) leírásában pedig a törökök által használt 
bombardákat találjuk meg. Az általunk használt oszmán-török források ostromgépekről nem tettek említést.

Az ostromgépek, ágyúk eredményességéről szólva meg kell jegyeznünk, hogy a vár falainak rombolásáról ellentmondásosak a források információi. Míg a források egy része (Thuróczy) a falak teljes rommá lövéséről szól, addig mások csak részleges pusztításról tudnak (Bonfini, Dlugos). Khalkokondülész pedig Evrenosz fia Ali támadása során tudósított a várfal egy részének lerombolásáról. A falak pusztítása valószínűleg nem lehetett teljes, hiszen a Thuróczy és Bonfini, valamint Anonymous Zoras szerint a védők a nappal lerombolt falakat éjszaka meg tudták erősíteni vagy fel tudták építeni. Figyelembe kell venni, hogy vár több oldalát már kettős falrendszer védte. Az alacsonyabb magasságú, külső falszakaszok károsodása esetén azokat gyorsabban felemelhették, a két fal közötti helyeket pedig a törmelék, föld belehordásával megerösíthették.

Amíg a Nándorfehérvárt védő kapitányt, Tallóci Jovánt forrásaink megnevezik (Thuróczy, Bonfini, Dlugos, Callimachus, Anonymous Zoras), az ostromló sereg vezéreiröl, a szultánon kívül, alig van információnk. Érdekes módon erröl az oszmán-török források sem számolnak be. Talán ebben a vereség ténye is közrejátszhatott. A bizánci források közül egyedül Khalkokondülész nevezi meg az elöbb említett és az ostromban vitézkedő Evrenosz fia Ali-t, aki a török forrásokban jól azonosítható korábbi magyarországi, majd albániai portyázásai kapcsán. ${ }^{1066}$ A szultán megérkezésekor először hagyományos módon, a falak ellen - szárazon és vizen - indított általános rohamokkal kezdte az ostromot. Véleményem szerint a névtelen lengyel levélíró az egyik ilyen utolsó rohamról tudósított.

A szultán, miután a hagyományos módon, a falak töretésével és a falakra vezetett rohamokkal célt nem ért, más technikát választott: földalatti aknákkal próbált bejutni. $\mathrm{Az}$ ostrom második szakaszát innen számítom. Az aknák létéről azonban a forrásaink megoszlanak.

A magyarországi latin nyelvü forrásaink, Thuróczy és annak nyomán Bonfini írják le a földalatti aknák alkalmazását, a bizánci források közül pedig az őket feltehetően felhasználó Anonymous Zoras. Az oszmán-török forráscsoportból, a Tarihi Üngürüszből ismert, a védők által alkalmazott ,föld alatti folyosókat" is ide soroljuk. Ezek egységesek abban is, hogy a védők is ellenaknával, annak berobbantásával hárították el sikeresen e támadást.

${ }^{1066}$ Melikoff 1965. 721. Lásd az 5. 4. és a 6. 2. fejezeteket. 
A forrásaink másik része is hivatkozik robbantásra, de nem a föld alatt, hanem a várárok sáncában. A latin nyelven író lengyel krónikásaink, Dlugos és Callimachus szerint a védők a törökök által a várárokba előzőleg belehordott fahasábokra puskaport szórtak. Majd ezt akkor gyújtották meg, amikor a falakra irányuló roham megindult. A bizánci szerzők, valamint az oszmán-török források nem tesznek említést aknák vagy várárkok felrobbantásáról.

A szakirodalomban egyedül Jefferson reflektált erre az ellentmondásra. Véleménye szerint Dlugos leírása a megbízhatóbb. ${ }^{1067}$ Csakhogy Belgrádban az aknák létének régészeti bizonyítékai vannak, melyeket később tárgyalok. ${ }^{1068}$ A kérdés megoldásához közelebb visz bennünket az, ha tudjuk, hogy mindkét ostrommódszernek lehetett valóságalapja. A várárok feltöltése még az ostrom első szakaszához tartozhatott, amennyiben ezáltal nemcsak a létrákat, hanem az ostromtornyokat is így lehetett a falakhoz közel vinni és onnan eredményes rohamot indítani.

A hosszan elhúzódó ostrom során folyamatos kísérlet történt a védők megadásra kényszerítésére. Míg Thuróczynál és Bonfininél, valamint Anonymous Zorasnál a török táborból a nyílvesszőn belött üzenet a védőket csupán a török akna helyéröl informálta, addig Dlugos és Callimachus szerint a várba belőtt nyílvesszők a vár megadásáért kilátásba helyezett jutalmakat is tartalmazták. II. Murád szultán ugyanezt tette már 1430-ban, Thesszaloniki ostromakor is. Jóannész Anagnósztész szerint „a legtöbb levelet nyílvesszőkkel küldte be (a várba)."1069

A forrásokból az a következtetés vonható le, hogy a szultánt végül a veszteségei kényszerítették a hosszú ostrom második szakaszának abbahagyására és a visszavonulásra. Konkrét adatokról azonban alig van tudomásunk. A védők soraiban lévő veszteségekről egyik forrás sem hagyott ránk információt. A török veszteséget a berobbantott aknában Thuróczy és Bonfini 17000 före teszi. Ennek nagyságát Bonfini jobban érzékelteti azzal az adatával, hogy 20000 ember dolgozott az ásás során. Bonfini szerint a város ostromában ezenkívül még 8000 ember esett el. Dlugos és Callimachus sem írt számszerüsített veszteségekről, a bizánci forrásaink közül egyedül Anonymous Zoras vette át Bonfini adatait. A bizánci Dukasz erről nem tesz említést, de írt a török táborban pusztító dögvészről és a védők puskái által okozott pusztításokról. Az oszmán-török források pedig a törökök által szerzett zsákmány óriási voltát hangsúlyozzák.

\footnotetext{
1067 Jefferson 2012. 243.

${ }^{1068}$ Lásd a 10. 4. fejezetet.

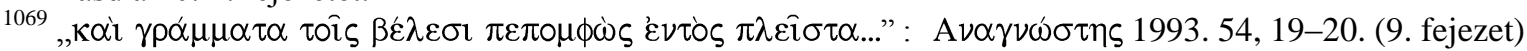


Az ostromló török flotta harcáról és veszteségeiről egyedül a névtelen lengyel levélíró, Dlugos és Callimachus emlékezett meg. Pedig az ostromban fontos szerepe volt, mert a folyók felőli vízi utat - egy felmentő sereg érkezésének fontos útját - zárták el. Tudjuk, hogy a törökök az 1430-as évekre felismerték az Al-Duna fontosságát a Magyar Királyságba való betörésekhez, illetve a nagyobb ágyúik szállításához. ${ }^{1070}$ A török flotta egyre növekvő fenyegetéséről és funkciójáról már az átutazó Bertrandon de la Brocquière beszámolójából tudjuk, hogy a Nisava és a Morava-folyóknál 80-100 gályát, tutajt tartanak a törökök azért, hogy seregüket át tudják szállítani a háború idején. ${ }^{1071}$ Galambócnál pedig „A törököknek itt száz naszádjok van Magyarország megtámadására. "1072 Az 1437. évi hadjárat egyik célja pedig ezek megtámadása és megsemmisítése volt. 1456-ban 200 hajóval, köztük 64 gályával vonult fel Nándorfehérvár ostromára a török sereg. A Dunán a 16. században Galambócon és Szendrőn és Kruşevacon már török hajóépítő telepek voltak. $^{1073}$

Figyelembe kell vennünk azt is, hogy Nándorfehérvár ostromával egyidejüleg portyázófosztogató török seregek is betörtek az országba. Dlugos szerint Erdélyben a török sereg sok foglyot szedett és rabszolgává tett. A kortárs török történetíró, Âșik Pașazade például a Száván átkelő seregben lehetett. Nesri és Szeád-Eddin munkájában szintén megemlékezik a Száván túli portyázásról. Ez azt jelentette, hogy a vár ostromában nem a teljes haderő vett részt, hanem az ostromra nem alkalmas, főleg lovas alakulatokat portyázni küldték.

A latin nyelvű lengyel forrásaink szerint Murád szultán a lengyel követeket csak az ostrom befejeztével engedte el. A névtelen lengyel levélíró még a tárgyalásokban reménykedett, annak végkimenetelét nem ismerte. Dlugosnál bővebben erről Callimachustól tudunk meg részleteket. Ulászló király nem fogadta el Murád túlzó békefeltételeit és katonai segítséget kért és kapott Lengyelországból.

A szultáni sereg 1440. évi visszavonulását követően, a vár környezetében megmaradt az oszmán-török katonai aktivitás. Az ostrom következményeképpen a várhoz közel egy erődöt építettek - vagy ha korábban épült - azt megerösítették. Ez Zsarnó vára (Žrnov), amelyet a szakirodalom többsége szerint 1441-ben Szeád-ed-Din (Sehabeddin) ruméliai beglerbég építtette fel. ${ }^{1074} \mathrm{Ez}$ oszmán ellenerődként nyugtalaníthatta a védőket, és mivel

\footnotetext{
1070 Gábor Ágoston: Guns for the Sultan. Military Power and Weapons Industry in the Ottoman Empire. Cambridge 2005. 18. A továbbiakban: Ágoston 2005.

1071 Brocquière. 1848. 358.

${ }^{1072}$ Szamota 1891.81. Lásd még az 5. 4. fejezetet.

1073 Ágoston 2005. 49-50.

1074 Szakály 1986. 33.
} 
magas és meredek hegyen, 511 méteren volt, innen beláthattak Nándorfehérvárba. ${ }^{1075}$ Colin Imber is - bár néven nem nevezi- egy ellenerőd építését emeli ki az 1440-es ostromban. ${ }^{1076} \mathrm{Az}$ oszmán források ezt a várat Havále néven nevezik. Ez megőrződött a mai Avala-hegy nevében, ahol a vár helyén ma az Ismeretlen katona emlékmüve áll. A vár építését a 17. századi világutazó Evlia Cselebi, bár I. Bayezid idejébe helyezte, de Sehabeddin pasát említi meg építőjeként, kifejezetten „Belgrád vára hitetleneinek meggyengitése végett." 1077

Bonfini tudott az ostromot követő portyákról is, amelyek a Tisza, Dráva és a Száva környékét érintették. ${ }^{1078}$ Valószínünek tartjuk, hogy amikor Hunyadi János 1441 júniusában átvette Nándorfehérvár parancsnokságát és Izsák (Īsa) szendrői béget Nándorfehérvár közelében legyőzte, ${ }^{1079}$ ebben Havale ellenerődje is szerepet kapott. Erről a győzelemről szintén Bonfinitől tudunk meg részleteket, ám az ellenerőd említése nélkül. Izsák szándéka az volt, hogy „végre elfoglalhassa a végszükségre jutott Fehérvárt, amelyet a császár nem bírt bevenni" (Kulcsár Péter fordítása). ${ }^{1080}$

Zsarnó vára a második nándorfehérvári szultáni ostrom (1456) alkalmával ismételten fontos szerephez jutott. Sőt, véleményem szerint a bizánci Khalkokondülész is erről a Belgrádhoz közeli ellenerődről ( $\left(\varepsilon \pi \imath \varepsilon \imath \chi \imath \sigma \mu \varsigma_{\varsigma}\right)$ írta, hogy egykor Sehabeddin (Szabatinész) építette és, hogy Hunyadi Mátyás - 1463. évi török ellenes harcai során megostromolta (II. 283.). ${ }^{1081}$

Az 1440-es ostrom következménye a déli vármegyék népesedésében is megmutatkozott. A szerb lakosok egy része, föleg Kevéröl, a töröktől való félelemben a Csepel-szigetre költözött és 1440. október 10-én I. Ulászló engedélyezte számukra Kis-Keve (a mai Ráckeve) megalapítását. Keve és Krassó vármegyék törvényhatóságai megszüntek. Az utolsó föispán Kevében és Krassóban éppen Tallóci Frank volt. ${ }^{1082}$ A helyzet megnövelte a Szörényi Bánság katonai feladatát. A volt szörényi bánt, Tallóci Frankot (1436-1438) - az

\footnotetext{
${ }^{1075}$ Cseh 2007. 7, 14.

1076 Imber 2002. 279-280. „In 1440 Murad II. opened his unsuccessful siege of Belgrade with the construction of a blockading fort to the south of the city."

1077 Evlia Cselebi török világutazó magyarországi utazásai 1660-1664. Fordította és jegyzetekkel ellátta Dr. Karácson Imre. In.: Török- magyarkori Történelmi emlékek. Török történetírók III. Budapest, 1904. 157. (A továbbiakban: Karácson 1904) A kérdéshez bővebben lásd a 13. 3. fejezetet.

${ }^{1078}$ Lásd a 8. 5. fejezetet.

1079 Teke 1980. 106; Pálosfalvi 2005. 68.

${ }^{1080}$ Bonfini 1995. 593, 8-9.

1081 Baán 2013. 328. Lásd a 13. 4. fejezetet.

1082 Milleker 1914. 39.
} 
ifjabb (Hunyadi) János nevü testvérével - Hunyadi János követte a tisztségben (14381446). ${ }^{1083}$

\section{2. Az ostrom kezdete, vége és a szultáni hadsereg akciórádiusza}

Az 1440. évi nándorfehérvári ostrom kevés konkrét adata közül a legfontosabb a források által említett hosszú ostromidő. Ezt Thuróczy, Bonfini, Anonymous Zoras és a Tarihi Üngürüsz hét hónapban, Dlugos és Dukasz hat hónapban határozta meg. Ezt azért fontos kiemelnünk, mert Thuróczy szerint a törökök is számon tartották és az 1456. évi ostrom alkalmával erre emlékeztették II. Mehmed szultánt (1444-1446, 1451-1481).

Sajnos a rendelkezésre álló források a vár 1440. évi ostromának pontos kezdetét és befejezését nem, csupán az időtartamát határozzák meg. Így következtetnünk kell a valószínű időpontokra. A csillagászati módszer sem segít, a forrásokban nincs szó napvagy holdfogyatkozásról. 1440. február 3-án Európából jól látható lett volna egy napfogyatkozás, azonban ez még az ostrom előtti időben történt. Július 29-én volt ugyan egy gyürüs napfogyatkozás, de az csak Ausztráliából és a Déli Sarkról volt látható, így Nándorfehérvár ostromának időpontjában sem nyújthatnak segítséget. ${ }^{1084}$ Míg 1456. június 3. körül a Halley-üstökös feltünését nagy visszhang kísérte, addig 1440-ben nem tünt fel üstökös. ${ }^{1085}$

A török sereg legkorábban - a később évszázadon át is követett szokásos időben - az oszmán katonai hagyomány szerint, az első fü kisarjadásakor, a török nyári félév kezdetén, Hizir Iljász napjától, április 23-ától (a keresztény Szent György-nap közelében) indulhatott útnak. ${ }^{1086} \mathrm{Ez}$ a lovasság szempontjából volt meghatározó. A hadműveletek befejezésének hagyományos ideje pedig október 26. Kászim-napja, török téli félév kezdete volt (a keresztény Szent Demeter-nap közelében). ${ }^{1087}$

Mivel a szultáni hadseregek a 15. században - sőt később I. Szülejmán szultáni seregei sem - még nem tudtak az országban áttelelni, a szultáni fővárosból elinduló és visszatérő

\footnotetext{
1083 Pesty Frigyes: A Szörényi Bánság és Szörény vármegye története. Első kötet. Budapest 1877. 42 (Pesty 1877); Mályusz 1984. 131.

$1084 \mathrm{http}: / /$ eclipse.gsfc.nasa.gov (A belépés ideje: 2012. 03. 13)

${ }^{1085} \mathrm{Az}$ 1456-os Halley-üstökös feltünésére lásd: Seláf Levente: Belgrád felett az ég. In.: Miscellanea, tanulmányok a régi magyar irodalomról. Szerkesztette: Szentpéteri Márton. Budapest 2001. 179. A továbbiakban: Seláf 2001 .

${ }^{1086}$ A kérdés áttekintése: A kérdés áttekintése: Tóth Sándor László: A Kászim-nap és a tizenöt éves háború. Hadtörténelmi Közlemények 1995/2. 25-33.(A továbbiakban: Tóth 1995) Tóth Sándor László: A mezőkeresztesi csata és a tizenöt éves háború. Szeged, 2000. 90. (A továbbiakban: Tóth 2000)

1087 Tóth 2000. 89.
} 
sereg hatékonysága kapcsán nem feledkezhetünk meg az akciórádiusz, a hadsereg müködési hatósugarának figyelembe vételéről sem.

Első megközelítésben komoly különbséget találunk, mivel ez a hatósugár Nándorfehérvár 1440. évi ostroma esetében más feltételekkel alkalmazható. Ebben is lényegesen különbözik Nándorfehérvár második, 1456. évi szultáni ostromától, amikor már a törökök a bizánci fővárost elfoglalták. 1440-ben az Oszmán Birodalom központja közelebb, az európai Drinápolyban volt. Ahogyan Perjés Géza is megállapította az „oszmán állam helyzete igen kedvezö, mivel a hadmüveleti vonala rövidebb, azonfelül belső vonalon volt." ${ }^{1088}$ Elvileg az akciórádiuszban Nándorfehérvár így könnyebben volt elérhető, mint 1453-ban, Konstantinápoly oszmán-török elfoglalása után.

A Magyar Királyságot egyrészt délről Drinápolyból (Edirne) a Havasalföld felől gyorsabban lehetett elérni. Ezt a reális lehetőséget már Zsigmond király is felismerte. Pásztói János volt országbíróhoz írott 1399. március 23-án írt oklevele (DL 42 705) szerint: „Bajazid, a törökök ura óriási hadseregével személyesen a Tengeren innen, Adrianopolis városában van, ahonnan 5 nap alatt (sic!) könnyen el tud érkezni a Dunához..."1089 Az egyedüli nehézséget viszont a Dunán való átkelöhely keresése jelentette, amelyen csak Gyurgyevó (Jerköki) megépítése segített. Ezt az útvonalat használták a törökök már az első támadó portyáik során, de szultáni fősereg is választotta: II. Murád 1438-ban, Erdély elleni támadásakor. Havasalföld oszmán függésével pedig ezen útvonal akadálytalanul rendelkezésre állott és az a királyi jóslat is, amelyet még Zsigmond tett a fenti oklevélben szintén beteljesült. „...a vlahok látják, hogy segitségünktől meg vannak fosztva, nem maradnak meg hüségünkhöz, hanem rövidesen alávetik magukat a török igának..." (Rázsó Gyula fordítása). ${ }^{1090}$

A másik útvonal Szerbia felől kínálkozott. Perjés Géza szerint a DrinápolyNándorfehérvár közötti rövidebb távolság körülbelül 50 - 70 nap alatt volt teljesíthető. ${ }^{1091}$ Az indulás kezdő időpontjaira nézve későbbi analógiát keresve megtudjuk, hogy 1526-ban például Konstantinápolyból április 23-án indult a szultáni sereg és június 30-án ért Nándorfehérvárba. Ez kb. 900 - 1000 km, 67 nap alatt. Még így is legalább négy hónapos

\footnotetext{
1088 Perjés Géza: Az oszmán birodalom európai háborúinak katonai kérdései. (1356-1699) Hadtörténelmi Közlemények 1966. 866. (Perjés 1966)

1089 Idézi: Rázsó 1973. 424. „Bayzat turchorum dominus cum maximo exercitu in civitate Adrianopolis sit personaliter citra mare, unde faciliter posset in diebus quinque usque ad Danubium pervenire..." (Zsigmond okl. I. 5769)

1090 Rázsó 1973. 424.

1091 Perjés 1979. 64.
} 
hadműveleti időt tett lehetővé. ${ }^{1092}$ Perjés Géza szerint 1526-ban a szultáni sereg és a zsoldosok május 3-án érkeztek meg Drinápolyba, ahol várakoztak és csak 8-án indultak tovább. ${ }^{1093}$ Vagyis 53 nap alatt tették meg ezt az utat Nándorfehérvárig.

Azonban tudnunk kell, hogy a magyar területek ellen vezetett hadjáratokban a szultán vezette sereg Drinápolyban gyülekezett, még Konstantinápoly 1453-es elfoglalása után is. Itt csatlakozott a Dardanelláknál átkelt anatóliai sereg, a Balkán török egységei pedig Szófia közelében. Szabó Tibor szerint a Drinápoly-Szófia-Nis útvonalon körülbelül 25 nap alatt ért a sereg Nándorfehérvárra. ${ }^{1094}$

Ehhez képest Szántó Imre a szülejmán-i hadjárati naplók alapján 1526-ban 71, 1529ben 68, 1532-ben 60 napot említ Isztambulból Nándorfehérvárra és 2 vagy 2,5 - 3 hónapos hadműveleti idővel számolt. De 3 hónapnál (július-augusztus-szeptember) az élelemszállítás és a szállítás nehézségei miatt nem többet. ${ }^{1095}$

Rázsó Gyula szerint a 14-17. században a szultáni sereg legkorábban áprilisban gyült össze, Konstantinápolyban, május elején Magyarország felé indult, július derekára érte el Belgrádot és 3, 3,5 hónap hadműveleti idő állt rendelkezésükre. Rázsó is bár figyelembe vette Drinápolyt, de hozzátette: „a török hadak 1453 elött Bizánc helyett Drinápolyban gyülekeztek, éppúgy július (sic!) derekán érték el Belgrádot, mint utódaik." ${ }^{1096}$ Ebben éppen 1440-es ostromra hivatkozik, amikor szerinte „1440. június végén vagy július elején kezdődhetett Belgrád ostroma" Ehhez a megállapításához viszont nem vette figyelembe a tizenhat évvel korábbi ostromra vonatkozó források nagyjából egybehangzó adatait, és az 1456. évi ostromot vette párhuzamnak. Mégpedig azt Thuróczy leírásából, amikor is az ostrom kezdetén „Phoebus szekere pedig az Ikrek mezején haladt, midön a törökök császára rettenetes ostrommal szállotta meg Nándorfejérvárat..."1097

Azonban számunkra úgy tűnik, hogy mind Perjés, mind Rázsó megállapításait módosítanunk kell. Mert ismertetett forrásaink következetesen 6-7 hónapos hosszú ostromról szólnak és a hadtörténészeknek így - látszólag - ellentmondanak.

A fenti adatokkal számolva a török sereg 1440 áprilisától csak június vagy július közepére ért volna oda, amelyet forrásaink nem támasztanak alá. Tehát mindenképpen a korábbi odaérkezés a lehetséges. A cseh történész Jireček szerint a török sereg

\footnotetext{
1092 Perjés 1979. 54.

1093 Perjés 1979. 337.

1094 Szabó Tibor: Fetislam -egy török erősség a Vaskapunál. Várak, kastélyok, templomok 2011 (december) 22. (Szabó 2011b)

1095 Szántó 1980. 117. (64. számú lábjegyzet)

1096 Rázsó 1973. 410.

${ }^{1097}$ Rázsó 1973. 410. (25. lábjegyzet)
} 
valószínüleg már áprilisban érhetett Nándorfehérvár alá, de május második felében a vár már mindenképpen ostrom alatt lehetett. ${ }^{1098}$ Ezt alá is támasztják az ostrom előzményeinél tárgyalt, május 20-i és a június 17-i oklevelek, amelyekben Tallóci Frank már pénzbeli segítséget kért, illetve a király hadisegély fizetését parancsolta meg Szomolnoknak. Sőt pontosítani tudjuk az ostrom kezdetét is. Dlugos krónikája szerint Ulászló székesfehérvári megkoronázása után, Budára érkezésekor a török ostrom már három hónapja folyt. Akkor tehát már április második felében ténylegesen meg kellett kezdődnie.

A kérdés megoldásához azt kell tekintetbe kell vennünk, hogy milyen oszmán-török sereg érkezett meg Nándorfehérvár falai alá? Tudjuk, hogy később sem az egész szultáni sereg gyülekezett Drinápolynál, hanem általában csak a ruméliai (európai) hadsereg, amelyhez a felvonulási területen vagy a határvidéken csatlakoztak az irreguláris alakulatok, a könnyülovas akindzsik és a könnyüfegyverzetủ azábok. Ez meggyorsította a menetidőt, megnövelte a szultáni sereg akciórádiuszát. Ha mindkét hadsereg részt vett az európai háborúkban, akkor ruméliai sereg rendszerint Szófiánál gyülekezett, az anatóliaiak pedig Gallipolinál átkelve Drinápolynál csatlakoztak a szultánhoz.

De nemcsak a központi haderőt kell számításba vennünk, hanem a tartományi alakulatokat is. Ezek közül a határvidéki akindzsi-katonaság legalább ilyen fontos szerepet töltött be és valamelyik felvonulási területen lévő végvárnál gyülekezett. ${ }^{1099}$ Az akindzsik a hadsereg portyázói és elővédjei voltak. ${ }^{1100}$ Ezen a ponton azzal számolunk, hogy az áprilisi ostrom megkezdését még nem az úton lévő szultáni fősereg(ek), hanem a határhoz legközelebb lévő végek őrsége, a közeli szandzsákok alakulatai és az akindzsik kezdhették meg. Szántó Imre szerint az ostromokat még a 16. században is „A török végek örségei, valamint egyes közeli szandzsákok csapatai már március-április hónapokban megkezdték..."1101

Véleményem szerint Nándorfehérvár 1440. évi ostrománál is ehhez hasonló történt. A latin nyelvü forrásokban nem szerepel korábban érkező török sereg, sőt a török sereg vezéreit sem tudjuk meg. Annyit tudunk csupán, hogy a védők kezdetben az ostromló sereg elővédjei elé vonultak harcolni és Thuróczy szerint is a védősereg „amikor $a$ közeledö ellenséget látta, eléje vonult, és csatázva tért vissza a várba,"1102

\footnotetext{
1098 Јиречек 1952. 363.

1099 Perjés 1979. 63.

${ }^{1100}$ Generál 1987. 178.

1101 Szántó 1980. 18.

1102 Thuróczy 2001. 276, 18-19.
} 
Hogyan történhetett mindez? Nem a teljes szultáni sereg vonul ekkor még fel a vár falai alá, amellyel még a kisebb védősereg is fel tudta venni a harcot. A bizánci források leírását is ennek megfelelően kell értelmeznünk. Így a Khalkokondülész által megemlített Aliész, azaz Evrenosz fia Ali az elsők között harcolt. Már korábban idéztem, hogy „...Ali, Vrenedzésznek a fia, aki a táborban bátorságáról volt híres, elsöként kezdett harcot a falnál az övéivel, és miután árkot ásott, a városhoz a lehetö legközelebb táborozott le saját csapatával.",1103

Aliról azt tudjuk, hogy a híres Evrenosz-família tagjaként az akindzsik vezetője volt. Már Thesszaloniki 1430. évi ostrománál kitüntette magát és felderítő hadjáratot is vezetett a Magyar Királyságba. Sőt, - némi túlzással - Melikoff az Iszlám Enciklopédia szócikkében tett megjegyzése szerint még a Nándorfehérvár elleni ostromot az akindzsikkel is ő vezette. Testvére Îsa bég (Izsák) is az akindzsik vezére volt, aki szendröi bégként harcolt Hunyadi János ellen és II. Mehmed vezéreként részt vett a szerbiai hódításokban. ${ }^{1104}$

1440 áprilisában - véleményem szerint - elöször az Ali vezette sereg érkezett meg Nándorfehérvár falai alá, és kezdte meg a harcot, ahogyan erről Khalkokondülész beszámolt. A II. Murád vezette összegyüjtött szultáni fösereg pedig a szokott „menetrend” szerint később érkezhetett a várhoz. Dlugos adatával számolva, júliusban, I. Ulászló koronázása után, amikor az új király követet küldött a szultánhoz, II. Murád már valóban a helyszínen volt.

Ezt a legalább kétfázisú mozgósítási gyakorlatot II. Murád szultán korábbi, legalább ilyen nagyszabású hadjáratával is alátámaszthatjuk, amelyet 1422-ben Konstantinápoly ellen vezetett. A poszt-bizánci Névtelen Krónika (Anonymous Zoras) beszámolójából erről is értesülünk (Codex Barberinus Graecus 111. 37). Murád szultán „a ruméliai sereggel előreküldte Mikháloglu-t, aki megszállta a Város területeit, felprédálta és sokakat rabszolgává tett a Város és a rómaiak területéröl. Elérte és a falakhoz közel elkezdte az ostromot. Akkor még bombardákból és puskákból nem sok volt. Néhány nap múlva érkezett meg Murád szultán a maradék sereggel, a janicsárokkal és az anatóliai seregekkel. Megközelitette, majd a falakhoz közel letáborozott. A sátrai a Város egyik oldalától egészen a másikig tartottak és elkezdte a falakat a bombardákkal ostromolni..."1105

\footnotetext{
${ }^{1103}$ Darkó 1923. 25, 18-21.

${ }^{1104}$ Melikoff 1965, 721. „,he laid siege to Belgrade, but the akindzis were defeated by the Hungarians.”

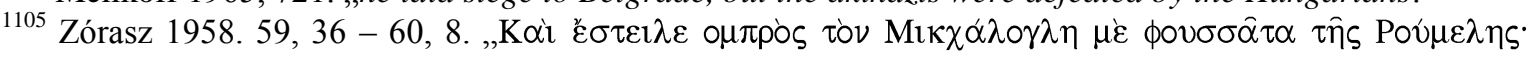

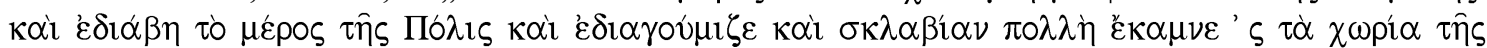

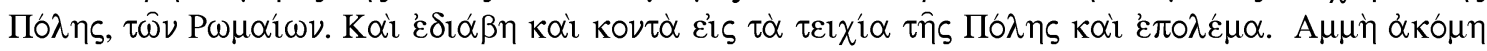


Murád kétfázisú mozgósítása e forrás által jól érzékeltethető. A ruméliai sereg vonult elsőként a falakhoz, majd ezután érkezett a szultáni fösereg. Csak a Drinápoly és Konstantinápoly közötti - Nándorfehérvárnál rövidebb - távolságon múlott, hogy a szultáni sereg megérkezése csupán néhány napot vett igénybe, míg ugyanez 1440-ben három hónapot. Az is feltünő, hogy Konstantinápolyt is a szárazföld felöl teljesen körülvette seregével, ahogyan később Nándorfehérvárt is, elzárva egy leendő felmentő sereg útját. Hogy 1440-ben nem Mikháloglu volt ott, annak az is oka, hogy ő nem sokkal Konstantinápoly ostroma után meghalt. ${ }^{1106}$

1440-ben az akciórádiusz másik fontos összetevője, a hadmüveleti idő is legalább két hónappal meghosszabbodott, az Ali által megkezdett, majd a szultán vezette ostrom összességében 6 hónapig is eltarthatott. Ezt mind az ismertetett latin nyelvü lengyel, mind a görög nyelvű bizánci forrásaink alátámasztják. Így, véleményem szerint az ostrom október második feléig is eltarthatott. Sőt, a Thuróczy, Bonfini, Anonymous Zoras és a Tarihi Üngürüsz által említett 7 hónappal számolva még novemberig is kitolódhatott. Ehhez hozzávesszük azt a tényt is, hogy a hadmüveletek záró időpontja Nándorfehérvár első ostromakor még nem alakulhatott ki kötelezően. Mert a 16. századi történetírónk, Istvánffy Miklós az 1551-es török hadjárat leírásakor közbevetően megemlítette, hogy éppen II. Murád szultán az 1444-es várnai győzelmét követően adományozta azt a jogot hadseregének, hogy Szent Demeter napja elmúltával már nem kényszeríthetők a további táborban maradásra. Bár Istvánffy - tévesen - I. Murádot írt, a szövegből egyértelmü II. Murád személye. „I. Murád szultán, amikor Ulászlót, Magyarország és Lengyelország királyát a várnai csatában legyözve és megölve nagy gyözelmet aratott, megadta azt a jogot, hogy Szent Demeter napja után -ezt a napot ök Kassonginnak nevezik-, nem kényszerithetök arra, hogy táborban legyenek. " (Juhász László fordítása). ${ }^{1107}$

Vélhetően éppen az ilyen elhúzódó ostromok - mint az 1440. évi is - és hadjáratok vezettek a rendelkezés megalkotásához. Sőt hat évvel később, 1450-ben az albániai Kruja ostromakor Murád egészen télig elhúzhatta az ostromot, akkor azonban abba kellett hagynia. Khalkokondülész alábbi szöveghelye legalábbis ezt bizonyítja: „...mivel nem

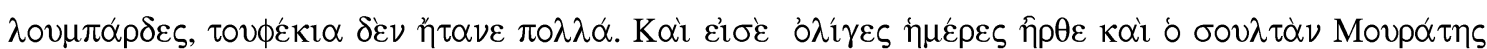

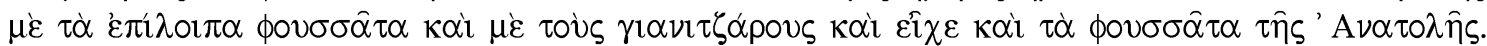

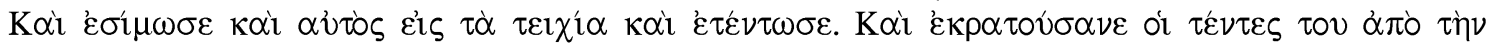

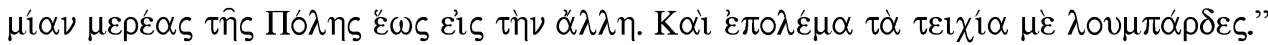

${ }^{1106}$ Imber 1990. 95.

${ }^{1107}$ Istvánffy Miklós: A magyarok történetéböl. (ford.: Juhász László) Budapest 1962. 205. (Istvánffy 1962) Idézi: Tóth 1995. 31. 
tudta elfoglalni, elvezette a katonákat. Mert látta, hogy a tél és az év végének közeledte már gyötri a sereget."1108

1440 kapcsán a lengyel humanista, Callimachus is említi a szultán félelmét a seregben kitörő elégedetlenségtől az elhúzódó eredménytelen ostrom miatt. Ezután a török katonaság szükség esetén kényszeríthette is a vezérét a téli szállásra való hazatérésre. ${ }^{1109}$

Figyelembe vehetjük azt is, hogy október közepe után a Duna és a Száva meg szokott áradni, megindul az északkeleti szél, a „Kossava”, amely olyan hullámverést okoz, hogy a nagyobb hajók közlekedését is lehetetlenné teszi. Ez még a 1915-ben, Belgrád akkori elfoglalásakor (október 6-10) a Mackensen-hadsereg számára is komoly tényező volt, bizonyára az oszmán-flotta hajózását is megnehezítette. ${ }^{1110}$

$\mathrm{Ki}$ kell térni a rövidebb ostromidő kérdésére is. Itt elöször is visszautalunk a névtelen lengyel levélíró 1440-es keltezés nélküli, Budáról küldött levelére. John Jefferson ugyanis ennek egyetlen mondatára alapozva rövid ostromidővel számol. Érvelése szerint legfeljebb 2 - 3 hónapos (szultáni) ostrom lehetett. ${ }^{1111}$ Mert az oszmánok a rövidebb ostromokat részesítették előnyben. Következtetésének alapja a levél egy mondata, amely - véleménye szerint - az ostrom abbahagyásáról ír: „Így a barbárok, miután szemmel láthatóan vereséget szenvedtek, az ostromtól és a királyságból visszavonultak."1112

A levél keltezési dátuma nem ismert, viszont egyéb budai udvari hírekről beszámol, így Cillei Ulrik fogságáról, a magyar bárók és nemesi küldöttek Ulászló előtti országgyüléséről, amelyre várták Garai Lászlót is. Jefferson ezek alapján a keletkezési dátumot június 19 - 26 közöttire valószínűsítette. Jefferson ismeri I. Ulászló segélykérö oklevelét, de azt tévesen június 20.-ra datálja, holott az június 17.-i keltezésű. ${ }^{1113}$ A kis időkülönbség az érvelésében mégis fontossá válik, mert ebből arra a megállapításra jut, hogy ez az utóbbi oklevél a későbbi és a törökök veresége ,június 20.-ra” még nem jutott el a budai udvarba. A rövid ostrom melletti érvként hozza fel azt a tényt is, hogy Tallóci Matkó a fogságból való kiszabadulása után nem segített az ostromlottaknak. ${ }^{1114}$

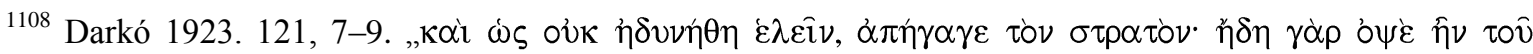

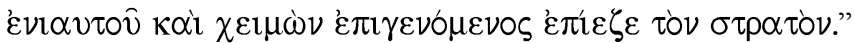

1109 Tóth 2000. 89.

${ }^{1110}$ Nagy Vilmos: Belgrád 1915. évi ostroma. Hadtörténelmi Közlemények 1926. 313. (Nagy 1926)

1111 Jefferson 2012. 240. (20. lábjegyzet)

1112 „Sic barbari illi tam notabili strage recepta ab obsidione et de regno recesserunt.” Jefferson 2012. 240.

1113 Thallóczy-Áldásy 1907. 137. „Datum Bude feria sexta proxima post festum beatorum Viti et Modesti martirum, anno Domini millesimo quadringentesimo quadragesimo." 1440-ben az ünnep (június 15) utáni legközelebbi feria sexta június 17-én, nem 20-án volt. Szentpétery 1985. 143.

1114 Jefferson 2012. 241.
} 
Jeffersonnak az oklevélből levont következtetésével - a fentiekben elmondottak alapján - nem értek egyet. Egyrészt a krónikás forrásainkban egyaránt 6 - 7 hónapos ostrom van. Sőt, Thuróczy - az 1456-os szultáni ostrom eseményei előtt - még török oldalról is számon tartottnak ismeri a hét hónapos, korábbi ostromot. Másrészt a teljes szultáni haderő amennyiben erről lenne szó - a korábban ismertetett vonulási idők miatt nem is érkezhetett meg korábban Nándorfehérvárra. Így véleményem szerint a levél beszámolója „,csak” az Ali vezette akindzsikre vonatkozhat, amelynek kudarcáról Khalkokondülész egyébként beszámol. Továbbá, a Thuróczy és Bonfini által említett kitámadás és mezei harc vállalása a szultáni fösereg ellen túl kockázatos és értelmetlen vállalkozás lett volna. Ez is egyik bizonyítéka a 6-7 hónapos hosszú ostromnak. A kétfázisú mozgósítás esetén, a szultáni fősereg vereségéröl nem lehet szó. Már csak azért sem, mert a fenti levél nem említi meg szultánt, csak a barbárok kudarcáról és visszavonulásáról szól. Az ostrom kudarcai között nincs szó az alagutak berobbantásáról vagy a várárok meggyújtásáról, amely a forrásaink szerint mindenképpen az ostrom második felének záró eseménye lehetett.

Ez a levél az ostrom első szakaszára vonatkozik, amikor a falak lövetése és a gyalogsági rohamok váltották egymást, amelyekről Thuróczy és Bonfini is beszámol. Jefferson ezek kudarcából vont le túl messzemenő következtetést, mivel ezután következett - a szultáni fősereg megérkezése után - az óriás akna ásása, amely értelemszerüen több hónapos munka kellett, hogy legyen. Miután ezt a várvédők berobbantották az ostromlóknak óriási emberveszteséget okozva - állítólag 17000 halott - a szultán csak ezt követően adta fel az ostromot és vonult vissza.

Ami Jefferson Matkóra vonatkozó véleményét illeti, az oklevelek alapján valóban ismerjük Tallóci Matkó szlavóniai tevékenységét. Azt viszont korábban láttuk, hogy a Tallóci-testvérek „munkamegosztásban” látták el a déli védelmi vonal felügyeletét tisztségeikben. Matkó a testvérével, Petkóval a szlavón, illetve a horvát-dalmát bán tisztét látta el haláláig. Míg Tallóci Frank „,munkaköre” - kevei, krassói ispánként, volt szörényi bánként - öccsével, Jovánnal a nándorfehérvári kapitányságra korlátozódott. ${ }^{115}$ Eszerint Matkónak nem volt szükséges segítenie öccseinek. Tallóci Frank 1440-es tevékenységéről július 7-e után nem tudunk. Ez jelentheti azt is, hogy ő sem segített öccsének, de azt is, hogy a körülzárt városban volt, a források azért nem szólnak róla.

Jeffersontól függetlenül, a korábbi magyar szakirodalomban régóta elterjedt a rövid ostromidő 1440-es ostrommal kapcsolatban. Ennek forrása Thuróczy krónikája. Itt hívjuk

1115 Mályusz 1984. 130, 131. 
fel a figyelmet, hogy az 1978. évi, közkeletü, Horváth János-féle magyar fordításban tévesen csupán 2 hónap szerepel a 7 helyett, amely pedig sajnos átkerült az ostromot említő szakirodalomba is. Így Thuróczy valós adatának tartotta a két hónapot legutóbb Cseh Valentin is. ${ }^{1116}$

A hiba nyilvánvalóan nem Horváth János hibája, hanem a kiadás során a „hét” és „,két” hallásban is összetéveszthető hasonlóságából keletkezhetett. De - véleményem szerint - ez a hiba is rányomta bélyegét az 1440. évi ostrom későbbi szakirodalmi mellőzésére is, amelyet munkánk elején ismertettünk. Annak ellenére, hogy Thuróczy újabb, 2001-ben megjelent magyar fordítása már helyesen hét hónapot közöl. „A szultán ugyanis népéböl mint mondják- tizenhétezer embert elveszitve és hét hónapot az ostrommal eltöltve, zaklatottan tért vissza hazájába." (Bellus Ibolya fordítása) ${ }^{1117}$

Horváth János szövegének nyomdahibáját igazolja egy másik Thuróczy-szöveghely, ahol nála is - helyesen - hét hónapot olvashatunk. A hét hónap török szempontból is túl hosszú volt és éppen ezért számon tartották. Ezt bizonyítja Thuróczy leírása - az 1456. évi, Nándorfehérvár második szultáni ostroma alkalmával - hogy II. Mehmed éppen ezért rövidítette volna le azt. Ugyanis „Hallotta a törökök császára (II. Mehmed szultán), hogy Amurát, az apja, életében hét hónapot (septem mensium) töltött ugyanezen Nándorfehérvár várának ostromával, és mégsem tudta hatalmába keriteni, gyözelem nélkül és gyalázattal vonult el alóla. Ezért a török császár az apját serege vezéreinek jelenlétében nem kis gyalázkodással illette, és azt mondta, hogy ö ugyanezt a várat tizenöt nap alatt beveszi." (Horváth János fordítása) ${ }^{1118}$ Ezt az információt Bonfini is átvette Thuróczytól, de Kulcsár Péter 1995-ös magyar fordításában ismét két hónapos időtartammal találkozunk: „Atyai barátai elmesélték neki, hogy Murád hajdanán két (sic!) hónapot töltött Fejérvár ostromával, dolgavégezetlenül távozott, ezért atyja szellemét gyalázattal illette, és azzal kérkedett, hogy két héten belül megszerzi a várost” (3. 8. 60, Kulcsár Péter

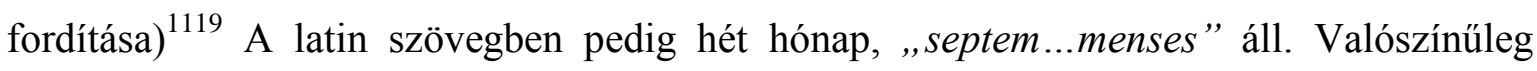
Kulcsárt is befolyásolhatta Horváth 1978-as Thuróczy-kiadásának az 1440. évi ostromra vonatkozó része, annak ellenére, hogy Horváthnál 1456 kapcsán helyesen hét hónap

\footnotetext{
${ }^{1116}$ Cseh 2007. 36.

1117 Thuróczy 2001. 277.

1118 Thuróczy 1978. 422; Thuróczy Textus 1985. 269. „Audierat ante hec cesar Thurcorum predictus, quod genitor suus Amrates, dum viveret, sub eodem castro Nandoralbensi septem mensium consumpsisset obsidionem, et eodem potiri valuisset minime, ac absque victoria cum dedecore desub illo recessisset. Quapropter idem cesar Thurcorum astantibus sibi sui exercitus ductoribus, ipsum genitorem suum vituperassime non modico affecit, seque idem castrum dies per quindecim expugnare posse dixit."

${ }^{1119}$ Bonfini 1995. 675.
} 
szerepelt. ${ }^{1120}$ Azt csak megemlítjük, hogy Thuróczy 2001-es fordításában, e szöveghelyen is, helyesen hét hónapot találunk. ${ }^{1121}$

Összegezve megállapítható, hogy a szultán 1440-ben a teljes hadműveleti időszakot Nándorfehérvár ostromára szánta, ebben is eltérve az 1456. évi ostromtól.

\section{3. A szemben álló seregek létszáma}

Sajnos a szembenálló hadseregek létszámát forrásaink nem említik. Így a nándorfehérvári védősereg létszámát csupán valószínüsíthetjük. Szerencsénkre az ostrom előtt 7 évvel korábbról rendelkezünk Zsigmond király 1433. évi hadügyi javaslatával, amelyben már számszerüsítve szerepelnek az egyes tisztségviselők és vármegyei zászlóaljak tervezett létszámai is. ${ }^{1122}$ Bár ez a nemesi hadfelkelésre vonatkozik, de belöle összegyüjthetjük a mozgósítható seregeket. A horvát báné 500 lovas, a szlavón báné 500 lovas, a vránai perjelé 500 lovas, a szerb despotáé 8000 lovas, a macsói báné 400 lovas, Tallóci Matkóé 1000 lovas (Szrebernik miatt), a kalocsai érseké 500 lovas. A vármegyei dandárok közül: Keve 100 lovas, Krassó 100 lovas, Temes 200 lovas, Zaránd 300, Arad 100, Csanád 300, Csongrád 200, Torontál 100 lovas. ${ }^{1123}$ Az ekkori bandérium 500 föből állt. Ebből azonban hiányoznak még a főurak bandériumai, a jászok, kunok és a városok fegyveres csapatai.

Bár e javaslatból végül országgyülési dekrétum nem lett, de a vármegyék megtárgyalták és a későbbiekben felhasználták. Számunkra irányszámokként jól használhatók. Tudjuk, hogy Branković nem vett részt a vár védelmében, bandériumával nem számolhatunk. Újlaki Miklós macsói bán bandériumával sem. A Tallóciak ekkor viselt tisztségei alapján szóba jöhet a horvát-szlavón báni 500-500 fő, Tallóci Matkó 1000 fö, vránai perjeség 500 fö, a kalocsai érsekség jövedelmeiböl 500 lovas, valamint a megyei bandériumok közül Keve, Krassó 100-100 fös csapatai. A megelőző török határbetörések alkalmával láttuk, hogy Tallóci Frank kevei ispánként a vármegye bandériumát többször is összehívta. Ezeket

\footnotetext{
1120 „Cum paterni sibi amici retullisent Amoratem olim septem (sic!) in Albana obsidione menses trivisse ac irrito tandem conatu abiisse, multis paternos manes probris affecit et ante quintum decimum se diem urbe potiturum gloriatus est." Antonius de Bonfinis Rerum Ungaricarum decades. Ediderunt: I. Fogel et B. Iványi és L. Juhász. Tomus III. Decas III. Lipsiae, 1936. 185.

1121 „A törökök már emlitett császára hallotta, hogy az apja, Amurat, életében hét hónapot töltött ugyanennek a Nándorfehérvárnak az ostromával, mégsem tudta hatalmába keriteni, gyözelem nélkül, gyalázattal vonult el alóla. Ezért a török császár-serege vezéreinek jelenlétében-nem kis szidalommal illette apját, és azt mondta, hogy ö ugyanezt a várost tizenöt nap alatt képes bevenni" (Bellus Ibolya fordítása). Thuróczy 2001. 308-309.

1122 Idézi: Horváth1871. 498-502.

${ }^{1123}$ Horváth 1871. 498-500.
} 
is összegezve a teljes mozgósítható létszám még mindig csak 3200 fö, de a helybéli - nem reguláris - hadra fogható lakosok száma nélkül!

Némileg közelebb visz Bertrandon de la Brocquière azon megjegyzése, amely szerint Belgrád „mintegy 5 - 6000 lovat fogadhat be” (Szamota István fordítása). ${ }^{1124}$ A lovas egységekkel számolnunk kell, mert a felvonuló akindzsik ellen kitörve, többször harcba bocsátkoztak velük, ahogy ez Thuróczy leírásából kikövetkeztethető. Mindezek alapján a védősereget 3-5 000 főnyire becsüljük. Ehhez kell a nem reguláris létszámot, a lakosság részvételét is hozzászámítani. Az 1456. évi ostrom adatait felhasználva Barta Gábor az akkori védősereget 6-7 000 főben állapította meg. De hozzá kell tennünk, hogy a vár befogadó képessége szerinte nem volt nagy. ${ }^{1125}$ 1450-ben az albániai Kruja erődjében 1500 fönyi védősereg sikeresen szembe tudott szállni II. Murád ostromló seregével. ${ }^{1126}$

Összehasonlításképpen említjük csak meg, hogy az 1498. évi országgyülés dekrétumában viszont rögzítették a bandériumok számát, azonban a megyei bandériumok számának megállapítása nélkül. A kalocsai érsek 1 bandériumot, a vránai perjel 1 bandériumot (20. cikkely), a horvát bán, a temesi ispán 1 bandériumot volt köteles kiállítani (21. cikkely), a despota pedig 1000 lovast (22. cikkely). ${ }^{1127}$ A II. Ulászló-féle 1492. évi Decretum Maius szerint minden egyes bandériumban 400 katona, a félben 200 katona volt, akiknek egyik részét fegyveresek, másik részét könnyü fegyverzetűek, huszárok (huszarones) alkották (20. cikkely 1. §). ${ }^{1128}$

A védősereg összetételéről nem szólnak a források. A Német Lovagrend kivonulása után (1432) a német lovagok számára Nándorfehérvár is egy menekülési lehetőség volt, de más, johannita lovagokkal Brocquière is találkozott. ${ }^{129}$ Ami a vránai perjel védte várban egyáltalán nem lenne meglepő. A magyarok a Felsővárosban lehettek. Az Alsóvárost, mint tudjuk, szerbek lakták. Brocquière szerint: „E várban vagyis erődben igen sok rácz van, azonban a többi négybe (t. i. várrészbe) nem szabad bemenniök."1130

Az ostromló török sereg létszámát sem adják meg forrásaink. Talán leginkább a veszteségek révén becsülhetjük meg az ostromlók számát. Láttuk, hogy Thuróczy és Bonfini a nagy akna berobbantásakor meghalt törökök számát igen sokra, 17 000-re tette.

\footnotetext{
${ }^{1124}$ Szamota 1891.78.

1125 Barta 1985. 230.

${ }^{1126}$ Lásd a 10. 6. fejezetet.

${ }^{1127}$ CJH. 606-607.

${ }^{1128}$ CJH. 492-493.

${ }^{1129}$ Калић-Мијушковић 1967. 107.

${ }^{1130}$ Szamota 1891. 78.
} 
Bonfini emellett megemlítette, hogy 8000 ember a város körüli harcok során halt meg. ${ }^{1131}$ Ekkor legalább 25000 fős török veszteséggel kell számolnunk.

$\mathrm{Az}$ 1456. évi ostromra vonatkozóan már számszerű adatokkal is dolgozhatunk. Legutóbb Cseh Valentin összegezte a létszámadatokat. Az oszmán hadsereg létszáma a 15. században kb. 70000 fö lehetett, de ezt egyszerre fegyverbe hívni nem volt lehetséges. ${ }^{1132}$ Ehhez képest a források kb. 160000-100 000 föt említettek, amely mindenképpen túlzónak tekinthető. A kutatók (Held József, Fodor Pál) egy kb. 50 000-70 000 fös létszámot valószínűsítenek. ${ }^{1133}$

Legutóbb John Jefferson már konkrét adatot közölt, az 1438-1444 évek közötti oszmán haderőt kb. 64000 föben állapította meg, amelyben kb. 30000 a tartományi lovas alakulat. ${ }^{1134} \mathrm{Az}$ 1440. évi ostrom vonatkozásában ezt vesszük mi is figyelembe. További adatok nélkül csak feltételezzük, hogy ennél kevesebben, kb. 34000 katona vett részt az ostromban, hiszen a lovas alakulatok az országban portyázást hajtottak végre. Kalić és Marko Popović szerint még ennél is kevesebb, kb. 20000 fö. ${ }^{1135}$ Thuróczy szerint az ostromlók vesztesége a nagy akna berobbantásakor 17000 fó, azaz a fenti létszámmal számolva az ostromló sereg fele: 17000 ember. Ha a Bonfini által megadott 8000 fôs város körüli veszteséget hozzávesszük, akkor csupán 9 000. Mégha ez a szám túlzónak is tűnik, a szultáni sereg felének elvesztése, a portyázó csapatok ideiglenes nélkülözése, meggondolásra kellett, hogy késztesse a szultánt. Az ostromlóknál szükséges minimális létszámnál pedig figyelembe kell vennünk az ostromtanban Carl von Clausewitz által már korábban idézett megállapítást, hogy a vár ostromához, körülzárásához „amennyiben a védösereg derekasan viselkedik, kétszeres túleröre van szükség". ${ }^{1136}$ A Brocquière által említett 5-6000 fös várvédelem esetén a szultán ezt már alig érhette el.

Azt tudjuk, hogy az oszmán sereg nagyszámú foglyot tudott ejteni, amelyet török forrásaink kiemelnek. A nagyszámú foglyok őrzése és szállítása is megkövetelt egy bizonyos létszám-limitet, amellyel ez még biztonságosan végrehajtható. Âșik Pașazade és az őt felhasználó Hadīdī szerint a foglyok száma nagyobb lett az ostromból visszavonuló seregnél, amely a fenti clausewitzi-formula szerint, bizonyára nehézséget is okozott.

Az oszmán sereg fenntartható létszámát pedig a hosszú, féléves időszakig tartó élelmiszer-ellátás is jelentősen korlátozhatta. Ugyanis a környező vidékekre vezetett

\footnotetext{
${ }^{1131}$ Szabó 2012d 113,114.

${ }^{1132}$ Cseh 2007. 92.

${ }^{1133}$ Cseh 2007. 101.

1134 Jefferson 2012. 198.

1135 Калић-Мијушковић 1967. 110; Popović 2011. 36.

1136 Perjés Géza: Clausewitz. Budapest 1983. 170. (Perjés 1983) Lásd még a 6. 4. fejezetet.
} 
portyázás, rablás sem bírt ellátni hosszú időn keresztül egy óriási ostromló haderőt. Ezt jelzi, hogy a források közül Callimachus arról ír, hogy a szultán éhség miatt lázadástól kezdett tartani.

\section{4. Az ostromban alkalmazott haditechnika: aknászat}

$\mathrm{Az}$ 1440. évi várostromban, bármelyik leírást nézzük, meghatározó volt az aknász ostromtechnika (undermining) és a védők által újszerüen alkalmazott tüzfegyver.

Az aknaásás, a föld alatti folyosó (cuniculus) az ókorban is ismert és alkalmazott haditechnika volt és ehhez föleg bányászok kellettek. Legkorábbi alkalmazása az asszírokhoz köthető. A dombormüveiken látható, hogy - a faltörö kos és ostromtornyok használata mellett - a falakat aláaknázták, az aknák támfáit meggyújtva beomlasztották az erődítményeket. $^{1137}$ De keletebbre is ismert volt, például a kínai haditechnikában (Hadakozó Fejedelemségek Kora, Kr. e. 453-221). ${ }^{1138}$

Hérodotosz görög történetíró többször említi, hogy a perzsák is szívesen alkalmazták. A perzsa sereg például kilenc hónapon át sikertelenül ostromolta Barké városát. A perzsák föld alatti aknákat ástak, a védők azonban felfedezték és ellenaknákat ásva, az árokásó perzsákat megölték (IV. 200). ${ }^{1139}$ A perzsák elleni ión felkelés során a ciprusi Szoloi vára öt hónapig állta az ostromot. A perzsák csak úgy tudták elfoglalni, hogy alagutat ástak a várfal alá (V. 115). ${ }^{1140}$ Sőt Milétosz ostromakor (Kr. e. 494), minden hadieszközt bevetése mellett, aláásták a várfalat is (VI.18). ${ }^{141}$

A görög történetíró, Polübiosz (Kr. e. 200. k.-118) leírja, hogy V. Philipposz makedón király (Kr. e. 229-179), amikor Prinasszosz erődjét akarta bevenni, ilyen cselt alkalmazott (XVI. 11) I. Attalosz pergamoni király (Kr. e. 241-197) ellen. Ugyanis elhitette, hogy aláaknázta a városfalakat, és ha a védők nem adják fel a várat, akkor az aknákban a falakat alátámasztó gerendákat meggyújtja. A védők hittek neki és megadták magukat. ${ }^{1142}$

\footnotetext{
${ }^{1137}$ Hahn István: A hadmüvészet ókori klasszikusai. (szerkesztette, a bevezető tanulmányt írta Hahn István) Budapest 1963. 24-25. (Hahn 1963)

1138 A Hadakozó Fejedelemségek időszaka a technikai újítások legtermékenyebb időszaka az egyre kegyetlenebbé váló háborúkkal. Jaques Gernet: A kínai civilizáció története. Budapest 2001. 71. (Gernet 2001)

${ }^{1139}$ Hérodotosz: A görög-perzsa háború. Fordította: Muraközy Gyula. Budapest 2004. 337. A továbbiakban: Hérodotosz 2004)

${ }^{1140}$ Hérodotosz 2004. 392.

${ }^{1141}$ Hérodotosz 2004. 402.

1142 „Elrendelte, hogy emberei nappal a föld szine alatt csapjanak olyan zajt, mintha teljes erövel folytatnák az ásást, éjszaka aztán nagy mennyiségü sziklatörmeléket hordatott a gödrök mellé, hogy a város lakói
} 
Ez volt az az ostromtechnika, amely az évszázadok során alig változott és a középkori aknakészítés is ezt alkalmazta. A késő császárkori római hadászati író, Publius Flavius Vegetius Renatus (Kr. u. IV-V. sz.) Epitoma rei militaris címü munkájának IV. könyve információt szolgáltat e technikáról. ${ }^{1143}$ A 15 . fejezet szerint az aknakészítés megkezdésekor „lugasokat” (vinea) használtak, amelyek deszkákból és vesszőfonatokból álltak és a rázúdított kövektől, hajítófegyverektől védték meg az akna készítöit. Vagy pedig kerekeken mozgatható ostromfedeleket (pluteus) használtak, amelyek boltozat formájúra készített vesszőfonatból állottak. ${ }^{144}$ Láthattuk, hogy 1440-ben az oszmánoknak nem volt ilyenre szükségük, mert a domb mögött rejtőzve tudtak hozzáfogni az akna készítéséhez.

A 24. fejezet ismerteti az aknakészítés fogalmát és két lehetséges módját. „Ezt cuniculusnak hívják azokról a nyulakról, melyek a föld alatt üregeket fúrnak maguknak és ott rejtözködnek. Nagy tömeg munkába állitásával tehát a bányák mintájára ... nagy eröfeszitéssel leásnak a földbe és barlangot vájva alagúton törnek a város elestére. ... Vagy behatolnak ugyanis a városba és éjszaka, úgy, hogy a városbeliek semmit sem vesznek észre, az aknán keresztül kimásznak, a kapukat megnyitva csapataikat beengedik. ... Vagy pedig, amikor a falak alapzatáig jutottak, nagy részét aláássák és száraz támfákkal hevenyészve feltartják a fal leomlását. Felülröl rözsét kötöznek és egyéb tüztápláló szereket, majd elökészitve a harcosokat, tüzet bocsátanak a szerkezetre. A faoszlopok és a deszkázat leégvén a fal hirtelen beomlik, s út nyílik a betörésre" (Várady László fordítása). ${ }^{1145}$

A rómaiak által alkalmazott aknaásás hadtörténeti párhuzamaiból kettőt emelünk ki, melyek leírásukban emlékeztetnek az 1440. évi ostrom egyes mozzanataira. Titus Livius: A római nép története címü nagyszabású munkájának V. könyvében (19-21. fejezet) írja, hogy a dúsgazdag Veii városának rómaiak általi ostroma túlságosan elhúzódott. ${ }^{1146}$ Amikor Kr. e. 396-ban M. Furius Camillust a rómaiak dictatorrá nevezték ki, ő azonnal „,katonáit ostrommüvek épitésére fogta. Legtöbbet és legfáradtságosabban egy földalatti folyosón (cuniculus) dolgoztak, amelyet az ellenséges vár irányában kezdetek ásni ... óránként

azt higgyék a magas kőhalmokat látva, hogy nagyon jól halad a munka, és ettöl félelem töltse el öket" (Muraközy Gyula fordítása). Polübiosz 2002. 167.

${ }^{1143}$ Flavius Vegetius Renatus: A hadtudomány foglalata négy könyvben. In.: A hadmüvészet ókori klasszikusai. Szerk.; bev. tanulmányt írta Hahn István. Budapest 1963. 753-865. A továbbiakban: Vegetius 1963.

1144 Vegetius 1963. 847.

1145 Vegetius 1963. 852.

1146 Livius: A római nép története a város alapításától. I. kötet. Budapest 1982. 410-414. (A továbbiakban: Livius I. 1982) A szövegrészlet latin szövegkiadása: Livy with an English translation in fourteen volumes. III. Books V, VI and VII. The Loeb Classical Library. Edited by: G. P. Goold. Translated by Evan T. Sage. Cambridge, Massachusetts, London 1967. 68. (Livius Text 1967) 
váltották egymást, nem pihenve sem éjjel, sem nappal, míg a fellegvárba vezető alagút el nem készült." ${ }^{1147}$ Mindeközben „,megrohanta a város minden pontját, hogy elterelje a figyelmet az alagút felöl fenyegető veszélyröl". ${ }^{1148}$ A rómaiak az alagúton át elözönlötték Veii fellegvárát és az ostromlók előtt kinyitották a kapukat. A város, amely „tíz nyáron és tíz télen volt egyfolytában körülzárva" elesett. ${ }^{1149}$ Szembetűnő az 1440-es török ostrommal való hasonlatosság abban, hogy a rómaiak az erőd ellen indított rohamokat tovább folytatták, hogy az akna ásását elvégezhessék. E haditechnika későbbi ismeretében nem érthetek egyet a fordító Muraközy Gyula e részhez írt megjegyzésével, amely szerint „,eléggé valószinütlen, hogy az ostromlók a meredek hegyen álló fellegvárat egy alagúttal meg tudták volna közelíteni. "1150

Az ostrom során alkalmazott aknaásás részleteiről a történetíró Livius további adalékkal szolgál, amely érdekes párhuzamot mutat Nándorfehérvár török ostromának humanista leírásával. A szerző a XXXVIII. könyvben (5-9. fejezetek) a rómaiak III. Antiokhosz (Kr. e. 223-187) elleni háborúját tárgyalja, a Kr. e. 189-187 közötti eseményeket. Kr. e. 189ben az épeiroszi Ambrakia erődjét, amely Pürrhosz egykori székhelye volt, a római consul, Marcus Fulvius Nobilior ostromolta. A 9. 1. fejezetben e szövegrészlet filológiai elemzését tárgyaltuk. Itt, kissé részletesebben, az ostrom menetét ismertetjük. A consul a várat sáncokkal és árkokkal körülvette. Három ostromgépet is használt. „A falakat faltörö kosokkal (arietibus) döngették, a faloromzatot vaskampókkal ellátott gerendákkal bontották meg." ${ }^{1151}$ A védők eredményesen védekeztek, így a rómaiak „,mégsem tudtak behatolni a nagyrészt védtelenné vált városba, mert a védök a lerontott fal helyett, a lehetö leggyorsabban, újat épitettek." "1152 A consul, látva a közvetlen rohamok és ostrom kudarcát, ,egy ostromfedéllel elözöleg eltakart helyen rejtett akna (cuniculum occultum) ásását kezdte meg. Az ellenség, noha a rómaiak éjjel nappal dolgoztak, nemcsak ezt nem vették észre, de azt sem, hogy a földet kihordják."1153 Ekkor a védők ellenakna ásását kezdték meg: ,félelmükben, hogy az ellenség falaik alatt már utat is készitett a városba, elhatározták, hogy árkot ásnak a falon belül (fossam intra murum) a védtetökkel befedett hely irányában.” A védők a helyes irányt jól megtalálták, ugyanis ,,teljes csendben, fülüket

\footnotetext{
${ }^{1147}$ Livius I. 1982. 410.

${ }^{1148}$ Livius I. 1982. 412.

${ }^{1149}$ Livius I. 1982. 414.

${ }^{1150}$ Livius I. 1982. 695.

${ }^{1151}$ Livius III. 1982. 712, 14-16. A szövegrészlet latin kiadása: Livius text 1983. 20-24.

${ }^{1152}$ Livius III. 1982. 715, 1-3.

${ }^{1153}$ Livius III. 1982. 715, 6-9.
} 
odaszoritva hallgatóztak, merről hallják az ásás zaját." "1154 Amikor a két akna összeért, láthatatlan viadal kezdődött a föld alatt, amelynek során egymást megpróbálták kiűzni az aknából. Erre egy tollal megtömött hordót használtak, amelynek aljára egy csövet erősítettek. „A tollpihe közé parazsat tettek, s ezt a hordó végében elhelyezett csövön át, fújtatóval lángra lobbantották” (Muraközy Gyula fordításai). ${ }^{1155}$ A keletkező sürü füst és büz „harci gázként” hatásosnak bizonyult. A consulhoz követek érkeztek, kérve tőle, hogy kímélje meg a várat. A háborút végül III. Antiokhosszal Kr. e. 188-ban, az Apameiában megkötött béke zárta le.

A bizánci ostromtechnikának is részét képezte az aknászat. A témánk szerint ezek közül egyet feltétlenül meg kell említenünk, amelyről bizánci forrásaink szólnak, és amely egyúttal párhuzammal szolgálhat Nándorfehérvár 1440. évi ostromához is. Mégpedig a bizánci-magyar háborúk során a Nándorfehérvár melletti Zimony 1165-ös bizánci ostromát $^{1156}$

Ebben az ostromban nem egymás után, hanem egyidejüleg alkalmazták a falak töretésével a várfal aláaknázását. Az ostromlóknak elöször a várárkokat kellett betömni, hogy közelebb tudják az ostromgépeket vinni. Joannész Kinnamosz bizánci történetíró szerint „Az árkokat, melyek a várost övezték, s meglehetösen mélyek és szélesek voltak, rözse és vesszönyalábok hiányában kövekkel töltötte meg, s így vitette át a hadigépeket." 1440-ben az oszmánok hasonló célból töltötték fel a nándorfehérvári várárkot, ahogyan erről a latin nyelvü lengyel krónikák beszámoltak. A harmadik roham alkalmával a bizánciak a falak aláaknázását alkalmazták. A bizánciak „aláaknázták az alapépitményeket" (Moravcsik Gyula fordításai). ${ }^{1157}$

Ugyanerről az ostromról szól Nikétasz Khóniatész történetíró is, akinek beszámolójából kiemeljük a számunkra fontos részleteket. „Ez a vár (t. i. Zimony) dél felöl megközelithetetlen, mivel egy magaslat és a folyam sodra alkot egy falat...” A császár „az

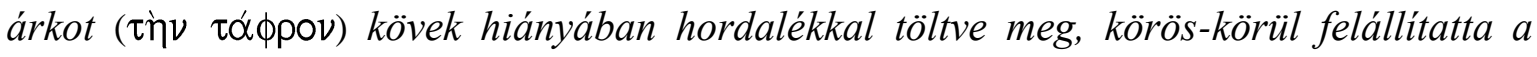
hajitógépeket (négy ilyen volt), és elrendelte, hogy törjék a falakat... a bástyák közti fal is, amelyre a kövek súlya irányult, ingadozni kezdett, s nem állt már egyenesen, annál is kevésbé, mert az aknaásók is aláemeltyüzték. ${ }^{1158}$ (Moravcsik Gyula fordítása) ${ }^{1159}$

\footnotetext{
${ }^{1154}$ Livius III. 1982. 715, 10-13, 15-16.

1155 Livius III. 1982. 715, 34-716, 1-2.

${ }^{1156} \mathrm{Az}$ eseményekre lásd a 3. 1. fejezetet.

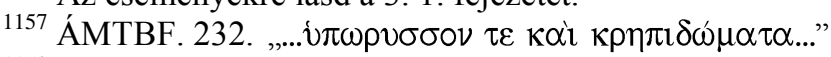

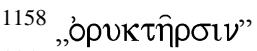

1159 ÁMTBF. 278-279.
} 
Az aknák használatára középkori haditechnikai párhuzamokat is találunk. A keresztes háborúkban a keresztes államok várainak, erődjeinek ostroma (Crac des Chevaliers, Margat, Kerak) során - a faltörő kosok, hajítógépek, ostromtornyok és létrák mellett - a leghatásosabb ostromtechnika a falak, tornyok aláaknázása volt. Például Baybars szultán, amikor 1271. március 3-án megkezdte Crac des Chevaliers ostromát, aknászait alkalmazta. Az erőd délnyugati tornya összedőlt, a védők április 8-án megadták magukat. ${ }^{1160}$

Főleg azt a módszert alkalmazták, amikor az alagutat csak a falig ásták. Az aknászok egy fedélszerkezet védelme alatt a falak támpillérei alatt járatokat ástak, amelynek végét kibővítve és gerendákkal aládúcolva gyúlékony anyagokkal megtöltötték, majd meggyújtották. Így a fal összedőlt, rés támadt az erődön. ${ }^{1161}$ Szaladin krónikása, Imád adDín Askalon elfoglalásáról költői stílusban összegzi az alkalmazott eljárásokat: „Ostromgépeink nyilai fogpiszkálóikkal megérintették a várorom metszőfogait s kitörték öket, a hajitókövek nekivágódtak az épitmény falainak és szétrombolták, összezúzták öket. Megzendült bennük az aknász csákánya... és a falak kövei visszatértek eredetükhöz, vagyis a porba."1162

Európa nyugati felén, a százéves háborúban (1339-1453) maga V. Henrik angol király (1387-1422) is aknát ásatott Caen ostrománál. ${ }^{1163}$ Zsigmond király 1396-ban, törökellenes hadjárata során, Nikápoly alá érve a várat ostromolta és két nagy aknát is ástak, de eredményt így sem sikerült elérni, mert szeptember 24-én megérkezett I. Bayezid szultán felmentő serege. ${ }^{1164}$

Az aknakészítés Zsigmond-kori Magyarországon is ismert volt, elsősorban az ekkoriban elterjedő német és itáliai haditechnikai traktátusokból. Konrad Kyeser (1366-1405) Bellifortis címü munkájának második fejezete az aknakészítés eszközeivel foglalkozik. ${ }^{1165}$ A sienai hadmérnök, Mariano di Jacopo Taccola: De ingeneis címü munkájában (14271433) - amelyet a szerző egyúttal Zsigmond királynak ajánlott -, a III-IV. könyv ismerteti az ellenséges városfal aknák és lőpor segítségével való megsemmisítését. Taccola az aknák alkalmazásának módszereiben pedig a híres építész, Brunelleschi tanácsait is figyelembe vette. ${ }^{1166}$ Ezek a munkák segítenek a forrásokban leírt eljárásokat tipizálni és azonosítani.

\footnotetext{
${ }^{1160}$ Spiteri 1994. 40.

${ }^{1161}$ Walter Zöllner: A keresztes háborúk története. Budapest 1980. 211, 219. A továbbiakban: Zöllner 1980.

1162 Zöllner 1980. 127.

1163 Jim Bradbury: The Routledge companion to medieval warfare. London-New York 2006. 303. (A továbbiakban: Bradbury 2006)

1164 Veszprémy László: Haditechnikai újítások és kéziratok Zsigmond környezetében. In.: Lovagvilág Magyarországon. Budapest 2008. 188. (A továbbiakban: Veszprémy 2008b)

${ }^{1165}$ Veszprémy 2008b. 190.

${ }^{1166}$ Veszprémy 2008b. 195-196; Veszprémy 2008a 210-211.
} 
Vegetius müve a középkorban - számos szemléltetett kiadásával $(1471,1532,1534)$ együtt - ismert volt ${ }^{1167}$ az aknakészítés két módszerével együtt. Az alagutat többnyire csak a várfalig ásták. ${ }^{1168}$

A várfalon túli akna ásásának módszere jól azonosítható Nándorfehérvár 1440. évi ostrománál, Thuróczy és a Bonfini leírásaiból. ${ }^{169}$ Khalkokondülész nem említ föld alatti alagutakat, aknákat, hacsak az Ali-féle harcnál a falak leomlását nem tekintjük a fal aláaknázásának. Pedig II. Murád szultán már korábban is alkalmazta a föld alatti aknatechnikát.

Thesszaloniki (Thermé) városát a törökök még 1422 nyarán blokád alá vették, majd egy év múlva Andronikosz Palaiologosz deszpotész, mivel úgy vélte, hogy tovább nem tudja megvédeni a várost, felajánlotta a velenceieknek. ${ }^{1170}$ Végül 1430 márciusában maga II. Murád szultán indult a város és a velenceiek ellen. ${ }^{1171}$ Khalkokondülész egyértelmü megfogalmazással beszámol föld alatti aknákról, alagutakról. „Murád (Amouratész) pedig ezek után Thermé ellen vonult, és minden erejét mozgósitva megostromolta a várost és még ostromgépeket vitetett a városfalhoz. Ám a város elfoglalása neki egyáltalán nem sikeredett. Ekkor, ahogyan mondják, megalkudott a városban lévőkkel az árulásról. Azonban, ahogyan mondják, a házaik alól kifelé vezetö alagutakat (orügmata ektosz feronta) ásó személyeket a velenceiek tetten érték. Az alagutat ásók (aknászok, orüsszontes) a falakról leereszkedve, elmenekültek Murád táborába. Később, amint egy magaslati pontról megrohamozta (t. i. Murád), erővel elfoglalta és leigázta a várost."1172

Az aknák oszmán-török használatáról az ostrom szemtanúja, Jóannész Anagnósztész (Joannisz Anagnosztisz) is beszámolt (13-14. fejezet). ${ }^{1173}$ A végső roham alkalmával, 1430. március 29-én „akiknek nem volt lehetséges (t. i. bejutás), azok az ostromlétrákon,

${ }^{1167}$ Zöllner 1980. 215.

1168 J. E. Kaufmann-H. W. Kaufmann 2001. 60.

${ }^{1169}$ Veszprémy 2008b. 217-218; Szabó 2012d 111-112, 114.

${ }^{1170}$ Imber 1990. 97.

${ }^{1171}$ Bréhier 1997. 443, Imber 1990. 109-110.

1172 Darkó 1923. 14, 1-10. „A A

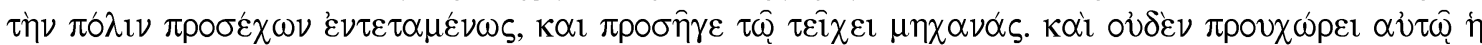

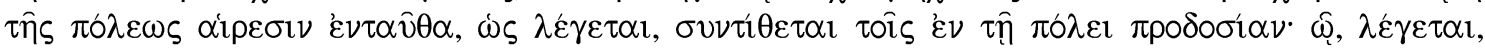

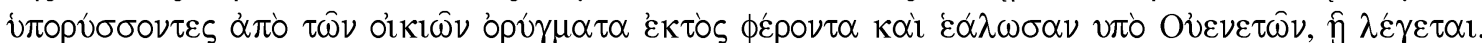

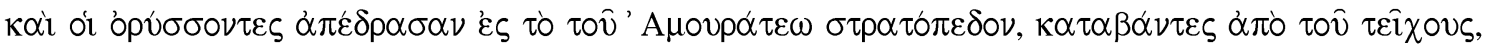

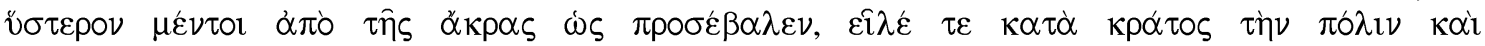
$\eta \nu \delta \rho \alpha \pi \circ \delta \dot{\sigma} \sigma \tau 0 . "$

${ }^{1173}$ E török ostrom összegyüjtött bizánci forrásairól lásd még: Thessalonique. Chroniques d'une ville prise, textes présentés et traduits du grec par Paolo Odorico. Toulouse 2005. (Odorico 2005) 
aknákon át, amelyekből sokat készítettek, a városba futva beözönlöttek."1174 „A létrákon és az alagutakon át - ahogyan elmondtuk -, a harcosok a városba jutottak. Egyesek a házakat és az embereket támadták meg, mások pedig a város kapuit azért, hogy kinyissák, és Murád az egész hadseregével a városba bejusson."1175

Azt is megállapíthatjuk, hogy Thesszaloniki ostromakor a szultáni sereg már gyarapodhatott átmenekült aknászokkal, de a török hadseregben is voltak aknászok, a lagumdsik (lağımcıs), akik a müszaki szolgálathoz tartoztak. Nevük a lagum akna szóból ered. ${ }^{1176}$ Egyik részük közvetlenül a szultáni sereghez tartozott, a másik pedig a tartományokban állomásozott. A nagy hadjáratok alkalmával a birodalom bányáiból toborozták a szakképzett bányászokat. ${ }^{1177}$ (Ezért is lett fontos az oszmánoknak Novo Brdo elfoglalása 1441-ben.) A mesterek a hozzájuk rendelt bányászokkal az aknák fúrását, ellenaknák készítését, betömését és robbantását végezték. Ilyen csapattestek a 16. században, Isztambulban már laktanyában voltak, ${ }^{1178}$ és a bányász és utász alakulatokat alkották. Számukat a nagyobb hadjáratok és ostromok elött megnövelték. 1453-ban, Konstantinápoly ostromához aknászokat hozattak Novo Brdo-ból. ${ }^{119}$ Az oszmán ostromtechnika kiemelten fontos része volt az bányászok és az utászok munkája. A tüzérséggel ekvivalens fontosságú a földmunkák, lövészárkok, töltések építése és a falak aláaknázása. Ezekben az oszmánok kiválóak voltak ${ }^{1180}$

Az aknák ásása, alagutak és ellenaknák készítése nemcsak szakképzettséget, hanem bizony sokszor hosszú időt is igényelt. Ebben állt a kockázata is. Az alkalmazása - egyéb ostromeszközök eredménytelensége esetén - több hónapossá elnyújthatta az ostromidőt.

Az alagút ásási helyének észrevétele a védök különös éberségét kívánta meg. Ennek többféle módszere volt. A legegyszerübb az, hogy vizes edényeket helyeztek a várfalra, figyelvén azoknak rezgését, fodrozódását. ${ }^{1181}$ Egy dobra helyezett sörét- vagy borsószemek mozgása is hasonló elven „müködött”. Szofisztikáltabb módja volt az, amelyet már Polübiosz leírt Ambrakia ostrománál. A védők párhuzamosan a várfallal belülről hosszú

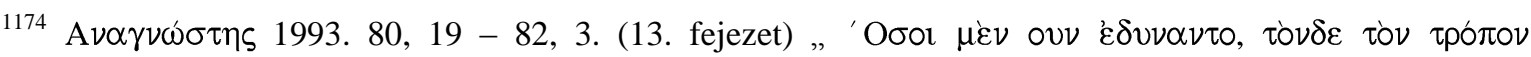

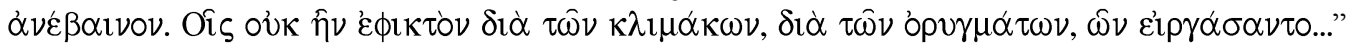

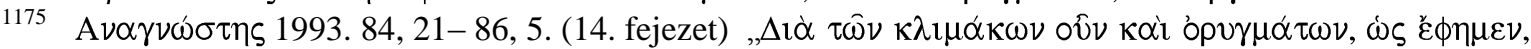

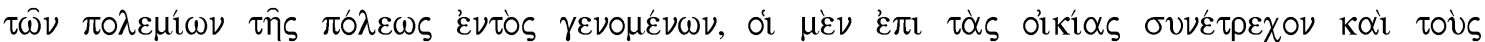

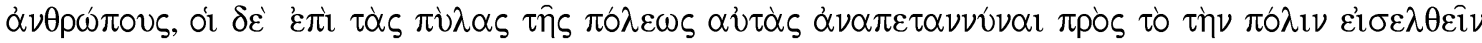

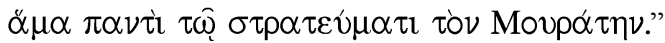

1176 Török történetírók I. kötet 1893. 413-414.

1177 Ágoston 2005. 40.

1178 Generál 1987. 157

1179 Ágoston 2005. 40.

1180 Imber 2002. 279.

${ }^{1181}$ J. E. Kaufmann-H. W. Kaufmann 2001. 60; Bradbury 2006. 198.
} 
árkot ástak, amelynek falára, egymáshoz közel, vékony bronzlemezeket helyeztek el. A lemezkék rezgése jelezte a falhoz közeledő akna helyét. ${ }^{182}$ A másik módja az, amikor a földfelszín felett kifeszített fémhuzalokra függesztették fel a fémlapocskákat. A Nándorfehérvár ostromáról szóló források nem említik a védőknél ilyen módszer alkalmazását, hanem a török táborból egy nyílvesszőn beröpített levél közölte az akna helyét.

Ami számunkra viszont máig nehéz kérdés az az, hogy Thuróczy és Bonfini Nándorfehérvár 1440. évi ostrománál sajnos nem közli az aknaásás lehetséges helyét. A Thuróczy-kommentár például a távolibb Avala hegyről valószínüsíti, ahol a középkori Zsarnó vára állt. ${ }^{1183}$ Thuróczy szerint ez a hely „a vártól egy fél magyar mérföldnyire vagy közelebb" helyezkedett el. ${ }^{1184}$ Az 1 magyar mérföld eltérő volt, attól függően, hogy régi vagy új mértékben számították. Bogdán István szerint ez eléggé eltérö, a régi 11, $3 \mathrm{~km}$, az új 1, 74-8, $36 \mathrm{~km}$ is lehetett. ${ }^{1185}$ Ha csupán a régi mérték felét vesszük, akkor is ez $5,6 \mathrm{~km}$, amely túl távolinak tünik. Bonfini is csupán annyit közöl, hogy „két mérföldnyire.”1186

Szeretném ezt pontosítani. A Reuters 2009. június 8-i számában Alexander Vasovic arról írt, hogy a belgrádi Underground (Andergraund) klub falaihoz közel van egy középkori tömegsír, amely egy berobbantott aknában őrzi a török holttesteket az 1440. évi ostromból. A török holttestek a kőtörmelék alatt maradtak, elzárták az egyik ilyen alagutat. ${ }^{1187}$ Ezt a cikket vette át a magyar internetes sajtó Kultúrpart hírportálja június 16án. ${ }^{1188}$

Itt válik érdekessé a probléma. Nemcsak azért, mert igazolja Thuróczy hitelességét, hanem mert feltételezésem szerint a club helyének azonosításával meghatározható lenne az egykori akna berobbantásának helye is. Belgrádi terepbejárásom alkalmával ezt ellenőriztem (2012. április 20.).

A vár 1440. évi ostromának e fontos emlékében egy szórakozóhely üzemel. Ez a club ma Soho Republic néven müködik a Pariska és a Karađorđeva ulica kereszteződésében - az

\footnotetext{
1182 Polübiosz 2002. 255. (24. könyv 27. fejezet)

1183 Johannes de Thurocz: Chronica Hungarorum II. Commentarii. 2. Ab anno 1301 usque ad annum 1487. (composuit Elemér Mályusz adiuvante Julio Kristó) 1988. 319. (Ad. cap 230) (Thuróczy kommentár 1988)

1184 Thuróczy 2001. 277, 1. „in medio miliari Hungarico vel citra distans” Thuróczy textus 1985. 242, 21.

1185 Bogdán István: Régi magyar mértékek. Budapest 1987. 58. (Bogdán 1987)

${ }^{1186}$ Bonfini 1995. 591, 12.

1187 „Only a few patrons enjoying drinks at Belgrade's Underground club know that a Medieval mass grave lies just beyond the bar's walls. To repel Turkish invaders in 1440, Christian defenders of the city used a giant gunpowder mine to blow up hundreds of attackers digging tunnels beneath the city, Turkish bodies remained in the rubble that sealed one of the tunnels, meters away from the club's bar."

1188 KultúrPart. 2009. június 16. „Tömegsírok Belgrád alatt!” (Tömegsírok 2009)
} 
egykori Szabácshoz vezető út elágazásánál (Pariska 1, 11000 Beograd), a Száva-felőli parthoz közel. Jól látható a bejárat széles íve és mélysége. A belső felméréshez, fényképezéshez a tulajdonos és a hatóságok engedélye szükséges. A külső felvételeink viszont a terepmagasságok helyszíni ellenőrzésére kitünően alkalmasak. Ezek megerősítik Thuróczy és Bonfini azon beszámolóját, hogy ez olyan hely, ahonnan a védők a várból valóban nem láthatták az akna ásását (29. melléklet). De pontosítja Bonfini azon megjegyzését is, hogy a kijárat „, a folyóhoz közel” van, ez pedig így a néhány méterre lévő Száva-folyó. Az is beigazolódik, hogy a bejárat a vártól messzebb, valóban körülbelül „egy-két római mérföldnyire” van, de ez semmiképpen nem lehet az innen túl távoli Avalahegyen.

Kiinduló hipotézisem az volt, hogy mivel más aknáról a források nem tesznek említést, azt kell feltételezni, hogy ez volt az egyetlen, amelyet az ostrom idején a törökök használtak. 2002-ben Zoran Lj. Nikolič és Dr. Vidoje D. Golubovič szerzőpárostól hiánypótló munka jelent meg, amely Belgrád alagútjait veszi sorra és a fent említett alagutat kapcsolatba hozzák az 1440-es ostrommal. ${ }^{1189}$ Ebben röviden áttekintették az 1440-es ostromot is és az alagútkészítést is. Az akna alapterülete kb. $500 \mathrm{~m}^{2}$ nagyságú, amelyet a hegybe vájtak ki. A magassága 1, 2 - 4, 2 m közötti, a szélessége pedig 1, 6 -12 méter. ${ }^{1190}$ Ezt az aknát egyáltalán nem csak alagútszerű „folyosónak” kell elképzelni, hanem egy kiszélesedő barlanggá vájták, amelyek boltozatát támfalakkal és erős oszlopokkal erősítették meg. Ez igazolja Bonfini leírását, amely „,barlang formájú vájatot” említett meg. A barlangból pedig további elágazó folyosók indulnak (30. melléklet). Feltételezhető, hogy a helyszín a későbbi török uralom alatt löporraktárként vagy börtönként is szolgálhatott. Mögötte van egy másik barlang is, amely a club raktára mögött található. Két folyosója közül az egyik a mai Francia Nagykövetség irányába vezet, a másik a mai „Győztes” szobor felé, de mindkettő beomlott, feltárása viszont lehetséges. ${ }^{1191}$

Mivel a club mellett közvetlenül létezik még egy barlang, amely azonban nincs feltárva és feltételezhetően ugyanebből az időszakból származik (Pariska 1a). ${ }^{1192} \mathrm{~Kb} .200 \mathrm{~m}^{2}$ alapterületű, 1, 1-3, 8 méter magas és 7, 12 m széles. ${ }^{1193}$ A szerzők szerint valószínű, hogy a közelben rejtőzhet más eddig fel nem tárt török tömegsír is. ${ }^{1194}$

\footnotetext{
1189 Zoran Lj. Nikolič-Dr. Vidoje D. Golubovič: Beograd ispod Beograda. Beograd 2002. A továbbiakban: Nikolič-Golubovič 2002.

${ }^{1190}$ Nikolič-Golubovič 2002. 196.

${ }^{1191}$ Nikolič-Golubovič 2002. 31.

${ }^{1192}$ Nikolič-Golubovič 2002. 31.

${ }^{1193}$ Nikolič-Golubovič 2002. 196.

${ }^{1194}$ Nikolič-Golubovič 2002. 34.
} 
Azt a helyszínen ellenőriztem, hogy ezt az alagutat nem a Duna felől, hanem a Száva felől kezdték ásni az aknászok. Az is látható volt, hogy a fent említett föld alatti tömegsír a vár délkeleti és délnyugati falától elég messze van. Az aknaásásról szóló két forrásunk közül, Thuróczy arról ír, hogy a törökök alagútja elérte a várfalat, mégpedig „a vár falain belül" (intra menia). ${ }^{1195}$ De egyáltalán nem biztos, hogy ez a törökök alagút-szakasza volt. Ezt erösíti meg másik forrásunk is. Bonfini szerint ugyanis a törökök csak „, a falakig vitték az alagutat...(ad menia) ${ }^{" 1196}$ A tömegsír mai helye alapján sokkal valószínübb, hogy a berobbantás helye nem a várfalon belül, hanem azon jóval kívül lehetett. Ennek is megvan a maga ésszerű magyarázata, hiszen ha a védők igyekeztek minél gyorsabban megelőzni a törökök aknájának a falak közelébe jutását, annak berobbantása egyre kevésbé veszélyeztette a vár saját falainak stabilitását. Így inkább a védők alagútja haladhatott át a várfaluk alatt, mintsem a törököké. Ezzel az „előrefúrással” még idejében elérhették a félig elkészült ellenséges aknát és a vártól távol, annál nagyobb, biztonságos távolságban robbanthatták be, amelynek emléke lehet ez az előbb említett török tömegsír

Az aknák ásását alkalmazta később II. (Hódító) Mehmed szultán (1451-1481) is 1453ban, Konstantinápoly erős falai ellen. Konstantinápoly török ostroma analógiákkal szolgálhat az előbbi, szükös ismeretek kiegészítéséhez. ${ }^{1197}$ Amikor április 6-án Mehmed elrendelte a falak ágyúzását, ezzel egyidejüleg elrendelte az aknák ásását is. Mivel nem volt kellő szakértelmű aknásza, hivatásos bányászokat kellett hozatnia. Így szerbeket például a Novo Brdo-i ezüstbányából. A falaktól messze kezdték el a munkálatokat, hogy ne vegyék észre a védők. Ez a technika ott eredményes, ahol a talajviszonyok is lehetővé teszik, valamint, ahol egyszeres a védőfal. Ez a Blakhernai-falnál volt. Amikor a védők május 16-án felfedezték, Johannes Grant mérnök ellenaknát ásatott. Bejutottak a török aknába és felégették a fa tartóelemeket, a tető beomlott, maga alá temetve az aknászokat. A törökök május 21-én újabb aknát a Kaligarai-kapunál kezdtek. Ezt vízzel árasztották el, vagy kifüstölték. Május 23-án a Blakhernai-falnál újra próbálkoztak aknák ásásával, de Grant ezt is megsemmisítette, s ezután a törökök felhagytak az akna építésével. ${ }^{1198} 1480$ ban a szultán Rodosz erődjének sikertelen ostromakor aknák ásásával nem foglalkozott.

Aknák ásására 1456-ban nem került sor, ám Nándorfehérvár végső, 1521. évi török ostroma szintén jó párhuzamot kínál számunkra. A szultáni sereg - ekkorra birtokában

\footnotetext{
1195 „,hostilis fossa intra menia castri ad fossam per castrenses egestam deducta esset...” Thuróczy textus 1985. 243, 5-6.

1196 ,illi ad menia cuniculos continuato labore prope subduxerant” Rerum 1936. 102, 20-21.

1197 Lásd még: Philippides-Hanak 2011.

${ }^{1198}$ Runciman 2000. 123-124.
} 
lévén a várostromra alkalmas nehéztüzérségnek - jól felszerelkezve látott hozzá az ostromhoz, de az aknászok szerepe szintén döntő jelentőségü volt a vár feladása szempontjából. Lutfi pasa leírása szerint, amikor a külső várat elfoglalták, a 28. napon aknával robbantották fel az éléskamrául szolgáló tornyot. ${ }^{199}$ Ferdi is ezt erősíti meg, bár nem ír az 1440. évi ostromról, csak az 1456. esztendeiről. Az 1521. éviben pedig kiemeli a megfelelö tüzérséget: „,mennydörgő ágyúk és villámhatású puskák”, ,sárkányhoz hasonló ágyúk”. Elfoglalták a külső várat, a védők a belső várba zárták be magukat, de ezt nem bírták ágyúkkal, vívó árkokkal bevenni. Ekkor ,lagimdsiket hozattak a bányákból és aknák nyitásához fogtak.” (Thúry József fordításai) ${ }^{1200}$ Amikor ezzel a „Nebojsza” tornyot felrobbantották, a védők feladták a várat.

Amikor a török haderő 1522 júliusában Rodosz erődjét kezdte ostromolni, de a tüzérségi támadások az 1480-as ostrom után felújított korszerü erőd ellen eredménytelennek bizonyultak (főleg a Szent Miklós-erődnél), a szultán aknák ásásába kezdett. A törökök szeptemberre a városfalak felé több mint 50 alagutat ástak, de a védők ellenalagutakkal ezeknek útját állták. Szeptember 4-én az egyik akna berobbantásakor a városfal egy része beomlott, a további aknarobbantások kevésbé voltak eredményesek. A vár védői végül decemberben az ellátás és lőszer elfogytával kénytelenek voltak megadni magukat. $^{1201}$

A korszerü tüzérség a szülejmáni hadjáratokban már beépült a török hadseregbe. Még a költői művekben is tisztelettel adóztak előtte. Például Behári (1492-1551): Magyarország elfoglalásának története címü elbeszélö költeményében a tüzérség ábrázolása olyan hangsúlyos szerepet és olyan szemléletes költői képeket kapott, amelyeknél ma sem lehet írni jobbat. Ilok (Újlak) várának ostrománál a következőket olvassuk: „Zarbzeneket állits, $s$ a harc égi labdáit, / követ hullas a fejükre a magasból” (140.); „Az ágyúk tüzet szóró sóhajtása és lôpora / fejükre szórta az égről a csillagokat" (150, Sudár Balázs fordítása). ${ }^{1202}$

\footnotetext{
${ }^{1199}$ Török történetírók II. 1896. 8.

${ }^{1200}$ Török történetírók II. 1896. 52-53.

${ }^{1201}$ J. E. Kaufmann-H. W. Kaufmann 2001. 173.

${ }^{1202}$ Sudár Balázs: A végítélet könyve. Oszmán elbeszélő költemény a mohácsi csatáról. Történeti Szemle 2010/3. 407. (Sudár 2010)
} 


\subsection{Lő „,por”-e a lőppor? -a bizánci források tanulsága}

A tüzfegyverek korai alkalmazása Európa keleti felén, a haditechnika iránt érdeklődő bizánciak számára is újnak számított, alkalmazásukról egy-egy esemény kapcsán történetíróik is pontosan beszámolnak. A már többször idézett Laonikosz Khalkokondülész munkája V. könyvében egy egyedülálló, hosszabb részt szentelt ennek az új találmánynak és müködésének, amelyet II. Murád szultán Konstantinápoly elleni ostromában már használhatott. A vonatkozó szöveget érdemesnek tartom teljes terjedelmében közölni, amelyből jól lemérhető a 15. század kíváncsi-kutató emberének csodálkozása új, rejtett kémiai erők láttán.

Khalkokondülész először az eredetük kideríthetetlenségéről elmélkedik, majd német földről származtatja azt. „Úgy látszik, hogy az ágyú (télebolosz) egyáltalán nem annyira régi (találmány), hogy úgy halljunk róla, mint ami a régieknek jutott volna eszébe. Azt, hogy honnan vette eredetét, és hogy az emberek közül kik jutottak el az ágyú ismeretéhez, én nem tudom biztosan megmondani. Mindenesetre úgy gondolják, hogy azok a németektöl erednek. Nekik jutott eszükbe ez a szerkezet (mékhané). A puskák ${ }^{1203}$ (téleboliszkoi) a németektöl rövidesen eljutottak a lakott világ más népeihez. Az ágyúkról (téleboloi) azonban lehetetlenség biztosan tudni, hogy honnan vették eredetüket. "1204

Khalkokondülész az ún. fekete lőpor vagy „füstös” löpor összetételét is ismertetve, alkalmazásának hatékonyságát méltatja. A bizánci szerzőnél feltünik a használatának elítélendő, „ördögi” volta, kémiai reakciójának démoni ereje. „Azt tartják, hogy az az erő és a rendkívüli gyors mozgás, ahogyan a fenyegetö kölövedék, ahová csak eljut, az emberi testnek rendkívül nagy sérülést okoz és minderre a löpor képes. A salétrompornak van ilyen ereje, antracittal (t. i. tiszta szénporral) és kénnel összekeverve. Így tehát jobban uralja a világot a (hagyományos) fegyverekkel szemben. Amiért is kevesebb vitézsége, ám démoni gyorsasága van.",1205

${ }^{1203}$ Lásd a 8. 3. és a 9. 2. fejezeteket, valamint az 1440-es eseményeket tárgyaló Khalkokondülész szöveg alapján általunk korábban meghatározott jelentést.

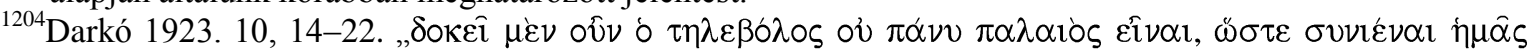

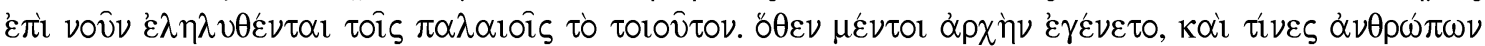

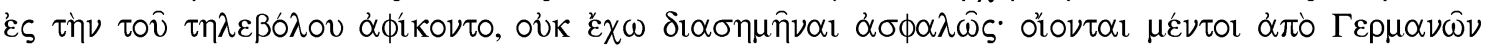

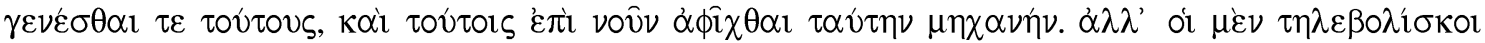

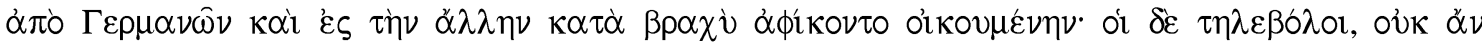

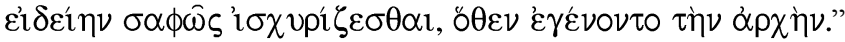

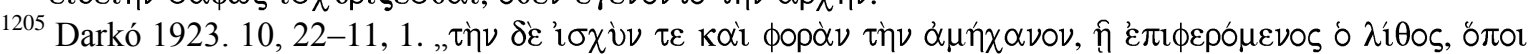

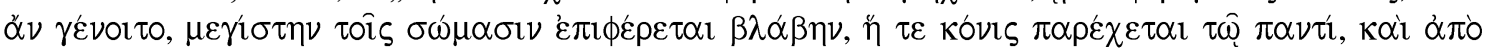

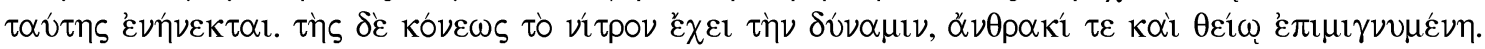


A bizánci szerző megállapítása máig érvényes. Gorszt definíciója szerint: „A füstös vagy fekete löpor kálisalétrom, kén és szén mechanikus keveréke.” A fekete löporban a szén az éghető anyagot, a kén a kötőanyagot, a salétrom pedig a kén és a szén égéséhez szükséges oxigént biztosítja. A kén továbbá „megkönnyiti a löpor begyulladását, mivel a gyulladási hömérséklete kisebb, mint a széné."1206

A bizánci szerző helyesen észrevette, hogy ezek közül a legföbb összetevő a salétrom, amely a kálisalétrom vagy kálium-nitrát $\left(\mathrm{KNO}_{3}\right)$. Egyébként jó minőségü salétrom lelőhelyek csak Indiában, Arábiában és Kínában voltak, ahol a természetes salétromképződés számára megfelelő az éghajlat (a magas hőmérséklet, páratartalom miatt). Európában csak kevés helyen, Spanyolországon, Lengyelországon és Magyarországon, de ezeket már tisztítani kellett. ${ }^{1207}$ A fekete lőporban lévő kálium-nitrát miatt kisebb a löpor nedvszívó képessége, nem higroszkópos vegyület, de érzékeny a levegőben lévő nedvességre, a későbbi korokban ezért grafitozzák. ${ }^{1208}$ A kén mint kötőanyag csökkenti a löpor higroszkóposságát. ${ }^{1209}$

Khalkokondülész ezután a korai ágyúk anyagát és az ágyúöntés tökéletesítését ismerteti, a bronzot tartva a legjobbnak. Ami számára a legmegdöbbentőbb, az a hatalmas távolság, ahova az ágyú ellőhet. „Úgy tünik, hogy először vasból készitették, majd az úgynevezett öntés feltalálása után, ötvözve a rezet az ónnal, ezt jobbnak és erösebbnek találták kölövedékek kilövésére. Részletesen leirni, hogy milyen is az alakja, bizony teljesen fölösleges, mindenki számára bárhol látható. Hosszúkás, viszont amennyivel hosszabb, annyival messzebbre lövi ki a kögolyót, úgyhogy a »messzire lövö« (télebolosz), amint ezt hallottam, kilövi a kögolyót 70 sztadionnyi távolságra, ${ }^{1210}$ körülötte körben, minden irányban reng a föld. "1211

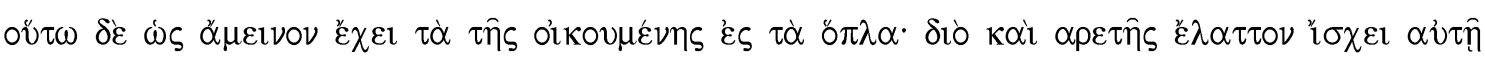

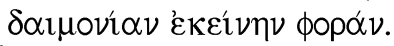

${ }^{1206}$ A. G. Gorszt: Lőporok és robbanóanyagok. Nehézipari Könyv- és Folyóirat-kiadó Vállalat. Szerk.: Tóth István. Budapest 1954. 177. A továbbiakban: Gorszt 1954.

${ }^{1207}$ Ágoston 2005. 96-97.

${ }^{1208}$ Béni Szabolcs-Szakács Zoltán-Ungváriné Nagy Zsuzsanna: Általános és szervetlen kémiai gyakorlatok. (Laboratóriumi elöiratok és számítási feladatok) Budapest 2006. 185. (Béni-Szakács-Nagy 2006)

${ }^{1209}$ Bár a nátrium-nitrát oxigénben gazdagabb, mint a kálium-nitrát, de éppen a nagyobb nedvszívó képessége miatt nem alkalmas a lőpor alapanyagának. Gorszt 1954. 177.

${ }^{1210}$ Ha 1 sztadion=177 m, akkor ez 12390 m lenne. Habár ez a szám túlzónak tünik, harmadára, negyedére az ágyú ellőhetett (3-4 km).

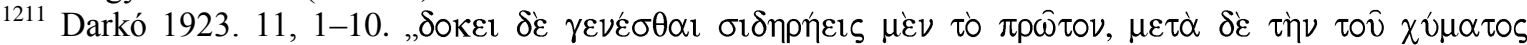

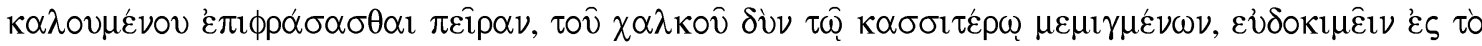

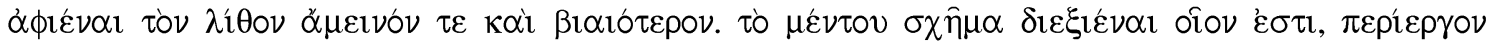

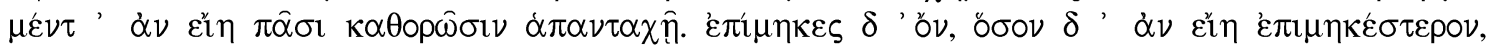

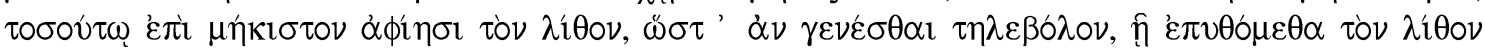

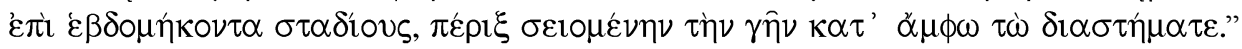


A bizánci tudós számára megmagyarázhatatlan ez az erő, amely a fekete lőporban keletkező robbanásban rejlik. Ennek okát keresve követi az ókori szerzők (Arisztotelész, Hérón) pneumatikai nézeteit a csőbe szorított levegő (lőporgáz) viselkedéséről. ${ }^{1212}$ Ebben felfedezhetjük a világ alapelemeinek egymásba való átalakulását (itt: levegőből tűz), a levegő testként való kezelését (ami a lövedékre kölcsönhatást képes kifejteni), valamint az ún. horror vacui elv meglétét, amely szerint a természet nem türi légüres tér, vákuum keletkezését. Mivel ez esetben, szerintük, a robbanáskor az égés elpusztítaná a teljes levegőt. ${ }^{1213}$ Azt viszont megsejtették, hogy a fekete lőpor a levegőtől elzárva is „ég”, csak azt nem tudták, hogy azért, mert egyik alkotóelemében (a kálisalétromban) már „beépítve” tartalmazza az égéshez szükséges oxigént. Sőt, szabad levegőn a fekete lőpor valójában rosszul ég. „Úgy látszik, hogy a tüznek az ereje okozza a dörgést és a rendkívüli gyorsaságot, ahogyan a kölövedék halad. Úgy látszik, hogy ez a hatalmas öselem (azaz a tüz) képes valamiféle démoni erökifejtésre, ahogyan a tüzzé átalakult levegö (azaz löporgáz) mennydörgést (azaz robbanást) okoz. Akár úgy -hogy ne jöjjön létre vákuum (kenosz) - dörgés és gyors mozgás keletkezik; akár pedig úgy, amikor a tüzet hozzáteszik ehhez az eröhöz, miután (t. i. a csőben) kényszeritve van, hatalmába keríti az anyagot (hülé) és ez a kényszeritö (erő) keletkezik, amely mindkét esetben ezekre képes! Úgy tünik, hogy valamennyi ennek a tüznek az ereje, és hogy a löpor (konisz) megnöveli a tüznek - a természetétöl fogva már benne lévő - erejét, és a tüz által mozgatja és lövi ki rendkívül messzire (t. i. a lövedéket)."1214

Khalkokondülész az újnak számító találmány, az ágyú müködésének leírásakor a fekete vagy „füstös” lőporra a konisz (por) szót használta. ${ }^{1215}$ Külön figyelmet érdemel itt a puskapor megnevezése. Mert ebben a bizánci szerzők nem egységesek.

Kritobulosz értékes leírása II. Mehmed szultán életéről szóló munkájának I. könyvében (I. 30. 7.) így szólt a fekete lőporról, amelyet botanénak nevez, bár ez Szabó Károly

\footnotetext{
${ }^{1212}$ Kádár Zoltán-Szabó Árpád: Antik természettudomány. Budapest 1984. 169. A továbbiakban: KádárSzabó 1984.

${ }^{1213}$ Kádár-Szabó 1984.173.

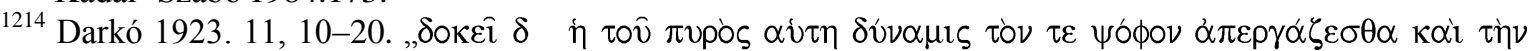

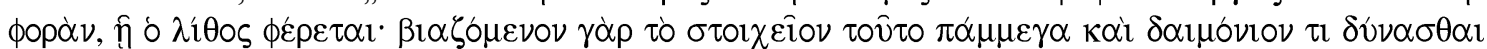

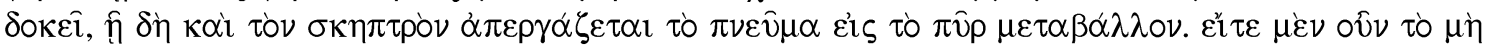

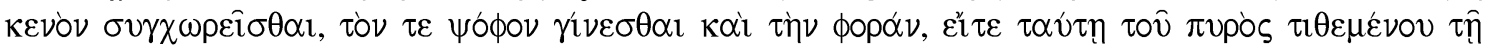

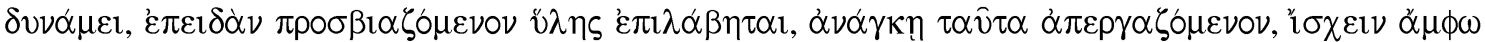

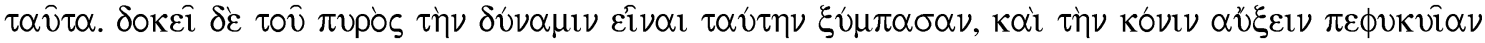

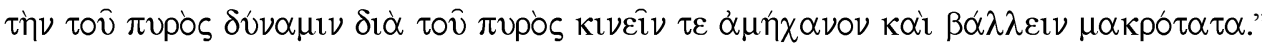

${ }^{1215}$ Lásd: 10. 4. fejezetet. Illetve: Bartusis 1997. 336.
} 
fordításából nem derül ki. ${ }^{1216}$ „Ez a germánok és a kelták körülbelül százötven esztendős vagy valamivel régibb, igen okos és fölötte elmés találmánya; s különösen elmés találmány a töltés (botané=löpor) egybeállitása és elkészitése, mely a legmelegebb és legszárazabb félékböl, salétromból, kénkőböl, szénböl és száraz, meleg gözt adó füvekböl (botanón) van egybeállitva... (I. 139. Szabó Károly fordítása). ${ }^{1217}$

1430-ban thesszaloniki védőinél volt puskapor, amelyet az ostrom egyik szemtanúja, Jóannész Anagnósztész szintén botanéként említett meg. „... lévén nálunk sok, elkészitett puskapor..." ${ }^{1218}$ De térjünk vissza az 1440-es ostrom során ismertetett löpor bizánci megnevezésére!

Dukasz az 1440. évi szultáni ostrom kapcsán leírja a védők által használt tűzfegyvereket. „Hátulról pedig ez a nádhoz hasonló érccső meg van töltve salétromból, kénböl és faszénböl álló »füvel«.” A továbbiakban is „füvet” említ a lövedékek kilövésekor, amelyet érdemes megtartani a fordításban is. „A kilött lövedékek közül az, amelyik a »fühöz« közel van, löki az elötte levöt, emez pedig megelözöt."

Láttuk, hogy a Névtelen Krónika sem pornak, hanem „fünek” mondta a fekete löport: „...a vránai parancsok, belülröl egy ellenaknát ásatott és ásás közben megtalálta a törökök aknáját és tüzet dobatott a puskaporra (t. i. a »füre«)."1220

A technikatörténeti „por” vagy „fü” kérdésének megoldásához közelebb vitt Dani Dániel Pál hadtörténész kezdeti észrevétele, amely szerint a szövegekben szereplő „salétrom” lehet ammónium-nitrát, $\left(\mathrm{NH}_{4} \mathrm{NO}_{3}\right)$ amely a vizeletnek egyik alkotóeleme. Azonban ez rendkívül instabil és égő elegyet képez, amelyet át kell alakítani a stabilabb kálium-nitráttá $\left(\mathrm{KNO}_{3}\right)$, azaz kálisalétrommá, „salétrommá.” A problémával Szajkó István nemzetközi tekintélyü vegyészmérnökhöz és lőporszakértőhöz fordultunk. ${ }^{1221}$ Véleménye szerint ezt kálium-klorid, „könnyüsó” $(\mathrm{KCl})$ hozzáadásával lehet előállítani. A könnyűsó a közönséges konyhasó $(\mathrm{NaCl})$ mellett a természetben előforduló só, amely minden

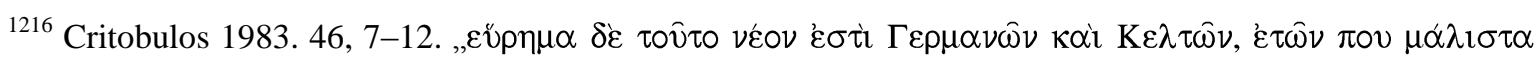

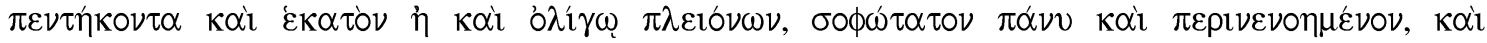

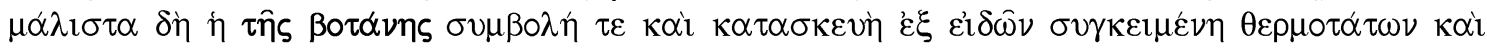

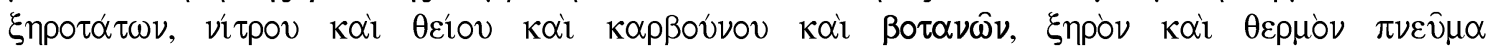
$\dot{\alpha} \pi \mathrm{\varepsilon} \varepsilon \lambda \circ \tilde{v} \nu \tau \omega \nu^{\prime \prime}$

${ }^{1217}$ Kritobúlosz 1875. 56, 28-57, 1. Idézi még: Iványi 1926. 397.

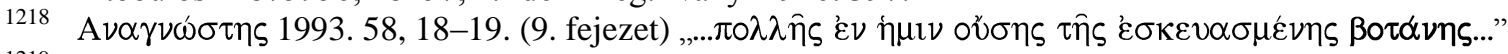

${ }^{1219}$ A forrásszövegekhez lásd a 10. 6. fejezetet.

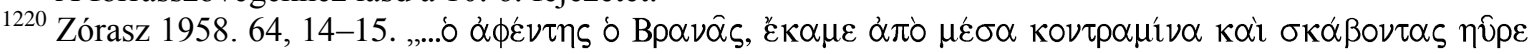

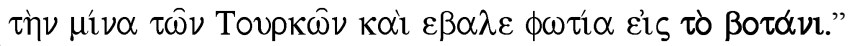

${ }^{1221}$ A szerző a Polgári Kézilőfegyver- és Lőszervizsgáló Kft. vezető szakértője, 1972 óta a Magyar C. I. P. (Commission Internationale Permanente pour l'Epreuve des Armes a' Feu Portatives) delegáció tagja. A brüsszeli szervezet a fekete lőporral müködő fegyvereket is vizsgálja, egyébként 2014. július 15-én ünnepli megalakulásának centenáriumát. 
természetes só egy részét alkotja. $\mathrm{Ha} \mathrm{a} \mathrm{Na}^{+}$ion $\mathrm{Cl}^{-}$ionnal nem tud kémiai kötést létesíteni, akkor azt leginkább a $\mathrm{K}^{+}$ion teszi. A védők salétrom hiányában nem lehettek, mert ez az alapanyag, mivel a Tallóciak sókamara ispánságot is bírtak, valószínüleg egyéb használatra is a rendelkezésre állhatott.

Dani Dániel Pál szerint a fekete lőporhoz szükséges kálisalétrom úgy is előállítható, hogy állati vizeletet gyüjtünk össze, a hadseregnél például ló vizeletet, ehhez rövid szárú takarmányt például töreket, valamint „könnyüsót” (sziksó) adunk. Ezt a keveréket dehidratáljuk, amikor is a takarmány szálakra kicsapódik az újonnan keletkezett káliumnitrát. Ehhez kell hozzáadni a többi összetevőket. A mai standard arány 75 \% salétrom, 15 $\%$ faszén és $10 \%$ kén. ${ }^{1222}$ Az összeállítás után megkapjuk a 14-15. századi fekete lőpor primitív változatát. Ennek állaga durva poros, darabos képződmény, amelyet fünek, törek állagúnak is tekinthetünk. Ami azért érdekes, mert a 15. századi francia lőpormanufaktúrák a durva, pasztaszerü állagot fejlesztették ki, amelyet óvatosan szárítani kellett és szemcsésre őrölni. Amelynek megvolt az az előnye, hogy nincs alkotóelemeire bontva, könnyebb szállítani és nem a helyszínen kell a nagyon robbanásveszélyes elkészítést elvégezni. ${ }^{1223}$

Továbbgondolásra érdemes a botané szó másik jelentése is: takarmány. ${ }^{1224} \mathrm{Ez}$ is közel vihet a megoldáshoz. „Ha nitrogén tartalmú szerves anyagok káliumvegyületekkel keverve rothadnak, kálium-nitrát képződik." Ezt már Roger Bacon angol filozófus, természettudós (1214 k.-1294) 1248-ban írt könyvében is leírta. Hullából, állati tetemekből bőven állt rendelkezésre egy ostrom során. Vagy mésszel kevert törekkel töltünk meg egy gödröt, amelybe bevezetjük az istállók állati vizeleteit. A salétrom kicsapódik, amelyet pár évenként ki lehetett „termelni."1225

Figyelemreméltó a Szajkó István által leírt egyik „salétromgyártási” módszer: „Ha bomlásnak induló állati eredetü anyagokat mésszel és hamuval kevernek össze, salétromot nyernek. Nitrogéntartalmú anyagokat - bört, húst, vért, szört - fatörmelékkel rakásba halmoztak, és időnként trágyalével öntöztek, nedvesen tartották addig, amíg a rothadás befejezödött. A rakásokat és a képzödö salétromot deszkafedéllel védték az esötöl. Ha a salétrom „,megérett”, akkor a rakás felületén akár $10 \mathrm{~cm}$ vastag salétromsavas mész is

\footnotetext{
${ }^{1222}$ Gorszt 1954. 177; Norris 2003. 47. A 14. században többször módosították az arányokat. Például: $41 \%$ salétrom, 30 \% kén, $29 \%$ szén. Az arány országonként is eltérő volt.

${ }^{1223}$ Norris 2003. 48.

1224 ÓGM.1993. 192.

1225 Szajkó István: A fekete (füstös) lőpor. (kézirat) Balatonfüzfő 2005. 6. A továbbiakban: Szajkó 2005.
} 
keletkezett... A salétromsavas meszet hamuzsirral alakitották át kálisalétrommá." Képletben összegezve: $\mathrm{Ca}\left(\mathrm{NO}_{3}\right)_{2}+\mathrm{K}_{2} \mathrm{CO}_{3}=2 \mathrm{KNO}_{3}+\mathrm{CaCO}_{3}{ }^{" 1226}$

Véleményem szerint ez utóbbi „eljárás” pedig - szinte szó szerint leírva! - felfedezhető Antonio Bonfini az ostromról szóló leírásában. Az olvasónak - első megközelítésben csupán egy elég bizarrnak tünő védekezés az ostromló törökök „távoltartására” az, hogy a védők „az összehordott földböl, szemétböl, állati ürülékböl fával boritott sáncot emeltek.” (Kulcsár Péter fordítása). ${ }^{1227}$ Akkor miért fedték be deszkával, fával? A latin szövegben ez áll: „egesta terra, fimo et pecorum excrementis aggerem lignis circummunitum ducunt..."1228 Ha a fenti szempontok szerint átértelmezzük e sort, úgy az alábbira módosítanám Kulcsár Péter fordítását: „Az összehordott földből, trágyából és állatok vizeletéből fával boritott sáncot emeltek." A deszkával való befedés megakadályozta, hogy az esővíz felhígítsa a képződő salétromot.

Ez az előállítási mód is lehetséges. Ezeket a megoldásokat használták abban az esetben, amikor nem állt a rendelkezésre nagyméretü füves, sziksós terület, ahol szintén lehet salétrom kristályokat gyüjteni. A fekete lőpor alkotóelemeit a természetben előforduló ásványokból, fából is előállíthatták. A kén egyébként a pirit ásvány izzításával is nyerhető. ${ }^{1229}$ (FES $\left.{ }_{2}=\mathrm{FES}+\mathrm{S}\right)$ A pirit helyett ,gyepvas” is használható, amely szinte mindenütt fellelhető. A faszenet oxigéntől elzárva, redukciós izzítással a száraz fából nyerik. Nándorfehérvár védőinek az alapanyagoknak - a hosszan tartó körülzárás miatt - a környékről való beszerzése eleve lehetetlen volt.

Az így készített fekete lőpor az átalakítás folyamán a szálastakarmány jellegét nem veszíti el. Mivel a kálium-nitrát képezi a legnagyobb részét a fekete lőpornak, a kén és faszén hozzáadása után sem változik az állaga. Az így előállított fekete „lőpor” pedig nem por, hanem inkább törek állagú lehetett, amely a „lőpor” legdurvább, legkezdetlegesebb változata volt. Az erről szóló bizánci megnevezések helytállóak. Ilyen lehetett a bizánci szövegekben a fekete lőporként szereplő „fü” és ilyenek lehettek a kritobulosz-i „száraz, meleg gőzt adó füvek”is. Egyúttal megerősítettük Iványi Béla korábbi sejtését. ${ }^{1230}$

\footnotetext{
${ }^{1226}$ Szajkó 2005. 6.

${ }^{1227}$ Bonfini 1995. 590, 35-36.

${ }^{1228}$ Bonfini 1900, 101. 34-36.

${ }^{1229}$ Szajkó 2005. 7

${ }^{1230}$ Iványi 1926. 397. (295. lábjegyzet)
} 


\section{6. Alkalmazott tüzfegyverek: ágyúk, puskák, mozsarak}

Nándorfehérvár 1521. évi török ostrománál már az oszmán hadsereg birtokában volt a megfelelő modern tüzérségnek, amely 1440-ben még hiányzott. A 15. század volt ugyanis a tüzfegyverek megjelenésének a kora. Az új fegyverfajtát kezdetben a közelharcon alapuló, kifinomult lovagi harcmodor megszégyenítésének, sőt - mivel a hangjuk a mennydörgést utánozta - egyenesen Istenkáromlásnak tartották, amelyet Khalkokondülész démoniként említett és a török Ferdi az 1521. évi ostrom leírásában is visszaköszönt. ${ }^{1231}$ Ebben fontos szerepe volt az egyházi álláspontnak is, mert kifejezetten tiltotta a lőpor és a tűzfegyverek használatát, azt az okkult tudományok közé sorolta. ${ }^{1232}$

A „messzire lövő” fegyverekkel szembeni ellenszenv nem középkori, feltűnt már az ókori görögöknél is az íj használatával kapcsolatban. Az Íliászban például, amikor Parisz íjjal messziről lőtt Diomédészre, aki így korholta a közelharcot kerülő ifjút:

„Ejh, ijas-szájas, fonatos hiu, lányra-lesö, te, szemtöl-szembe ha fegyveresen mersz állni elébem, hasznát nem veszed ijadnak, nem sürü nyiladnak: most megkarcoltad talpam, s dicsekedsz, de hiába. Annyi, mikéntha egy asszony lö rám, vagy buta gyermek: semmirekellö gyávának nyila sem sokat érhet. Másként röppen az én éles gerelyem, ha kevéssé érint is valakit, tüstént elorozza a lelkét... (XI. 384-392.) ${ }^{1233}$

Homérosz némileg helytelenítve említette a közelharc fegyvereit nélkülöző íjászokat:

„míg hös Oiliadész mellett nem voltak a lokrok: mert a közelharcot kedves szivük ki nem állta: hisz nem volt lobogós, forgós, rézmívü sisakjuk, szépkörü pajzsuk sem, nem volt köris-kelevézük: csak kézívükben s jólsodrott gyapjuzsinegben bizva követték Trója alá: hol a sürü nyilakkal lödözvén törték meg a trósz csapatok hadirendjét." (XIII. 712-718.)

A középkori Nyugat-Európában az ágyúknak a százéves háborúban főleg a várak ostromában és védelmében volt jelentősége, együtt alkalmazva még a mechanikus kőhajító gépekkel. ${ }^{1235}$ Már a 14. században igen elterjedtek voltak. Ezek lehettek nagy, nehéz ágyúk, amelyeket a falakon való rés ütésére használtak, a kisebb, hosszú csövü ágyúkat

\footnotetext{
${ }^{1231}$ Veszprémy 2008b. 217.

1232 John Norris: Early gunpowder artillery. c. 1300-1600. 2003. 12. A továbbiakban: Norris 2003.

1233 Homérosz: Íliász. Fordította Devecseri Gábor. Budapest 1957. 181-182. A továbbiakban: Homérosz 1957.

1234 Homérosz 1957. 225.

${ }^{1235}$ Engel 1990. 252.
} 
pedig a védők lövésére. Az anyaguk a 15. században még a költséges bronzból (réz és ón ötvözete) volt, az öntése nagy szakértelmet kívánt, elsősorban a harangöntőktől. A golyók nagysága is a kis söréttől a hatalmas kö- és vasgolyókig terjedt. Az ágyúkat felhevített vasrúddal sütötték el. Használatukat akadályozta, hogy a töltés, tüzelés, újratöltés hosszadalmas volt és minden lövés után ecetes vízzel ki kellett mosni. ${ }^{1236}$

Amint az előző fejezetben láthattuk Európa keleti felén, a haditechnika iránt érdeklődő bizánciak számára is újnak számított, alkalmazásukról egy-egy esemény kapcsán történetíróik is pontosan beszámolnak. A bizánciaknak is volt saját tüzfegyver- és lőporgyártásuk a 14. század utolsó évtizedeiben, de erről kevés ismeretünk van. Kelly DeVries szerint az ágyúik inkább közepes méretűek, 1 méteres csőhosszal és kb. $20 \mathrm{~cm}$-es átmérővel. Ehhez társult néhány nagyobb bombarda. A tüzfegyvereket bár Konstantinápolyban is használták, de egyáltalán nem olyan nagymértékben, mint európai és oszmán szomszédjaik ellenük, a Város ostromai során. Ennek oka még kutatásra vár. A bizánci gazdaság gyengesége sem tette lehetővé azok költséges előállítását. Ágyúhoz inkább ajándékként vagy kölcsönként jutottak hozzá. ${ }^{1237}$ Khalkokondülész és Dukasz szerint az erdélyi Orbán mestert sem alkalmazták a bizánci udvarban, aki ezután kereste meg a szultánt ajánlatával. ${ }^{1238}$

Az oszmán sereg, bár használta, de még sokáig nélkülözte a várostromra alkalmas nehéztüzérséget. Bár a bizánci források szerint korábban is lehettek ágyúik, de ezek többszörös falak áttörésére elégtelennek bizonyultak. Erre a legjobb példánk az, amikor II. Murád 1422 júniusától augusztusig ostrom alá vette Konstantinápolyt, de a falak és a védők bátor helytállása kifogtak rajta. ${ }^{1239}$ Óriási földhalmokat hordatott össze. A hagyományos ostromgépei (hajítógépek, ostromtornyok) között viszont már ott voltak a tüzfegyverek, talán az ágyúk, „mozsárforma bombavetők” amelyek nagyobb robajt csaptak, mint amekkora kárt okoztak. ${ }^{1240}$ Az előző fejezetben idézett ágyúleírás éppen ennek az ostromnak az ismertetését szakította meg. Khalkokondülész munkája is jól

\footnotetext{
1236 John Gillingham: A Rózsák háborúja. Budapest 1985. 31-32. (Gillingham 1985)

${ }^{1237}$ Kelly DeVries: Gunpowder weapons at the siege of Constantinople. In.: War, Army and Society in the Eastern Mediterranean, $7^{\text {th }}-16^{\text {th }}$ centuries. Edited by: Yaacov Lev. Leiden 1996. 350-351. (DeVries 1996)

1238 Khalkokondülész beszámolója szerint „,korábban a helléneknél tartózkodott, majd pedig otthagyta a helléneket, mert vagyonra volt szüksége, és a császári Portához ment. Jól megfizették tehát, és ágyúkat

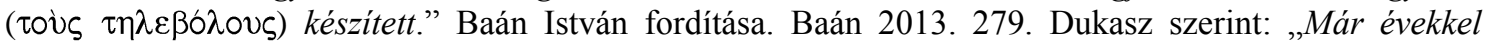
ezelött Konstantinápolyba jött, és jelentette, hogy mi a mestersége...A császár a tudásához nem illö bért határozott meg a számára, de még ezt az értéktelen, csekély összeget sem adták oda a mesternek. " A szultán pedig „...örömmel fogadta, élelemmel és ruhával becsülte meg, és akkora fizetséget adott neki, hogy ha a császár annak csak a negyedét adta volna meg, nem menekült volna el Konstantinápolyból." Baán István fordítása. Baán 2013. 359.

${ }^{1239}$ Runciman 2000. 54. Veszprémy 2008b 200.

${ }^{1240}$ Bréhier 1997. 439. Bréhier szerint ezek „mozsárforma bombavetők” lehettek.
} 
mutatja, hogy bár a szultán a régi és az új eszközöket egyaránt bevetette, mégsem érte el velük a célját.

„Amint Murád (Amouratész) felkerekedett és ostromgyürübe fogta a tengertöl a tengerig (t. i: a Fekete-tengertől a Márvány-tengerig) Büzantiont. Ágyúkkal (téleboloisz) lövette a falat, bár próbálta, nem sikerült lerombolnia. A kölövedékek 3 féltalanton ${ }^{1241}$ súlyt nyomtak, minthogy a falazat ellenállt, erős lévén még ezekkel az ágyúkkal szemben is és sehol nem lazult meg... ${ }^{1242}$ Akkor tehát Murád, Mehmed fia megpróbálta ágyúkkal és más ostromszerkezetekkel a falakat igen-igen sok napon át törni, a falakon mindenfelé, és megpróbálta elfoglalni. Azonban visszaverték öt és a görögök az ostromlétrákról letaszitották a szultán újonnan érkezett harcosait, s közülük néhánynak levágva a fejét, (győzelmet) arattak. Murád, mivel semmit sem jutott elöbbre a vár bevételében, bosszankodott és elcsüggedt, mégis vágyott a város elfoglalására. A görögök követeket küldtek az ott táborozóhoz (t. i. a szultánhoz), de ő nem akart egyezséget kötni. Néhány nap múlva hazatért és seregét elbocsátotta. „1243

Ezt megerösíthetjük Anonymous Zoras (Codex Barberinus Graecus 111) beszámolójával is $\left(37^{\vee}\right)$. „Murád, amikor rendbe szedte, megerösitette uralmát és megszilárditotta azt, összegyüjtötte seregét és arra készült, hogy megtámadja Konstantinápolyt, azért hogy bosszút álljon... ${ }^{1244}$ A Névtelen Krónikás e szövegrészletét a kétfázisú, szultáni mozgósítással kapcsolatban már említettük, most az ágyúk használatát közlő passzusát idézem. „Akkor még bombardákból és puskákból nem sok volt. Néhány nap múlva érkezett meg Murád szultán a maradék sereggel, a janicsárokkal és az anatóliai seregekkel. Megközelitette, majd a falakhoz közel letáborozott. Sátrai a Város egyik

${ }^{1241}$ Ha 1 talanton=20,4 kg, akkor ez $30 \mathrm{~kg}$. A legnagyobb 6-16 tonna súlyú óriáságyúk 150-700 kg-os kőgolyót is ki tudtak löni. Ágoston 2005. 64.

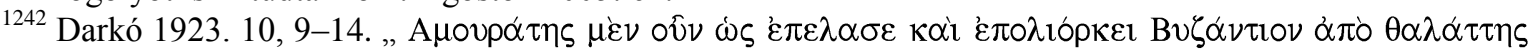

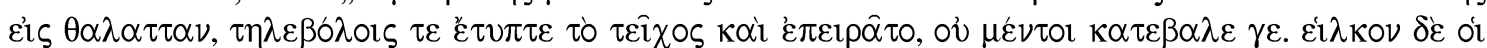

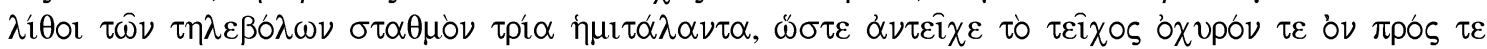

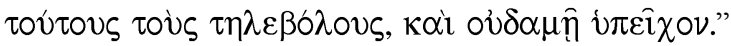

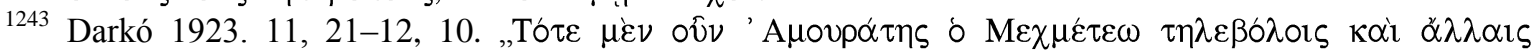

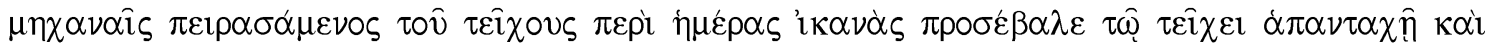

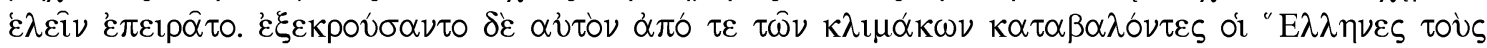

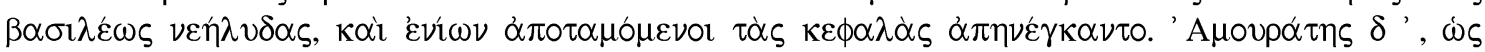

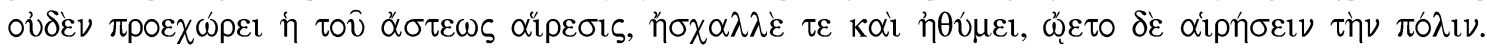

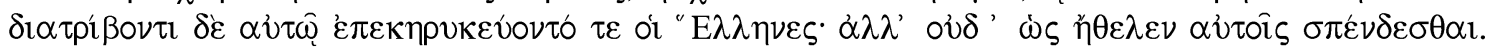

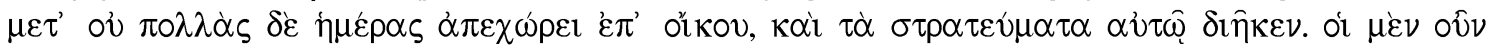

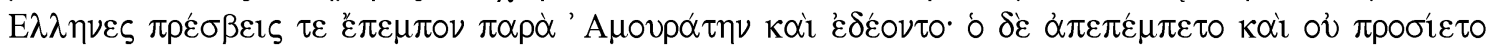
$\tau \grave{\eta} \nu \dot{\alpha} \xi \hat{\imath} \omega \sigma \mathrm{v} v . "$

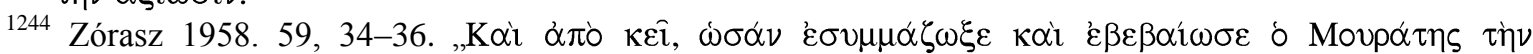

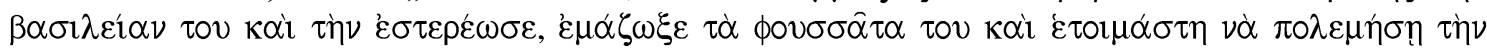

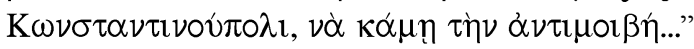


oldalától egészen a másikig tartottak és elkezdte a falakat bombardákkal ostromolni, de a falak erösek voltak és nem omlottak le." 1245

Láttuk, hogy hasonló történt az 1439-ben, Szendrő ostromakor használt ágyúk és ostromgépek esetében is, amíg a várat át nem adták a szultánnak.

A Nándorfehérvárral való párhuzamként említjük még az albán erődök közül a Kruja elleni oszmán-török ostromokat. Mert 1440 után tíz évvel II. Murád más hadszíntéren sem boldogult a nagy várak ostromával. A szultán 1450-ben személyesen indult el a hadseregével. A több mint öt hónapos - május 14-től október 26-áig tartó! - ostrom során a környéket elpusztították, de az 1500 fös védősereg sikeresen megvédte a várat. Ebben az is segített, hogy a vár teljes körülzárása nem sikerült, mert Szkander bég kívülröl tudta támadni az ostromlókat. ${ }^{1246}$ Khalkokondülésztől tudjuk azt is, hogy Murád ágyúkat használt Kruja (Kroué) ostromakor. „Amuratész előkészitette az ágyúkat (télebolousz) maga letáborozott, hogy a falakat töresse, és ott maradt a városba az újonnan érkezettekkel. Miután itt mindent elökészitett, a falat ágyúkkal (téleboloisz) lövette és nagy részét lerombolta. Szkenderész pedig a hegyröl tüzeket gyújtott, jelezvén a városban lévőknek, hogy mihelyt szükség lesz rá, ö maga fog segíteni." ${ }^{\prime 247}$

Kruja erejét is jól mutatta, hogy II. Mehmed 1466-ban, 1467-ben ismét megostromolta, de csak harmadjára, 1478-ban tudta elfoglalni. ${ }^{1248}$ Erröl Kritobulosz is írt (V. 12. 1.). „Vala ott az illüreknek egy teljességgel bevehetetlen, igen erös váruk, Krúesz nevezetü...Ezt a császár atyja azelött is megkísértette minden módon, fegyverrel, köhajitó gépekkel és hosszú megszállással: de még sem vehette be; olyan bevehetetlen vala." (Szabó Károly

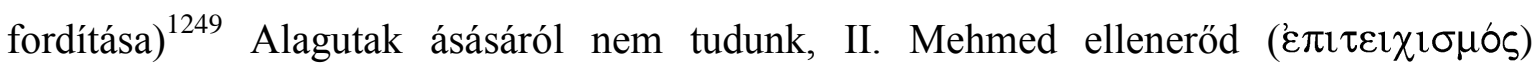

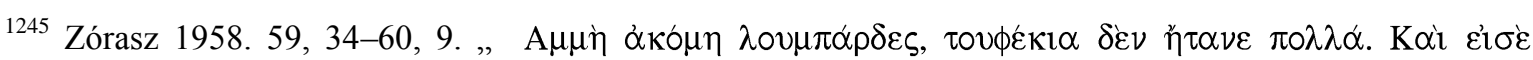

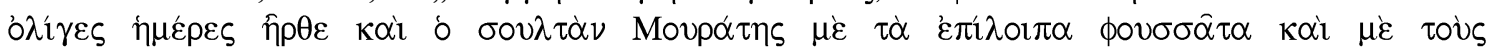

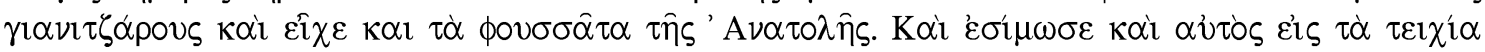

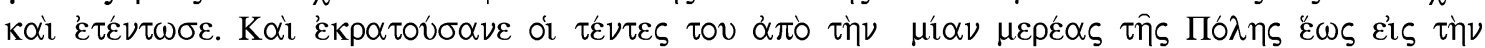

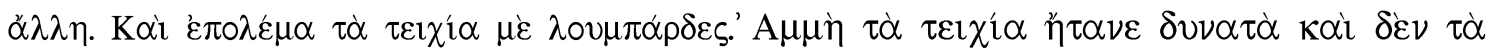
$\dot{\varepsilon} \beta \lambda \alpha \dot{\alpha} \tau \alpha \nu \varepsilon . ”$ Lásd a 10. 2. fejezetet is.

${ }^{1246}$ Balla Lóránt: Az albánok harca a törökök ellen a 15. században. Világtörténet 1991. (tavasz-nyár) 52. A továbbiakban: Balla 1991.

${ }^{1247}$ Darkó 1923. 124, 4-10. „A А

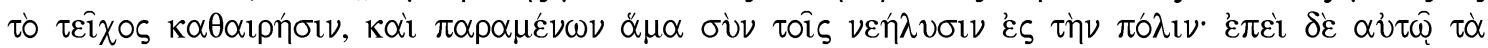

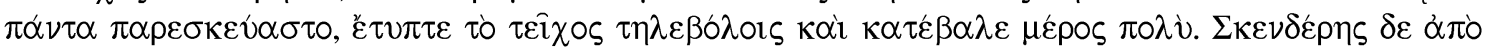

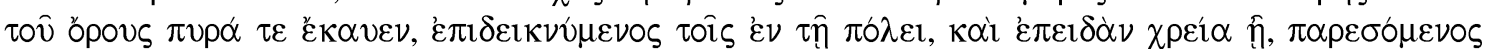

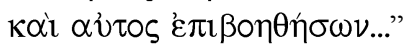

${ }^{1248}$ Balla 1991. 54. Lásd a 2. 4. fejezetet.

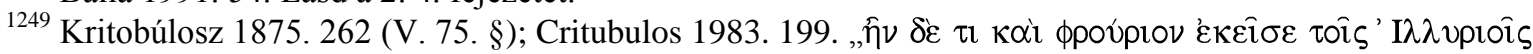

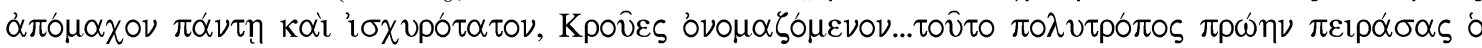

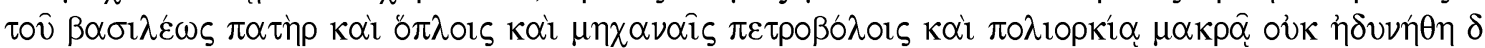

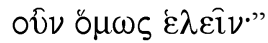


építésével próbálta meggyengíteni a várat, hogy ,mindig bezárva tarthassa és sanyargathassa az illüreket" (Szabó Károly fordítása). ${ }^{1250}$ Hasonló módon, mint II. Murád tette 1441 után Nándorfehérvár mellett Zsarnó várának fenntartásával és megerösítésével Evlia Cselebi szavaival - „Belgrád vára hitetleneinek meggyengitése végett.”(Karácson Imre fordítása) ${ }^{1251}$

Bár a szakirodalomban vannak korai dátumok, az oszmán tüzérség gyors fejlődése II. Murád és II. Mehmed korában indult meg. İdris Bostan által tudunk arról, hogy egy II. Murád korabeli összesített timár defter említett egy települést, ahol egy Ömer nevü tüzér (topçus) élt I. Bayezid szultán idejében. ${ }^{1252}$

II. Mehmed korában a törökök az ágyúöntéshez elsősorban külföldi mestereket alkalmaztak. Ezek magyarok, németek, később pedig olaszok voltak. ${ }^{1253}$ Mert az új technológiát még nem tudták tökéletesen kezelni. Ehhez - ahogy erről Kritobulosz és Khalkondülész is beszámol - éppen az erdélyi magyar származású Orbán mester segítette hozzá a törököket. Miután Bizánc nem tudta őt szolgálatába fogadni, az addigi fővárosban, Drinápolyban a török ágyúöntő műhely vezetője lett, és a hatalmas méretű „Basilica” nevü ágyút is ő készítette el. ${ }^{1254}$ II. Mehmed szultán 1453-ban már ennek birtokában foghatott Konstantinápoly ostromához. ${ }^{1255}$ Nem túlzás azt állítanunk, hogy a várostromokhoz szükséges falromboló nehéztüzérség feltalálása Orbán mester nevéhez füződik. Az ehhez szükséges technológiát tőle vették át. Ennek közismert példája az az óriáságyú, amelyet a török Munir Ali 1464-ben készített és ma a londoni Towerban látható. ${ }^{1256}$

Ágoston Gábor az oszmán-török tüzérségről írt monográfiájában megerősítette a bizánci forrásaink információit azzal, hogy a törökök az 1422-es Konstantinápoly elleni ostromban, Thesszaloniki 1430. évi ostromában használtak ágyúkat. Az İnalcık által felfedezett dokumentum az 1438-es erdélyi betörés során is tud ágyú használatáról, amely még nem volt alkalmas várak ostromára. ${ }^{1257}$ II. Murád szultán uralkodása alatt a janicsárokat már kézi tüzfegyverekkel látták el (tüfenk, tüfek). Ágoston továbbá azt is feltételezi, hogy a tüzérség, mint elkülönített és fizetett hadtest II. Murád időszakában

\footnotetext{
${ }^{1250}$ Kritobúlosz 1875. 263.

1251 Karácson 1904. 157.

1252 Ágoston 2005. 20. Lásd korábban: İdris Bostan: A szultáni ágyúöntő műhelyben (Tophâne-i Âmire) folyó tevékenység a 16. század elején. (Fordította: Papp Sándor) Aetas 2003/3. 6.

1253 Ágoston 2005. 46.

${ }^{1254}$ Veszprémy 2008a. 201.

1255 Runciman 2000. 86, 121.

1256 A méretei: a hossza 5,18 m, súlya 18,6 tonna. Charles Efoulkes: Tha Dardanelles' Gun at the Tower. Antiquarian Journal. Vol. 10. (1930), 217-227. (Efoulkes 1930)

${ }^{1257}$ Lásd a 6. 3. fejezetet.
} 
szerveződött meg. ${ }^{1258}$ Fodor Pál hasonló véleményen van. Az oszmán-török tüzérség felállítása szerinte is az 1440-es évekhez köthető. II. Murád korában már létezett egy fizetett, elkülönített tüzérség. A használt tüzfegyverek viszont sokkal inkább a mezei ütközetekben voltak hatékonyak, mintsem a várostromoknál. ${ }^{1259}$ Colin Imber is - az oszmán tüzérségről szólva - az 1440-es éveket tekinti a döntő fordulatnak, éppen a magyar háborúknak köszönhetően. Az 1443/44-es hadjáratban a szultánnak nem volt mezei tüzérsége. A magyarok ezzel szemben sikerrel alkalmazták a huszita szekérvárat (wagenburg). A szekerek - egymással összekapcsolva - mobil falként lehetővé tették a védekezést, másrészt a szekereken az ágyút, a tűzfegyvereket lehetett szállítani. A várnai hadjáratban, 1444-ben a magyarok tüzérségi fölénnyel bírtak. A második rigómezei (Kosovo) csatában 1448-ban, amikor az oszmánok is átvették ezt a szekérvár-technikát és a janicsárok fegyverekkel védekeztek benne, a magyar taktikai fölény elmúlt. ${ }^{1260}$ Hozzátesszük, hogy egy olyan komoly várostrom kudarca, mint Nándorfehérváré, mindenképpen sürgette az 1440-es években az oszmán tüzérség fejlesztését is a várostromló nehéztüzérség megteremtése céljából.

Nemcsak a magyar várostromoknál 1439-ben és 1440-ben, hanem már 1422-ben és 1430-ban is II. Murád - Khalkokondülész szerint - használt ágyúkat, de nem bízhatott eléggé bennük, mert mellettük - Dukasz beszámolója alapján - kőhajítógépekkel is törette a falakat. Ez a tüzérség nem volt hatásos a nagyobb várak ellen. A hosszú ostromok jelzik a hagyományos oszmán technikát, a blokádot, kiéheztetést. ${ }^{1261}$ A védők viszont már fel voltak szerelve tüzfegyverekkel is. Az ostromlók nem állták a falakról rájuk zúduló puskák lövedékeit. A védők tüzfegyvereiről nemcsak Khalkokondülész tanúskodik, hanem Bertrandon de la Brocquière lovag is, aki 1432-ben 3 nagy bronz ágyút említ, kőgolyókkal. ${ }^{1262}$ Nándorfehérvár fegyverrel való felszerelésében fontos évnek tűnik az 1435. esztendő, amikor hajókon küldtek korszerü fegyvereket a várba.

A Magyar Királyságban a tüzérség Zsigmond király idején honosodott meg, megszaporítva a hadászati szakmunkákat is. ${ }^{1263}$ Nálunk elsősorban a déli, dalmáciai hatás

\footnotetext{
1258 Ágoston 2005. 17, 23.

${ }^{1259}$ Fodor 2009. 209, 218.

${ }^{1260}$ Imber 2002. 268-269. A szekérvár tüzérségi alkalmazásáról lásd: Norris 2003. 93-95.

1261 Ágoston Gábor: Az oszmán és az európai tüzérség. Párhuzamok és eltérések az oszmán és az európai tüzérség fejlődésében a 15-17. században. Történelmi Szemle 1992. 180. A továbbiakban: Ágoston 1992.

1262 Szamota 1891.80; Cseh 2007. 67.

${ }^{1263}$ Iványi 1926. Illetve legutóbb: Veszprémy László: Illusztrált technikai és haditechnikai kéziratok Zsigmond korában. Müvészet Zsigmond király korában. II. kötet. Budapest 1987. 212-225. (Veszprémy 1987) Uő.: Zsigmond a katonai reformer? A haditechnikai írásbeliség és a technikai újítások kora. Hadtörténelmi Közlemények 1998/3. 657-665. (Veszprémy 1998b)
} 
érvényesült a balkáni hadjáratok miatt. Azt is meg kell jegyezni, hogy a tüzérség ekkor még nem fegyvernem, katonasággá csak eseti jelleggel válik. A királyok is gyakran a városoktól kölcsönöztek hadianyagot. A tüzfegyverek készítése is a városokban céhkeretek között müködő mesterség. Például jellemző a korban az a városi harangöntőmester, aki ágyút is tud önteni. ${ }^{1264}$

A Balkánon a bombarda szó először egy 1392. évi zágrábi oklevélben fordul elő. Sőt 1351-ben, a magyarok ellen a velenceiek Zárába puskásokat küldtek. ${ }^{1265}$ 1351-ből, Raguzából való az első említés egy tüzfegyverről. November 22-én Nikola Nijemac (Teutonicus) vállalta, hogy egy „Spingarda”t (kisebb kovácsoltvas ágyúféle) készít el. ${ }^{1266}$ A mester azonban decemberben elment a városból.

Raguzának azonban fontos szerepe lett a tüzfegyverek kereskedelmében. 1378-ra a nemcsak a saját védelmükben vált általánossá (parti őrség), hanem a város hamarosan a tüzfegyvergyártás központjává nőtt, ahonnan más balkáni államok beszerezhették tűzfegyvereiket. ${ }^{1267}$ A török növekvő hatalmát és kereskedelmi igényét finoman jelezte, hogy II. Murád 1442 februárjában kiváltságokat adott a raguzaiaknak. ${ }^{1268}$ Főleg azok után, hogy XI. Gergely pápa (1370-1378) 1373. május 15.-i bullájában megtiltotta a keresztényeknek az oszmánokkal való kereskedést, beleértve a hadianyagnak minősülő vasat is. ${ }^{1269}$ Az oszmánok a 14-16. században is Raguzából, Genovából, Velencéből és Firenzéből vásárolták a lőfegyvereket. ${ }^{1270}$

Mivel a Tallóciaknak megmaradt a kapcsolatuk Raguzával, igen valószínü, hogy a Nándorfehérvár védelmében helytálló, korszerü tűzfegyvereket innen szerezhették be. Bár elsősorban az ostromra vonatkozó bizánci források nevezik meg a tüzfegyvereket, a latin nyelvü forrásainkban is szerepelhetnek.

A Thuróczy leírásában szereplő „ceteris tormentorum generibus” kifejezésbe a tüzfegyvereket is bele kell érteni. Ugyanis a tormentum fogalmába többféle fegyver beletartozott: nemcsak a hajítógép (tormentum iaculamentarium), hanem a puska, vállpuska (tormentum humerale) is. ${ }^{1271}$ Sőt véleményem szerint ide vehetjük az 1435 . év

\footnotetext{
1264 Iványi 1926. 15.

1265 Veszprémy 2008b. 197-198.

1266 Ágoston 2005. 17.

1267 Ágoston 2005. 17.

${ }^{1268}$ Monumenta Serbica spectantia historiam Serbiae Bosniae Ragusii. Edidit: Fr. Miklosich Viennae 1858. 409- 411 (339. sz. okl) A továbbiakban: Monumenta Serbica 1858.

1269 Ágoston 1992. 178.

${ }^{1270}$ H. İnalcık: „Osmanlılarda Ateşli Silahlar” TTK Belleten (83) 1957. 509.

${ }^{1271}$ Bartal 1901. 668.
} 
korábban említett perhalasztó iratában szereplő ,aliorum ingeniorum ac instrumentum bellicalium" kifejezést is. ${ }^{1272}$

Nándorfehérvár 1440-es ostromában használt tüzfegyverek számos technikai újítással rendelkeztek, amelyekről a bizánci forrásokból értesülünk.

Dukasz egyedülálló részletességgel leírja azt a védők által használt, bronzból készített mékhanét, valamint pontosan ismerteti a fekete lőpor három összetevőjét is. A szövegrészletet új fordításban közlöm. ${ }^{1273}$,Mivel reájuk (t. i. a törökökre) pontoszi dió nagyságú ólomlövedékeket löttek bronzból készitett ágyúból, amelyben belül egyenes sorban 5 vagy 10 lövedék (bolida) van. Hátulról pedig ez a nádhoz hasonló érccsö meg van töltve salétromból, kénböl és faszénböl álló »füvel«(t. i. löporral). Ha a parázsnak, azaz a tüz szikrájának a robbanékony erejét közelitik ehhez a keverékhez, nyomban meggyullad. Amikor a levegö összeszorul, a lövedékektöl, az kényszeritö erövel kilövi a lövedékeket. A kilött lövedékek közül az, amelyik a »fühöz« közel van, löki az elötte levöt, emez pedig megelözöt." 1274

Megjegyzem, hogy e fontos tüzérségi szövegrészlet harmadik mondata a Dukasz-i

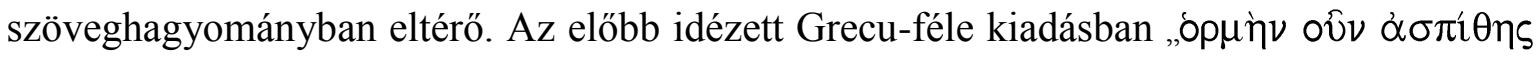

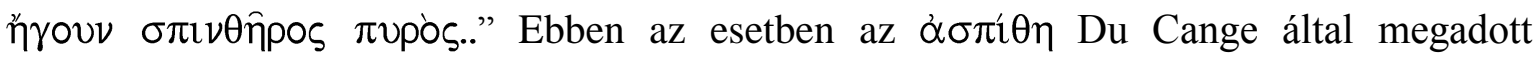
jelentései közül a „,parázs” illeszkedik legjobban a mondatba. ${ }^{1275}$ A Grecu által közölt jelentés: $\sigma \pi \imath \nu \theta n \rho ~(=s z i k r a)$, amely szerint csupán szinonímáról lenne szó. ${ }^{1276}$ Az viszont figyelemre méltó, hogy a Grecu által közölt román fordításban „,kovakő” szikrája szerepel, amely igen korai említését mutatná a kovaköves puskáknak. ${ }^{1277}$

A mü 16. századi kéziratában (Codex Parisinus 1310), amelyet a Bekker-féle régi

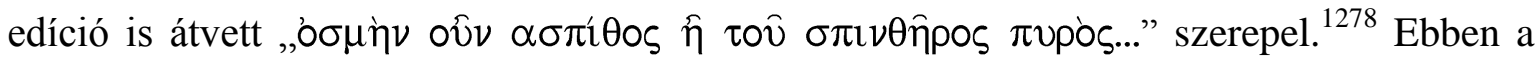
szövegvariációban az ơ $\sigma \mu \eta \dot{~(=s z a g) ~ s z e r e p e l, ~ a z ~} \alpha \sigma \pi i ́ \theta o s$ jelentései közül a Du Cange által

\footnotetext{
${ }^{1272}$ Lásd a 6. 2. fejezetet.

${ }^{1273}$ E szövegrészlet többen lefordították: Déri Balázs In.: Veszprémy 2008a. 218. (Veszprémy tanulmánya eredetileg 1988-ban jelent meg Hadtörténelmi Közlemények 1988. 1. 19) Szabó 2010.77; Szabó 2012d 65-66. Legutóbbi fordítása: Baán 2013. 349

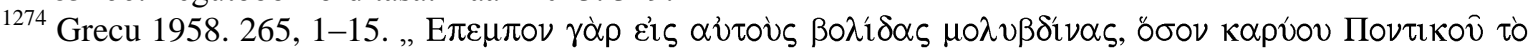

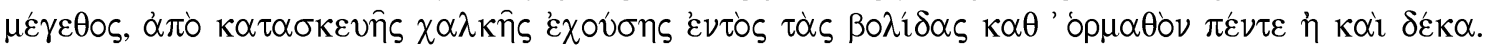

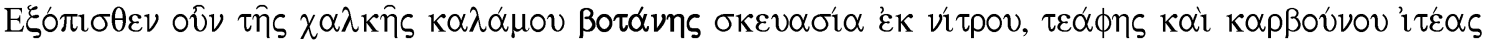

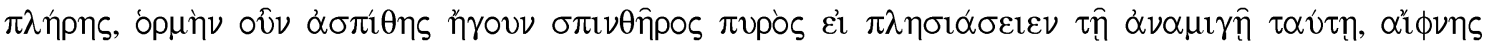

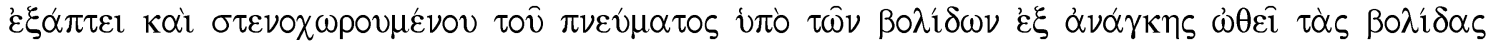

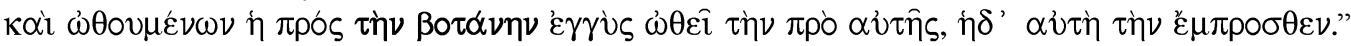

${ }^{1275}$ Glossarium ad scriptores mediae et infimae graecitatis auctore Carolo du Fresne, Domino du Cange. Tomus primus. Parisiis et Lipsiae. 1905. 143. A továbbiakban: Du Cange 1905.

1276 Grecu 1958. 446.

1277 Grecu 1958. 264. Valószínübb, hogy inkább a tüz gyújtásához használt kovakőre utal.

${ }^{1278}$ Bekker 1834. 211, 14; Baán 2013. 349. (apparatus)
} 
megadottakon kívül a „kátrány” jelentését vettem alapul, ezt használták az edíció mellékelt latin fordításban (odorem bituminis). Ezt követte fordításában a Bekker szövegkiadást használó Déri Balázs is. Ennek megfelelően: „Kátrányszagot (t. i. áraszt), ha ehhez a keverékhez a tüz szikráját közelitik, nyomban meggyullad. ${ }^{1279}$ Ez a szövegvariáns a bizánci szerző számára jobban leírja a lőpor robbanásakor keletkező szurok-szagot, amely a görögtüzre emlékeztethette, mivel annak viselkedése volt hasonló a lőporéhoz. Szajkó István szerint ugyanis a görögtüz ,gyújtóanyagának összetétele: kóc, szurok, kén, földiszurok és földi-olaj, azaz petróleum volt. A cél akkor is a gyújtogatás és nem a robbantás vagy lövés volt. Az ismertetett keverék nem feketelöpor volt, mert azok annak nélkülözhetetlen alkotórészét, a salétromot (oxigént) nem tartalmazták." ${ }^{1280}$ Ennek alapján itt a Bekker-féle szövegvariáns tekinthető - a gyakorlat szempontjából - hitelesebbnek.

Már Khalkokondülész is említett a védők között puskákat. Azonban iménti filológiai érveink után, Dukasz leírása alapján megkíséreljük rekonstruálni a fent leírt fegyvert, ami ilyen nagy hatékonyságú. Ez az ún. szakállas-vagy sáncpuska lehetett, amelynek e forrás alapján elkészített rekonstrukciós vázlatrajzát Dani Dániel Pál készítette el és az alábbiakban közöljük (31. melléklet). A szerb történész, Kalić is megemlíti, hogy: „A védöknek puskáik is voltak, amelyektöl sok török elesett." "1281

A forrás leírása tartogat számunkra néhány haditechnikai újdonságot. A szakállas puskák tulajdonképpen átmenetet képeznek az ágyúk és a későbbi puskák között. A szakirodalomban „kézi ágyúként” is emlegetik (hand-cannon). Tulajdonképpen ki voltak támasztva, nem kézzel kellett megtartani, ami pontosabb célzást tett lehetővé. A várfalra is helyezhették és a kilövéskor keletkező visszarúgó erőt a lövész teste nem tudta megtartani, egyedül a „szakáll” fogta fel. Emiatt nagyobb lőportöltetet használhattak és messzebbre lehetett lőni, mint a kisebb - szakáll nélküli - kézi puskákkal vagy az íjakkal, számszeríjakkal. A nagyobb tüzerővel könnyedén át lehetett a páncélt is lőni, holott a korabeli kézifegyverek erre képtelenek voltak. A kézi tüzfegyverek még a 16. században is gyengék voltak a jó minőségü páncélok ellen. Talán ez okozhatta, hogy az 1440. évi ostrom során a törökök mindenképpen közel merészkedtek a falakhoz, bízva e fegyverek gyengeségében és a hagyományos hidegfegyverek elhárításában.

A szakállas puskák ekkor újnak számítottak a korabeli hadászatban. Az anyaguk kezdetben bronz, később pedig vas volt. Az elnevezésüket a cső alatti „szakállról” (haken)

\footnotetext{
1279 Szabó 2010. 77.

1280 Szajkó 2005. 2.

${ }^{1281}$ Калић-Мијушковић 1967. 112.
} 
kapták. Korabeli német nevük: hakenbüsche. A francia harquebusche, az olasz archibugio, az arquebus is a német elnevezésből eredt. ${ }^{1282} \mathrm{Az}$ első példányok a 14. század végén jelentek meg. Ilyen a svédországi Mörkö mellett előkerült lelet. Egy hatszögletű bronzból készült cső, alul jellegzetes „,szakállal”, felül pedig egy Jézus-irányzék figurával. 1426-ból való a németországi Schleswig tartományból, a Vedelspang-kastélyból előkerült ötszögletü, vasból készített cső. Továbbá fennmaradtak a 14-15. század fordulójából eredeti fa ággyal és hosszú tussal készített példányai is, amelyekre maga a cső vaspántokkal volt felerősítve. ${ }^{1283} \mathrm{E}$ viszonylatban - véleményem szerint - Dukasz fenti leírása 1440-ből a szakállas puska közép-európai várostromban való alkalmazásának első említése. A szakállas puskákat később az oszmánok is használtak, sőt a magyar megnevezést átvették a nyelvükbe (şakaloz). ${ }^{1284}$ Említettük már, hogy Windecke szerint az 1424-ben, Budán járt, oszmán-török követ Zsigmondnak már török puskákat vitt ajándékul. ${ }^{1285}$ A szakállasok kiváló kutatója, Kelenik József szerint az átlagos kézi fegyvereknél jóval messzebre hordtak, rendkívüli tüzerővel rendelkeztek. Tömeges tüzelésük a gyalogsági rohamokat verte vissza, az ostrommunkálatokat akadályozta, a tüzéreket megzavarta. ${ }^{1286}$

A nyelük anyaga alapján vasnyelü és fanyelü szakállasok voltak, ez utóbbit a 16. században magyar nyelvterületen nyélbetütős, botos szakállasnak is nevezték. Egy vasnyelü szakállas, müködőképes replika példányt a 32. melléklet mutat. Ennek lőképességének bemutatása a Vásárhelyi Történelmi Kör V. Történettudományi Találkozóján megtörtént. A nyél helyett a tusás ágyazatú szakállasok a másik nagy csoportot alkották. ${ }^{1287}$

A dukaszi leírás a lövedékek szempontjából is újszerü. A bizánci szerző megemlíti, hogy 5 vagy 10, „pontoszi dió nagyságú ólomlövedékeket” lőtt ki. A lövedék nagyságának meghatározásához tisztázásra vár: $\mathrm{Mi}$ az a ,pontoszi dió”? Az idősebb Plinius: Természetrajz című munkájának XV. könyvében a dió több fajtájáról értekezik. Megemlíti, hogy a dióbél négy részre osztott a diók többségénél, míg másoknál egységes egész. Vagyis a rendszertanában a diók fajtáihoz sorolta a mogyorót is. A keresett faj a Pliniusnál szereplö abellai dió, amely valójában mogyoró, amelyet korábbi hazájáról mondanak csak

\footnotetext{
${ }^{1282}$ Kelenik József: Szakállas puskák a XVI. századi inventáriumokban (A terminológia problémái). Hadtörténeti Közlemények 1988/3. 486. A továbbiakban: Kelenik 1988.

${ }^{1283}$ William Reid: Tha lore of arms. Gothenburg. 1976. 58-59. A továbbiakban: Reid 1976.

1284 Ágoston 2005. 87.

${ }^{1285}$ Lásd a 2. 4. fejezetet.

${ }^{1286}$ Kelenik József: A kézi lőfegyverek jelentősége a hadügyi forradalom kibontakozásában. Hadtörténelmi Közlemények 1991/4. (december) 23. A továbbiakban: Kelenik 1991.

${ }^{1287}$ Kelenik 1988. 503-504.
} 
pontuszinak. Puha szakáll borítja, de a héj és a mag egy egészet alkot (15. 24. 88.). ${ }^{1288} \mathrm{Az}$ abellai mogyoróról már M. P. Cato is megemlékezett (X. 8. 2.; 18. 9). ${ }^{1289}$

A bizánci szöveg szerint ezeket a mogyorónyi lövedékeket egymás után egyenes sorban tölthették be a csőbe. A lőpor robbanóereje miatt a lőpor melletti golyó után a többi golyók egymást „,ökték ki”, mégpedig a mögötte levő az előzőt. E módszer a nem célzott lövésnél, föleg a várfalnál nagy tömeg ellen vívott közelharc visszaverésére kiválóan alkalmas lehetett. Hasonlatosan az ágyúk kartácstüzéhez. A lövés „,nagy terítése” miatt ez a használat a mai értelemben vett „sörét” elődjének tekinthető. ${ }^{1290}$ Dukasz kifejezetten említi az ilyen lövedékek okozta pusztítást az ostromlók között.

A lőszerek egyes fajtáinak korabeli magyarországi elterjedésében a városi számadáskönyvek nagy segítséget nyújtanak. Monografikus hadtörténeti munkájában Iványi Béla is elismerte, hogy a 15. század második felében a kő mellett már vas- és ólomgolyók is voltak. Az 1430-as, 1440-es években főleg a kőgolyók faragási díjait rögzítették, de az eperjesi számadáskönyv például Pozsonyban 1439-1440-ben ólomgolyókat említ, Dukasszal egybehangzóan. ${ }^{1291}$ De 1440-ben Pozsonyban kőből készített öntőformában ólomgolyók öntéséröl is tudunk. 1442-ben az eperjesiek „löfegyverekhez való sörétet” (,ad pixides wlgo schrote”) vásároltak. ${ }^{1292}$ 1443-ban pedig Szomolnokbányától szerezték be a lőporgyártáshoz szükséges salétromot és ként. ${ }^{1293}$ Ugyanehhez a bányavároshoz intézte parancsát Ulászló is 1440. június 17.-én. ${ }^{1294}$

Dukasz a gömbölyü alak mellett viszont leírja, hogy a lövedék lehetett hosszúkás alakúra kovácsolva, amely félelmetes röppályát és átütőerőt biztosított. Ezzel a páncélt is át tudták lőni. Ez pedig magyarországi viszonylatban, véleményem szerint, közép-európai várostromban, az első említése a kúpos, hegyes lövedéknek. ${ }^{1295}$ „Így jut el az erő a

${ }^{1288}$ C. Plinius Secundus: Naturalis historia. (Természetrajz XIV-XVIII) Fordította: Hoffmann Zsuzsanna, Szeged. 2009. 56. Itt köszönöm meg Dr. Hoffmann Zsuzsanna egyetemi docens segítségét. Az avellai/abellai mogyoró (Corylus avellana) valójában nem pontoszi eredetü, a jégkorszaktól kezdve egész Európában elterjedt vadmogyoró fajta volt. (Plinius 2009)

${ }^{1289}$ M. Portius Cato: A földmüvelésröl. Fordította: Kun József, Budapest 1966. 107. (Cato 1966)

${ }^{1290} \mathrm{Ez}$ a korai elv mindenképpen figyelemre méltó, mert ma is használatos például a 00 -ás vadász sörétben, ahol 3x3 golyó van egymásra rétegezve.

${ }^{1291}$ Iványi 1926. 274, 277.

1292 Iványi Béla: Adatok az eperjesi ágyúöntőház és puskapormalom középkori történetéhez. Hadtörténelmi Közlemények 1914. 318. A továbbiakban: Iványi 1914.

1293 Iványi Béla: Eperjes középkori ágyúöntő háza és puskapormalma. Hadtörténelmi Közlemények 1913. 120. Ugyanehhez a bányavároshoz szólt I. Ulászló segélykérő parancsa. Lásd a 7. 2. fejezetet.

${ }^{1294}$ Lásd a 7. 2. fejezetet.

1295 Grecu 1958. 265, 7-15. E szövegrészlet fordításai: Veszprémy 2008a 218; Szabó 2010. 78; Szabó 2012d

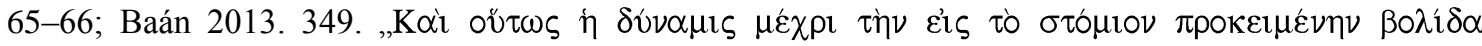

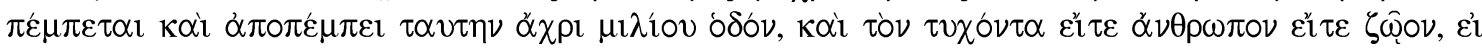

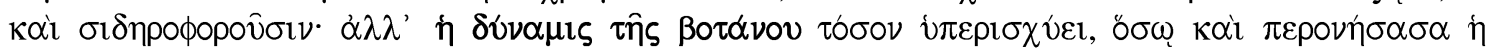

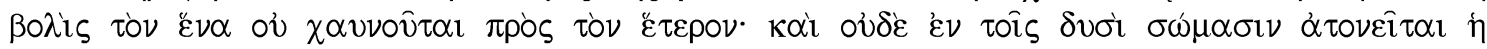


csőnyilásban levö lövedékig, és kilövi azt egészen egy mérföldnyi távolságra az ott lévö emberig vagy állatig, mégha páncélt viselnek is. Ám e »fü« ereje olyannyira nagy, hogy mégha a lövedék áthatol is valakin, nem gyengül el a másikig érve. Söt, nemcsak két testben nem merül ki az ereje - noha azok fegyvert viselnek és páncélozottak - hanem, amikor a golyó vasból vagy valamilyen más tömörített anyagból van, a kalapács pedig hosszúkás alakúra alakítja - mint egy hálószeg - áthatol az, mint egy tüz-folyó a testek legmélyéig is. "1296

A célzott lövéseik leadását pedig a tusás ágyazat tette lehetővé. Ehhez a korábbi, ún. nyélbeütős szakállasok alkalmatlanok voltak. ${ }^{1297}$ A vázlatrajz is ilyen formában ábrázolja a dukaszi szövegben szereplő fegyvert. A szakállas puska e funkciójában pedig a mesterlövész puskák elődjének is tekinthető. Nagy távolságból irányzott, nagy tüzerejü lövés leadására is alkalmas lehetett. A várostrom során mind a terítő, mind az irányzott lövésre való alkalmassága miatt egyaránt hasznosnak nyilvánulhatott a védők számára. Kelenik megállapítása szerint a szakállasok a mai elefántölő puskák torkolati energiájával rendelkeztek, a kilőtt vas és ólomgolyóik pajzsot, páncélt, csontot szétzúztak, egyszerre 23 embert is leterítettek. ${ }^{1298}$ A Dukasz-féle fegyverleírás tehát mindenképpen figyelemre méltó magyar hadtörténeti vonatkozásban.

Dukasz figyelemre méltó megnevezését a lőpor állagára a 10. 5. fejezetben már tárgyaltam. Nándorfehérvár 1440-ben, az ostrom idején a lőporral való ellátottságban is jól állhatott. A végvárak tüzérségi anyaggal, lőporral való ellátása elvileg a király feladata volt. Lőporhiány esetén gyakran a várak egymástól kölcsönöztek vagy erőszakkal vettek el. Iványi megállapítása szerint ugyanakkor a középkori Magyarországon a löporkészlet csak kevés várban volt a lőfegyverállománnyal megfelelő arányban. ${ }^{1299} \mathrm{Mi}$ ide soroljuk Nándorfehérvárt is. Lőporhiányról nem írnak forrásaink, sőt a latin nyelvü lengyel forrásainkban (Dlugos, Callimachus) láthattuk, hogy a védők a puskaport szórták a törökök által a várárokba dobott fahasábokra, hogy azokat meggyújtsák. Az aknakészítést említő forrásaink pedig megemlékeznek arról, hogy a török akna berobbantását szintén

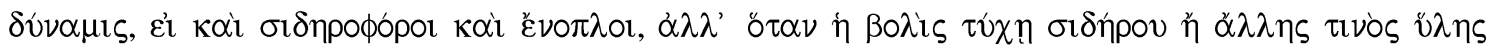

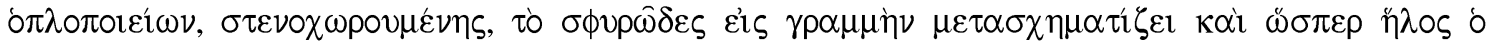

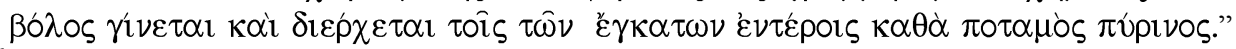

${ }^{1296}$ A szerző szóhasználata utalhat az Alvilágban folyó Phlegethón-folyóra.

${ }^{1297}$ Kelenik 1991. 23, 29. A tusás szakállasok a 16. század utolsó harmadára teljesen kiszorították a nyélbeütős szakállasokat.

${ }^{1298}$ Kelenik 1991. 45.

${ }^{1299}$ Iványi 1926. 273. 
puskaporral végezték el. A salétrom előállítását pedig - Bonfini leírása szerint - egy sajátos módszerrel is biztosították. Ez mindenképpen a várvédő Tallóciaknak köszönhető.

Ezzel még korántsem fejezhetjük be a Tallóciak magyarországi haditechnikai érdemeit. Szeretném kiemelni egy másik újnak számító tüzfegyver korai alkalmazását: a bombavető mozsarakét, amelynek rajzát Dani Dániel Pál készítette el és az alábbiakban közöljük (33. melléklet).

A mozsár - ellentétben a tarackkal és az ágyúval - meredek röppályán (magas szögcsoportban) rövid és nagy kaliberü csövön át robbanólövedék (bomba) kilövésére is alkalmas. Ebben van a hatékonysága is, ugyanis itt a rombolást nem a lövedék átütőereje, hanem a kilőtt bomba robbanása okozta. Közelről, magas várfalakra mintegy „ráejtve” fejtette ki hatását. A pontos célzáshoz a megfelelő csőbeállítást általában szögmérővel végezték el, befüggőzték. Mivel a cső a faágyra szorosan rá volt illesztve, a faágyat is alá kellett dúcolni. A mozsár kezelése viszont nagy szakértelmet és gyakorlottságot követelt meg, hiszen kettős időzítéstől függött. Meg kellett gyújtani elöször a csőbe behelyezett lövedék kanócát. E bombákba a robbanóanyagot többnyire ólomdugóval zárták és a belőle kivezetett gyújtózsinórt a kellő időben kellett meggyújtani, a lövés távolságától és magasságától függően. Az ilyen bomba akkor fejtette ki legnagyobb pusztítást, ha nem a felszínre érve, hanem még közvetlenül elötte robbant fel. Végül a mozsár hátulsó részét, a lőporkamrát kellett begyújtani. A mozsarak kezelésénél csak az elkészítése volt nehezebb, amely alapvetően a hordóépítés technikáját követte. ${ }^{1300}$

Az 1437. szeptember 27-i adományozó oklevél szerint már Galambóc 1428. évi magyar ostromakor bombavető mozsarakat használtak a Tallóciak. ${ }^{1301}$ Galambóc földrajzi elhelyezkedését látva érthető, hogy a meredek várfalak ellen a nagy átütőerejü, de alacsonyabb és hosszabb röppályájú (alacsony szögcsoportú) lövésre képes ágyúk vagy a fából készült kőhajítógépek nem megfelelőek. Azt is megállapíthatjuk - Dukasz a nándorfehérvári, valamint Khalkokondülész az 1422-es konstantinápolyi és az 1439-es szendrői ostromról szóló beszámolóiból következtetve -, hogy Murád szultán hasonló problémával küszködhetett Nándorfehérvár 1440. évi ostroma során is. Az oszmánok bombavető mozsarakat először csak Konstantinápoly 1453-es ostromában használtak. ${ }^{1302}$

\footnotetext{
${ }^{1300} \mathrm{Az}$ öntöttvas lőporkamrára kovácsoltvas dongákat kovácshegesztés útján rögzítettek. Ezt követően a felmelegített kovácsoltvas abroncsokkal szorosan egymás mellé illesztve felgyürüzték a csövet a lőporkamrával együtt (Dani Dániel Pál szóbeli közlése). Az ilyen ,hoop and stave” típusú cső készítésére lásd még: Norris 2003. 36-37.

${ }^{1301}$ Lásd: az 5. 1. fejezetet.

1302 Ágoston 2005. 68.
} 
1428-ban Tallóci Matkó „a kövek lövedékeinek sokaságával, a bombavető mozsarakkal lövést lövésekkel folytatva hevesen végezte az ostromot.” Azt is tudjuk róla, hogy 1436-ban a dalmáciai Szinj várának ostromakor szintén így volt eredményes. ${ }^{1303}$

A bombavető mozsarak közép-európai alkalmazásában ez az időpont az elsők között szerepel. Tudunk híres ausztriai mozsárról az 1425 körüli időkből, amely 34,6 hüvelyk (88 cm) kaliberü, 1,44 m hosszú és súlya 9,8 tonna, amellyel 690 kg súlyú kőgolyót lőhettek ki (Der Grosse Pumbard von Steyr). ${ }^{1304}$ 1409-ben, Marienburgban a Német Lovagrend ágyúöntödéjében készített mozsár (Faule Grete) csőhossza $150 \mathrm{~cm}$, súlya 4,6 tonna. ${ }^{1305}$ A francia Musée de l'Armée őriz 1450-ből egy 82 cm-es mozsarat.

Mi pedig vegyük ezekhez hozzá Bertrandon de la Brocquière lovag tudósítását a Nándorfehérváron látott három bronzágyú közül különösen az egyikről: „,...melyek egyike oly óriási volt, minöt még soha sem láttam, csövének belseje ugyanis 42 hüvelyk széles

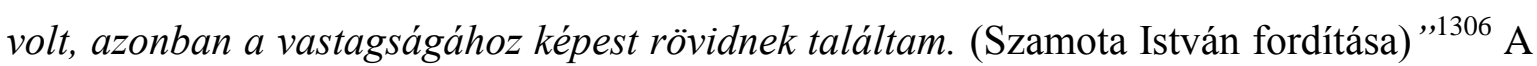
hüvelyk fajtájától függően ez $84-130 \mathrm{~cm}$-es csőátmérőt jelentett. ${ }^{1307}$ Hogy ez mennyire korszerü technikát jelentett, azt jól mutatja, hogy még a sokat látott burgundiai lovag számára is hihetetlennek és újnak számított. Megállapításunk szerint ez egy bombavető mozsár volt, amelyet Nándorfehérvárott tartottak. Ha felidézzük a perhalasztó oklevelek rövid tudósításait a Nándorfehérvárba irányuló 1435. évi fegyverszállításról, feltűnő a vízi út használata. Ezek a mozsarak is ugyanis olyan óriási súlyúak voltak, hogy szárazföldön nemigen lehetett szállítani. Erre a legalkalmasabb a Dunán a Pozsony-BudaNándorfehérvár hajóút használata, amelyet Hunyadi János 1448-ban is használt. ${ }^{1308}$

Brocquière megjegyzi, hogy a Nándorfehérváron látott 3 bronzágyú közül kettő két darabból állt. ${ }^{1309}$ Az ágyúk is általában két - esetenként összeszerelhető - részből álltak, a csőből és a lőporkamrából. Még az óriás ostromágyúk is szétszerelhetők voltak, ez Orbán mester technológiai újítása, amelyet Kritobulosz leírása is megerősít (I. 30. 1.). ${ }^{1310} \mathrm{Ha}$ a

\footnotetext{
${ }^{1303}$ Lásd az 5. 3. fejezetet.

${ }^{1304}$ Reid 1976. 113,

1305 Ágoston adata ettől eltér: 1411-ből való, a súlya 8, 2 tonna, a cső hossza $290 \mathrm{~cm}$, a csőátmérő $76 \mathrm{~cm}$, a kilőtt golyó súlya $409 \mathrm{~kg}$. Ágoston 2005. 65.

${ }^{1306}$ Szamota 1891. 80; hibásan idézi Rázsó Gyula 32 hüvelyk szélességet említve (Rázsó Gyula: A lovagkor csatái. Budapest 1987. 185-186); Cseh 2007. 67.

13071 hüvelyk=2,0-3,1 cm. 1 királyi hüvelyk 2,6 cm. Általában 2,54 cm. Megjegyzendő, hogy éppen Zsigmond király volt az, aki az 1405. évi városi dekrétumában (1. capitulum) egységesítette a mértékrendszereket, a budait téve meg országosnak. Bogdán 1987. 55.

${ }^{1308}$ Iványi 1926. 135.

${ }^{1309}$ Idézi: Cseh 2007. 67. Viszont ez a részlet Szamota kiadásában nem található. Szamota 1891. 80.

${ }^{1310}$ Idézi: Philippides-Hanak 2011. 414.
} 
Cseh Valentin által idézett Brocquière-szövegrészletnek hitelt adhatunk, Nándorfehérváron léteztek leszerelhető lőporkamrás nehézágyúk.

Az ágyú elsősorban, mint várvívó fegyver, támadófegyverként vált be, de a védelem is alkalmazhatta az ostromműveletek állandó megzavarására. ${ }^{1311}$ 1440-ben mind a támadó, ostromló, mind a védő tüzérség egyaránt alkalmazta. Azt is megemlíthetjük, hogy az a forrásainkban gyakran szereplő epizód, amikor a védők kirohanásokat intéztek a támadók ellen, az ostromló tüzérség ellen is irányulhatott, akár a tüzérszemélyzet megölésére, akár az ostromgépek és ágyúk tönkretételére, ahogyan az később, 1456-ban, a második szultáni ostrom alkalmával történt.

Összegezve megállapíthatjuk, hogy mind 1428-ban Galambóc magyar, mind az 1440ben Nándorfehérvár török ostromakor a Tallóciak korszerü tűzfegyvereket használtak. Mivel a Tallóci-család raguzai kapcsolatai révén nemzetközi déli kereskedelem fontos szereplője volt a térségben, a Magyar Királyságba importálhatták ezeket a fegyvereket is. Mindkét ostromban tanúsított magatartásuk egyúttal megmutatta a tüzérségben és az ostromtechnikában való jártasságukat, szakértelmüket is.

${ }^{1311}$ Iványi 1926. 408. 
„Néktök emléközöm - ha meghallgatjátok - jó Hunyadi Jánosról, nagy jámborságárúl, hív szolgálatjáról, erös viadaljáról, az ö idejében két László királyról, Amurátes császárról, Nándorfejírvárrúl, Jankula vajdának utólszor haláláról."

(Nagybáncsai Mátyás, 1560)

\section{Vég nélkül... a végeken: a Tallóciak és a Hunyadiak}

Az 1456. évi nándorfehérvári diadallal összehasonlítva szembetűnő, hogy az 1440. évi ostrom során a védőknek sokkal hosszabb ideig - hat-hét hónapig! - kellett szembenézni a szultáni sereg túlerejével és külső katonai segítséget sem várhattak. A védők és a Tallóciak helytállásának e tekintetben az őket megillető helyre kellene kerülniük a hazai történetírásunkban.

Az eseményekből az is látszik, hogy maguk a kortársak sem fordítottak kellő figyelmet a déli végvár sikeres megvédésére, a polgárháborús események kötötték le erejüket. Nemzetközi visszhangot, elsősorban a Pápaság figyelmét sem keltette fel, hiszen nem is szerveztek keresztes sereget, a két egyház uniója lett a fontosabb probléma.

A tények alapján továbbá azt gondolhatnánk, hogy Nándorfehérvár sikeres megvédéséért hálátlan volt az uralkodó. 1441-ben ugyanis Tallóci Jovánt leváltották és Hunyadi Jánost nevezték ki erdélyi vajdává, temesi ispánná és nándorfehérvári kapitánnyá. A vár kapitányságát Hunyadi 1441 júniusában vette át. ${ }^{1312}$ Mintegy generáció-váltásként Hunyadi ekkoriban emelkedett fel az országos politika szintjére. Hunyadi már korábbról ismerte a Tallóciakat és Nándorfehérvárt. Legutóbb, Engel Pál is rekonstruálta a „pályakezdés éveit.” Hunyadi Csáki György székely ispán familiárisa, 1426-ban Lazarević Istvánhoz került apródként. ${ }^{1313}$ Ekkor ismerhette meg igazán Nándorfehérvárt. A despota halála után a Tallóciakkal való kapcsolata is megkezdődött. Az akkori szörényi bán, Tallóci Frank szolgálatába állhatott.

Habsburg Albert király 1439-ben a két Hunyadit nevezte ki szörényi bánná Tallóci Frank helyére. Önmagától adódik a történelmi regényírók által is felvetett izgalmas kérdés: részt vett-e valamelyik Hunyadi az 1440-es nándorfehérvári ostromban? A Hunyadiak mert Hunyadi János testvérét, az ifjabb Jánost is meg kell említenünk-1439. és 1440. évi

\footnotetext{
1312 Mályusz 2003. 160; Pálosfalvi 2005. 68.

1313 Teke 1980. 85.
} 
tevékenységére vonatkozóan három oklevél ad választ. Az egyébként ismert okleveleknek ebben a kontextusban különösen megnő a hírértékük.

Albert király 1439. május 9-én, Pozsonyban - Hédervári Lörinc nádor által - kelt királyi oklevele, amelyből azt tudjuk meg, hogy ekkoriban Hunyadi az ifjabb Jánossal a Nándorfehérvártól keletebbre lévő végvonal várainak - Szörény, Győrény, Orsova és Miháld (Zewrin, Gewryn, Orswa, et Myhald) - korszerüsítésével, megőrzésével (conservatio) voltak elfoglalva. A feladatukból adódó költségek fedezésére pedig „,mindkét Hunyadi Oláh Jánosnak" (utriusque Johannis Olah de Hunyad) a király zálogba adta Szabadka, Madaras, Tavankút, Halas mezővárosokat és a Bodrog vármegyében lévő Csőszapa birtokának felét „ugyanezen váraink megvédésére” (pro eorundem Castrorum nostrorum conservatione). ${ }^{1314}$

Albert király szeptember 27-én, Futakon kiadott okleveléből pedig megtudjuk, hogy mindkét Hunyadi János szörényi bánok magukra vállalták Szörény, Győrén, Orsova, Miháld és Pecs ${ }^{1315}$ határmenti, a Dunán inneni királyi várak védelmét, amelyek eddig is az ő kezükön voltak, de a király nevében most további 3 hónapra megörzik és gondozzák. Továbbá, az ellenséggel szemben 200 lovas katonát tartanak fegyverben "in campis.” E feladatok biztosítására a király lekötötte számukra zálogképpen az egész temes megyei Ikws kerületet Morsina városával és minden a kerülethez tartozó faluval és jövedelemmel együtt. ${ }^{1316}$ Ez az adat azt bizonyítja, hogy a Hunyadi-testvérek az 1439. év végéig is távol voltak Nándorfehérvártól, más várakat kellett védelmezniük.

I. Ulászló pedig 1440. augusztus 9-én, Pozsonyban királyi birtokadománnyal megjutalmazta „mindkét Hunyadi Jánost, Wajk fiait” (utriusque Joannis filiorum Wayk de Hunyad), szörényi bánokat az addigiakban a török ellen tanúsított hadi érdemeikért. Azonban a király ezek közül a Csáki László erdélyi vajdával együtt a „Hegyeken túli részeken" (in partibus Transalpinis contra et aduersus perfidissimos Turcos) folytatott törökök elleni harcokat emeli ki. Továbbá azért, mert „mindkét János a Dunán inneni várainkat, amelyek a mi Alsó Részeink végvonalában vannak, különösen Orsovát, Szörényt, Miháldot és Györént és más ezekkel szomszédos erödöket megtartják és

\footnotetext{
1314 Iványi István: Szabadka szabad királyi város története. II. rész. Szabadka, 1892. 4-5. (2. sz. oklevél). (Iványi 1892) Itt köszönöm meg Szabó Józsefnek (Bajmok, Vajdaság) a segítségét.

1315 Zewren, Gewren, Orswa, Myhald, Peech

${ }^{1316}$ DL 13439.
} 
kormányozzák". ${ }^{1317}$ A király pedig új adomány jogcímén nekik adományozza az addig Erdélyhez tartozó Solymos, Berekszó, Nyavalyás ${ }^{1318}$ és Burján településeket. ${ }^{1319}$

Így nem valószínű, hogy feladatukból adódóan Nándorfehérvár 1440. évi ostromakor ők is jelen lettek volna. A forrásaink nem tesznek erről említést. Egyedüli lehetőségként az marad számunkra meg, hogy a portyázó török seregrészek talán érinthették a felügyeletük alá tartozó várak körzetét is. Hiszen Dlugos szerint Erdélyből is számtalan rabszolgát szedtek.

Az idős Tallócival mégis igazi barátságba került az ifjú Hunyadi. Bonfini említést tesz egy bizonyos Csanádi Ferencről, akiről Engel Pál derítette ki, hogy nem más volt, mint Tallóci Frank. Bonfini leírja, hogy Tallóci („Csanádi”) annyira megkedvelte, hogy öt fiaként tartotta, Hunyadi (Corvinus János) nála kezdte az újonc éveit. Sőt Hunyadi később, már kormányzóként, továbbra is tisztelte Tallócit. Amikor ő belépett a tanácsterembe, mindig felállt előtte vagy előre engedte. Így tisztelgett, és megvárta, amíg leült, utána foglalt helyet (3. 9. 195-200.). Mályusz Elemér szerint Tallóci Frank megérezte, hogy Hunyadi lesz az ifjú és méltó utóda a déli végeken. Azt mondhatjuk, hogy a király őt nem leváltotta, hanem felváltotta Hunyadival és Tallóci a korban szokatlan módon visszalépett a javára. $^{1320}$

A Tallóciak a házasságuk révén illeszkedtek be a magyar főurak közé, a hatalmuk azonban csak a királyi hatalmon alapult, ezért volt törékeny. Bár különböző jogcímeken, de csupán honor-birtokként tartották kezükben a várakat, és nem magánbirokként, mint a bárók. Így a mindenkori királyi hatalom függvénye volt e várláncolat kézben tartása. ${ }^{1321}$

A Tallóciak 1440 utáni sorsa kevésbé ismert. Tudjuk, hogy 1441-1443 között Tallóci Frank török fogságba esett, ahonnan 1444 januárjában szabadult ki. ${ }^{1322}$ A Hunyadival való barátsága továbbra is megmaradt. Kiszabadulása után ott volt az 1444-ben II. Murád ellen vívott várnai csatában. Részt vett Hunyadi újabb hadjáratában, és Thuróczy beszámolója

1317 Teleki 1853. 89-90. (39. sz. oklevél). A továbbiakban Teleki 1853. „vterque Johannes castra nostra cis decursum Danubij, in confinijs parcium nostrarum inferiorum situata, presertim Orsauam, Zewryniem Myhald et Gyewren, aliaque fortalicia hys propinqua tenentes et gubernantes..."

1318 „Nawalyas”. Nyavajásfalva, a mai Lunca Erdélyben. A falut ez az oklevél említi először.

1319 Teleki 1853. 89-90. (39. sz. oklevél). „vterque Johannes castra nostra cis decursum Danubij, in confinijs parcium nostrarum inferiorum situata, presertim Orsauam, Zewryniem Myhald et Gyewren, aliaque fortalicia hys propinqua tenentes et gubernantes..."

1320 C. Tóth Norbert: Mesélő krónikák, 149. rész (2004. február 17-i adás, MR1 Kossuth Rádió) (C. Tóth 2004). Ahogyan Tallóciak a szörényi bánságról is lemondtak a javukra. Szakály 1990. 37.

${ }^{1321}$ Mályusz 2003. 157.

${ }^{1322}$ Mályusz 2003. 162. 
szerint 1448-ban, a második rigómezei csatában halt meg (241. fejezet). ${ }^{1323}$ Petkó megtartotta haláláig a horvát-dalmát bánságot (1453). Matkó, aki a család támasza volt, folytatva a Cillei Ulrik déli terjeszkedésével a harcot a szlavón bánságért, 1445-ben halt meg. A szlavón bánság így visszatért a Cillei-családhoz. ${ }^{1324}$ Sőt, a rivális Cilleiek azonnal rátették a kezüket az uralma alatt lévő várakra. ${ }^{1325}$

A várvédő Tallóci Jován sorsáról még kevesebb ismeretünk van, őt 1441 júniusában Hunyadi János követte a kapitányságban. 1442. december 10-án már Laak-i Crepiolus-t találjuk, mint nándorfehérvári kapitányt, aki az aradi ispánnak ajánlja Dóczi Mihályt. ${ }^{1326}$ Azt tudjuk, hogy Jován 1444-ben kérte a pápától a hivatalos kinevezését a vránai perjelségbe. Végül Pekrec várának védelmében esett el, midőn már Szlavónia Cillei Ulrik kezébe került. ${ }^{1327}$

${ }^{1323}$ Mályusz 2003. 162; Mályusz 1984. 132. Thuróczy beszámolója ellenére Teke Zsuzsa a várnai csata áldozatai közé sorolta. Teke 1980. 138.

${ }^{1324}$ Pálóci László országbíró 1450. március 9.-i oklevelében Matkó halálát említi DL 67 434, Teke 1980. 161.

${ }^{1325}$ Neumann Tibor: A Korlátköviek. Egy elökelő család története és politikai szereplése a 15-16. században. Györ 2007. 27 (Neumann 2007); Pálosfalvi 2000. 82-84.

${ }^{1326}$ DL 55267

${ }^{1327}$ Mályusz 2003. 161-162; Mályusz 1984. 132. 
„Mikor látta volna Amurátes császár népének veszedelmét, bánat és félelem, csuda nagy rettegés foglalá császár szivét, szégyenvallására megtérité azért esmét földébe népét,

kiért Fejirvárban oly igen dicsérék az Úristennek nevét."

(Nagybáncsai Mátyás, 1560)

\section{2. „eltekintve Belgrád 1440. évi sikertelen ostromától”? -Az ostrom elhelyezése a magyar hadtörténetben}

Az 1440. évi ostrom súlyát, szerepét értékelve nem mindegy, hogy azt a Magyar Királyság vagy az Oszmán Birodalom szempontjából vizsgáljuk. A magyarországi oszmán-török hódítás menetét, módszerét 1973-ban Rázsó Gyula - İnalcık nyomán - négy szakaszra bontva tárgyalta. İnalc1k 1954-es tanulmánya - I. Bayezid politikájából kiindulva eredetileg két fázist tartalmazott. Az első eszerint a szomszédos államok feletti szuverenitás birtoklásával, a második szakasz pedig a közvetlen irányítással, a helyi dinasztiák eltávolításával jellemezhető. ${ }^{1328}$

Rázsó ebből kiindulva alkotta meg a szakaszait. Számunkra az első két szakasz bír fontossággal. Az első szakasz a határvidékeken török portyázók támadásával, állandó betörésekkel indult. Nálunk ez a szakasz az 1390-es évektől egészen 1526-ig húzható meg, de Szerbiában már az 1360-as évektől kezdődött el. Ezzel párhuzamosan már elkülöníthető egy második szakasz is, amelyben pedig reguláris török hadseregek hódítási kísérleteivel kell számolnunk. Rázsó ide sorolta az 1456. évi és az 1526. évi szultáni támadást, de 1440et nem említette. ${ }^{1329}$

Az általunk tárgyalt események e két szakaszba nehezen illeszthetők bele. Már Perjés Géza - a híres szülejmáni ajánlat vitapartnereként, a mohácsi csata kapcsán - kifogásolta a szakaszos hódítás elméletének teljes alkalmazhatóságát. „...sem Bulgária, sem pedig Szerbia esetében nem mutatható ki a hóditásnak ez a négy fázisa." ${ }^{1330}$ Míg Szerbia déli részeit azonnal bekebelezte, a kosovói győzelme után az északi rész, Lazarević Szerbiája „csak” vazallussá vált. A magunk részéröl az 1438., 1439. és az 1440. évi hadjáratokat nem tudjuk az első szakasz „csupán” határmenti pusztításainak tekinteni, mert ezek mindössze a helyszínük alapján határmentiek, de szultáni vezetésű, reguláris hadjáratokként indultak az ország megdöntésére vagy legalább is annak előkészítésére. II. Murád ezen szándékát jelzi az 1440. évi hadjárat külpolitikai-diplomáciai előkészítése is,

\footnotetext{
1328 İnalc1k 1954. 103.

${ }^{1329}$ Rázsó 1973. 413.

${ }^{1330}$ Perjés 1979. 129.
} 
amely nemcsak a Lengyel Királysággal való szövetségkötést - Magyarország ellenében hanem az egyiptomi Mameluk Szultánsággal - az iszlám védelmében való - katonai koordinációt is magában foglalta, éberen figyelve a firenzei zsinat az oszmánok ellen létrehozandó keresztény összefogásra való felhívását és Bizánc álláspontját. Clausewitz-zel szólva ezek nem „korlátozott célú”, hanem az ellenség teljes legyőzésének szándékával indított, „megsemmisítő” háborúk, szultáni hadjáratok voltak. Nem árt azt is figyelembe venni, hogy portyázó sereget nem a szultán szokott vezetni. Az, hogy a törököknek ekkor a teljes hódítás már a szándékukban állt, jól mutatja, hogy már I. Bayezid szultán is tervbe vette és vezetett hadjárato(ka)t a Magyar Királyság ellen és csak a keleti külpolitikai helyzet szerencsétlen alakulása térítette el szándékának megvalósításáról. ${ }^{1331}$

$\mathrm{Az}$ Oszmán Birodalom szemszögéből nézve nagyobb időtartamú léptékeket kell használnunk. Perjés Géza az 1356-1699 közötti európai török háborúk időszakát osztotta fel szakaszokra. Az első periódust 1356-1453 között különítette el, Konstantinápoly oszmán elfoglalásáig. Perjés szerint ekkor az oszmán hódítás üteme felgyorsult. Ebben a szakaszban megemlítette Nándorfehérvár 1440-es oszmán ostromát, de érezhetően kivétel(es)nek tartotta, amely nem illik bele az általános jellemzőkbe. „Megalapozatlan vállalkozásokba nem fogtak és a zsákmányszerzést és felderitést szolgáló portyázásokon kívül nagyobb szabású hadjáratokba nem kezdtek, eltekintve Belgrád 1440. évi sikertelen ostromától."1332 Kétségtelenül érdekes megfogalmazású mondat, amely látszólag mindent tartalmaz, de a negatív elemeket jobban hangsúlyozza, és amelyben az 1440-es ostrom csupán be nem illeszthető kivételnek mutatkozott.

Az oszmanisták figyelmét sem keltette fel. Fodor Pál legutóbbi nagyívü áttekintésében az ostrom elhelyezése nem szerepel. ${ }^{1333}$ Papp Sándor a diplomácia- és kapcsolattörténet szempontjából vizsgálta az egész időszakot. ${ }^{1334}$ Szakály Ferenc a hadtörténész szempontjából szisztematikusan tekintette át a török-magyar küzdelem Mohács előtti időszakát. ${ }^{1335}$ Alapmegállapítása akár 1440 máig hiányzó kutatástörténetét is megmagyarázza: „A részletekig hatoló kutatás nálunk mindig is néhány csomópontra föként Hunyadi János és Mátyás háborúira, Magyarország bukására- összpontosult."1336

\footnotetext{
${ }^{1331}$ Lásd a 13. 2. fejezetet.

1332 Perjés Géza: Az oszmán birodalom európai háborúinak katonai kérdései (1356-1699). Hadtörténelmi Közlemények 1967. 353. (Perjés 1967)

${ }^{1333}$ Fodor Pál: A szimurg és a sárkány: Az Oszmán Birodalom és Magyarország (1390-1533). In.: KözépEurópa harca a török ellen a 16. század első felében. (szerk.: Zombori István) Budapest 2004. 9-35. (Fodor 2004)

${ }^{1334}$ Papp 2004. 37-90.

1335 Szakály 1986. Ugyanez korábban: Szakály 1979. 65-111

${ }^{1336}$ Szakály 1986. 11.
} 
Szakály már felismerte és elkülönítette az 1438-1442 évek szakaszát, amelyben „minden korábbinál erősebb és koncentráltabb török támadássorozat kezdődött." II. Murád erdélyi hadjárata, Szendrő elfoglalása után Nándorfehérvár ostromát is ide sorolta, de kellő súllyal ő sem értékelte, inkább a déli vármegyék elnéptelenedését emelte ki. „Bár a három hónapos ostrom (sic!) sikertelenül végzödött, s a szultán elfogadta I. Ulászló békeajánlatát, az 1440-es hadjárat betetözte a Délvidék pusztulását."

A történészek, oszmanisták eddigi értékelése átfogó és nagy időszakokat vett alapjául, ahhoz viszont, hogy „finomítani” tudjunk rajta, részletesen fel kellett térképeznünk a korábbi török-magyar hadieseményeket, de az 1440. évi ostrom szempontjából. Később kutatásaim során - időben még elörébb kellett kitekintésem folytatni, egészen I. Bayezid szultán hódítási kísérletéig. Hiszen egy İnalcık által felfedezett dokumentum jól mutatja, hogy még II. Mehmed szultán idejében is nyilván tartották Bayezid Magyar Királyság elleni támadását. ${ }^{1337}$

Nándorfehérvár 1440. évi szultáni ostromát elhelyezve a magyar és európai események sorában, munkánkat összegezve megállapíthatjuk, hogy magyar részröl a török-magyar küzdelemben az 1389-től kezdődően alapvetően védekező török elleni stratégiát 1440-től felváltotta egy támadó szakasz a város második török ostromáig, 1456-ig. ${ }^{1338}$

Ebben az ún. védekező szakaszban egy 1428-tól kezdődő alperiódust különítek el, amely Galambóc magyar ostromától indult. Tulajdonképpen ezt egy ún. Tallóciszakasznak tekintem, mert a határvédelem egyre inkább a Tallóci testvérek kezében összpontosult. Az oszmán vezetésben a konzervatív politikát követő Halil Csandarli nagyvezírsége (1429-1453) alapvetően a békét szorgalmazta. Míg 1438 körül a szultán környezetében befolyást szerző csoport révén kiújulnak az ország ellen indított támadások. Ez a tendencia a fokozatos határmenti török betörések után II. Murád szultán Magyarország ellen személyesen - a nagyvezír távollétével - vezetett hadjárataiban éri el tetőpontját $(1438,1439,1440)$. A hadmüveletekben a kulcsfontosságú várak elfoglalása volt a kitüzött cél. Tegyük hozzá, nemcsak a magyar hadszíntéren. Ezt mutatta a velenceibizánci „fronton” Thesszaloniki elhúzódó ostroma és elfoglalása (1430). A balkáni szerbmagyar hadszíntéren szultáni célponttá fokozatosan ekkor válik Szendrő, azután Nándorfehérvár, egyre fokozódó török betörésekkel.

\footnotetext{
${ }^{1337}$ Lásd a teljes 6. és a 13. 2. fejezeteket.

${ }^{1338}$ Figyelemre méltó, hogy Engel Pál és Szakály Ferenc is a Magyarok Európában I-II. című szintéziseikben 1440-nél húzták meg a határt. Engel 1990; Szakály 1990.
} 
A belháború végén, magyar részről, 1441-től egy offenzív szakasz, egy ún. Hunyadiszakasz vette kezdetét, amelynek során - Zsigmond király módszerét folytatva - ismét támadó hadműveletekre került sor a Balkánon. Ide sorolható Hunyadi 1443-44-es téli hadjárata, az 1444-es várnai csata, 1448-as második rigómezei ütközet és az 1454-es hadjárat. ${ }^{1339}$ Ha a mezei ütközetekben győzelmeket is aratott, de az erős várakkal II. Murád továbbra sem boldogult, amelyet az albániai Kruja 1450-es ostromkísérlete jól példázott.

Az 1440. évi ostrom oszmán-török oldalról is ezt az alperiódust, a Tallóci-szakaszt zárta le. Egyetértve John Jefferson megállapításával, ez volt az utolsó Magyarország elleni szultáni hadjárat, amelyet II. Murád személyesen vezetett. ${ }^{1340}$ Összességében Murád támadó politikájának részbeni kudarcai (Konstantinápoly, Nándorfehérvár, valamint az albániai sikertelen várostromok) igazolták Halil Csandarli nagyvezír békepolitikájának helyességét. A pozíciója akkor ingott meg, amikor a második rigómezei csatában Hunyadi János vereséget szenvedett, nem tudta Szkander béget megsegíteni és megjelent a legerösebb a vár (Konstantinápoly) elfoglalására is alkalmas nehéztüzérség, ami lendületet adott Mehmed szultán támadó politikájának.

A saját korában Nándorfehérvár 1440. évi ostromának sikere serkentőleg hathatott volna egy egységesnek szánt európai törökellenes fellépéssorozatra is. Ebben IV. Jenö pápa Albert királyban látta a lehetséges erőt. Albert halála után ez későbbre tolódott. Itt elősorban a keresztes háborúk szervezését vagy támogatását emeljük ki (1443-44, 1456). Továbbá I. Ulászló magyar királyságával a lengyel érdeklődés is megnőtt e térségben, a lengyel külpolitikában Kis-Lengyelország nemességének elsődlegesen törökellenes álláspontja lett egy ideig domináns, hiszen a lengyel-magyar király könnyebben harcolhatott magyar földön a török ellen, mint a sajátján. ${ }^{1341}$

Azt is meg kell említeni, hogy ennek az aktív balkáni katonai tevékenységnek nem csupán törökellenes éle volt. A hadjáratok irányát figyelembe véve ezek részét képezték az oszmánoktól szorongatott Bizánc megsegítésének, egészen Konstantinápoly 1453-ban bekövetkezett oszmán elfoglalásáig. ${ }^{1342}$

Ha 1521-ról szólva általában kiemelik azt a tényt, hogy az 1456-os nándorfehérvári diadal hatvanöt évvel akadályozta meg az ország déli végvárának elfoglalását, tegyük

\footnotetext{
1339 Teke 1980. 198. Gyula Rázsó: Hungarian strategy against the Ottomans (1365-1526). 230. In.: Ch. Oman: The art of war in the Middle Ages. New York 1953. (Rázsó 1953)

1340 Jefferson 2012. 246.

1341 Jakub I. Grygiel: Great powers and geopolitical change. 2006. The geostrategy of the Ottoman Empire (1300-1699) 105. (Grygiel 2006)

1342 Kapitánffy 2003. 99-119.
} 
hozzá: 1456-nak az előzménye 1440 volt és a vár az 1440-es, első sikeres ellenállásától számítva, összességében nyolcvanegy évig tartóztatta fel az oszmán-törökök hódítását. 


\section{Kitekintés}

\section{1. Nándorfehérvár megnevezésének egy földrajzi-topográfiai problémája (a Taurinum-kérdés)}

Belgrád birtoklásáért évszázadokon át a magyar-bizánci-bolgár-szerb és oszmán kapcsolatok szövevényes nyomai húzódnak meg, amelyet jól mutat a vár(os) többféle elnevezése. Nem célunk a város névetimológiájának bemutatása, de röviden át kell tekintenünk Nándorfehérvár különböző megnevezéseit.

A kelta eredetü, római kori Singidunum nevet kivéve, valamennyi név jelentése: fehér vár. Ami másoknak Belgrád, nekünk Nándorfehérvár. Amennyiben elfogadjuk, hogy a (dunai) bolgárok neve nándor volt ${ }^{1343}$ az Árpád-korban, akkor ezt őrzi a „Bolgárfehérvár” (Alba Bulgarica) név. ${ }^{1344}$ Anonymus Gesta Hungarorumában is a „Bolgárfehérvár” elnevezés szerepel $\left(39,41\right.$. capitulum). ${ }^{1345}$ Azonban Nándorfehérvárott a 11. században voltak ún. izmaeliták is. E „magyarországi böszörmények az izmaelita, másként siíta felekezet hívei voltak”. Karácsonyi János szerint káliz-török nemzetiségüek voltak, akiket a várat ekkoriban birtokló bizánci császárok ${ }^{1346}$ Nándorfehérvár környékére telepítettek, hogy féken tartsák a bolgárokat. A 14. századi Krónikakompozíció említ a bizánci, bolgár védők között szaracénokat is, a vár 1071-es magyar ostromakor és elfoglalásakor (106108. fejezet). ${ }^{1347}$ A Szerémségbe is telepítették őket, amelynek elfoglalását követően a megkeresztelkedésük fejében I. (Szent) László király alattvalói lettek és vélhetően rájuk vonatkozott az 1092. évi szabolcsi zsinat (Szent László I. dekrétuma) rendelkezése is (9.). ${ }^{1348}$

A Bizánci Birodalomban a magyar állam elleni határvédelem fő központja volt. Innen ered Nándorfehérvár „Görögfehérvár” neve (Alba Graeca), amelyet a német elnevezés

\footnotetext{
${ }^{1343}$ Korai magyar történeti lexikon (9-14. század) Föszerk. Kristó Gyula, szerk.: Engel Pál-Makk Ferenc Budapest 1994. 481. A továbbiakban: KMTL 1994; Barta 1985. 8.

${ }_{1344}^{1345}$ Engel 1990. 90.

${ }^{1345}$ Scriptores Rerum Hungaricarum. Tempore ducum regumque stirpis Arpadianae gestarum. Edendo operi praefuit Emericus Szentpétery. Volumen I. Budapestini 1937. 82-83, 86. (SRH I)

${ }^{1346}$ X. Konsztantinosz Dukasz (1059-1067), IV. Romanosz Diogenész (1068-1071), aki a dunai határvidék föparancsnoka is volt. Írott források az 1050-1116 közötti magyar történelemröl. Szegedi Középkortörténeti Könyvtár 22. Az elöszót írta, a szövegeket válogatta, a kötetet szerkesztette Makk Ferenc, Thoroczkay Gábor. Szeged 2006. 128. (671. jegyz. Olajos Terézia jegyzete) A továbbiakban: ÍF 2006.

${ }^{1347}$ ÍF 2006. 384.

${ }^{1348}$ Karácsonyi János: Kik voltak s mikor jöttek hazánkba a böszörmények vagy izmaeliták? Budapest 1913. 6. (Karácsonyi 1913)
} 
őrzött meg (Griechisch Weissenburg). ${ }^{1349}$ Ennek ellenére a bizánci görög és újgörög források sem ezt, hanem a Belgrád alakot hozzák. ${ }^{1350}$ Bár a 7. században Theophülaktosz Szimokattész bizánci történetíró még a latin Singidunum alakot használta (Szingédón). ${ }^{1351}$ VII. (Bíborbanszületett) Konstantín császár (945-959) „A birodalom kormányzásáról” címmel megjelölt munkájában Belegrada, Belegradon alakban, a 40. fejezetben, említi a várost. A 42. fejezetben pedig a Belegradá-nak nevezett római eredetű kasztront (=castrum) találjuk. Mindamellett használta a latin eredetü Szingidón alakot is (25. fejezet). ${ }^{1352}$ Joannész Szkülitzész történetíró 11. századi történeti műve, a Szünopszisz hisztorión a II. Baszileiosz császárról (976-1025) és VIII. Konstantín császárról (10251028) szóló fejezetében hasonlóan nevezi meg a várat (43. fejezet). De Belgrád várának földrajzi-stratégiai elhelyezkedéséről is jó jellemzést ad: „, A belgrádi erődítmény nehezen megközelithető és az ellenség számára megtámadhatatlan. Ugyanis dél felöl mindenütt meredek kőszirtek koszorúzzák, melyek között az Aszón nevü folyó folyik és egy bejárata van az erődnek." "1353 Szkülitzész a IV. (Paphlagóniai) Mihály császárról (1034-1041) szóló fejezetében pedig Delján Péter bolgár felkelése kapcsán említi (23. cap). „Bulgáriában csavargott, és eljutott Moravosig és Belgrádig (Pannonia erödjei ezek, melyek a Dunán túl fekszenek, és szomszédosan a magyar királlyal)" (Moravcsik Gyula fordítása). ${ }^{1354}$ Szkülitzész azonban csak VI. Mihály császárig (1056-1057) tárgyalja az eseményeket. A 12. századi események kapcsán hasonlóan Belgrád $(B \varepsilon \lambda \varepsilon \dot{\varepsilon} \gamma \rho \alpha \delta \alpha)$ elnevezéseket találjuk a Zimony vára körüli bizánci-magyar háborúkban. ${ }^{1355}$ A 14 . századi Niképhorosz

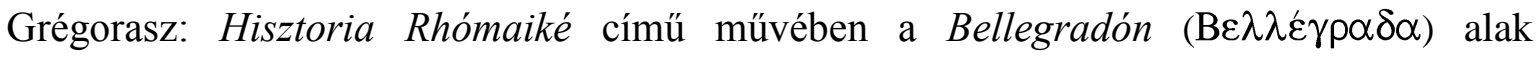

\footnotetext{
${ }^{1349}$ Egy 15. századi angol verses költemény az 1456. évi oszmán-török ostromról még a „Görögfehérvár” elnevezést (Grecuswissinburgh) örizte meg. Lásd: Petrovics 2015. 126-134.

${ }^{1350}$ Például VII. Bíborbanszületett Konstantín, Jóannész Szkülitzés, Niképhorosz Grégorasz, Khalkokondülész, Dukasz.

${ }^{1351}$ Theophülaktosz 2012. 59, 64- 65, 78, 218, 252-253, 269, 299. A. Kazhdan: Singidunum. ODB. 1904.

1352 Bíborbanszületett Konstantin: A birodalom kormányzása. Fordította: Moravcsik Gyula. (Olajos Terézia bevezető tanulmányával) Budapest $2003^{2}$. 176-177, 182-183; illetve 104-105. (DAI)

${ }^{1353}$ Ioannis Scylitzae Synopsis Historiarum. Recensuit: Ioannes Thurn. Berolini et Novi Eboraci, 1973. 364 ,

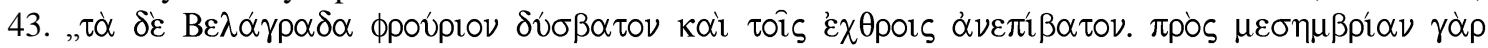

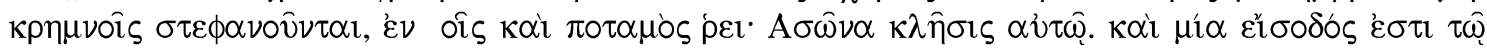
фpovpíw.." A továbbiakban: Thurn 1973.

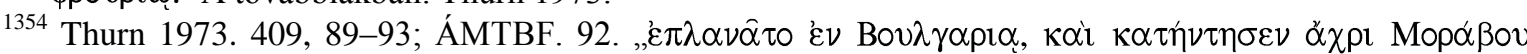

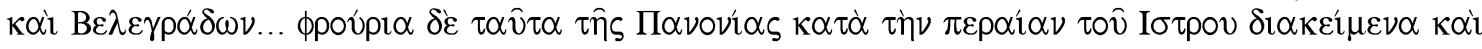

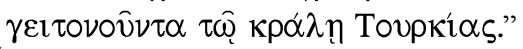

${ }^{1355}$ Lásd a 3.1 és 10. 4. fejezeteket.
} 
szerepel. ${ }^{1356}$ A két 15. századi késő-bizánci szerző, Laonikosz Khalkokondülész a Belográdész alakot hozza, Dukasz hasonlóan Belogradó ostromát említi. ${ }^{1357}$

A magyar „Nandorfeirwar” név az Anjouk idején keletkezett 14. századi krónikakompozícióban jelenik meg (104. cap). ${ }^{1358}$

Azonban az 1440-es ostromra vonatkozó magyarországi latin nyelvü, humanista forrásainkban egy másik elnevezéssel is találkozunk, amely véleményem szerint nem csupán egy szinonímát, hanem egy földrajzi-topográfiai problémát rejt magában.

Thuróczy János krónikájában, a 215. fejezetben, ugyanis megjegyzi, hogy a várost „...az ókorban Taurinumnak, a mi öregjeink pedig állitólag Bolgárfehérvárnak neveztek". ${ }^{1359}$ Ehhez nagyon hasonló névalakot említ a Thuróczyt is felhasználó Antonio Bonfini is, amikor elbeszéli, hogy Murád „király” (Amrates rex Turcorum) ostrom alá vette Görögfejérvárt (Albam Grecam), korábbi nevén Taurun(i)umot. ${ }^{1360}$ Bonfiniről tudjuk, hogy felhasznált földrajzi munkákat is.

Honnan eredhet ez az elnevezés? ${ }^{1361}$ Megemlítjük, hogy Gaius Plinius Secundus (Kr. e. 23-79) Naturae historiarum triginta septem vagy röviden Naturalis historia címü munkájában szerepel ez a névalak. Plinius valóban megemlítette a „makktermö Pannoniá”ban (,glandifera Pannonia”) Taurunum városát, - ihletet is adva a humanista történetíróinknak - „, ahol a Savus összevegyül a Danubiusszal.” (III. 25.) ${ }^{1362}$

A híres Klaudiosz Ptolemaiosz (Kr. u. 2. század, †161) a nyolc könyvből álló Geographia című munkájában viszont mindkét alakot megtaláljuk. Alsó Pannoniában említi (II. 16. 5.) a Danubiosz-folyó mentén haladva Tauroron-t vagy Taurunon-t, ${ }^{1363} \mathrm{a}$ dákiai területen találunk egy Szingidana-t (III. 9. 8.). ${ }^{1364}$ Ptolemaioszt alapul véve a két név nem lehet ugyanannak a városnak a megnevezése.

${ }^{1356}$ Fontes Byzantini Historiam Populorum Jugoslaviae Spectantes Tomus VI. Beograd, 1986. 160, 202. Gregoras kiadása: Nikephoros Gregoras, Rhomäische Geschichte. J. L. van Dieten I-II. Stuttgart 1973, 1979. (Greg. I. p. 72, 19-75, 8; Greg. I. p. 393, 21-397, 16) (Fontes Populorum 1973)

${ }^{1357}$ Lásd a 8. 3. fejezetet.

1358 ÍF. 2006. 382.

1359 „...quod abolito evo Taurinum, nostros autem per seniores Alba Bulgarica vocatum extitisse perhibetur.” Thuróczy Textus 1985. 228, 12-13. Thuróczy 2001. 259.

${ }^{1360}$ Rerum 1936. 101, 14-15. „...Albam Grecam Taurunium prius dictam...” Bonfini 1995. 590. A fordító itt tévesen Taurunum alakot írt.

${ }^{1361}$ Paulys Real-Encyclopädie der Classischen Altertumwissenschaft. Zweite reihe (R-Z) Neunter halbband (Taurisci-Thagori) Stuttgart 1934. 70. (Paulys 1934)

1362 C. Plinii Secundi Naturalis historia. Recensuit D. Detlefsen. Vol. I. Libri I-VI. Berolini 1866. 161. (Plinius 1866)

${ }^{1363}$ Claudii Ptolemaei Geographia. Tom. I. Edidit Carolus Fridericus Augustus Nobbe. Lipsiae 1843. 132. A továbbiakban: Ptolemaiosz 1843.

${ }^{1364}$ Ptolemaiosz 1843. 179. 
Tudnunk kell azt is, hogy a Római Birodalom pannoniai limes-szakaszán, a Száva torkolatánál valóban állt Taurunum, amely a dunai flotta (classis Flavia Pannonica) legfontosabb támaszpontjaként szolgált. Taurunum erődjét a rómaiak a torkolat melletti dombon építették fel. A Száva-folyó túlsó partján lévő Singidunum pedig már nem Pannonia, hanem Moesia superior részét képezte. Visy Zsolt limes-kutató is Taurinumot egyértelműen a mai Zimonyként azonosította. ${ }^{1365}$

Mindezek az adatok megerősítik azt, hogy a szerzőink által leírt Taurunum, amely szintén a Duna és a Száva torkolatánál fekszik, csak a Singidunummal (Belgráddal) szemben lévő oldalon: a középkori Zimony vára, amely névalak már a 7-9. századi szláv elnevezést/fordítást őrzi (,zemlin"=földből való, t. i. a földvár). ${ }^{1366}$ Ezt bizonyítja az is, hogy mivel a 12. századi bizánci-magyar háborúk állandó színterévé vált ez a Nándorfehérvárhoz közeli erőd, e háborúra vonatkozó bizánci forrásokban sűrün szerepel.

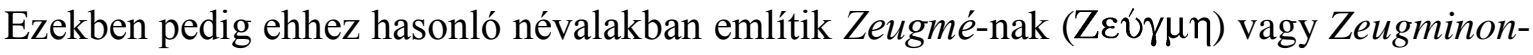

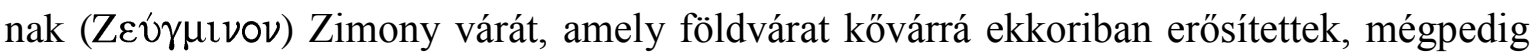
éppen Belgrád falaiból!! ${ }^{1367}$

Felvetett földrajzi topográfiai kérdésünkre visszatérve, Thuróczy és Bonfini vajon Taurinum-ot tényleg Nándorfehérvárral vagy esetleg Zimonnyal azonosította? Az általam Taurinum-kérdésnek nevezett probléma megoldásához meg kell vizsgálnunk munkáikban más, olyan szöveghelyet is, ahol biztosan Zimony a helyszín. Tudjuk például, hogy IV. István király Zimony várában halt meg. ${ }^{1368}$ Thuróczy szerint is: „Zemlen várában halt meg...(95. fejezet)" ${ }^{\text {1369 }}$ Bonfini szerint szintén itt történt a halála: „,nem sokkal később egy várban, amelynek Zimony (=Zemlen) a neve...(2. 6. 488.)"1370 Csakhogy mindkét szerzőnk e szöveghelyen a Zemlen névalakot használja. Beláthatjuk, hogy Zimonyra semmiféleképp nem gondoltak Taurunum említésekor, hanem azt - tévesen - a közeli Nándorfehérvárral (Belgráddal) azonosították.

Még Bonfini kortársa, a Magyarország rövid történetét megíró Petrus Ransanus (14281492) sem kerülte el ugyanezt a hibát, pedig - igazi humanista módon - Ptolemaioszt is felvette hivatkozásai sorába. Az 1456. évi (második) szultáni ostrom kapcsán, a 26.

\footnotetext{
1365 Visy Zsolt: A római limes Magyarországon. Budapest 1989. 125. (Visy 1989)

${ }^{1366}$ KMTL 745. Zimony, Takács Miklós szócikke.

${ }^{1367}$ Lásd a 3. 1. fejezetet. ÁMTBF 203, 205, 217, 234.

${ }^{1368}$ KMTL. 294. IV. István. Makk Ferenc szócikke.

1369 Thuróczy 2001. 148, 1. „Obiit in castro Zemlen...” Thuróczy textus 1985. 135, 1.

${ }^{1370}$ Bonfini 1995. 375, 18-19. ,,in castello quodam, quod Zemlen appellant...” Antonius de Bonfinis: Rerum Ungaricarum decades. Ediderunt: I. Fógel-B. Iványi-L. Juhász. Tomus II. Decas II. Lipsiae, 1936. 140, 33-34. (Rerum II. 1936)
} 
fejezetében így írt: „E helynek négy neve is van: Ptolemaiosz Taurinumnak hívja, bizonyos más régi földrajztudósok Fehérvárnak, az újabbak közül egyesek Belgrádnak, mások Nándorfehérvárnak nevezik" (Blazovich László és Sz. Galántai Erzsébet fordítása). ${ }^{1371}$

Christoforo Batti, a 16. század elején élt humanista levelezésében is feltünik a szávaszentdemeteri ütközet (1523. augusztus) leírásakor ugyanez a topográfiai kérdés, amely a tévedés továbbélését bizonyítja: „Pannónia egy városában, mely nem messze van Taurominustól, amit manapság népnyelven Belgrádnak neveznek..."1372 Egyetértek Seláf Levente idevágó véleményével, mely szerint a szerző a Zimony alatti római erődítmény, Taurunum nevét deformálhatta Taurominussá és kötötte össze Belgráddal. Mert a középés kora újkori forrásokban Belgrádot Taurunum, Taururum, Taurynum neveken is emlegették. ${ }^{1373}$

\section{„Now shalt thou feel the force of Turkish arms which lately made all Europe quake for fear... and as the heads of Hydra, so my power, subdu'd, shall stand as mighty as before."}

(Christopher Marlowe: Tamburlaine the Great)

\section{2. I. Bayezid szultán hadjáratai}

\section{a Magyar Királyság ellen}

A korai török-magyar háborúk tárgyalásában a fö hangsúly a szinte évenkénti, határmenti, török betörések, portyák összegzésére esett. A reguláris szultáni haderő egy vagy több valószínü magyarországi betörése kívül maradt a kutatás nézőpontján. Nem szólva arról, hogy a Rázsó Gyula, Szakály Ferenc által leírt szakaszos hódítási elméletbe nehezen beilleszthető. A magyar szakirodalomban - tudomásom szerint - ezidáig nem foglalkoztak I. Bayezid szultán (1389-1402) Magyarországra vezetett hadjáratával vagy hadjárataival; és természetesen egy Nándorfehérvár (Belgrád) elleni szultáni támadással sem.

Azt is hozzátesszük, hogy alapvetően csak a hazai latin nyelvü - elsősorban okleveles források kizárólagos vizsgálata volt a jellemző, amelyben erre alig vagy egyáltalán nem találunk írásos feljegyzéseket. Viszont a bizánci-görög, szláv vagy az oszmán-török források nem kaptak helyet a vizsgálódásokban. Ha ezen tovább akarunk lépni, elsősorban

\footnotetext{
1371 Ransanus 1999. 123, 25-28. „Quatuor sunt huic loco vocabula, Ptolemaeus Taurinum nominat, alii quidam geographi veteres Albam, recentiorum alii Belgradum, nonnulli Ander Albam appellant." Epithoma 1977. 148, 14-16.

1372 Seláf 2001. 186.

${ }^{1373}$ Seláf 2001. 191.
} 
a nemzetközi bizantinológiai szakirodalmat kell vallatóra fognunk, különösen az oszmanobizantinológia néhány évtizedes eredményeit, alapos kitekintéssel a bizánci-bolgár-szerb forrásokra, történeti munkákra is. Jelen munkánk - rekonstruálva az eseményeket - a hiánypótlás igényével kíván új megállapításokat tenni.

A hazai historiográfiában az első mérvadó tudományos elemzés a korai török támadásokra 1914-ben Milleker Bódog nevéhez füződik. ${ }^{1374}$ Rázsó Gyula 1973-as, alapvető tanulmányában a török portyázásokat vagy a magyar ellentámadásokat vette sorra $^{1375}$ és Szakály Ferenc az 1986-ban írott, a török-magyar küzdelem 1526 elötti szakaszait elemző nagyívű szintézisében szintén nem találunk támpontot. ${ }^{1376}$ A török portyázásokat természetesen Szakály is említette, valamint felsorolta Zsigmond szerbiai hadjáratait is $(1389,1390,1392)$. Néhány megállapítását azonban fontos kiemelnünk. Így azt, hogy a király hadi sikereinek legnagyobb eredménye 1395-ben Kis-Nikápoly elfoglalása volt. Valamint azt, hogy az 1396-os nikápolyi oszmán-török győzelem után a szultáni udvarban a balkáni renegátokból állók kerültek hatalmi túlsúlyba és a kisázsiai hódításokat szorgalmazták. Ezáltal Bayezid 1397-1398-ban már nem jött személyesen az európai hadszíntérre. ${ }^{1377}$

Zsigmond király török politikájának, 1994-ben, Engel Pál is egy tanulmányt szentelt. Egyúttal feltérképezte a lehetséges magyarországi célpontokat is: Krassó, Keve, Temes, Torontál megyék; a Dráva-Száva folyók köze, különösen a Szerémség. A szerző ugyanakkor előrevetítette számunkra - így akaratlanul - el is határolta ezeket a szultáni, reguláris támadástól is, amennyiben a zsákmányszerző betörések sosem (ország)hódító céllal indultak és központi haditerv vagy (szultáni) irányítás nélkül történtek. ${ }^{1378}$ Engel szerint Zsigmond személyesen $(1389,1390,1391,1392)$ vagy bárói által vezetett (1393) szerbiai ellentámadásai nem vezettek eredményre. A szerző - Szakályhoz hasonlóan egyedül Kis-Nikápoly elfoglalását tartotta az első eredménynek 1395-ben. ${ }^{1379}$

Biztató kezdeményezésnek tekinthetjük a nikápolyi csata 600. évfordulóján, 1996-ban megrendezett tudományos emlékülésen („Nikápoly 1396-1996”, 1996. szeptember 27.) Engel Pál az 1389-1392 közötti időszakról, a török-magyar háborúk első éveiröl tartott előadását és a Hadtörténelmi Közlemények tematikus számában, 1998-ban megjelent

\footnotetext{
${ }^{1374}$ Milleker 1914.

1375 Rázsó 1973. 413. A szerző főleg Zsigmond király (1387-1437) Havasalföldre vezetett hadjáratait (1392, 1394, 1395) ismerteti, amelyeket Mircea, havasalföldi vajda ellenállásának támogatására vezetett.

1376 Szakály 1986. 11-57.

1377 Szakály 1986. 20.

1378 Engel 1994. 274.

${ }^{1379}$ Engel 1994. 275.
} 
tanulmányát. ${ }^{1380}$ Ebben részletesen megvizsgálta évenként a török betöréseket, királyi ellentámadásokat. Az 1392-es évre vonatkozó okleveles adatot I. Bayezidről és a magyar seregről ismertette, de nem minősítette az ország ellen irányuló, reguláris szultáni hadjáratnak.

Legutóbb például Csömöre Zoltán tekintette át a temesközi török portyázásokat a 14 . század végétől a 16. századig. ${ }^{1381}$ Jómagam azonban a fenti szempontok figyelembe vételével kezdtem meg vizsgálataim és addigi eredményeimet elsőként 2013 nyarán publikáltam. $^{1382}$

Kindulópontként, az I. Bayezid által vezetett reguláris török haderő magyarországi tartózkodásának meghatározásban, pontosítani kell a szultán egyes nyugati, ruméliai és a keleti, anatóliai hadszíntereken való tartózkodását. Érdemes ebből a szempontból röviden áttekinteni uralkodását. Halil İnalcık I. Bayezidról szóló szócikkében - az Iszlám Enciklopédiában - a szultán főbb tartózkodási helyeit is megtaláljuk. ${ }^{1383}$ A keresendő magyarországi hadjárat lehetősége ez alapján biztosan kiolvasható és ebben İnalciknak sokat köszönhetünk.

Először az 1389. évi rigómezei szerb vereséget követő évek jöhetnek számításba, amikor a szultán vazallusi szerződést kényszerített a szerbekre, amely segédcsapatok kiállítását követelte meg a szultáni hadseregbe. ${ }^{1384}$ I. Bayezidnak 1392-ben ismét a nyugati hadszíntér felé kellett fordulnia, föleg Velence és Magyarország aktivitása miatt. A hódítása immár a két bolgár cárság, Shisman és Stracimir országa ellen irányult. ${ }^{1385} 1393$ ban elfoglalta a trnovói bolgár cárságot. Különösen érdekes számunkra İnalcık azon megállapítása, hogy a szultán 1395-ben betört a Magyar Királyságba és Havasalföldre. A következő szultáni tartózkodás lehetőségét 1396-ban a nikápolyi csata adja. Matuz József szerint a csatát követően az oszmán-török portyázók a Szerémségig is elértek. ${ }^{1386}$ Fontos tény, hogy a szultán ebben az évben foglalta el a vidini bolgár cárságot is. Bár 1397-ben a szultán Evrenosz nevü hadvezére még görög földön folytatott háborút, a szultán ezután

\footnotetext{
${ }^{1380}$ Engel Pál: A török-magyar háborúk első évei 1389-1392. Hadtörténelmi Közlemények 1998/3. 561-577. A továbbiakban: Engel 1998

${ }^{1381}$ Csömöre Zoltán: Temesközi várak, erődített templomok a török portyázások időszakában (1390-1551). Középkortörténeti Tanulmányok 7. Szerk.: Kiss P. Attila, Piti Ferenc, Szabados György. A VII. Medievisztikai PhD-konferencia előadásai (2011. június 1-3). Szeged 2012. 485-503. (Csömöre 2012) ${ }^{1382}$ Szabó 2013c 73-89.

${ }^{1383}$ Halil İnalcık : Bayazid I. (Yildirim „,the Thunderbolt”) The encyclopaedia of Islam. New edition. Volume I. A-B. Ed. by: H. A. R. Gibb, J. H. Kramers, E. Lévi-Provencal, I. Schracht. Leiden, London 1960. 1118-1119. A továbbiakban: İnalcik 1960.

${ }^{1384}$ İnalc1k 1960. 1118.

${ }^{1385}$ Lásd még a 2. 4. fejezetet.

${ }^{1386}$ Matuz 1990. 38.
} 
már végérvényesen keletre fordult, ugyanis az anatóliai hadszíntéren volt kénytelen harcolni az 1399-ben feltűnő Timur Lenk seregeivel. ${ }^{1387}$

1955-ben, a X. Nemzetközi Bizantinológiai Kongresszuson, Isztambulban (szeptember 15-21) İnalcık előadást tartott egy addig ismeretlen török forrásról, amelyet a Topkapi Szeráj Levéltárában talált Ar. 6374. jelzettel. A keltezetlen, 15. századi oszmánli nyelven írt hivatalos jelentés éppen I. Bayezid Magyarország és Havasalföld elleni hadjáratáról szól, illetve II. Murád szultán (1421-1451) Erdély elleni támadásáról. ${ }^{1388}$ A forrás évszámot nem, de pontos itineráriumot ad. İnalcik megállapítása szerint ez a dokumentum II. Mehmed szultán (1451-1463) parancsára készülhetett egy Magyarország elleni hadjárat előtanulmányaként. ${ }^{1389} \mathrm{~A}$ forrást teljes terjedelmében közlöm:

„a néhai Gházi Ylldırım Khan elhatározta, hogy háborút robbant ki Magyarország ellen. Elöször átkelt a Dunán Pojejannál ${ }^{1390}$ Braniceva $^{1391}$ körzetében és a folyó másik oldalán végigvonult. Abban az időben Nándorfehérvár és Szendrö várai még nem voltak kiépitve. Megtámadta Islankamen ${ }^{1392}$ várát, amely teljesen Nándorfehérvár körül helyezkedik el és elfoglalta azt. Azután megszerezte még Titel várát, a Duna és a Tisza összefolyásánál. Követte a Temes-folyó vonalát, elpusztítva a várakat és falvakat ennek a (folyónak) a völgyében. Felégette vagy megszerezte ezeket a várakat: úgymint Bishkerek, ${ }^{1393}$ Dimishkar, ${ }^{1394}$ Nagy Shemillik, Kis Shemillik, ${ }^{1395}$ Karashova, ${ }^{1396}$ Shebesh ${ }^{1397}$ Mehediye, ${ }^{1398}$ Risova, ${ }^{1399}$ Severin ${ }^{1400}$ és mások. $" 1401$

${ }^{1387}$ Inalcık 1960. 1118-1119. Anatóliában érte Timur Lenk első támadása, aki kikiáltotta a meghódított vezérek függetlenségét, magát a Dzsingiszidák örökösének állítva. Bayezid „kán” pedig a szeldzsuk szultánok örökösének nyilvánítva magát, elsőként használta a „szultán” címet.

1388 İnalcık 1957. 220. Lásd még a 6. 3. fejezetet.

1389 İnalc1k 1957. 220

${ }^{1390}$ Pozsazsin.

${ }^{1391}$ Barancs, Branicevo a Pek-folyón, a Duna jobb oldala felől van. Fontos állomás volt a Nándorfehérvártól Niš-ig a Konstantinápoly felé vezető úton. Lázár fejedelem 1378-1379 körül foglalta el. Ivan DjuričAlexander Kazhdan: Braničevo. In: ODB. 320.

${ }^{1392}$ Szalánkemén.

1393 Becskerek.

1394 Temesvár.

${ }^{1395}$ Mezősomlyó (Grossschemlak), Kissomlyó (Kleinschemlak) Lásd: Decei 1978. 209-222.

1396 Krassó.

1397 Karánsebes.

1398 Mehádia.

1399 Orsova.

1400 Szörény.

${ }^{1401}$ İnalcık 1957. 220-221. A szöveget İnalcik saját angol fordításában tette közzé. „The case was that the deceased Ghazi Ylldirtm Khan setting out to make war against Hungary first passed over the Danube at Pojejan in the province of Braniçeva and moved along on the other side of the river. At that time the castles of Belgrade and Semendere were not yet built up. He attacked the castles of Islankamen which is situated all the round Belgrade and took it; then seized also the castle named Titel at the confluence of the Danube and Tisa. He followed up the course of Temish river destroying the castles and villages on its 
A forrásban rögtön ezután egy havasalföldi hadjárat leírása következik. „Azután behatolt Havasalföldre, ahol Mircse vajda ${ }^{1402}$ felvonulva hadseregével megakadályozta a szultán útját. Egy hétig harcolt a vlah sereggel az Arkhis-folyónál, ${ }^{1403}$ végül békét kötött Havasalföld vajdájával, aki visszatért országába. Azután Yıldırım Khan átkelve az Arkhisfolyón, Nikápoly erödje elé ért, amelynek a kapitánya egy Shishman nevü úr volt. Ö éppúgy adót fizetett a szultánnak, mint Havasalföld vajdája. A szultán megparancsolta neki, hogy küldje el a hajókat, amelyeket felszerelt. Amint a szultán a túlpartra ért, elfogatta Shismant, lefejeztette őt és elfoglalta Nikápolyt, átalakitotta oszmán szandzsákká. Így dicsöségesen és biztonságban tért haza a zsákmánnyal."1404

A fenti havasalföldi hadjárat említése terminus ante quem-időpontot nyújt Bayezid ezen - általunk elsőnek nevezett - magyarországi hadjárata időpontjának meghatározásához. Elöször is, tudjuk, hogy Trnovót a szultán 1393-ban foglalta el, a trnovói bolgár cár, Ivan Shisman (1371-1393) kivégzésére pedig később, 1395. június 3-án került sor. ${ }^{1405}$ Az erről szóló szakirodalom többsége így az 1395. évre helyezte a szultáni támadás időpontját.

A Bayezid-féle hadjárat datálása a rovinei csata datálásának függvénye. Az argesi vagy rovinei csatának elég nagy a kronológiai „szóródása” és bár a szakirodalom 1391-től 1395ig lehetségesnek tartja, ${ }^{1406}$ Ostrogorsky, valamint İnalcık időpontként 1395. május 17-ét jelölte meg. ${ }^{1407}$ İnalcık az Iszlám Enciklopédiában írt szócikkében ugyanezt a datálást megismételte. A magyarországi hadjáratot 1395-re helyezte, az argesi csatát pedig 1395. május 17-ére. ${ }^{1408}$ A 2009-ben, a New Yorkban megjelent Oszmán Birodalom Enciklopédiájában Ágoston Gábor Bayezidról szóló szócikkében is hasonlót találunk. A Nikápoly török elfoglalását és Shishman cár kivégzését 1395 júniusára helyezte. ${ }^{1409}$ A román Ion-Aurel Pop összegző tanulmányában megerősítette, hogy Bayezid a Trnovói

valley and burning down or seizing such castles as Bishkerek, Dimishkar, Great Shemillik, Small Shemillik, Karashova, Shebesh, Mehediye, Risova, Severin and others"

1402 „Öreg” Mircse havasalföldi fejedelem (1386-1418)

1403 "Az Arges-folyó ma.

1404 Inalc1k 1957. 221. „Then he entered into Wallachia where Voyvode Mirdja coming up with his army hindered the Sultan's passage. He fought against Wallachian army on Arkhiş river for one week and finally made peace with the Voyvode of Wallachia who returned to his country. Yildirtm Khan then crossing Arkhiş river came before the fortress of Nicopolis of which the ruler was a lord named Shishman. He was paying tribute to the Sultan in the same way of the Voyvode of Wallachia. The Sultan asked him to send ships which he furnished. As soon as the Sultan was on the other side he fetched Shishman, beheaded him and seized Nicopolis and transformed it into an Ottoman sandjak. So he returned home gloriously and safely with booty."

${ }^{1405}$ Lásd alább a Névtelen „Bolgár” Krónika adatát.

1406 İnalc1k 1957. 221.

1407 İnalc1k 1957. 221.

1408 İnalc1k 1960. 1118.

${ }^{1409}$ Gabor Agoston: Bayezid I. (Thunderbolt) In: Encyclopedia of the Ottoman Empire. Ed.: Gabor Agoston, Bruce Masters, New York 2009. 81. A továbbiakban: Agoston 2009. 
Bolgár Cárságot 1393-ban foglalta el és a Dunán túlra tervezett támadni, mert Mircea seregei a bolgárokat támogatták. Az 1393-1395 közötti, Havasalföld elleni oszmán támadások közül a legnagyobb a rovinei csata volt, amelyet 1394. október 10. vagy 1395. május 17-re datálhatunk. Ebben a szultán oldalán - keresztény vazallusokként - részt vett Lazarević István szerb despota és egyes önálló szerb tartományurak mint Marko Kraljević $^{1410}$ és Konstantin Dejanović. Mircse vajda a győzelme után pedig 1395. március 7-én szövetséget kötött Zsigmonddal, és részt vett a nikápolyi hadjáratban. ${ }^{1411}$

A rovinei csatáról ún. Névtelen „Bolgár” Krónika is tudósít, amely a 16. század közepéről másolatban maradt fenn, és az 1296 - 1413 közötti éveket tárgyalja. Az első kiadása J. Bogdan nevéhez füződik, 1891-ben. Azóta latin, francia és angol fordításban is napvilágot látott, 2008-ban Kiril Petkov publikálta. ${ }^{1412}$ A vonatkozó részt idézem: „Bayezid átvette apja, Murád cárságát, hatalma alá hajtotta a szerb földet, kényszeritette öket arra, hogy adót fizessenek, seregeket adjanak és menjenek vele a háborúkba és István deszpotészt apja trónjára helyezte Szerbiában. Nem sok nappal azután, hogy a török sereg nagy sokasága összegyült és útnak indult, hogy Mircse vajda és vlahjai ellen támadjon, egy nagy csata zajlott és a legerösebb török és a keresztény uralkodóknak nagyszámú, válogatott katonája csapott össze. Köztük volt Konstantin Dragash és Marko király. Megszámlálhatatlan sok lándzsa tört össze és a rengeteg nyíltól az ég nem volt látható. Valóságos vérfolyam zúdult le az emberi hullák óriási mennyiségéböl, amely Bayezidot is megrémítette és megfutamitotta. Éppen ezért, amint Mircse magyar földre menekült, a szultán egyik legerösebb emberét helyezte ezen ország élére, hogy azt kormányozza. Bayezid maga pedig elmenekült és át akart kelni a Dunán. Örséget helyezett el végig a dunai átkelöhely teljes hosszában. Elfogatta a bolgár Shisman cárt és megölette öt 6903. (=1395) június 3-án, meghódította a bolgár földet, valamint egész Bulgária élére kormányzókat helyezett." ${ }^{, 1413}$

${ }^{1410}$ Prilep fejedeleme (1371-1395), a szultán vazallusa, ebben a csatában esett el. Baán 2013. 527. (13. lábjegyzet)

${ }^{1411}$ Ion-Aurel Pop: Romanians in the 14th-16th centuries: from the Christian Republic to the Restoration of Dacia. In.: History of Romania. Compendium. Edited by: Ion-Aurel Pop, Iovan Bolovar. Cluj-Napoca, 2006. 254. (Pop 2006)

1412 J. Bogdan: Ein Beitrag zur Bulgarischen und Serbischen Geschichtschreibung. Arciv für Slavische Philologie, XIII. (1891). Legutóbb angol fordításban: Kiril Petkov: The Voices of Medieval Bulgaria, Seventh-Fifteenth Century: The Records of a Bygone Culture (East Central and Eastern Europe in the Middle Ages, 450-1450) Leiden 2008. 456-464. A továbbiakban: Petkov 2008.

${ }^{1413}$ Petkov 2008. 460, 17-30. „Not many days after that a very great multitude of Turks gathered and set out against Mircho Voevoda and his Vlachs. A great battle was fought and many picked (warriors) fell from among the strongest of the Turks and the Christian rulers. Among them were Constantine Dragash and King Marko. Innumerable spears were broken and the air could not be seen because of the many arrows. Such a river of blood ran from the massive amount of human corpses that Bayazid himself got scared and 
A forrás a kosovói csata után tárgyalja a rovinei ütközetet és nem tesz említést a havasalföldi hadjárat elött magyarországi betörésről, csak a visszavonulás kapcsán említ dunai átkelést. A bolgár cár kivégzéséről viszont megbízható dátumot ad. ${ }^{1414}$

Konstantin Filozófus Lazarević István életéről írt munkája (Žitije despota Stefana Lazarevića) is beszámol Bayezid havasalföldi hadjáratáról és a rovinei csatáról. „Azután a büszke és fennséges Bayezid háborút kezdett a magyarokkal és vlachokkal és teljes hadseregét ellenük vezette. Átkelt a Dunán a 6903. évben (t. i. 1394-ben), csatát vívott a hatalmas és független vajdával, Ioan Mircha-val és nagy vérontás következett. A csatában meghalt Marko király és Konstantin. Stefan herceg, akiröl itt mi beszélünk, e vezérek oldalán harcolt a csatában. Mindannyian az izmaeliták mellett voltak, bár kényszerböl és akaratuk ellenére. ${ }^{1415}$ Azt mondják, hogy az áldott Marko ezt mondta Konstantinnak: „Most csak ezt fogom mondani. Imádkozom az Istenhez, hogy ebben a csatában a keresztényeket segítse és adja meg nekem, hogy az első legyek, aki meghal!"1416 Bár Konstantin Filozófus sem említ külön egy magyarok elleni hadjáratot, csak annyit, hogy a rovinei csata előtt a szultán háborút kezdett velük és a teljes, reguláris hadseregével ellenük is vonult. A rovinei csatát pedig 1394-re helyezi.

Azonban oszmán-török krónikában is felbukkan az ország elleni támadás. İbn Kemal (Kemalpaşazâde) müvének IV. defterében (140a). ${ }^{1417}$ Eszerint a hitharcosok Magyarországon több helyen tartózkodtak, az igazság szablyájával az ellenséget éjjelnappal pusztították. Míg a békeszerződés létrejött, a király biztonságba került és Budán (Būdūn), amely az utat tévesztőnek a székhelye, az iszlám vallástörvényének folyója szétáradt, a hitetlenségé pedig kiszáradt. ${ }^{1418}$ İbn Kemal beszámolója szerint a pusztítást még egy békeszerződés is lezárta. A szövegrészlethez írt lábjegyzet az eseményt a később

took to flight. However, as Mircho fled to the Magyar land, he (Bayazid) put one of his powerful men to rule over this country. Bayazid himself fled, and wanted to cross the Danube. He put guards alongside the entire crossing of the river Danube. He seized the Bulgarian Tsar Shisman and slew him in 6903, on the third day of the mouth of June, conquered the Bulgarian land as well and put governor over the entire Bulgarian land."

1414 Petkov 2008. 460. (353. lábjegyzet)

1415 Konstantin Filozófus arra utal, hogy mindannyian oszmán-török vazallusokként kötelesek voltak a szultánt a hadjárataiban katonailag támogatni.

${ }^{1416}$ Petkov 2008. 401, 31-402, 7. „After that the proud and majestic Bayazid opened war on the HungaroVlachs and moved his entire army against them. He crossed the Danube in the year 6903, engaged in battle the great and sovereign Voevoda Ioan Mircha and a great bloodshed ensued. In that battle perished King Marko and Constantine. Prince Stephen, about whom we relate here, fought alongside these rulers in the battle. They were on the side of the Ishmaelites althought under duress and against their will. They said that the blessed Marko told this to Constantine: I will only say this now: I pray to God to help the Christians in this battle and grant me to be the first to die in this battle!"

1417 Kemalpaşazâde: Tevârih-i Âl-i Osman IV. defter. Hazırlayan Koji Imazawa. Ankara 2000. 281. (İbn Kemal 2000)

${ }^{1418}$ Köszönöm Papp Sándor segítségét. 
említendő, Nikápoly utáni támadásról író Schiltberger és a Névtelen „Bolgár” Krónika adataival kötötte össze, ugyanakkor felhívja a figyelmet İnalcik dokumentumára is, így nem dönthetö el, hogy kronológiailag hova illeszthetö be.

A Bayezid-kori hadjáratnak az eredménye İbn Kemal monumentális művében később, a mohácsi csatáról szóló részben (az ún. Mohács-náme) bukkan fel, amikor a Duna és a Száva közötti tartományról, „Szerém szigetéről” ír. „Ez boldogult Jildirim Bajezid khán idejében elszakittatván a szerencsétlen hitetlenek országától, az iszlám területéhez csatoltatott és e nagy tartomány lakói adót fizettek a nevezett uralkodónak...Később, mikor Timurnak mennyköve lesújtott, e tartomány lakói megszegték frigyüket és földjök ismét a hitetlenség tanyája lön..." (Thúry József fordítása) ${ }^{1419}$ İbn Kemal szerint Bayezid hadjáratát hódítás is követte, a Szerémség - Timur Lenk győzelméig - adót is fizető iszlám tartomány lett. Egy békeszerződésről korábban is említést tett, ez utóbbi szövegrészletben pedig a ,frigy” megszegéséről szól. A kronológia szempontjából itt sem derül ki az, hogy mindez a nikápolyi csata elött vagy azt követően történt.

A bizánci forrásokban is találunk említést a rovinei csata körüli időpontban szultáni támadásról Magyarország ellen. A poszt-bizánci, nyugati görög történeti munkák közül a 17. századi, népi (újgörög) nyelven íródott Névtelen Krónika (Codex Barberinus Graecus 111. Anonymous Zoras) ${ }^{1420}$ a rovinei csatáról így írt: Bayezid „összegyüjtötte egész hadseregét, és megtámadta Márk királyt...ott esett el Márk fejedelem is. Sok várat és falut is bevett Magyarországon. És visszatért székhelyére, Drinápolyba..." (Baán István fordítása). ${ }^{1421}$

Colin Imber az 1300-1481 közötti oszmán-török birodalomról írott munkájában is 1395 tavaszára helyezte ezt a havasalföldi hadjáratot, figyelembe véve az Inalcik által felfedezett forrást és Inalcik datálását. Észrevette azonban, hogy a havasalföldi hadjárat részletei teljesen nem összeegyeztethetőek más forrásokkal (pl.: a Névtelen Firenzei Krónika, a Névtelen „Bolgár” Krónika), Shisman 1395. évi kivégzését azonban megerősítik. ${ }^{1422}$

Sőt, a konstantinápolyi Hierax logothetész megasz 1580 táján, jambikus versus politicusban írt költeménye közvetlenül Bayezid hatalomátvétele után (1389) említ meg egy Magyarország elleni szultáni támadást. „Nagy hirtelen megérkezik / Paióniába, és ott / férfiakat, gyermeket / legyilkolva fosztogat, / nem kímélve sihedert sem, / vagy bármilyen

\footnotetext{
${ }^{1419}$ In.: Török hadak 1984. 14.

${ }^{1420}$ Lásd a 8. 4. fejezetet.

${ }^{1421}$ Baán 2013. 527.

${ }^{1422}$ Imber 1990. 45.
} 
életkort, / Bulgáriával szomszédos / igen sok nép felé megy..." ${ }^{, 1423} \mathrm{Ez}$, habár ez kései forrás, de a kosovói győzelme után helyezi el Bayezid támadását.

Véleményem szerint van azonban ezzel az 1395. évvel egy kis kronológiai probléma, mert a magyar hadtörténeti szakirodalom többsége egybehangzóan ebben az évben említi még Zsigmond király egyetlen eredményes hadjáratát a törökök ellen, amikor elfoglalta Kis-Nikápoly várát, (Nagy-) Nikápollyal szemben. ${ }^{1424}$ Ha pedig Bayezid a havasalföldi hadjáratáról ekkor érkezett volna Nikápolyba, Kis-Nikápoly elfoglalásáról az İnalcik által felfedezett török forrás miért nem tesz említést? Akkor inkább a rovinei csata korábbi datálása lenne célszerübb, ahogyan Konstantin Filozófus tette.

A Magyarország elleni szultáni támadás forrásainak kutatása során számomra úgy tünt, hogy a forrásokban a nikápolyi csata kiemelt időpont. Mert a források többsége a nikápolyi csata után említ szultáni hadjáratot. Ebben pedig a bizánci források adtak számomra alapvető támpontot.

Laonikosz Khalkokondülész bizánci történetíró értékes adalékkal szolgál ehhez, amelyet a nikápolyi csata eseményeinek elmondása után tett. „Bayezid, Murád fia, mihelyt megfutamitotta a paionokat és a keltákat, s kifosztotta vidéküket, még arcátlanabbul nyomult ellenük, és igen sok foglyot hurcolt el. Söt már Buda, a paionok fövárosa felé (sic!) vonult, amikor megbetegedett, ugyanis köszvényben szenvedett. Ámde ha nem kínozta volna a betegség, el sem tudom képzelni, mi is akadályozhatta volna meg abban, hogy Budáig ne vonuljon, megadásra ne kényszeritse Budát, a paionok fôvárosát, és meg ne hóditsa országukat. Most pedig nagyon is valószinü, hogy azért tért haza, és vitte vissza országába a hadsereget, mert betegség kínozta." (Baán István fordítása) ${ }^{1425}$

Az elöbb idézett poszt-bizánci, Névtelen Krónika (Anonymous Zoras) is beszámol erről: A nikápolyi győzelme után Bayezid „Akkor felkerekedett hadával, és győztesként elindult. És azért vonult, hogy visszatérjen székhelyére, felprédálta Bulgária falvait, és sokakat rabszolgaságra hurcolt. És háborút szándékozott indítani, hogy bevegye Vidint (Bodonyt), amely nagy és erős vár, Magyarország kulcsa. Mivel azonban köszvény gyötörte, és fájt a lába, felhagyott (tervével), és Drinápolyba, székhelyére vonult." (Baán István fordítása) ${ }^{1426}$ A névtelen szerző beszámolójában ezután Mircea, havasalföldi fejedelem (1386-1418) elleni támadást mondja el.

\footnotetext{
${ }^{1423}$ Baán 2013. 513.

${ }^{1424}$ Szakály 1986. 26; Rázsó 1973. 413; Engel 1994. 275.

1425 Baán 2013. 211-212; Darkó 1922. 70-71, 3-13.

${ }^{1426}$ Baán 2013. 531; Zórasz 1958. 34, 5-10.
} 
A Névtelen Krónikaíró, aki valószínüleg felhasználhatta Khalkokondülész munkáját is, azonban nem a magyar, hanem egyértelmüen a bulgáriai hadszíntérre helyezi ugyanezt az információt. Így nem Buda, hanem Bodony, azaz Vidin elleni ostrom tervét említette. A

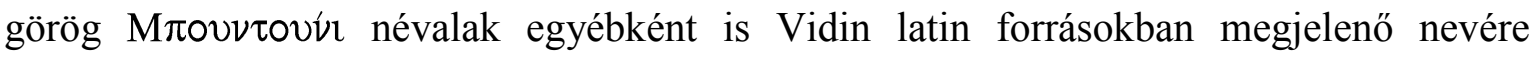
emlékezet (Bdyn=Vidin). ${ }^{1427}$ Bár ez 1990-ben még ismételten megtévesztette a szöveget legutóbb angolra fordító Marios Philippidest is, aki még egyértelműen Budának értelmezte a görög névalakot. ${ }^{1428}$ Baán István szöveggyüjteményében is a Buda alakjai között szerepel a névmutatóban. ${ }^{1429}$

További késői bizánci forrásokban is fellelhető egy-két utalás. Pszeudo-Szphrantzész Chronikon Maius címmel a 16. században összeállított műve az 1258-1478 közötti eseményekkel foglalkozik. ${ }^{1430}$ A nikápolyi csatát követően írja: „Azután újra visszafordulva Európába a magyarok ellen viselt hadat, s egyszer-kétszer legyözte őket, és Albánia egy részét is meghóditotta."1431 Egy másik szöveghelye szintén erről szól: „egészen Nikápolyig nyomult elöre Zsigmond. A hadak megütköztek egymással, és egy rossz döntés miatt a keresztények seregei teljes vereséget szenvedtek, és megfutamitva üldözték öket és foglyul ejtették."(Baán István fordításai) ${ }^{1432}$ Ami lényeges számunkra az az, hogy a szultán üldözőbe vehette a megvert keresztes sereg maradványait.

Akármennyire is hihetetlen, a bizánci forrásaink szerint a törökök - már jóval 1541 előtt - potenciális hadicélként tüzhették ki a Magyar Királyság és talán a fővárosa, Buda elfoglalását.

Vannak azonban további források is, amelyek megerősítenek egy ilyen Nikápoly utáni második hadjáratot. Colin Imber az 1990-ben írt - szükebb időintervallumot tárgyaló könyvében - idéz két másik olyan kortárs forrást is, amely a nikápolyi csata után is megemlít egy Magyarország elleni szultáni akciót.

A bajor Johannes Schiltberger - aki maga is részt vett Zsigmond keresztes hadjáratában - a fogságáról és utazásáról írt könyvének elején a nikápolyi csatáról írt. ${ }^{1433}$ „A harmadik nap után a török király (Wyasit)... Ungern ellen vonult és átkelt a Saw-nak nevezett folyón

\footnotetext{
1427 A hasonló latin névalakok miatt összetévesztésre legutóbb Papp Sándor - Johann Christian Engel óta újfent felhívta már a figyelmet. Papp 2004. 46.

${ }^{1428}$ Philippides 1900. 27. „He decided to conquer Buda by the sword, the large, strongly fortified city, and key of Hungary."

${ }^{1429}$ Baán 2013. 666.

1430 1573-1575 között Makariosz Melisszénosz monembasiai metrpolita állította össze.

1431 Baán 2013. 431.

1432 Baán 2013. 432.

${ }^{1433}$ The Bondage and travels of Johann Schiltberger, a native of Bavaria, in Europe, Asia, and Africa 13961427. Translated J. Buchan Telfer. New York 1879. A továbbiakban: Buchan 1879.
} 
egy Mittrotz-nak nevezett városnál. Elfoglalta azt és a környezö vidéket. Ezután, amikor behatolt Petaw vidékére, és vele együtt elrabolt a mondott vidékröl 16000 embert feleségeikkel és gyermekeikkel és minden vagyonukkal. Elfoglalta az említett várost és felégette." 1434

A 3. fejezetben leírtak szerint tehát Bayezid (Wyasit) a csata után három nappal (sic!) már Magyarországba vezette hadseregét, amely tény alapján is méltán kiérdemelhetné a „Villám” melléknevet. Átkelt a „Saw”-folyón egy „Mittrotz” nevű helyen, amelyet elfoglalt, elpusztította a környező vidéket. Ezután behatolt egy „Petaw” hercegségének nevezett területre, elfoglalta és felégette a várost, 16000 embert ${ }^{1435}$ rabszolgává tett. Schiltbergert fogolyként ezalatt Gallipoliból Burszába, az akkori fővárosba vitték, ahol még 12 évig szolgált a szultánnak. Imber a Száva-folyót és Mitrovicát, és Buda városát vélte felfedezni e beszámolóban. ${ }^{1436}$

A bajor beszámoló fejezetcíme arról szól, hogyan hódított meg Bayezid egy egész országot. Ezt erősíti meg a már idézett forrásunk, az ún. Névtelen „Bolgár” Krónika. A vonatkozó részt közlöm: „Bayezid nem vesztegette az idöt, hanem útnak indult onnan (t. i. a nikápolyi csata helyszínéről) és nyugat felé fordult, meghóditva cárságokat és országokat. Elfogatta és legyözte Stratsimir cárt a 6906. évben (=1397-1398). Ezután betört a magyar földre, egészen hamuvá felégetve azt, ahogyan a láng felperzseli az erdöt, így kifosztotta a vidéket egészen Buda városáig. Nagy győzelemmel tért onnan vissza, ahogyan a régi időkben Nabukodonozor jött vissza Izraelböl Babilónba, maga elött vezetve a mezitlábas és bilincsekbe vert embertömeget, ahogyan a Szent Írás beteljesedett: »A szenvedés felé fordultam, amikor egy tövis megszúrt." A nagy győzelemböl való visszatéréskor, Bayezid megérkezett Makedóniába, átment Drinápolyon és Neapolison ${ }^{1437}$ és azt tervezte, hogy Konstantinápolyt támadja meg."1438

${ }^{1434}$ „How Wyasit subjugated an entire country. On the third day after the Turkish king had killed the people and sent us prisoners to the above named city, he marched upon Ungern and crossed the river called Saw, at a city called Mittrotz, and took it and all the country around; and then he went into the Duchy of Petaw, and took with him from the said country sixteen thousand men with their wives and children and all their property, and took the city of above name and burnt it; and the people he took away and some he left in Greece." Buchan 1879. 6.

${ }^{1435}$ Imber itt egyébként tévesen 15000 foglyot írt. Imber 1990. 47.

${ }^{1436}$ Imber 1990. 47.

${ }^{1437}$ Neapolis, Philippi melletti város, ahol Pál apostol is átutazott (Ap. Csel. 16: 11), a mai Kavala.

1438 Petkov 2008. 461, 27-462, 3. „Bayazid did not waste time, but set off from there and turned westwards, conquering tsardoms and lands. He captured and subjugated Tsar Stratsimir in the year 6906. (Then) he invaded the Magyar land, burning and reducing it to ashes; just like the blaze burns down the forest, so did he loot the land all the way to the very city of Buda. He came back from there with a great victory, as in ancient times Nebuchadnezzar came back from Israel to Babilon, driving before himself a barefooted and shakled mulitude, so that the Scripture was fulfilled: „I turned to suffering when a thorn pricked 
D. Nastaze kutatásai szerint azonban a krónika - egészében véve - nem bolgár, hanem bizánci nézőpontból mutatja be az eseményeket. Arra a következtetésre jutott, hogy ez feltehetően átdolgozása, bolgár fordítása a bizánci történetíró Joannész Khortaszmenosz (kb. 1370-1437) elveszett Krónikájának. ${ }^{1439}$ Így közvetve a bizánci források közé lehetne sorolnunk. Anthony Kaldellis - bár Nastaze véleményével szemben nem Khortaszmenosz munkájának tartja e bizánci Krónikát - filológiai vizsgálatában kimutatta, hogy Khalkokondülész forrásként több ponton felhasználta azt munkájában. Így ez rokoníthatja Khalkokondülész és a Krónika Bayezid hadjáratáról szóló beszámolóját is. ${ }^{1440}$

Mert ez a krónika I. Bayezid olyan hadjáratáról tudósít, amely az ország belsejéig is elért és a szultán számára sikeres volt. ${ }^{1441}$ Ha İbn Kemal beszámolóját a Szerémség elfoglalásáról a nikápolyi csata után helyezzük el, ez nagyon is valószínü. A krónika időrendjében - azt is megemlítette, hogy ez már Stracimir-t, a vidini bolgár cár (13561396) elfogása után történt, 1398-ban. Azonban ebben az évben Bayezid az anatóliai hadszíntéren volt, így Imber egyedüli lehetséges dátumként közvetlenül a nikápolyi csata utáni időszakot, 1396 őszét állapítja meg. ${ }^{1442}$

Megkerülhetetlen és becses forrás a nikápolyi csata eseményeire a francia krónikaíró, Jean Froissart munkája. A szerző szerint Zsigmond király a rodoszi johannita nagymesterrel, Philibert de Naillac-kal hetedmagával egy rodoszi bárkán tudott megmenekülni, hátrahagyva minden poggyászát, ékszereit. A csata után Bayezid szultán megkereste a magyar király díszes sátrát, és ott tanácskozásra hívta főembereit. Kijelentette, hogy mihamarabb a Magyar Királyság ellen fog vonulni és azt meghódítja. A csata utáni rendelkezései között volt, hogy megtudakolja a magyar király él-e vagy meghalt. Azután Bayezid felkereste a csatamezőt. A foglyok közül összegyüjtette a förangú nemeseket, akikért nagy váltságdíjat remélt, a többi foglyot pedig kivégeztette. Miután meggyőződött arról, hogy a király élve megmenekült, elhatározta, hogy visszatér Burszába, és ide hozatta az életben hagyott foglyokat is. ${ }^{1443}$ Tudjuk, így menekült meg Schiltberger is. A francia krónikás nem említ csata utáni közvetlen szultáni hadjáratot, csak

me." On his way back from that great victory Bayazid arrived in Macedonia, went through Adrianopolis and Neapolis, and from there planned to go against the City of Constantine."

1439 Anthony Kaldellis: The greek sources of Laonikos Chalkokondyles' Histories. In.: Greek, Roman, and Byzantine Studies 52 (2012) 751. A továbbiakban: Kaldellis 2012.

${ }^{1440}$ Kaldellis 2012. 752-753.

${ }^{1441}$ Imber 1990. 47. „Betört Magyarország földjére, felgyújtva és porig égetve, elpusztitotta egészen Budáig, ahonnan nagy gyözelemmel tért vissza, maga elött vezetve a mezítlábas és összekötözött kezü, menetelö foglyok sokaságát."

${ }^{1442}$ Imber 1990. 47. ,it is clear that he removed Sratsimir in the autumn of 1396, immediately after the battle of Nikopol."

${ }^{1443}$ Froissart 1904. 446-447. 
azt, hogy Bayezid ekkor eldöntötte: mihamarabb az ország ellen indul, hogy azt meghódítsa. A szerző ezen információját valószínűleg a csatából megmenekültektől merítette, akik már nem tudtak beszámolni gyors hadmozdulatról.

A források között kutatva, csak sajnálni tudjuk, hogy Eberhard Windecke emlékirata Zsigmond királyról és koráról címü munkájában - németes precizitással - „,kifelejtette” az 1396. évben történt események közül a nikápolyi vereséget, csak Vitold litván nagyfejedelemnek és feleségének ajándékairól szól, amelyeket a királynak és a királynénak ekkoriban ajándékoztak (13-16. fejezetek). ${ }^{1444}$

A magyar énekmondó hagyományban a 16. században Tinódi Lantos Sebestyén (1505k-1556): Zsigmond császárnak fogságáról és szabadulásáról Magyarországban történt dolgáról című históriájában nem bukkanunk a szultáni támadás nyomára, viszont megemlíti, hogy Zsigmond nem mert hazajönni.

„Jőni nem merte az Zsigmond király is Magyarországba, mert magyaroktól igen fél vala, hogy ott vesztek vala..."1445

Az európai kontinensen kívül a majdnem kortárs Christopher Marlowe (1564-1593), kora egyetemi szinten képzett, magas mủveltségű drámaírója, Nagy Tamerlán címü, 1587/1588-ban írt drámájában, majdnem két évszázad múltán is, jelentkezett az a félelemmel átszőtt életérzés, amely egész Európát megrázva „villám” Bayezid nikápolyi győzelmét „nemrég” követte. Ez sem támogatja azt a feltevést, hogy egy céltalan győzelem után a szultán visszavonult volna.

A fenti releváns forrásokban a Nikápoly utáni hadjáratot elkülönítem a Nikápoly előttitől, amely föleg az İnalcık-féle dokumentum alapján a Temes vidékre tört be. Ezt pedig egy második magyarországi hadjáratnak tekintem, amely nagyobb volumenü lehetett, mint az első, és akár elérte Budát, akár csak a környékét, a célja nagyon is az lehetett.

Ezek után jogosan felvetődik a kérdés: miért állt volna meg Bayezid szultán a nikápolyi győzelme után? Miért nem használta ki stratégiai szempontból a győzelmét? Mert a nikápolyi csatáról szóló hazai szakmunkákból látszólag ez kép tünik elénkbe. A szerzőik többnyire a katonai veszteségek és föleg a magyar belpolitikai következmények

\footnotetext{
${ }^{1444}$ Windecke 2008. 27-28.

${ }^{1445}$ In.:Tinódi 1881. 359.
} 
számbavételénél megállnak. ${ }^{1446}$ Valószínűleg azért, mert a magyar források ezekről hallgatnak. Pedig 1977-ben például Stanford J. Shaw az Oszmán Birodalomról írt átfogó munkájában hasonlóan tette fel a kérdést a nikápolyi csatát megnyerő Bayezid kapcsán. Miért ne használná fel arra a győzelmét, hogy beljebb nyomuljon Európába? ${ }^{1447}$ Shaw szerint erre inkább a ghazi-hagyományt követő Çandarl1-család ösztönözte. A keresztény tanácsadói viszont inkább arra, hogy hagyja el Európát és térjen vissza Anatóliába a türk fejedelemségek meghódítására. Míg visszatért Drinápolyba seregei betörtek Havasalföldre, Magyarországba, Boszniába és meghódították az utolsó bolgár államot, a Vidini Cárságot. $^{1448}$

Ne felejtsük el, hogy maga az uralkodó, Zsigmond alig tudott elmenekülni a csatából. Az egyedüli menekülési útja a Dunán kínálkozott. Innen hajóval Konstantinápolyba, II. Palaiologosz Mánuél bizánci császárhoz (1391-1425) ment a kíséretével. Itt egy újabb és gyors törökellenes szövetség létrehozásán fáradozott, amelyben fontos szerepet kaptak volna a rodoszi johanniták is. ${ }^{1449}$

Ebbéli szándékát mutatja az innen írt levele a johannita nagymesterhez, - akivel a bizánci források szerint egy bárkában menekült el a nikápolyi csatából - Philibert de Naillachoz (1395-1421). ${ }^{1450}$ „Ami bennünket illet, a legrövidebb idön belül visszatérünk országunkba, összehívjuk és összegyüjtjük a segíteni kész keresztényeket és mindenkivel tárgyalni fogunk a kereszténység szabadságának megvédése érdekében." (Rázsó Gyula fordítása). ${ }^{1451}$ Azonban Zsigmond sokáig kénytelen volt távol lenni országától. A Balkánfélszigetet megkerülve, tengeri úton, 1397 februárjában érkezett vissza Magyarországra! ${ }^{1452}$ Az Engel Pál és C. Tóth Norbert-féle Zsigmond-itinerárium szerint a király 1396 végéig Konstantinápolyban, majd 1397. január 4-én Spalatóban, februárban (3-6.) Kninben, Toplicában volt, február 27-én keltezett oklevelet Körösön, Budára április

\footnotetext{
${ }^{1446}$ Néhány példa: Rázsó Gyula: Az első harcok, a nikápolyi hadjárat. In.: Magyarország hadtörténete két kötetben. I. kötet. Budapest 1984. 87; Generál 1987. 44; Engel 1990. 321-322; Pálosfalvi 2005. 50-58; C. Tóth 2009. 34-39.

${ }^{1447}$ Stanford J. Shaw: History of the Ottoman Empire and Modern Turkey. Volume 1. Empire of the Gazis: The Rise and Decline of the Ottoman Empire, 1280-1808. Cambridge 1977. 33. A továbbiakban: Shaw 1977.

${ }^{1448}$ Shaw 1977. 34.

${ }^{1449}$ Rázsó 1973. 421. A johanniták oszmán-török ellenes harcaira és segítségére a 15. században is szükség volt. Lásd a 2. 5. fejezetet.

${ }^{1450}$ Rázsó Pihilbert Noilles névalakban említette.

${ }^{1451}$ Idézi: Rázsó 1973. 422.

${ }^{1452}$ Engel 1994. 276.
} 
1-re érhetett. ${ }^{1453}$ Elgondolkodtató az a tény is, hogy Zsigmond miért nem azon a hadjárati útvonalon vonult vissza, amelyen érkezett a szárazföldi útján? Valószínüleg, mert Bayezid azt elzárta, ezért is volt szükséges ez hatalmas tengeri kerülőút.

Véleményem szerint alaposan feltételezhető, hogy a „villám”-gyorsaságáról híres I. Bayezid szultán szándéka a nikápolyi győzelme után az lehetett, hogy még addig akart gyors ellentámadást indítani az ország ellen, amíg a magyar király távol volt az országától és ellenállásra képes hadsereggel sem rendelkezett. Erről szólnak az ismertetett bizánci, német és a névtelen „bolgár” forrásaink. Így fogalmazódhatott meg talán távolabbi célként az ország meghódításának terve is.

De Bayezidnek adódott más indoka is egy ilyen gyors hadjáratra, mégpedig a Zsigmond uralmával ellenséges főurak felhasználásával. Ezt erősíti meg Thuróczy János ismert krónika fejezete is (207. fejezet). Csáktornyai Lackfi István ,amikor Zsigmond király a Nikápoly közelében elszenvedett vereség után a tengerparti vidékeken tartózkodott...követeket küldött Bajazidhoz, a törökök császárához...azzal a feltétellel, hogy legyen a segítségére (Nápolyi) Lászlónak Zsigmond király ellenében; azt is mondogatták, hogy ennek bizonyságául hatalmas török csapatokat hozott be a Száva és a Dráva folyók között fekvő magyar területekre, s hogy ezekkel súlyos pusztítást vitt ott véghez. Ezelött a törökök még nem keresték fel a magyar földet. Ez volt a törökök elsö bevonulása Magyarországra." (Bellus Ibolya fordítása) ${ }^{1454}$ Bár Mályusz Elemér ezt a történetet csupán Lackfi kivégzése (1397. február 22.) ürügyének tartotta, ${ }^{1455}$ de Papp Sándorral egyetértve ${ }^{1456}$ valószínübb, hogy ez a történet egy reguláris erőkkel végrehajtott támadást takar, esetleg a szultán vezetésével és a hódítás igényével, kihasználva az ország belső megosztottságát. Bár ebben a passzusban Thuróczy nem szól szultánról, de oszmán betörésről igen. Ez az értesülés pedig İbn Kemal fontos közléseit megerősíti, kiegészíti. Amennyiben kronológiailag erre vonatkoztatjuk tudósítását, a Lackfi-féle oszmán politikának a Száva és a Dráva vidékén komoly következményei lettek. Nem csupán oszmán haderők behívásáról és pusztításáról volt szó, hanem a Szerémség átmeneti meghódoltatásáról és elcsatolásáról is.

Számunkra az 1396. év azért érdekes, mert egy velencei oklevélből Bayezid szultánnak a nikápolyi csata utáni támadásáról újfent értesülünk, amelyre ezúton kívánom felhívni a

\footnotetext{
${ }^{1453}$ Engel Pál- C. Tóth Norbert: Itineraria regum et reginarum (1382-1438) Zsigmond király és császár (1382-1437) itineráriumát készítette Engel Pál. Kiegészítette, szerkesztette és mutatóval ellátta C. Tóth Norbert. Budapest 2005. 72-73. (Engel -C. Tóth 2005)

1454 Thuróczy 2001. 250, 11-14, 18-22.

1455 Mályusz 1984. 37-38.

${ }^{1456}$ Papp 2004. 54.
} 
figyelmet. Az 1396. december 16.-i keltezésü oklevél szerint ugyanis Velence arra a hírre, hogy Bayezid betört Magyarország területére, egy bizalmas ember kiküldését határozta el a prelátusok és bárók rendelkezéseinek kipuhatolására. ${ }^{1457}$ A király hosszú távollétét igazolva egy ugyanezen napra keltezett oklevél pedig azt tudatta a magyar föurakkal, hogy Zsigmond ekkor több hajóval az Adriai-tengerre érkezett. ${ }^{1458}$ Azaz még mindig nem volt az országban.

A velencei diplomácia frissen informáltságára jó példa egy október 28-i oklevél, amelyben Velence a török hadjáratról érkezett hírek hatására két megbízott küldését határozta el. ${ }^{1459}$ Az oklevélből sajnos nem derül ki egyértelmüen, hogy ez a török hadjárat a nikápolyi csatavesztésre utal vagy esetleg az azt követő „villám” gyors, magyarországi szultáni támadásra. Mindenesetre az 1394 óta szultáni blokádtól szenvedő Konstantinápolyban tartózkodó hajóhada számára utasítást küldött, amely tény - egy hónappal a nikápolyi csata után - haditaktikai lépésnek is tekinthető. ${ }^{1460}$ A közeljövőben tervezett újabb törökellenes hadjárat tervét erösíti meg az az október 31-i oklevél is, amely szerint Velence majd a török hadjárattal kapcsolatban megkeresi levélben a pápát, a francia és az angol királyt és a császárt is. ${ }^{1461}$ Azonban 1397-ben és ezután Magyarország nem került szembe oszmán-török támadással, mert Bayezid keletre fordult: Anatóliába. A karamán emír, Aleaddin lázadásával volt elfoglalva. 1397-ben bevette fővárosát, Konya-t, őt magát pedig kivégeztette. ${ }^{1462}$

I. Bayezid Magyarország ellen indított második, gyors hadjáratának időpontját hozzávetőlegesen tudjuk meghatározni. Mindenképpen a nikápolyi csatavesztést hamarosan kellett követnie. A szultán gyors ellentámadást indíthatott. Az 1396. december 16-i oklevél pedig már megtörtént eseményként ismertette, hiszen ekkor küldött az országba egy hírszerzőt. De egy 1397. március 8-án keltezett oklevél idején már az országban ez a török veszély is elmúlhatott, mert Velence megengedi a hírszerzés végett Magyarországra küldött megbízottjának a visszatérést. ${ }^{1463}$

Bayezid hadjáratainak a magyar okleveles forrásokban alig bukkanunk a nyomára, nyilvánvalóan e forrástípus sajátosságainak megfelelően. Mert az oklevelek létrejöttének

\footnotetext{
${ }^{1457}$ Mályusz 1951. 506, 4569. sz. okl. Az oklevél elérhetőségét Mályusz Elemér megadta. Shafárik: Acta archivi Veneti spectantia ad historiam Serborum et reliquorum Slavorum meridionalium. Belgrad, 187072. 326.

${ }^{1458}$ Mályusz 1951. 506, 4570. sz. okl.

${ }^{1459}$ Mályusz 1951. 503, 4539. sz. okl.

${ }^{1460}$ Mályusz 1951. 503, 4540. sz. okl.

${ }^{1461}$ Mályusz 1951. 503, 4542. sz. okl.

1462 Imber 2002. 15.

${ }^{1463}$ Mályusz 1951. 515, 4662. sz. okl.
} 
alapvetően jogi célja van, így csak közvetetten tudósítnak egy-egy hadieseményről. Másrészt háborús állapotokban szünetel az ítélkezés, a perek intézését elhalasztják. Egy ilyen kutatásban azonban a perhalasztások értékesek a számunkra, mert a hadi szolgálatban, hadjáratban való részvétel egy időre felfüggesztette a bírói eljárásokat is. A birtokadományozások narratioja is hordozhat értékes információt, ha a megadományozott személynek valamely háborúban kifejtett érdemeit is megnevezi.

Figyelembe véve I. Bayezid szultán nyugati hadszíntéren való tartózkodási lehetőségeit, ennek megfelelően az 1389-1398 közötti, közel tíz évnyi, megjelentetett okleveles anyagát tekintettem át, párhuzamosan követve Engel Pál 1998-as tanulmányának adataival. ${ }^{1464} \mathrm{Az}$ oklevelekben elsősorban Zsigmond király törökellenes hadjáratait találjuk. ${ }^{1465}$ Néha

${ }^{1464}$ Mályusz Elemér: Zsigmond kori oklevéltár I. (1387-1399). Budapest 1951. A továbbiakban: Mályusz 1951; Thallóczy-Áldásy: Magyarország melléktartományainak oklevéltára II. A Magyarország és Szerbia közötti összeköttetések oklevéltára. 1198-1526. 1907. (A továbbiakban: Thallóczy-Áldásy 1907).

1465 1390. május 8-án a István nádor - a hadjárat miatt - pert halasztott (DL 52 683, Mályusz 1951. 167, 1488. sz. okl.). Július 10-én Zsigmond birtokot adományozott Keresztúri Miklósnak Gomnec vár ostrománál szerzett érdemekért (DL 285 494, Mályusz 1951. 177, 1586. sz. okl.). Szeptember 1-én Mária királynő a királyi hadba vonult Bátmonostori László perét halasztatta el a bíróságokon. (DL 78 057, Mályusz 1951. 185, 1647. sz. okl.). Szeptember 23-án, Temesváron Zsigmond a hadjárat miatt halasztotta el a Szeretvaiak perét. (DL 52 695, Mályusz 1951. 188, 1668. sz. okl; Thallóczy-Áldásy 1907. 26). Szeptember 29-én Zsigmond Olnáson (Keve, Torontál megye) Perényi Miklós szörényi bánnak adományozott birtokot ,föleg a törökök elleni harcban szerzett érdemeiért." (DL 71 905, DL 7645, Mályusz 1951. 189, 1674. sz. ok1.) November 3-án már szerbiai hadieseményről tudunk „in descensu nostro campestri in terra Rascie prope castrum Ostrowech.” (DL 84 307, Mályusz 1951. 194, 1725. sz. okl.) November 4-én, 5-én, 7-én István nádor, Bebek Imre országbíró pert halasztott a hadjárat miatt. (DL 52 699, DL 52 702, DL 52 707, Mályusz1951. 195, 1731. 1736, 1739. sz. okl.; Thallóczy-Áldásy 1907. 26, 30. sz. okl.)

1391-ben IX. Bonifác pápa Zsigmondnak és a törökök, bosnyákok ellen indulóknak adott bünbocsánatot. (Mályusz 1951. 254, 2304. sz. okl.)

1392. február 25-én Zsigmond újra pert halasztott október 6-ra (Szent Mihály nyolcadára), mert a peres fél Szerbia végvidékein a törökök elleni szolgálatban volt:,,in nostris specialibus servitiis in confinibus regni Rascie contra Turcos" (DL 52 757, Mályusz 1951. 262, 2407. sz. ok1.) Március 28-án pedig már az induló seregről tudunk ,contra Turcos et emulos ac scismaticos”. (DL 52 758, Mályusz 1951. 269, 2454. sz. okl.) Április 27-én Zsigmond felmentett egy idős kassai polgárt és familiárisát öregségük miatt a jelen királyi hadjáratban való részvétel alól. (DL 60 470, Mályusz 1951. 272, 2491 . sz. okl.) Június 24-én, a Krassó folyó melletti (iuxta fluvium Crassow) táborban a király Sárói László temesi és liptói ispánt, az akkori királyi hadsereg kapitányát (capitaneus generalis) intette, mert vonakodott a szolgálatban részt venni és alattomban eltávozott. (DL 94 446, Mályusz 1951. 278, 2543. sz. okl.). Július 9-én - a kiadott oklevelek szerint - a szerbiai Braničevo vidékén volt a királyi tábor. (, in descensu nostro campestri in districtu Branchow", DL 7799, Mályusz 1951. 279, 2559-2560. sz. okl.). Augusztus 6-án szintén. (,in districtu Branchow”, DL 52 764, Mályusz 1951. 281, 2585. sz. okl) Majd visszafelé a dunai révnél (Mályusz 1951. 281, 2587. sz. okl.), augusztus 9-én már Kevén. (Mályusz 1951. 281, 2588. sz. okl.) A király augusztus 14-én pedig Temesváron tartózkodott. (DL 95 922, Mályusz 1951. 282, 2596. sz. okl.). Augusztus 21-én a dunai átkelő révnél (,nuper in expeditione nostra exercituali contra Turcos in regno Rascie prope portum Danubii habita" DL 7805, Mályusz 1951. 282, 2600. sz. okl.); augusztus 24én a király a szerémségi harcokról tett említést. („pridem in conflictu contra Thurcos in comitatu Syrmiensi prope Nagengh habito" DL 7806, Mályusz 1951. 283, 2605. sz. okl; Thallóczy-Áldásy 1907. 34. sz. okl.)

1393. február 19-én, Budán, Zsigmond a jelenlegi hadjárat miatt pert halasztott („propter presentem nostram expeditionem exercitualem”, DL 7841, Mályusz 1951. 308, 2837. sz. okl.) Több hadmozdulatról ez évben nem tudunk. 
felbukkan a török betörés emléke is. De ezekben nem történik említés Bayezid szultánról. Így 1392. február 19-én Zsigmond Ilsvai Péter fia Leusták királyi ajtónálló mesternek és Kapolyai Benedek fia János volt vajdának ad adományt a „végvidékeken támadó hütlenek és pogányok elleni hadjáratban szerzett érdemeikért."1466 1392. augusztus 14-én pedig a király már Temesváron adományozott azon érdemekért „,amelyeket az ország végvidékeit háborgató törökök, a hütlen scismaticuok ellen, a mostani szerencsés hadjáratban szeme láttára harcolva szereztek." ${ }^{1467}$ Egy téli betörés emlékét őrizheti az az 1393. február 6-i oklevél, amelyben a király Szent György nyolcadára (május 1.) perhalasztást rendelt el, mert a törökök Magyarország alsóbb részein voltak (,,in partibus inferioribus”). ${ }^{1468}$

Csupán egyetlen olyan oklevél van, amelyben - egy Magyarország elleni szultáni hadjárat felbukkan. Az oklevél eddig is ismert volt, de ilyen összefüggésben nem tárgyalták. ${ }^{1469}$ Zsigmond király Cillei Hermannak adományozta Varasd városát, tekintettel néhai atyai testvérére, Cillei Vilmos érdemeire. Az 1397. augusztus 14-i oklevél narratiojában I. Bayezid hatalmas hadseregéről és a Keve mellett állomásozó szultáni

1394. április 2-án Dabissa István, Szerbia és Bosznia királya birtokot adományozott Zsigmond szolgájának a török hadjáratban tanúsított vitézségéért. (Mályusz 1951. 371, 3351. sz. okl) Május 16-án már az alsóbb részekre indított hadmozdulatokról tudunk. (,ad presentem nostram et regni nostri expeditionem exercitualem versus partes inferiores", DL 102 416, Mályusz 1951. 379, 3431. sz. okl.) Augusztus 24-én a Szörényi melletti táborból keltezett az uralkodó. (,in campestri nostro exercituali prope Zeuerinum” DL 7971, Mályusz 1951. 393, 3597. sz. ok1.) Szeptember 6-án keltezett oklevélböl pedig már a következő évre tervezett hadjárat előkészületeit ismerhetjük meg. Azaz Velence segítséget akkor fog majd adni, ha más állam sem vonja ki ez alól magát. (Mályusz 1951. 395, 3615. sz. okl.)

1395. február 14-én a király már perhalasztást adott, mert a fél „a törökök és az ország más ellenségei ellen a királyi seregben fog vonulni”. (DL 71 439, Mályusz 1951. 418, 3824. sz. okl.) Máricus 7-én pedig Mircea, havasalföldi vajda eskü alatt vallotta, hogy részt vesz a török elleni háborúban (DL 8043, Mályusz 1951. 421, 3864. sz. okl. Ugyanígy, május 15-én, Bátmonostori László is kinyilvánította, hogy részt szándékozik venni a törökök elleni hadjáratban (Mályusz 1951. 437, 3980. sz. okl.) Május 3-án a király az Isten által vezetett török elleni hadjáratról szól. (,propter presentem nostram expeditionem exercitualem quam deo duce contra Turcos et alios regni nostri emulos duximus", Mályusz 1951. 433, 3955. sz. okl.) Az ország határain túlra vezett hadjárat említése bukkan elő az október 14-én keltezett oklevélből. (,,in partibus nostris Transalpinis”, DL 84 801, Mályusz 1951. 451, 4114. sz. okl) Október 2án pedig a király Miskolc mezővárosnak pallosjogot adományozott „a törökországi hadjárat céljára beszolgáltatott adókért." (Mályusz 1951. 450, 4096. sz. okl.)

Ez már az 1396. évi keresztes hadjárat előkészületeit sejteti. A nikápolyi csatavesztést és a magyarország elleni szultáni támadást követően ismét királyi előkészületekröl értesülünk.

1397. április 7-én a velencei doge arról tudott, hogy Zsigmond elhatározta a felkészülést az új háborúra. (Mályusz 1951. 519, 4699. sz. okl.) Május 22-én a király a török hadjárat miatt általános törvényszünetet rendelt el. (DL 78 210, Mályusz 1951. 527, 4780. sz. okl.) A hadjárat költségeire pénzt is kölcsönzött (,pro presenti nostra valida exercituali expeditione contra Turcos habita” Mályusz 1951. 530, 4807. sz. okl.)

Az 1398. évben már nincs adatunk török ellenes hadjáratról.

${ }^{1466}$ DL 7 755, Mályusz 1951. 261, 2396. sz. okl.

${ }^{1467}$ DL 95 922, Mályusz 1951. 282, 2596. sz. okl.

${ }^{1468}$ DL 239 116, Mályusz 1951. 305, 2813. sz. okl.

1469 Az oklevél szövege kiadva: Codex Diplomaticus Hungariae ecclesiasticus ac civilis. Studio et opera Georgii Fejér. Tomi X. Volumen II. Ab anno Christi 1392-1400. Budae 1834. 418-425. (247. sz. okl.) A továbbiakban: Fejér X/II. 1834. Magyar fordítás, részletekben: Középkori Históriák Oklevelekben (10021410) A szövegeket válogatta, az előszót és a jegyzeteket írta Kristó Gyula. Szeged 2000. 351-354. (167. oklevél). (A továbbiakban: KHO) Azonban 1399. január 27. dátummal jelezve. 
haderőről hallunk. ${ }^{1470}$ „...amikor Szerbia Királysága felé útra keltünk, és Bayzathnak, a törökök császárnak hatalmas hadereje Keve közelében, a Dunán túl, mireánk, valamint a mi hü fegyveres követöinkre cselt tervezgetve várakozott, de ugyanazon törököknek ezen hadereje mielöttünk visszavonulást hajtott végre. És mi az Izdrylnek ${ }^{1471}$ nevezett vár felé, a mondott Szerb Királyság határán belül, és ugyanezen királyságban beljebb, elörenyomultunk, pusztítottunk és sok mindent felégettünk. Az elöbb mondott Vilmos úr mindig a mi oldalunkon állva, mint Isten leghüségesebb bajnoka és mi irántunk, valamint a mi szent királyi koronánk iránt a legnemesebb szolgánknak bizonyult." ${ }^{1472}$ Az oklevél szövege csak ezután (,„porro”) tér rá a nikápolyi hadjáratra és magára a csatára. ${ }^{1473} \mathrm{Ha}$ ez narratio az első szultáni hadjáratra vonatkoztatható - márpedig a magyar király ebben személyesen részt vett - az egyetlen említése annak, volt valamilyen királyi ellentámadás, sőt szerbiai betörés is a gyorsan kivonuló szultáni haderő mögött.

A fenti eseményeket megerősíti, és jól kiegészíti az az osztrák krónikarészlet, amelyre már Engel Pál is felhívta a figyelmet, de máshogyan értelmezte. Csak a török betörésre vonatkozó mondatot közölte, a folytatását nem. Véleménye szerint a szultán várta Keve közelében Zsigmond seregét és megpróbálta útját állni, majd kitért az összecsapás elől és visszavonult. $^{1474}$

Más értelmezés is lehetséges. A 95 Uralkodó Osztrák Krónikája 1392-re teszi a szultán támadását és időben csak ezt követően említi meg Cillei Vilmos gróf katonai segítségét. A vonatkozó teljes részlet a következö: „Krisztus születése után 1392-ben a törökök nagy erövel Magyarország ellen jöttek, és Buda felé vonulva pusztítottak az országban. Sok keresztényt is foglyul ejtettek. Így Zsigmond király segitségül hívta az urakat. Graf Wilhalm von Cilli lovon nagy csapattal segitségére indult; útközben számos lovagja és szolgája

\footnotetext{
${ }^{1470}$ Thallóczy-Áldásy 1907. 39, 89. sz. okl. Az oklevél szövege kiadva: Fejér X/II. 1834. 418-425. (247. sz. okl.)

${ }^{1471}$ Ma Ždrelo Szerbiában. KHO 352.

${ }^{1472}$ Fejér 1834. 419-420. „....versus regnum Rascie proficiscentibus, magnaque potentia Bayzath, Turcorum Imperatoris, prope Kewe vltra Danubium, nos, nostrosque fideles seqauces amigeros insidiose prestolante, sed huiusmodi potentia Turcorum eorundem ante nos gressus retroflexos faciente, nobisque versus castrum Izdryl appellatum, intra ambitum dicti regni Rascie habitum, regno vlterus in eodem progredientibus, deuastationesque et incendia magna committentibus, prefatus condam Dominus Wilhelmus, nostro lateri semper adherendo, vti atleta Dei fidelissimus, nobis et sacro nostro dyademati gratiosissimos exhibuit famulatus."

${ }^{1473}$ Fejér 1834. 420-421.

${ }^{1474}$ Engel 1998. 573.
} 
meghalt, és maga Cillei gróf is betegen ért Bécsbe, ahol meg is halt."1475 (Sántáné Túri Ágnes fordítása)

Véleményem szerint mindkét forrás a szultáni hadjárat más-más szakaszára vonatkozik. Az osztrák krónika a Buda felé támadó, az országba betörő szultáni hadjáratról szól. Több részletet erről nem tudunk. Zsigmond segélyhívása és ellentámadása, Cillei Vilmos hathatós támogatásával csak a visszavonuló török sereg kivonulására kezdődhetett meg. Eszerint értelmezve - terminus post quem - az 1397. augusztus 17-i oklevél szerint Zsigmond király nem a bevonuló fősereget, hanem az országból már visszavonuló szultáni sereget követhette. Jól mutatta ezt az is, hogy a szultán már átkelt Szerbiába. Vagy nem kívánt visszafordulni, vagy cselből színlelt megfutamodást végzett, hogy felvegye a harcot az idegen területen kelepcébe csalt magyar üldözőivel. Némi humorral megjegyezhetnénk, ha Laonikosznak hitelt adunk, a villámsebességű szultán a köszvénnyel küszködve nem „futhatott” olyan gyorsan a magyar sereg előtt. A szultáni haderő felvonulásának pontosabb rekonstrukciójához további kutatásokra van még szükség.

Engel Pál előre feltételezett magyar sikerként megállapította, hogy „győzelem, ütközet híján nem volt, hóditásról nem történik említés." ${ }^{1476}$ A fenti következtetést figyelembe véve viszont ez a döntetlen háború nem volt olyan dicsőséges. Ütközet nem azért nem történt, mert a szultán menekült volna, hanem azért, mert a magyar haderő - a szultán nyomában - csak követni tudta az országból kivonuló török sereget.

Közbevetőleg jegyzem meg, az 1397. évi oklevél összevetése a nem magyar forrásokkal nem segít. Ha az İnalcik-féle forrás útvonal leírásával vetjük össze nincs kapcsolódási pont. Továbbá, az oszmán forrásban arról sem történik említés, hogy Zsigmond seregével találkozott volna a szultáni haderő, nemhogy megfutamodott volna előtte. Ha az osztrák krónikával próbáljuk összehasonlítani, az sem jár különösebb eredménnyel. Mert többségében a Nikápoly utáni hadjáratról szóló forrásokban szerepel Buda, az osztrák krónika pedig egyértelmüen 1392-őt ír és Buda megtámadását, valamint Cillei helytállását bizonygatja, míg az 1397. évi oklevél az ország belseje felé támadó török seregről nem tudósít. A fenti gondolatmenetet követve, elképzelhető, hogy a Cillei adománylevél narratiója - a funkciójából adódóan - a szultáni sereg után vonuló királyi sereg érdemeit kissé eltúlozza.

\footnotetext{
${ }^{1475}$ Österreichische Chronik von Den 95 Herrschaften. Herausgegeben von Joseph Seemüller. Hannover und Leipzig 1909. 205. In.: Monumenta Germaniae Historica. Scriptorvm qvi vernacula lingva vsi svnt. Tomus VI. (Seemüller 1909)

${ }^{1476}$ Engel 1998. 575.
} 
Ha az 1397. évi oklevelet Zsigmond 1392. évi itineráriumával vetjük össze, akkor találunk már kapcsolódási pontokat, de ez már messzebbre vezet, mert Nándorfehérvár Bayezid általi ostromával függhet össze.

Véleményemet összegezve az eddigiekben ismertetett forrásokból egyértelmúen kiolvasható, hogy I. Bayezid szultán megtámadta Magyarországot, amely nem minősíthető határ menti betörésnek. Az idézett források adatainak alapján pedig elkülönítettem egymástól egy nikápolyi csata előtti és a havasalföldi hadjárattal összefüggő, valamint egy a nikápolyi csatát követő, gyors szultáni hadjáratot.

„A törökök és a magyarok elsö találkozását jóval korábbra kell tennünk, minthogy a két állam szemtöl szemben állhatott volna egymással."

(Papp Sándor)

\section{3. Ostromolhatta-e I. Bayezid Nándorfehérvárt?}

Nándorfehérvár (Belgrád) 1440. évi első oszmán-török ostromának kutatása indított el a címben megfogalmazott kérdésfeltevéshez, amelynek megválaszolása alapjaiban egészíti ki a korai oszmán-török-magyar háborúk Zsigmond-kori történetét (1387-1437).

Első megközelítésben azt kell mondanunk, hogy egyik, a bayezid-i hadjáratot alátámasztó forrásunkban sincs szó Nándorfehérvár ostromáról. Az İnalcik-féle hadijelentés nem írja. Laonikosz Khalkokondülész szövegrészlete a magyarok elleni harcokban Budát említi meg. A már többször idézett poszt-bizánci, 17. századi, Codex Barberinus Graecus 111. kódexben lévő névtelen krónika ugyan átvette Bayezid Magyarország elleni hódító tervét, de Buda helyett Bodonyt (Vidin) tette meg célpontként.

Ha filológiailag vizsgáljuk a Névtelen Krónika ezen passzusát, talán a várra használt „Magyarország kulcsa” kifejezése ,árulkodó”, amelyet - logikai okfejtéssel élve - aligha értelmezhetünk a vidini bolgár cár, Sratsimir székhelyére, Vidinre. Mert a korabeli nyugati és keleti forrásokban ez a jelző Nándorfehérvárral kapcsolatban volt inkább használatos. Példának okáért ezt nemcsak a nyugati, hanem a keleti, török kútfők is alátámasztják. A korai török források között - Nándorfehérvár II. Murád általi szultáni ostromáról szólva Âşik Paşazade (1400-1484k.) Az Oszmán-ház története című művében e várat a magyar nép kapujának nevezte (Bölüm 111). ${ }^{1477}$ Ugyanígy jellemezte a várat az I. Szelim idejében alkotó történetíró, Nesri is (IX. 183.): „Mondják, hogy Murád szultán, mikor

${ }^{1477}$ Yavuz-Sarac 2007. 170, 398. 
Magyarországot meglátogatta, úgy gondolkozott, hogy Magyarországnak kapuja Nándorfehérvár vára: elhatározta tehát, hogy ezt a kaput megnyitja." (Thúry József fordítása). ${ }^{1478}$ Ugyanezt a metaforát kibővítve, de a vár 1521-es, harmadik szultáni ostromakor Szeád-Eddin A történetek koronája címü munkájában is használta: ,,az ország kapuja és kapujának kulcsa Nándorfehérvár vára lévén ...(Thúry József fordítása). ${ }^{1479}$

A fenti források segítségével nem deríthető ki, hogy ezen hadjáratok alkalmával ostromolhatta meg I. Bayezid szultán Nándorfehérvár várát vagy nem, az azonban bizonyos, hogy egy ilyen ostromra sor került és ezt tekintem a vár „nulladik” szultáni ostromának, megelőzve az 1440. évi első szultáni ostromot. A „nulladik” elnevezést azért érzem találónak, mert kifejezi ugyan egyes történészek kételyét, de nem módosítja a vár későbbi szultáni ostromainak számozását. Az ostrom lehetőségéről először egy közvetett forrásbeszámolót olvashatunk.

Evlia Cselebi, a 17. századi világutazó beszámolója szerint ugyanis Bayezid Nándorfehérvár közelében egy ellenerődöt építtetett fel. Ez a Havále vára, más néven Zsarnó (Sarno). I. Bayezid valószínüleg már korábban tervezte Nándorfehérvárt elfoglalni, mert - Cselebi szerint - egy keresztény hercegnővel való házassága idejében „Nándorfehérvár vára hitetleneinek meggyengítése végett” építtette fel. „Épitője Jildirim Bájázid khán, a ki Sehábeddin pasával épittette, Belgrád vára hitetleneinek meggyengitése végett. Jildirim khán Szemendria kormányzójának, Deli-oglu Dudsia kereszténynek leányát feleségül vevén, Deli-oglu segítségével ezt a várat épitette s a belgrádi hitetleneknek nyugalmat nem engedve, biztonságukat elvágta. Mikor utóbb Jildirim khán Timur khán fogságában meghalt, a szerbek Havále várát elfoglalták." (Karácson Imre fordítása) ${ }^{1480}$

Bayezidnak valóban lett ekkor keresztény felesége is. Lázár szerb fejedelem egyik leánya, Olivera, aki a törvényes négy szultáni feleség közé emelkedett. Lázár fia, Lazarević az ellenerőd felépítésében Cselebi szerint aktívan részt vállalt. A „hitetlenek” kifejezés pedig a magyarokra vonatkozik, akik úgy látszik, hogy ekkor birtokolták a várat. A forrásban szereplő Szendrő vára és Szehabeddin személye időbelileg nem helytálló, de a keresztény feleség alakja mögött gondolhatunk Olivera hercegnöre.

A történeti szakirodalom szerint ez a házasságkötés a rigómezei csata után történt, amikor Lázár fejedelem özvegye, Milica megerősítette a vazallusi függést és leányát,

\footnotetext{
1478 Török történetírók. I. 1893. 55.

1479 Török történetírók. I. 1893. 129

${ }^{1480}$ Karácson 1904. 157.
} 
Maria Olivérát (Miléva) Bayezid feleségeként annak háremébe adta. ${ }^{1481}$ Mindez annak a jele is volt, hogy a szerb vezetés ekkoriban inkább a török vazallitás mellett állt ki. Konstantin Filozófus Lazarević despotáról írt életrajza szerint (Žitije despota Stefana Lazarevića) Bayezid a rigómezei csata után - Colin Imber szerint 1392-ben - küldött követeket Lázár fejedelem özvegyéhez, annak lányát a maga számára kérte. Ennek teljesítésével Lazarević a szultán hübérese lett. ${ }^{1482} \mathrm{Ez}$ azonban nem állította meg a török támadásokat, immár Szerbián át, a Magyar Királyság felé szabaddá vált az út.

A szultán már ekkor kiszemelte vagy tervbe vehette a déli határvédelem kulcsvárának, Nándorfehérvárnak az elfoglalását. Szerencsére van olyan forrásunk, amely kifejezetten Nándorfehérvár „nulladik” ostromáról szól, de ez az oszmán-török források közül az egyetlen is: Oruç Beğ Krónikája, amely Bayezid szultán 1 hónapos ostromkísérletéről tudott, amely végül is eredménytelen marad. E fontos részletet ezúton közlöm:

„És azután Rúmba jött. És Láz tartományba ${ }^{1483}$ érkezett. Elfoglalta Gügerdzsinliket. ${ }^{1484}$ Megtámadta Magyarországot és a magyar földet (tartományt) feldúlta. Belgrádba érkezett. Egy hónapig ostromolta. Anélkül, hogy bevette volna, visszajött, 792. év." (Tóth Hajnalka fordítása) ${ }^{1485}$

Bár ez az adat a nemzetközi turkológiában Franz Babinger tanulmánya ${ }^{1486}$ révén 1944 óta ismert volt, hazánkban mégis visszhangtalan maradt. Talán azért is, mert 1967-ben a magyar történészek számára jobban ismert szerb történész, J. Kalić is megemlítette a középkori Belgrádról szóló könyvében, de nem fogadta el hitelesnek, mondván, hogy a magyar források nem tesznek erről említést. ${ }^{1487}$ A szerb szakirodalomban azonban nem ez az egyedüli álláspont. Mások, mint Gliša Elezović és Gavro Škrivanić - Babingert követve - elfogadták az ostrom létét. ${ }^{1488}$

Az idézett forrásunk - a bizánci forrásokkal ellentétben - nem Buda vagy Vidin (Bodony), hanem Nándorfehérvár szultáni megtámadásáról tudósít! Figyelemre méltó, hogy Oruç kronológiája korábbra, nikápolyi csata előtt, Galambóc várának (Gügerdzsinlik)

\footnotetext{
${ }^{1481}$ Generál 1987. 39. Lásd még: Princess Olivera, a forgotten Serbian heroine. Belgrade 2009.

1482 Imber 1990. 42

${ }^{1483}$ Lázár fejedelem országába, Szerbiába.

1484 Galambóc várát.

${ }^{1485}$ Oruç 2007. 31. E fontos részletet Orovec Borbély Dianna fordításában is közlöm: „És azután Bayezid Ruméliába jött, és megérkezett a Laz Vilajetjébe. Meghóditotta Galambócot. Rajtaütvén a magyarokon, nagy pusztítást végzett a magyar vilajetben. Megérkezett Belgrádba. Egy hónapig ostromolta, de nem tudta bevenni."

${ }^{1486}$ Franz Babinger: Beiträge zur Frühgeschichte der Türkenherrschaft in Rumelien (14.-15. Jahrhundert). Brunn: R. M. Rohrer, 1944. 10. A továbbiakban. Babinger 1944.

${ }^{1487}$ Калић-Мијушковић 1967. 80, 365 (37. lábjegyzet).

1488 Aslantaş 2011. 17.
} 
oszmán elfoglalásához köti ezt a szultáni ostromot. Az Oruç beğ általi időpont a hidzsra 792. éve, azaz 1389. december 20 - 1390. december $8 .{ }^{1489}$ De ez sem sokat segít, mert Galambóc 1427 előtti birtoklásának korai története korántsem teljesen tisztázott.

Tudjuk, hogy a kosovói vereséget követően Lazarević István a szerb várakba török helyőrséget volt kénytelen beengedni. ${ }^{1490}$ Galambóc várának esetében nem egyértelmü, hogy átadás vagy ostrom történt, de a szerb történészek szerint ostrom lehetett. Galambóc vára 1388 táján még szerb, majd 1389 után török kézre került. ${ }^{1491}$

Âşik Paşazade nem írt Nándorfehérvár ostromáról, de amikor Bayezidnek Olivera hercegnőt feleségül adták, Galambóc már török kézen volt és Lazarević levelet írt a szultánnak, amelyben Galambóc várát kérte cserébe. „Továbbá azt mondta: „a boldogságos padisahtól a lánytestvérem szolgálatáért Semendrét szeretném alamizsnaként". A padisah ezt a kívánságát elfogadva mellette még Güverdzsinliket is odaadta. De Nikápolyt nem adták." (Tóth Hajnalka fordítása). ${ }^{1492}$

Tudjuk, hogy Zsigmond magyar király 1390-ben és 1392-ben is (hiába) ostromolta Galambóc várát. ${ }^{1493}$ Bár Sima Čirković szerint 1390 nyarán még magyar kézen volt Galambóc vára. ${ }^{1494}$ Babinger szerint Galambócot 1390-ben foglalják el a törökök és ő a Bayezid általi nándorfehérvári ostromot épp ezen Oruç szöveghely alapján, közvetlenül ez után, 1391-re helyezte. ${ }^{1495}$ Engel Pál 1998-as tanulmányában Zsigmond itineráriumát vizsgálva 1390 decemberére esetleg 1391-re tudta elhelyezni Galambóc török ostromát. Ezt a datálást a lábjegyzetében éppen Oruç Beğ általunk korábban idézett adatával igazolta, azaz a hidzsra 792. évével. Engel itt nagyon közel járhatott a címben feltett kérdésünkhöz, de e szöveghely kapcsán nem szólt Nándorfehérvár ekkori ostromának említéséről. Vélhetően azért, mert Trpković tanulmánya alapján idézte, amely azt is megállapította, hogy Galambócot a törökök nem a szerbektől, hanem a magyaroktól foglalták el. ${ }^{1496}$

A Nándorfehérvár elleni oszmán-török ostromokat legutóbb, 2011-es tanulmányában, Selim Aslantaş tekintette át az oszmán-török források alapján. ${ }^{1497}$ Megállapítása követi az Âşik Paşazade krónikájában leírtakat, véleménye szerint Olivera hercegnő házassága 1390-

\footnotetext{
1489 Aslantaş 2011. 17.

${ }^{1490}$ Engel 1994. 274.

${ }^{1491}$ Engel-Kristó-Kubinyi 1998. 147.

1492 Yavuz-Saraç 2007. 113, 341.

${ }^{1493}$ Szakály 1986. 19; Engel 1998. 571.

1494 Sima Čirković: Godine Kriza i Previranja. Istorija Srpskog Naroda, 1982. II, 48. (Čirković 1982)

${ }^{1495}$ Babinger 1944. 10.

${ }^{1496}$ Engel 1998. 571. (100. lábjegyzet)

${ }^{1497}$ Aslantaş 2011. 13-38.
} 
ben vagy 1391-ben történhetett. ${ }^{1498}$ Ha pedig a házasság Imber általi datálását fogadjuk el, akkor pedig feltehetöen 1392-ben. ${ }^{1499}$

Nándorfehérvár ekkori ostromát a fent említett szerb történészek, Elezović és Škrivanić az Âşik Paşazade által megemlített Alacahisar (Krusevac) környékén végbement csatával hozták kapcsolatba. ${ }^{1500}$

Aslantaş elfogadja Nándorfehérvár ekkori oszmán-török ostromát, de - Kalićhoz hasonlóan - megoldatlan problémának tartja, hogy a magyarországi forrásokban nincs az nyoma az ostromnak. Mi, elfogadva az ostrom lehetőségét, más szempontokat is figyelembe veszünk.

Beláthatjuk, hogy Nándorfehérvár „nulladik” török ostromára Bayezid uralkodása elején vagy - amennyire ez a forrásainkból rekonstruálható - a két magyarországi hadjárata előtt kerülhetett sor. Amennyiben a fenti eseményekhez - akár Galambóc török elfoglalásához, akár a házasságkötéshez - kötjük, akkor ez a lehetséges Nándorfehérvár elleni szultáni ostrom valamikor 1390-1391-1392 közötti évre datálható.

Itt érdemes Oruç Beğ szövegrészletének a folytatását is figyelembe vennünk. Mert a nándorfehérvári ostromkísérlet után, a következő évben (a hidzsra 793. évében) a szultán azon havasalföldi hadjáratát és az Arkhis-folyónál lévő csatát tárgyalja, amelyet az İnalc1kféle oszmán-török hadijelentés is ismertetett. ${ }^{1501}$ „És onnan eljőve elfoglalta Nikápolyt és Szilisztrát és Havasalföldre ment. Havasalföld urát abban az időben a hitetlen (gyaur) Mircsinek hívták. Mircsi a havasalföldi seregével jött és ellenszegült Bayezid szultánnak. Találkoztak egymással és nagy csatát vívtak." (Tóth Hajnalka fordítása). ${ }^{1502}$ Oruç Beğ szerint tehát az ostrom Galambóc oszmán-török elfoglalása után és a havasalföldi hadjárat elött történt.

Az időpont tovább pontosítható is, mégpedig az ostromról „hallgató” magyar okleveles anyag segítségével. Felvetődhet még annak lehetősége is, hogy kapcsolatba hozható Zsigmond király 1392-es szerbiai hadjáratával, Galambóc sikertelen visszafoglalásának kísérletével. ${ }^{1503}$ Megelőzhette a hadmozdulatokat egy év eleji oszmán-török betörés, amelyre válasz volt Zsigmond hadjárata. ${ }^{1504}$ Ennek a hadmozdulatnak útvonala az

\footnotetext{
1498 Aslantaş 2011. 17.

1499 Imber 1990. 42.

${ }^{1500}$ Aslantaş 2011. 18.

${ }^{1501}$ Lásd a 13. 2. fejezetet.

1502 Oruç 2007. 32.

${ }^{1503}$ Ezúton köszönöm C. Tóth Norbert észrevételét.

${ }^{1504}$ Engel 1998. 573.
} 
oklevelekből igen jól nyomon követhető. ${ }^{1505}$ Június 24 -én, a Krassó folyó melletti, ${ }^{1506}$ július 9-én -a kiadott oklevelek szerint- a szerbiai Braničevo vidékén volt a királyi tábor, ${ }^{1507}$ augusztus 6-án szintén, ${ }^{1508}$ majd visszafelé a dunai révnél, ${ }^{1509}$ augusztus 9-én már Kevén. ${ }^{1510}$ A király augusztus 14 -én pedig Temesváron tartózkodott, ${ }^{1511}$ augusztus 21-én a dunai átkelő révnél; ${ }^{1512}$ augusztus 24-én szerémségi harcokról tudunk. ${ }^{1513}$

Ha ezt az itineráriumot összevetjük az İnalcık által felfedezett oszmán-török forrás itineráriumával, már találunk közös földrajzi pontokat: Krassót és Temesvárt. Az 1397. évi Cillei-oklevél pedig kifejezetten Keve közelében említi a szultáni sereget, ahol Zsigmond serege 1392-ben is tartózkodott. Így nagy a valószínűsége, hogy ezek a hadjárati útvonalak mégis egyazon hadjáratra vonatkoznak, amelynek része lehetett Nándorfehérvár rövid és eredménytelen megtámadása is. Akkor pedig - véleményem szerint - ez 1392-ben történhetett. Oruç Beğ elöbb ismertetett adatára támaszkodva feltehető, hogy ez a „nulladik” ostrom esetleg a szultán első hadjáratának is része lett volna. Mert bár az İnalcık-féle, 15. századi török hivatalos jelentésben nem szerepel Nándorfehérvár ostroma, a térképre tekintve, a sereg vonulási útvonalát követve, Nándorfehérvárt is érinteniük kellett. Csak az egykori megfogalmazó azon kijelentése, hogy „Abban az időben Nándorfehérvár és Szendrö várai (castles) még nem voltak kiépítve” sugallja azt, hogy reális, potenciális célként - egyelöre - ekkor (még) nem jött számításba. Szendrő váráról viszont valóban nem lehetett szó, mert azt Branković György szerb fejedelem építette 1428-1430 közötti években. ${ }^{1514}$

Vajon azért nem jöhetett számításba a 14. században a vár elfoglalása, mert valóban nem volt kiépítve vagy a II. Mehmed szultánnak készített török forrás próbálta ilyen jelentéktelennek beállítani? Meglehet, mert II. Mehmed idejében apja, II. Murád szultán első nándorfehérvári kudarca rossz emlékként élhetett még a török köztudatban, ahogyan erről Thuróczy János krónikája is megemlékezett (250. fejezet). ${ }^{1515}$ Erről nézve az İnalc1k-

\footnotetext{
${ }^{1505}$ Lásd: Engel-C. Tóth 2005. 66.

${ }^{1506}$ Mályusz 1951. 278, 2543. sz. okl.

1507 „,in descensu nostro campestri in districtu Branchow”, DL 7799, Mályusz 1951. 279, 2559-2560. sz. okl.

1508 „,in districtu Branchow”, DL 52 764, Mályusz 1951. 281, 2585. sz. okl.

${ }^{1509}$ Mályusz 1951. 281, 2587. sz. okl.

${ }^{1510}$ Mályusz 1951. 281, 2588. sz. okl.

${ }^{1511}$ DL 95 922, Mályusz 1951. 282, 2596. sz. okl.

${ }^{1512}$ DL 7805, „,nuper in expeditione nostra exercituali contra Turkos in regno Rascie prope portum Danubii habita" Mályusz 1951. 282, 2600. sz. okl.

1513 DL 7806, ,pridem in conflictu contra Thurcos in comitatu Syrmiensi prope Nagengh habito” Mályusz 1951. 283, 2605. sz. okl; Thallóczy-Áldásy 1907. 34. sz. okl.

${ }^{1514}$ Lásd a 3. 4. fejezetet.

1515 „A törökök már említett császára hallotta, hogy az apja, Amurat, életében hét hónapot töltött ugyanennek a Nándorfehérvárnak az ostromával, mégsem tudta hatalmába keríteni, gyözelem nélkül, gyalázattal
} 
féle hadijelentés sem azt sugallja, hogy a várat nem ostromolhatták volna meg, csak azt, hogy a vár nem volt kiépítve, így a kudarc még kisebb annál hogysem megemlítsék.

A kiépítettséget tekintetbe véve a várat bizony régen, legutóbb a bizánci uralom idejében, I. (Komnénosz) Mánuél idejében (1143-1180) építették újjá. Láttuk, hogy az 1150-1160 közötti időszakban. Azonban ezek a munkálatok a (felleg)várat érintették, amely a várost már nem foglalta magába. ${ }^{1516}$

I. Bayezid szultán idején tehát a törököknek Nándorfehérvár ostromakor „csupán” e Fellegvárral kellett megküzdeniük. A vár jelentős kibővítése és város erődített várossá kiépítése majd a 15. század első felében indult meg, éppen Lazarević Istvánnak köszönhetően. Kalić szerint Nándorfehérvár a 15. században még egy kis magyar határ menti vár volt, egy kis település. ${ }^{1517}$

Jó lenne tudnunk, hogy ebben az időben ki lehetett Nándorfehérvár védője, sikeres várkapitánya. Sajnos ezirányú adataink nagyon hiányosak. Engel Pál világi archontológiája megemlíti az 1386. évi királyi birtokbavételt, de csak a tatai szerződés utáni időtől kezdve ismertet adatokat. Az 1440. évi ostrom kutatása során, került látókörünkbe a Bátmonostori Töttös család, amelynek tagjai királyi kapitányként, várnagyokként tünnek elénk, egészen a Tallóci testvérek kinevezéséig (1429. szeptember 3.). Bátmonostori Töttös János (1428ban), Bátmonostori Töttös (II.) László pedig 1429-ben. Ez utóbbi azért is fontos, mert a vár fő részeit együtt irányította, a későbbi Alsóváros és a Felsőváros várnagyaként (castellanus inerioris castri, castellanus superioris castri). ${ }^{1518}$

A Bátmonostori-család nevét a bodrog megyei Bátmonostorról vette, amelyet 1323-ban vett birtokba Becsei Imre, valamint Töttös (Thutus) és Vesszős (Vezes) nevü fiai, akik I. Károly, majd I. Lajos király híveiként a királyi udvarba kerültek. Becsei Töttös I. Lajos királyi ajtónállómesterként szerepel 1342 októberében. ${ }^{1519}$ A birtokadományaik révén pedig Bács-Bodrog vármegye legtekintélyesebb birtokosai lettek. De emellett Baranya, Bars, Tolna megyékben, sőt a Dráván túl is szereztek birtokokat. ${ }^{1520} \mathrm{Az}$ egyik birtokközpontjukat pedig Bátmonostoron építették fel. ${ }^{1521}$

vonult el alóla. Ezért a török császár-serege vezéreinek jelenlétében-nem kis szidalommal illette apját, és azt mondta, hogy ö ugyanezt a várost tizenöt nap alatt képes bevenni” (Bellus Ibolya fordítása). Thuróczy 2001. 308-309. Lásd bővebben a 10. 2. fejezetet.

${ }^{1516}$ Lásd a 3. 1. fejezetet.

1517 Калић-Мијушковић 1967. 82.

${ }^{1518}$ Engel 1996. 374. Lásd az 5. 1. fejezetet.

${ }^{1519}$ Engel 1996. 48.

${ }^{1520}$ A Zichi és Vásonkeői Gróf Zichy-család idősb ágának okmánytára. V. kötet. (1383-1409) Szerk.: Nagy Imre. Budapest 1888. Nagy Imre bevezetője, VII. oldal. (Zichy 1888)

1521 Dr. Vágvölgyi Ferenc: Bátmonostor község története a felszabadulásig. (gépelt kézirat) Bátmonostor 1981. 7-9. A továbbiakban: Vágvölgyi 1981. 
Kézenfekvő feltevés lenne, hogy a Bátmonostori Töttös család valamelyik korábbi tagja lehetett Nándorfehérvár várkapitánya, amiért is ez a vár később is az irányításuk alatt maradt. Mert e nagybirtokos családnak komoly királyi kapcsolatai voltak. A „nulladik” ostromhoz közeli okleveleik közül az egyik (1393. január 20) az, amely szerint Bátmonostori Töttös fia (I.) László (megh. 1409. k.) Bátmonostor és Szeremle közötti határ megállapításnak folytonosan ellentmondást tett. A másik okleveles adatunk (1401. január 13) szerint Zsigmond király Bátmonostori Töttös (I.) Lászlónak bármelyik Bodrog vármegyében lévő birtokán fából vagy kőből építendő várépítési kiváltságot adott, aki bátmonostori birtokán, Dunaszekcsővel szemben, Szekcső és Bátmonostor között, építette fel Szembécs (Sembech, Zsembecz) várát. ${ }^{1522}$ Töttös (Thewtes) (I.) László fiai János, László, Miklós és György egy 1419.évi oklevélből tűnnek elénk. Évtizedekkel később a közel nyolcvan éves birtokos fiai fiú utód nélkül haltak meg, így Töttös két évvel a halála elött, 1466-ban örökösödési szerződést kötött a kalocsai érsekkel, Várdai Istvánnal, amely időszak már kívül esik vizsgálódási körünkön. ${ }^{1523}$

Még arra kell válaszolnunk, hogy egyáltalán miért kellett Bayezidnak Nándorfehérvárt a kosovói győzelme után ostrom alá vennie? Azt tudjuk, hogy az 1389-es kosovói vereség után Lazarević a török fennhatóságot kénytelen elismerni és egyes várakba a török helyőrségeket befogadni. Lazarević végig Bayezid vazallusa volt, egészen az ankarai csatavesztésig, minden hadjáratában részt kellett vennie, Nikápolytól Ankaráig. ${ }^{1524} \mathrm{Mi}$ sem lett volna egyszerübb, ha a szerb despotának a szultán megparancsolja, hogy Nándorfehérvárba is engedje be a török helyőrséget. Csakhogy nem tehette, mert úgy tünik ekkoriban még nem birtokolta. A vár ebben az időben magyar kézben volt. ${ }^{1525}$

A kérdés bonyolultabb és a vár birtoklásának 14. századi pontos története még kutatásra vár. Engel Pál archontológiájában általánosságban annyit találunk, hogy „,A 14. században többnyire magyar uralom alatt állt...úgy látszik a macsói bánok kormányozták..."1526

Az előzményekhez hozzátartozik, hogy e vár a szerb-magyar háborúk során a 14. században többször gazdát cserélt. ${ }^{1527}$ I. Lajos király halálakor, 1382-ben, még magyar

\footnotetext{
${ }^{1522}$ Vágvölgyi 1981. 14-15. Az oka a szekcsői birtokos, Herczeg Péterrel való folyamatos torzsalkodás volt. Az erősséget a Herczeg-család lerombolta, de azt újjápítették. Egy 1438-as oklevél szerint ez a vár fából épített erösség volt és akkorra elhagyatott, romos állapotú. Zsigmond király a pereskedésnek 1406-ban hozott döntésével vetett véget, amelyben megerösítette és átírta Töttösnek adott kiváltságlevelet. A vár mai helyének azonosítását 2012-ben Konkoly Sándor végezte el, aki szerint a castellum valóban Szekcsővel szemben, de az egykori Öreg (vagy baracskai) régi Duna-ág mészkőbányájának szirtjén állt. Konkoly Sándor: A titokzatos Szembécs vára. Bácsország 2012/2. 105, 107. (Konkoly 2012)

${ }^{1523}$ Vágvölgyi 1981. 19-20.

${ }^{1524}$ Engel 1994. 279.

${ }^{1525}$ Калић-Мијушковић 1967. 81.

${ }^{1526}$ Engel 1996. 374.
} 
uralom alatt állt. Kalić Belgrádról szóló munkájában hivatkozik egy szerb forrására (az ún. Tronos krónika), amely szerint Lázár fejedelem, Lajos halála után, 1382-ben feldúlta a várat és feltételezhetően el is foglalta. ${ }^{1528}$ Lázár fejedelem területe még magában foglalt néhány macsói települést is. Lázár egyébként lányai házassága révén kiterjedt befolyást gyakorolhatott a Balkánon. Öt lánya közül Mara a Branković-családba házasodott, ő lett a Branković György anyja. Teodora lánya Nikola II. Gorjanski macsói, horvát bán; Dragana a bolgár cár, Ivan Shisman (1371-1393), Jelena a zetai uralkodó, II. Stratimirović Balšić György (1385-1405), Olivera pedig I. Bayezid felesége lett.

Nándorfehérvár birtoklása a Zsigmond király elleni lázadásban is fontos szerepet játszott. A fellázadt Horváti fivérek megtámadták a macsói területet, benne Nándorfehérvárt és feltételezhetően el is foglalták. ${ }^{1529}$ Engel szerint „a macsói bánság Száván túli részének akkoriban magyar kézen kellett lennie."1530

A vár ekkori birtokviszonyaira némi fényt derít az az 1388. április 28-i oklevél, amelyből kiderült, hogy Zsigmond király számára a volt macsói bán, Kórógyi Fülöp fia István, sikeres harc után, foglalta vissza a macsói bánságot a megszálló Horvátiaktól (Horváti Péter fia Lászlótól és Jánostól), vele együtt „Bitva, Kölpény és Nándorfehérvár királyi várait" is. ${ }^{1531}$ Ezt erősíti meg Kalić véleménye is, aki szerint a Horváti fivérek megszállták a határ menti városokat, így Bitvát, Kupinovót (Kölpény) és Belgrádot (Nándorfehérvár). Kalić egy terminus ante quem-datálást is adott erre az eseményre. Mivel Kórógyi István visszafoglaló harcaiban egyedül Gorján visszafoglalását ismerjük pontosan, így az előbbi három vár visszafoglalására 1386. július 25 .-e előtt kerülhetett sor. ${ }^{1532}$

Lázár szerb fejedelem lovassága is harcolt a felkelők oldalán az 1386. évi harcokban, de Nándorfehérvár elfoglalásában való részvételükre nincs adat. Kalić megállapítása szerint tehát Lázár fejedelem nem foglalta el a várat, ekkor a város nem került szerb kézre. Zsigmondnak oka lett azonban arra, hogy megbüntesse a szerb támogatást. 1389 februárjában Zsigmond Lázár fejedelem ellen vonult. A fegyveres összecsapás azonban elmaradt.

\footnotetext{
${ }^{1527}$ Lásd a 3. 1. fejezetet.

${ }^{1528}$ Калић-Мијушковић 1967. 79

${ }^{1529}$ Калић-Мијушковић 1967. 78.

${ }^{1530}$ Engel 1998. 562-563.

${ }^{1531}$ Engel 1998. 564; Thallóczy-Áldásy 1907. 22, 62. sz. okl. „..Banatu de eodem expulit et effugauit, et castra regalia Bytva, Kulpen et Nandurfeyrwar nuncupata..." In.: Codex Diplomaticvs Hvngariae ecclesiasticvs ac civilis. Stvdio et opera Georgii Fejér. Tomi X. Volvmen I. Ab anno Christi 1382-1391. Budae 1834. 414-420. (Fejér X/I. 1834)

1532 Калић-Мијушковић 1967. 78-79, 364.
} 
Lázár fejedelem halála után a törökkel való „együttmüködés” előnyösebbnek látszott a szerb udvarban. Lazarević uralkodása kezdetétől I. Bayezid szultán ankarai vereségéig követte ezt az irányvonalat. A kosovói csata után a megmaradt szerbség a törökökkel való kapcsolatra összpontosította figyelmét. A szerb vezetés megosztottságát C. Imber is hangsúlyozta. 1392-ben azzal éppen a török párti irány kerekedett felül, amikor szövetkeztek I. Bayeziddel Zsigmonddal szemben. Így Bayezidhoz feleségül adták Lazarević nővérét, Olivera-t és megállapodás született Lazarević-el. ${ }^{1533} \mathrm{~J}$. Kalić szerint Szerbia túl gyenge volt ahhoz, hogy két fronton védekezzen és a magyar nyomás hatására indult el a törökkel való megegyezés felé. ${ }^{1534}$

1390. augusztus 4.-e előtt a szövetséges szerb és török csapatok már magyar határ menti területeket támadtak: Macsóba, Szerémbe, ahogyan Krassóba és Temesbe is. 1390 novemberében Zsigmond azért, hogy visszaállítsa a déli határok stabilitását, ellentámadásba lendült. Betört Szerbiába egészen Osztrovicáig. ${ }^{1535} \mathrm{Ez}$ is mutatja, hogy magyar-szerb-török harcok folytak az 1390-es évek folyamán Magyarország déli részén. A török és vazallus szerb csapatok átkeltek a Dunán és a Száván. Ennek során Nándorfehérvárt is megtámadhatták. Kalić ebben az értelemben rögtönzött támadásnak tekintette, amennyiben megtörtént. A Magyarország határai ellen irányuló török támadásokat nem lehet csupán török hódítási célnak tekinteni, a szerb motiváció is benne lehetett. Engel is kihangsúlyozta, hogy a magyar vezetés sem kapott világos képet arról, hogy Szerbia milyen státuszú. Kosovo után török vazallus lett. ${ }^{1536}$

A magyarországi oklevelekben a törökökkel kapcsolatban érdemes felfigyelni a „hütlenek”, „szakadárok” kifejezések rendszeres felbukkanására. Például 1392-ben. Március 28-án keltezett oklevél szerint az induló sereg „,contra Turcos et emulos ac scismaticos” ellen vonul. ${ }^{1537}$ Így 1392. február 19-én Zsigmond Ilsvai Péter fia Leusták királyi ajtónálló mester és Kapolyai Benedek fia János volt vajda adományt kapott a „végvidékeken támadó hütlenek és pogányok elleni hadjáratban szerzett érdemeikért."1538 1392. augusztus 14-én a király Temesváron adományozott azon érdemekért „,amelyeket az

\footnotetext{
${ }^{1533}$ Imber 2002. 14.

${ }^{1534}$ Калић-Мијушковић 1967. 80.

1535 „,in descensu nostro campestri in terra Rascie prope castrum Ostrowech”, Mályusz 1951. 194, 1725. sz. okl.

${ }^{1536}$ Engel 1998. 564.

${ }^{1537}$ DL 52 758, Mályusz 1951. 269, 2454. sz. okl.

${ }^{1538}$ DL 7755, Mályusz 1951. 261, 2396. sz. okl.
} 
ország végvidékeit háborgató törökök, a hütlen scismaticusok ellen, a mostani szerencsés hadjáratban szeme láttára harcolva szereztek."1539

Ezek, véleményem szerint, az oszmán-törökök mellett a velük szövetséges szerbekre vonatkoznak, akik rendszeres közös támadásokat, határ menti betöréseket folytattak. Ebbe pedig nagyon is beillett, hogy Nándorfehérvár várát a szerbek a törökök segítségével foglalják vissza. Így ez az ostrom nemcsak török, hanem legalább annyira oszmán-törökszerb akció is lehetett. Annál is inkább, mert Lazarevićnek jó kapcsolata volt az idős Bayeziddel, aki fogadott fiaként kezelte. Olivera húga - a szultán szeretett feleségeként igen nagy hatást gyakorolt a szerbek érdekében. Egyébként vazallusi szerződése kötelezte a szultáni hadjáratokban való részvételt. Ha Nándorfehérvár ellen felvonult Bayezid, akkor Lazarevićnek is ott kellett lennie. De a vár visszafoglalása nem önmaga ellen irányult, hiszen ő nem volt a birtokában és a visszaszerzés csakis török segítséggel lehetett elérhető. Ezt az „együttmüködést” támogatja Evlia Cselebi azon megjegyzése is, hogy a várral szembeni ellenerődöt (Havale) közösen építették fel és Bayezid bukása után azt a szerbek el is foglalták. ${ }^{1540}$

A törökkel való együttmüködés szemlélete jól látszik Lazarević életéröl szóló munkában is (Žitije despota Stefana Lazarevića). Konstantin Filozófus (Konstantin Kostenečki) érzékletesen mutatja be ekkor a szerb despota dilemmáját. A szerb udvarban voltak, akik a magyarok felé való tájékozódásra ösztönözték a despotát. Lazarević azonban látta a magyarokkal való kapcsolat gyengeségét. Azért hogy tisztázza magát a vád alól, Drinápolyba ment a szultánhoz, aki meghallgatta és megbocsátott neki, bár elrettentő példaként említette neki a bolgár cárok sorsát. Söt, a forrásrészlet a magyar föld meghódításának szándékát is megörökítette. „Mit akartál elérni a magyarokkal? Hát nem tudod, hogy én tervezem elvenni és sajátommá tenni a földjüket? Mit fogsz ott tenni? Voltak olyanok az uralkodók közül, akik meghajtották fejüket a magyarok elött és megörizték országukat? Akkor ö (t. i. a szultán) név szerint emlitette a bolgár cárokat és másokat, majd igy folytatta: Ezért, ha velem vagy és oda mégy, ahová én nem, hibázol, de ha velem maradsz, történetesen bárhol vagyok, nincs okod az aggodalomra...Én Téged a legidősebb és legkedvesebb fiamnak tartalak és ezt kijelentem mindenki elött, a sajátjaim és a keletiek elött is. ...majd képes leszel megtartani a saját földed és más földeket is

\footnotetext{
${ }^{1539}$ DL 95 922, Mályusz 1951. 282, 2596. sz. okl.

${ }^{1540}$ Karácson 1904. 157.
} 
akörül és nagy és híres uralkodó leszel..." "1541 A szerző ezután Bayezid havasalföldi hadjáratát ismerteti.

A szerb-török „együttmüködés” nem példa nélküli, hiszen láthattuk, hogy Âşik Paşazade szerint Lazarević a magyaroktól elfoglalt Galambóc várát is „vissza” kérte a szultántól. Elképzelhető, hogy Nándorfehérvárral is hasonló célja lehetett, ekkor még török segítséggel. Nándorfehérvár együttes oszmán-török és szerb ostromára azért kerülhetett sor, mert akkor az nem volt szerb kézen. Lazarević tehetséges reálpolitikusként később, az Oszmán Birodalom válságos évtizedében, ugyanezt a magyarok révén - most már békés úton - mégis elérte! Mert I. Bayezid szultán ankarai csatavesztése (1402) fogsága és halála (1403) után éles külpolitikai irányváltással Zsigmond király felé fordult. 1403-1404 körül, miután most már a magyar király vazallusságát ismerte el, Zsigmond a Száván túl megmaradt „magyar” birtokokat, a korábbi macsói bánságot, Nándorfehérvárral együtt átengedte számára. Magyarországon pedig óriási birtokokat adományozott neki. ${ }^{1542}$ Lazarević megtette székhelyévé Nándorfehérvárt és hozzáfogott kiépítéséhez, mert Szerbia korábbi fővárosa Lázár fejedelem és az ő idejében még Krusevac volt. ${ }^{1543}$

Mindez annak is köszönhető, hogy a „nulladik” ostrom nem sikerült, így Nándorfehérvár - legalábbis várostrom révén - nem lett újra Belgrád. Ezt sikernek kell tekintenünk és beilleszthetjük a korai magyar-török várostromok történetébe. Hozzátesszük azt is, hogy Nándorfehérvár 14. századi szultáni ostroma korai volt. Elfoglalása esetén nem tudták volna a törökök tartósan megtartani, mert az igaz ugyan ahogyan Szakály Ferenc megjegyezte - „Az oszmán hóditók elöször Szerbiában jutottak ki a magyar határokhoz," 1544 de az ország határáig az Oszmán Birodalom még nem ért el és a szerbiai területeket sem birtokolta. Erre csak a 15. században értek meg a feltételek és ekkor a vár már két szultáni ostrommal is kénytelen volt szembenézni.

\footnotetext{
${ }^{1541}$ Žitije despota Stefana Lazarevića. In.: Petkov 2008. 400, 27-401, 1, 3-4, 10-12. ,What did you think to accomplish with the Hungarians? Didn't you know that I plan to take (their) land and make it mine? What will you do there? Did some of the lords who bowed their heads to the Hungarians preserve their lordships?" He then mentioned by name the Bulgarian tsars and some others, and continued: „Therefore, if you are with me and you go where I do not go you would make a mistake. But if you stay with me wherever I happen to be, there is no reason to worry...I hold you as the greatest and most beloved son: this I declare to everyone, my own (people) an the Easterners...you will be able to hold onto your land and other lands around it and you will become a great and famous ruler."

${ }^{1542}$ Engel 1994. 279.

${ }^{1543}$ S. M. Stern: Krusevac. ODB 348.

${ }^{1544}$ Szakály 1986. 18.
} 


\section{4. Hunyadi Mátyás ismeretlen győzelme Nándorfehérvárnál -Zsarnó ostroma (1463)}

Baán Istvánnak a bizánci-magyar kapcsolatokról szóló szöveggyüjteményéhez kapcsolódó munkálataim során adódtak olyan forrásrészletek, amelyek nem illeszthetők be az eddigi ismereteink közé. A vegyesházi királyok koráról szóló bizánci források remélhetően számos új részlettel gazdagítják ismereteinket. Az alábbiakban egy eddig ismeretlen részletet illesztek be egy ismert hadjárat menetébe.

A kiinduló textus a bizánci történetíró, Laonikosz Khalkokondülész rövid részlete (II. 282-283), amelyben Hunyadi Mátyás (1458-1490) Velencével folytatott tárgyalásáról ír és szerbiai-boszniai hadjáratának egyes epizódját ismerteti. A Velencei Köztársaság és a Magyar Királyság közötti kölcsönös segélynyújtási szerződést 1463. szeptember 13-án kötötték meg. ${ }^{1545}$ Az összehangolt tervben az szerepelt, hogy míg Mátyás Bosznia ellen vonul, addig Velence a tengeren 40 hajóval, a szárazföldi sereggel pedig Moreában, azaz a Peloponnészoszon támadna. ${ }^{1546}$ Ebben az összefogásban aktív szerepe volt az idős II. Pius pápának, azaz Enea Silvio Piccolomininek (1458-1464), aki a Magyarországon pápai legátusként ismert Don Juan de Carvajal bíborost bízta meg a Velencével való tárgyalással. ${ }^{1547}$

Szélesebb összefogás alakult volna ki, mert 1463 októberében az idős pápa keresztes háborút hirdetett a törökök ellen. Mindössze 10 évvel vagyunk Konstantinápoly török elfoglalása után, a szándékban benne élt ennek megbosszulása is. Maga a pápa szeretett volna a keresztes hadjárat élére állni. Azonban a felhívása eredménytelen maradt az európai udvarokban. 1464. augusztus 15-én, amikor a súlyos köszvénnyel küszködő pápa meghalt Jajca várát a török megpróbálta visszafoglalni. A kitörő második török-velencei háború (1463-1479) célja a balkáni oszmán terjeszkedés visszaszorítása, a Peloponnészosz, azaz Morea visszafoglalása volt. Emlékezzünk, hogy 1428-1430 között

\footnotetext{
1545 Szakály 1990. 56.

1546 Teke Zsuzsa: Mátyás, a győzhetetlen király. Budapest 1990. 42. A továbbiakban: Teke 1990.

${ }^{1547}$ II. Pius török terveiről lásd: Nótári Tamás: A török terjeszkedés állomásai Aeneas Sylvius Piccolomini Europa című művében, Aetas 1999 14/4. 149-162. (Nótári 1999) Ígéretes kutatás kezdetét jelenti Carvajal tevékenységéről: Törtei Renáta: Egy spanyol pápai legátus tevékenysége a középkori Magyarországon. Don Juan de Carvajal bíboros életútja, szerepe és tevékenysége a magyar történelem viharos éveiben (Szakdolgozat) Piliscsaba 2013. 60. (Törtei 2013).
} 
Thesszaloniki birtoklásáért már kirobbant egy velencei-török háború. Mivel akkor kezdődött meg a velenceiek kiszorítása az égei-tengeri szigetekről és Moreából. ${ }^{1548}$

A velencei szövetségben Mátyásnak az lett szerepe, hogy északon egy „második frontot" nyisson meg a török erők megosztása céljából. ${ }^{1549}$ Erre Khalkokondülész is egyértelmüen utal: „Ha ez ügyben szövetséget kötünk a paionokkal, akkor ők a Duna, mi pedig a Peloponnesos felöl indulva támadjuk meg azt a birodalmat." (Baán István fordítása ${ }^{1550} \mathrm{~A}$ vizsgált Khalkokondülész textus pedig a következő:

„Ö tehát így készült fel a háborúra, huszonötezres csapatot gyüjtött össze, s a Dunán átkelve pusztította a császár országát. Addig az erödig nyomult, amelyet Sehabeddin Nándorfehérvárnál akkor emelt, amikor Paioniát fosztogatta, és örséget hagyva benne, a császári Porta alakulatainak katonáit, eltávozott. Ezt a véderődöt, amely a legközelebb volt a városhoz, megrohamozva megostromolta. Majd sebtiben végigfutott a császár országán a Száváig, és miután végigfosztogatta, rabszolgasorba hurcolva triballosokat és törököket, ellenkezö irányban eltávozott hazafelé. Azt mondják, hogy közel húszezer rabszolgát vitt magával. Így történtek a paionokkal kapcsolatos események." (Baán István fordítása) ${ }^{1551}$

Érdekes és hiányos ez a részlet, mert a bizánci szerző Mátyás 1463. évi szerbiaiboszniai hadjáratáról csak mozaikszerüen számol be, de épp egy a latin nyelvü források által nem ismert részletet említ meg. Zsarnó (Sarno) várának ostromát, amelyet viszont néven nem nevez meg. Érdekes, hogy vizsgált szövegrészletünk már Jajca elfoglalásáról és a következő évi szultáni visszafoglalási kísérletéröl sem írt.

Tekintsük át röviden ezt az 1463. évi szerbiai-boszniai hadjáratot! Mátyás a hadjárata előkészítésére 1463 márciusában Tolnaváron országgyülést hívott össze. ${ }^{1552}$ Azonban, csak miután III. Frigyessel július 19-én Bécsújhelyen szerződést kötött és július 24-én visszakerült hozzá a Szent Korona, ${ }^{1553}$ indult meg július 28-án személyesen a török ellen. ${ }^{1554}$ Pünkösdre teljes mozgósítást rendeltek el, a sereg Péterváradnál gyülekezett. Júniusban a király az ország déli része felé vonult, mert a török főerők Magyarország elleni

\footnotetext{
1548 Hóvári János: Az oszmán birodalom és a levantei kereskedelem a 15-16. században. Világtörténet 1983/2. 49-50. (Hóvári 1983) Lásd még a 2. 4. fejezetet.

1549 Szakály 1990. 57.

${ }^{1550}$ Laonici Chalcocandylae Historiarum Demonstrationes. Ad fidem codicum recensuit, emendavit annotatibusque criticis instruxit Eugenius Darkó. Tomi II. Pars posterior. Libros VIII-X. et Indices continens. Budapestini 1928. 294, 15-17. (A továbbiakban: Darkó 1928) Baán 2013. 323.

${ }^{1551}$ Darkó 1927. 298, 4-15. Baán 2013. 328.

1552 Pálosfalvi 2009. 55.

1553 Gr. Teleki József: Hunyadiak kora Magyarországon. III. kötet. Pest 1853. 332-333. A továbbiakban: Teleki III. 1853.

1554 Teleki III. 1853. 342.
} 
támadására számított. ${ }^{1555}$ Ezt jól mutatja, hogy a Duna mellett Futak és Nándorfehévár között táborozott. ${ }^{1556}$ A török hadsereg azonban a jól ismert haditaktikája alapján ahogyan 1438-ban Erdély ellen, 1439-ben Szendrö vára ellen vagy Titel kapcsán vagy 1442-ben az erdélyi betörés során - párhuzamos hadoszlopban vonult fel, szándékosan bizonytalanságban tartva a magyar erőket afelől, hogy valójában melyik lesz támadásuk fő iránya. A fő erőket a Drina-folyó mentén felfelé haladva végül Boszniába vezényelték, Magyarország ellen pedig Ali béget küldték. Ali bég elterelő betörése Magyarországot és Erdélyt valamint a Temesközt is érintette. ${ }^{1557}$ Ezalatt a boszniai területeket elfoglalták, a bosnyák királyt, Štefan Tomaševićet (1461-1463) elfogták és lefejezték. ${ }^{1558}$ Bosznia (Illüria) 1463. május-júniusában oszmán kézre került ${ }^{1559}$ Mátyás eközben nem támadott Boszniában, szeptember 13-án állapodott meg a velenceiekkel.

A második velencei-török háború délen megosztotta a török erőket. A helyzetet Mátyás jól ki tudta használni. Mert, amikor a török főerők már a téli szálláshelyükön pihentek gondoljunk az október 26-i Kászim napra - októberben Jajca vára alá érkezett és ostrommal december 26-ra elfoglalta. ${ }^{1560}$ Mindez jól ismert epizód. Bosznia kormányzója, bánja Szapolyai Imre lesz. 1464 augusztusában II. Mehmed ostrom alá vette Jajcát, de nem járt sikerrel. Mátyás - hosszú távon - számolt a rodoszi johannita lovagrend katonai erejével is Bosznia megtartásában. Ehhez pedig kellett a vránai perjelség. 1465-ben, II. Pál pápához (1464-1471) írt levelében ${ }^{1561}$ kérte, hogy a Bosznia kormányzójává tett Szapolyai Imrét 8-10 évre bízza meg a vránai perjelség administratio-jával is, mert a perjelség régóta üresedésben van és kellenek a perjelség Boszniával határos várai az eredményes védekezéshez. 1468-ban már Székely Jánost említi a forrás, mint vránai perjelt, aki nagy érdemeket szerzett a törökök által megostromlott Jajca védelmében. ${ }^{1562}$

Nézzük meg, hogy a latin nyelvü forrásaink említenek-e ebben a hadjáratban Nándorfehérvár körüli harcokat? Ali bég betöréséről Antonio Bonfini számol be részletesen (3. 10. 252-263). ${ }^{1563}$ Ali bég szultáni parancsra átkelt a Száván, kikerülte Nándorfehérvárt! Felégette és lerombolta Kölpényt (Cheulpen) és Szávaszentdemetert. Majd a Duna felé, Futakig (ad Futhacum) támadt (3. 10. 255.). Ekkor jött a magyar válasz:

\footnotetext{
1555 Teke $1990.40-41$.

${ }^{1556}$ Pálosfalvi 2009. 55

1557 Teleki III. 1853. 323.

1558 Teke 1990. 42.

${ }^{1559}$ Pálosfalvi 2009. 55.

1560 Szakály 1990. 57.

${ }^{1561}$ DL 16290

${ }^{1562}$ DL 16728

${ }^{1563}$ Bonfini 1995. 730-731.
} 
Szokoli Péter, a csanádi püspök atyja Futaknál támadt rá a bő zsákmánnyal megrakodott törökökre. Bonfini szerint Alinak le kell raknia az addig megszerzett zsákmányt, hogy felvehesse a harcot a magyar sereggel. Szokoli Péter azonban kemény harcban legyőzte és a Száváig üldözte vissza a törököket. A törökök belevetették magukat a folyóba, még a nyílzápor is sürgette őket. Bonfini megemlíti: „Azt mondják, Péter egészen Sarno városkáig kergette öket (3. 10. 262). ${ }^{1564} \mathrm{Ez}$ a rész fontos számunkra, mert Nándorfehérvárhoz közeli helyet jelölt meg. Ali bég Szendrőbe futott vissza (3. 10. 263). ${ }^{1565}$

Janus Pannonius a magyarországi elégiái között egyik versében utal erre a betörésre, de Nándorfehérvár említése nélkül: Mátyás magyar király válasza Antonio Constanzi olasz költőnek. (Matthias rex Hungarorum, Antonio Constantino poetae Italo). A költeményben Bosznia török elfoglalását Jajca kapcsán idézi fel költőnk. Egyúttal remek nemzetközi körképet ad; a velencei szövetségről, Ali bég betöréséről megemlékezik, ám Zsarno-t nem említi, csak Ali menekülését.

„Rég Illyria, -Bosznia most, így hívja a népe... ezt a lebirhatlan tájat, mellyel csak a villám küzdhet meg-hinnök-, ámde az is nehezen, kímélet nélkül leigázta a zsarnok e nyáron, karddal vétetvén volt fejedelme fejét."

„, Gallia alszik, Ibéria? nem fontos neki Krisztus. Anglia pártharcban veszti sovány erejét. elvetemült Germánia meg csak ülésezik egyre, ad-vesz Itália, és pénzügyeket bonyolit.

Senkit sem bánt gondunk, legföljebb ha Velencét, öt szerzödéses jog köti össze velünk."

„Lám, Ali bég, roppant büszkén erejére, a Száván átúsztat, s a Szerém-földre orozva lecsap.

Úgy gondolta: vitézi dicsőségét gyarapítja? hogyha szemem láttán égeti, dúlja hazám."

Mátyás király II. Pius pápához 1464. január 22-én írt ${ }^{1567}$ levelében (1464. január 27, Dombro) ${ }^{1568}$ részletesebben közli az előző év hadieseményeit. A király nevében a levelet

\footnotetext{
${ }^{1564}$ Bonfini 1995. 731, 5-6; „Ad Sarnon usque oppidum hos Petrum profligasse ferunt.” Rerum 1936. 242, 3-4.

1565 Bonfini 1995. 731, 7.

1566 Janus Pannonius összes munkái. Közrebocsátja: V. Kovács István. Budapest 1987. 349-351. (Janus 1987)

1567 A levél kritikai kiadásában „die 22 Ianuarii anno Domini 1464” Ioannes Vitéz de Zredna. Opera quae supersunt. Edidit Iván Boronkai. Budapest 1980. 216. A továbbiakban: Vitéz 1980. A levél V. Kovács
} 
Vitéz János írta. ${ }^{1569}$ Ebben jól látható az 1463. évi török támadás pontos irányának szándékos kiszámíthatatlansága. Ez a kiszámíthatatlanság 1463 tavaszán még nagyobb volt, mert Mátyás Poděbrad Viktorinnak írt levelében sem tudta pontosan, hogy hol lesz a szultáni sereg fö csapása. ${ }^{1570}$

Ugyanez jelentkezik a pápához írt levelében is. A felderítők által hozott hírekben felmerült Nándorfehérvár újabb oszmán-török ostroma is, mert az a hely, amelyet a török tábor elfoglalt, több útirányba nézett. ${ }^{1571}$ „Kezdetben eléggé rejtve volt, hogy milyen irányban szándékozik támadni, mivel a tábora által elfoglalt térség többfelé is nyitott volt, és több útvonal is összetalálkozott rajta, amelyek bármelyikén elindulhatott. Földeritöink gyakorta s igen különbözö jelentéseket hoztak: az egyik azt állitotta, hogy Nándorfehérvárt akarja körülsáncolni." (Bellus Ibolya fordítása). ${ }^{1572}$

A levél a boszniai hadjáratot megelőző magyarországi betörésről is tudósította a pápát. „Mielött azonban még betört volna Boszniába, seregének nem kis részével a Száva folyó gázlóinak az irányába küldte ki Ali béget, Szerbia Prefektusát, hogy addig is akadályozza meg átkelésünket vagy kényszeritsen bennünket visszafordulásra."(Bellus Ibolya fordítása). ${ }^{1573}$ A sikeres visszaűzésről szól, amikor a Száváig üldözték a törököket: „,végül is nyilt csatában két, nem sokkal egymást követö támadással megtörtük, legyöztük és megfutamitottuk." (Bellus Ibolya fordítása). ${ }^{1574}$

Mátyás csak ekkor - azaz a Bonfini által említett Szokoli Péter győzelme után - kelt át a Dunán. „átkeltem a Dunán, és erőltetett menetben a Száva gázlóihoz vonultam, amelyeket

Sándor általi kiadásában közölt fordításban pedig január 27. szerepel. Mátyás király levelei 1460-1490. Magyar Levelestár. Válogatta, a szöveget gondozta, az utószót és a jegyzeteket írta: V. Kovács Sándor. Budapest, 1986. 23. A továbbiakban: V. Kovács 1986.

1568 Dombro a mai Dubrava Horvátországban.

${ }^{1569}$ Vitéz 1980. 213-216.

1570 Idézi Rázsó 1990. 198. (131. lábjegyzet) „Communis noster...hostis cum magno...apparatu in tali loco positus, ut dubium relinquat quas tandem christianorum partes sit invasurus"

1571 „nam locus, quem castris occupaverat, plures partes respiciebat... Exploratores nostri varium saepe nuntium afferebant, aliis ad castrum Nandor Albense vallo circumdandum..." Vitéz 1980, 16-20.

1572 Vitéz János levelei és politikai beszédei. Magyar Ritkaságok. Válogatta, a szöveget gondozta és a bevezető tanulmányt írta Boronkai Iván. Budapest 1987. 287. (A továbbiakban: Boronkai 1987).

A levél fordítása megtalálható még: V. Kovács 1986. 23-28. „Eleinte meglehetősen bizonytalan volt, hogy merre fordul majd a török arcvonal, táborhelyük több irányba nézett, és félreesö is volt, tehát bármerröl várhattuk a támadást. Felderítöink gyakran a legkülönbözöbb híreket hozták; az egyik szerint fallal vették körül Nándorfehérvárat, a másik viszont bizonygatta, hogy a török másra készül. A kétség azonban kisvártatva elmúlt, és kiderült, hogy a török néhány áruló hívására Bosznia felé indult..."(Ballér Piroska fordítása).

1573 Boronkai 1987. 288. „Mielött azonban a török Boszniába ért volna, seregének jó részét Ali bég nevu prefektusával az élen Szerbiába, mégpedig a Száva partjához küldte, hogy hátráltasson vagy megakadályozzon bennünket a folyón való átkelésben...”(Ballér Piroska fordítása). V. Kovács 1986. 24.

1574 Boronkai 1987. 288. „elöbb az egyik, majd a másik oldalon legyöztük és megfutamítottuk öket, jogos harcban, nyílt csatában...A vezér és maroknyi csapata sajkákban, csónakokban menekült el." (Ballér Piroska fordítása). V. Kovács 1986. 24. 
az ellenség korábban már elfoglalt. Ezeket könnyüszerrel visszafoglalva elüztem onnét a már elözöleg megfutamitott ellenség maradékait, és üldözésükre indultam Szerbia felé." (Bellus Ibolya fordítása). ${ }^{1575}$

Az itteni szerbiai hadieseményekröl tömören ír. Miközben a török fösereg visszavonult Boszniából, Szerbiában letáborozott. Az itteni hadmüveletei közül portyázást említett, de várostromról nem esik szó. „Kiadtam hát a parancsot, hogy ezt széltében-hosszában portyázzák be, tüzzel-vassal pusztítsák el és rabolják ki. Sok, ott kószáló ellenséges csapatba ütköztünk, amelyeket részben megsemmisitettünk, részben elfogtunk..." (Bellus Ibolya fordítása). ${ }^{1576}$ Majd a király visszavonult Szerbiából, amelyet Khalkokondülész is megemlített. A levél folytatása már a leghíresebb eseményt, Jajca ostromát ismerteti a Szentatyának. $^{1577}$

De térjünk vissza a Khalkokondülész által említett „,véderőd” azonosításhoz. Láttuk, hogy a szövegrészlet Nándorfehérvárhoz közeli ellenerődöt ( $\varepsilon \pi \iota \tau \varepsilon \imath \chi \imath \sigma \mu o \varsigma)$ említ, név nélkül. De azt közli, hogy Sehabeddin építette fel, amely számunkra fontos információ. Mert oszmán török forrásokban lehet azonosítani. A 17. századi török világutazó Evlia Cselebi írt Havále váráról, amelynek ,épitöje Jildirim Bajazid khán, aki Sehébeddin pasával épittette. Belgrád vára hitetleneinek meggyengítése végett." ${ }^{1578}$ Ez Havále vára, más néven Zsarnó (Žrnov), amely Bonfininél Sarno-ként szerepel. Nem kell feltétlenül kronológiai hibának tartanunk azt, hogy Cselebi ennek felépítését már I. Bayezid szultán idejébe helyezte. Erről Nándorfehérvár „nulladik” ostroma kapcsán már szóltunk. ${ }^{1579}$ A forrásban szereplö Sehabeddin ruméliai beglerbégről viszont tudjuk, hogy az 1440-es sikertelen szultáni ostrom után, 1441-ben azt felújította vagy újra felépíttette. ${ }^{1580} \mathrm{Az}$ oszmánokat e kudarcok egy időre meggyőzték, hogy az ország elleni támadások eredménytelenek. Nándorfehérvár közelében ezért lett fontos egy közeli ellenerőd fenntartása.

\footnotetext{
${ }^{1575}$ Boronkai 1987. 288. „átkeltem a Dunán, és folyvást menetelve a Szávához értem, amelyet már elfoglalt ugyan a török, de én könnyen visszaszereztem; elüztem az ellenség és a korábban odaszököttek maradványait, majd Szerbia felé indultam, hogy a nyomukban legyek. Közben a török befejezte az ügyeit Boszniában, határait visszavonva eltávozott, és már Macedóniában volt." (Ballér Piroska fordítása). V. Kovács 1986. 24.

1576 Boronkai 1987. 288. „Megparancsoltam, hogy széltében-hosszában dúlják fel, pusztitsák tüzzel-vassal, és rabolják ki. Sok csapatosan kóborló török esett fogságba vagy pusztult el." (Ballér Piroska fordítása). V. Kovács 1986. 24.

1577 V. Kovács 1986. 25.

${ }^{1578}$ Karácson 1904. 157

${ }^{1579}$ Lásd a 13. 3. fejezetet.

${ }^{1580}$ Lásd a 10. 1. fejezetet.
} 
E vár stratégiai jelentősége és katonai szerepe jobban megmutatkozott Nándorfehérvár második oszmán-török ostromakor, 1456-ban. Ezt Cselebi is közli: „Mohammed khán Belgrád elfoglalására jött, ezt a várat Gházi Porcsával elfoglaltatta...” „Havále várnak azért nevezték, mert mint mondják az említett vilájetokban magaslatul (havále) szolgáló vár." Innen folyamatosan szemmel tarthatták a végvárat és beláthattak Nándorfehérvárba. Cselebi szerint innen „egészen Herczegovina hegyeiig ellátni.” II. Mehmed korában (1451-1481) külső fallal erősítették meg. „Gházi Porcsa ezt a várat negyven vitézzel meghódítván, e váron kívül egyszeres erös falat vont, s e falon keletre nézö egyszeres vaskaput is készitvén, meredek erös várrá tette. E vár környéke négy oldalról oly meredek, hogy Isten mentsen az ember még lenézni sem mer." "1581

1456-os ostrom után Bonfini szerint a nyíllövéstől megsebesült és félholt II. Mehmed szultánt is ide vitték. „a törökök felszedték táborukat, és a császárt Sarno városába vitték” Sőt a szultán „miután Sarnónál valamelyest magához tért, érdeklödött a háború kimenetele felöl' (3. 8. 99-100.) $)^{1582}$

A zsarnói ellenerődből az ott állomásoztatott csapatok gyakran kitörtek Nándorfehérvár közelébe. Cselebi szerint: „Porcsa idején ebböl a kis várból ezer válogatott vitéz hitharcos felfegyverkezve és lóháton kiment és Belgráddal elmondatták, hogy »Kegyelem! « mert a Duna partján zsákmányolván ebbe a sasfészek gyanánt álló Haváléba jöttek vissza."1583 1463-ban az Ali vezette seregben is lehettek itteni katonák, mert Bonfini szerint Szokoli Péter ide üzte őket vissza.

Nándorfehérvár mindig is központi célja maradt az oszmán-török hódításnak. II. Mehmed a vár blokád alá vételével vagy újabb ostromával - 1456 után - egyelőre nem, de ellenerőd fenntartásával tovább próbálkozott. Ezt jól mutatta, hogy Hunyadi Mátyás idejében 1471-ben a Száván felépítették Nándorfehérvár második ellenerődjét, Szabács várát, miközben a király a cseh háborúval volt lekötve. ${ }^{1584}$

Az oszmán-török ostromok eszköztárában az ellenerőd létesítése bevált módszer volt. Például a szultán 1452-ben Konstantinápoly ostromának előkészítéseképpen a Boszporusz európai partján lévő Rumeli Hisszar erődjét újra felépíttette. ${ }^{1585}$ Az albániai Kruja erődjénél II. Murád sikertelen ostromkísérlete (1450) után inkább Elbasan ellenerödjét

\footnotetext{
${ }^{1581}$ Karácson 1904. 157.

1582 Kulcsár 1995. 677, 24-25, 26-27. „Turcos ad Sarnon oppidum motis” „ad Sarnon cum ille aliqantulum respirasset, de belli exitu fuisse percontantum.” Rerum 1936. 187, 36-37, 39-40.

1583 Karácson 1904. 158.

${ }^{1584}$ Pálosfalvi 2005. 144; Teke 1980. 81.

1585 J. E. Kaufmann-H. W. Kaufmann 2001. 163.
} 
építették fel. II. Mehmed kétszer ostromolta Kruját hiába $(1466,1467)$ harmadjára, 1478ban foglalta el. ${ }^{1586}$

A Nándorfehérvár melletti Havale várának fontosságát a 16. századi magyar nyelvü források közül Zay Ferenc (1505-1570) végvidéki huszárkapitány Az Lándorfejírvár elvesztésének oka e vót és így esött címü munkája is megerősíti. Ami számunkra kiemelten fontos az az, hogy Zay összekapcsolja a Bonfini által említett Sarnót az oszmán Havaléval. „szultán Mehmet, aki Konstantinápolyt megvette vót...hogy Magyarországra réve lehessön, kiböl mindenkoron rejátörhessen, gondolta vót csináltatni...egy várat”. „az fejéváriak ellen az sabáciaknak oltalmul és strázsájul Havalát, kit mi Sarnónak hívunk, csináltatta vót." ${ }^{, 1587}$ Zay szerint Mátyás 1476-ban, a Szabács elfoglalásakor szerzett török foglyokat is „, király Sarnóba békével késértetött vót”. ${ }^{1588}$

Így a Khalkokondülész által említett ostrom csak Havale, azaz Zsarnó ostroma lehetett. Nem marad más hátra, mint hogy Zsarnó ezen ostromát az 1463. évi hadjáratba helyezzük el. Ali bég hadjárata kezdetén Nándorfehérvárt kikerülve ért Futakhoz (Bonfini), ahonnan visszaüzték. A Bonfini által közölt szóbeli forrás említi, hogy már ekkor elérhették Sarno várát, de annak ostromáról nem tudunk. Ezután a király kelt át a Dunán és betört Szerbiába, ahogy azt Mátyás levele leírta. Itt föleg portyázó és gyors hadműveletekre került sor, várostromra nem. A bizánci forrásunk alapján az egyetlen lehetséges időpont közvetlenül a Dunán való átkelés után lehetett, de még a szerbiai hadműveletek előtt.

A Horváth Richárd által összeállított királyi itinerárium szerint Mátyás 1463. július 5 28 között Futakon adott ki okleveleket. ${ }^{1589}$ Majd augusztus 29 - szeptember 8. között Nándorfehérváron. Azonban július 28 és augusztus 29-e között nincs királyi oklevél. Horváth szerint e hosszú szünet egyértelműen hadieseményre, gyakori csapatmozgásra utalhat és a szerbiai betörések időpontját valószínűsíti ekkorra. ${ }^{1590}$ A fentiek alapján ezt kiegészítem Zsarno ostromával, amelyre valószínűleg július-augusztusban kerülhetett sor, még a szerbiai betörést megelőzően.

Végül ugyanerről a hadjáratról szóló másik bizánci forrással zárom munkámat. Egyúttal ez egy jó filológiai példát mutat arra, hogy Khalkokondülész fenti információja az őt felhasználó későbbi poszt-bizánci történeti munkákban hogyan torzult, romlott, amelyet

\footnotetext{
${ }^{1586}$ Balla 1991. 54.

1587 Zay Ferenc: Az Lándorfejírvár elvesztésének oka e vót és így esött. Sajtó alá rendezte: Kovács István. Utószó: Szakály Ferenc. Budapest 1980. 42. (A továbbiakban: Kovács 1980).

1588 Kovács 1980. 45.

1589 Horváth Richárd: Itineraria regis Matthiae Corvini et reginae Beatricis de Aragonia (1458-1476-1490) Budapest 2011. 73. (A továbbiakban: Horváth 2011)

${ }^{1590}$ Horváth 2011. 74. (369. lbj)
} 
csak az eddig elmondottak alapján érthetünk meg. A 17. századi Codex Barberinus Graecus 111. Névtelen Krónikája is közli Mátyás ezen hadjáratát.

„És százötvenezres sereget gyüjtött össze, elindult és átkelt a Duna folyón, és felprédálta a szultán területeit. Szabatinosz pedig, aki kijavitotta Nándorfehérvár falát, elindult, és ugyanez a király megverte. És onnan átkelt a Száva folyón, amely ott van, felprédálta a szultán földjeit, és mintegy húszezer embert hurcolt rabságba. Onnan pedig győztesként boldogan tért vissza országába. " (Baán István fordítása). ${ }^{1591}$

Láthatjuk, hogy a szövegrészletben Szehabeddin Nándorfehérvár falainak kijavítójaként és nem Zsarnó ellenerődjének felépítőjeként, valamint Hunyadi Mátyás ellenfeleként szerepel. Mindez onnan ered, hogy a szövegbanalizáció eredményeként a legközelebbi ellenerőd kifejezés helyére Nándorfehérvár neve került. ${ }^{1592}$

${ }^{1591}$ Baán 2013. 571.

${ }^{1592}$ Így megállapíthatjuk azt is, hogy nem Jajca ostromáról van szó. Baán 2013. 571 (190. lábjegyzet) 


\section{Felhasznált irodalom}

\section{FORRÁSMUNKÁK}

ÁMTBF = Az Árpád-kori magyar történet bizánci forrásai. Összegyűjtötte, fordította Moravcsik Gyula. Budapest 1988.

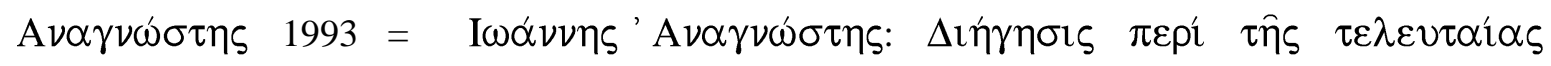

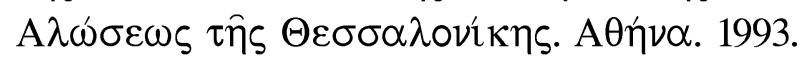

Baán 2013 = A XIV-XVI. századi magyar történelem bizánci és kora újkori görög nyelvü forrásai. Összegyüjtötte, fordította, bevezetéssel és jegyzetekkel ellátta Baán István. (A versek müfordítása Szabó Pál munkája) Budapest 2013.

Baştav 1973 = Şerif Baştav, 16. asırda yazılmış Grekçe anonim Osmanlı tarihi: giriş ve metin (1373-1512). Ankara 1973.

Bekker 1834 = Corpus Scriptorum Historiae Byzantinae. Ducae Michaelis Ducae Nepotis Historia Byzantina. Recognovit Immanuel Bekkerus. Bonnae 1834.

Blaskovics 1982 = A magyarok története. (Tarih-i Üngürüsz; Madzsar Tarihi) Fordította Blaskovics József Budapest. 1982.

Bonfini 1995 = Antonio Bonfini: A magyar történelem tizedei. Ford. Kulcsár Péter, Budapest. 1995.

Boronkai 1987 = Vitéz János levelei és politikai beszédei. Magyar Ritkaságok. Válogatta, a szöveget gondozta és a bevezető tanulmányt írta Boronkai Iván. Budapest 1987.

Brocquière $1848=$ The travels of Bertrandon de la Brocquière. In.: Early travels in Palestine. London 1848. 283-383.

Buchan 1879 = The Bondage and travels of Johann Schiltberger, a native of Bavaria, in Europe, Asia, and Africa 1396-1427. Translated J. Buchan Telfer. New York 1879.

C. Tóth - Neumann 2009 = Zsigmond kori Oklevéltár XI. (1424). Közzéteszi: C. Tóth Norbert-Neumann Tibor. Budapest, 2009.

Callimachus 1961 = Philippus Callimachus: Historia de rege Vladislao. Edidit: Irmina Lichonska. Commentariis historicis illustravit: Thadeus Kowalewski. In linguam Polonam traduxit: Anna Komornicka. Varsoviae 1961.

Cato 1966 = M. Portius Cato: A földművelésről. Fordította: Kun József. Budapest 1966. 
$\mathrm{CDH}=$ Collectio Diplomatica Hungarica. A középkori Magyarország digitális levéltára. Szerkesztette: Rácz György. Arcanum Adatbázis Kft. Budapest 2009.

$\mathrm{CJH}=$ Corpus Juris Hungarici. Magyar Törvénytár. 1000-1526. évi törvényczikkek. Fordította: Nagy Gyula, Dr. Kolosvári Sándor, Dr. Óvári Kelemen; szerkesztette: Dr. Márkus Dezső. Budapest 1899.

Critobulos 1983 = Critobuli Imbriotae Historiae. Recensuit Diether Roderich Reinsch. (Corpus Fontium Historiae Byzantinae, vol. XXII). Walter de Gruyter, Berolini et Novi Eboracii MCMLXXXIII.

DAI = Bíborbanszületett Konstantin: A birodalom kormányzása. Ford. Moravcsik Gyula. (Olajos Terézia bevezető tanulmányával) Budapest $2003^{2}$.

Darkó 1922 = Laonici Chalcocondylae Historiarum demonstrationes. Ad fidem codicum recensuit, emendavit annotatibusque criticis instruxit Eugenius Darkó. Tomus I. Praefationem, codicum catalogum et libros I-IV. continens. Budapestini 1922.

Darkó 1923 = Laonici Chalcocondylae Historiarum demonstrationes. Tomi II. Pars prior. Libros V-VII. continens. Ad fidem codicum recensuit, emendavit annotatibusque criticis instruxit Eugenius Darkó. Tomi II. Pars prior libros V-VII. continens. Budapestini 1923.

Darkó 1928 = Laonici Chalcocandylae Historiarum Demonstrationes. Ad fidem codicum recensuit, emendavit annotatibusque criticis instruxit Eugenius Darkó. Tomi II. Pars posterior. Libros VIII-X. et Indices continens. Budapestini 1928.

Decei 1978 = Aurel Decei: Două documente Turceşti privitoare la expediţiile sultanilor Baiazid I. şi Murad al il-lea în ţările române. In: Relaţii Româno-orientale. Bucureşti, 1978. 209-222.

Decreta 1976 = Decreta Regni Hungariae. Gesetze und verordnungen Ungarns 1301-1457. Collectionem manuscriptam additamentis auxerunt, commentariis notisque illustraverunt Georgius Bónis, Franciscus Döry, Vera Bácskai. Budapest 1976.

Dlugos 2001 = Dlugos: Annales seu Cronicae incliti regni Poloniae. Liber duodecimus. Varsaviae, 2001.

Epithoma 1977 = Petrus Ransanus: Epithoma Rerum Hungaricarum. Id est annalium omnium temporum liber primus et sexagesimus. Curam gerebat Petrus Kulcsár. Budapest 1977.

Fejér X/ II. 1834 = Codex Diplomaticvs Hungariae ecclesiasticvs ac civilis. Stvdio et opera Georgii Fejér. Tomi X. Volvmen II. Ab anno Christi 1392-1400. Budae 1834.

Fejér X/I. 1834 = Codex Diplomaticvs Hvngariae ecclesiasticvs ac civilis. Stvdio et opera Georgii Fejér. Tomi X. Volvmen I. Ab anno Christi 1382-1391. Budae 1834. 
Fontes Populorum 1973 = Fontes Byzantini Historiam Populorum Jugoslaviae Spectantes Tomus VI. Beograd, 1986. 160, 202. Gregoras kiadása: Nikephoros Gregoras, Rhomäische Geschichte. J. L. van Dieten I-II. Stuttgart 1973, 1979.

Froissart $1904=$ The Chronicles of Froissart. Translated John Bourchier, Lord Berners. Edited and reduced into one volume by G. C. Macaulay. London $1904 .^{3}$

Giese $1925=$ Die altosmanischen anonymen Chroniken. Text und Ubersetzung herausgegeben von Dr. Friedrich Giese. Teil II. Leipzig 1925.

Grecu 1958 = Ducas Istoria Turco-Bizantină (1341-1462) ediţie critică de Vasile Grecu. Editio Academiae Reipublicae Popularis Romanicae. Bucureşti 1958.

Grecu 1966 = Georgios Sphrantzes, Memorii 1401-1477. Ediţie critică de Vasile Grecu. Bucureşti 1966.

Hadîdî 1991 = Hadîdî: Tevârih-i Âl-i Osman (1299-1523) Hazırlayan Dr. Necdet Öztürk, İstanbul 1991.

Házi 1924 = Sopron szabad királyi város története. I. rész, 3. kötet. Oklevelek és levelek 1430-tól 1452-ig. Közli vitéz Házi Jenő dr. Sopron 1924.

Hérodotosz 2004 = Hérodotosz: A görög-perzsa háború. Fordította Muraközy Gyula. Budapest. 2004.

History of Egypt 1958 = History of Egypt. A. D. 1382-1469, A. D. 1382-1399. Abū AlMahāsin, Yūsuf Ibn Taghrībirdī. California 1958.

Homérosz 1957 = Homérosz: Íliász. Fordította Devecseri Gábor. Budapest 1957.

Horváth 2005 = Horváth Richárd: Györ megye hatóságának oklevelei 1328-1525. Győr 2005.

İbn Kemal 1957 = İbn Kemal (Kemalpaşazâde): Tevârih-i Âl-i Osman. VII. Defter. Ankara, 1957.

İbn Kemal 2000 = İbn Kemal (Kemalpaşazâde): Tevârih-i Âl-i Osman IV. defter. Hazırlayan Koji Imazawa. Ankara 2000.

ÍF 2006 = Írott források az 1050-1116 közötti magyar történelemröl. Szegedi Középkortörténeti Könyvtár 22. Az elöszót írta, a szövegeket válogatta, a kötetet szerkesztette Makk Ferenc, Thoroczkay Gábor. Szeged 2006.

İnalc1k 1957 = Halil İnalc1k: An Ottoman document on Bayezid I. S Expedition into Hungary and Wallachia. In.: X. Milletlerarasi Bizans Tetkikleri Kongresi Tebliğleri-Actes d' X. Congres International D'Etudes Byzantines. İstanbul 1957. 220-222. 
İnalcık-Oğuz 1989 = Halil İnalc1k-Mevlûd Oğuz: Gazavât-i Sultân Murâd b. Mehemmed Hân. İzladi ve Varna Savaşları (1443-1444). Üzerinde Anonim Gazavâtnâme. Ankara 1989.

Istvánffy 1962 = Istvánffy Miklós: A magyarok történetéből. (Fordította: Juhász László) Budapest 1962.

Janus 1987 = Janus Pannonius összes munkái. Közrebocsátja: V. Kovács István, Budapest 1987.

Karácson 1904 = Evlia Cselebi török világutazó magyarországi utazásai 1660-1664. Fordította és jegyzetekkel ellátta Dr. Karácson Imre. In.: Török - magyarkori Történelmi emlékek. Török történetírók III. Budapest, 1904.

KHO = Középkori Históriák Oklevelekben (1002-1410). A szövegeket válogatta, az előszót és a jegyzeteket írta Kristó Gyula. Szeged 2000.

Kołodziejczyk 2000 = Dariusz Kołodziejczyk: Ottoman-Polish diplomatic relations (15th18th century) An annotated edition of 'Ahdnames and other documents. Leiden 2000 .

Kovács 1980 = Zay Ferenc: Az Lándorfejírvár elvesztésének oka e vót és így esött. Sajtó alá rendezte: Kovács István. Utószó: Szakály Ferenc. Budapest 1980.

Kreutel 1959 = Osmanische Geschichtsschreiber. Herausgegeben von Dr. Richard F. Kreutel. Band 3. Vom Hirtenzeit zur Hohen Pforte. Übersetz, eingeleitet und erklärt von Richard F. Kreutel. Graz-Wien-Köln. 1959.

Kreutel 1971 = Leben und Taten der türkischen Kaiser. Die Anonyme vulgargriechische Chronik Cod. Barb. 111 (Anonymous Zoras). Übersetzt, eingeleitet und erläutert Richard F. Kreutel. Graz 1971.

Kritobúlosz 1875 = Kritobúlosz: II. Mehemet élete. Fordította Szabó Károly. Budapest 1875.

Lewicki 1891 = Monumenta Medii Aevi Historica Res gestas Poloniae Illustrantia. Tomus XII. Codex Epistolaris saeculi decimi quinti. 1382-1445. Tomus II. Collectus opera Dr. Anatolii Lewicki. Krakowie 1891.

Livius I. 1982 = Livius: A római nép története a város alapításától. I. kötet. Budapest 1982.

Livius III. 1982 = Livius: A római nép története a város alapításától. III. kötet. Budapest 1982.

Livius Text 1967 = Livy with an English translation in fourteen volumes. III. Books V, VI and VII. The Loeb Classical Library. Edited by: G. P. Goold. Translated by B. O. Foster, Cambridge, Massachusetts, London $1967^{2}$. 
Livius Text 1983 = Livy with an English translation in fourteen volumes. XI. Books XXXVIII-XXXIX. The Loeb Classical Library. Edited by: G. P. Goold. Translated by Evan T. Sage. Cambridge, Massachusetts, London $1983^{2}$.

Mályusz 1951 = Mályusz Elemér: Zsigmond kori oklevéltár I. (1387-1399). Budapest 1951.

Ménage 1971 = V. L. Ménage: Hadīdī. In.: The Encyclopaedia of Islam. Volume III. HIRAM, Edited by: B Lewis, V. L. Ménage, Ch. Pellert, J. Schlacht. LeidenLondon 1971. 22-23.

Ménage $1976=$ V. L. Ménage: The 'Annals of Murād II' Bulletin of the School of Oriental and African Studies, University of London. Vol. 39, No. 3. (1976) 570-584.

Mollay 1978 = A korona elrablása. Kottanner Jánosné emlékirata 1439/1440. Fordította és közzéteszi Mollay Károly. Budapest 1978.

Monumenta Serbica 1858 = Monumenta Serbica spectantia historiam Serbiae Bosniae Ragusii. Edidit: Fr. Miklosich Viennae 1858.

Moravcsik 1934 = Moravcsik Gyula: A magyar történet bizánci forrásai. Budapest 1934.

Moravcsik 1942 = Gyula Moravcsik: Byzantinoturcica I. Die Byzantinischen Quellen der Geschichte der Türkvölker. Budapest 1942.

Nagybáncsai 1560 = Nagybáncsai Mátyás: História az vitéz Hunyadi János vajdáról. In.: Régi magyar irodalmi szöveggyüjtemény II. A 16. század magyar nyelvü világi irodalma. Budapest 2000. 552-553.

Odorico $2005=$ Thessalonique. Chroniques d'une ville prise, textes présentés et traduits du grec par Paolo Odorico. Toulouse 2005.

Oruç 2007 = Oruç Beğ Tarihi (Osmanli Tarihi 1288-1502) Hazırlayan Prof. Dr. Necdet Öztürk. Istanbul 2007.

Petkov 2008 = Kiril Petkov: The Voices of Medieval Bulgaria, Seventh-Fifteenth Century: The Records of a Bygone Culture (East Central and Eastern Europe in the Middle Ages, 450-1450) Leiden 2008.

Philippides $1990=$ Byzantium, Europe and the early ottoman sultans 1373-1513. An Anonymous Greek Chronicle of the Seventeenth Century (Codex Barberinus Graecus 111). Translated and annotated by Marios Philippides. (Late Byzantine and Ottoman Studies, 4) New Rochelle, New York 1990.

Plinius $1866=$ C. Plinii Secundi Naturalis historia. Recensuit D. Detlefsen. Vol. I. Libri IVI. Berolini 1866.

Plinius 2009 = C. Plinius Secundus: Naturalis historia. (Természetrajz XIV-XVIII) Fordította: Hoffmann Zsuzsanna, Szeged. 2009. 
Polübiosz 2002 = Polübiosz történeti könyvei. II. kötet Máriabesnyő-Gödöllő 2002.

Polybius 1995 = Polybius: The Histories. Volume VI. The Loeb Classical Library. Edited by: G. P. Goold. With an English translation by W. R. Paton. Cambridge, Massachusetts, London 1995.

Priscos 1983 = R. C. Blockley: The fragmentary classicizing historians of the later Roman Empire. II. Text, translation and historiographical notes. Liverpool 1983. Priscos: $222-400$.

Ptolemaiosz 1843 = Claudii Ptolemaei Geographia. Tom. I. Edidit Carolus Fridericus Augustus Nobbe. Lipsiae 1843.

Raguzai oklevéltár 1887 = Raguza és Magyarország összeköttetéseinek oklevéltára. Összeállította: Gelcich József, bevezetéssel és jegyzetekkel ellátta Thallóczy Lajos. Budapest 1887.

Ransanus 1999 = Petrus Ransanus: A magyarok történetének rövid foglalata. Fordította: Blazovich László és Sz. Galántai Erzsébet. Budapest 1999.

Rerum 1936 = Antonius de Bonfinis: Rerum Ungaricarum decades. Ediderunt: I. Fógel et B. Iványi és L. Juhász. Tomus III. Decas III. Lipsiae 1936.

Rerum II. 1936 = Antonius de Bonfinis: Rerum Ungaricarum decades. Ediderunt: I. FógelB. Iványi-L. Juhász. Tomus II. Decas II. Lipsiae, 1936.

Schmitt 1904 = The Chronicle of Morea. Edited by John Schmitt. London 1904.

Schreiner 1975 = Peter Schreiner: Die Byzantinischen kleinchroniken 1. Wien 1975.

Seemüller $1909=$ Österreichische Chronik von Den 95 Herrschaften. Herausgegeben von Joseph Seemüller. Hannover und Leipzig 1909. 205. In.: Monumenta Germaniae Historica. Scriptorvm qvi vernacula lingva vsi svnt. Tomus VI.

SRH I. = Scriptores Rerum Hungaricarum. Tempore ducum regumque stirpis Arpadianae gestarum. Edendo operi praefuit Emericus Szentpétery. Volumen I. Budapestini 1937.

Szamota 1891 = Régi utazások Magyarországon és a Balkán-félszigeten. Összegyüjtötte és jegyzetekkel kísérte Szamota István, Budapest 1891.

SZOkl. 1890 = Székely Oklevéltár. Szerkesztette: Szabó Károly III. kötet (1270-1571) Kolozsvár 1890.

Sztrabón 1977 = Strabón: Geógraphika. Fordította: Dr. Földy József. Budapest 1977.

Tardy 1977 = Rabok, követek, kalmárok az Oszmán Birodalomról. Közreadja: Tardy Lajos. Budapest 1977.

Teleki 1853 = Gr. Teleki József: Hunyadiak kora Magyarországon. X. kötet. Pest 1853. 
Thallóczy-Áldásy $1907=$ Thallóczy Lajos-Áldásy Antal: Magyarország melléktartományainak oklevéltára II. A Magyarország és Szerbia közötti összeköttetések oklevéltára. 1198-1526. 1907.

Thallóczy-Barabás 1910 = A Frangepán család oklevéltára. (In.: Magyar Történelmi Emlékek. Első osztály, okmánytárak, harmincötödik kötet.) Kiadják: Dr. Thallóczy Lajos, Barabás Samu. Első kötet 1133-1453. Budapest 1910.

Theophülaktosz 2012 = Theophülaktosz Szimokattész: Világtörténelem. Fordította, a bevezetést és a jegyzeteket írta Olajos Teréz. Budapest 2012.

Thurn 1973 = Ioannis Scylitzae Synopsis Historiarum. Recensuit: Ioannes Thurn. Berolini et Novi Eboraci, 1973.

Thuróczy 1978 = Thuróczy János: A magyarok krónikája. Fordította Horváth János Budapest 1978.

Thuróczy 2001 = Thuróczy János: A magyarok krónikája. Rogerius mester: Siralmas ének. Milleniumi Magyar Történelem. Fordította: Bellus Ibolya, Horváth János, Kristó Gyula. Budapest 2001.

Thuróczy kommentár $1988=$ Johannes de Thurocz: Chronica Hungarorum II. Commentarii. 2. Ab anno 1301 usque ad annum 1487. (composuit Elemér Mályusz adiuvante Julio Kristó) Budapest 1988.

Thuróczy Textus 1985 = Johannes de Thurocz: Chronika Hungarorum. I. Textus. Ediderunt Elisabeth Galántai et Julius Kristó. Budapest 1985.

Tinódi 1881 = Tinódi Lantos Sebestyén összes müvei. Régi magyar költők tára. III. kötet. Budapest 1881.

Török hadak 1984 = Török hadak Magyarországon. 1526-1566. Kortárs török történetírók naplórészletei. Thúry József fordítását válogatta, jegyzeteit bővítette Kiss Gábor. Budapest 1984.

Török történetírók I. 1893 = Török történetírók. Fordította Thúry József. I. kötet. Budapest 1893.

Török történetírók. II. 1896 = Török történetírók. II. kötet (1521-1566) Fordította Thúry József. Budapest 1896.

V. Kovács 1986 = Mátyás király levelei 1460-1490. Magyar Levelestár. Válogatta, a szöveget gondozta, az utószót és a jegyzeteket írta: V. Kovács Sándor. Fordította: Ballér Piroska. Budapest 1986.

Vegetius = Flavius Vegetius Renatus: A hadtudomány foglalata négy könyvben. In.: A hadmüvészet ókori klasszikusai. Szerk.; bev. tanulmányt írta Hahn István. Budapest 1963. 753-865. 
Vitéz 1980 = Ioannes Vitéz de Zredna. Opera quae supersunt. Edidit Iván Boronkai. Budapest 1980.

Werbőczy 1990 = Werbőczy István: Tripartitum. A dicsőséges Magyar Királyság szokásjogának Hármaskönyve. Latin-magyar kétnyelvü kiadás. Budapest 1990.

Windecke 2008 = Eberhard Windecke emlékirata Zsigmond királyról és koráról. Fordította, sajtó alá rendezte és a bevezető tanulmányt írta Skorka Renáta. Budapest 2008.

www. mol.arcanum.hu (A középkori Magyarország levéltári forrásainak adatbázisa)

Yavuz-Saraç 2007 = Âșik Pașazade Osmanoğulları'nim Tarihi. Hazırlayanlar Kemal Yavuz-M. A. Saraç İstanbul, 2007.

Zichy 1888 = A Zichi és Vásonkeői Gróf Zichy-család idősb ágának okmánytára. V. kötet. (1383-1409) Szerk.: Nagy Imre. Budapest 1888.

Zichy 1895 = A Zichy és Vásonkeői Gróf Zichy-család idősb ágának okmánytára. VIII. kötet, szerk. Kammerer Ernő, Budapest, 1895.

Zichy 1899 = A Zichy és Vásonkeői Gróf Zichy-család idősb ágának okmánytára. IX. kötet, szerk. Kammerer Ernő. Budapest 1899.

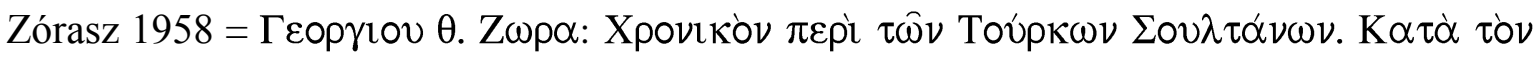

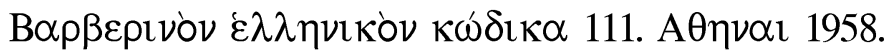

Zrínyi 2009 = Zrínyi Miklós: Szigeti veszedelem, Az török áfium ellen való orvosság. Budapest 2009.

Zsigmond szabályzat 1892 = Zsigmond király két honvédelmi szabályzata. Hadtörténelmi Közlemények 1892. 586-608.

\section{SZAKIRODALOM}

Ágoston 1992 = Ágoston Gábor: Az oszmán és az európai tüzérség. Párhuzamok és eltérések az oszmán és az európai tüzérség fejlődésében a 15-17. században. Történelmi Szemle 1992. 173-198.

Ágoston 2005 = Gábor, Agoston: Guns for the Sultan. Military Power and Weapons Industry in the Ottoman Empire. Cambridge 2005.

Ágoston 2009 = Gabor Agoston: Bayezid I. (Thunderbolt) In: Encyclopedia of the Ottoman Empire. Ed.: Gabor Agoston, Bruce Masters, New York 2009.

Áldásy $2008^{2}$ = Áldásy Antal: Címertan. Máriabesnyő-Gödöllő 2008. ${ }^{2}$ 
Angold 2001 = Michael Angold: Bizánc. Híd az ókor és a középkor között. Fordította: Sándor Bea. Budapest 2001.

Angyal 1911 = Angyal Dávid: Bosznia követei és a budai országgyülés 1440 júniusában. Századok (1911) 1/ 49-50.

Aslantaş 2011 = Selim Aslantaş: Belgrad-i Dárü'l-Cihád. Hacettepe Üniversitesi Türkiyat Arastirmalari Ankara, 2 Aralık 2011. 13-37.

Babinger $1944=$ Franz Babinger: Beiträge zur Frühgeschichte der Türkenherrschaft in Rumelien (14.-15. Jahrhundert). Brunn: R. M. Rohrer, 1944.

Bakirtzis $2003=$ Charalambos Bakirtzis: The Urban Continuity and Size of Late Byzantine Thessalonike. Dumbarton Oaks Papers, (Vol. 57), Symposium on Late Byzantine Thessalonike (2003) 35-64.

Balla 1991 = Balla Lóránt: Az albánok harca a törökök ellen a 15. században. Világtörténet 1991. (tavasz-nyár) 47-55.

Bán 2011 = Bán Mór: Hunyadi. V. A mennydörgés kapuja. Budapest 2011. (történelmi regény)

Bánlaky Doberdói 1928 = Bánlaky (Doberdói Breit) József: A magyar nemzet hadtörténelme. 10. Budapest 1928.

Baranyai 1926 = Baranyai Béla: Zsigmond király ún. Sárkány-rendje (1. közlemény) Századok 1926. 561-591, 681-719.

Bárczay 1897 = Bárczay Oszkár: A heraldika kézikönyve. Budapest 1897.

Barta 1985 = Barta Gábor: Nándorfehérvár 1456. Budapest 1985.

Bartal $1901=$ Glossarium mediae et infimae latinitatis regni Hungariae. Condidit Antonius Bartal. Lipsiae 1901.

Bartusis 1997 = Marc C. Bartusis: The late Byzantine army: arms and society, 1204-1453. Philadelphia 1997.

Bayerle 1997 = Gustav Bayerle: Pashas, begs and effendis. A historical dictionary of titles and terms in the Ottoman Empire. Istanbul 1997.

Béni-Szakács-Nagy 2006 = Béni Szabolcs-Szakács Zoltán-Ungváriné Nagy Zsuzsanna: Általános és szervetlen kémiai gyakorlatok. (Laboratóriumi előiratok és számítási feladatok) Budapest 2006.

Beritić 1989 = Luksa Beritić: The city walls of Dubrovnik. Dubrovnik 1989.

Bertényi 1989 = Bertényi Iván: Nagy Lajos király. Budapest 1989.

Bogdán 1987 = Bogdán István: Régi magyar mértékek. Budapest 1987. 
Bostan 2003 = İdris Bostan: A szultáni ágyúöntő műhelyben (Tophâne-i Âmire) folyó tevékenység a 16. század elején. Fordította: Papp Sándor. Aetas 2003/3. 5-29.

Both 2003 = Both Ödön: Fejezetek a nyugat-európai állam- és jogtörténet köréből. Szeged 2003.

Bradbury 2006 = Jim Bradbury: The Routledge companion to medieval warfare. LondonNew York 2006.

Bréhier 1997 = Louis Bréhier: Bizánc tündöklése és hanyatlása. II. Fordította: Baán István. Budapest 1997.

Bréhier 2003 = Louis Bréhier: A bizánci birodalom intézményei. Budapest, 2003.

Brósz-Pólay 1989 = Brósz Róbert-Pólay Elemér: Római jog. Budapest 1989.

C. Tóth $2004=$ C. Tóth Norbert: Mesélő krónikák, 149. rész (2004. február 17-i adás, MR1 Kossuth Rádió)

C. Tóth $2009=$ C. Tóth Norbert: Luxemburgi Zsigmond uralkodása. 1387-1437. Magyarország története 6. Budapest 2009.

Cambridge Medieval History 1966 = The Cambridge Medieval History. Volume IV. Part I. The Byzantine Empire. Edited by: J. M. Hussey. Cambridge 1966.

Čirković 1982 = Sima Čirković: Godine Kriza i Previranja. Istorija Srpskog Naroda, 1982. II, 47-64.

Clausewitz 1999 = A háborúról. Clausewitz Károly tábornok hátrahagyott müve. Magyarra fordította és magyarázatokkal ellátta Báró Hazai Samu. (Második kiadás, Budapest 1917) Reprint: Veszprém 1999.

Cvekan 1985 = Paškal Cvekan: Franjevci u Baču. Virovitica 1985.

Cvetkova 1988 = Bisztra Cvetkova: A várnai csata. Budapest 1988.

Csáki $2001^{2}$ = Csáki Éva: Török-magyar szótár. Budapest $2001{ }^{2}$

Cseh 2007 = Cseh Valentin: Nándorfehérvár ostroma 1456. Keszthely 2007.

Cseh 2010 = Cseh Valentin: Nándorfehérvár szerepe a déli végvárrendszerben 1427-1521. Várak, kastélyok, templomok. 2010. (december) 29-31.

Csiky 2012 = Csiky Gergely: Konstantinápoly városfalai és a 626. évi avar ostrom. In.: Középkorténeti tanulmányok 7. Szerk.: Kiss P. Attila, Piti Ferenc, Szabados György. Szeged 2012. 165-183. 
Csömöre 2012 = Csömöre Zoltán: Temesközi várak, erődített templomok a török portyázások időszakában (1390-1551). Középkortörténeti Tanulmányok 7. Szerk: Kiss P. Attila, Piti Ferenc, Szabados György, Szeged 2012. 485-503.

Csörsz Rumen 2004 = Csörsz Rumen István: „Hallám egy ifjúnak minap éneklését” Versformák és dallamok Balassi Bálint költészetében. In.: Balassi Bálint és kora. Budapest 2004. 81-96.

Dennis 1964 = G. T. Dennis: The second Turkish capture of Thessalonica 1391, 1394 or 1430? Byzantinische Zeitschrift (57) 1964/ 1. 53-61.

DeVries 1996 = Kelly DeVries: Gunpowder weapons at the siege of Constantinople. In.: War, Army and Society in the Eastern Mediterranean, $7^{\text {th }}-16^{\text {th }}$ centuries. Edited by: Yaacov Lev. Leiden 1996. 343-362.

DeVries 1999 = Kelly DeVries: The Lack of a Western European Military Response to the Ottoman Invasions of Eastern Europe from Nicopolis (1396) to Mohács (1526). In.: Journal of Military History 63 (1999). 539-559.

DeVries 2002 = Kelly DeVries: Guns and Men in Medieval Europe 1200-1500. Studies in Military History and Technology. Aldershot-Burlington 2002.

Djurdjev 1960 = B. Djurdjev: Belgrade In.: The Encyclopaedia of Islam. New edition, volume I. A-B. Edited by: H. A. R. Gibb; J. H. Kramers; E. Lèvi-Provençal; J. Schlacht. Leiden-London 1960. 1163.

Draskóczy 2000 = Draskóczy István: A tizenötödik század története. Budapest 2000.

Du Cange $1905=$ Glossarium ad scriptores mediae et infimae graecitatis auctore Carolo du Fresne, Domino du Cange. Tomus primus. Parisiis et Lipsiae. 1905.

Efoulkes $1930=$ Charles Efoulkes: Tha Dardanelles' Gun at the Tower. Antiquarian Journal. Vol. 10. (1930) 217-227.

Emecen 1999 = Feridun M. Emecen: Egy régi imágó újbóli felfedezésére: Oguz hagyomány és Közép Ázsia ismerete. (Fordította: Papp Sándor) Aetas 1999/4. $19-26$.

Encyclopedia 2009 = Encyclopedia of the Ottoman Empire. Ed.: Gabor Agoston, Bruce Masters, New York 2009.

Engel 1990 = Engel Pál: Beilleszkedés Európába a kezdetektől 1440-ig. Magyarok Európában I. Budapest 1990.

Engel 1994 = Engel Pál: Magyarország és a török veszély Zsigmond korában (1387-1437). Századok 1994 / 2. 273-287.

Engel 1996 = Engel Pál: Magyarország világi archontológiája. I. kötet. Budapest 1996. 
Engel 1998 = Engel Pál: A török-magyar háborúk első évei 1389-1392. Hadtörténelmi Közlemények 1998/3. 561-577.

Engel 2001 = Engel, Pál: The estates of the Hospitallers in Hungary at the end of the Middle Ages. In.: The Crusades and the Military Orders. Expanding the Frontiers of the Medieval Latin Christianity. Edited by Zsolt Hunyadi, József Laszlovszky. Budapest 2001. 291-302.

Engel-C. Tóth $2005=$ Engel Pál - C. Tóth Norbert: Itineraria regum et reginarum (13821438) Zsigmond király és császár (1382-1437) itineráriumát készítette Engel Pál. Kiegészítette, szerkesztette és mutatóval ellátta C. Tóth Norbert. Budapest 2005.

Engel-Kristó-Kubinyi 1998 = Engel Pál-Kristó Gyula-Kubinyi András: Magyarország története 1301-1526. Budapest 1998.

Erdély 1986 = Erdély története. A kezdetektől 1606-ig. Szerk.: Makkai László, Mócsy András. Budapest 1986.

Erlich 2002 = Haggai Erlich: The Cross and the River. Ethiopia, Egypt, and the Nile. Colorado-London 2002.

Farkas 2009 = Farkas Péter: Cseh Valentin Nándorfehérvár ostroma 1456. Hadtörténelmi Közlemények 2009/2. 557-559.

Fedeles 2011 = Fedeles Tamás: Nemzeti nagylétünk tanúsága. Nándorfehérvár 1456. Rubicon 2011/7. 9.

Fedeles 2012 = Fedeles Tamás: Fegyverek, felszerelés, logisztika a késő középkori Magyarországon. In.: Középkortörténeti tanulmányok 7. Szerk.: Kiss P. Attila, Piti Ferenc, Szabados György. Szeged 2012. 505-527.

Finkel 2006 = Caroline Finkel: Osman's dream. The story of the Ottoman Empire 13001923. London 2006.

Fodor 1983 = Fodor Pál: Ahmedi elbeszélése, mint a korai oszmán történelem forrása. Világtörténet 1983/2. 3-18.

Fodor 1991 = Fodor Pál: Magyarország és a török hódítás. Budapest 1991.

Fodor 1995 = Fodor Pál: Török és oszmán: Az oszmán rabszolga elit azonosságtudatáról. Történelmi Szemle 1995/4. 367-383.

Fodor 2004 = Fodor Pál: A szimurg és a sárkány: Az Oszmán Birodalom és Magyarország (1390-1533). In.: Közép-Európa harca a török ellen a 16. század első felében. (szerk.: Zombori István) Budapest 2004. 9-35.

Fodor 2008 = Fodor, Pál: The Ottoman Empire, Byzantium and Western Christianity the implications of the siege of Belgrade, 1456. Acta Orinetalia 2008. (68.) 1-2. sz. $43-51$. 
Fodor 2009 = Fodor, Pál: Ottoman warfare 1300-1453. In.: The Cambridge History of Turkey. 1071-1453. Volume I. Byzantion to Turkey. Edited by: Kate Fleet. Cambridge 2009. 192-226.

Font 1997 = Font Márta: A német lovagrend alkonya. Pécs 1997.

Font-Krausz-Niederhauser-Szvák 2001 = Font Márta-Krausz Tamás-Niederhauser EmilSzvák Gyula: Oroszország története. Budapest 2001.²

Foss-Winfield $1986=$ C. Foss-D. Winfield: Byzantine Fortifications, an introduction. Praetoria 1986.

Földi-Hamza 1996 = Földi András-Hamza Gábor: A római jog története és instituciói. Budapest 1996.

Fraknói 1895 = Fraknói Vilmos: A Hunyadiak és a Jagellók kora. I. könyv: I. Ulászló uralkodása In: A magyar nemzet története. VI. kötet (1440-1526) Budapest $1895 .^{2}$

Fraknói 1902 = Fraknói Vilmos: Magyarország egyházi és politikai összeköttetései a Római-Szent-Székkel. II. kötet. A konstanzi zsinattól a mohácsi vészig (14181526). Budapest 1902.

Fügedi 1974 = Fügedi Erik: Uram, királyom... A XV. századi Magyarország hatalmasai. Budapest 1974.

Galamb 2000 = Galamb György: A ferences obszervancia magyarországi térnyeréséhez. In.: „Magyaroknak eleiröl” Ünnepi tanulmányok a hatvan esztendős Makk Ferenc tiszteletére. Szerk.: Piti Ferenc, 2000. 165-181.

Gáspár 2011 = Gáspár Ferenc: Pogányokkal táncoló. A holló jegyében. Coldwell. Budapest 2011. (történelmi regény)

Generál 1987 = Generál Tibor: Allah hadserege. Budapest 1987.

Gergely 1999 = Gergely Jenő: A pápaság története. Budapest 1999.

Gernet 2001 = Jaques Gernet: A kínai civilizáció története. Budapest 2001.

Gerő 1975 = Gerő László: Jellegzetes építési korszakok és ezek történeti előzményei az európai várfejlődés keretében. In.: Várépítészetünk, föszerkesztő: Gerő László, Budapest 1975. 9-44.

Gillingham 1985 = John Gillingham: A Rózsák háborúja. Budapest 1985.

Gorszt 1954 = A. G. Gorszt: Lőporok és robbanóanyagok. Nehézipari Könyv- és Folyóirat-kiadó Vállalat. Szerk.: Tóth István. Budapest 1954. 
Grygiel 2006 = Jakub I. Grygiel: Great powers and geopolitical change. The geostrategy of the Ottoman Empire (1300-1699) Baltimore 2006.

Гузина 2002 = Зорица Гузина: Тајне Београда. Београд, 2002.

Hahn 1963 = Hahn István: A hadművészet ókori klasszikusai. Szerkesztette, a bevezető tanulmányt írta Hahn István. Budapest 1963.

Hammer 1830 = Joseph von Hammer: Geschichte des Osmanischen Reiches. Pest 1830.

Heka 2005 = Heka László: Szerbia állam- és jogtörténete. Szeged 2005.

Herczeg 1952 = Herczeg Gyula: Olasz-magyar szótár. I-II. Budapest 1952.

História 2007 = História. Nándorfehérvár 1456. 2007/ 1.

Hóman 1936 = Hóman Bálint-Szekfü Gyula: Magyar történet. II. kötet, írta Hóman Bálint. Budapest, 1936.

Horváth 1868 = Horváth Mihály: A magyarok története rövid elöadásban. Pest 1868.

Horváth 1871 = Magyarország történelme. Írta Horváth Mihály. Második kötet. Pest 1871.

Horváth 2011 = Horváth Richárd: Itineraria regis Matthiae Corvini et reginae Beatricis de Aragonia (1458-1476-1490) Budapest 2011.

Hóvári 1983 = Hóvári János: Az oszmán birodalom és a levantei kereskedelem a 15-16. században. Világtörténet 1983/2. 42-61.

Hóvári 1998 = Hóvári János: A nikápolyi csata. fordulópont a balkáni oszmán hódítások történetében. Hadtörténelmi Közlemények 1998/3. 578-582.

Hunyadi 2011 = Hunyadi Zsolt: A keresztes háborúk világa. Debrecen 2011.

Imber 1990 = Colin Imber: The Ottoman Empire. 1300-1481. İstanbul 1990.

Imber 2002 = Colin Imber: The Ottoman Empire. 1300-1650. The structure of power. New York, 2002.

İnalcık 1954 = Halil İnalcık: Ottoman methods of conquest. Studia Islamica 1954. 103129.

İnalcık 1957 = Halil İnalcık: „Osmanlılar’da Ateşli Silahlar” TTK Belleten 21 nr. 81-84 (1957) 509-513.

İnalcık 1960 = Halil İnalcık: Bayazid I. (Yildirim ,the Thunderbolt”) The encyclopaedia of Islam. New edition. Volume I. A-B. Ed. by: H. A. R. Gibb, J. H. Kramers, E. Lévi-Provencal, I. Schracht. Leiden, London 1960. 1118-1119. 
İnalc1k 1973 = Halil İnalcık: The Ottoman Empire. The Classical Age 1300-1600. London 1973.

Irwin 1995 = Robert Irwin: Islam and the Crusades 1096-1699. In.: The Oxford History of Crusades. Szerk.: Jonathan Riley-Smith Oxford 2009.

Историја 2000 = Историја српског народа II. Београд, 2000.

Iványi 1892 = Iványi István: Szabadka szabad királyi város története. II. rész. Szabadka, 1892.

Iványi 1913 = Iványi Béla: Eperjes középkori ágyúöntő háza és puskapormalma. Hadtörténelmi Közlemények 1913. 113-122, 264-278.

Iványi 1914 = Iványi Béla: Adatok az eperjesi ágyúöntőház és puskapormalom középkori történetéhez. Hadtörténelmi Közlemények 1914. 311-328, 484-495, 665-679.

Iványi 1926 = Iványi Béla: A tüzérség története Magyarországon 1711-ig. Hadtörténelmi Közlemények (27) 1926.1-36, 125-166, 259-289, 393-419.

J. E. Kaufmann-H. W. Kaufmann 2001 = J. E. Kaufmann-H. W. Kaufmann: The medieval fortress. Castles, forts and walled cities of the Middle Age. London. 2001.

Јиречек 1952 = Константин Јиречек: Историја Срба. Веоград 1952.

Jefferson 2012 = John Jefferson: The Holy Wars of King Wladislaus and Sultan Murad. The Ottoman-Christian conflict from 1438-1444. Leiden -Boston 2012.

Juhász 2007 = Juhász Ágnes: A raguzai tisztségviselők a XIV. század közepén. Középkor történeti tanulmányok 5. Szerk.: Révész Éva-Halmágyi Miklós. Szeged 2007. 41-53.

Juhász 2010 = Juhász $2010=$ Juhász Ágnes: A raguzai (dubrovniki) diplomácia a XIV. század közepén (1343-1367). Középkortörténeti tanulmányok 6. Szerk.: G. Tóth Péter-Szabó Pál. Szeged 2010. 95-108.

Juhász 2012 = Juhász Ágnes: A magyar diplomácia a raguzai-cattarói háborúban (13611362). In.: Középkortörténeti tanulmányok 7. Szerk.: Kiss P. Attila, Piti Ferenc, Szabados György. Szeged 2012. 475-484.

Kádár-Szabó 1984 = Kádár Zoltán-Szabó Árpád: Antik természettudomány. Budapest 1984.

Kaldellis 2012 = Anthony Kaldellis: The greek sources of Laonikos Chalkokondyles' Histories. In.: Greek, Roman, and Byzantine Studies 52 (2012) 738-765.

Калић 2001 = Јованка Калић: Срби у позном средњем веку. Београд 2001.

Калић-Мијушковић 1967 = Јованка Калић-Мијушковић: Београд у средњем веку. Београд 1967. 
Kálmán-Veszprémy 2013 = Európa védelmében. Kapisztrán Szent János és a nándorfehérvári diadal emlékezete. (szerk.: Kálmán Peregrin-Veszprémy László) Budapest 2013.

Kapitánffy 2003 = Kapitánffy István: Propugnacula Christianitatis. Magyar-bizánci kapcsolatok a birodalom bukásának idején. Hungaro-Byzantina. Budapest 2003.

Karácsonyi 1910= Karácsonyi János: Az első magyar hadijelentés (1437). Hadtörténelmi Közlemények 1910. 15-22.

Karácsonyi 1913 = Karácsonyi János: Kik voltak s mikor jöttek hazánkba a böszörmények vagy izmaeliták? Budapest 1913.

Karácsonyi 1922 = Dr. Karácsonyi János: Szt. Ferenc rendjének története Magyarországon 1711-ig. I. kötet, Budapest 1922.

Katus 2000 = Katus László: A középkor története. Budapest 2000.

Kelenik 1988 = Kelenik József: Szakállas puskák a XVI. századi inventáriumokban (A terminológia problémái). Hadtörténeti Közlemények 1988/3. 484-520.

Kelenik 1991 = Kelenik József: A kézi lőfegyverek jelentősége a hadügyi forradalom kibontakozásában. Hadtörténelmi Közlemények 1991/4. 3-52.

Kiel $2009=$ Machiel Kiel: The incorporation of the Balkans into the Ottoman Empire, 1353-1453. In.: The Cambridge History of Turkey. 1071-1453. Volume I. Byzantion to Turkey. Edited by: Kate Fleet. Cambridge 2009. 138-191.

Kiss 1857 = Kiss Károly: Hunyadi János utolsó hadjárata bolgár- és szerbországban 1454ben és Nándorfehérvár fölmentése a török táborításától 1456. (A nándorfehérvári diadal negyedik százados napján. júl. 21. 1856.) Pest, 1857.

KMTL = Korai magyar történeti lexikon (9-14. század) Főszerk. Kristó Gyula, szerk.: Engel Pál-Makk Ferenc, Budapest 1994.

Konkoly 2012 = Konkoly Sándor: A titokzatos Szembécs vára. Bácsország 2012/2. 105108.

Kordé 2002 = Kordé Zoltán: A székely ispáni méltóság a Zsigmond halála utáni években. Acta Universitatis Szegediensis de Attila József Nominatae. Acta Historica, Tomus CXVI. Szeged, 2002. 49-58.

Kordé 2004 = Kordé Zoltán: A székelyispáni méltóság a Zsigmond korban. Történelmi Szemle 2004/3-4. 193-239.

Kordé 2005 = Kordé Zoltán: Megjegyzések a székely ispánok 1467 előtti katonai szerepéhez. Hadtörténelmi Közlemények 2005/3. 721-732. 
Kristó-Barta-Gergely 2002 = Kristó Gyula-Barta János-Gergely Jenő: Magyarország története. Elöidőktől 2000-ig. Budapest 2002.

Kristóf 2006 = Kristóf Ilona: Egy lengyel humanista Magyarországon, az elfeledett Szánoki Gergely. Acta Academiae Paedagogicae Agriensis Sectio Historiae XXXIII. Szerk.: Gebei Sándor. Eger 2006. 21-32.

Krzyżaniakowa 1979 = Jadwiga Krzyżaniakowa: Kancelaria królewska Władysława Jagiełły. Studium z dziejów kultury politycznej polski w XV wieku. Poznań 1979.

Kubinyi $2006=$ Kubinyi András: Nándorfehérvártól Mohácsig. Kérdések és következtetések. Hadtörténelmi Közlemények 2006/4. 923-941.

Kubinyi 2007 = Kubinyi András: Nándorfehérvártól Mohácsig. A Mátyás- és Jagelló-kor hadtörténete. Budapest, 2007.

Kulcsár 1973 = Kulcsár Péter: Bonfini Magyar Történetének forrásai és keletkezése. Budapest 1973.

Lewis 1981 = Bernard Lewis: Isztambul és az oszmán civilizáció. Budapest 1981 .

Magyar kronológia 1981 = Magyarország történeti kronológiája. I. kötet. Budapest 1981 .

Magyar kronológia 1984 = Magyar történelmi kronológia. Az östörténettől 1970-ig. Budapest 1984.

Magyar kronológia 2001 = A magyar történelem kronológiája (830-2000) Magyar Századok. Budapest 2001.

Magyar nép története 1951 = Heckenast Gusztáv, Karácsonyi Béla, Lukács Lajos, Spira György: A magyar nép története (rövid áttekintés). Budapest 1951.

Magyarország hadtörténete 1984 = Magyarország hadtörténete I. A honfoglalástól a kiegyezésig (föszerk. Liptai Ervin, szerk. Borus József). Budapest 1984.

Makk 1989 = Makk, Ferenc: The Árpáds and the Comneni. Political relations between Hungary and Byzantium in the 12th century. Budapest 1989.

Makk 1996 = Makk Ferenc: Magyar külpolitika (896-1196) Szeged 1996.

Mályusz 1984 = Mályusz Elemér: Zsigmond király uralma Magyarországon. Budapest 1984.

Mályusz 1994 = Mályusz 1994 = Mályusz Elemér: Az első Habsburg a magyar trónon. Albert király 1438-1439. Aetas 1994/1. 120-150.

Mályusz 2003 = Mályusz Elemér: A négy Tallóci fivér. Klió szolgálatában. Budapest 2003. Szerk. Soós István. Eredeti megjelenési helye: Történelmi Szemle 23 (1980), 531-576. 
Massoud 2007 = Sami G. Massoud: The Chronicles and Annalistic Sources of the Early Mamluk Circassian Period. Leiden (Brill) 2007.

Matuz 1990 = Matuz József: Az Oszmán Birodalom története. Budapest 1990.

Melikoff 1965 = I. Melikoff: Ali Ewrenos Oghullari. In.: The Encyclopaedia of Islam. New edition, volume II. C - G Edited by: B Lewis; J. Schacht; Ch. Pellart Leiden-Boston 1965.

Milleker 1914 = Milleker Bódog: A törököknek első betörései Dél-Magyarországon Zsigmond és Albert királyok idejében és Keve és Krassó vármegyék megszünése 1393-1439. Temesvár 1914.

Milleniumi magyar történet 2001 = Milleniumi magyar történet (Magyarország története a honfoglalástól napjainkig) Szerk.: Tóth István György, Budapest 2001.

Mohay 1988 = Mohay András: Újgörög-magyar szótár. Budapest 1988.

Molnár-Jakab 2003 = Molnár Imre-Jakab Éva: Római jog. Szeged $2003^{2}$.

Nagy 1926 = Nagy Vilmos: Belgrád 1915. évi ostroma. Hadtörténelmi Közlemények 1926. $301-333$.

Nagy Képes Milleniumi 2000 = Nagy Képes Milleniumi hadtörténet. 1000 év a hadak útján. Szerk.: Rácz Árpád, Budapest 2000.

Nándorfehérvár évfordulóján $1956=$ A nándorfehérvári diadal 500. évfordulóján. Hadtörténelmi Közlemények. 1956 (3. évf.) 2. szám. 3-8.

Natho 2009 = Kadir I. Natho: Circassian history. New York 2009.

Necipoğlu 2009 = Nevra Necipoğlu: Byzantium between the Ottomans and the Latins. Politics and Society in the Late Empire. Cambridge 2009.

Négyesi 2003 = Négyesi Lajos: Nándorfehérvár ostroma. 1456. július 4-22. In.: „Fegyvert s vitézt” A magyar hadtörténet nagy csatái. (szerk.: Hermann Róbert) Budapest, 2003. 43-60.

Neumann 2007 = Neumann Tibor: A Korlátköviek. Egy elökelő család története és politikai szereplése a 15-16. században. Győr 2007.

Nikolič-Golubovič 2002 = Zoran Lj. Nikolič-Dr. Vidoje D. Golubovič: Beograd ispod Beograda. Beograd 2002.

Norris $2003=$ John Norris: Early gunpowder artillery. c. 1300-1600. Ramsbury 2003.

Nótári 1999 = Nótári Tamás: A török terjeszkedés állomásai Aeneas Sylvius Piccolomini Europa címü müvében, Aetas 1999 14/4. 149-162. 
Nótári 2011 = Nótári Tamás: Római köz- és magánjog. Szeged 2011.

Obolensky 1999 = Dimitri Obolensky: A Bizánci Nemzetközösség. Varia Byzantina III. Ford. Bódogh-Szabó Pál, Budapest 1999.

ODB $=$ The Oxford Dictionary of Byzantium. Editor in chief. A. P. Kazhdan New York, Oxford 1991.

ÓGM = Györkösy Alajos-Kapitánffy István-Tegyey Imre: Ógörög magyar nagyszótár. Budapest 1993.

Osmanli Tarihi 1983 = Osmanli Tarihi II. Cilt. 4. Bask1. Ankara 1983.

Osmanli Tarihi Kronolojisi 1925-1947 = İsmail Hami Danişmend: İzahli Osmanli Tarihi Kronolojisi Cilt 1. İstanbul 1925-1947.

Ostrogorsky 2003 = Georg Ostrogorsky: A bizánci állam története. Fordította: Magyar István Lénárd, Németh Ferdinánd, Prohászka Péter. Budapest 2003.

Óváry 1884 = Óváry Lipót: Jelentés olaszországi kutatásaimból. Századok (18) 1884. 504 510.

Pálffy 1996 = Pálffy Géza: A török elleni védelmi rendszer szervezetének története a kezdetektől a 18. század elejéig. Történelmi Szemle 1996/2-3. 163-217.

Pálosfalvi 2000 = Pálosfalvi 2000 = Pálosfalvi Tamás: Cilleiek és Tallóciak: küzdelem Szlavóniáért (1440-1448) Századok 2000/1. 45-98.

Pálosfalvi 2001 = Pálosfalvi Tamás: Az 1442. márciusi török hadjárat. Adalékok Hunyadi János első törökellenes harcaihoz. Történelmi Szemle 2001/1-2. 43-54.

Pálosfalvi 2003 = Pálosfalvi Tamás: A Rozgonyiak és a polgárháború (1440-1444). Századok 2003/4. 897-928.

Pálosfalvi 2005 = Pálosfalvi Tamás: Nikápolytól Mohácsig 1396-1526. Budapest 2005.

Pálosfalvi 2009 = Pálosfalvi Tamás: A Hunyadiak kora 1437-1490. Magyarország története 7. Budapest 2009.

Pálosfalvi 2010a = Tamás Pálosfalvi: Die Familie Tallóci im Mittelalter. In.: Lajos Thallóczy, der Historiker und Politiker, Die Entdeckung der Vergangenheit von Bosnien-Herzegowina und die moderne Geschichtswissenschaft. Hrsg. von Dževad Jubašić. Sarajevo-Budapest 2010. 183-191.

Pálosfalvi 2010b = Pálosfalvi Tamás: A Brankovicsok a középkori Magyarországon. História 2010/ 1-2. 6-9.

Papp 1997 = Papp Sándor: Az oszmán hódítás török szemmel. Beszélgetés Halil Īnalcik professzorral. Belvedere Meridionale 1997/ IX. 3-6. 164-170. 
Papp 2004 = Papp Sándor: Magyarország és az Oszmán Birodalom (A kezdetektől 1540ig) Közép-Európa harca a török ellen a 16. század elsö felében. (szerkesztette: Zombori István) Budapest 2004. 37-90.

Paulys 1934 = Paulys Real-Encyclopädie der Classischen Altertumwissenschaft. Zweite reihe $(\mathrm{R}-\mathrm{Z})$ Neunter halbband (Taurisci-Thagori) Stuttgart 1934.

Perjés 1966 = Perjés Géza: Az oszmán birodalom európai háborúinak katonai kérdései. (1356-1699) Hadtörténelmi Közlemények 1966. 862-872.

Perjés 1967 = Perjés Géza: Az oszmán birodalom európai háborúinak katonai kérdései (1356-1699). Hadtörténelmi Közlemények 1967. 339-372.

Perjés 1979 = Perjés Géza: Mohács. Budapest 1979 .

Perjés 1983 = Perjés Géza: Clausewitz. Budapest 1983.

Pesty 1877 = Pesty Frigyes: A Szörényi Bánság és Szörény vármegye története. Első kötet. Budapest 1877.

Pesty 1882 = Pesty Frigyes: Krassó vármegye története. III. kötet Budapest 1882 .

Petrovics 2000 = Petrovics István: Galambóc ostroma. In.: Nagy képes millenniumi hadtörténet. Szerk. Rácz Árpád, Budapest 2000. 64.

Petrovics 2006 = Petrovics István: A délvidék és a török veszély: a nándorfehérvári diadal és előzményei. Bácsország 2006/2. 11-19.

Petrovics 2008 = Petrovics István: A középkori Temesvár. fejezetek a Bega-parti város 1552 előtti történetéböl. Capitulum IV. Szeged 2008.

Petrovics 2013 = Petrovics István: Capystranus. Egy 1515-ben Londonban kinyomtatott névtelen angol elbeszélö költemény. In: Kálmán-Veszprémy 2013. 126-134.

Philippides 1998 = Marios Philippides: The fall of Constantinople 1453: Bishop Leonardo Giustiniani and his Italian Followers. Viator 29 (1998) 189-227.

Philippides-Hanak 2011 = Marios Philippides-Walter K. Hanak: The Siege and the Fall of Constantinople in 1453. Farnham-Burlington, 2011.

Pintér 2010 = Pintér Éva: Időrendi áttekintés. Magyarország története 24. Budapest 2010 .

Pop 2006 = Ion-Aurel Pop: Romanians in the 14th-16th centuries: from the Christian Republic to the Restoration of Dacia. In.: History of Romania. Compendium. Edited by: Ion-Aurel Pop, Iovan Bolovar. Cluj-Napoca, 2006.

Поповић 1982 = Марко Поповић: Београдска Тврђава. Београд 1982.

Popović 1991 = Marko Popović: Fortress of Belgrade. Belgrade 1991. 
Popović 2011 = Marco Popović: Belgrád 15. századi erődítményei. In.: Déli harangszó Magyarországon és a nagyvilágban. Szerk.: Visy Zsolt. Budapest 2011. 27-37.

Pósán 1998 = Pósán László: Zsigmond és a Német Lovagrend. In: Hadtörténelmi Közlemények 1998. 3. 630-656.

Rázsó 1953 = Gyula Rázsó: Hungarian strategy against the Ottomans (1365-1526). 226237. In.: Ch. Oman: The art of war in the Middle Ages. New York 1953.

Rázsó 1973 = Rázsó Gyula: A Zsigmond-kori Magyarország és a török veszély (13931437). Hadtörténelmi Közlemények 1973/ 3. 403-441.

Rázsó 1987 = Rázsó Gyula: A lovagkor csatái. Budapest 1987.

Rázsó 1990 = Rázsó Gyula: Hunyadi Mátyás török politikája. In.: Hunyadi Mátyás. Emlékkönyv Mátyás király halálának 500. évfordulójára. (szerk.: Rázsó Gyula, V. Molnár László). Budapest, 1990. 149-200.

Rázsó 1994 = Rázsó Gyula: Magyarország és a török veszély Zsigmond korában (13871437). Századok 1994. 281-283.

Reid $1976=$ William Reid: Tha lore of arms. Gothenburg. 1976.

Rossignol 1991 = Gilles Rossignol: Pierre d'Aubusson, le "bouclier de la chrétienté". Les Hospitaliers à Rhodes. Besançon 1991.

Runciman 2000 = Steven Runciman: Konstantinápoly eleste 1453. Budapest $2000{ }^{2}$

Sakcinski 1886 = Ivan Kukuljević Sakcinski: Priorat vranski. Vitezi Templari i Hospitalici St. Ivana u Hrvatskoi. Zagreb 1886.

Salamon 1864 = Salamon Ferencz: Magyarország a török hódítás korában. Pest 1864.

Seláf 2001 = Seláf Levente: Belgrád felett az ég. In.: Miscellanea, tanulmányok a régi magyar irodalomról. Szerkesztette: Szentpéteri Márton. Budapest 2001. 175196.

Shaw 1977 = Stanford J. Shaw: History of the Ottoman Empire and Modern Turkey. Volume 1. Empire of the Gazis: The Rise and Decline of the Ottoman Empire, 1280-1808. Cambridge 1977.

Sörös 1903 = Sörös Pongrác: Lévai Cseh Péter. Századok 37 (1903) 824-837.

Spiteri $1994=$ Stephen C. Spiteri: Fortresses of the Cross. Malta 1994.

Sroka 1996 = Sroka, Stanisław A.: I. Ulászló itineráriuma (1440-1444). In: Acta Universitatis Debreceniensis de Ludovico Kossuth Nominatae. Series Historica XLVIII. Történeti tanulmányok IV. (szerk.: L. Nagy Zsuzsa és Veress Géza) Debrecen, 1996. 21-48. 
Stephenson 1994 = Paul Stephenson: Manuel I Comnenus and Geza II: A revised context and chronology for Hungaro-Byzantine relations, 1148-1155. Byzantinoslavica Tome LV (1994) Fasc. 2. 251-277.

Stojan-Szabóky 1978 = Vujičić D. Stojan-Szabóky Zsolt: Dubrovnik. Budapest 1978.

Sudár 2010 = Sudár Balázs: A végítélet könyve. Oszmán elbeszélő költemény a mohácsi csatáról. Történeti Szemle 2010/3. 329-340.

Szabó 2009 = Szabó Pál: Megjegyzések a középkori nomád harcmodor ókori előzményeihez. Belvedere Meridionale (XXI. évf.) 2009. (február-március) 7986.

Szabó 2010a = Szabó Pál: „Ahol Magyar Királyságunk épsége ered”-Nándorfehérvár első török ostroma (1440). Belvedere Meridionale XXII. évf. (2010) 3-4, 59-85.

Szabó 2010b = Szabó Pál: Árukidobás a tengeren? - A bizánci nomosz rhodión nautikosz római jogi párhuzamairól. Középkortörténeti tanulmányok 6. Szerk.: G. Tóth Péter-Szabó Pál, Szeged 2010. 215-232.

Szabó 2011a = Szabó Tibor: Mehádia várai. Várak, kastélyok, templomok. 2011 (február) 6-9.

Szabó 2011 b = Szabó Tibor: Fetislam -egy török erösség a Vaskapunál. Várak, kastélyok, templomok 2011 (december) 22-24.

Szabó 2011c = Szabó Pál: „kitolta Vazul szemeit” - a megvakítás büntetésének bizánci eredetü gyakorlata a XI-XIII. századi Magyarországon, valamint a szláv és az oszmán-török jogi régiókban. Ünnepi tanulmány a 70 éves Makk Ferenc professzor tiszteletére. Bácsország 2011/2 (57.). 82-85.

Szabó 2011d = Szabó Pál: „nem jegyeztek fel többet néhány szükszavú mondatnál” Nándorfehérvár első török ostroma a magyar történetírásban Partium 2011/2012 (XX. évf. tél). 12-19.

Szabó 2012a = Szabó Pál: Karó vagy bitófa? A bizánci források jogi szóhasználatáról Bulcsú kivégzése kapcsán. In.: Középkortörténeti tanulmányok 7. Szerk.: Kiss P. Attila, Piti Ferenc, Szabados György. Szeged 2012. 545-567.

Szabó 2012b = Szabó Pál: Új fejezetek Nándorfehérvár első török ostromáról (1440) 1. rész. Partium 2012, XXI. évf. (nyár) 80-96.

Szabó 2012c = Szabó Pál: Nándorfehérvár első török ostromának kül- és belpolitikai előzményei (Második közlemény) Partium 2012, XXI. évf. (ősz) 8-29.

Szabó 2012d = Szabó Pál: Nándorfehérvár első török ostromának forrásai (Harmadik közlemény) Partium 2012, XXI. évf. (ösz) 109-131. 
Szabó 2012e = Szabó Pál: Értékelés és következtetések Nándorfehérvár első török ostromáról (1440) (Negyedik közlemény). Partium 2012/13 XXI. évf. (tél) 4575.

Szabó 2013a = Szabó Pál: Egy elfeledett hadisiker nyomában: Nándorfehérvár első török ostromáról (1440). Vajdasági Magyar Helytörténeti Társaság, Évkönyv 3. Szerk.: Szabó József. Bajmok, 2013. 3-58.

Szabó $2013 b$ = Szabó Pál: Nándorfehérvár első erőpróbája. Történeti szinopszis az 1440 . évi szultáni török ostromról Bácsország 2013 / 2. (65.) 24-28.

Szabó 2013c = Szabó Pál: I. Bayezid szultán Magyarország ellen vezetett hadjáratai és Nándorfehérvár „nulladik” ostromának lehetősége. Partium 2013, XXII. évf. (nyár) 73-89.

Szabó 2014a = Ostromolhatta-e I. Bayezid szultán Belgrádot? In.: Középkortörténeti tanulmányok 8. Szerk.: Bartha Annamária, Kruták Anita, Tóber Márta. Szeged 2014 (s. a.)

Szabó 2014b = Szabó Pál: Névtelen bizánci krónikák Nándorfehérvár első török ostromáról. In.: A Kárpát-medence, a magyarság és Bizánc. Szerkesztette: Olajos Terézia. Szeged 2014 (s. a.)

Szajkó 2005 = Szajkó István: A fekete (füstös) lőpor. (kézirat) Balatonfüzfő 2005.

Szakály 1978 = Szakály Ferenc: Nándorfehérvár 1521-es ostromához. Hadtörténelmi Közlemények 1978/ 4. 484-499.

Szakály 1979 = Szakály, Ferenc: Phases of Hungarian Warfare before the Battle of Mohács (1365-1526). Acta Orientalia Academiae Scientiarum Hungariae 33 (1979) 65111.

Szakály 1986 = Szakály Ferenc: A török-magyar küzdelem szakaszai a mohácsi csata előtt (1365-1526). Mohács. Tanulmányok a mohácsi csata 450. évfordulója alkalmából (szerk.: Rúzsás Lajos, Szakály Ferenc) Budapest, 1986. 11-57.

Szakály 1990 = Szakály Ferenc: Virágkor és hanyatlás 1440-1711. Magyarok Európában II. Budapest 1990.

Szakály-Fodor 1998 = Szakály Ferenc-Fodor Pál: A kenyérmezei csata (1479. október 13.). Hadtörténelmi Közlemények 1998/2. 309-350.

Szalay 1863 = Magyarország története Szalay László által. Harmadik kötet, Pest 1863.

Szántó 1980 = Szántó Imre: A végvári rendszer kiépítése és fénykora Magyarországon 1541-1593, Budapest, 1980.

Szántó 1983 = Szántó Konrád: A katolikus egyház története. I. kötet Budapest 1983. 
Szentpétery 1985 = Szentpétery Imre: A kronológia kézikönyve. Sajtó alá rendezte: Gazda István, kiegészítette: Érszegi Géza, Raj Tamás, Szögi László. Budapest 1985.

Szilágyi 1895 = A magyar nemzet története. VI. kötet (1440-1526) Szerk. Szilágyi Sándor. Budapest 1895. ${ }^{2}$

Szokolay 1996 = Szokolay Katalin: Lengyelország története. Budapest 1996.

Szőcs 2009a = Szőcs Tibor: Egy „legendás” hős: Dugovics Titusz története. Hadtörténelmi Közlemények 2009/1. 3-35.

Szőcs $2009 b=$ Szőcs Tibor: Nagyfejedelmeink temetkezési helyei az írott források tükrében. Belvedere Meridionale 2009/ 1-2. 16-44.

Szörényi 2002 = Szörényi László: Az epikureus premachiavellista és Mátyás király udvara. Callimachus Experiens. Philologica Hungarolatina Budapest 2002. 38-50.

Спремић 2006 = Момчило Спремић: Ђурађ Бранковић 1427-1456. Београд 2006.

Tardy 1971 = Tardy Lajos: Régi magyar követjárások Keleten. Budapest, 1971 .

Teke 1980 = Teke Zsuzsa: Hunyadi János és kora. Budapest 1980.

Teke 1990 = Teke Zsuzsa: Mátyás, a győzhetetlen király. Budapest 1990.

Teleki 1852 = Gr. Teleki József: Hunyadiak kora Magyarországon. Első kötet, Pest, 1852.

Teleki III. 1853 = Gr. Teleki József: Hunyadiak kora Magyarországon. III. kötet. Pest 1853.

Thúry 1893 = Thúry József: Ki volt „a vak török császár”? Századok 1893. 839-849.

Tóth 1995 = Tóth Sándor László: A Kászim-nap és a tizenöt éves háború. Hadtörténelmi Közlemények 1995/2. 25-33.

Tóth 2000 = Tóth Sándor László: A mezőkeresztesi csata és a tizenöt éves háború. Szeged, 2000.

Tóth 2006 = Tóth Sándor László: Harangszó és diadal: Nándorfehérvár, 1456. Szeged (A város folyóirata) 2006/7-8. 9-12.

Tömegsírok 2009 = KultúrPart. 2009. június 16. „Tömegsírok Belgrád alatt!”

Törtei 2013 = Törtei Renáta: Egy spanyol pápai legátus tevékenysége a középkori Magyarországon. Don Juan de Carvajal bíboros életútja, szerepe és tevékenysége a magyar történelem viharos éveiben (Szakdolgozat) Piliscsaba 2013.

Tringli 2003 = Tringli István: Az újkor hajnala. Magyarország története 1440-1541. Budapest, 2003. 
Vágvölgyi 1981 = Dr. Vágvölgyi Ferenc: Bátmonostor község története a felszabadulásig. (gépelt kézirat) Bátmonostor 1981.

Veszprémy 1987 = Veszprémy László: Illusztrált technikai és haditechnikai kéziratok Zsigmond korában. Müvészet Zsigmond király korában. II. kötet. Budapest 1987. 212-225.

Veszprémy $1998 \mathrm{a}=$ Veszprémy László: A nikápolyi hadjárat értékelése az újabb hadtörténetírásban. Hadtörténelmi Közlemények 1998/3. 603-609.

Veszprémy 1998b = Veszprémy László: Zsigmond a katonai reformer? A haditechnikai írásbeliség és a technikai újítások kora. Hadtörténelmi Közlemények 1998/3. 657-665.

Veszprémy 2000 = Veszprémy László: „Latrunculi, cursatores, hussarones” Megjegyzések Kézai latinságához. In.: „Magyaroknak eleiről” Ünnepi tanulmányok a hatvan esztendős Makk Ferenc tiszteletére. Szerk.: Piti Ferenc, 2000. 673-680.

Veszprémy 2007 = Veszprémy László: „Európa védelmében” Időszaki kiállítás a Hadtörténeti Múzeumban. 2006. június 15 - 2007. szeptember 30. In.: A Hadtörténeti Múzeum Értesítője 9. Budapest 2007. 291-301.

Veszprémy 2008a = Veszprémy László: Egy korareneszánsz haditechnikai kézirat és szerzője. Mariano di Jacopo detto il Taccola: De rebus militaribus. In: Lovagvilág Magyarországon. Lovagok, keresztesek, hadmérnökök a középkori Magyarországon. (Válogatott tanulmányok.) Budapest 2008. 203-218. (Eredeti megjelenési helye: Hadtörténelmi Közlemények 1988/1. 3-20.)

Veszprémy 2008b = Veszprémy László: Haditechnikai újítások és kéziratok Zsigmond környezetében. In.: Lovagvilág Magyarországon. Budapest 2008. 187-202.

Veszprémy 2008c = Veszprémy László: Zsigmond Galambócnál 1428-ban. Hadtörténelmi Közlemények 2008. június (2. szám). 283-302.

Veszprémy 2010 = Veszprémy László: Nándorfehérvár ostromai - a reneszánsz hadügyi elmélet kezdetei Magyarországon. Várak, kastélyok, templomok. 2010. (december) 33-35.

Visy 1989 = Visy Zsolt: A római limes Magyarországon. Budapest 1989.

Weiszhár A-Weiszhár B. 2000 = Weiszhár Attila-Weiszhár Balázs: Csaták kislexikona. 2000.

Wertner 1904 = Dr. Wertner Mór: „Baxat imperator turcorum” Családtörténeti adalékok 1904. 31-33.

Wertner 1911 = Dr. Wertner Mór: Magyar hadjáratok a XV. század első felében. Négy közleményben. Hadtörténelmi Közlemények 1911. márczius (1401-1406) 63- 
76; junius (1407-1418) 251-276; szeptember (1419-1432) 410-448; deczember (1433-1450) 537-574.

Withworth 1858 = Withworth Porter: A history of the Knights of Malta. Volume 1. London 1858.

Вујовиђ 2003 = Бранко Вујовиђ: Београд у прошлости и садашњости. Београд, 2003.

www. eclipse.gsfc.nasa.gov

Zombori 2004 = Zombori István: Jagelló-Habsburg rendezési kísérlet 1523-ban Krysztof Szydłowiecki naplója alapján. In.: Krysztof Szydłowiecki kancellár naplója 1523-ból. Sajtó alá rendezte: Zombori István. Budapest 2004. 219-335.

Zombori 2010 = Zombori István: A Nándorfehérvárra vezető út: Kapisztrán János és Szeged. Várak, kastélyok, templomok. 2010/6. 20-23. (Déli harangszó Magyarországon és a nagyvilágban. Szerk.: Visy Zsolt. Budapest 2011. 42-50.)

Zöllner 1980 = Walter Zöllner: A keresztes háborúk története. Budapest 1980. 


\section{Mellékletek}

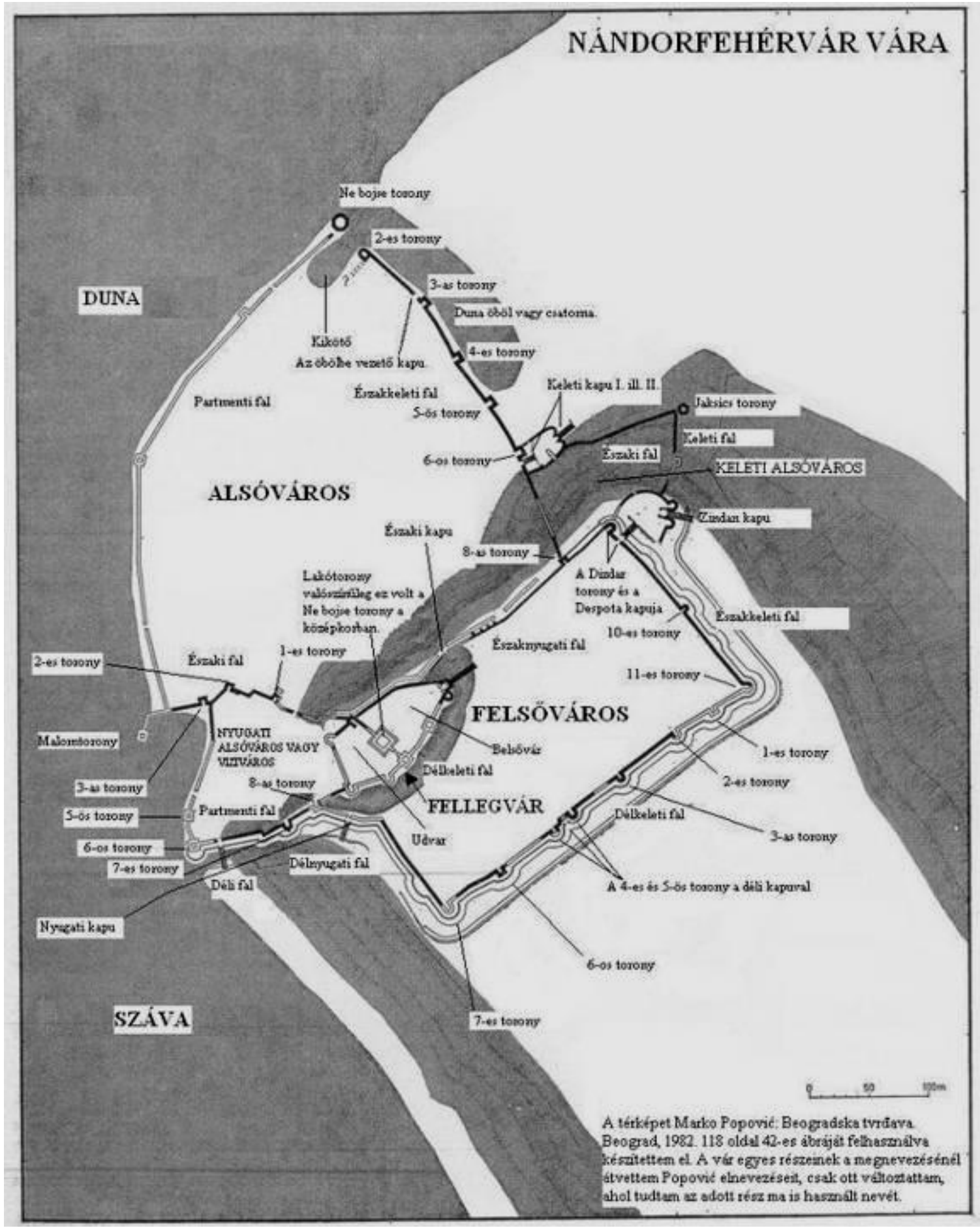

1. melléklet. A 15. századi vár.

(Készítette: Cseh Valentin, http:// www. users.atw.hu/duna/nfvcsv/nfv1456.html) 


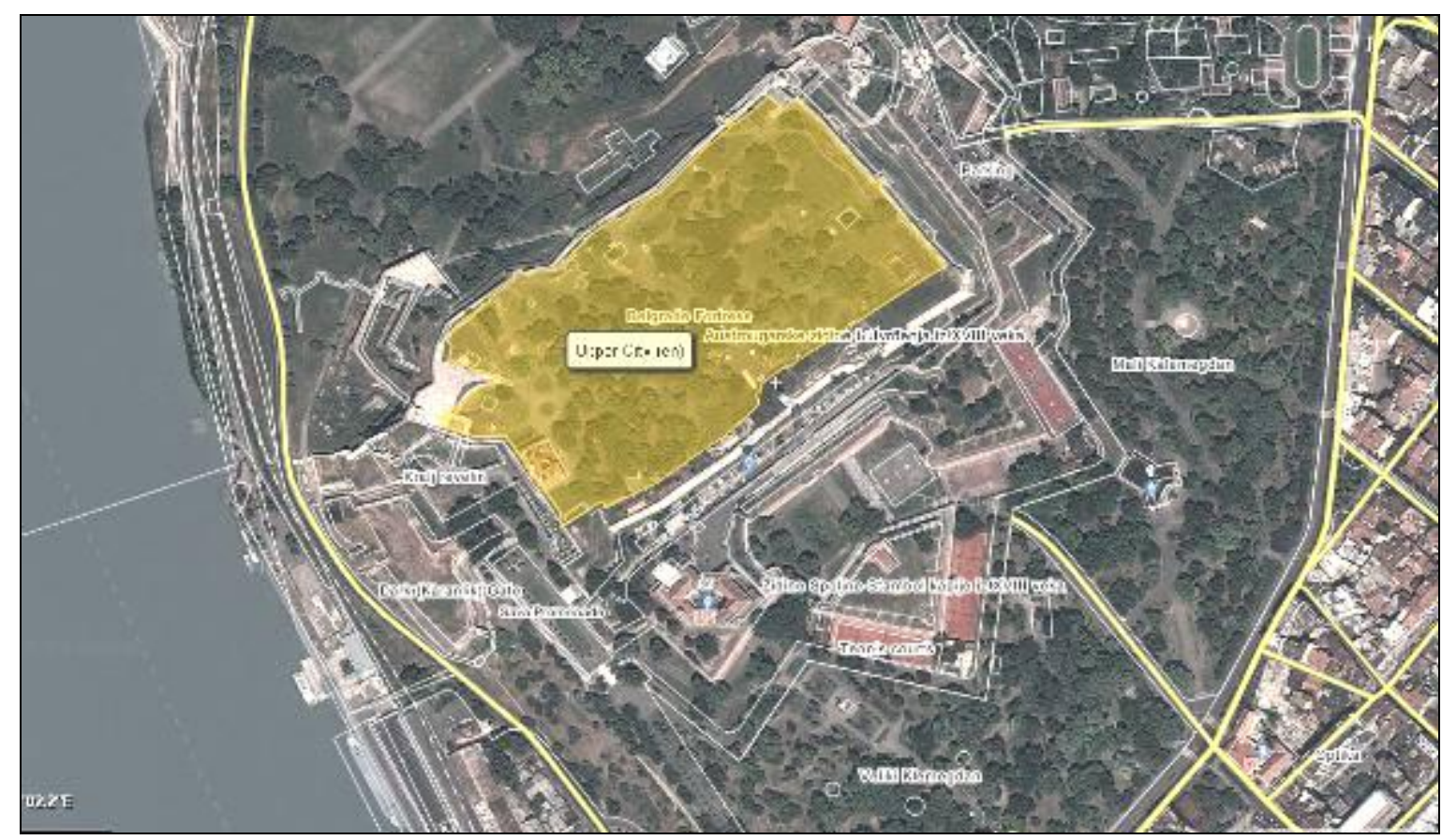

2. melléklet. A vár falainak mai müholdképe.

http://wikimapia.org/\#lang=hu\&lat=44.822878\&lon=20.449408\&z=17\&m=b (Letöltés: 2013. IX. 26.)

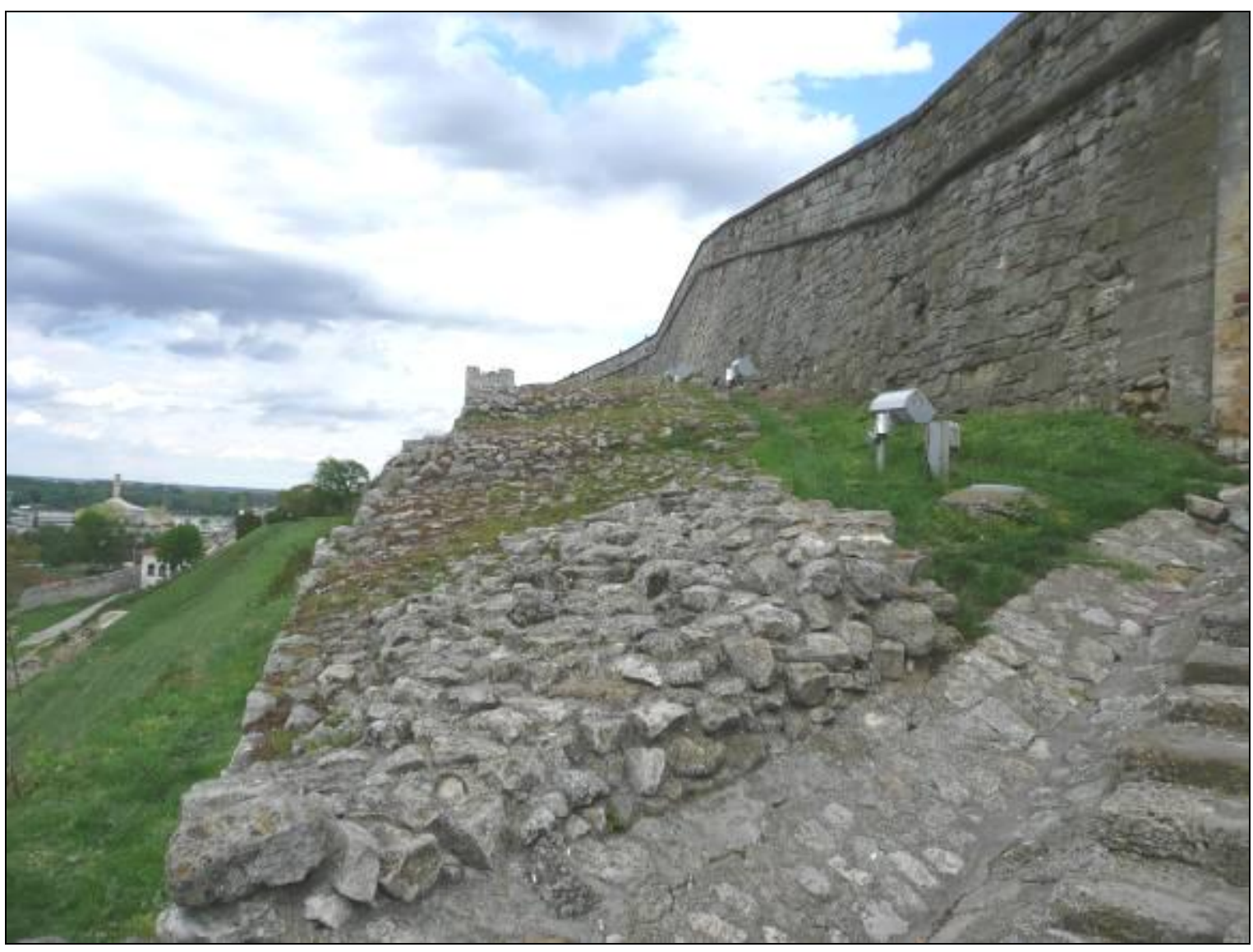

3. melléklet

Az északnyugati kettős falrendszer (a szerző felvétele). 


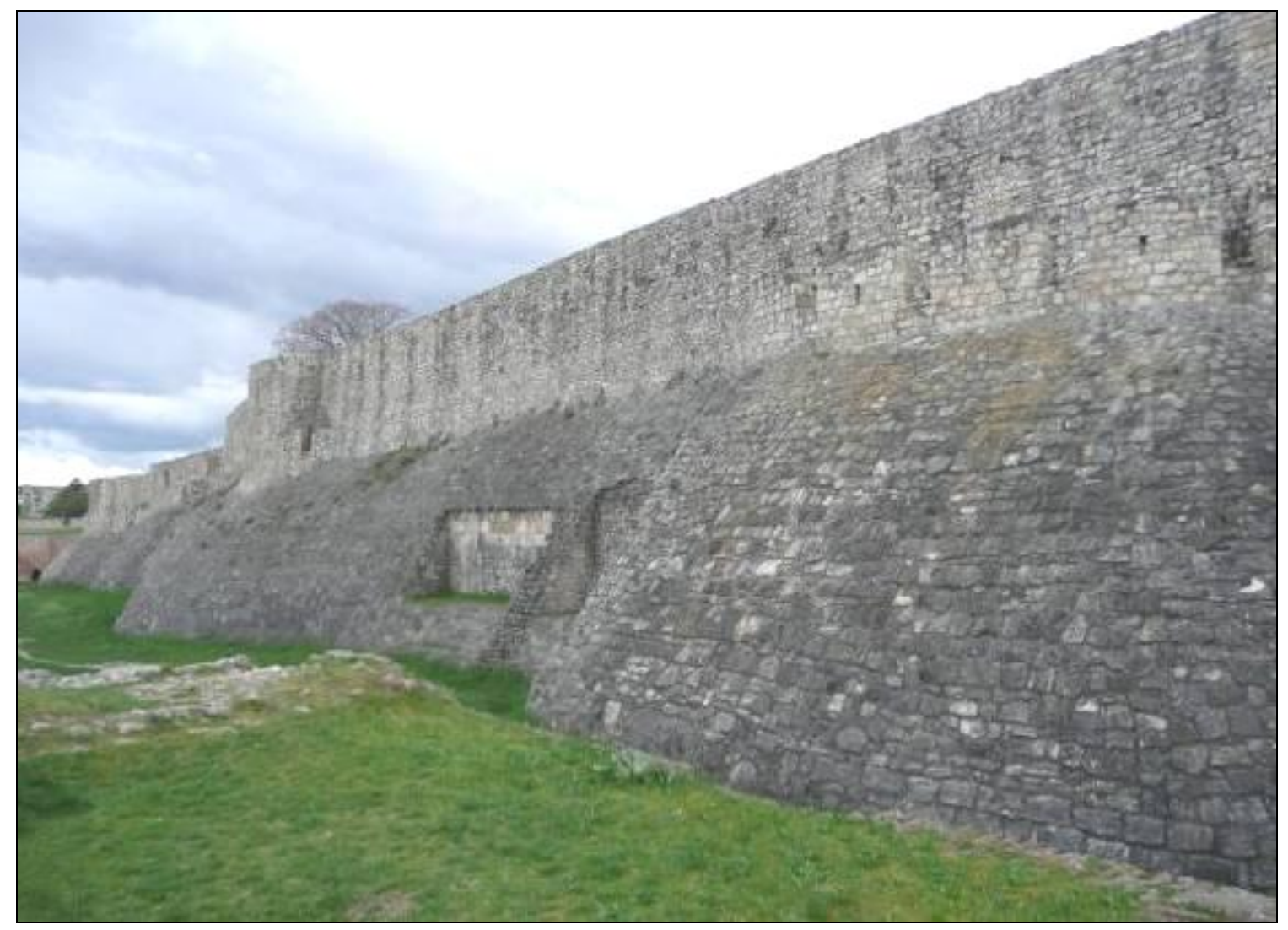

4. melléklet. Az északkeleti fal megerősítése (a szerző felvétele).

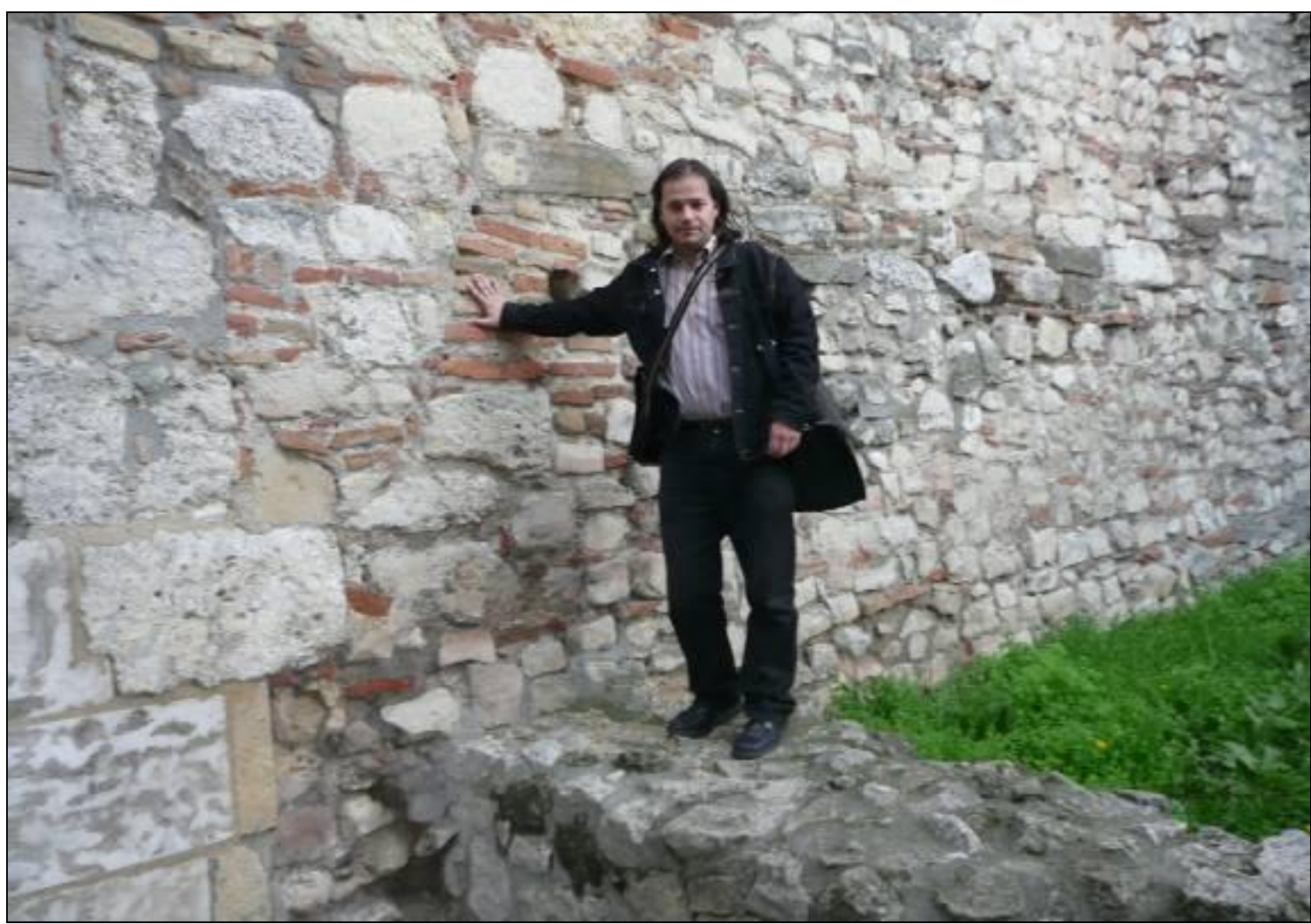

5. melléklet. Rekeszes falazás nyomai a Despota-kapujánál. 


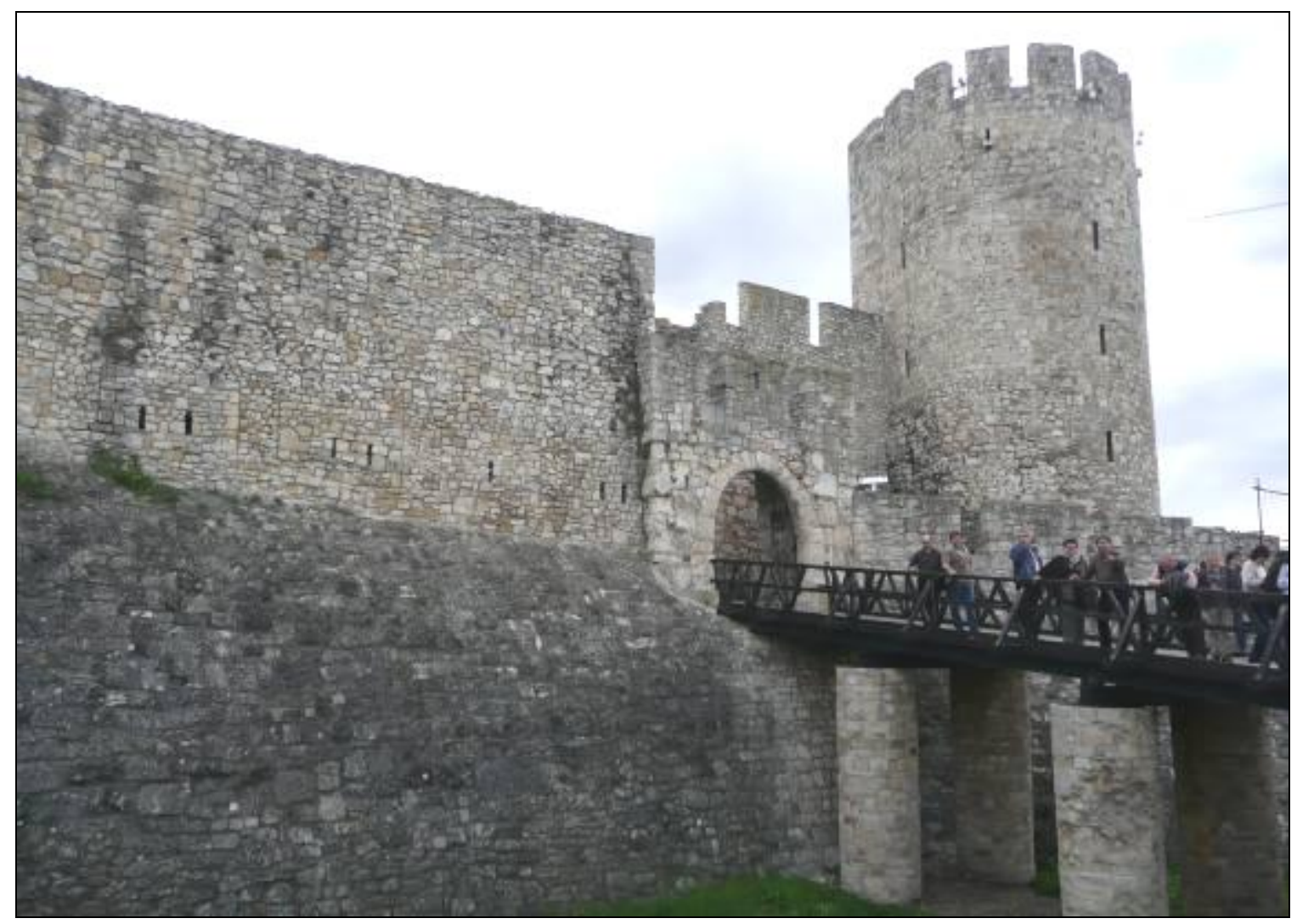

6. melléklet. Az északkeleti fal, a Despota kapuja és a Dizdar-torony (a szerző felvétele).

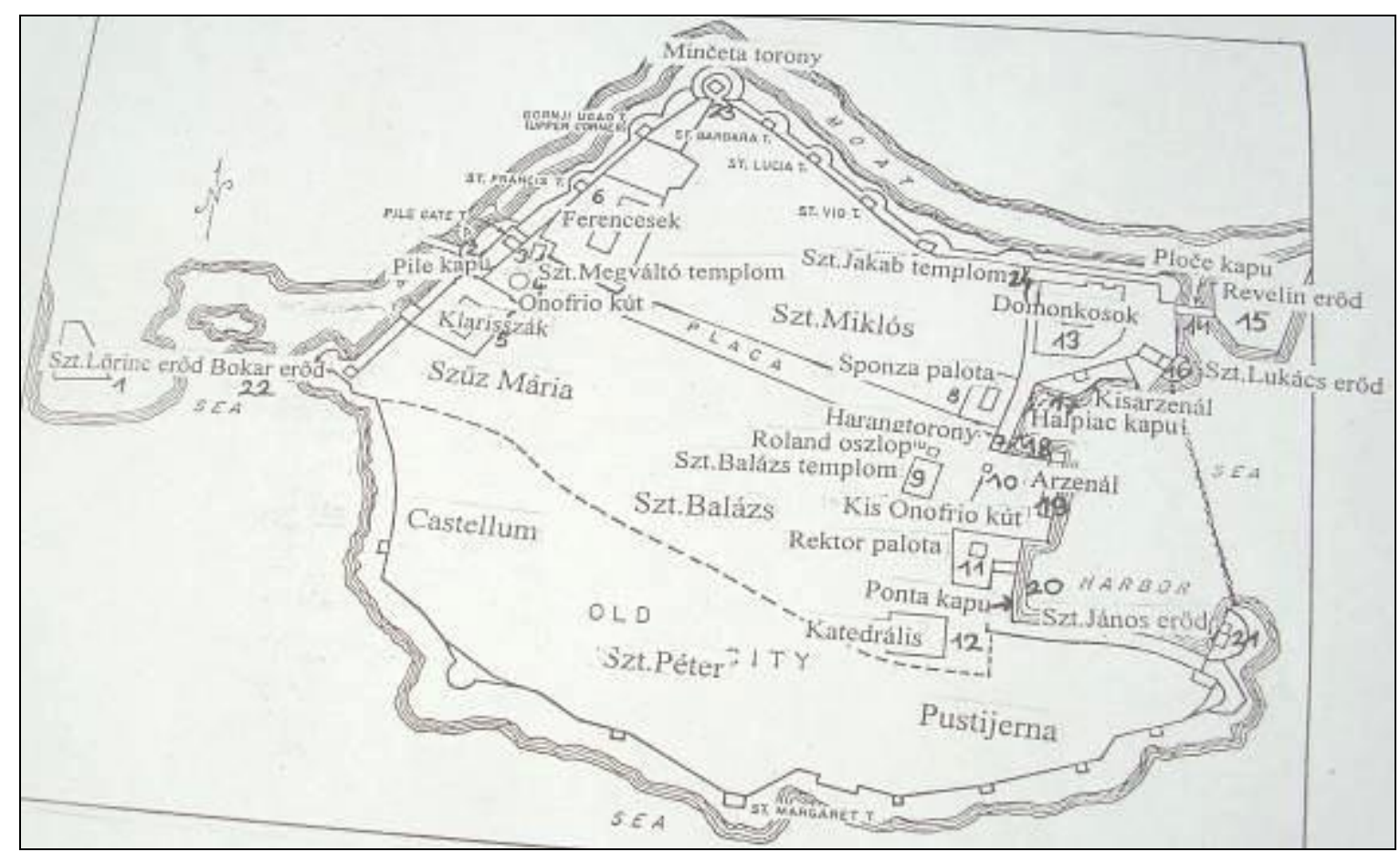

7. melléklet. Raguza (Dubrovnik) erődített városa (a magyar változatot készítette: Juhász Ágnes) 


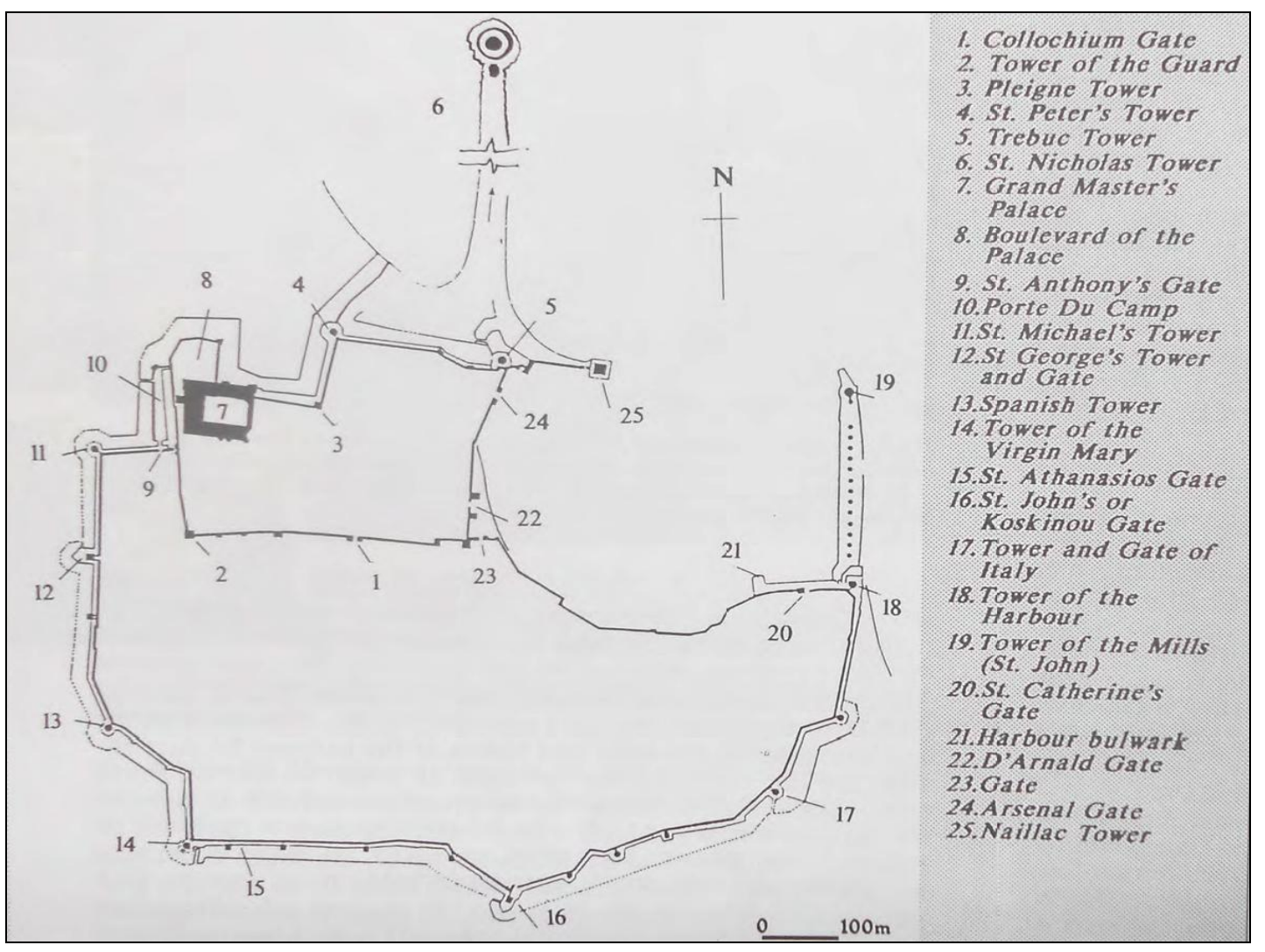

8. melléklet. Rodosz erődített városa (Spiteri 1994. 78.)

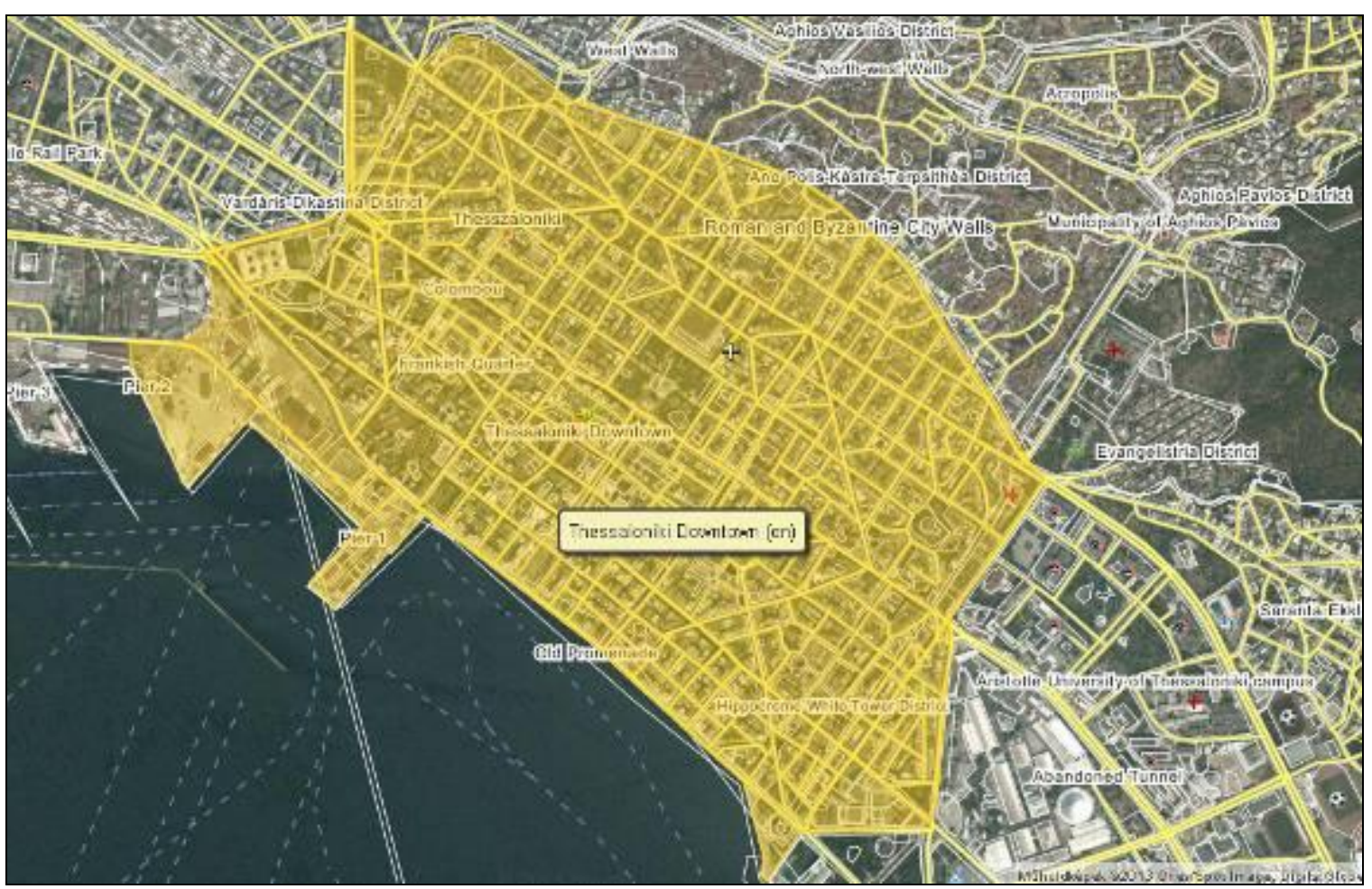

9. melléklet. Thesszaloniki, a mai Alsóváros müholdképe (http://wikimapia.org/\#lang=hu\&lat=40.637339\&lon=22.94679\&=z15\&m=b) (Letöltés: 2013. IX. 26.) 


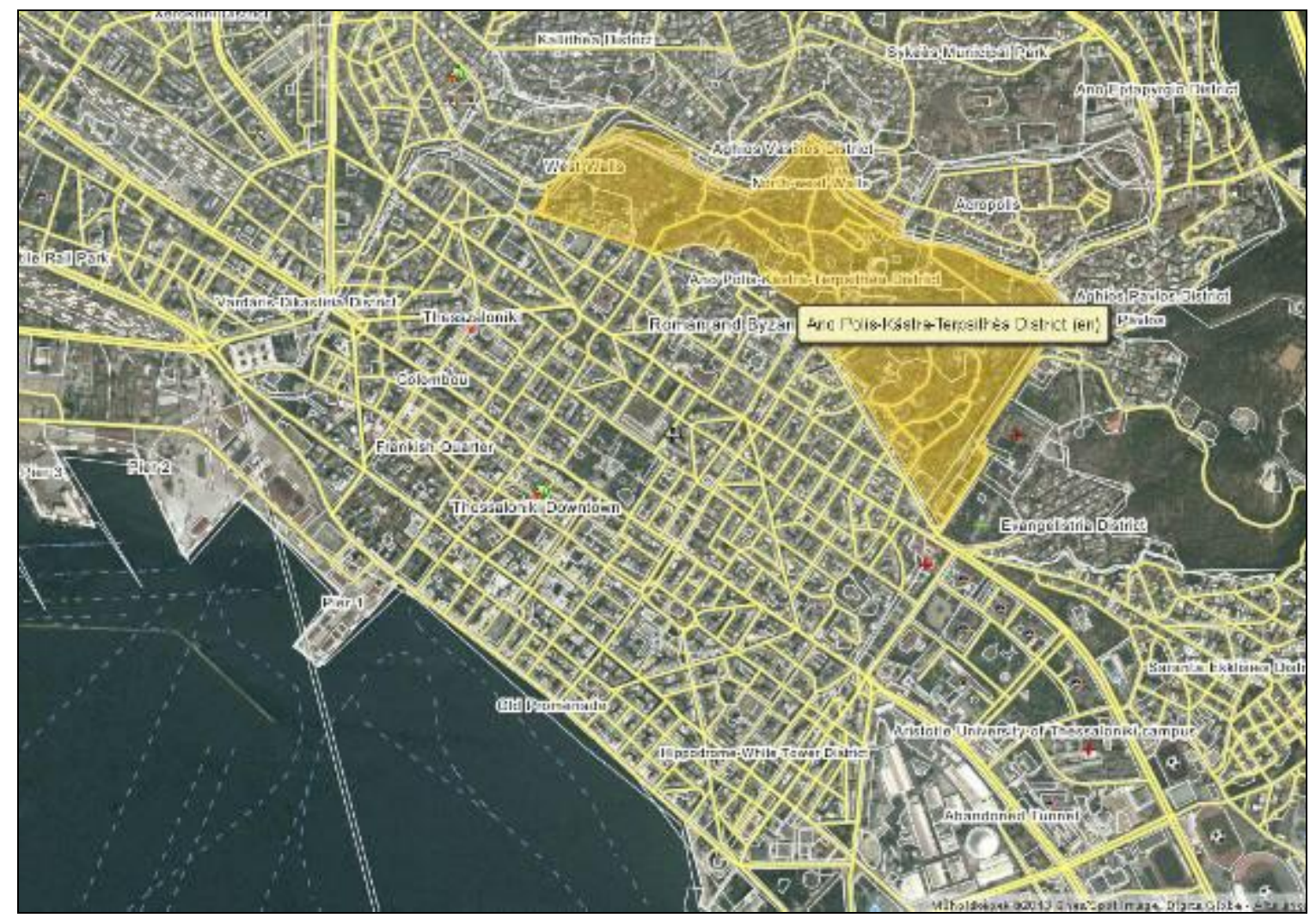

10. melléklet. A Felsőváros müholdképe

(http://wikimapia.org/\#lang=hu\&lat=40.637339\&lon=22.94679\&=z15\&m=b). (Letöltés: 2013. IX. 26.)

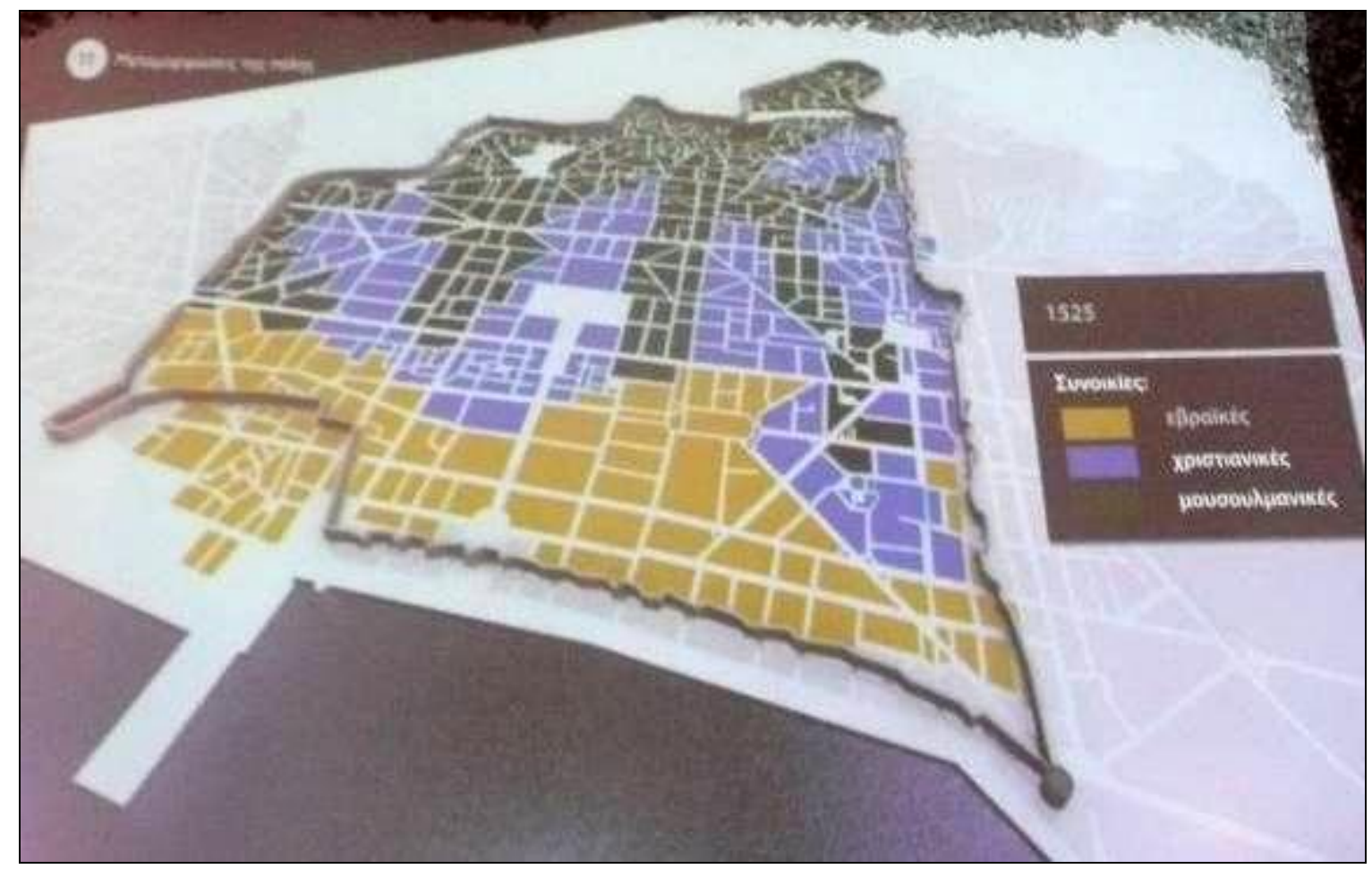

11. melléklet. Thesszaloniki városfalai és lakosságának összetétele az oszmán-török uralom alatt. (Thesszaloniki, Lefkosz Pürgosz kiállítása) 


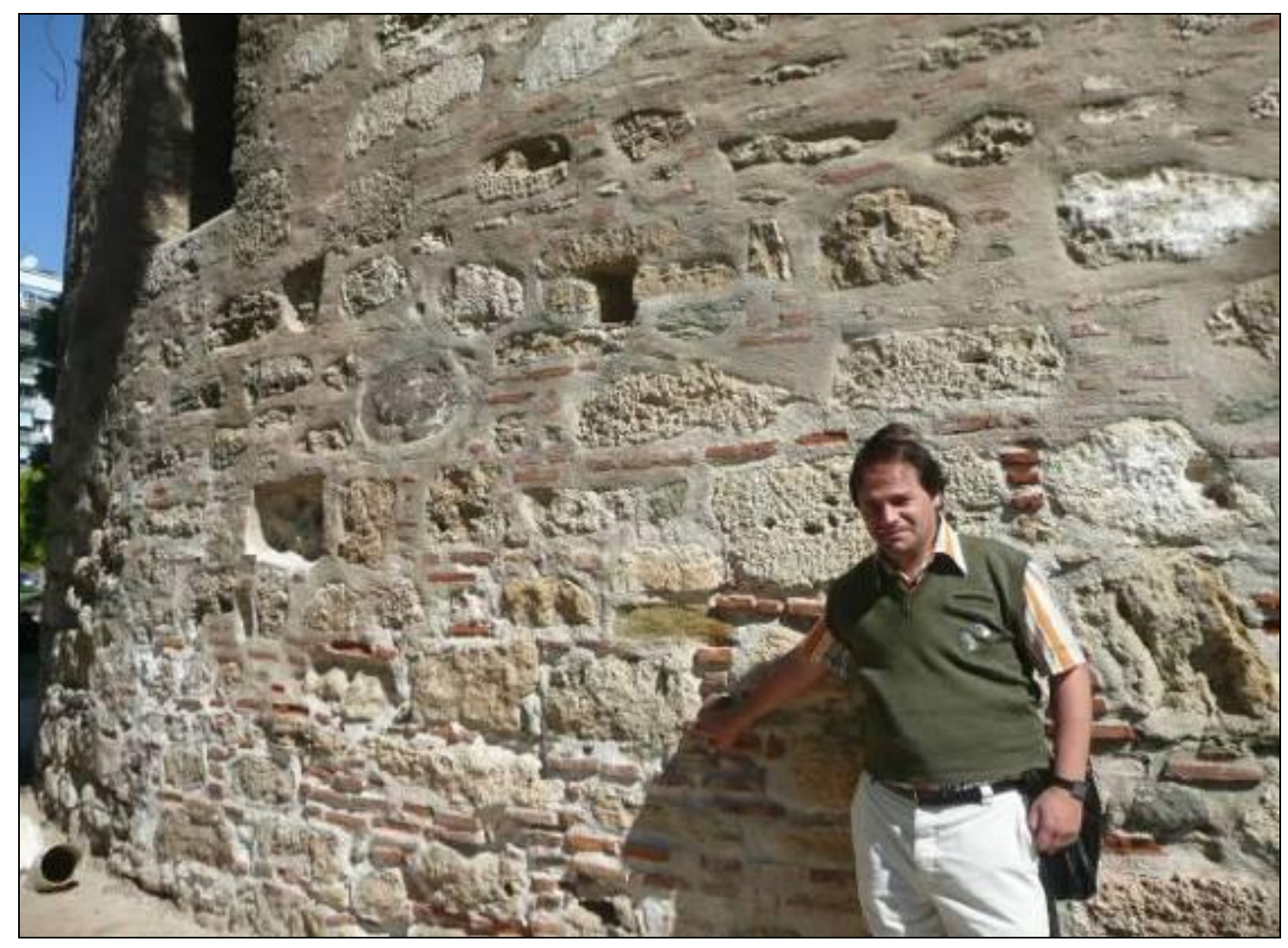

12. melléklet. A Lefkosz Pürgosz rekeszes falazata (Thesszaloniki).

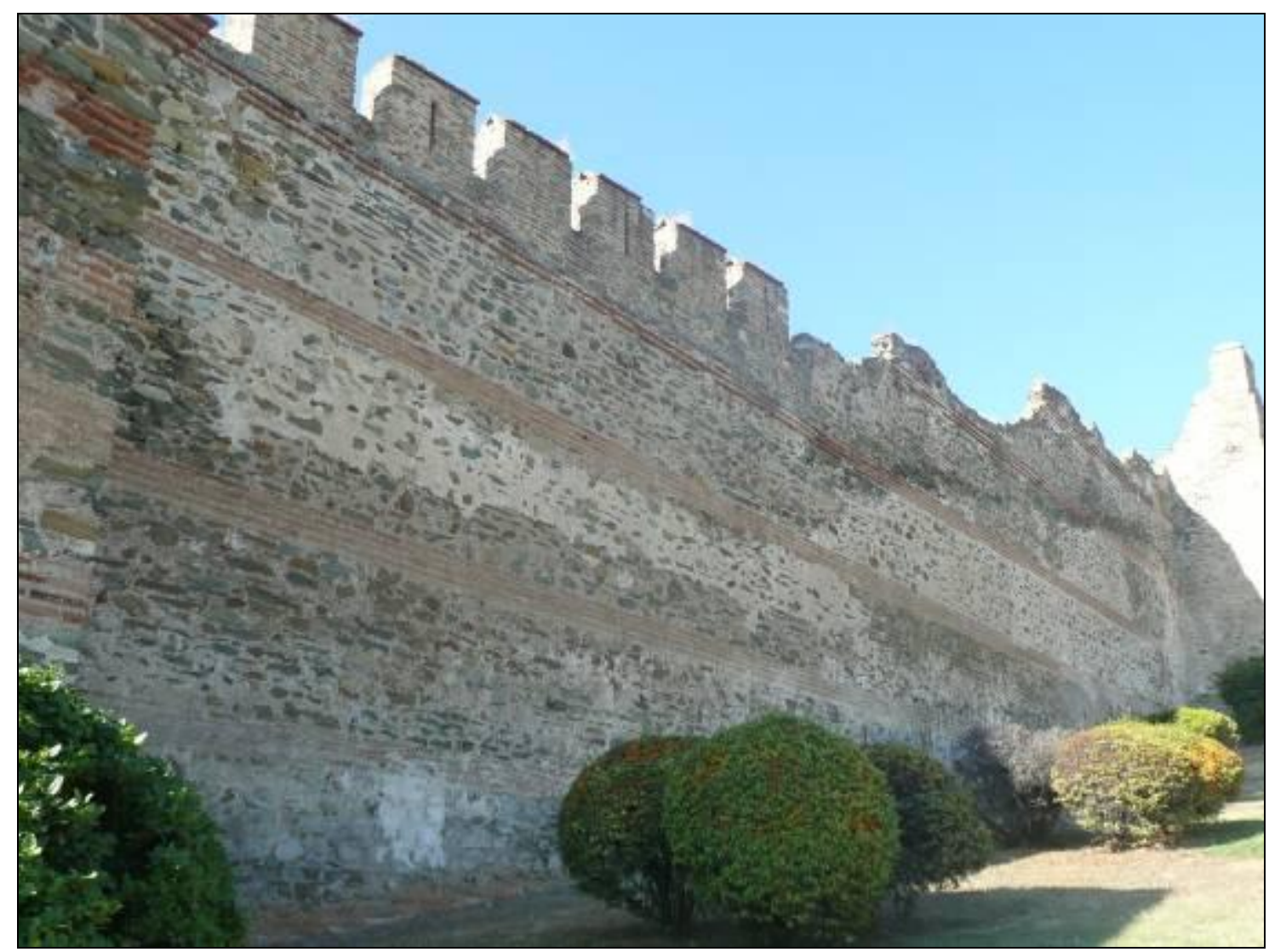

13. melléklet. Thesszaloniki keleti városfala (a szerző felvétele). 


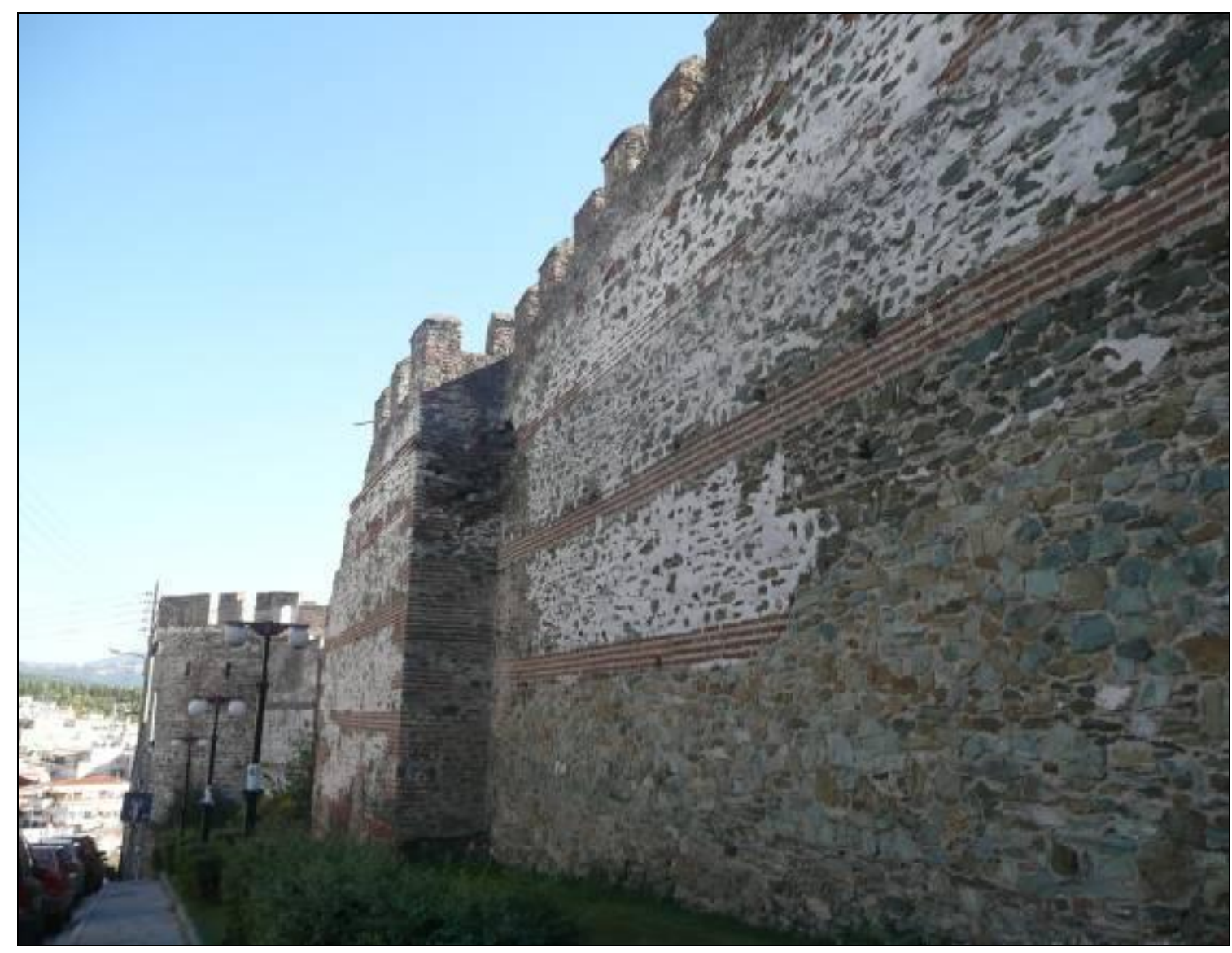

14. melléklet. Thesszaloniki északi városfala (a szerző felvétele).

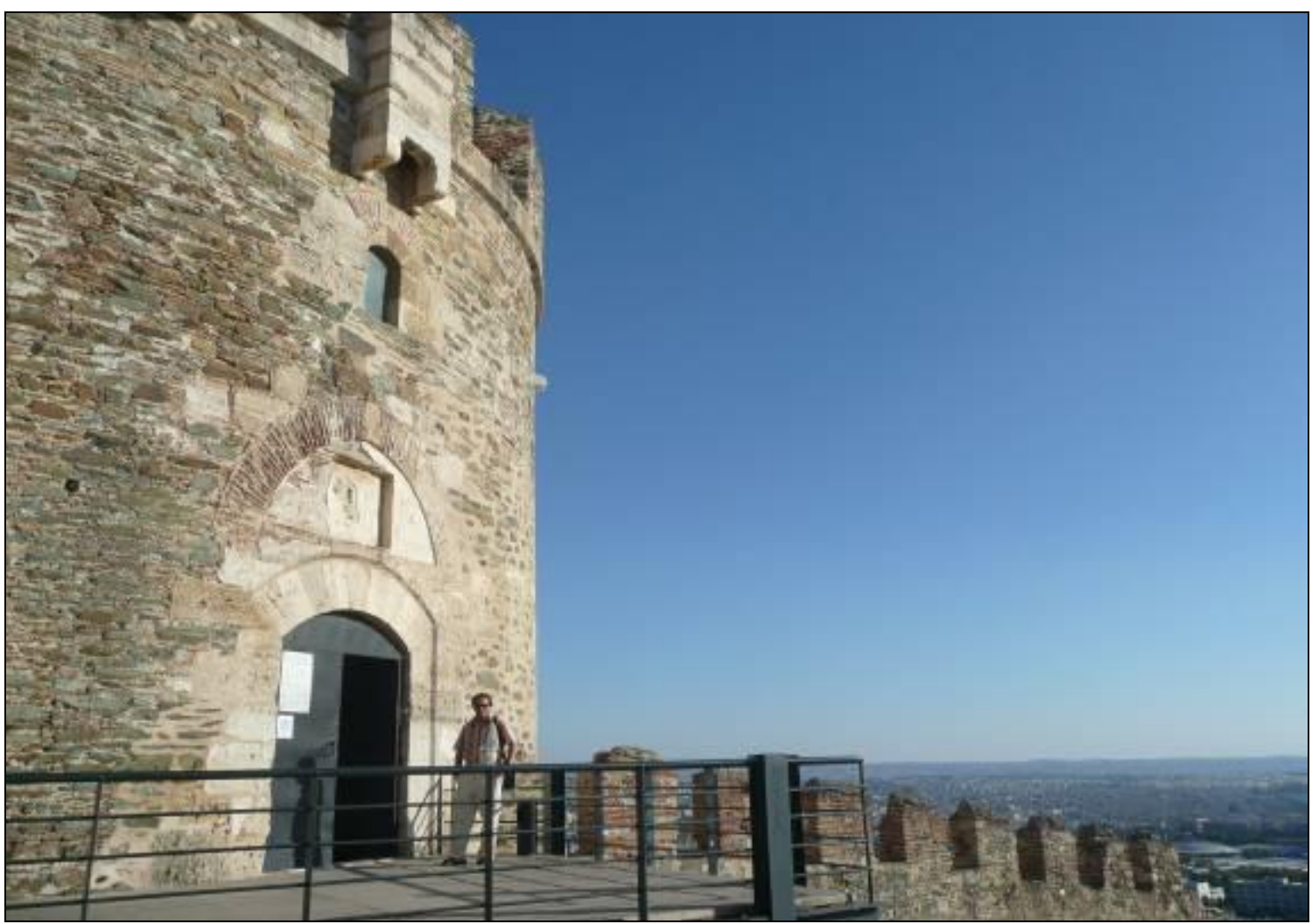

15. melléklet. A Trigónion-torony és a keleti fal vége (a szerző felvétele). 


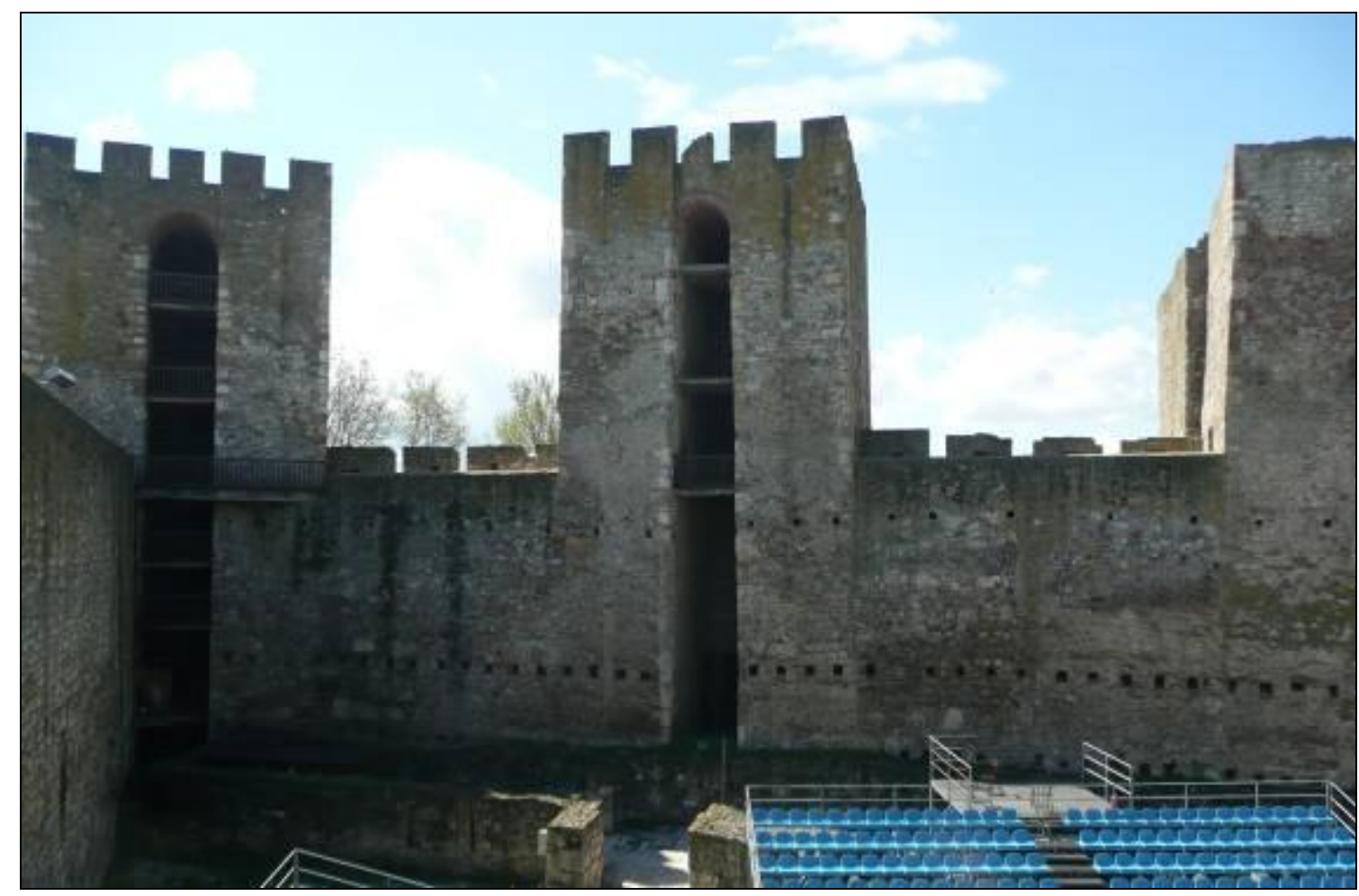

16. melléklet. Szendrő erődjének tornyai belülről (a szerző felvétele).

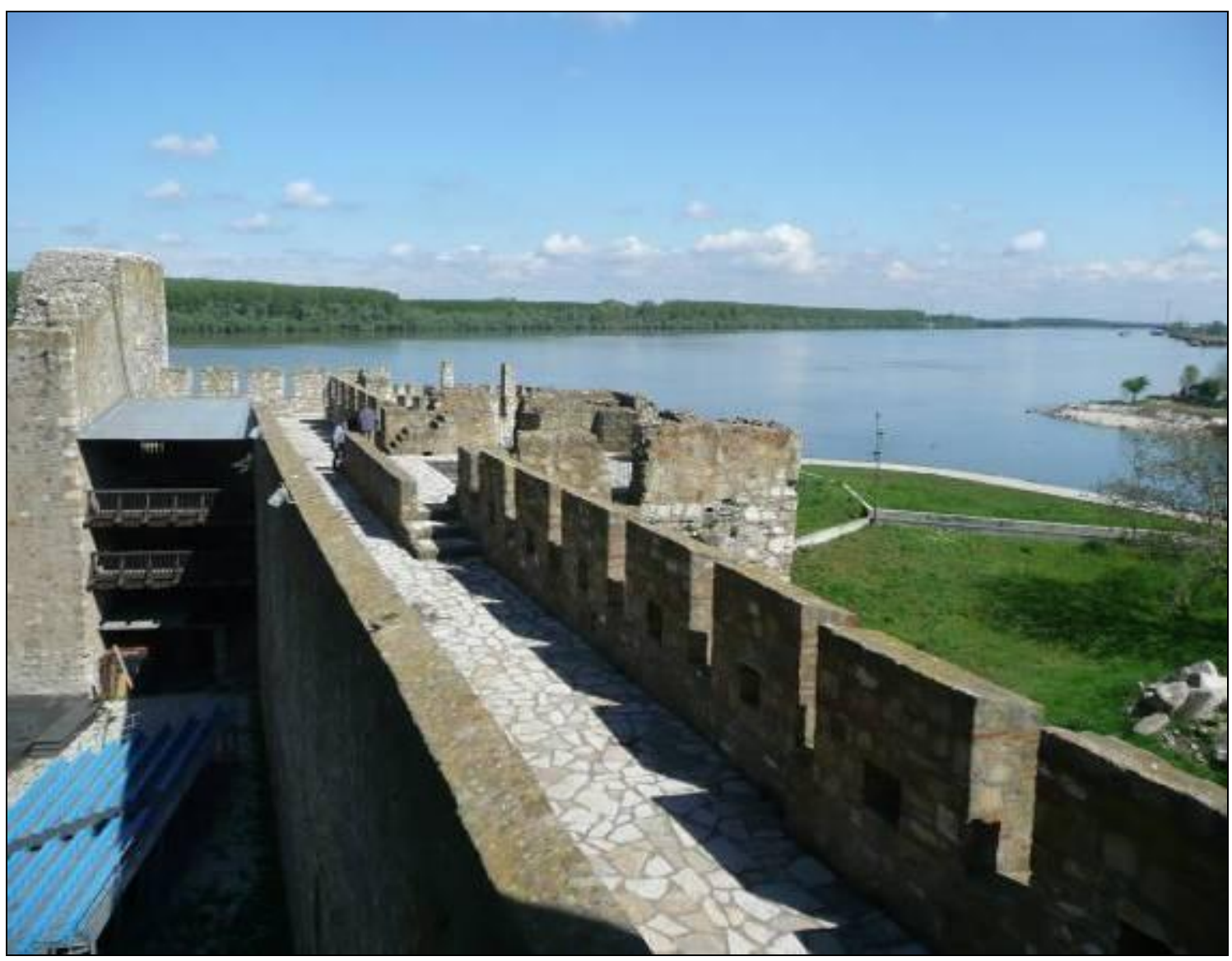

17. melléklet. Szendrő belső Fellegvárának fala (a szerző felvétele). 


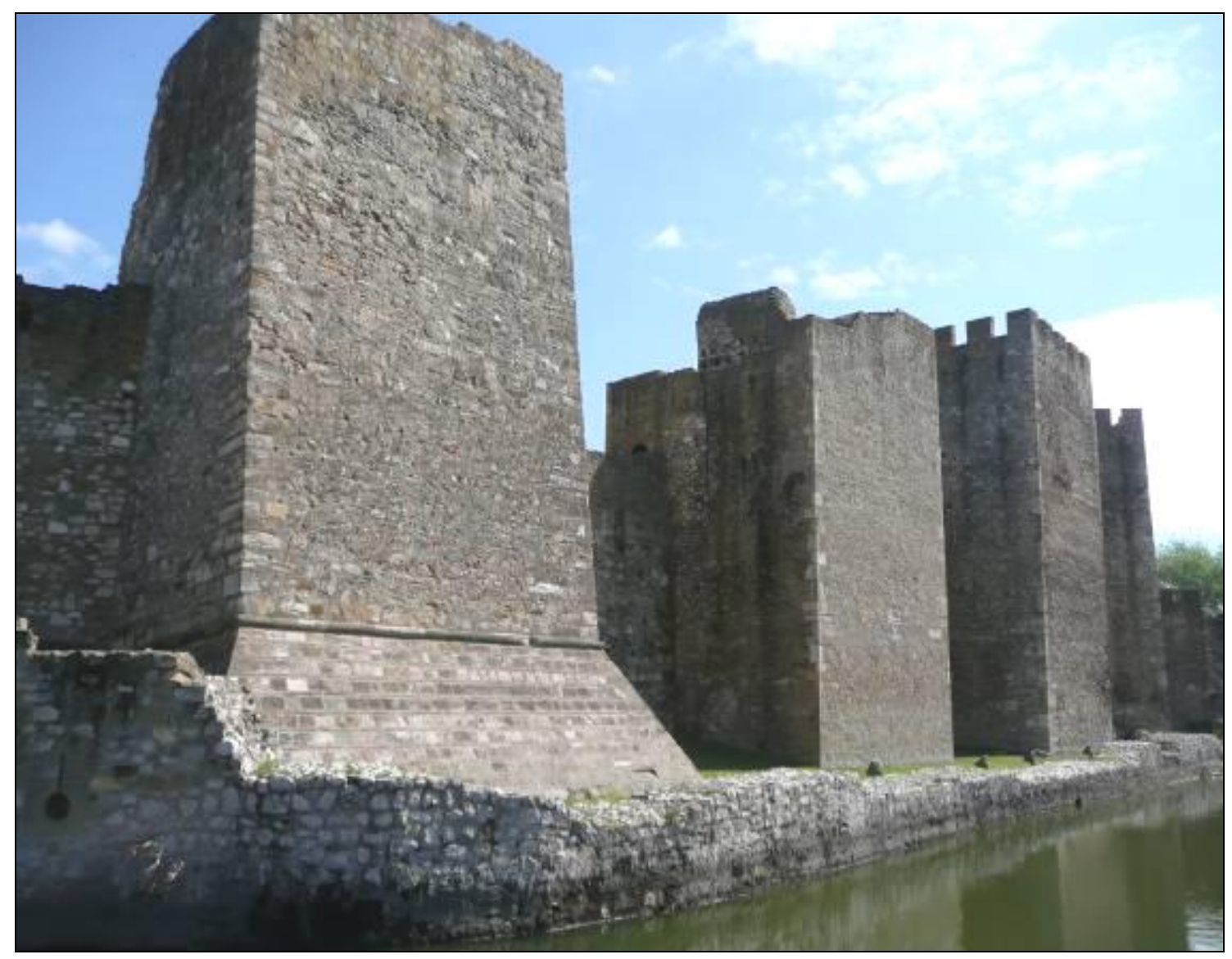

18. melléklet. A vizesárokkal elválasztott Fellegvár tornyai (a szerző felvétele).

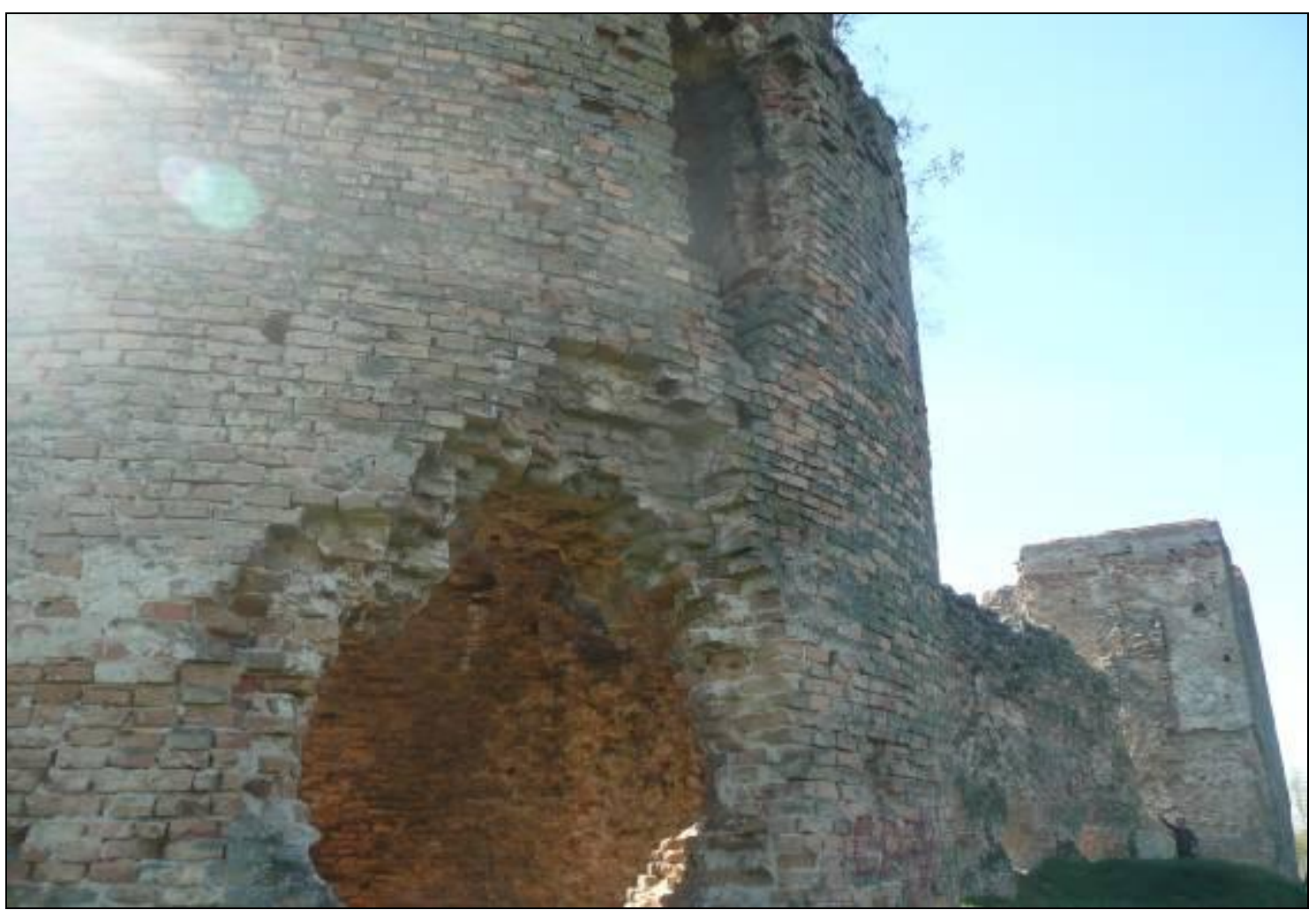

19. melléklet. Bács téglavárának falai a tornyokkal (a szerző felvétele). 


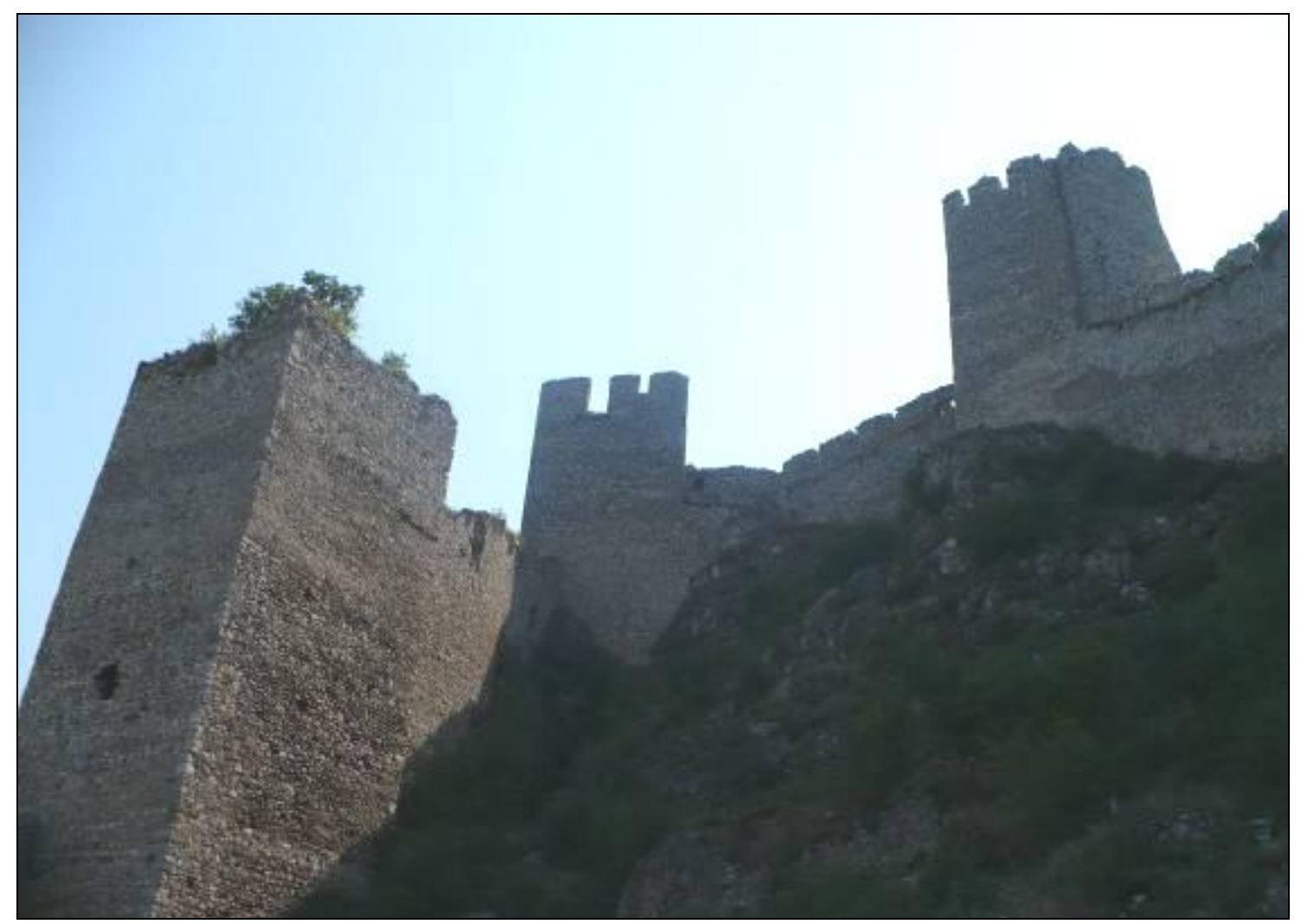

20. melléklet. Galambóc meredek falai (Despotov Katalin felvétele).

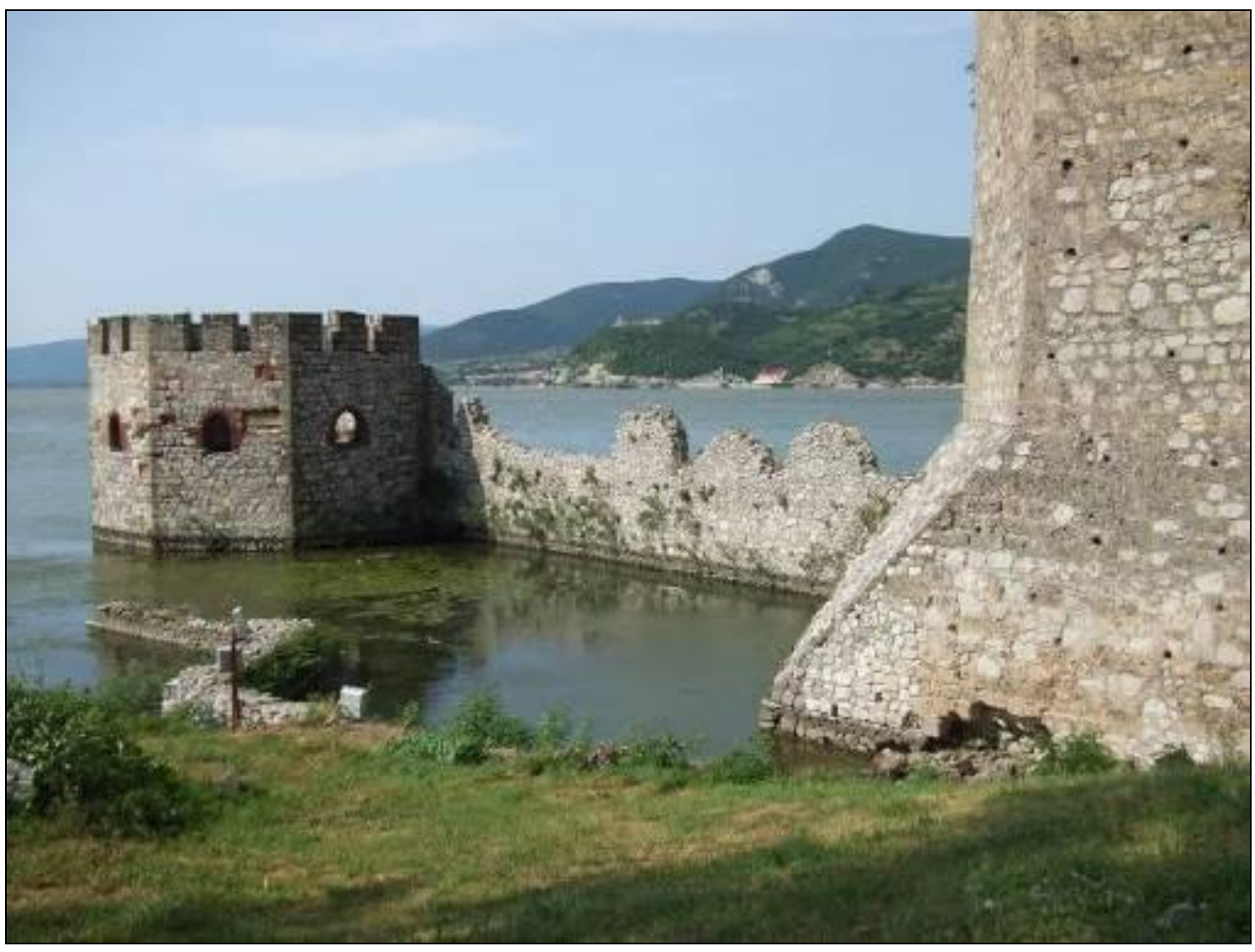

21. melléklet. A vár vízzel elárasztott része ma (Tóth Mihály felvétele). 


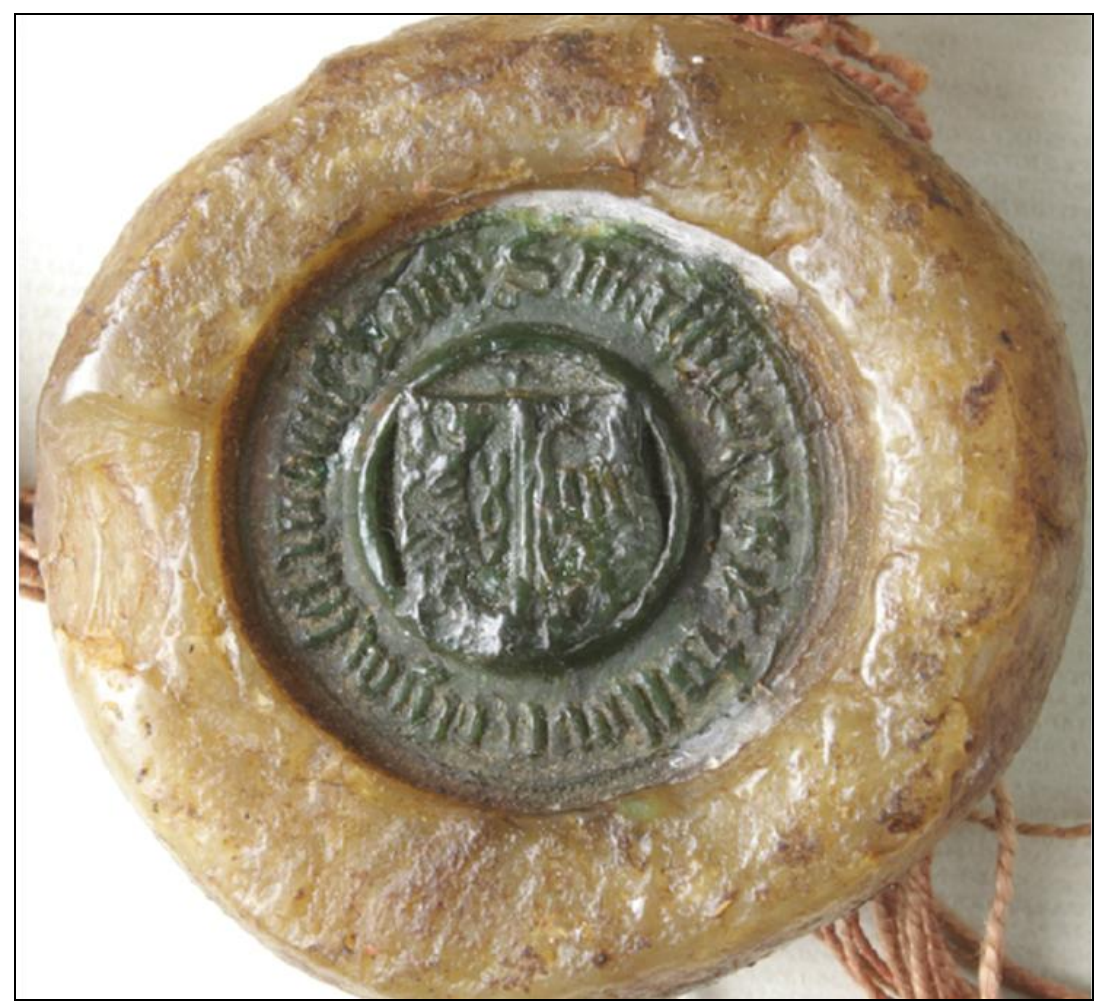

22. melléklet. Tallóci Matkó 1437. január 29-én kiállított oklevelének pecsétje (DL 88 112)(_ecw/dldf/ol/088200/DL_088112_sigil.ecw-AAGISView) (http://mol.arcanum.hu/dldf/opt/a110505htm?v=pdf\&q=KIAD\%3D\%28matk\%F3\%29\&s=D AT\&m=2\&a=rec) (Letöltés: 2013. 11. 15)

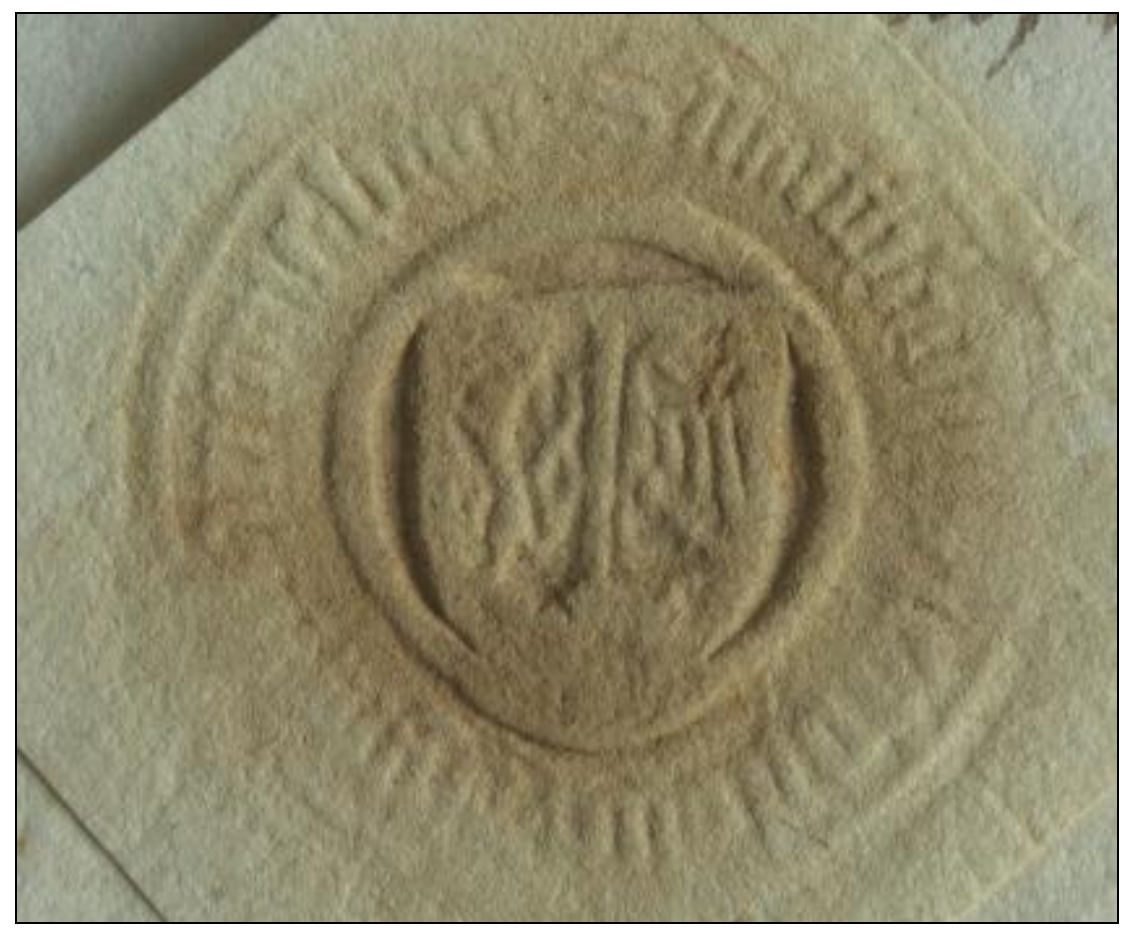

23. melléklet. Tallóci Matkó 1440. október 1.-i oklevelének pecsétlenyomata (DL 44 302). (_ecw/dldf/ol/044400/DL_044302_sigil_r_1.ecw-AAGISView) http://mol.arcanum.hu/dldf/opt/a1 10505htm?v=pdf\&q=KIAD\%3D\%28matk\%F3\%29\&s= DAT\&m=2\&a=rec) (Letöltés: 2013.11 .15$)$ 


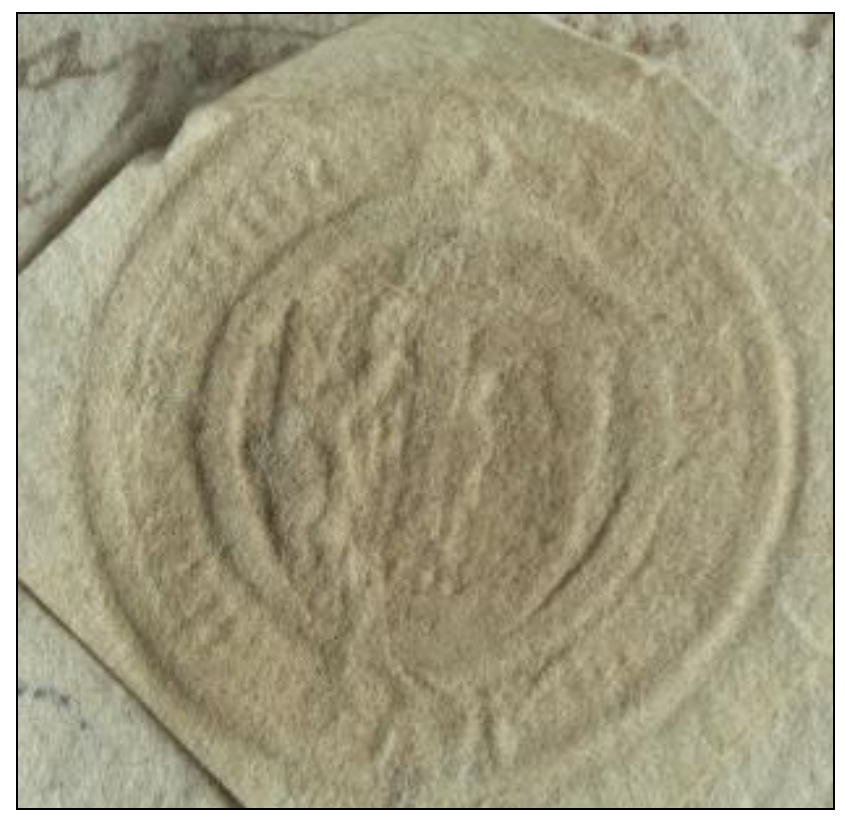

24. melléklet. Tallóci Frank Szalatnokon, 1440. május 20-án kiadott pénzkérő oklevelének papírral fedett gyürüs pecsétlenyomata.

(DL 55 204).(_ecw/dldf/ol/055400/DL_055204_sigil_r_1.ecw -AAGISView)

(http://mol.arcanum.hu/dldf/opt/a110505htm?v=pdf\&q=KIAD\%3D\%28Frank\%29\&s $=$

DAT\&m=681\&a=rec) (Letöltés: 2013. 11. 15)

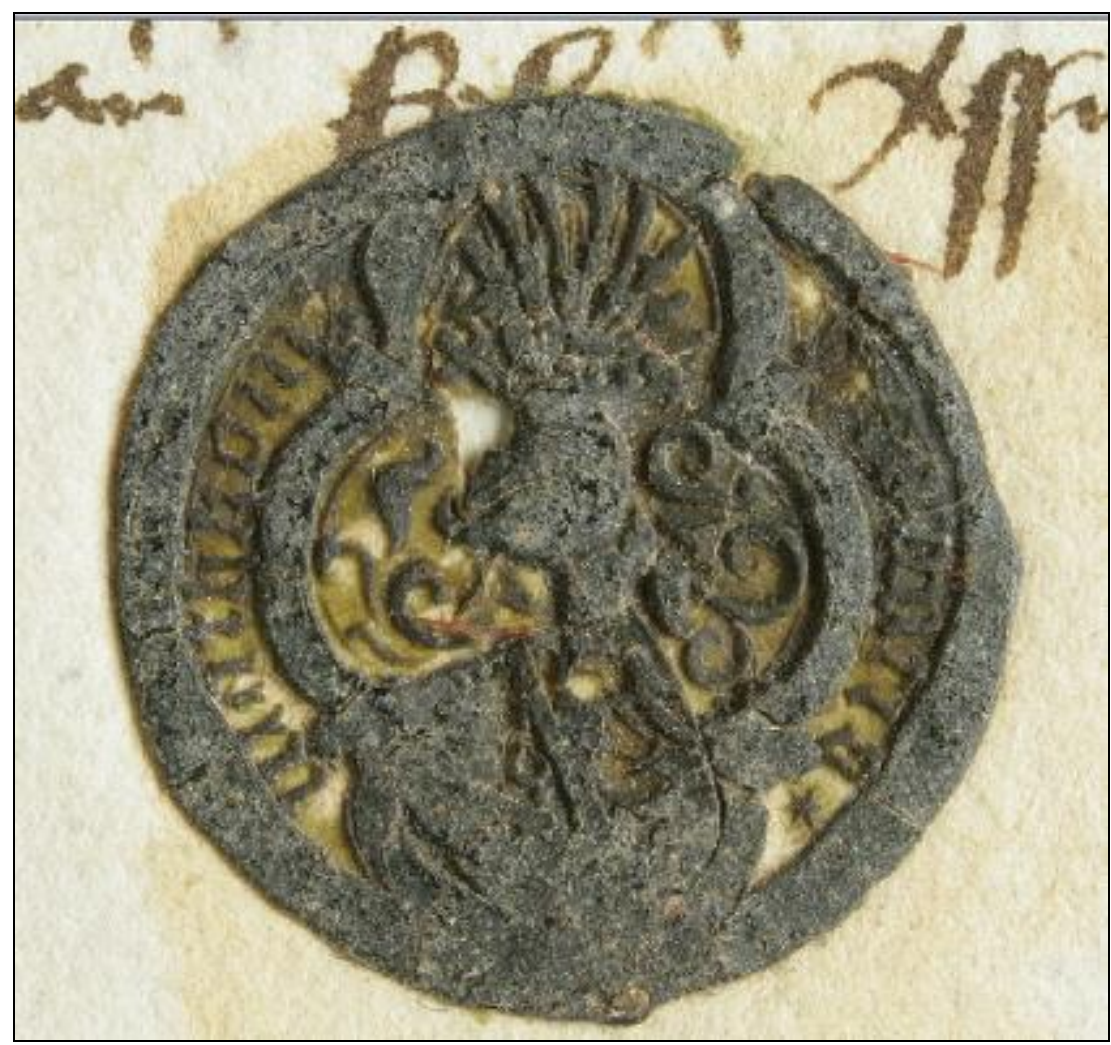

25. melléklet. Tallóci Frank 1434. augusztus13-i oklevele Matkó pecsétjével (DL 80 468) (_ecw/dldf/ol/080600/DL_080468/DL080468_sigil.ecw-AAGISView) (http://mol.arcanum.hu/dldf/opt/a110505htm?v=pdf\&=KIAD\%3D\%28tall\%\%F3ci\%20fra $\underline{\mathrm{nk} \% 29 \& \mathrm{~s}=\mathrm{DAT} \& \mathrm{~m}=1 \& \mathrm{a}=\mathrm{rec})}$ (Letöltés: 2013.11.15) 


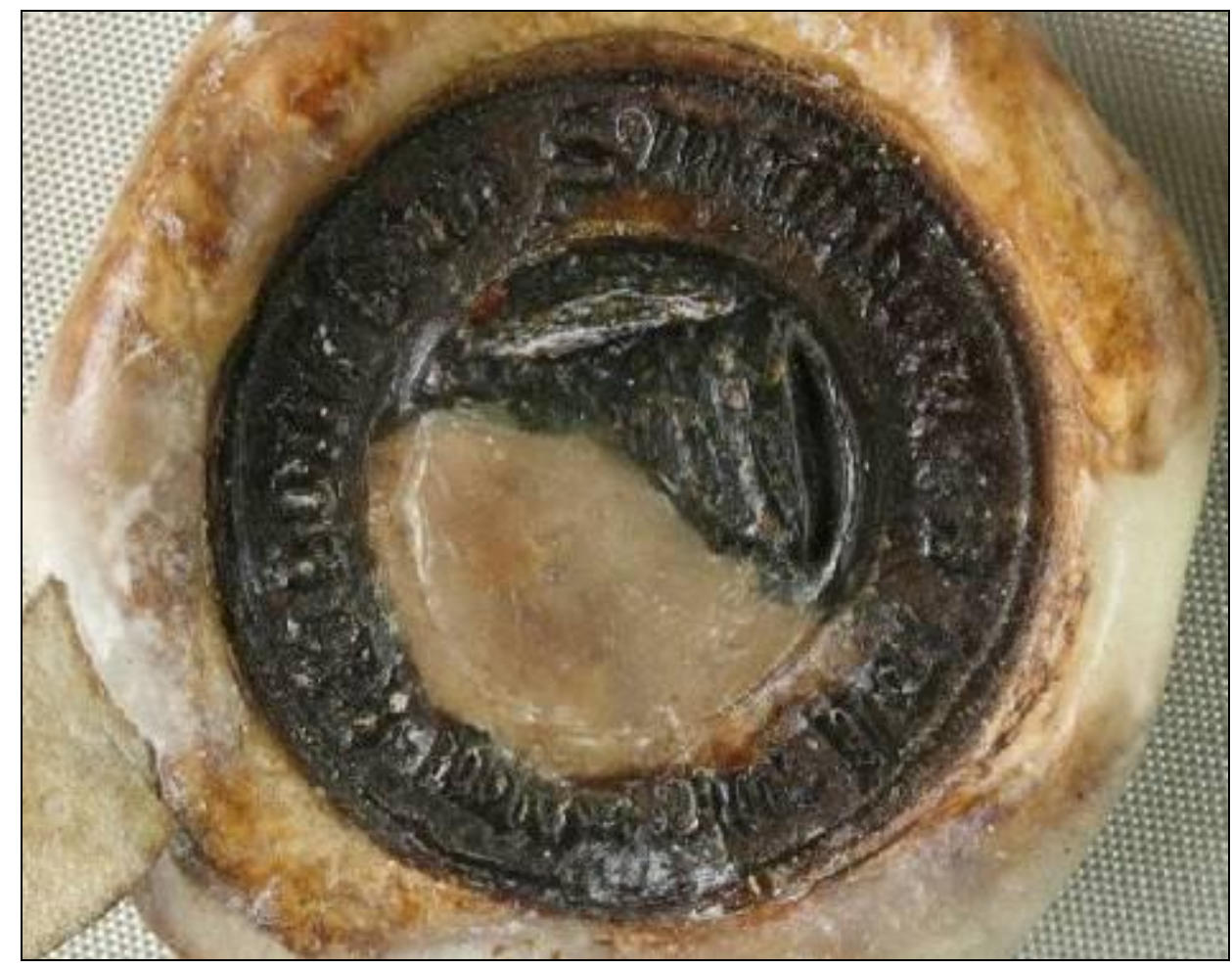

26. melléklet. Tallóci Matkó töredékes pecsétje Albert király és Erzsébet királyné 1439. szeptember 17-én kiadott oklevelén (DL 39 290) (_ecw/dldf/ol/039400/DL_039290/DL_039290_sigil_r_07.ecw-AAGISView) (http://mol.arcanum.hu/dldf/opt/a110505htm?v=pdf\&q=JELZ\%3D\%283920\%29\&s=DAT\&m $=0 \& \mathrm{a}=\mathrm{rec})$ (Letöltés: 2014. 01. 12)

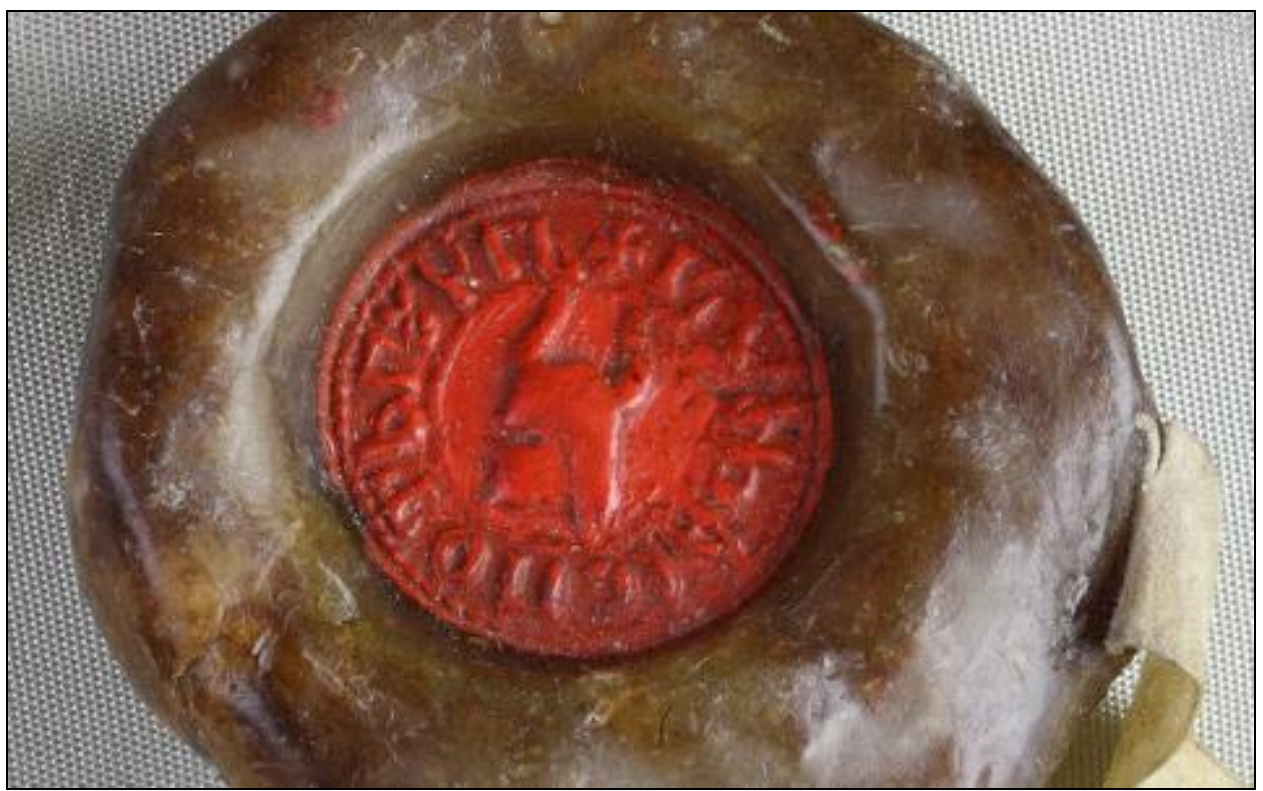

27. melléklet. Branković György szerb despota pecsétje Albert király és Erzsébet királyné 1439. szeptember 17-én kiadott oklevelén (DL 39 290). (_ecw/dldf/ol/039400/DL_039290/DL_039290_sigil_r_03.ecw-AAGISView) (http://mol.arcanum.hu/dldf/opt/a110505htm?v=pdf\&q=JELZ\%3D\%283920\%29\&s=DAT\&m $=0 \& \mathrm{a}=\mathrm{rec})$ (Letöltés: 2014. 01. 13) 


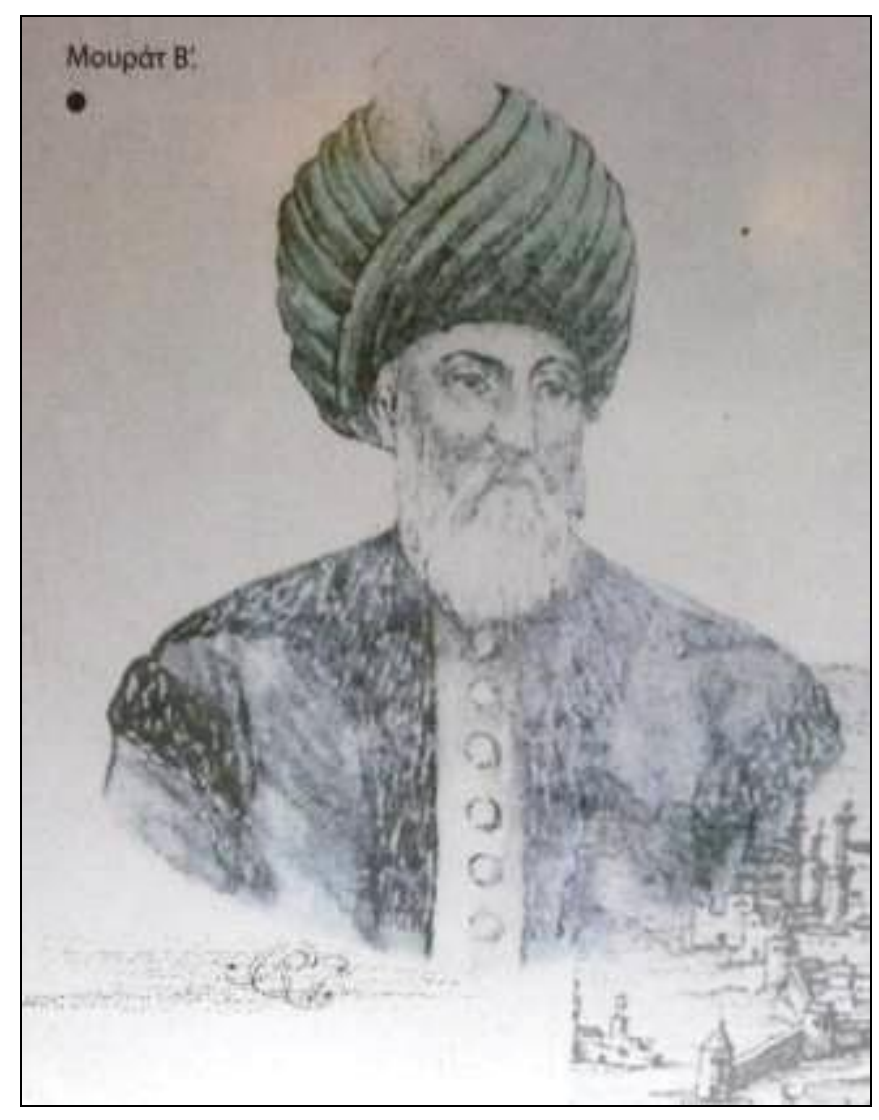

28. melléklet. II. Murád szultán

(Thesszaloniki, Lefkosz Pürgosz Múzeum kiállítása)

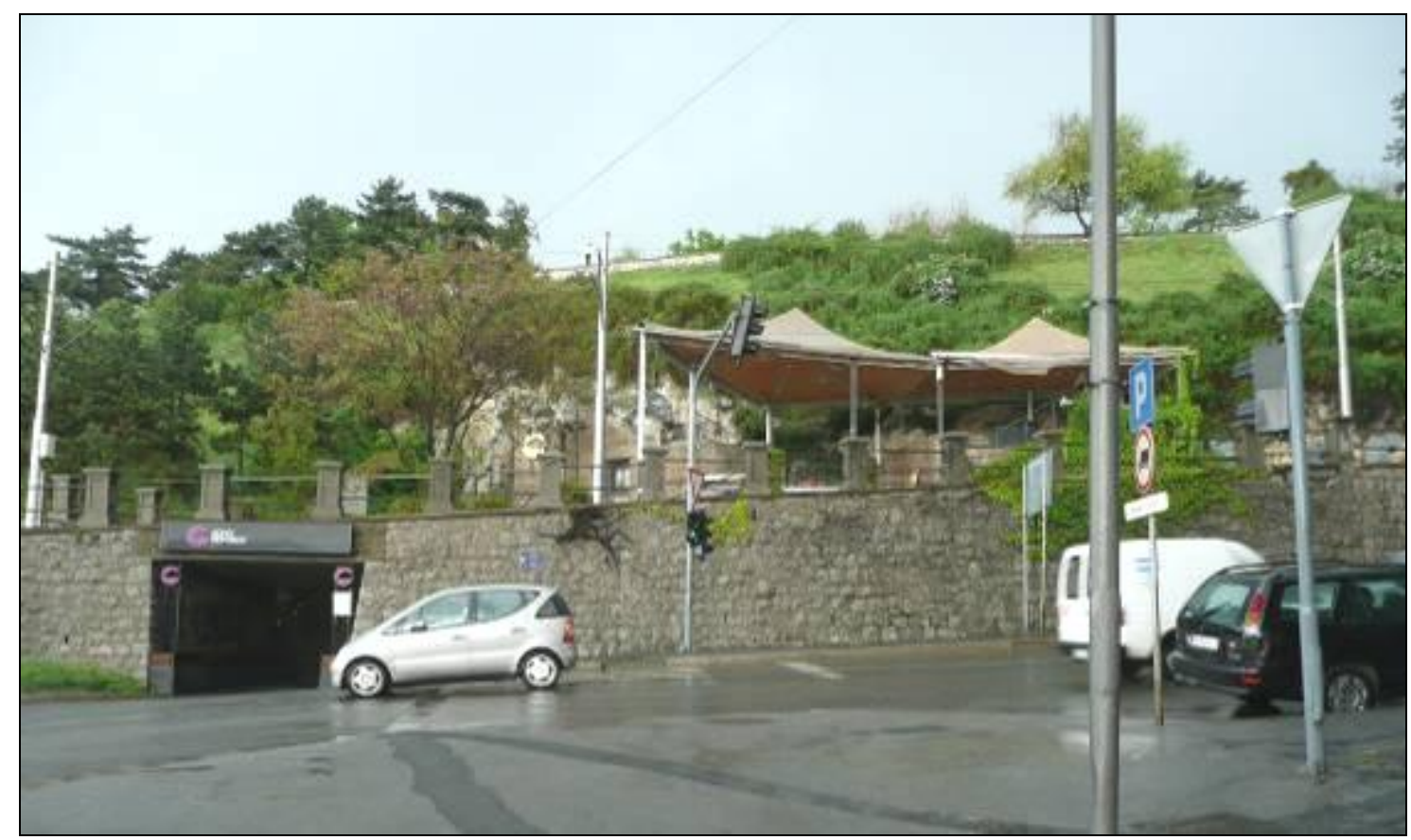

29. melléklet. Az egykori alagút bejárata a mai Belgrádban (a szerző felvétele). 


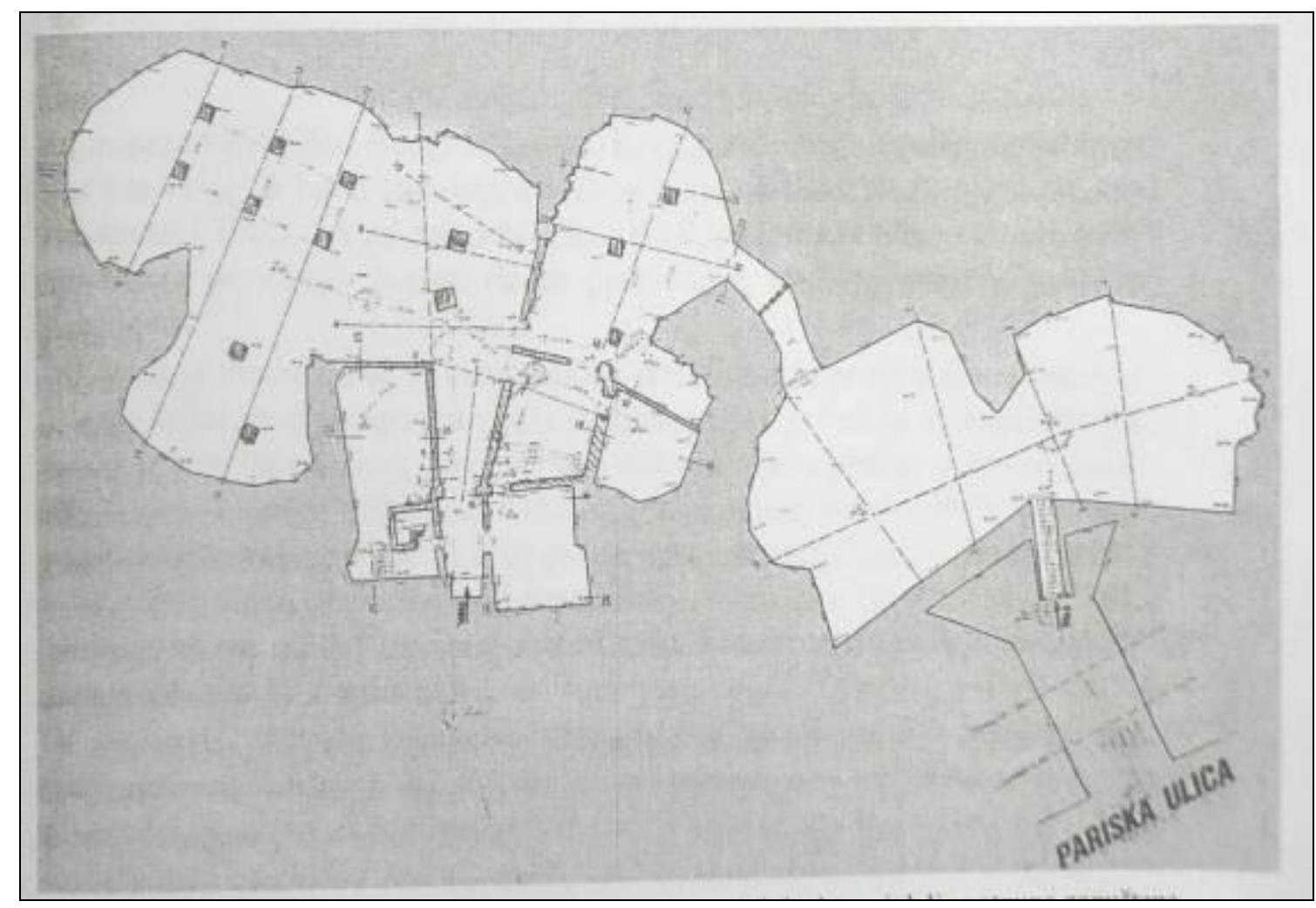

30. melléklet. Az alagút feltárt alaprajza. (Nikolič-Golubovič 2002. 33)

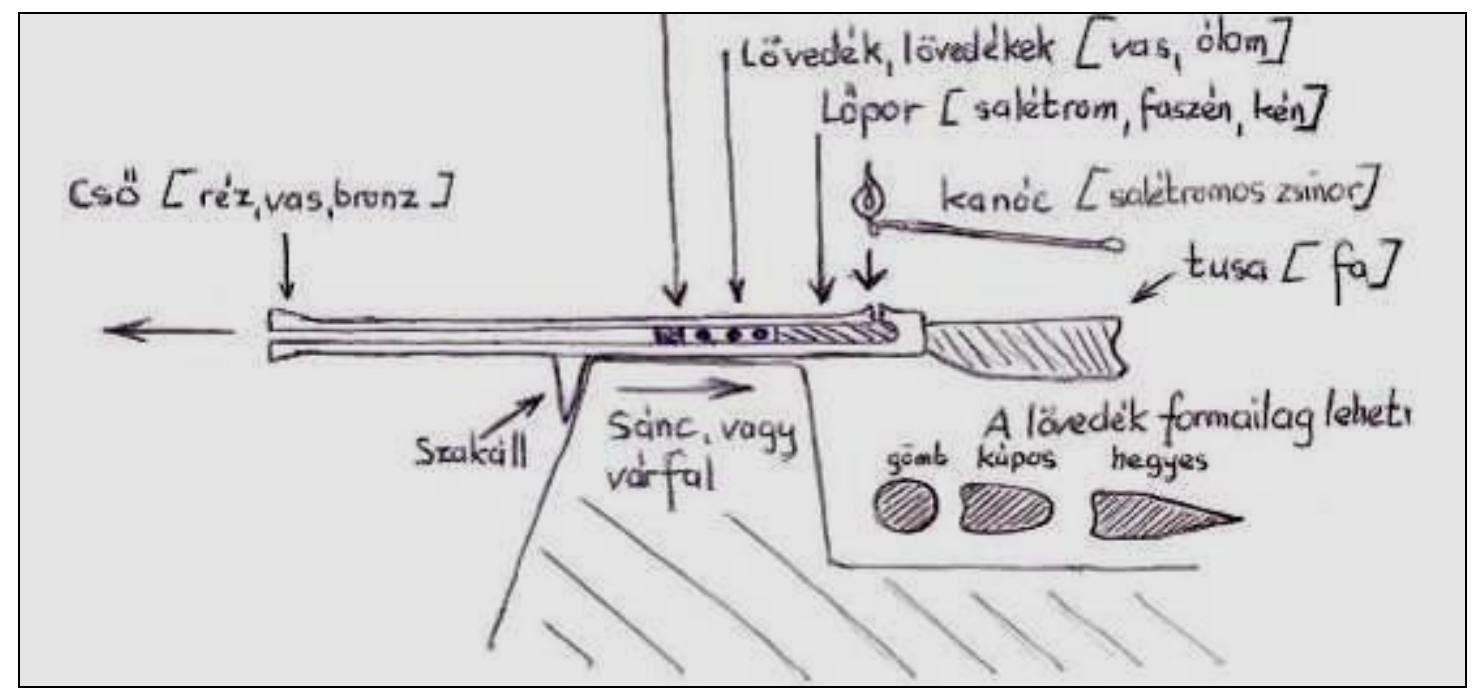

31. melléklet: Tusás szakállas- vagy sáncpuska vázlatrajza (Készítette Dani Dániel Pál) 


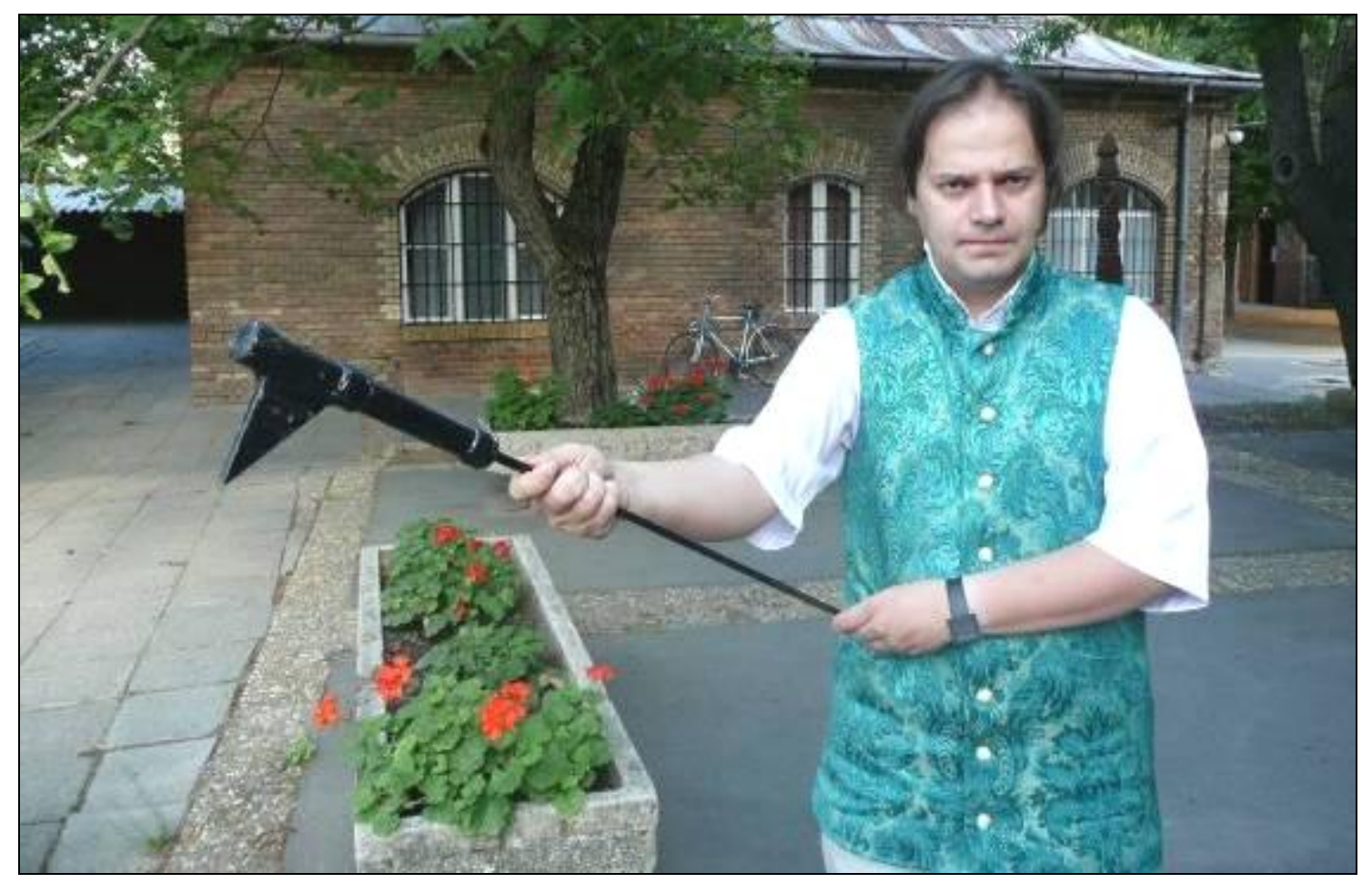

32. melléklet. Vasnyelü szakállas puska. (A Hunyadiak Örökében Történelmi Hagyományőrző Egyesület müködőképes, replika példánya,

V. Történettudományi Találkozó, Hódmezővásárhely, 2012. július 14-22)

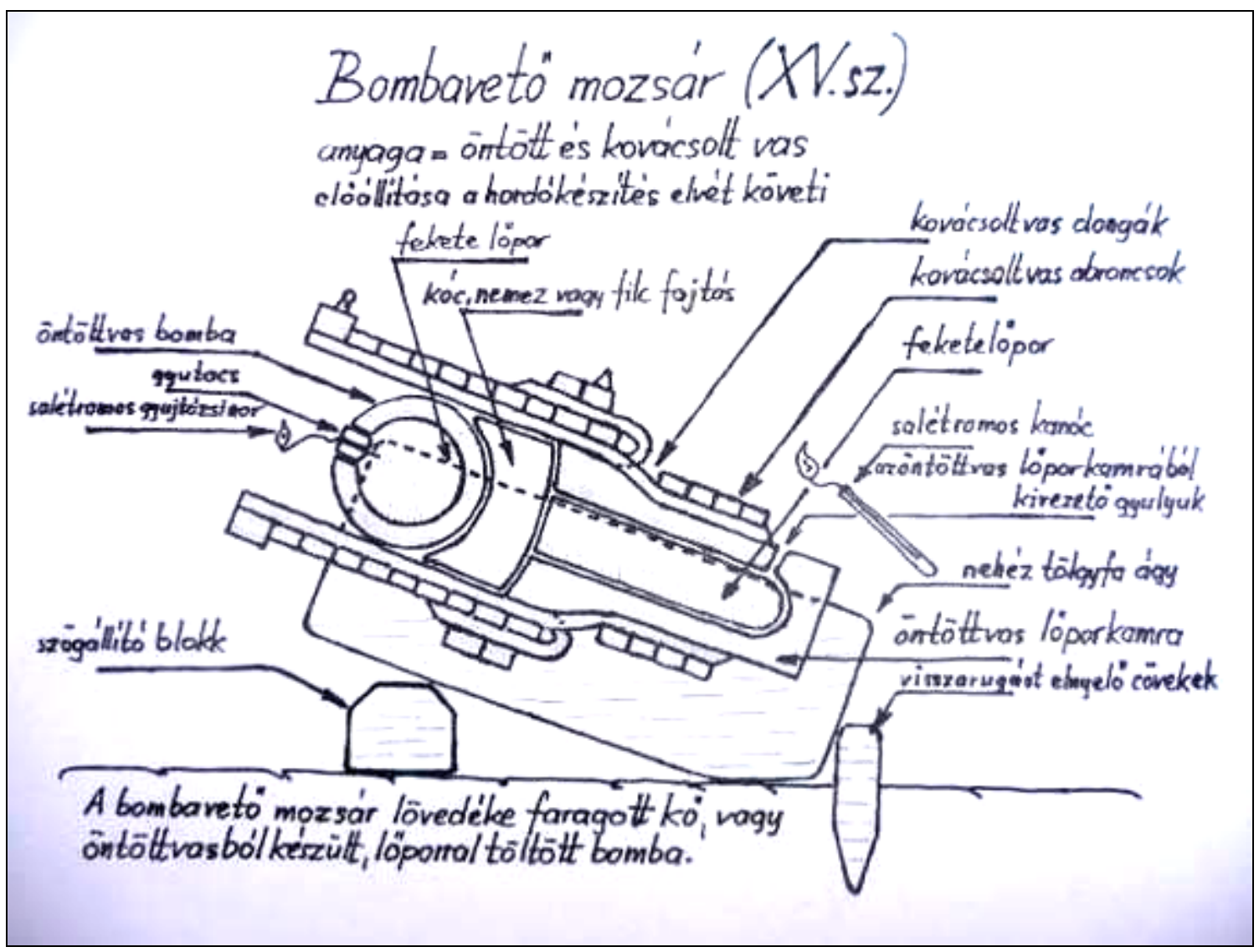

33. melléklet: A bombavető mozsár rekonstrukciós rajza (Készítette Dani Dániel Pál) 